\title{
The Southern Version of
}

Cursor Mundi

\author{
Volume I \\ Edited by \\ SARAH M. Horrali.
}

General Editor

SARAh M. Horrall

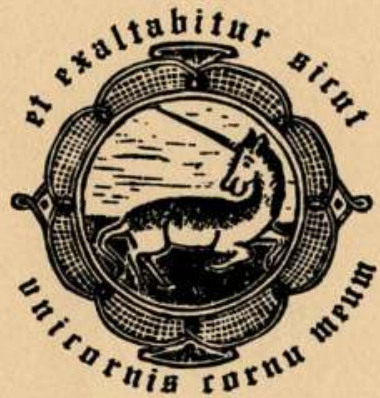

The University of Ottawa Press

Ottawa, Canada

1978 


\title{
The Southern Version of \\ Cursor Mundi
}

\author{
Volume I
}




\section{ÉTUDES MÉDIÉVALES DE L'UNIVERSITÉ D'OTTAWA OTTAWA MEDIAEVAL TEXTS AND STUDIES}

No. 1 - Miracles de Notre-Dame de Chartres, de Jean Le Marchant, publiés par Pierre Kunstmann, 1973. 300 pages.

No. 2 - The Tiberius Psalter, Edited from British Museum MS Cotton Tiberius $\mathrm{C}$ vi, by A. P. Campbell, 1974. 304 pages.

No. 3 - Le vocabulaire des Lais de Marie de France, par Denise McClelland, 1977. 212 pages.

No. 4 - "Commemoratio Brevis de Tonis et Psalmis Modulandis", Introduction, Critical Edition, Translation, by Terence Bailey, 1978. 128 pages.

No. 5 -The Southern Version of "Cursor Mundi", Vol. I. Edited by Sarah M. Horral, 1978. 450 pages.

(- University of Ottawa Press, 1978.

ISBN-0-7766-4805-5 


\title{
The Southern Version of \\ Cursor Mundi
}

\author{
Volume I \\ Edited by \\ Sarah M. Horrall
}

General Editor

Sarah M. Horrall

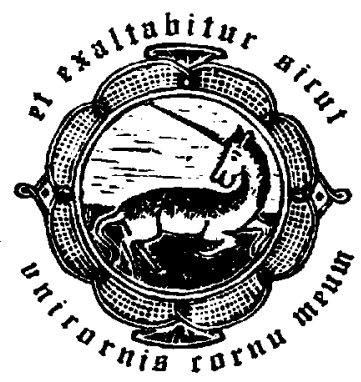

The University of Ottawa Press

Ottawa, Canada

1978 
This page intentionally left blank 
TABLE OF CONTENTS

Acknowledgments $\ldots \ldots \ldots \ldots \ldots \ldots \ldots \ldots \ldots \ldots \ldots, \quad 9$

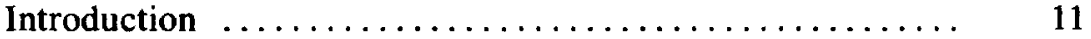

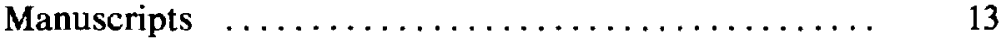

Selection of a Base Text $\ldots \ldots \ldots \ldots \ldots \ldots \ldots \ldots .23$

Structure of the Poem $\ldots \ldots \ldots \ldots \ldots \ldots \ldots \ldots \ldots .24$

Editorial Principles $\ldots \ldots \ldots \ldots \ldots \ldots \ldots \ldots \ldots \ldots . \ldots \ldots$

Introduction to this Volume: Sources ............... 29

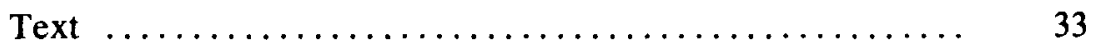

List of Abbreviations Used $\ldots \ldots \ldots \ldots \ldots \ldots \ldots \ldots . . \ldots \ldots$

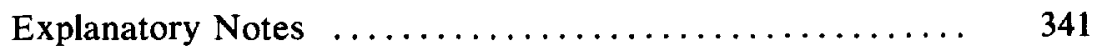

Appendix A: Errors in Morris' Texts $\ldots \ldots \ldots \ldots \ldots \ldots . \quad 412$

Bibliography $\ldots \ldots \ldots \ldots \ldots \ldots \ldots \ldots \ldots \ldots \ldots, \quad 421$ 
This page intentionally left blank 


\section{ACKNOWLEDGEMENTS}

I should like to thank first of all those teachers who aroused my interest in biblical paraphrases and encouraged me at various stages in my study: J. D. Pheiffer of Trinity College, Dublin, L. M. Eldredge of the University of Ottawa, and especially A. P. Campbell of the University of Ottawa whose love for Cursor Mundi encouraged me to take on this work.

I must also thank the staffs of various libraries for their constant help: in Canada, the University of Ottawa Library and especially their Inter-Library Loans Department, and in England the staffs of the British Library, the Bodleian Library, and the Library of Trinity College, Cambridge. I must also thank those people at the College of Arms in London who went to unusual trouble to give me access to their manuscript.

For permission to publish manuscripts in their possession I thank the Corporation of the Kings Heralds and Pursuivant of Arms and in particular for the good offices of Dr. Conrad Swan, Ph. D., M. A., F. S. A., York Herald of Arms; the Master and Fellows of Trinity College, Cambridge; and the Bodleian Library, Oxford.

Special thanks go to Margaret Rejhon, who spent long hours of labour in deciphering my handwriting and typing the manuscript.

The research for this book was made possible first by doctoral fellowships from the Canada Council, and then by a research grant from the same organization.

The book has been published with the help of a grant from the Canadian Federation for the Humanities, using funds provided by the Social Science and Humanities Research Council of Canada. 
This page intentionally left blank 


\section{Introduction}

The Cursor Mundi is a verse history of the world, based on scripture, telling the story of mankind from Creation until Doomsday. The poem, which is almost 24,000 lines long in some versions, was written by an unknown poet in the north of England about 1300 . Although the original composition has not survived, it was copied many times over the next 150 years, and is now extant in nine manuscripts. ${ }^{1}$

The poem is the best and most comprehensive of its kind in Middle English. Most Middle English biblical paraphrases base themselves on a very few sources, usually relying heavily on the Historia Scholastica of Petrus Comestor. The CM poet, on the contrary, has shown a wide knowledge of the traditional motifs of biblical exegesis, and he draws on an unusual variety of French, Latin and English sources. The poem which he produced is a wellproportioned compilation of pre-existing material translated into serviceable Middle English verse.

The only modern edition of the work appeared between 1874 and 1893, when Richard Morris and several colleagues published a transcription of five manuscripts of the $C M$, four of which were in northern or north Midland dialects. The transcriptions were accompanied by a sketchy, inaccurate critical apparatus which is now completely out of date. However, because Morris' work is the only edition of the whole poem available, most generalizations about the $C M$ are based on it, and on the conclusions suggested by his critical apparatus. A new edition of the poem, with thorough analysis of the poet's sources, ideas and techniques, has long been needed.

Since Morris' version appeared, many more of the sources used by the $C M$ poet have come to light. Comparison with these sources confirms Morris's finding that $\mathrm{MS} \mathrm{C}^{2}{ }^{2}$ a northern version,

1 MS McGill Univ. 142. listed as a tenth MS of $C M$ in Brown, Index, 2153, is in fact part of a version of the Southern Assumption. See Michael G. SERGENT, "The McGill University Fragment of the Southern Assumption", Mediaeval Studies, XXXVI (1974), 186-98.

${ }_{2}$ See below, p. ff., for an explanation of the MSS sigla. 
is the extant MS which is closest to the poem actually written by the mediaeval poet. Morris stopped there, however, considering that all other MSS, though perhaps dialectally interesting, were simply less perfect copies of the poet's original. Because the southern MSS (HTLB) differed most from MS C, Morris and his collaborators considered them to be merely hopelessly corrupt copies of the original poem, worthless for establishing the text of the original.

The present edition is based on entirely different assumptions. At some time in the late fourteenth century, someone in the south central Midlands came across a copy of the $C M$ in a MS something like the extant MS G. The MS, or perhaps MSS, which he found, contrary to Morris' assumption, did preserve several original readings which are lost in each of the northern versions. Systematically this person revised the poem he found in the MS or MSS, changing phonology, morphology, rhymes, vocabulary and ideas, and completely revising the ending of the poem. As a result, southern England acquired not a corrupt copy of a northern poem, but a new poem, substantially changed in language and scope from its original. ${ }^{3}$

Southern audiences seem to have appreciated the revisor's efforts. The new version of the poem was copied at least four times, in formats ranging from parchment volumes with decorated initials, to large paper compilations of romances, adventures, and works of moral improvement. One of these is known to have belonged to a nun at the Bridgittine double monastery of Syon, just outside London. As late as 1442, the scribe of MS B was so aware of the $C M$ as a living poem that he again modified the work, revising many lines and substituting extracts from another poem for some parts of the $C M$, exactly as the scribe of MS C had done 100 years before him. ${ }^{4}$

The text of the northern versions of the $C M$ has long been available in Morris' edition, which was reprinted in 1961-6. For the first time, the present volume makes the southern translation of the work, including the highly interesting Bedford MS (MS B), equally available for consideration by scholars. The $C M$ is here printed from a little known MS in a south Midland dialect (College of Arms Arundel LVII), with variants from three more, two of which have never been printed before (MSS Trinity College, Cambridge R.3.8; Bodleian Laud Misc. 416; British Library Additional 36983). The present volume contains approximately one third of the southern version of the poem. The rest will appear in two further volumes,

3 Cf. Rolf F.AISER, Zur Geographie, whose work documents some of these processes of revision.

4 See, e.g., Carleton Brown, "CM and the Southern Passion". 
the last one containing a discussion of the authorship, place and date of composition, MS relations, etc.

The present volume constantly invites the reader to compare the readings of the southern version of $C M$ with those of the northern MSS as printed by Morris. In order that these comparisons be as accurate as possible, each volume will contain a list of corrections to Morris' transcriptions of the northern MSS.

Each volume of this edition will also contain extensive explanatory notes. These are designed first of all to explain the $C M$ itself. They deal first with the poet's sources, how he combines them or shifts from one to another while composing his own work. They also show how his original conception, most often preserved in MS C, changes as the poem is copied, revised, and copied again. However, the notes also attempt to place the $C M$ in the context of similar literature in Old and Middle English, Old French, Latin, Hebrew and to some extent Celtic. This study of analogues to the $C M$ enables the editor to determine in each instance whether the poet is using a commonplace of biblical exegesis, or a motif rare in Middle English but common in Old French biblical paraphrases, or an idea so rarely found in extant works that the $C M$ poet's use of it remains a mystery. These notes should help to illuminate not only the $C M$ itself, but also the large body of biblical literature in several mediaeval languages which has been relatively little studied of late. In this biblical literature, the $C M$ occupies a unique place, because of its length, its scope, and its author's broad and eclectic knowledge of the traditions of exegesis in his time.

\section{THE MANUSCRIPTS}

\section{H Arundel LVII ${ }^{5}$ College of Arms, London}

Vellum, 175 fols., approximately $12 \frac{1}{2} \times 8^{1 / 2}$ inches, usually in double columns ${ }^{6}$ of forty lines each. Fols. 1-132 contain the $C M .^{7}$

5 See William Henry Black, Catalogue of the Arundel Manuscripts in the Library of the College of Arms (London, 1829), pp. 101-3; Hupe, CM, p. 68*

6 In MSS GHTLB the passion story, 11.14934-17110, is copied in single columns of long lines.

${ }_{7}$ Fols. 133-75 contain a copy of the Pricke of Conscience, imperfect at beginning and end. Cf. Richard MorRIs, ed., The Pricke of Conscience. 
Collation: ${ }^{8}$ flyleaf

$a^{8} \quad$ with $a^{i}$ missing fols. 1-7

$b^{8}$ fols. 8-15

$c^{8}$ with $\mathrm{c}^{\mathrm{i}}$ missing fols. 16-22

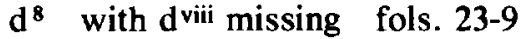

$\mathrm{e}^{8}$ with $\mathrm{e}^{\mathrm{i}}$ missing fols. $30-6$

$f^{8}-i^{8}$ fol. $37-68$

$\mathrm{j}^{8}$ with $\mathrm{j}^{\mathrm{v}}$ missing fols. 69-75

$\mathrm{k}^{8}-\mathrm{o}^{8}$ fols. $76-115$

$\mathrm{p}^{8}$ with $\mathrm{p}^{\text {viii missing fols. } 116-22}$

$q^{8}$ with $q^{i-i i i}$ missing fols. 123-7

$r^{6}$ with $r^{i}$ missing fols. 128-32

$\mathrm{s}^{8}$ with $\mathrm{s}^{\mathrm{i}-\mathrm{v}}$ missing fols. 133-5

$\mathrm{t}^{8}-\mathrm{x}^{8}$ fols. 136-75

y missing; perhaps contained 10 fols.

to accommodate the remainder of Pricke of Conscience.

Handwriting: A clear, regular bastard hand. $y$ and $\mathrm{p}$ are always distinguished, $\mathbf{u}$ and $\mathbf{n}$ only sometimes. Initials, etc. are decorated in red and blue.

Date: About 1400?

History: The MS was probably copied at or near Lichfield. ${ }^{9}$ Although it is kept with the Arundel MSS at the College of Arms, it was not part of the original bequest of the Duke of Norfolk. ${ }^{10}$

Previous editions: Morris, $C M$, printed a few lines of the MS, chiefly $11.153-270$, pp. 1657-63, and $11.17853-18028$, pp. 102432.

\section{T Trinity College, Cambridge R.3.8 ${ }^{11}$}

Vellum, 144 leaves, approximately $12^{1 / 4} \times 8^{1 / 4}$ inches, usually in double columns ${ }^{12}$ of 40 lines each.

Contains only $C M$.

Collation: $\mathrm{a}^{8}-\mathrm{r}^{8} \quad \mathrm{r}^{\text {vii-viii blank. }}$

${ }^{8}$ The collation printed by MorRIs, $C M$, p. 1663 , contains a number of errors. The MS itself has pencilled signatures in a modern hand, but these err at fol. 128 and thereafter.

9 Dareau and McIntosh, "A Dialect Word", p. 21.

10 See BLACK's Catalogue, p. [99].

11 See Montague Rhodes JAmES, The Western Manuscripts in the Library of Trinity College Cambridge, II (Cambridge, 1901) ; HUPE, CM, pp. 67*-8*.

12 See note 6 above. 
Handwriting: A clearly written bastard hand. $\mathrm{p}$ and $\mathrm{y}$ are distinguished and so often are $u$ and $n$. Large initials are decorated in red and blue. There are frequent marginal notes in 16th and 17 th century hands, mainly summarizing the content of the poem.

Date: About 1400 ?

History: McIntosh believes this MS was copied at Lichfield by a scribe who is responsible for several other extant MSS. ${ }^{13}$ Various names in later hands appear at the end of the MS, which was given to Trinity College by George Willner.

Previous editions: Printed in full by Morris, $C M$.

\section{Laud Misc. $416^{14}$ Bodleian Library}

Paper, 289 leaves approximately $12 \times 8^{1 / 2}$ inches.

The $C M$ occupies fols. $65 \mathrm{r}-181 \mathrm{v}^{15}$ usually in double columns ${ }^{16}$ of about 46 lines each.

Collation: ${ }^{17}$ a fols. 1-8 The original folio numbers in Roman numerals indicate that 36 fols. are missing from the beginning.

$b^{12}-d^{12}$ fols. $9-44$

$\mathrm{e}^{12}$ fols. 45-55 $\mathrm{e}^{\mathrm{ix}}$ is partly torn out.

$f^{12}$ fols. 56-64 with $f^{x-x i i}$ missing.

$\mathrm{g}^{12}$ fol. 65 with gi-xi missing.

$h^{16}-k^{16}$ fols. $66-129$

$1^{16}$ fols. 130-43 with $\mathrm{lii}^{\mathrm{ii}}$ and $\mathrm{l}^{\mathrm{xv}}$, conjugate leaves, missing.

The bottom half of fol. 141 is also gone.

$\mathrm{m}^{16}$ fols. 144-59

$\mathrm{n}^{16}$ fols. 160-71 with $\mathrm{n}^{\text {iii-iv }}$ and $\mathrm{n}^{\mathrm{ix}-\mathrm{x}}$ missing.

13 McIntosh, "A New Approach", pp. 6-7; DAREAU and McInTosh, A Dialect Word", p. 26 ' n. 5.

${ }_{14}$ See H. O. Coxe, Catalogi Codicum Manuscriptorum Bibliothecae Bodleianae Partis Secundae (Oxford, 1858), p. 306; HuPE, CM, pp. 68*-9*.

15 The MS also contained: unknown material on the missing first 13 fols.; Peter Idley's Instructions, lacking about 1900 lines, on 23 fols. at beginning and otherwise imperfect, fols. 1-64v (Index 1540); Vegetius in prose, fols. 182r-226v (Index 3185); LyDGATE's Siege of Thebes, fols. 227r-254r (Index 3928); LYDGATE and Burgh's Secrees of Old Philisoffres, fols. 255r-287v (Index 935); CHAuCER's Parlement of Foules, fols. 288r-9v, imperfect at end (Index 3412).

16 See note 6 above.

17 Determined by original numbering of folios, catchwords and watermarks. The latter indicate that fols. 66-226 are on different paper from the rest of the MS. These fols. contain the entire $C M$, except for its table of contents, and the prose Vegetius. 
$\mathrm{o}^{10}$ fols. $172-81$
$\mathrm{p}^{12}$ fols. $182-92$ with $\mathrm{p}^{\mathrm{ix}}$ missing.
$\mathrm{q}^{12}-\mathrm{r}^{12}$ fols. $193-216$
$\mathrm{~s}^{12}$ fols. $217-26$ with $\mathrm{s}^{\text {xi-xii }}$ missing.
$\mathrm{t}^{12}$ fols. $227-38$
$\mathrm{u}^{16}$ fols. $239-54$
$\mathrm{v}^{12}$ fols. $255-65$ with $\mathrm{v}^{\text {xii missing. }}$
$\mathrm{w}^{12}$ fols. $266-76$ with $\mathrm{w}^{\mathrm{i}}$ missing.
$\mathrm{x}^{12}$ fols. $277-87$ with $\mathrm{x}^{\text {xii missing. }}$
$\mathrm{y}$ only fols. $288-9$ remain. Approximately 8 fols. would be
required to complete the Parlement of Foules.

Binding: The covers are wooden and the back is leather. The MS formerly had clasps, which are now broken. MSS Laud Misc. 503 and 512 have similar bindings.

Handwriting: A neat bastard hand. $\mathrm{p}$ and $\mathrm{y}$ and $\mathrm{u}$ and $\mathrm{n}$ are clearly distinguished. Final $\mathbf{n}$ and $\mathrm{r}$ sometimes end in a flourish.

Date: 1459 , from an inscription on fol. $226 \mathrm{v}$ :

"Scriptus Rhodo per Johannem Newton die 25 Octobris 1459".

History: Belonged to the Bridgettine Abbey at Syon, just outside London. ${ }^{18}$ On the back flyleaf is the name Syster Anne Colvylle. Archbishop Laud's name appears on fol. 1.

Previous editions: Morris, $C M$, printed 11.1-270, pp. 1651-62. He also printed $11.9325-11614,11.16227-18512$, and various smaller sections to fill in gaps in MS F. Brandl and Zippel print 11.10647-10782 and 11177-11276.

\section{B MS Additional $36983^{19}$ British Library}

Paper, 305 leaves, approximately $11 \times 8 \frac{1}{2}$ inches. The $C A i t$ occupies fols. $1-174,{ }^{20}$ usually copied in double columns ${ }^{21}$ of 31 lines each.

18 See F.ER, Medieval Libraries.

19 See Catalogue of Additions to the Manuscripts in the British Museum in the Years MDCCCC-MDCCCCV (London, 1907); HUPE, CM, p. 68*.

20 However, $C M$ 11.14916-17288 are replaced, on fols. 118r-127v, by 11.11140 of the Meditations on the Supper of Our Lord; see the edition by J. M. CowPER (London, 1875), EETS OS 60. CM 11.22005-23898 are replaced, on fols. 159r ff. by 11.4085-6407 of the Pricke of Conscience. Cf. the edition by R. Morris.

The MS also contains: CHAUCER's ABC Hymn to the Blessed Virgin, fols. 175r-178v (Index 239); The Three Kings of Cologne in prose, fols. 179r-215v; the rhyming Titus and Vespasian, fols. 216r-254v (Index 1881); "Michael III" from the SEL., fols. 255r-261v (Index 3453); CHAuCER's Truth, vol. 262 r (Index 809); LYDGATE's "A knyght that is hardy as a lyon", fol. 262r-263r (Index 55); "The ABC of Aristotle", fols. 263r-v (Index 471); a single stanza in praise of Mary, fol. 263v (Index 4091); "The Legend of Ipotis", fols. 264r-268r (Index 220); Speculum Gy de 
The first $\mathbf{1 7 4}$ fols. are numbered in Roman numerals in the upper right hand corner.

Collation: ${ }^{22}$ a indeterminate, fols. 1-16. Probably $a^{16}$, with $a^{i x}$ missing and an extra leaf added after $a^{x v i}$.

$b^{16} j^{16}$ fols. $17-160$

$k^{18-j^{18}}$ fols. $161-96$

$m$ indeterminate; fols. 197-215. Sewing and watermarks suggest $\mathrm{m}^{20}$, with $\mathrm{m}^{\mathrm{xx}}$ missing.

$\mathrm{n}^{14}$ fols. 216-29

$\mathrm{o}^{18}$ fols. $230-47$

$\mathrm{p}^{16}$ fols. 248-63

$\mathrm{q}$ indeterminate; fols. 264-80. Sewing and watermarks suggest $\mathrm{q}^{16}$ with a leaf added at the end.

$r$ indeterminate; fols. 281-92. Probably $r^{12}$, but $r^{i}$ and $r^{x i i}$ are not conjugate.

The rest of the gatherings cannot be determined. Modern pencil numbering says $\mathrm{s}^{3}$ and $\mathrm{t}^{10}$. Three more fols. are required after fol. 305 to complete the "Life of St. Dorothy".

Handwriting: A vernacular hand, with many tags and tails, especially on final letters. $p$ and $y$ are distinguished but $u$ and $n$ are not. Many words are separated by dots or by fine vertical strokes.

Date: Fol. 215v bears the date Jan. 1, 1442.

History: The MS came to the British Museum from the Bedford Public Library.

Previous editions: Morris, $C M$, printed 11.1-270 and the colophon in his edition, pp. 1651-62.

\section{Cotton Vespasian A iii $^{23}$ British Library}

Vellum, 163 leaves, approximately $8^{7 / 8} \times 6^{1 / 2}$ inches, in double columns containing about 46 lines per col.

Warewyke, fols. 268r-275r (Index 1101); William LychefELDE's "Complaint of God", fols. 275r-279v (Index 2714); "Passio Sancti Erasmi", fols. 279v-280v, imperfect at end (Index 173); "The Abbey of the Holy Ghost", fols 281r-285v; "The Charter of the Abbey of the Holy Ghost", fols. 285v-297v; "The Myrrour of Mankind", fols. 298r-305r (Index 1259) ; Osbert BoKenHAM's "Life of St. Dorothy", fol. 305v, imperfect at end (Index 3936).

21 See note 6 above.

22 Determined by original numbering of folios 1-174, catchwords, watermarks and sewing. There is also a pencilled signature in the upper left corner of the first folio of most of the gatherings. This was presumably done when the MS received its modern binding. The watermark throughout is very similar to Briquet 2784-5.

23 See $A$ Catalogue of the MSS in the Cottonian Library Deposited in the British Museum (London, 1802); HUPE, CM, pp. 63*-5*; LAMBERTs, Dialect, p. 7. 
Contains only $C M$.

Collation: ${ }^{24}$ fol. 1 a flyleaf

$\mathrm{a}^{12}-\mathrm{g}^{12}$ fols. $2-85$

h, fols. 86-101, originally had fourteen leaves, with sewing visible after fol. 92 . Fols. 96 and 97 have been pasted on to stubs.

$i^{12}$ with $i^{i}$ missing fols. $102-112$

$j^{12}-^{12}$ fols. 113-48

$\mathrm{m}^{15}$ fols. 149-63

Handwriting: Wright calls the first hand in the MS "a round heavy characteristic 14th-century hand." 25 p and y are not distinguished, nor are $u$ and $n$. A second hand appears on fol. 92r and continues until 8 lines down on fol. 93v col. 1. Much of the material in this hand is unique to MS C. The first hand resumes until halfway down fol. $95 \mathrm{v}$ col. 2 . The second hand then carries on until the end of fol. $98 \mathrm{v}$. This second hand is a much more cursive bastard. It does differentiate between $u$ and $n$, but still fails to distinguish $p$ and $y$. A third hand has made occasional corrections in the MS.

The MS is decorated with occasional red capitals and with a few marginal sketches, such as that of Noah's ark on fol. $12 \mathrm{v}$. These are labelled in the same handwriting as the text.

The lines which appear in Morris' text as headings in heavy type are actually running headlines in the MS. Several more have been cropped after fol. 28.

Date: About $1340 .{ }^{26}$

Previous studies: This MS has had more attention than any other because it represents the original poem more closely than any of the other complete MSS extant. It was edited in full by Morris, $C M$, and extracts have often been printed. Several studies of the MS have also been done. Wright reproduces part of fol. $123 \mathrm{v}$ in facsimile. ${ }^{27}$

${ }^{24}$ Several pages have been copied in the wrong order. They must be read as follows: $2 \mathrm{r} 3 \mathrm{r} 2 \mathrm{v} 3 \mathrm{v} ; 131 \mathrm{r} 132 \mathrm{r} 131 \mathrm{v} 132 \mathrm{v}$.

2s C.E. WRIGHT, English Vernacular Hands, p. 11.

26 Ibid.

27 MORRIS and SKEAT, Specimens of Early English, II 11.11373-11796; ZUPITZA, Ubungsbuch, 11.19603-19732 ; EMERSON, A ME Reader, 11.1-270;S AMPSON, Cambridge Book of Prose and Verse, 11.7439-7592; BRANDL and ZIPPEL, Mittelenglische Sprach-, 11.10647-10782, 11177-11276; Dickens and WILSON, Early ME Texts, 11.1-38; Brown, Religious Lyrics of the XIVth Century, 11.25403-25486, 2548725618; BennetT and Smithers, Early ME Verse and Prose, 11.1-100, 1237-1432. Work on this MS alone is by BRown, "CM and the Southern Passion""; LAMBERTS, Dialect of CM ; SNOUFFER, Verbal Syntax of CM. The facsimile is in C.E. Wright, English Vernacular Hands, Sample 11. 


\section{F Fairfax $14^{28}$ Bodleian Library}

Vellum, 125 leaves, approximately $10^{1 / 4} \times 6 \frac{1}{2}$ inches in double columns of 48 lines per col. Contains only $C M$, to which is appended a version of the Distichs of Cato.

Collation: fols. 1-3 consist of one flyleaf and 2 fols. of table of contents.

$a^{12}-d^{12}$ fols. 4-51. The pricking of gathering $d$ was done with an awl.

$\mathrm{e}^{12}$ missing. This would have contained 11.9325-11614.

$\mathrm{f}^{12}$ This is incorrectly bound. $\mathrm{f}^{\mathrm{i}-\mathrm{xi}}$ are fols. 53-63. $\mathrm{f}^{\mathrm{xii}}$ is fol. 52.

$g^{12}$ fols. $64-75$

$\mathrm{h}^{12}$ missing. This would have contained 11.16227-18512.

$i^{12}$ fols. $76-85 i$ iii and its conjugate $i^{x}$ are missing.

$\mathrm{j}^{12} \mathrm{l}^{12}$ fols. $86-121$

$\mathrm{m}$ fols. 122-5 An indeterminate number of fols. is missing from the beginning of this gathering. ${ }^{29}$

Handwriting: A neat bastard hand. $y$ is clearly distinguished from $p$, but $u$ and $n$ are not.

Date: Late fourteenth century?

History: The MS is connected with Lancaster.

A colophon on fol. 123v says: "Stokynbrig scripsit istum librum willo keruour de lancs". Fols. 1 and 3v contain scribbled accounts related to that county. ${ }^{30}$

Previous editions: Printed in full by Morris, $C M$. Furnivall also printed 11.304-78 of the Distichs of Cato from this MS. ${ }^{31}$

See Fausb $\emptyset$ Ll, $A$ Study.

\section{G Göttingen University theol. $107 \mathrm{r}^{32}$}

I have examined this MS only on microfilm.

28 See Falconer MAdan and H.H.E. CRAster, A Summary Catalogue of Western Manuscripts in the Bodleian Library at Oxford (Oxford, 1937), II ii, pp. 7778; HUPE, $C M$, pp. 66*-7*.

${ }_{29}$ The gathering probably contained 14 leaves. The Table of Contents in this MS indicates that it would have contained the same material as MS C. C's 1648 further lines would have filled about $81 / 2$ fols. in $F$. No other copy of this version of the Distichs of Cato exists (BRowN's Index 169 is in error here). Comparison with the Latin version of the Distichs printed by Boas and the French version edited by Furnivall, Minor Poems, suggests that no more than 13 cols. are missing from the Fairfax poem, and probably rather less. Thus gathering $\mathrm{m}$ would have been composed of $81 / 2$ fols. of $C M$, about 3 fols. of Cato (missing) and 2 fols. of Cato (extant).

30 See also Moore, Meech and Whitehall, ME Dialect Characteristics, p. 2.

31 Furnivall, "How Cato was a Paynym"; cf. Whiting, "Notes on the Fragmentary Fairfax Version"

32 See Die Handschriften in Göttingen. II Universitäts-Bibliothek (Berlin, 1893), p. 353 ; HUPE, $C M$, pp. $65^{*}-66^{*}$. 
Vellum, 169 fols., approximately $27 \times 18 \mathrm{cms}$., usually in double columns ${ }^{33}$ with about 36 lines each. Contains only $C M$, but the table of contents shows that it would have ended with "Saint Patrick's Purgatory". ${ }^{34}$

Collation: $:^{35} \quad a^{12}-f^{12}$ fols. $1-72$

g 14 fols. 73-86

$\mathrm{h}^{12}-\mathrm{m}^{12}$ fols. $87-158$

$\mathrm{n}^{12}$ fols. $159-69$ with $\mathrm{n}^{\text {ii }}$ missing.

G's Table of Contents indicates that the MS would have contained approximately the same material as C. This would have required another 25 leaves, plus more to accommodate "Saint Patrick's Purgatory". Probably at least three gatherings are lost at the end of the MS.

Handwriting: A neat vernacular hand. $\mathrm{p}$ and $\mathrm{y}$ are not always distinguished, nor are $u$ and $\mathbf{n}$.

Date: Second half of the fourteenth century?

History: A colophon on fol. $114 \mathrm{v}$ gives the name of the man who had the MS made: "Iohn of lindbergh" 36 On the flyleaf is a book-plate of C. T. Sullow, with a note that he purchased the MS at auction in Hanover, June 14, 1786.

Previous editions: Morris, $C M$, prints the MS in full. Brown also prints the "Song of the Five Joys", 11.25619-25683. ${ }^{37}$

\section{E Edinburgh Royal College of Physicians ${ }^{38}$}

I have seen this MS only on microfilm.

Vellum, 50 leaves plus several fragments, in double columns containing approximately 40 lines per col.

Collation: This is impossible to determine, as the leaves are now pasted on to modern paper. The pages are incorrectly bound. $C M, 11.18989-22417$ appears on fols. $37 \mathrm{r}-50 \mathrm{v} . C M, 11.22418-$ 24968 appears on fols. $1 \mathrm{r}-15 \mathrm{v}$, although one fol., containing 11.24520-24968, is missing. Four leaves are lost between fols. 43 and 44 , and two are lost between fols. 45 and 46.

33 See note 6 above.

34 See Morris, $C M$, V, p. 4 a.

35 Based solely on catchwords.

36 See Morris, CM, p. 979.

37 See Brown, Rel. Lyrics of the XIVth Century, 31.

38 See John Small, Engl. Met. Homs., xi-xxii ; Hupe, pp. 62*-3*. 
Handwriting: The MS is in three different 14th century vernacular hands. Hand 1 (fols. 1-15) distinguishes $p$ and $y$, but not $u$ and $\mathrm{n}$. Hand 2 (fols. 16-36) is somewhat smaller. Although $\mathrm{u}$ and $\mathrm{n}$ are not distinguished, $\mathrm{y}$ is frequently dotted to distinguish it from $p$. Hand 3 is the largest and least neat in appearance. $\mathrm{u}$ and $\mathrm{n}$ are sometimes distinguished here.

Date: Late 14th century?

History: The MS was bequeathed to the Library of the Royal College of Physicians in 1741 by Dr. John Drummond, its president from 1722-1727.

Previous editions: A short extract is printed in John Small, English Metrical Homilies, and 11. 19603-19732 in Zupitza, Übungsbuch. The MS appears in full in Morris, CM, pp. 1587-1616, 1237-51, 1616-37, 1367-1429. The MS was studied by Hörning, Die Schreibung der Hs.E des CM.

\section{Add. MS Additional $31042^{39}$ British Library}

Paper, 183 fols., counting 2 flyleaves at each end, approximately $10^{3 / 4} \times 8$ inches. The $C M$ fragments, ${ }^{40} 11.10630-14914$ and $17111-$ 17188 , are found on fols. $3 \mathrm{r}-32 \mathrm{v}$. These are in double columns of 34-42 lines per col.

Collation: This is impossible to determine finally, as the individual leaves are now pasted on to modern paper. However, the

39 See Catalogue of Additions to the MSS in the British Museum in the Years 1876-1881 (London, 1882), pp. 148-51; H.L.D. WARD, Catalogue of Romances in the Department of Manuscripts in the British Museum I (1883; rpt. London, 1961), pp. 928-54; F. BrunNer, "Hs Brit. Mus. Additional 31042", Archiv CXXXII (1914), 316-27; Dieter MenL, The Middle English Romances of the Thirteenth and Fourteenth Centuries (London, 1968), p. 260.

40 The MS also contains: The Northern Passion, fols. 33r-50r (Index 1907); the alliterative Seige of Jerusalem, imperfect, fols. 50r-66r (Index 1583); The Sege of Melayne, imperfect, fols. 66v-79v (Index 234); a hymn to the Virgin, lacking its first stanza, fols. 80r-81v (Index 2168); Roland and Otuel, fols. 82r-94r (Index 1996); LYDGATE's "Complaint pat Crist maketh of his Passioun", fols. 94r-96r (Inder 2081); verses on the kings of England by Lydgate, imperfect at end, fol. 96 (Index 3632) ; LYDGATE's Dietary, imperfect at beginning, fol. 97 (Index 824); a four-line song, fol. 97v (Index 3778); The Quatrefoil of Love, fols. 98r-101v (Index 1453); a short rhymed prayer, fol. $101 \mathrm{v}$ (Index 1051); a translation of Psalm 51, imperfect at end, fol. 102 (Index 990); LYDGATE's Interpretacio Misse, imperfect at beginning, fols. 103r-110v (Index 4246); "The Rose of Ryse", fol. 110v (Index 3457); the rhymed Three Kings of Cologne, imperfect at beginning, fols. 111r-119v (Index *31; Supplement to Index *854.3); stanzaic "Prouerbis of Salamon", fols. 120r-122r (Index 3861); "Merci Passith Riztwisnes", fols. 122v-123r (Index 560); "Do Merci bifore thi Judement", fol. 123 (Index 3533); "Mercy Passes all Things", fol. 123v124v (Index 583); Richard Coer de Lion, imperfect, fols. 125r-163v (Index 1979); Apocryphal History of the Infancy, fols. 163v-168v (Index 250); Parlement of the Thre Ages, fols. 169r-176v (Index 1556); Wynnere and Wastoure, imperfect at end, fols. 176v-181v (Index 3137). 
evidence of catchwords, watermarks, ${ }^{41}$ and the comparison with other copies of the same texts suggests the following:

fols. 1-2 flyleaves of vellum from a 15th century breviary.

a indeterminate, fols. 3-8. Watermarks suggest at least $\mathrm{a}^{10}$. Watermark A.

$\mathrm{b}^{24}$ fols. 9-32. Watermark $\mathrm{A}$. This ends the $C M$ portion of the MS.

$\mathrm{c}^{22}$ fols. 33-53 with $\mathrm{c} x \mathrm{xii}$ missing. ${ }^{42}$ Watermark $\mathrm{B}$.

$\mathrm{d}^{20}$ fols. 54-73. Fols. 54-60 and 67-73 have watermark $C$, fols. 61-6 have watermark $D$.

Fols. 74-124 indeterminate. Fols. 74-9 have watermark E, with at least one leaf lost after fol. 77 and at least one after fol. 79. ${ }^{43}$ Fols. 80-90 have watermark F. Fols. 95-102 have watermark $E$ with a leaf missing after fol. 96 and another after fol. 10244. Fols. 104-119 have watermark G with two unnumbered stubs visible after fol. 110. Fols. 121-4 have watermark $\mathbf{E}$.

e indeterminate but possibly $\mathrm{e}^{22}$, fols. $125-44$, with one leaf added after exxii. Three fols. are missing after fol. $143 .{ }^{45}$ Watermark $\mathrm{H}$.

$\mathrm{f}^{24}$ fols. 145-68. Watermark I.

$\mathrm{g}$ indeterminate, fols. 169-81. Watermark I. Watermarks suggest that five leaves are missing at the end of Wynnere and Wastoure.

fols. 182-3 flyleaves as at beginning.

Handwriting: The handwriting is more cursive here than in any of the other $C M$ MSS.

Date: Mid-flfteenth century.

History: The MS was copied by Robert Thornton, who also copied Lincoln Cathedral Library MS A i 17. Thornton's signature appears on fols. 50r col. 2 and 66r. He probably came from East Newton near Pickering in Yorkshire. ${ }^{46}$ Unlike the Lincoln Cathedral MS, this one seems to have left the Thorn-

41 Nine different watermarks appear in the MS: A-a bull; B-rather like Briquet 15203-4, 15206; C-a wagon; D-somewhat like Briquet 4399; E-a long thin spear shape; F-a round mass; G-somewhat like Briquet 11632 ; H-very like Briquet 3868; I-somewhat like Briquet $\mathbf{4 6 4 2}$ and 4644.

42 Cf. E. KölbING and M. DAY, ed., The Siege of Jerusalem (1932; rpt. Oxford, 1971), EETS OS 188, 11.289-374 ; WARD, Catalogue, p. 928.

43 Cf. S. J. Herrtage, The English Charlemagne Romances II (London, 1880), p. 44 ; WARD, Catalogue, pp. 953-4.

44 Cf. Brown, Index, 3632, 990.

45 Cf. F. BRUNNER, Der Mittelenglische Versroman über Richard Löwenherz (Vienna, 1913), p. 251 ; WARD, Catalogue, pp. 945, 947.

46 See M. S. OGDEN, The "Liber de Diversis Medicinis", rev. rpt. (London, 1969), EETS OS 207, pp. X-xvii. 
ton family's possession before the middle of the 16th century. Offord has suggested that the John Nettleton whose name appears in a 16th century hand on fols. $49 \mathrm{r}$ and $139 \mathrm{v}$ is the same man whose name appears in 1565 in a list of people who owned MSS. ${ }^{47}$ The MS apparently found its way to America and was purchased by the British Museum through J. Pearson on July 12, 1879.

Previous editions: This MS has never been printed. See STERN, "London Thornton"; Horrall, "London Thorton".

\section{SELECTION OF A BASE TEXT}

The base text for this edition has been selected for reasons both scholarly and pragmatic. The northern versions of $C M$ have long been available in Morris' text. His transcriptions are reasonably accurate and could easily be made more so by a list of corrected readings such as appears at the end of the present volume. However, the MSS of the southern version of $C M$ have been rather poorly served because of the attitude to them shown by Morris and his collaborators. ${ }^{48}$ The only southern MS which Morris printed, T, is an excellent one, but its choice was probably dictated largely by its availability and completeness. MS L, while it is a reasonably good text, shows several omissions and misunderstandings as against HT, and would be unsuitable for use as a base. MS B is an extremely interesting version of $C M$ which has been virtually unknown until now. The scribe has taken considerable liberty with the phrasing of his exemplar, and has eventually interpolated large sections of a different poem into the $C M$. MS B is obviously unsuitable as a base text, but it deserves to be much better known. Hence the very full apparatus of variants, largely from MS B, which appears in this edition.

MS $\mathrm{H}$, which was finally chosen as a base text for the present edition, contains a text which is very slightly better than MS T's. Unfortunately MS $\mathrm{H}$ is missing several leaves, but in the present

47 See M. Y. OfFord, ed., The Parlement of the Thre Ages (London, 1959), EETS OS 246, p. xii; cf. C. E. WRIGHT, "The Dispersal of the Libraries in the Sixteenth Century" in WORMALD and WRIGHT, The English Library, pp. 157-8 and 173 nn. 24-5.

${ }_{48}$ See above, p. XI. 
edition these are supplied from MS T. MS $H$ has also been less readily available for use by scholars because of its location in the College of Arms.

\section{STRUCTURE OF THE POEM}

The $C M$ may be roughly divided into the following sections: ${ }^{49}$

I - Chronological History
(a) Prologue 11.1-270
(b) 1st age: Creation to Noah, 11.271-1626
(c) 2nd age: Noah's Flood to the building of Babel 11.1627- 2314
(d) 3rd age: Abraham to the death of Saul 11.2315-7860
(e) 4th age: David to the Babylonian captivity 11.7861- 9228
(f) 5th age: birth and early life of the Virgin and Christ 11.9229-12751
(g) 6th age: Baptism of Christ to the finding of the Cross 11.12752-21846
(h) 7th age: Doomsday 11.21847-23908

\section{II - Short Poems}

(i) Prayer to the Blessed Virgin 11.23909-23944

(j) Sorrows of Mary 11.23945-24658

(k) Apostrophe to St. John 11.24659-24730

(l) Festival of the Conception of the Virgin 11.24731-24970

III - Additional Poems

(m) Exposition of the Creed 11.24971-25102

(n) Exposition of the Pater Noster 11.25103-25402

(o) Prayer to the Trinity $11.25403-25486$

(p) Prayer for the Hours of the Passion (Matins of the Cross) 11.25487-25618

(q) Song on the Five Joys of Our Lady 11.25619-25683

49 These divisions are based on Morris, $C M$. V, pp. vii-ix. 
(r) Book of Penance (Prologue and three parts) 11.2568429547

(s) Cato's Morals Morris, CM, pp. 1669-1674

The $C M$ exists in three different forms:

(A) The oldest appears to have contained only Sections I and II above, ending with item (1). This is the poem described in the prologue, 11.131-222. The only extant MS which might have had this shape is MS E, which ends at 1.24968. Unfortunately this MS survives only as a fragment, beginning at 1.18989 . No one can now say whether or not the MS originally contained a full text of the $C M$ in a form exactly as described in the prologue.

(B) The second form of the $C M$ is found in three northern MSS. These are the MSS which contain Morris' so-called "additions":

MS $C$ contains items a-n, $p$, o and $r$.

MS F contains items a-p, $r$ and $s$

MS $G$ would have contained items a-r ${ }^{50}$

(C) The southern version, MSS HTLB, contains only the material of chronological history, ending after the account of Doomsday, although the prologue in these MSS retains 11.217-20, which state that the poem will deal with items (j) and (l).

\section{EDITORIAL PRINCIPLES}

This edition is intended to be a copy of MS H, with only obvious scribal blunders corrected on the basis of the other MSS. Leaves which are missing in MS $\mathrm{H}$ are printed from MS T. Abbreviations are expanded in italics, and headings and decorated capitals appear in bold face type. The first letter of every line of the poem is capitalized in this edition, although the scribe occasionally forgot to do so in the MS. Otherwise the scribe's own capitalizations are allowed to stand. The spacing of words is made to conform, as much as possible, to modern practice. Any other changes in the text are enclosed in square brackets and the MS reading is recorded in the variants. 
The variants are not designed to include differences of dialect or spelling. Only differences in words or phrases, or in word order are included. Rules for transcription of the variants are much the same as for the text itself, except that square brackets which appear in the text are not repeated in the variant. Also, because the capitalization in MS B is so erratic, I have capitalized in that MS only in accord with modern practice. The form for each variant is as follows: the word or phrase as it appears in my transcription of MS $\mathrm{H}$, followed by a square bracket, then the variant readings for that word as they appear in the other MSS, in the order TLB. Different variants of the same word are separated by semi-colons; the whole is followed by a period.

Appendix A is a list of corrections to Morris' transcriptions. In these, the reading from the printed text is followed by a square bracket, the initial representing the MS, and the correct reading of the MS itself. Emendations to Morris' text, printed in square brackets in his edition, are allowed to stand without comment if they are purely conjectural. However, if the letters were originally written by the scribe but have since become illegible through blots, holes, etc., I enclose them in pointed brackets in the MS reading. Thus if Morris' transcription of MS C reads " $b[\mathrm{ad}]$ " and no note appears in Appendix A, then the MS reads simply " $b$ ". If Appendix A, however, has " $b[\mathrm{ad}]] C \mathrm{~b}\langle\mathrm{ad}\rangle$ ", then the scribe originally wrote "bad", but the "ad" has since become illegible.

References to other works in the Explanatory Notes and in the Introduction are either by abbreviation or by author and short title. An explanation of abbreviations used precedes the Explanatory Notes. Full information about other works will be found in the Bibliography. Transcriptions in the notes from unpublished MSS consulted on microfilm follow the same rules as all other transcriptions except that no emendations at all are attempted.

To produce the text and variants, I worked originally on microfilms of the MSS. I have since carefully compared my transcriptions of the microfilms with the MSS themselves, except for MSS G and E, which I have seen only on film.

This edition retains the line numbering used in Morris' text. This numbering is often unsatisfactory, for Morris sometimes numbered spurious lines, and at other times printed in parallel columns lines which were not in fact the same. However, I must make frequent references to the northern MSS for comparison with this edition, and a dual system of line numbers proved impossibly cumbersome. 
This edition is based on certain assumptions about the relationship among the various MSS of the poem. I can accept none of the previously published MSS stemma, for reasons which will be fully discussed and justified in Volume III. Therefore my own assumptions must be outlined here.

MS C is clearly the extant MS which is closest to the $C M$ poet's original version, although it contains many corruptions. In the notes, I assume that MS C's reading is closest to the original French or Latin, unless I state otherwise. The southern version of the poem, represented by MSS HTLB, is derived from a MS similar to G, though not $G$ itself. To produce the southern version, this MS, in a North Midland dialect, was systematically revised and translated. 
This page intentionally left blank 


\title{
Introduction to This Volume
}

\author{
SOURCES
}

It is not possible to document in a short space the $C M$ poet's indebtedness to each of his sources. When composing his poem, he apparently sat with several books open before him, choosing lines from each one to be combined in his own narrative.

The major sources, aside from the text of the Vulgate, which the poet has used for the Old Testament section of his work are:

(1) the Elucidarium of Honorius Augustodunensis ${ }^{51}$

(2) an anonymous Old French poetic paraphrase of the books of Genesis and Exodus to which was added a poem on the history of the wood of Christ's cross ${ }^{52}$

(3) the Old French Bible of Herman de Valenciennes ${ }^{53}$

(4) the Historia Scholastica of Petrus Comestor ${ }^{54}$

51 Elucid. Yves Lefèvre, L'Elucidarium et les lucidaires (Paris, 1954). This poem was much translated but the $C M$ poet seems to have used the Latin text. This source was first pointed out by KaluZA, "Zu den Quellen", pp. 451-2.

52 Trad. anon. MS BN fr. 763 fols. 211r-272. This is not the MS which the $C M$ poet used, but it is the closest of the extant copies to the version which the poet must have known. Another partial copy exists in MS Montpellier, B. municipale, 437, and the poem is also combined with Herman de Valenciennes' Bible in MS Arsenal 3516. A. S. NAPIER, Rood Tree, pp. xxiiiff, first pointed out that the $C M$ version of the cross wood story came from this source. No one has previously noticed the CM's indebtedness to this version of Genesis, however.

${ }_{53}$ Bible. Herman de VAlENCIENNES, La Bible von Herman de Valenciennes II, ed. Otto Moldenhauer (Griefswald, 1914), and extract in Farl BARTSCH, Chrestomathie de l'ancien français, 10th ed. (Leipzig, 1910), pp. 71-6. The first volume of the Griefswald edition has apparently never been published. For the early section of the work, therefore, I have consulted a microfilm of University of Chicago MS H.27. B.6.12. The $C M$ poet's debt to Herman is discussed by Lois Borland, The Cursor Mundi, and "Herman's Bible", and by Philip BUEHLER, "The Cursor Mundi".

54 Hist. Schol., PL CXCVIII 1053ff. This was first mentioned as a. source by Haenisch, "Inquiry into the Sources of the Cursor Mundi" in MoRris, ed., CM. EETS OS 99, pp. 1*-56*. 
(5) the Latin Legende version of the story of the Cross Wood ${ }^{55}$

(6) Honorius Augustodunensis' De Imagine Mundi ${ }^{56}$

The poet here and there interjects a few lines from additional sources. These borrowings are very brief and may have come to the $C M$ poet through an intermediate source not yet discovered.

(1) Hugh of St. Victor's Adnotationes Elucidatoriae in Pentateuchon ${ }^{37}$

(2) the Revelations of the pseudo-Methodius 58

(3) the Chateau d'amour of Robert Grosseteste ${ }^{59}$

(4) the Etymologiarum of Isidore of Seville ${ }^{60}$

(5) the Speculum Ecclesiae of Honorius Augustodunensis ${ }^{61}$

ss Legende. The Latin Legende has been printed by W. MEYER, "Die Geschichte des Kreuzholzes vor Christus"; SUCHIER, Denkmäler; C. HORSTMANN, "Nachträge zu den Legenden", pp. 465-70; LAZAR, "La Légende de l'Arbre de Paradis"; Betty HILl, "The Fifteenth-Century Prose Legend". I quote from Lazar's text, which is closer to the version which the $C M$ poet used than any of the others.

56 DIM, PL CLXXII 165ff. This was first pointed out by KALUZA, "Zu den Quellen"', p. 452.

57 See below, n. to 11.359-72 et passim.

s8 See below, $n$. to 11.1465-6 et passim.

s9 See below, n. to 11.701-10.

so See below. $n$. to $11.2091 \mathrm{ff}$.

61 See below, n. to 11.5745-50, 6909-10. 


\section{Text of \\ the Southern Version of Cursor Mundi}


This page intentionally left blank 
Here bigynneb pe boke of storyes

pat men callen cursor mundi

Men zernen iestes for to here

And romaunce rede in dyuerse manere

Of Alisaunder pe conqueroure

Of Iulius cesar pe emperoure

Of gre[c]e \& troye pe longe strif

pere mony mon lost his lif

Of bruyt pat barounbolde of honde

Furste conqueroure of engelonde

Of kyng Arthour pat was so riche

Was noon in his tyme him liche

Of wondris pat his knyztes felle

And auntres duden men herde telle

As Wawayn kay \& opere ful abul

For to kepe pe rounde tabul

How kyng charles \& rouland fauzt

Wip Sarazines nolde pei [be] sauzt

Of tristram \& of Isoude pe swete

How pei wip loue firste gan mete

Of kyng Ion and of Isombras

Of Idoyne \& of amadas

Storyes of dyuerse pinges

Of princes prelatis \& of kynges

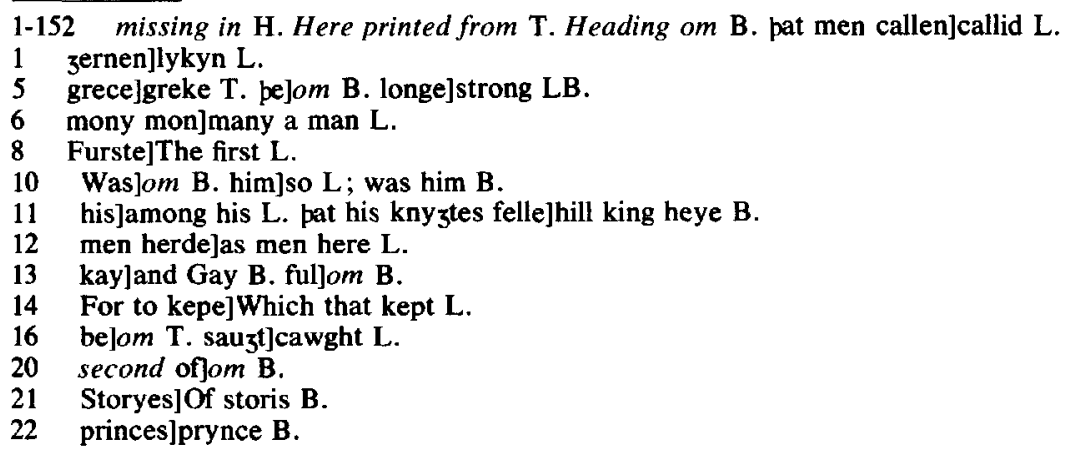


Mony songes of dyuerse ryme As englisshe frensshe \& latyne

To rede \& here mony are prest

Of pinges $\mathrm{p} a \mathrm{t}$ hem likep best

pe wise mon wol of wisdome here

Pe fool him drawep to foly nere

Pe wronge to here rizt is loop

And pride wip buxomnes is wroop

Of chastite pe lecchoure hap lite

Charite azeyn wrappe wol flite

But bi be fruyte may men ofte se

Of what vertu is vche a tre

And vche fruyt pat men may fynde

He hap from pe rote his kynde

Of good pire com gode perus

Werse tre wers fruyt berus

pat i saye pus of pis tre

Bitokenep mon bope be \& me

Pis fruyt bitokenep alle oure dedes

Bope gode \& euel who so rizte redes

Oure dedes fro oure herte take rote

Wheper pei turne to bale or bote

For bi pat ping mon drawep tille

Men may him knowe for good or ille

Ensaumpel herby to hem I sey

pat rage in her riot al wey

In ryot $\&$ in rigolage

Spende mony her zoupe \& her age

23 of]\& B.

24 As]In B.

25 are]is $\mathrm{L}$.

27 here]lere B.

29 riztlpe right $\mathrm{L}$.

32 charite...wol]And wrap agens charite $B$.

33 But]And L. may men]men may B.

34 vche a] pe $B$.

35 vche] euery L.

37 pire]pyrthe L; pery $B$. com]comep B.

38 first Werse]A wers $\mathrm{L}$; pe wers $\mathrm{B}$. second wers] pe wers $\mathrm{B}$.

39 pat...saye] Whan I speke L.

40 Bitokenep] Hyt bytokeny $\mathrm{b}$ L.

44 turne]com B.

45 mon]men B.

46 Men]Then L; Mon B.

47 In sapil to hem I may say B.

48 rage]regnep $B$. riot]reame $B$.

50 Spende mony]Many spend L. zoupe...her]zounge B. 
For now is he holden nouzt in shouris

But he con loue paramouris

Pat foles lif pat vanite

Him likep now noon opere gle

Hit is but fantom for to say

Today hit is tomorwe away

Wip chaunce of dep or chaunge of hert

Pat softe bigan endep ful smert

For when ne pou wenest hit trewest to be

pou shalt from hit or hit from pe

He pat wenep stiffest to stonde

War him his fal is nexte at honde

Whenne he so soone doun is brouzt

Whider to wende woot he nouzt

But to whom his loue hap him led

To take suche mede shal he be sted

For pere shal mede wipouten let

Be sett to him for dew dett

Perfore blesse we pat paramoure

Pat in oure nede dop vs socoure

Pat sauep vs in erpe fro synne

And heuen blisse helpep to wynne

For pouze I sumtyme be vntrewe

Hir loue is euer I liche newe

Hir loue is euer trewe and lele

Ful swete hit is to monnes hele

Suche opere in erpe is founden none

For she is modir \& mayden alone

Modir \& mayden neuer pe les

Perfore of hir toke ihesu flesshe

Who pat louep trewely pis lemmon

He shal have loue pat neuer is woon

51 shouris]storijs $B$.

52 conjom $\mathbf{B}$.

53 foles]folye $B$.

54 Him likep]Ther is lykyd $\mathrm{L}$.

55 fantom]fantasy LB. for to]y you L.

56 tomorwe]tomorn B.

57 chaunge]chaunce $B$.

59 Tolom B.

62 at] to $B$.

64 Whider] Wheper $L$.

72 heuen...helpep]makip vs pe blis $B$.

73 pouze] yf B. I]pou L.

77 Opere] onoper $\mathbf{B}$. founden] om $\mathbf{B}$.

80 perfore] om $B$. toke] take perfor $B$.

81 line om $\mathrm{L}$. Who pat]Scho so B. trewely] welle $\mathrm{B}$.

82 line om L. loue] be loue B. is woon] schall whan B. 
For in pis lif she failep neuer And in pat oper lastep euer

Of suchon shulde ze matere take

ze crafty pat con rymes make

Of hir to make bope geest \& songe

And preise hir swete son amonge

What bote is hit to sett trauaile

On ping pat no ping may availe

Pat is but fantom of pis Werd

As we ynowze han seen \& herd

Materes fynde we may in dede

Rymes of hir to make \& rede

Who so wol of hir fairnes spelle

Fynde he may ynouze to telle

Of hir goodnesse of hir trouphede

Fynde men may aboute to sprede

Of treupe of loue of charite

Was neuer hir make ne neuer shal be

Lady she is of peples alle

Meke \& mylde wipouten galle

Next to nedeful to calle on

And reisep euer pe synful mon

Ihes $u$ made pat mayden swete

Alle oure bales for to bete

Herby men may her helpe wel knowe

She pre yep for synful heze \& lowe

Whoso dop hir worshepe may be bolde

She wol him zelde an hundride folde

In hir worshepe bigynne wolde I

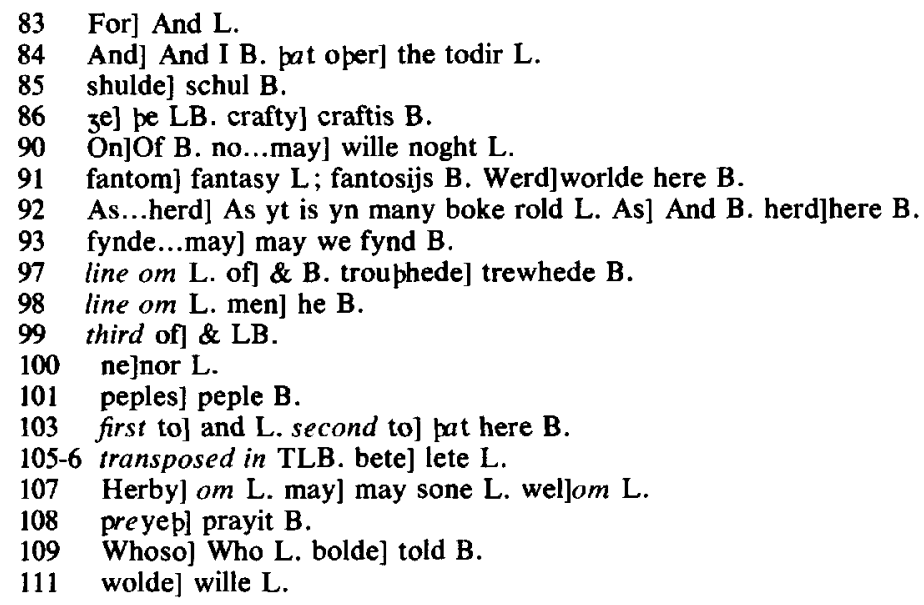


A werke pat shulde be lastyngely

For to do men knowe hir kyn

pat muche worshepe dud vs wyn

Sum maner ping is good to knawe

pat done was in pe olde lawe

Bitwixe pe olde lawe \& pe newe

How crist vs bote bigan to brewe

I shal zou shewe bi myn entent

Sopely of hir testament

120

Al pis world ar pis book blynne

Wip cristis helpe I shal ouer rynne

And telle sum geste principale

For al may no man haue in tale

But no werk wel laste may

125

Wipoute good grounde to laste ay

Perfore pis werke I wol founde

On a selcoup studfaste grounde

Pat is pe holy trinite

Pat al is made of his bounte

Furst at him self I sett my merk

And aftir to telle of his hond werk

Of pe aungels pat firste felle

And sip I wol of adam telle

Of his ospringe and of Noe

And sum what of his sones pre

Of Abraham \& als of ysaac

pat holy weren wipouten lac

Sipen shal I telle zou newe

Of Iacob \& of Esaue

Sipen shul ze here hit tolde

How Ioseph was bouzte $\&$ solde

Of pe iewes \& of Moises

pat god his folke to lede him chees

How god bigan pe lawe him zyue

Whiche pe iewes shulde in lyue

114 pat] And pat B.

118 vs... .bigan] began our bote $B$.

120 Sopely] Trewly B.

123 sum geste] of pe $B$.

128 selcoup] ful $B$.

130 is] om B.

134 sip...adam] dep of adam I wille B.

137 als] om B.

139 newe] now $B$.

141 hit] om B.

144 him] he B.

145 pe...him] hym pe law to $B$. 
Of saul pe kyng \& of dauy

How he fauzte azeyn goly

And sippe of salomon pe wise

How he was crafti iustise

How crist cam pourze prophecie

His owne folk for to bye

Sippe hit shal be rad zow panne

fol. Ir col. 1

Of ioachym and of seynt anne

Of mary also hir douzter mylde

How sheo was born \& bare hir chylde

How sheo was bore whenne \& whare

How sheo hym to pe tempel bare

Of po kynges pat hym souzte

That pre presentes to him brouzte

How pat heroude kyng wip wrong

For crystes sake slowze childeren zong

How pat ihesu to egipte fledde

And how he was pennes ledde

And pere shul zee here many [a] dede

Pat ihesu dide in his childehede

Sipen of pe baptiste Ion

pat baptized ihesu in flum iurdon

How ihesu aftir his fastynge longe

Was temptide wip pe spirit of wronge

Sipen of iones baptizyng

And how hym heuedede heroude pe kinge

How pat ihes u crist hymselue

Chees to hym apostles twelue

And openly bigan to preche

And alle pat seke were to leche

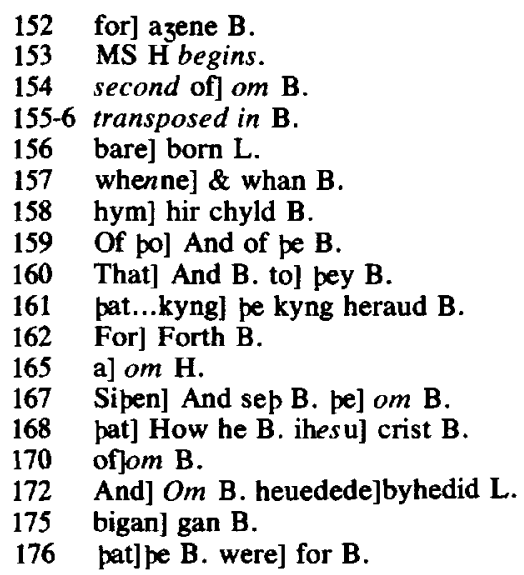


And dide myracles mony \& ryfe

Wherfore pe iewes bigon to stryfe

Sippe how god of his myzte

Turned watir into wyn rizte

Of fyue pousande men pat he

Wip fyue looues fedde $\&$ fisshes pre

Of a man shal we pen fynde

Pat god $z^{\text {af }}$ sizte \& borne was blynde

And of pe spousebriche of o wommon

Pat pe iewes demed to stoon

How he heled a man vnfere

Pat seck was eyzte \& twenty zere

How mary maudelene wip grete

Coom to wasshe oure lordes fete

Of hir and of martha also

Pat bisy was aboute cryst poo

Of lazar pat deede lay vndir stoon

fol $1 \mathrm{r} \mathrm{col.} 2$

How he was reised in flesshe \& boon

How iewes ihesu ofte bisette

And for his prechyng also him prette

How pei pyned hym on pe rode

And how pei shedde his blessed blode

And zif god wole penne shal I telle

How he sippen harrewede helle

How iewes wip her greete vnskille

Wende his vprysynge to stille

How he vproos \& sipen vpstay

Mony a man hit herde \& say

How pat he of myztes moost

178 bigon] gan $\mathrm{B}$.

180 into] to $B$.

181 Of] How B.

182 Wip...fedde] Fede with v loues B. pre]pe B.

186 stoon]stond $B$.

187 he] om $B$. vnfere] in feere $L$; pat was vnfer $B$.

188 twenty] prety $B$.

191 Of...of] How sche and B.

192 bat....was] Wer bessy $B$.

193 vndir] in B.

194 in] om B.

195 iewes] pe Iewis LB. ihesu ofte] oft Ihesu B.

196 And] $o m$ B.

197-8 transposed in MSS HTLB. blessed] preshious L.

198 pyned] naylid $L$; payned $B$.

199 I telle] stelle $B$.

200 he sippen] pat gode B. harrewede] heryed B.

201 iewes] be Iewes B. her] om B.

202 vprysynge] resurection $B$. 
Sende to erpe pe holy goost

Touchynge pe apostles of her feest

How pei endede meest and leest

How oure lady endede and zolde

Hir semely soule hit shal be tolde

How be holy cros was kidde

Longe aftir pat hit was hidde

Of antecristes coome pat shal be kene

And of pe dredeful dayes fiftene

Pat shul come bifore pe domes day

Sipen of pe doom wole I say

Pen of oure ladyes mournyng mode

Whenne hir sone henge on rode

Pe laste resoun bat I shal spelle

Of hir concepcioun wole I telle

Pese are pe materes red on rowe

Pat in pis book wole I showe

Shortly rennynge on pis dede

For mony per aren for to spede

Nedeful me pinke hit were to man

To knowe hymself how he bigan

How he bigan in world to brede

How his osprynge bigan to sprede

Bope of pe firste and of pe la[st]e

In what course pis world is paste

Aftir holy chirches astate

Pis ilke book is translate

Into englisshe tonge to rede

fol. Iv col. 1

206 erpe] pe erpe $B$.

207 apostles] postilles B.

208 How] And how B.

212 pat] om $\mathrm{B}$

213 coome] comyng $L$.

215 bifore] tofore TL; afore B. pe] om LB.

218 hir sone] Thes $\mathrm{u} B$. henge] hang $\mathrm{B}$. on] on pe $\mathrm{T}$; vpon pe $\mathrm{B}$.

219 shal] wille B.

220 hir] be $B$.

221 are] ben $B$. red on rowe] good \& trew L; rede \& row B.

222 wole I ] I wille B.

224 mony....aren] per be mane pere $B$.

225 pinke] pinkit $\mathrm{B}$.

227 bredel dred $B$.

228 bigan] gan $\mathrm{B}$.

$229 \mathrm{la}[\mathrm{st}] \mathrm{e}$ There is a hole in MS H where the missing letters should be.

230 In] How \& B. pis] pe $L$.

231 astate] state $B$.

232 book] om B.

233 tonge] for $B$. 
For pe loue of englisshe lede

For comune folke of engelonde

Shulde pe better hit vndirstonde

Pat speche pat moost vs may spede

Moost to speke hit were greet nede

Selden hit is for any chaunce

Englisshe tonge preched in fraunce

3 yue we vche londe his langage

penne do we noon outrage

To lewed men englisshe I spelle

pat vndirstondep what I con telle

And to hem speke I alper moost

pat ledep her lyues in pryde \& boost

And spenden her lyues in treuandise

And myzte amenden in mony wyse

Wo shal hem be her lyf so spende

pat fynde perof no fruyt at pe ende

Now of pis prolouge wole we blynne

In crystes nome oure book bygynne

Cours of pis world men shul hit calle

For almeest hit rehersep alle

Take we oure bigynnynge pan

At hym pat al pis world bigan

Herep now of pe trynite dere And of pe makyng of pis world here

Alle men owe pat lord to drede

Pat made man to haue mede

Pat euer was \& euer shal be

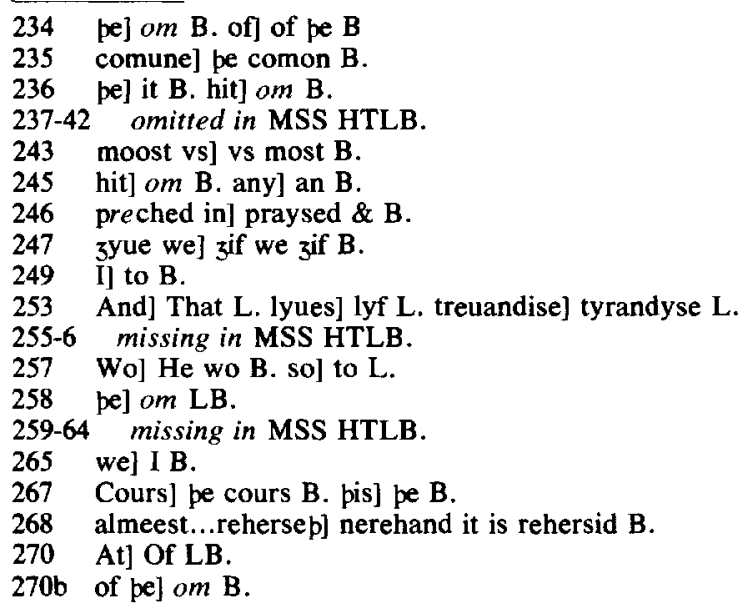


Wipouten ende in trynite

He pat lorde bope god an man

Al maner ping of hym bigan

pouze he bigan al opere pinge

Hymself hadde neuer bigynnynge

Of hym coom al in hym is al

Al holdep he vp from doun fal

He h[ol]dep heuen \& erpe stidefaste

Wipouten hym may no ping laste

pis lord pat is so mychel of myzte

Purueyed al into his sizte

And pat he ordeyned wip his witt

285 fol. lv col. 2

He multeplied and gouernep hit

Perfore he is pe trynite

Pat is o god \& persones pre

And zif pow wenest hit may not be

Byholde be sonne penne maist pou se

In be sonne pat shynes clere

Is o ping \& pre seere

A body rounde hoot and lizte

Pese pre we fynde at a sizte

Pese pinges pre wip noon art

Mow not be fro opere depart

For zif pou take pe lizte away

Pe erpe hap no sonne parfay

And zif pe heete away be goon

Sonne forsope hastou noon

But vche maner man wel woote

Pe kynde of sonne is to be hoote

Pe sonnes body pat I neuene

Bitokenep pe fadir god of heuene

And bi pe lizte pat lastynge is

Hit is pe sone kynge of blis

And bi pe hete vndirstonde hit so

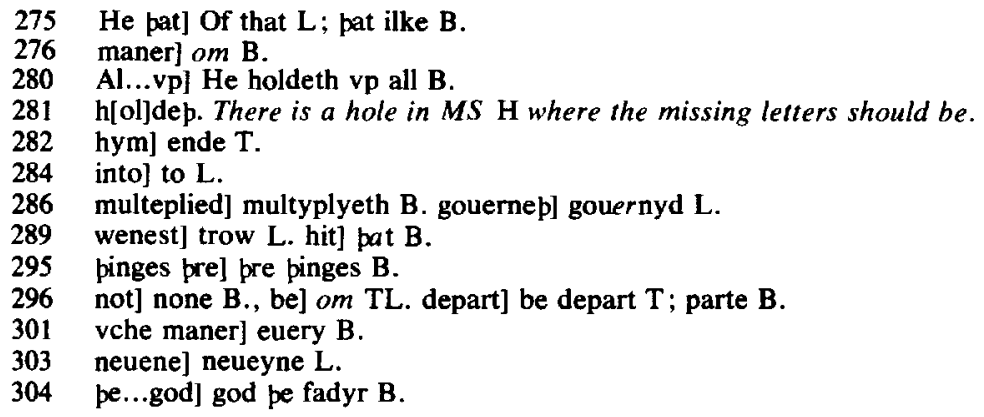


Pe holy goost comep of hem two

And fadir is he calde forpi

For he is welle pat neuer is dry

And ouer pis hymself wrouzte

Alle pinges whenne pei were nouzte

His sone is wisdome pat al ping wate

For al be world he halt in state

$\mathrm{Al}$ ping he halt from mysfare

pat pei not turne to sorwe \& care

Pe holy [goost] is pe godhede

Pat zyuep lyf to alle we rede

pis lord pat I bifore of seide

Firste in his witt he al purueyde

His werkes he doop as sotele wrizte

And sipen he reisep hit in sizte

Forpi is god as seip scripture

Non elder pen is creature

Elder of tyme nys not he

But elles more in dignite

fol. $2 \mathrm{r} \mathrm{col} .1$

Pis wrizte pat I speke of here

Is prynce ouer al wipouten pere

For opere wriztes mot tymber take

But he hymself con tymber make

For of hymself he took pe euene

Pat he made wip bope erpe \& heuene

But we shul vndirstonde

Pat he wrouzte not al his werke wit honde

But seide wib worde $\&$ also soone

310 For] om B. first is]ys pe B. second is] shalle L:

312 pinges] thyng $\mathrm{L}$.

313 is] his L.

314 halt] holdeth $B$.

315 ping] pinges $T$. halt] holdeth $B$.

316 not] ne $L$.

317 goost] om $\mathrm{H}$.

323 bifore] ere B; seide] red L.

324 he] om $\mathrm{B}$.

325 as] as a $\mathrm{L}$.

326 hit] all $B$.

327 as] om $B$.

329 nys] is TB.

331-2 reversed in $\mathrm{B}$.

332 Is] He ys B. ouer] of B.

333 mot] most $B$.

334 But] And L., con] gan B.

pe] om B.

shul] shull alle well $B$.

pat] om L. his] om T. his werke] om B. honde] his honde TB. 
Al his biddynge hit was doone

Smartlyere pen ze may wynke

Or any mannes herte may pinke

And as clerkes saye bat are wyse

He wrouzte hit not bi partyse

But he pat made al pinge of nouzt

Al pe world togider he wrouzt

To be set in lengpe and brede

pe mater firste perof I rede

Pat is pe elementes to say

Pat firste shaples togider lay

He delt hem ful in sixe dayes

In parties as be scripture sayes

Pe elementes firste in dayes pre

Pre pinges wipinne hem per be

Pese elementes pat al ping byndes

Foure per ben as clerkes fyndes

Pe lowest hit is watir and erpe

Pe pridde is eyr and fuyr be ferbe

And we seye pat he pus bigan

As austyn seip pat holy man

As we in his bookes fynde

Firste he wrouzte aungel kynde

Pe world and tyme pese pinges pre

Byfore alle opere ping made he

Pe world I calle in myne ententes

pe matere of foure elementes

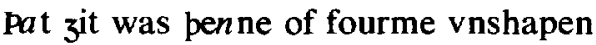

Wherof was sippe partyes taken

Al shaples was hit not forby

For hit of shappe had sum party

342 any...herte] manys hert any tyme $B$.

347 be set] bysette $L$.

348 firste perof] perof fyrst $B$.

351 in] $o m$ B.

352 parties] scripture B. scripture] party B.

353 firste] om $\mathbf{B}$.

354 hem] om L. per]om B.

355 pese] be TB.

356 Foure] Foure pinges B. per] they L.

357 hit] om L. hit is] bene pe B. and] \& pe B.

358 is] pe B. and] the LB., second pe] is $L$.

360 As] And L. pat] be B.

365 in] be $B$.

366 of] of be $B$.

368 was sippe] sip was $T$; were sip $B$.

369 shaples] chapels $B$. 
But perfore shaples hit was how For hit hadde not as hit hap now He wrouzte vpon pe opere day pe firmamente pat is to say Pe sky wip sterres grete \& smalle

Wip watir shynynge as cristalle Pat is on hyze and pat is vndir In pis he souned al to wondir Pe pridde day god dide bi grace Pe wattres drawe into a place And bad a drye place shulde be Pe wattres alle he calde pe see Pe drye he calde erpe pat kynge And bad hit grisyng fruyt forp brynge Al ping to be waxinge pere

And in hemself her seed to bere Pe ferpe he bad and was done Bope were made sonne and moone Eyper wip his dyuerse lizte To parte pe day fro be nyzte In tokenynge of tydes to stonde Dayes and zeres bope dwellonde And pe sterres greete and smale pat we may se wipouten talle In pe hyzest element of alle Pereynne fuyre hap his stalle Pe fifte day he failed nouzte Of watir foul \& fysshe he wrouzte Pe fisshe to watir as we fynde Pe foules he toke to the wynde Alle goynge beestes pe sixte day And adam als he made of clay He was laste made as lordyng To be maister ouer al ping In a dale he wrouzte adame

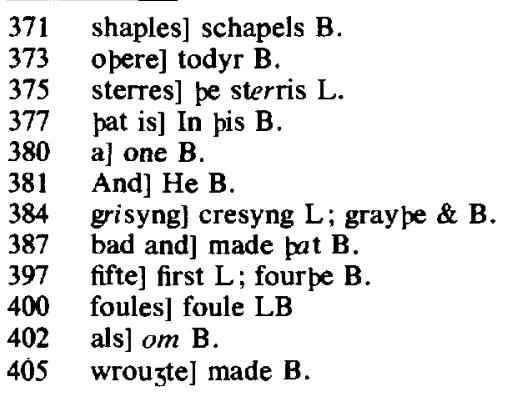


Pat ebron hette in ebreu name

Pese sixe dayes he wrouzte his wille

pe seuenpe of werke he helde him stille

He vs zaf ensaumpel pore

pat we shulde holde hit euermore

Pe firste werke as ze herde neuen God wrouz[t]e pe angels of heuen And sette hem in his hyze pales Wibouten pryde to ben in pees For pis peleys was so ryche

As myzty kyng noon oper lyche

He ordeyned hym two creatures

To serue hym pere wip honures

Pat shulde a hool noumber be

Many a pousande to telle and se

Pe whiche tale no wey shulde be more

And nedeful bihoued hit wore

Pis noumbrary he ordeyned pon

Shulde be bope of aungel $\&$ mon

For he wolde be pat kyng of crafte

Worsheped wip two maner shafte

Pe ton wip aungel pat is goostly

And als wip mannes body

Of aungels wolde he serued be

pat ordres shulde ha pryes pre

He chees to hym pat lorde hende

pat man pe ordre shulde be tende

But be aungels he wrouzte formast

Ouer alle he made her pouste past

Pei were bope faire and wyse

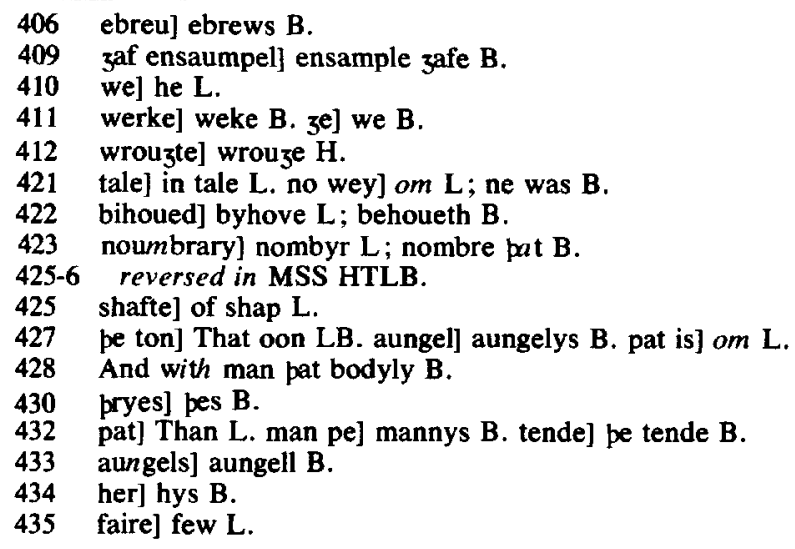


Somme of lasse somme of more prise He zaf on most to knowe \& fele zif pat he coupe haue born hym wele And sette hym beste in his halle

As prynce \& syre of opere alle

And for he was so wondir lizt

Lucifer to name he hizt

And whenne he hadde perceyued pis

Pat he was ouer alle oper in blis

Alas caytif he knewe nouzt

Pat god himseluen hadde hym wrouzt

Ful sorweful sawe he pat tyde

Azeynes god he toke a pryde

Liztly he lette of alle his fere

To god hymself wolde he be pere

fol. $2 \mathrm{v}$ col. 2

Not pere alone but myche moore

For vndir hym he wolde alle wore

And he hymself her commaundour

Who herde euer of siche traytour

Pat he pat not hadde but of hym

Azeyn his lorde shul[d] waxe so grym

He seide sette my sete I shal

Azeynes hym pat is beste of al

In pe norp syde shal sitte my sete

Seruyse of me shal he noon gete

Why shulde I hym seruyse zelde

Al shal be at myn owne welde

But he was marred of his wille

Ful soone he fonde hit ful grille

For lenger pen he pouzte pat pryde

In heuen myzte he not abyde

For in pat court pat is so clene

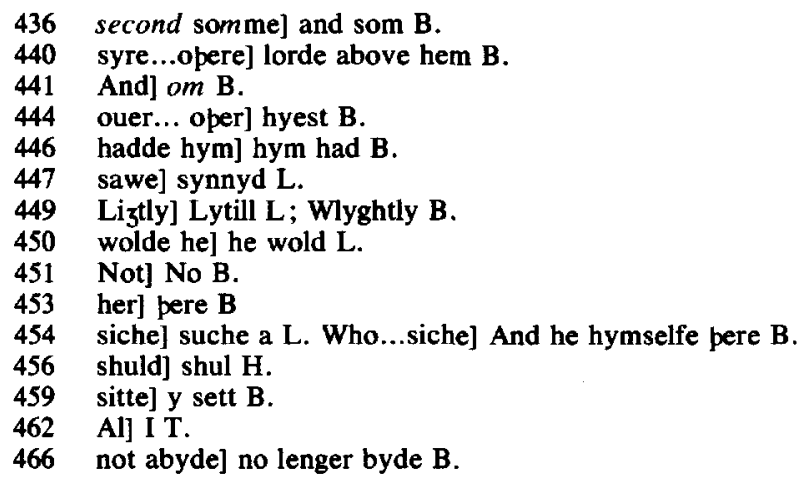


No filpe may dwelle ne be sene

Seynt mychael for her aller rizt

Roos azeyn hym to fizte

Azeyn hym zaf he batel grym

Out of pat court caste he hym

Lucifer firste doun he brouzt

And sippe pat wip hym held ouzt

And scoured pat court of hem so clene

pat sippe her stide was pere not sene

pis was pe fende pat formeste felle

For hys pryde from heuen to helle

For penne his name chaunged was

Fro lucifere to sathanas

Fro ful hyze he fel ful lawe

Pat of his lorde wolde stonde noon awe

Wipoute koueryng of his soore

For mercy getep he neuer more

For god owe not zif hym mercy

Pat peraftir wolde not cry

And pus he loste pat hyze tour

pere was he not fully an hour

For soone aftir pat he was made

fol. $3 \mathrm{r}$ col. 1

$\mathrm{He}$ fel wipouten lenger abade

Pe opere aungels pat fel hym wip

Whiche forsoke goddes grip

Aftir pe wille pei to hym bore

Fel pei to helle lasse and moore

Somme in pe erpe somme in pe lifte

468 ne] no $B$.

469 aller] ansuerde $B$.

470 azeyn] azenst $B$.

471 Azeyn]Azens $B$.

472 pat] the $L$. caste he] pay caste $B$.

473 firste doun] doune fyrst $B$.

474 sippe] alle po $L$.

475 scoured] made $B$.

476 pat] $o m B$. her] his $L$; in pat $B$. not] non $B$.

479 For] And B.

481 ful] om $T$.

482 wolde...awe] he wille not know $L$.

483 Wipoute...his] And for pat grete trespas \& L. koueryng] gouernyng B.

484 For] om L. getep] gete $B$.

485 owe...hym] wolde zeve hym no $B$.

486 wolde] wille LB.

489 pat] om B.

490 wipouten] \& no L. abade] bad B.

492 Whiche] be which B.

493 Aftir... pei] And as many as good wille L. pei to] pat pay B.

495 erpe] ayre B. lifte] erp left B. 
Pere pei dryze ful harde drifte Her peyne pei bere on hem ay And so shul do to domes day But po pat lesten wipouten wyte Were confermed pere as tyte 500 Pei may neuer assente to ille No moore pen euel may do good wille Pe noumber pat out of heuen felle

No tonge in erpe hit con telle

$\mathrm{Ny}$ fro pe trone of pat blis 505 How fer into helle hit is But bede seip fro erpe to heuen Is seuen pousande zeer $\&$ hundrides seuen By iournees whoso go hit may Fourty myle eueryche a day

Of bodily substaunce for to wite Monnes soule Pat is hite As I zow telle pe kyng of craft

Wolde be worsheped with two shaft

Bope wip aungel \& wip mon Adam perfore made was pon Pe tende order to fulfille

Pat lucifer hade made to spille Of erpe only was adam nouzt But of foure elementes wrouzt Of watir his body is flesshe laire His heer of fuyr his honde of ayre His heed wipynne hap yzen tweyn Pe sky hap sonne \& moone certeyn

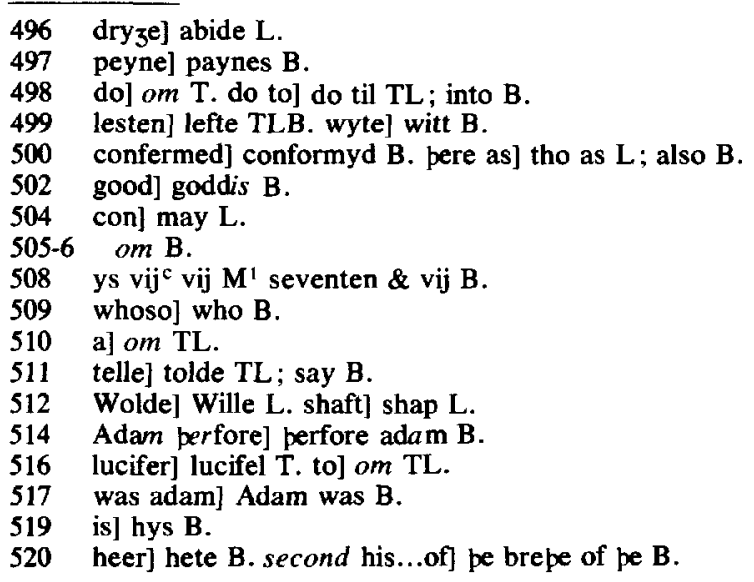


And as mennes yzen are sette to sizt

So seruep sonne \& moone of lizt

Maister sterres are per seuene

Seuen holes hap mannes heed euene

Whiche zif pou wolt pe bipinke

fol. 3r col. 2

Pow mayst hem fynde wip litel swynke

pis wynde pat we men drawen ofte

Bitokenep wynde pat blowep olofte

Whiche is ponder \& leityng led

As onde wip host in brest is breed

Into pe see al watir synkep

And monnes womb al licoures drynkep

His feet hym berep vp fro fal

Also pe erpe vpholdep al

Thonder fyre 3 yuep mon his sizte

Thonder eyer of heryng myzte

pis wondur wynde hym zyuep onde

pe erpe makep hym fele \& fonde

Pe hardenes pat men han in boones

Hit comep of pe kynde of stoones

On erpe as growep tres and gres

So nayle \& here of mannes flesshe

Wip beestes doumbe man hap fele

Of ping hym likep euel or wele

Of pese pinges I haue herd seide

Was adames body togider leide

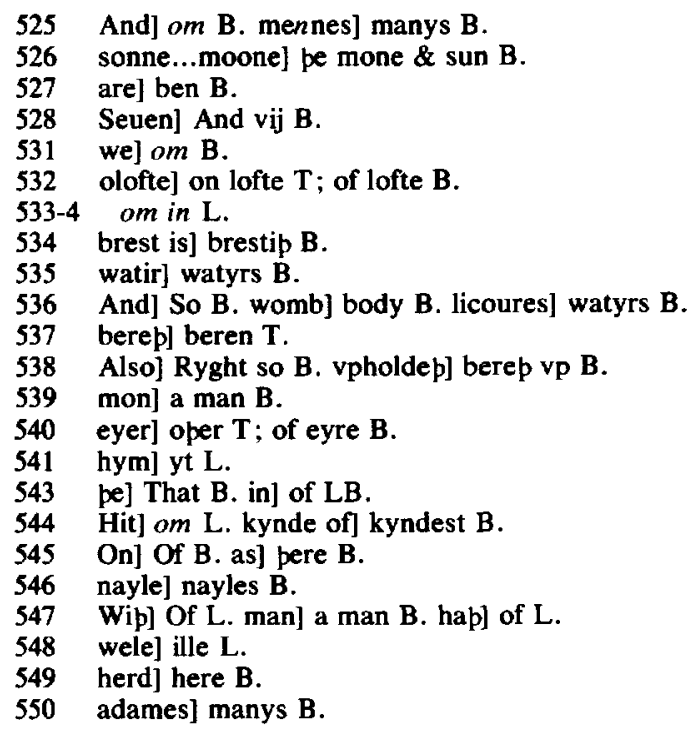


For pese resouns pat ze haue herde

Man is calde be lesse werde

// But resoun zitt herde ze nouzte

Wherof mannes soule is wrouzte

Of goostly lizte men seye hit is

pat god hap made to his likenes

As preent of seel in wexe prest

Perynne he hap his likenes fest

He hap hit wrouzte as frend \& fere

No ping to hym is so dere

His godhede is in trynite

Pe soule hap propur pinges pre

Menyng \& pat of pinges to se

pat is and was and euer shal be

Vndirstondynge hap hit rizte

Of pinges seyn and oute of sizte

Wisdome also hit hap in wille

pe goode to do and leue pe ille

Alle pe myztes pat may be

Wonen in pe hooly trynite

fol. $3 v \mathrm{col} .1$

Alle vertues hap a soule I wis

Pat oute of synne clensed is

And as god pat is in oon \& pre

Wip no manere creature may be

Vndirgropede ne ouergone

But he ouertakep euerychone

So pe soule wipouten wene

To al ping hit is vnsene

Pouze hit of al pinge haue sizt

To se a soule no man hap myzt

551 pese resouns] pis reson $B$.

to] in $\mathrm{L}$.

seel] wex $B$. wexe] seale $B$.

\&] or $\mathrm{L}$.

is] om $\mathrm{B}$.

of pinges] ys of ping $B$.

hit] he $B$.

pinges] ping $B$. oute] nought $B$.

also hit] he $B$. in] all att $B$.

pe myztes] thynggis $L$.

vertues] uvrtours $L$. a] be $B$.

pat] om LB.

Wip] May L. may] om L.

After 1.576, B adds a line: bough it of all ping haue be sene. wipouten] is as I B.

pouze] Thoght L; zef B. pinge] pingis $T$. haue] hape B. 
Now haue I shewed zow pus hider

How two pinges holden man togider

pe soule is goostly ping to telle

Pe body hit is flesshe and felle

Adam was made of mannes elde

As he myzte hymseluen welde

As austyn seip pat lyep nouzte

And wipouten paradys wrouzte

Here now ze resoun of his name

Why he was calde adame

In pis name are foure lettres leide

Pat of pe foure zates be seide

As eest. west. norpe. \& soupe

So myche is adam for to moupe

And pow maist aske wipouten blame

Why god hym zaf so greet a name

For sope pat is lizte to rede

Hit tokenep adam \& his sede

Ouer al pe world shul be sprade

And perof to be lorde made

And as oure lord hadde heuen in honde

So shulde man be lorde of londe

perfore he zaf hym to bigynne

A lufsome londe to dwellen ynne

A lond of lyf ioyes and delys

605

Whiche men callen paradys

Into pat lond pat swete place

Was adam brouzte when ne he made wase

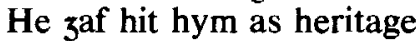

To zelde perfore no knowlage

fol. 3v col. 2

But to holde hit wel vnbroken

A forbode bitwene hem spoken

But for pat he helde hit nouzt

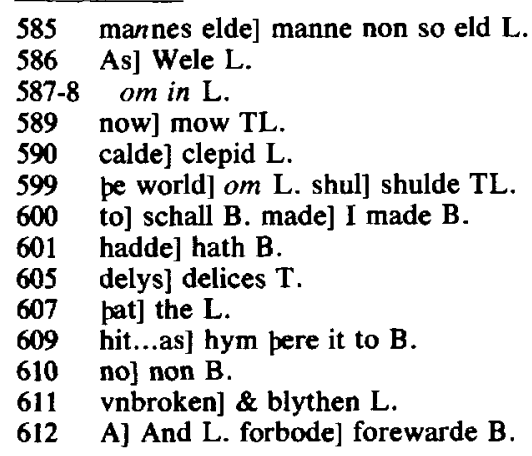


He made vs alle in bale be brouzt

In care he brouzte vs $\&$ in sore

As I shal telle zow forpermore

Of [be] astate pe world was ynne

Byfore be tyme of adames synne

Whan ne adam was made also soone

In paradise he was done

pe beestes bope he \& sheo

Adams sizte were brouzte to

Fisshe in watir \& foule to flizte

Al was brouzte in adam sizte

Alle were brouzte to serue adame

For pat he shulde zyue hem name

pis kyng pat con his craftes kepe

625

Slyly he made adame to slepe

Out of his syde as seip pe booke

Wipouten sore a ribbe he toke

Of pat ribbe he made a womman

To adam pat was firste his on

When ne sheo to adam was brouzte

Virago hir name he wrouzte

Perfore hette sheo virago

For of pe man made was sho

Naked were pei bope tweyn

Ashamed were pei nouzt certeyn

God hem blessed \& bad hem brede

And multeplye wip her in sede

Adam he seide how pinkep be

In pis place is feire to be

Pis is a stede of weleful wone

Of ioye and blisse wantep hit none

Here lastep lyf wipouten ende

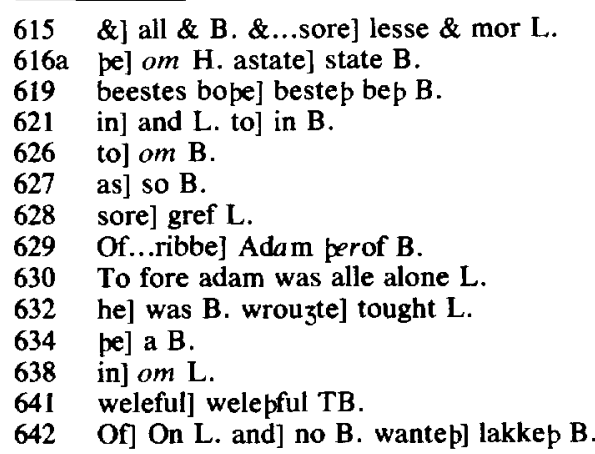


Here is no ping to amende

Here is blis pat lastep ay

Neuer nyzt bot euer is day

Is no man wip herte to penke

fol. $4 \mathrm{r}$ col. 1

Ne clerke pat may wryte wip enke

Pe mychel ioye pat hem is lent

Pat done here my com maundement

Of trees and fruyt here is good wone

Alle shul pei be byne but one

Of hem alle pi wille to do

But pat o tre come ze not to

Pat stondep amyddes paradyse

For zif ze do ze be not wise

pis tre haue I done in fripbe

For I wole haue hit to my grippe

zif $z^{\mathrm{e}}$ hit touche to zow seye yze

On doubel dep shul ze dyze

Bep war and takep good entent

Brekep not pis commaundement

Herby may we alle se

pat he hem zaf a wille fre

Pe good to do and leue be ille

Bope be put in her fre wille

Wit and wisdome he hem zaue

Mizte and fairhede for to haue

Of al erpe made adam kynge

To lasten wipouten endynge

Among hem euermore hele

Telle we sumwhat of his wele

Ar he brake pat god forbade

In mychel blisse was he bistade

of his wyf so faire and fre

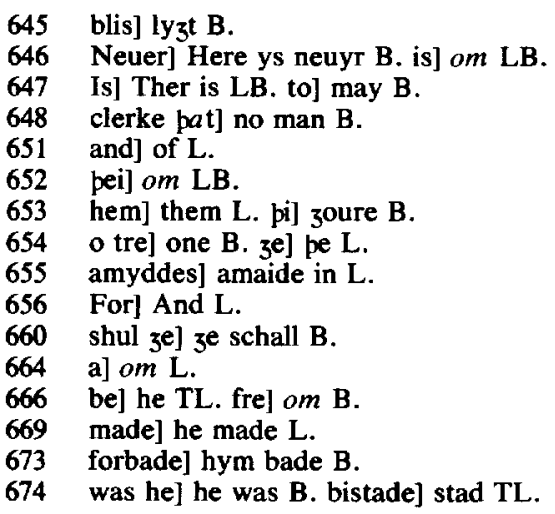


Pat myche myrpe was on to se Pese beestes coom hym alle aboute As to her lord hym to loute Foule in flizte fisshe on sonde Alle bowed hym to foot \& honde

At his wille pei zeode \& cam As he hadde ben makere of ham pese beestes were so meke in dole Wipouten hirtynge pei zeode hole Among be wolues lay pe shepe

Safly myzte pei togider slepe pe hound harmed not pe hare Ne no beest souzte opere to forfare By be deer pat now is wilde As lomb lay pe leoun mylde 690 Pe gryp also bysyde pe bere No beest wolde to opere dere Pe scorpioun forbare his tonge Fro beestes pat he lay amonge Al maner ping in dyuerse wyse zalde to Adam her seruyse pe nedder po was not bitter For he was euer wys $\&$ witter For as we rede in booke meest He was more wys pan any beest fol. $4 \mathrm{r} \mathrm{col} .2$ pe sonne was pat tyme we say Seuen sipe briztere pan now a day pe mone was pat tyme also brizt As sonne now on dayes lizt Holde no mon pis for no foly Pe prophete seip pus ysay

677 pese] That L.

678 hym] pay gan B.

679 in flizte] and B. on] on pe B.

680 hym to] to hym B. foot] fete B.

684 hirtynge] hurt $\mathrm{L}$.

686 myzte pei togider] to gadyr myght pay $B$.

687 hound] houndys $B$.

688 no beest] none B. forfare] fare $L$.

689 pat] as $L$.

690 lomb] a lambe L. mylde] wyld $L$.

692 No] None B. to] do L; po B.

694 Fro] For B.

696 zaldel zeldyd B.

697 po was] was pe B.

700 more wys] wyser LB.

704 now] ys now B. dayes] the day LB.

705 second noj om $\mathrm{B}$. 
Alle pinges as we may se

Hyze or lowe in world pat be

Pei were of gretter strengpe \& myzt

Bifore pat adam dide vnrizt

//To adam soone was sent a sonde

pat souzte hym selly for to fonde

Whenne sathan sey pat he was chosen

To haue pe blis pat he hadde losen

Sory he was pat false file

And pouzte man to bigyle

$\mathrm{He}$ pouzte po ioyes for to stynte

pat god to mankynde hadde mynte

Azeyn god he wexe so grille

His hondewerke he pouzte to spille

And trowed wip his greet enuy

Of god to wynne pe maystry

Now man is sett bitwene two

On eiper syde he hap a foo

Bitwene Sathan and his wyf

Adam is sette in mychel stryf

Bope were pei on adame

fol. $4 \mathrm{v}$ col. 1

For to brynge hym into blame

Bope pei ben on o party

To ouercome man wip tricchery

pe wyly fend hym helde on hyze

Hym geyned not com adam nyze

Namely in his owne shap

To spede he hoped ha non hap

perfore a messangere he sende

By whom beste to spede he wende

Penne he chees a litel beest

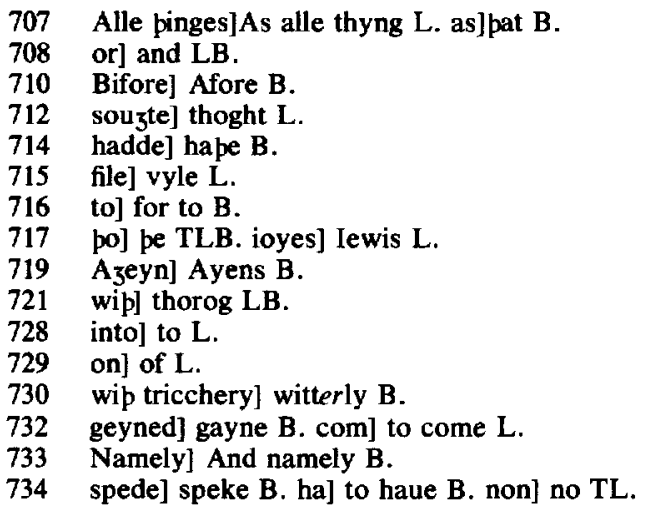


Whiche is not vnwylyeest

Pe nedder pat is of siche a shaft

Moost of queyntyse \& of craft

Queyntly tauzte he hym pe gynne

At pe wyf to bygynne

And pourze pe wyf to wynne pe man

Penne goop pis neddre \& not blan

In his slow satan penne was

Wondur is he entred in pat plas

But of his sufferaunce he hym lete

pat beest wiste how pat bale to bete

For mon he made pat he mouzte

Synne or leue as hym good pouzte

And by skile of his owne dede

Shulde be merked penne his mede

To bowe and lyue wipouten ende

Or elles to dyze and to woo wende

How adam brake goddes commaundement

Wherfore kynde of man was shent

Adam wandride in pat wele

In myche myrpe ioye $\&$ hele

When adam was fro eue a prawe

pe nedder nyze to hir gon drawe

And seide womman telle me why

Pat ze ete not al comynly

In paradise of eueryche tre

She seide sertes so nowe do we

Of alle trees but of one

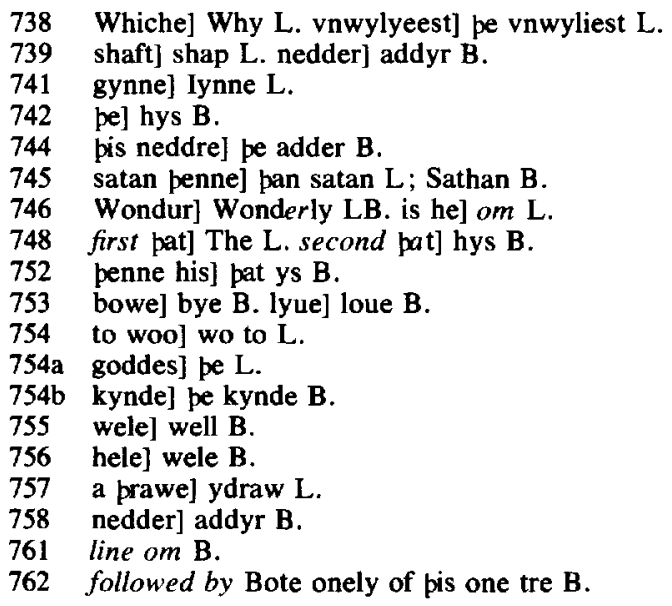


Pat is outtake to vs alone

Oure lord in forbode hap hit leide

765 fol. $4 \mathrm{v}$ col. 2

Wost pow pe why: nay sheo seide

But sheo seide zif we come per nyze

On doubel deep shul we dy ze

pis o tre shulde himseluen haue

And alle be opere to vs he zaue

And trowest pow pat hit so be

As he zow seide sheo seide ze

Nay seide he wip greet tresoun

But perynne lip suche resoun

But for he wolde not ze were

Paryngal to hym nor pere

Pe sope fro zow wole I not hyde

He woot wel pat what tyme or tyde

Pat ze hadde eten of pat tre

As goddes shulde $z e$ bope be

To knowe bope good and ille

ze shulde be lordes at zoure wille

Of hit ze ete so rede I zow

And ze shul fynde hit for zoure prow

pis hetyng was pat tyme ful mykel

But hit was ful false and fikel

Soone so sheo pis fruyt bihelde

Sheo zerned hit to have in welde

Sheo let not for drede nor blame

But took and ete \& zaf adame

What bote is longe pis tale to drawe

pei ete hit bope in litel prawe

764 to...alone] of euerychone $B$.

765 hit] vs B.

766 Wost pow] Wotyst L. pe] neuer $B$.

768 shul we] we schull $B$.

769 shulde] schall B.

770 opere] todyr B.

772 zow] the L.

773 wip greet] withoute B.

775 wolde not] nold L. 3e] pat ye ne L; pat he B.

776 Paryngal] Egall L. to] wip B. nor] ner no L; no B.

777 fro] for $B$.

779 hadde eten] ete $B$. pat] pis $B$.

780 goddes] god is so L. shulde] schall $B$.

782 shulde] schull $B$.

786 hit] his T. ful] pat tyme B.

787 Soone so] So sone as $B$.

788 zerned] lykyd L.

789 nor] ne $L$.

791 bote...to] is it bot lenger $B$.

792 hit] of yt L; om B. in] in a L; a B. 
Al for nouzte pei ete hit bope Wherfore oure lord god was wrope

For pat ilke appeles bitte

Her sones teep eggen zitte

And so shal do til domes day

Here azeyn may no man say

Whenne eyper sawe oper naked

For shame bei stoode bope \& quaked

Penne pei sey pat bare pei were

In welpe and ioye pat were clad ere

Pei hullud hem I telle hit pe

Wip leues of a fige tre

Whenne pe fend pus hadde hem nome

805 fol. 5 r col. 1

Wel he wende ha god ouercome

And seide wipynne his sory pouzt

I haue made hym worche for nouzt

His heuen shal he have his one

Of adam part getep he none

To brynge into pat heritage

pat I have lost bi myn outrage

He lyzed fals peef for why

zitt hadde god of adam mercy

Pat he were lost god wolde nouzt

For he wip tricchery was souzt

Pe fend was wel moore to blame

Pat so falsely gyled adame

God wiste pe fend had adam blent

zitt wolde he not pat he were shent

But pouze he wolde, zyue adam grace

First shulde he byze dere pat trespace

796 eggen] akyn L; eggyd B. zitte] tyte B.

797 do] om B. til] tell L.

798 Here] per $B$.

800 bope] om $\mathrm{L}$.

801 sey] seid L. bare] bope L.

802 welpe] wele $B$.

803 I] as I B. hit] om B.

805 pus hadde] had pus $L$.

806 ha god] god to L; he had $\operatorname{god} B$.

809 his one] allone $B$.

812 lost] left L. bi] porough B.

813 fals peef] falsly B.

814 of] on L.

815 god wolde] pat wold god B.

818 gyled] begyled $B$.

821 pouze] thoght $L$; zef $B$.

822 shulde he] he schall B. pat] hys B. 
Of Pe astate Pe world was Inne Aftir Pe tyme of adames synne

Als fast as pei had done pat synne

Oure wo bigan to bigynne

Al maner blis fro hem was went

For pei brake pat commaundement

Soone bigan he vengeaunce kype

As lord pat firste was meke \& blipe

Al bigan to stire and stryf

Azeyn adam and eue his wyf

Bytwene hemself roos stryf also

Pe strenger beest pe weyker slo

Vchone of opere to make his pray

As we may se now vche day

Fro pat tyme firste coom dep to man

And pat tyme al oure wo bigan

pese wronges pat ben of euel wrake

pere bigynnynge dide pei take

Synne and sake shame \& stryf

pat now ouer al pe world is ryfe

Mercy lord strong wickedhede

Made adam do so foule a dede

Hymself hadde lost \& al his kyn

fol. 5 r col. 2

But oure lord hadd raun soumde hym

On suche a wise as he hadde pouzt

Byfore er he pe worlde wrouzt

But pat was not done al for nede

But pourze his owne nobelhede

For zif he hadde wolde he myzte man

Wel better ha made pen he was pan

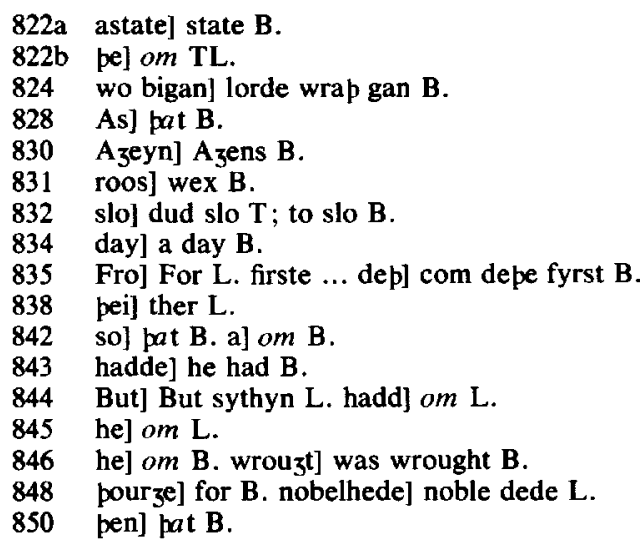


Wip flesshe perfore he coom in place

And filled pis world of his grace

His grace hit was \& noon opere

pat he wolde bicome oure bropere

Wip pe fend perfore he fauzte

And wip his fadir he made vs sauzte

//Leue we now of pis spelle

Of oure story furpere to telle

When ne adam sey he had mysdone

He wente to hyde hym also soone

He wende to hyde hym among be trees

Fro his sizte pat al sees

Al for nouzte hym hidde adame

Oure lord hym called by his name

Lord he seide When ne I pe herde

For I sawe pat I mysferde

I and my wyf wente vs to hyde

Shame vs pouzte pe to abyde

For oure bodyes al bare were

Adam he seide so tolde I pe ere

I pe tolde meest and leest

What hit was to breke my heest

But now is pis appel eten

And my biddyng is forzeten

And bat pou hast pus done pis mys

piseluen is to wite I wis

Lorde he seide of pis gilt here

Is sheo to wyte pat is my fere

Pat pow me zaf my wyf to be

For principally sheo beede hit me

Sheo bede hit me wipouten blynne

Sheo hap me fyled wip her synne

Al pis may sheo not zeynsey

fol. $5 v \mathrm{col} .1$

Sheo owe to bere be gilte awey

Ihesu seide to hir anoon

851 in] to $B$.

852 filled] hilled $T$.

856 he] om B.

858 Of oure] And of pis B. furpere] forpe L.

860 also] full $B$.

861 wende] went $B$.

866 For] $o m$ L.

870 pe] om $\mathrm{B}$.

875 bus] $o m$ LB.

879 pat] And pat B.

882 fyled] foulyd B. her] pis B.

885 Ihesul God L; Oure lorde B. 
Why dudest pou pis dede wommon

Sheo seide be worme me drowe pertille

Pat I haue done azeyn pi wille

To pat worm of wrappe \& wrake

Oure lord penne pus he spake

Pow worme pou shalt acursede be

Moore pen any opere beest to se

For on pi wombe pow shalt slyde

Moore ben any oper beest in tyde

Fro pis day forp shal hate be

Forsope bitwene wom man and pe

Erpe shal be pi mete for nede

Bytwene [pin] and wom mannes sede

Womman to stynge awaite pou shal

And pyn heed zitt tobreke sheo shal

Pouze pou in hete euer wolde be sted

In colde shal euere be pi bed

And pou wommon for pis dere

In sorwe shalt pou pi childer bere

Pow shalt be slayn wip double dede

Harde hit is for to rede

pow shalt be vndir mannes heeste

To hem be buxome meest \& leste

Pow shalt haue euer pi heed hid

pi shame shal not be vnkid

And zitt pat pow now hast mysgoon

Hit shal be [b]et bi a wommon

Of synneles man made I pe

In wom man shal zitt my wonyng be

But hit shal not be zitte so nyze

To keuer my loos firste mot I hyze

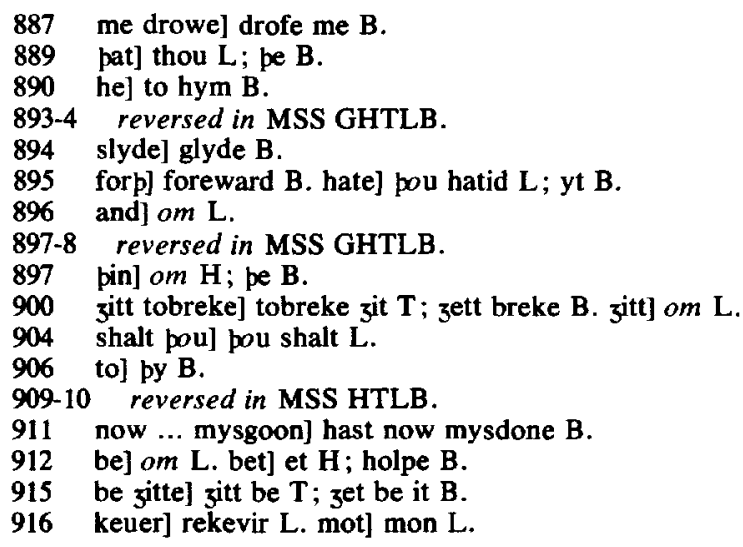


And pou man pat haast vndirtaken pi wyues rede and myne forsaken Noping shalt pou perwip wynne Pe world is cursed of pi synne

In erpe shalt pow swete \& swynke Wynne pat pou shalt ete \& drynke Alle pe dayes of pyn elde

Breres and pornes hit shal pe zelde perof shalt pou ete gresses sere Pow shalt bye pi breed ful dere Til pow turne azeyn \& quake To pat erbe pow were of take For pou art now but pouder pleyne To pouder shalt pow turne azeyne He turnede penne his wyfes name And Eue fro penne hir cald adame Eue sheo hette fro bat day Pat modir of many is to say God made hem po curteles of hyde Perwip her flesshe for to shryde Lo he seide Adam how Likep be pis dede now I made euel and good to zow knowen But zee were soone ouerprowen ze trespassed at pe tre of lyf Perfore ze ben in woo and stryf He put hem out of pat plase Into be world pere pei made wase Adam dere hit shal be bouzte

Til hit be bet pat pou hast wrouzte

Take pi wyf in pi honde

Leue zee shul pis lufsum londe

Into pe wrecched world to be

917 And] And take B.

922 Wynne] To wyn B. \&] or L.

924 hit...zelde] schall be py telde B.

925 shalt pou] schaltow B.

927 \&] in $T$.

930 shalt pow] pow schalt $B$.

931 benne]bo $\mathbf{B}$.

932 hir] om $\mathrm{B}$.

935 po] penne TLB.

936 shryde] hyde B.

939 zow knowen] zour knowing $B$.

940 ouerbrowen] ouer trowing $B$.

944 pei] he B.

946 Til] To B. bet] bote $L$. 
pi lyf shal pinke longe to pe

Longe peyne pere shalt pou dryze

And sippen on doubel deep to dyze

ze shul be flemed fro my face

Til pat I zow sende my grace

pe oyle of mercy zee mote abyde

I hete to sende hit 3 ow sum tyde

Alas seide adam woo is me

pat I trowed not lorde to pe

Lorde my lyf is me ful loop

pat I euere made pe wroop

I woot but pe I haue no frende

Tel me er I fro be wende

What manere and wip wha[t] pinge

fol. $6 \mathrm{r}$ col. 1

May I gete pi sauztelynge

Adam he seide wel seystou now

Herkene I wole telle be how

Amonge pine opere werkes hende

Of pi wynnyng zyue me pe tende

Of al pi fruyt holde partyes nyne

And I wole pat pe tenpe be myne

Lord he seide pou zyuest al

Why shulde pi part be so smal

pe haluendeel or parte pe pridde

We wole pe zyue zif pow bidde

Penne was he put out almeste naked

Into be londe pere he was maked

Perynne he led a longe lyf

And gate childeren bi his wyf

Out is he put adam pe wrecched

Fro paradyse fully flecched

951 pere] yet L. shalt pou] pou schalt B.

952 sippen] aftyr B.

954 zow...my] sende pe oyle of $B$.

956 hete to] schall $B$.

958 trowed... pe] schall not by face se B.

962 er] now or $B$.

963 first What] On what B. second what] whap $\mathrm{H}$.

966 I] \& I B.

967 pine...werkes] pi werkys oper $\mathrm{B}$.

969 pi] be $B$.

970 And] For B. pat] om B.

972 shulde] schall B.

973 parte] om $\mathrm{B}$.

975-88 not in MSS GHTLB.

990 pere] pat $\mathrm{B}$.

993 he] om $B$.

994 fully] fouly T; foule e L. flecched] fiyghtid L; flitted B. 
A wal of fyre per is aboute

May noon come yn pat is peroute

An aungel hap pe zate to gete

Wip swerde in honde of myche hete

//To telle man wip pi lore

What lond is paradise and whore

1000

Sippe we here perof spelle

Good hit were for to telle

Paradys hit is a pryue place

Ful of myrpe and of solace

pe louelyest of alle londes

Towarde pe eest in erpe hit stondes

Londe of lyf of roo and reste

Wip blisse and bote broiden beste

pere euer is day and newer nyzte

And al aboute ful of lizte

Mony vertues pere is sene

Pe herbes euer ylyche grene

Mony opere blisses elles

Floures pat ful swete smelles

Trees of fruyt of dyuerse mete

Pat dyuerse vertues han to ete

Pat zif man ete oper while of oon

fol. $6 \mathrm{r} \mathrm{col} .2$

Hunger shal he neuer haue noon

zif he ete of anopere tree

Fursty shal he neuer be

Pe pridde whoso etep moore or les

Shal he neuer haue werynes

Of oon who so etep at pe laste

In oon elde shal he euer be faste

Sekenes shal he neuer noon dryze

$\mathrm{Ne}$ neuer shal his body dyze

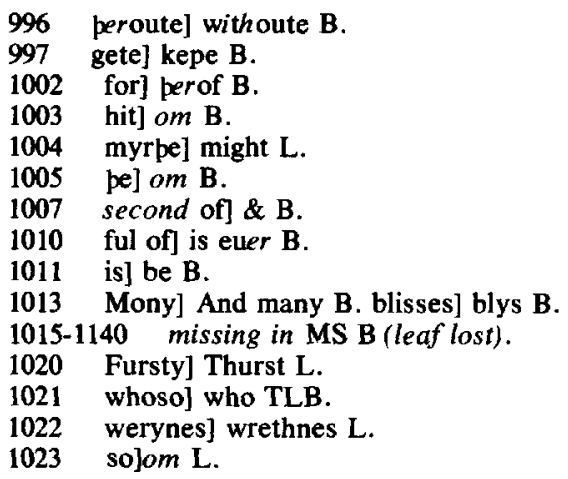


Hit is an orcharde of delyces

Wip all swetenes of dyuerse spices

Who so dwellep pere him par not longe

Her soun is softe \& swete of songe

1030

Soun of foules bat pere syngep

I mydde pat londe a welle spryngep

Pat rennep oute of foure stremes

Passynge into dyuerse remes

pese stremes pat pus pere bygynne

Pourze mony opere londes pei rynne

Pe firste is tigre wipouten lees

Pen iules pigre and eufratees

Pei bringe stoones fro paradis

So preciouse nowhere founden is

1040

pis paradis is sette so hye

Mizte neuer flode come per nye

Hit was free of noeus floode

pat al pis world ones ouerzode

How caym pe cursed wip wowe

Abel his broper slowe

Now adam is in erpe bistad

1045

Wip gras \& leeues is he clad

Soore he swanke \& eue his wyf

Vpon pe erpe to wynne her lyf

Wip myche swynke was pat pei wan

pe firste pei were to sawe bigan

1050

Pe firste childe bat euer sheo bare

Was caym cursed ful of care

And aftir hym I wole zow telle

A blessed childe hizte abelle

pis abel was a blessed blode

And caym was pe fendes fode

Was neuer worse of modir born

Perfore was he aftir forlorn

Pis abel was an herde of fee

Blessed and holy man was he

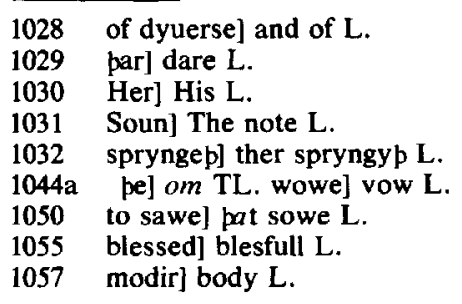


Riztwis he was goddes frende

And trewely $z^{\text {af }}$ to him his tende

For his offerynge was riztwise

God payed was of his sacrifise

For caym zaf his wip euel wille

Oure lord loked not pertille

For pis tipe pat pei delt

Caym pat I tofore of melt

To his bropere yre bare

Alas pat he bouzte sare

Azeyn abel he roos in stryf

Wip murp[r]e brouzte hym of his lyf

Wip a cheke boon of an asse

Men seyn abel slayn wasse

Whenne caym hadde his broper sloon

He wolde haue hidde his cors anoon

But preued was soone his sory pride

Pat body myzte he no weye hyde

For vndir erpe myzte hit not reste

Pe cley vp pe body keste

His broper deep he wende stille

But myzte he not be body hille

Perfore men say zit to pis tyde

Is noone pat longe murper may hyde

//Whenne he hadde done pis deolful dede

To his fadir hoom he zede

Whenne his fadir yze on him kast

A sikyng of his hert out brast

For mystrowynge hadde he soone

pat he sum wickede dede hadde done

1090

For by his chere he say hym wroop

So loked he euer breme and loop

Sone he seide to me pow tel

Where hastou done pi broper abel

He vnswered wordes were vnmylde

Whenne was I kepere of pi chylde

1067-8 reversed in MSS GHTLB.

1067 tofore] byfore L.

1068 pei] he $\mathrm{L}$.

1072 murpre]murpe $H$.

1077 preued] purveid $L$.

1078 pat] So that $L$.

1088 of] out of L. out] om L.

1091 say] made $L$.

1092 breme] grym $L$.

1095 wordes were] with wordis L. 
Tipinge of hym con I telle noon

To brenne his tipe he bigon

Vpon pe felde his fadir went

To seche abel wip his entent

pe fadir and pe modir bope

To blame caym were ful lope

Til pat pei pe sope hadde seene

Of ping pei wiste not but bi weene

Hem pouzte kynde hym wolde forbede

To haue done so cursed a dede

His dede hadde euer ben hid

Ne hadde ihesu hymself hit kid

Hit to hide myzte he nouzt

For ihesu pat al wrouzt

He pat firste flemed adam

For pat appel pat he nam

He nolde not hymself feyne

But caymes dede fully atteyne

And he wole pat men bye pe outrage

pat murperep so his owne ymage

He wende to haue scaped wip al

For any mannes clepe or cal

But penne coom oure makere

To speke wip pat traytour pere

Of pat morth and pat tresoun

He dide pat traytour to aresoun

//Caym where is pi broper abelle

Certes he seide I con not telle

Aske his fadir where he be

For he was not bitake to me

God seide telle me \& not layne

Whi hastou pi broper slayne

His blood on erpe shedde hit is

And aftir wreche cryep I wis

Hit leuep not wreche to crye

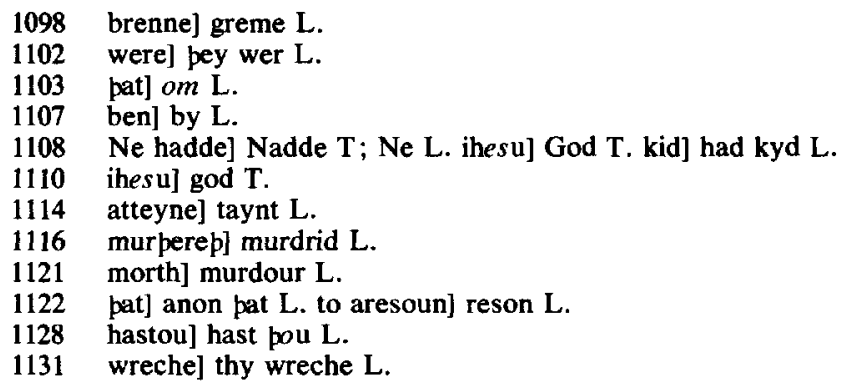


For to shewe pi felonye

For pi synful werke to se

Erpe pow shalt now cursed be

Pat so resceyued pi broper blode

1135 fol. $7 \mathrm{r}$ col. 1

Wip pyne hit shal pe zelde pi fode

For pi mychel felonye

Pis whete shal waxe cockul hye

In stide of pyn opere seede

pe shal not growe but porn \& wede

For pyne euele wrecched hede

pow shal euer lede pi lyf in nede

pi dredeful dede hap no make

Of alle dedes hit is out take

Sikerly I telle pe here

Pow shalt hit bye ful selly dere

For pouze I wolde forzyue hit pe

Hit is not worpi forzyuen to be

To what cuntre so pow wende

Shalt bou no man fynde pi frende

Among what folke pat pou abide

Pow and pyne be knowen shal wyde

Wip alle shal pou be knowen vile

Where pow wendes in exile

My hondewerke pus egup me

Pat I shal take vengeaunce on pe

For how shulde any erpely flesshe

Dwelle wip pe in sikernes

Whenne felowshepe \& broperhede

Myzte pe not kepe from foul dede

//Caym say his synne was knowed

And pat pe erpe hadde hit showed

He wiste azeynseyinge was noon

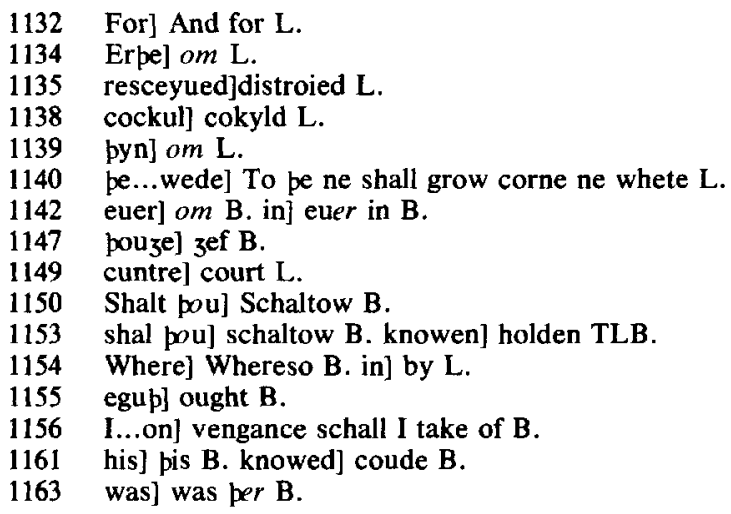


Oure lord he vnswered sone pon Lord he seide nowe se I wele

My synne hap sette me in vnsele I am ouertake wip siche tresoun

I am not worpi to haue pardoun

I shal be flemed for my synne

Vnkoupe londe to dwelle wibynne

In vnkoupe londe shal ende my wo

Whenne pei me fynde pei wol me slo

So fer I woot I shal be flede

God wolde nowe I were dede

Nay seide oure lord bep hit not so

1175 fol. $7 \mathrm{r}$ col. 2

Al pat pe seep shal not pe slo

But I shal sette on pe my merke

Alle shul hit se to rede as clerke

Shal noon be so bolde pe to sloo

But pi falsede to wite hem fro

In token of pi lastynge penaunce

pe shal be lent a long meschaunce

When ne adam abelles body fonde

For sorwe a fote myzt he not stonde

To bury pei his body bere

Adam and eue wipouten fere

Pis is pe mon men sayn was born

Bope his fadir \& modir biforn

He hadde his eldermodir maydenhede

And at his buryinge al maner lede

A hundride wynter fro pis stryf

Adam penne forbare his wyf

For sorwe of abel pat was slayn

Til counfort was sende him azayn

Bode word cam hym fro heuene

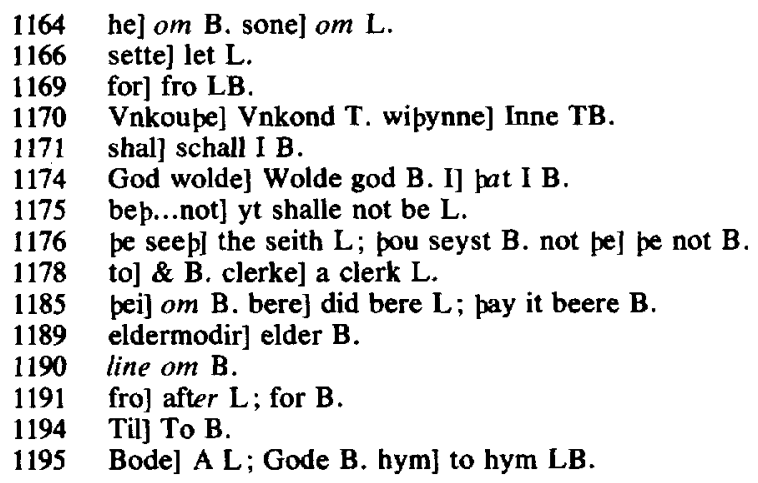


And bade hym by an aungels steuene

pat he shulde wip his wyf mete

For oure lorde hadde ordeyned zete

A childe to ryse in his osprynge

Pat many shulde out of bale brynge

He pat shulde saue pe folke fro synne

Shulde not be borne of caymes kynne

//Heraftir was born an holy childe

Seeth pat was bope meke \& mylde

Of whom cryst hymseluen caam

1205

Ful fer to telle fro firste adam

pis childe was goddes frende

And trewely zaf to hym his tende

He zaf hym al pat hym byhoued

His breper as hymself he loued

Eue pouzte herof ful feire

pat god wolde sende hem siche an heire

For abel was hem woo Inowze

pat caym so his bropere slowze

Of adam tellep pis story

1215 fol. $7 \mathrm{v}$ col. 1

pat he sones hadde pritty

And douzteres also fele to telle

Wipouten caym and abelle

pe sister was zyuen to pe broper

pe lawe penne myzte be noon opere

1220

So wolde god hit moste nede

To do oure kynde for to sprede

Vnsely kaym pat was in hate

Wip god and man at foul debate

Nouper he ne his ospringe

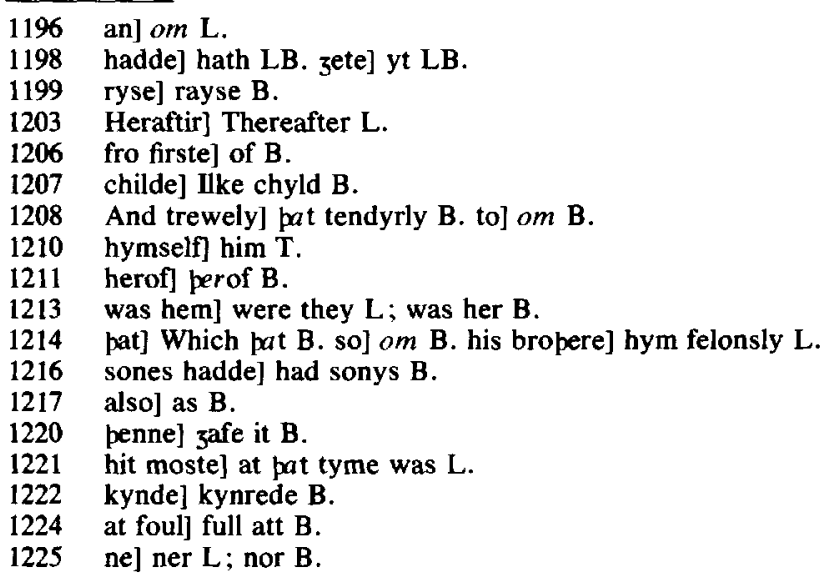


Loued oure lord no maner pinge For pei hym greued in her dedes He hem forsoke in alle her nedes To do pe euele myche pei souzte Awe of hym stode pei nouzte

Pat bouzte pei aftir wyf \& chylde

Wip watir were pei drenched wylde

As zee shul here how hit bifel

Of noe floode whenne I shal tel

For alle were euele \& noone gode

Pei drenched alle in noeus fiode

Of adam endynge telle wolle I And of pe oyle of mercy

Adam past nyne hundride zere No wonder pei he wex vnfere Al forwrouzte wip his spade Of his lyf he wex al mate

Vpon his spade his breste he leyde

To seeth his son pus he seyde

Sone he seide pow moste go

To paradyse pat I coom fro

To cherubyn pat zate warde

pat kepep po zates swype harde

Seeth seide to his fadir pere

How stondep hit fadir and where

I shal pe telle he seyde to sey

How pow shalt take pe rizte wey

Towarde pe eest ende of pe zonder vale

A grene way fynde pow shale

In pat wey shaltou fynde and se

fol. $7 v$ col. 2

pe steppes of pi modir and me

Forwelewed in pat gres grene

1229 pe] om B. euele myche] the worste alle L. souzte] pought B.

1230 stode] had LB.

1234 shal] om B.

1235 alle were] pay were all $B$.

1236 noeus] be B.

1238 pei] yef $B$. wex] were $B$.

1239 Al forwrouzte] And euyr wroght $B$.

1240 No wondyr pough he were made $B$. mate] made $T$.

1245 pat] the L.

1246 po] the LB.

1249 he seyde] be sope B. sey] seeth $L$.

1250 How] om L. take...wey] hold ovir this heth $L$.

1251 be] om $L$. vale] wall B.

1253 shaltou] shalt pou $L$. fynde and] om $B$.

1255 Forwelewed] Forstopyn L; forwelkyd B. 
Pat euer sipen hap ben sene Pere we comen goynge as vnwyse Whenne we were put fro paradyse Into pis ilke wrecchede slade pere myself firste was made

For pe greetnes of oure synne

Mizte siben no gras growe perynne

pat same wole pe lede pi gate

Fro hepen to paradise zate

He seide fadir say me pi wille

What shal I saye pe aungel tille

Pow shalt hym seye I am vnwelde

For longe lyued and am in elde

And so in stryf and sorwe stad

Pat forwery I waxe al mad

Pow him pray som worde me sende

When ne I shal fro pis worlde wende

Anoper ernede shal per be

Pat he me sende worde bi pe

Wheper I shal haue hit ouzte in hyze

pat me was hette pe oyle of mercyze

When ne I was dryuen fro paradis

And leste hit by my foly nys

Azeyn pe wille of god I wrouzte

Sumdel I haue hit bouzte

My sorwe hap euer sipen ben newe

Now were hit tyme on me to rew

//Seeth wente forp wipouten nay

To paradyse pat same day

He fonde pe steppes hym to wyse

1257 comen] were L. as] bope L.

1259 ilke] selfe B.

1260 myself] I myselfe B.

1262 sipen] Seth B.

1263 bi] om $B$.

1264 hepen] hennes TLB.

1265 fadir] aftyr $B$.

1268 lyued] lying B. and am] am I T.

1269 And so] Also B. sorwe stad] sebyll state B.

1270 waxe al] am nye $L$.

1272 pis] pe $\mathrm{B}$.

1274 worde]some worde $B$.

1275 Wheper] Wher TLB.

1278 And...by] pat I loste for B.

1279 Azeyn] Azens B.

1281 euer...newe] ben euer sepe to now $B$.

1282 hit] $o m$ B. on] of B.

1284 pat] pe TB. 
Til he come to paradyse

Whenne he per of hadde a sizte

He was aferde of pat lizte

So greet lizte he say pere

A brennynge fyre he wende hit were

He blessid hym as his fadir bad

And wente forp \& was not drad

Pe aungel at be zate he fond

fol. $8 \mathrm{r}$ col. 1

He asked him of his erond

Seeth set tale on ende

1295

And tolde whi he was sende

He tolde him of his fadir care

And of his elde $\&$ of his fare

But sende him worde when ne he shal dyze

Lenger to lyue may he not dryze

And whenne god hadde hym dizte

pe oyle of mercy pat was hizt

Whene cherubyn his ernde herde

Mekely he hym vnswerde

To zonder zate pou go \& loute

pi hede wipynne pi body wipoute

And tente to pingis wip al pi myzte

Pat shul be shewed to pi sizte

When ne seeth a whyle had loked In

He say so mychel wele \& wyn

In erpe is no tunge may telle

Of flouris fruyt \& swete smelle

Of ioye $\&$ blis so mony a pinge

Amydde pe londe he say a sprynge

Of a welle of honoure

Fro hir renne stremes foure

Fison. gison. tigre \& eufrate

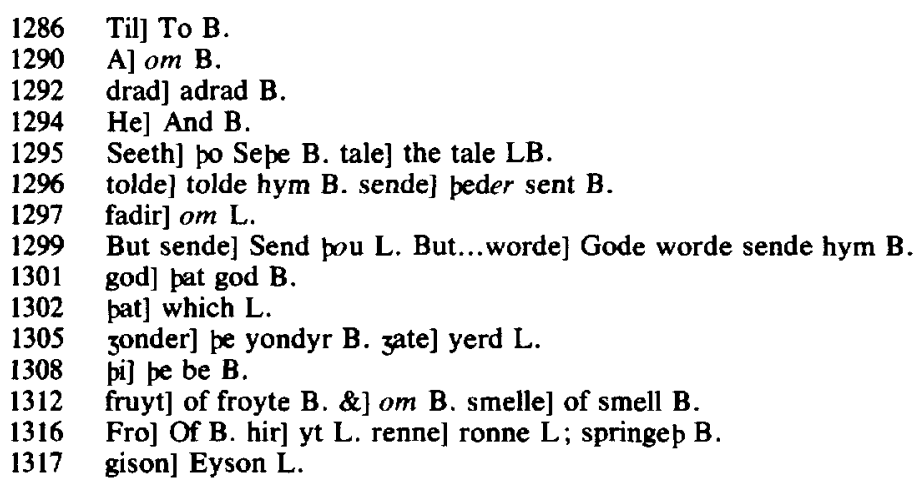


Alle erpe pese witen erly \& late

Ouer pat welle pen loked he And say pere stonde a mychel tre

Wip braunches fele no bark pat bere

Was per no lyf in hem pere

Seeth bigan to benke whyze

pat pis tre bicoom so dryze

And on pe steppes pouzte he pon

pat dryed were for synne of mon

pat ilke skil dude hym to mynne

Pe tre was dryze for adam synne

He coom po to pat aungel shene

And tolde hym pat he hadde sene

Whenne he hadde hym pus toold

He bad hym efte goo \& biholde

He loked in efte \& stood peroute

fol. $8 \mathrm{r}$ col. 2

And say pingis pat made him doute

pis tre pat I of eer seyde

A nedder hit hadde aboute bileyde

Cherubyn pe aungel brizte

Bad hym go se pe pridde sizte

Him pouzte penne pat he seize

pis forseyd tre rauzte ful heize

Vnto pe sky rauzt pe top

A newe born chylde lay in pe crop

Bounden wip his swapelynge bonde

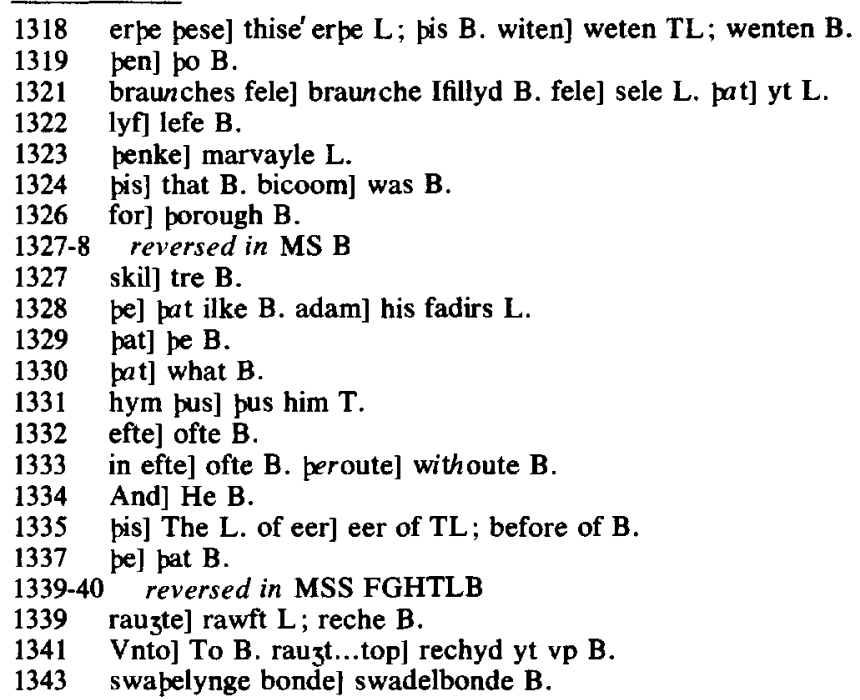


Pere pouzte him hit lay squelonde He was aferde whenne he hit size

And to pe rote he caste his yze

Him pouzte hit rauzte fro erpe to helle

pere he say his broper abelle

In his soule he say pat sizte

Pat kaym slowze forwaryed wizte

He wente azeyn for to shawe

To cherubyn al pat he sawe

Cherubyn wip chere mylde

Bigan to telle him of pat chylde

pat chylde he seide wipouten wene

Is goddis sone pat pou hast sene

Pi fadir synne now wepep he

He shal hit clense pe tyme shal be

Whenne pe plente shal come of tyme

pis is pe oyle was hizte to hyme

To hym \& to his progenye

Wip pite he shal hem shewe mercye

Whenne seep had vndirstonden wel

Pe aungelis seying euer a del

His leue he took of cherubyn

And pre curnels he zaf to hym

Whiche of pat tre he nam

pat his fadir eet of adam

pi fadir he seide pou shalt say

Pat he shal dyze pis pridde day

Aftir pou be comen hym to

Loke pat pou seye to hym so

But pou shalt take pe pepenes pre

fol. $8 v$ col. 1

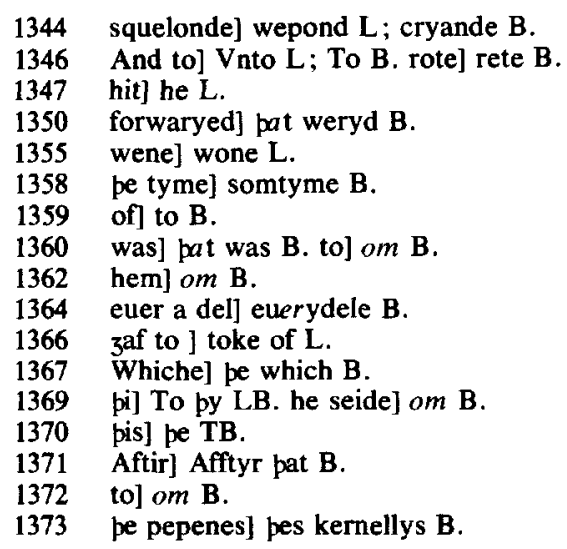


Pat I took of pe appul tre And putte vndir his tunge roote

To mony men pei shul be boote

pei ben cidur. cypres \& palme fyne

To mony pei shul be medicyne

pe fadir bi cidur shal pou take

Hit shal be tre wipouten make

Of cipres bi pat swete sauoure

Bitokenep pat swete sauyoure

Pe myche swetnes is pe sone

pe palme to fruite hit is wone

Mony cornels of o tre moost

Gode ziftis of pe holy goost

//Seeth was of his erned fayn

And soone come to his fadir azayn

Sone he seide hast pou sped ouzt

Hast pou any mercy brouzt

Sir cherubyn bat aungel

Pat porter is pe gretep wel

And seip pe world shal nyze han ende

Ar be oyle may to be wende

Pourz birpe of a blissed childe

pat shal pe world fro shame shylde

For pi deep he bad me say

Hit shal be pis day pridde day

Adam herof was glad ful blyue

So glad was he neuer er his lyue

Whenne he herde to lyue no more

1375 putte] putt yt B.

1376 men pei] a man it B. shul] shuld L. be] do B.

1377 cidur] sydrys $\mathrm{B}$.

1379 pe] Thy L. bi] this $L$; be pe $B$.

1381 Of] The L; Of pe B. bi pat] which is $\mathrm{L}$; be pe $\mathrm{B}$. sauoure] of savour $\mathrm{L}$.

1382 pat] oure TB. swete] om $B$.

1383 is] is in L.

1384 to...is] bytokenyp without $\mathrm{L}$.

1385 Mony] Thise L. of...tre] lest \& $L$.

1386 Gode...of] Come from L.

1389 hast pou] hastow $B$.

1390 Hast pou] Hastow B.

1392 is] om L. pe gretep] he gretyp pe B.

1393 nyze] neuere $B$. han] om $L$.

1394 Ar] Ar he T. wendel sende T.

1395 birpe] the byrth LB.

1397 For] And of $B$.

1398 Hit shal] bu schulde B. shal] shalbe L. first day] om B.

1399 herof was] was po B. ful] and B.

$1400 \mathrm{er}]$ in $\mathrm{L}$; er in $\mathrm{B}$. 
Po he lowze but neuere ore And pus to god gan he cryze

Lord Inowze mon lyued haue ize

Pou take my soule out of my flesshe

And do hit where pi wille is

For of pis world he was ful mad

Pat neuer o day perynne was glad

Nyne hundride zeer \& more zare

He luyed here in sorwe and kare

Leuer hym were to ben in helle

pen lenger in pis worlde to dwelle

Adam as him was tolde biforne

Dyzed on pe pridde morne

Grauen he was bi seeth pon

In pe vale of ebron

pe curnels were put vndir his tunge

Of hem roos pre zeerdis zonge

And soone an ellen hyze pei wore

Penne stode pei stille \& wexe no more

Mony a zeer yliche grene

Holynesse in hem was sene

Stille stoode po zerdes pre

Fro adames tyme to noe

Fro noe tyme \& fro pe flood

To Abraham hooly \& good

Fro Abraham zitt stille stood pay

Til moyses pat zaf pe lay

Euer stood pei stille in oon

Wipouten waxinge oper woon

1410

fol. $8 \mathrm{v}$ col. 2

1415

Nomore of pe zerde[s] now

But of a story I shal telle zow $^{\circ}$

Adam lyued nyne hyndride zere

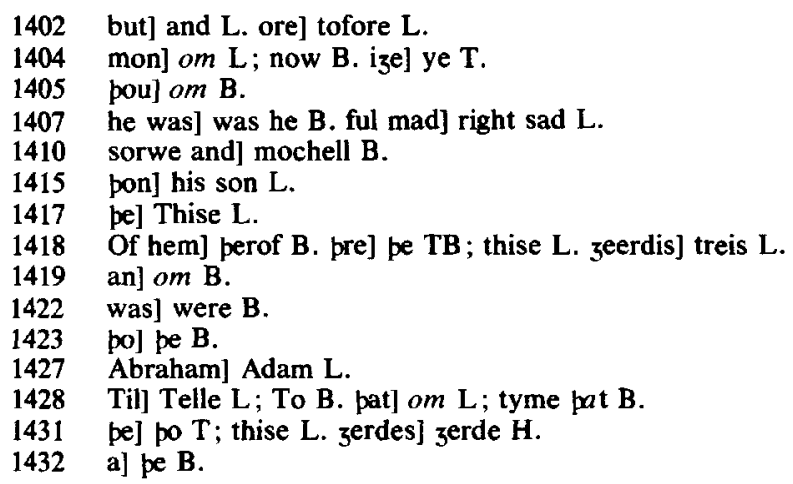


And pritty wynter also in fere

Whenne he was deed soone anoon

His soule was to helle goon

And alle pat dized fro pis to pon

pat Ihes u dized god and mon

Hem my 3 te helpe noon holyhede

But pei to helle muste nede

He myzte pinke pe stide stronge

pat in pat place was so longe

Foure pousande zeer in pat woo

Thre hundride zeer also

So longe fro Adam was to telle

Til oure lorde harwede helle

Pe genealogy of adam olde

Of seeth and caym shal be tolde

Seeth spoused his sister delbora po

Oure lord bad hit shulde be so

He gat a sone of hir enos

A man pat was of mychel loos

For he was pe firste man

fol. 9r col. 1

pat cry on goddes name bigan

Nyne hundride zeer seuene \& fyue

So longe lastede seeth his lyue

Enos his sone lyued by dene

Nyne hundride zeer \& fyue I wene

Caym his sone his lyf he led

Nyne hundride zeer as hit is red

Eyzte hundride zeer lyued malalyel

And fyue \& twenty zeer to tel

Nyne hyndride zeer \& sixe iareth

pat was pe fifte kyn fro seeth

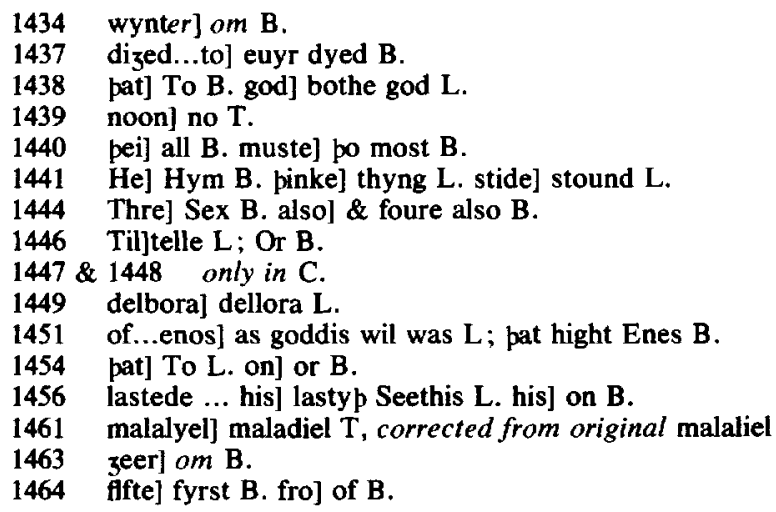


Of iareth elde pe fourty and

Was passed ouer pe firste pousand

Enok his sone wipouten pere

Lyued in erpe pre hundride zeere

He was be firste pat letturre fond

And wroot summe bookes wip his hond

1470

To paradise was he take pon

And pere he lyuep in flesshe \& boon

He comep tofore domes day

To fizte for pe cristen lay

Wip antecryst he shall fizte

For to were pe cristen rizte

He \& his felowe - Elye

Antecryst shal do hem dye

And wip her rysyng fro depe to lyue

Pei shul felle pat false stryue

1480

Adam as pe story sayes

Dyed in pis Enok dayes

Of Enok coom matussale

Lyued neuer man so longe as he

Til nyne hundride zeer was goon

1485

And seuenty failed hit but oon

Lameth his sone his elde to neuene

Seuen hundride zeer seuenty \& seuen

Of lameth coom his sone Noe

In whoos tyme pe flood gan be

pe formast world Adam bigan

perof lamep be laste man

Hit lasted wel a pousande zeere

Sixe hundride to \& sixty sere

But er pat oper world bigynne

Speke we more of kaymes kynne

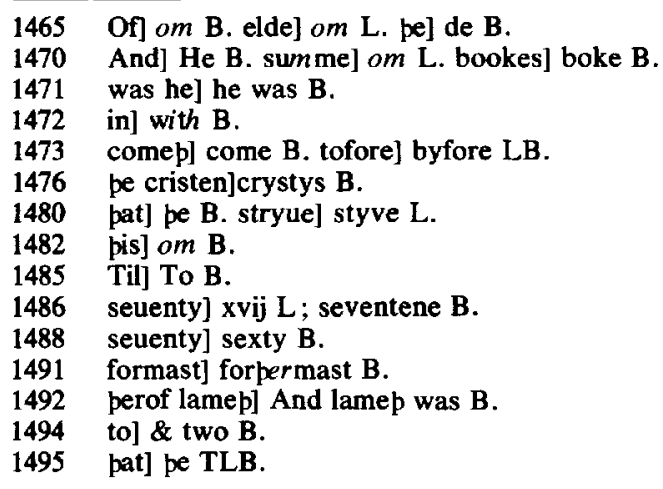


//When ne caym hadde don pat cursid dede

pat he was waryed alle we rede

He fledde away fro opere men

Into a stide pat hizte Eden

To him was spoused calmana

As was to seeth delbora

Soone a sone of hir gat he

pat enos het as a cite

Of pat ilke name he took

We fynde no terme of him in book

pere woned caym wip his brood

Pe firste cite bifore pe flood

Of enos coom malalyel

And of him coom matussalel

Lameth pre sones had wip mayne

Iobal . cabal . tubaltaine

pis lameth het lameth blynde

Kaym he slouze bi chaunce we fynde

In pe flood was he fordone

Iobal ben was his eldest sone

He was firste herde \& fe delt wip

Tubaltayne pe formast smyth

Tobal her broper firste vndirfong

Musyk pat is pe soun of song

Organes harpe \& opere glew

He drouze hem out of musyk new

A sistur hadde po breperen tweyne

Noema was called certeyne

She was pe formast webbe in kynde

pat men of pat crafte fynde

Hir fadir was pe firste on lyue

Pat bigan to double wyue

pei pat pese wondir werkes wrouzt

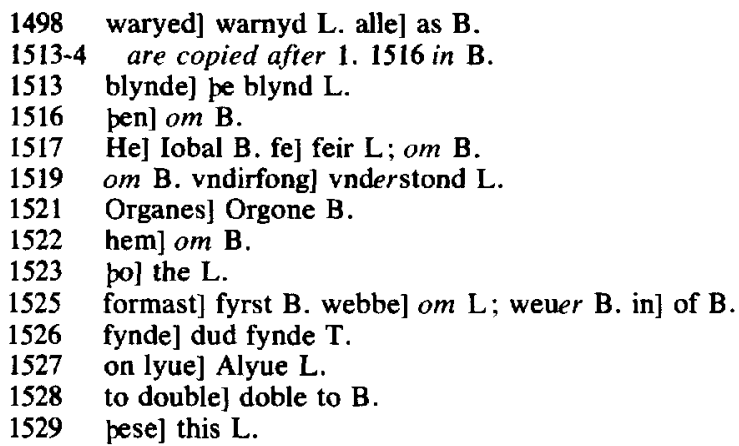


Hit ran hem wel pat tyme in pouzt

Pat pis worlde shulde come to ende

Wip watir dreynt or fyre brende

Two pilers pei made of tyel pat on

fol. $9 \mathrm{v}$ col. 1

pat oper was of marbul stoon

Pese craftes alle pat pei dide so

pei put hem in pese pileres two

Pe stoon azeyn pe watir to laste

pe tiel azeyn pe fire not braste

Pei wolde pat whoso aftir coom

Shulde be wissed bi her wisdoom

perfore let god hym lyue so longe

pat pei myzte seke \& vndirstonde

pe kynde of pingis pat were derne

Cours of sunne moone \& sterne

Whiche cours may noon al lere

Pouze he lyued an hundride zere

Whenne so mony zeer is past oute

pe mychel spire is ronnen aboute

In so long tyme is not to leyne

pe planetes are alle went azeyne

Of her firste makyng into pe state

As clerkes now wel woot pate

How mannes synne pat I of mene

Corrupted al pis world bidene

When ne iareth pat ze herde me neuen

Had elde of hundride winter \& seuen

Mikel malis was firste in mon

But newer tofore as was pon

In adames tyme was woo ynouze

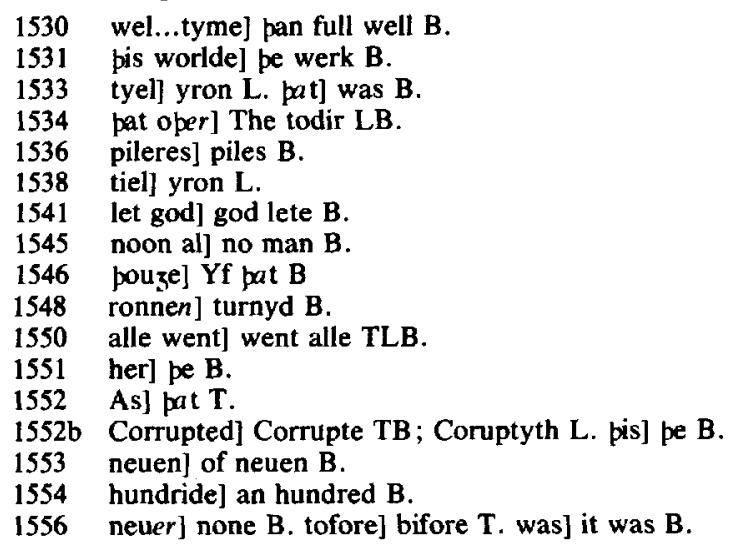


But penne was pere more wouze

Namely among kaymes kynne

pat delited hem but in synne

Hem pouzte al wel pat was her wille

pat pei drouze euere hem tille

On alle pinge was more her pouzt

pen on god pat hem wrouzte

So blynde pei wexe in her sizt

pat coupe pei do no maner rizt

Euer bei zaf her lyf to lust

Pat shende her soulis al to dust

Wymmen as we hit fynde

$1568 \mathrm{a}$

Wente togider azeyne kynde

$1568 b$

And men also be same wyse

As pe deuele wolde deuyse

$1568 \mathrm{c}$ fol. $9 \mathrm{v}$ col. 2

Of sopfastenes as seip pe sawe

$1568 \mathrm{~d}$

1569

pei left euer pe good lawe

1570

pe lawe of soopnes ny of kynde

1571

Wolden pei no tyme fynde

1572

Al wexe wicked \& in stryf

1573

pe broper took be operes wyf

1574

Her kursednes was not vnkid

1575

pe lawe of kynde bei so fordid

1576

pe shame \& synne pat pere was oute

1579

To telle were sumdel doute

1580

pe fende wende fully wip pis

1581

pat al mankynde shulde han ben his

1558 more wouze] wo mow $L$.

1560 pat] Which $L$. delited] delyte $B$.

1562 pat...hem] To god ner grace drew pey nevir $L$.

1563 On...her] Of worldly thyng was alle their $\mathrm{L}$.

1564 pen] \& no byng $L$.

1566 coupe pei] they cowde L. maner] man $B$.

1568 pat] And $B$.

1568a hit] om L.

1568 b azeyne] azeynes TLB.

$1568 \mathrm{c}$ pe] in pe $\mathrm{B}$.

1570 left] loste B.

1571 ny] \& L.

1572 Wolden] Nold L. no] neuyr no B.

1574 operes] bropers B.

1575 was] nas $L$. vnkid] vnkynde $B$.

1576 pei] $a m$ L. so] om B.

1577-8 om in FHTLB.

$1579 \&$ \& of $L$. pere was] bey wer $L$.

1580 Tol for to $B$. were sumdel] all wer grete $L$.

1582 shulde han] had $B$. 
So ferforply pat god not myzte

Brynge man into state of rizte

Into pe astate pat he had tynt

But god al operewyse mynt

His owne hondiwerke so soone

Wolde he not hit were fordone

Perfore in forme of iuggement

A newe vengeaunce on hem he sent

His foos to brynge alle of lyue

And clense be world of synne ryue

Bi his grace to $3 y u e$ hem gritth

Pat he monkynde shulde restore wip

When ne he bihelde be foly stronge

God pat biden hade so longe

pouze he were wroop no wonder nas

pis worde he seide anoon in plas

1600

pis was pe worde he seide panne

Me rewep pat I made manne

But alle pat pis word here \& sene

Woot not what hit is to mene

pis word was a prophecye

1605

pat was seyd for his mercye

Of pe reupe he sippe kidde

When ne he himself to pyne didde

For his chosen on rode tre

What was his reupe may we se

By pis word pat pere was seide

fol. 10r col. 1

His mercy was bifore purueide

To poo pat were on his party

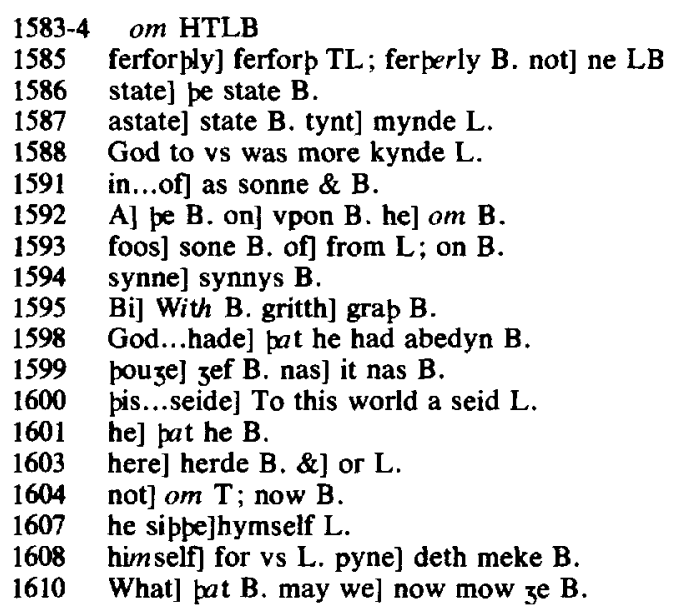


For to brynge hem myztily

As his owne his kyndam tille

His enemyes alle for to spille

Azeynes hem was so wroop

And bi his rizt hond swoor an oop

pat pei shulde alle haue shenful dede

Saue pe goode wolde he rede

Pouze alle pe foolis were forlorn

Pe goode shulde be forborn

As hit at noe flood bifelle

Wherof I shal sipen telle

But firste a tre of noe kynne

I shal here sette ar I bigynne

Here bigynnep of noe lede

pe secounde world for to sede

Fyue hundrid zeere had noe

When ne he had geten sones pre

Pe first was sem . cam pat oper

And Iapheth hette pe pridde broper

God spak vnto Noe pan

Pus his resoun he bigan

Noe he seide I telle pe

A! pis world bytrayep me

pei han lefte me \& my lawe

1635

Of me stonde pei noon awe

$\mathrm{Al}$ is forzeten pat fraunchise

Pat I zaf man in paradise

pe erpe wip synne is foule shent

Al riztwisnesse away is went

Foule lustis \& wicked hede

1615 second his] om LB.

1617 was] pat were B. wroop] wroght $L$.

1618 an] his $B$.

1619 shulde] schull B. shenful] shemful $T$; in word \& $\mathrm{L}$.

1620 Euyr lastyng ioy bat to god did rede $L$.

1621 pouze] Yf $B$. pe foolis] othir L.

1624 sipen] zow B.

1625-6 om L.

$1626 \mathrm{~b}$ sede] rede $B$.

1627 Fyue] Nyne B.

1629 pat oper] be toper $\mathrm{T}$.

1630 And] om B.

1631 vnto] to $B$.

1636 pei] hem $B$.

1638 man] hem $B$.

1639 wip synne] with in $B$. 
Han fuyled pis world in lengpe \& brede

No man her synne may say ne seke

Perof to heuen recheb pe smeke

Couetise lecchery and pryde

Hap spred pis world on euery syde

Alle are pei worpi to wite

Of woo is noon founden quyte

But I shal hem laye ful lawe

fol. 10r col. 2

pat set so lytil of myn awe

Wreche to take hit is to done

I shal hem drenche in watir soone

Alle hem but pi wyf and pe

pi sones \& her wyues pre

ze eizte for zoure leute

Alone I haue grantide gre

Wip pyn ospringe I haue mynt

Restore be folk pat shal be tynt

Fro pe moost to pe leest

Shal nouper haue lyf foule ne beest

But er pat I my vengeaunce take

I wol pat pou a vessel make

Sir telle me wherof hit shal be

Hit shal be made of square tre

A shippe must pou nedis dizte

pi self shal be pe mayster wrizt

I shal pe telle how brood \& long

Of what mesure \& how strong

Whenne pe tymbur is festende wel

Wynde pe sidis eueryche a del

Bynde hit firste wip balke \& bonde

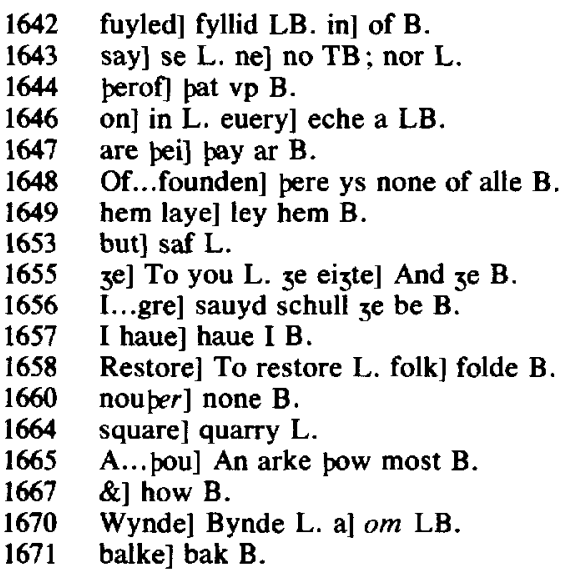


And wynde hit sippen wip good wonde

Wip picke loke hit be not pinne

Plastre hit wel wipoute \& ynne

Seuen score ellen longe $\&$ tene

pries eyzte on wyde on heizte fiftene

Fiftene on heizt is pe entent

Fro grounde to pe tabulment

Hit shal be made wip stages sere

Vchone for dyuerse manere

pou shalt bynepen on pat oon syde

Make a dore wip mesure wyde

A sperying wyndowe als on hyze

Loke pi werke be not vnslye

An hous perynne to drynke \& ete

1685

Wardrope pat pou not forzete

Of alle manere beestis take pe tweyne

To wone pere wip her makes certeyne

Of vche beest pat is wrouzt

Foule ne worme forzete $3 \mathrm{e}$ nouzt

In pe oue[r]mast stage shal pou be

Foules nexte vndir pe

Sipen alper nexte honde

Meke bestis bei shul vndirstonde

Po pat are tame \& mylde

And vndir hem penne pe wilde

Also pat pou make a boure

To kepe wipynne pi wardestoure

In be bopum shal be no stalle

For al her filpe shal perynne falle

fol. $10 \mathrm{v}$ col. 1

1690

1674 Plastre... wel] Plateyd B. ynne] with in B.

1675 ellen longe] zerdys $B$.

1676 first on] yt L; of B. second on] of B.

1677 on] of $B$.

1678 grounde] be grounde $B$.

1680 vchone for] Eche on B.

1681 pat oon] pe tone $B$.

1683 als] all $B$.

1685 An] And $H$.

1686 pat] loke B.

1688 her] hys B. makes] make LB.

1690 3e] bou L.

1691 ouermast] ouemast $H$.

1692 nexte] and next $L$.

1693 alper nexte] alleper next by $L$; aftyr next $B$.

1694 pei] om L.

1696 pennel pat $B$.

1698 wipynne] in B. wardestoure] warn stoure B.

1699 no] a LB. 
Hit shal be mychel wipouten pere

In makying sixe sipe twenty zere

So longe tyme I haue hem lent

pat wol come to amendement

And if any wol tente to pe

pat bei berynne may saued be

Whenne pou hast wel pi tymber layd

And hit is to pi wille payde

Pou \& pi wyf shul firste yn te

pi sones \& her wyues bre

Also pat ze take zow wip

Foule \& beest pat shal haue grip

pe meke togider two \& two

Pe wylde by hemself also

Of vchone take pou tweyne In

To holden vp her owne kyn

Be wel war for any swynke

pat pou ne wante mete ne drynke

Do now wel I leue pe

But I come efte pe to se

If I se pou worches rizt

I shal holde pat I pe hizt

Now woot noe what to do

And hewe tymbur pat fel perto

$\mathrm{He}$ zaf wriztis her mesure

And hymself dude his cure

pei wrouzte faste in dyuerse place

Him self fastened bope bonde \& lace

But euermore as he wrouzte

Folke to preche forzat he nouzte

fol. $10 \mathrm{v}$ col. 2

1730

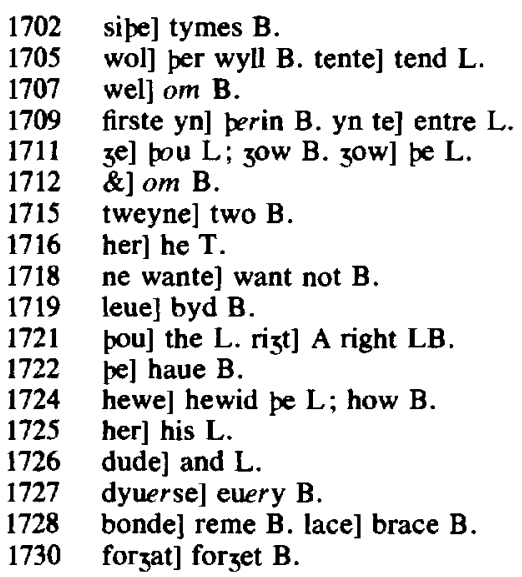


To warne hem of goddis wreche How god had wip hym a speche $\mathrm{He}$ hit tolde to many man

Wherfore he pat shipp bigan Wip skorn alle hym vnswered 1735

And seide why is pis cherle fered Pei seide greet wondir hem pouzte Why he was so ferde for nouzte He were pei seide worp to be $s[h]$ ent pat of his wordes toke tent 1740

Whenne noe say pis trauail tynt Of his prechyng penne he stynt Hit is but foly to zyue counsel to To hem pat wol but foly do perfore he lefte pat cursede lede

And went \& dude his owne dede

More wip hem he greued nouzt

Til he had his ship wrouzt

He was glad when ne hit was made

Rizt as god bifore hym bade

Whenne he hadde do[ne] be commaundement

He bode not but pe iugement

Pat god of myzte wolde worche his wille

As he bifore seide hym tille

Pen cam god at tyme his

To Noe for to speke of pis

When ne he hadde wip him spoken

Hymself pe dore soone hadde stoken

pe wyndowe was wip siche a gyn

Hit myzte open \& spere wipyn

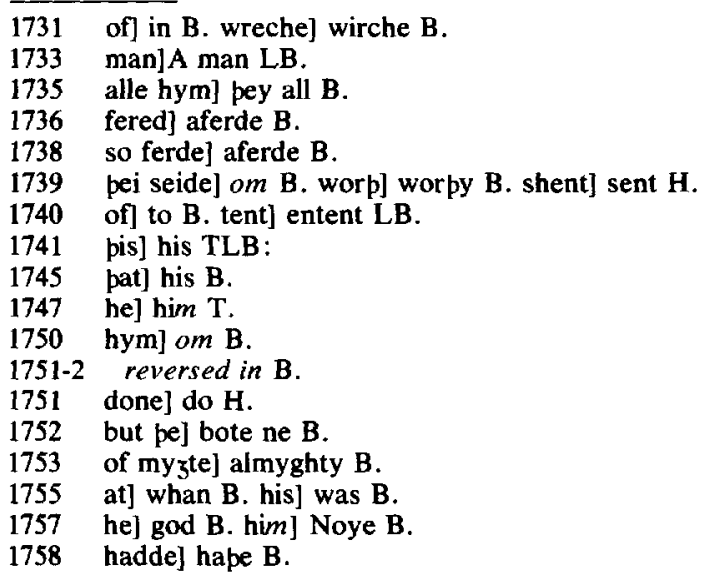


When ne pis was done per was no bide

Stormes roos on euery syde

Sunne \& moone pe lizt can hyde

Hit merked ouer al pis world wyde

pe reyn fel doun so wondir faste

pe welles wexe pe bankes braste

Pe see to ryse pe erpe to cleeue

pe spryngis alle oute to dreue

Leytynge fel wip pondir and reyn

Pe erpe quook and dened azeyn

fol. $11 \mathrm{r}$ col. 1

Sunne and moone lost her lizt

1770

Al pe world turned to nyzt

pat sorwe to se was greet awe

Pe buyldyngis fel bope hyze \& lawe

pe watir wex ouer pe pleynes

pe beestes ran to mounteynes

Men \& wymmen ran hem wip

Wel pei hoped to haue had grip

Al for nouzte pei wente afote

Whenne pei pere cam hit was no bote

Pe foulis flotered po on hyze

And fel whenne pei myzte not dryze

For nouzte fled beest \& man

Al to late pei hit bigan

In pat watir soone pe[i] swam

Syde bi syde wolf \& man

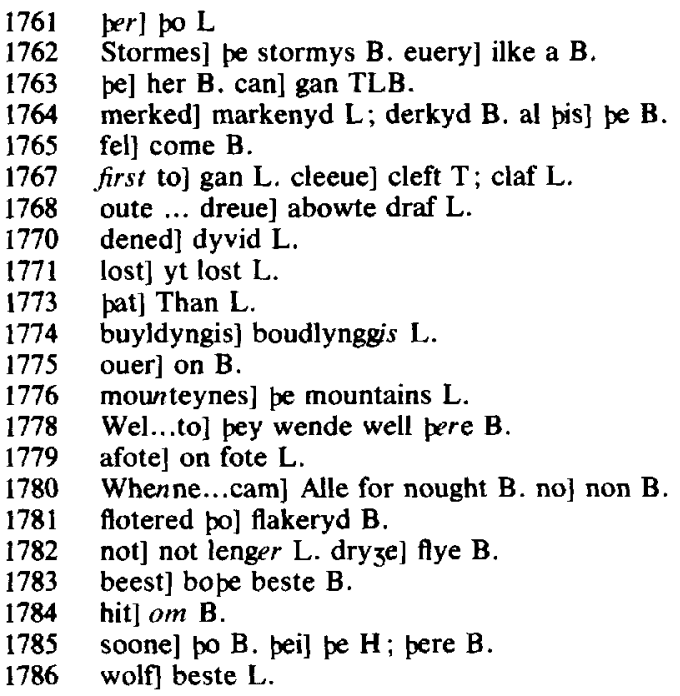


Pe lyoun swam bisyde pe hert Dide no beest to opere smert pe sparhauke bi pe sterlynge pei tentede opere no maner pinge

Pes ladyes tent not po to pride Pei swam bi her knaues syde For lordshipe was pere no stryf Was no man gelous of his wyf Opere to helpe was noon so slye Alle pei drenched by \& bye Alle pei drenched euerychone Was noon fro dep myzte gone For her synnes wepte pei pan Allas to late pei bigan 1800 Pen ne desired po caytifs badde pat pei hadde ben by noe ladde But pouze pat noe was in quert He was [not] al in ese of hert pe wynde hym ledde on pat flood He nuste whide[r]warde he zood Heuen \& erpe he flet bytwene He nuste where his ship wolde bene pei were ful ferde of her lyues Pat was wip hym m[e]n \& wyues But pe lord ful of myzt

To Noe bifore her lyues hizt Noe bo wiste wipouten wene pe folk was al dee'd bidene Wip soor wepynge he hem ment And turned to god al his tent

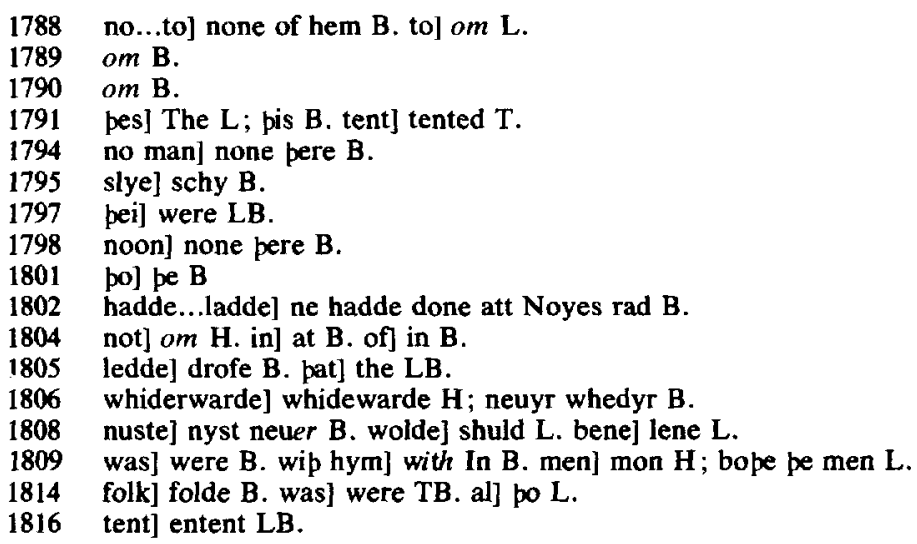


He fyned neuer nyzte nor day

For po caitifs for to pray

For monkynde as seip pe boke

But durste he neuer wip yze vp loke

1820

He preyed to god for her sake

No vengeaunce on po soulis to take

As was taken in pat whyle

On her bodyes pat were so vile

Sip pei were perisshed so reuly

1825

On her soulis to have mercy

So had pei hade wipouten faile

Hadde pei done noes counsaile

Whenne pei forsook his prechyng

And took his speche to scornyng

1830

But now bei fynde hit perfore

pat wolde not leue on Noe lore

For whil pat god 3 af hem grace

pei were not ferde of his manace

//Pis reyn reyned euer on one

Til fourty dayes were agone

pe hezest hil pat was owhore

pe flood ouer passed seuen ellen \& more

Per was no creature on lyue

Pe grounde myzte reche ne ryue

But hit were fisshe pat flet on sonde

Mizte no ping on grounde stonde

On pat streem be ship gan ryde

po wawes beten on euery syde

1817 fyned] faynyd L; blan B. nor] ne B.

1819 monkynde as] manhode $B$.

1820 he] they L.

1822 on...soulis] on po foulis $\mathrm{L}$; of hem $B$.

1824 On her] Of their L. bodyes] goodys B.

1825 perisshed] dede $B$.

1828 noes] by noies LB.

1830 tol in $\mathrm{B}$.

1832 wolde] nold $L$. leue] lere L; lyfe B.

1833 whil] why $B$.

1834 ferde] a ferde $B$.

1836 Til] To B. agone] come \& goon L; all gone B.

1837 owhore] thare L.

1838 passed] passep $B$.

1839 no] non LB.

1840 pe] pat pe B. ne] no $B$.

1842 on] on pe $B$.

1843 streem] flode $B$.

1844 pol be TLB. beten] went B. euery] eche a B. 
Pe stormes straked wip pe wynde

Pe wawes to bete biforn $\&$ bihynde

Noe \& his euere loked doun

To drenche wende pei hadde be boun

But be we truste wibouten stryf

fol. $11 \mathrm{v}$ col. 1

pei weren wery of her lyf

Til seuen sipes twenty dayes were gon

pe flood stood stille euer in oon

Aboute fyue monepes hit stoode

Wipouten fallyng pat fers floode

Ofte pei wende her ship wolde ha ryue

Wip wynde or wawe or dynt of clyue

But zitt is good kyng of blis

To helpe euer whenne his wille is

Whenne pis vengeaun [ce] pus was wrouzt

Oure lorde penne on noe pouzte

And bigan to haue pite

Of him his ship and his meyne

pat myzty kyng soone I wis

Turned her bale into blis

Azeyn he made pe wattres go

Into pe places pat pei coom fro

pe erpe wex bare er pei wende

pe ship on londe bigan to lende

On ermonye hit gon stonde

A heze hil in holy londe

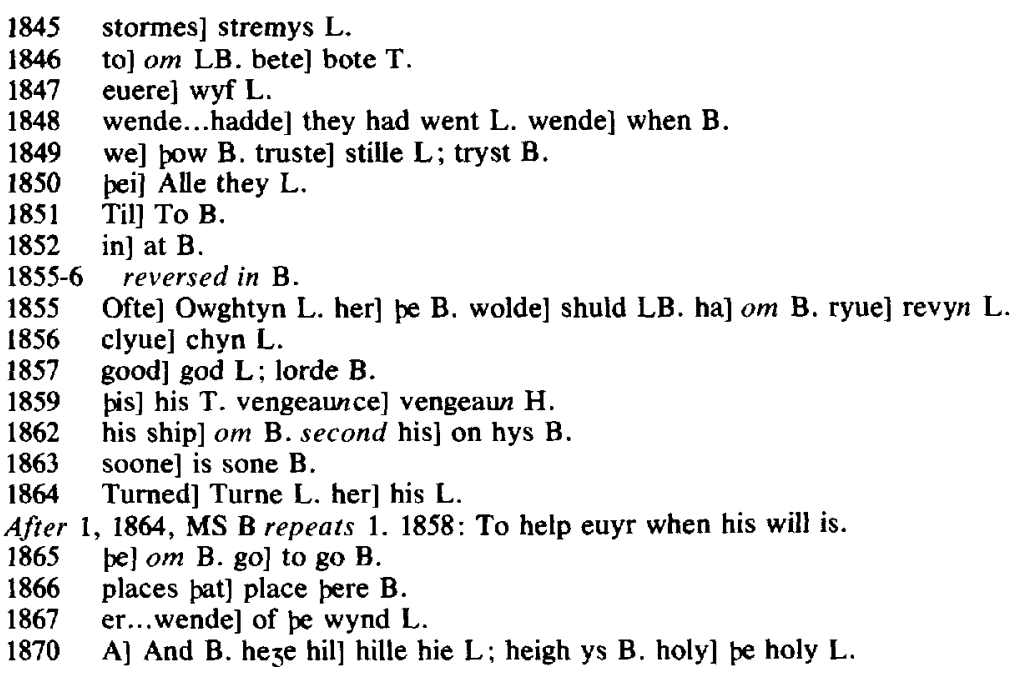


Pe sunne bigan po hir to kype

Noe wex benne ful blipe

And seyde to his sones pre

Childre he seide what rede zee

How shul [w]e of pis watir wit

1875

If pat hit be fallen zit

By a foule pei seide wite may we

If pe erpe bare be

To shippe wol he come no more

If he fynde bare erpe pore

His wyndowe opened po noe

And lete a rauen out fle

He souzte vp \& doun pere

A stide to sitte vpon sum where

Vpon pe watir pere he fond

1885

A drenched beest pere fletond

Of pat flesshe was he so fayn

To shippe coom he not azayn

perfore pe messangere men saye

pat dwellep longe in his iournay

fol. $11 \mathrm{v}$ col. 2

$\mathrm{He}$ may be calde wip resoun clere

1890

Oon of pe rauenes messangere

And whenne Noe perceyued was

of pe reauenes deseit in plas

He let out a dowfe \& took hir flizt

And fonde no place vpon to lizt

She coom azeyn wipouten blyn

Noe roos vp \& let hir In

Sipen abood he seuene dayes

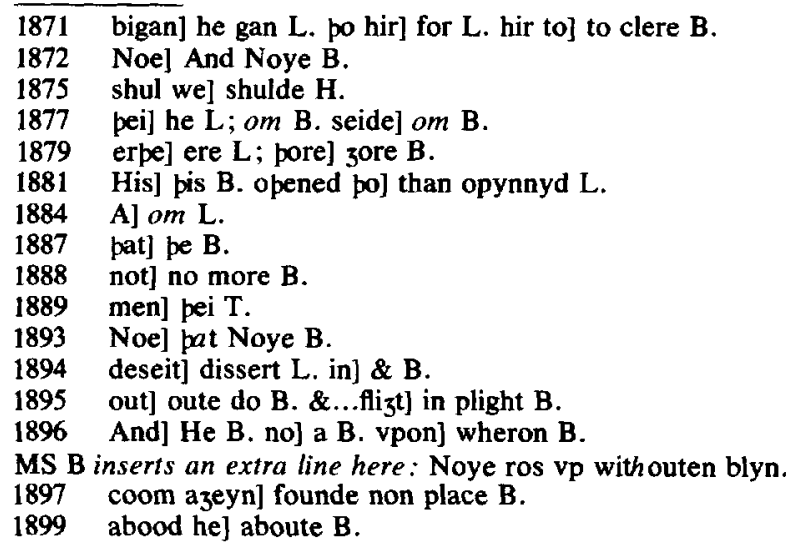


Aftir pat pe bibel sayes

1900

He sent pe dowfe anoper sipe

She wente forp \& was ful blipe

Soone she coom \& dwelt nouzte

An olyue braunche in moupe brouzte

Penne was Noe wel I knawe

1905

pat pe flood hit was wipdrawe

But zit bood he seuen dayes in rest

For fere lest any dam ming brest

Sip he made hem alle out dryue

Foule \& beest man \& wyue

1910

Pese beestis were ful glad in moode

Whenne bei hadde her kyndely foode

Oure lord dide hem soone to sprede

Wipinne her owne kynde to brede

penne bad god vnto noe

To leue pe ship wip his meyne

A tweluemoneb was go bi pis

Bi pat same day I wis

Pat day tweluemonep pat he zeode In

He hit left more ny myn

1920

As perus maior pe gode clerk

Tellep of hym in his werke

To him pen ne coom oure lord hende

And seide Noe leue frende

Pou \& pi sones wip her wyues

1925

I haue saued alle zoure lyues

3ow zitt haue I forborn

pat in my vengeaunce be not lorn

To zow zitt pat I haue let lyue

fol. $12 \mathrm{r}$ col. 1

My brode benesoun I zow zyue

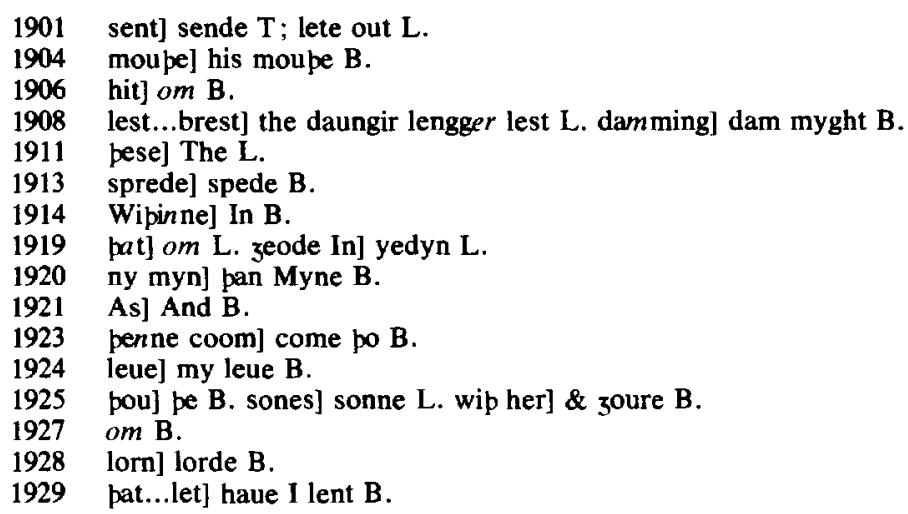


I wol pat of pi osprynge brede

Al maner nacioun and lede

Vche ping on his wyse

I wol pei do pe seruyse

Noe was of his blessyng blipe

And lete reyse an auter swype

He zeode to worshepe god as wyse

peron made he sacrifise

Oure lord god al weldyng

Him liked wel her offeryng

1940

He seide Noe for no chaunce

Shal I not take siche vengeaunce

Fro me doun ward man drouze his [p]ouzt

Now are pei fully doun ybrouzt

And if pou worche aftir my lore

1945

Pou shalt fare wel perfore

To gode pewes pou pe zyue

Loue wel troupe whil pou lyue

For pat ze biforn han sene

Vche man lyue trewely bidene

1950

If pou wolt trowe on my rede

Fle falshede $\&$ pefte as dede

Whoso of flesshe wol haue her fode

Loke pei kaste awey be blode

Alle pat wol trewely holde her lede

Blood to ete I hem forbede

Of beest wip clouen foot in two

Wip chowyng quode $z^{e}$ ete also

I warne zow now alle bidene

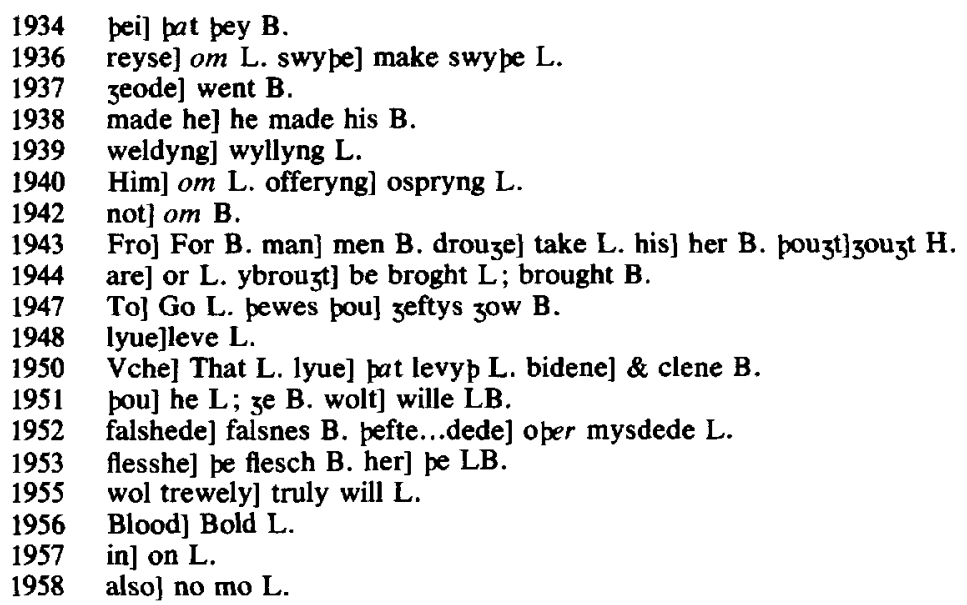


Ete of no beest of kynde vnclene

$O$ no maner worm pat is made

Ne foule pat reuep his lyflade

Also $z^{\mathrm{e}}$ ete of no flesshe ellis

Pat in slowze \& erpe dwelles

Siche fisshe \& flesshe of bope I say

1965

Loke ze caste pe body away

To pe and pyne I bidde also

Be noon so bolde oper to slo

For whoso sleep mon or wyf

Per is no raunsoum but lyf for lyf

fol. $12 \mathrm{r}$ col. 2

I made man aftir myn owne ymage

I wol noon oper do outrage

Euel ow no mon to do to opere

But vche to be opers bropere

A couenande now I hete pe

Pou shalt fro nowe my reynbowe se

Whil bou may se my bowe wipoute

Of siche a flood par pe not doute

If man mysdoop on opere wyse

On hem I shal sette my Iustise

Pat shal ben at pe day of Ire

When ne I shal come to deme wip fyre

Wip trewe werkis loke ze dele

As ze wol loue zoure soule hele

And zeldep to zoure creatour

1985

pe tenpe part of zoure labour

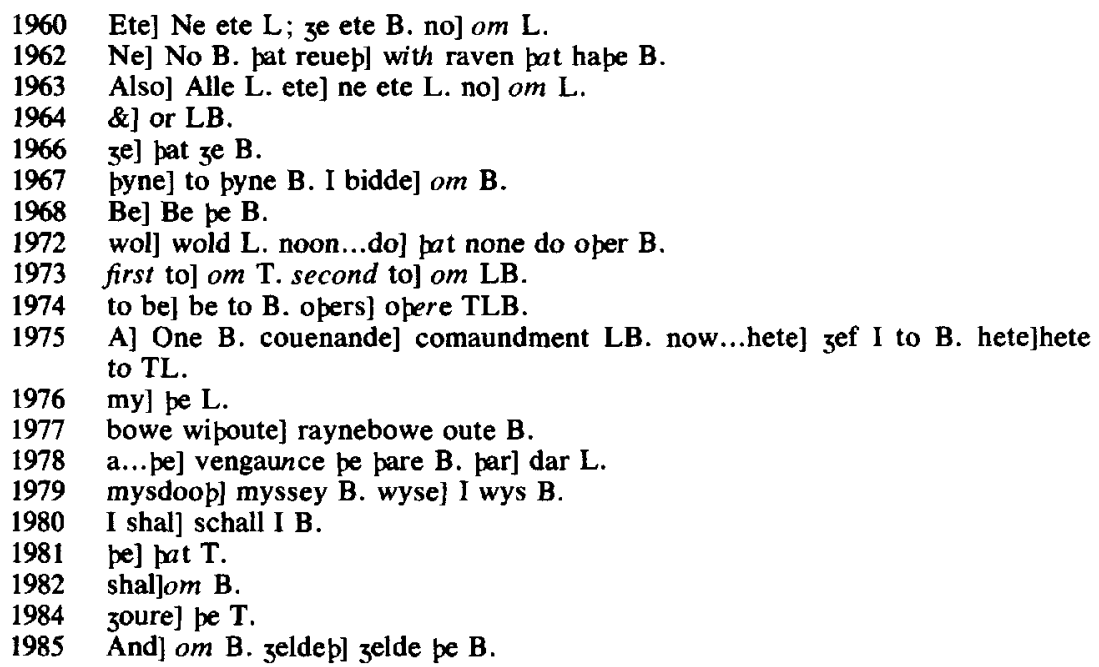


Gode men I wol pat ze se

Bytwene Adam and Noe

Pe tyme was euer lliche grene

pat no reynbowe pere was sene

1990

And pei no reyn on erpe felle

Plente on erpe myzte men telle

Ne purt no mon ete flesshe pat tyde

Til hit made mannes pride

Now is for synne \& pryd of man

1995

pe erpe feblere pen hit was pan

Fro pe watir pat hit so wesshe

Perfore man not now ete flesshe

And feblere mannes state now is

Pen hit was penne forsope I wis

2000

Whenn Noe left pe ship alone

He hadde six hundride zeer \& one

Pe elleuenpe wyntur was witterly

Peraftir as tellep vs metody

Whenne pe world was goonde

In elde of pe pridde pousonde

Noe pe trewe wipouten synne

A newe lyflode he dide bigynne

A newe lyflode went bei to be

Himself and his sones pre

fol. $12 v$ col. 1

2010

Moost to tilpe he zaf hym pan

2013

To flitte breres he bygan

So longe flittyng to hem he souzt

2015

pat vynetrees he hem wrouzte

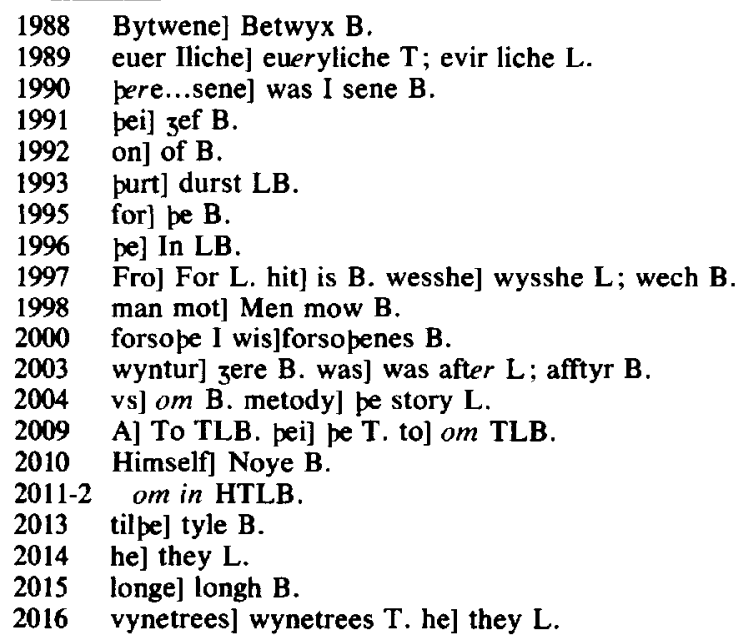


A day bifel he was forswonken And vnwarres of wyn dronken Pouze he himself firste hit wrouzt Perfore be wyn spared him nouzt Dronke he lay \& slept by his one Pere pe sunne vpon hym shone Naked on pat lyme lay he pat men pinke moost shame to se His mydelest sone was cald cam Bihelde \& say his fadris shame He kidde he was vnkynde ynouze To scorne he his fadir louze

To his broper Iapheth seide he Broper come now hider and se

What is pat seide lapheth broper pi fadir slepep seide pat oper He lyp here come se pou shalle Naked vpon his lymmes alle Broper he seide pou seist folye And pat I trowe pou wolt abye If pou of pi fadir make despit pou beest of his blessyng quyt His zonger broper was ful wo For pe elder wrouzte so A mantel fro his necke he toke And zeode bacwarde as seip pe boke $\mathrm{He} \&$ his elder bropere seem Blessedest of pat barnetem Til pei coom pere her fadir lay

2018 wyn] pe wyne B.

2020 him] he LB

2021 He lay aslepe hymselfe alone $B$.

2023 on] of $B$.

2025 His] be B. was] men $B$.

2026 Bihelde] Behynde B.

2027 He kidde] Vnkyd L. vnkynde] \& vnkynd L.

2030 now] om B.

2031 Iapheth] his B.

2032 pi] My B. pat oper] pe toper TB.

2034 vpon] on $B$.

2036 And] om B.

2038 beest] art L; schalt be B.

2039 His] be $B$.

2041 frol of $B$.

2042 as] so $B$.

2043 elder] eldest TLB.

2044 Blessid they were of pe kyng of hevyn L.

2045 Til] To B. 
perwip hym couered pay

Herby may we vndirstonde

Was no breech foundide po in londe

Noe wip pis mantel awoke

His sones scorne he vndirtoke

2050

His malisoun on hym he leyde

fol. $12 \mathrm{v}$ col. 2

And sip to him penne he seide

Cam wipouten any doute

Vndir pi breperen pou shalt loute

Vndir hem to be as pral

2055

Pou and pyn ospring al

Pe opere two for her couerynge

Noe $z$ af his brood blessynge

To seem \& lapheth penne seide he

Now shal hit al forzyuen be

Lathpe \& wrappe or any plizt

If 3 e azeyn me han done vnrizt

Of $z^{\circ}$ w shal pe ospringe sprede

pat shal ouer al haue lordehede

Blessed shal be zoure tabernacle

Ful of myrpe \& of myracle

And god hit grante pat hit be so

Pat al pis world be zouris two

To cam he seide foule feloun

Pou hast pe kynde of pat natioun

Of caym curside moost of opere

pat wip tresoun slouze his bropere

Do pe swithe out of my sizt

Pou art \& shalt be cursed wizt

By me owe pou not to dwelle

I drede pi wonynge be in helle

Fle fro me bou waryed ping

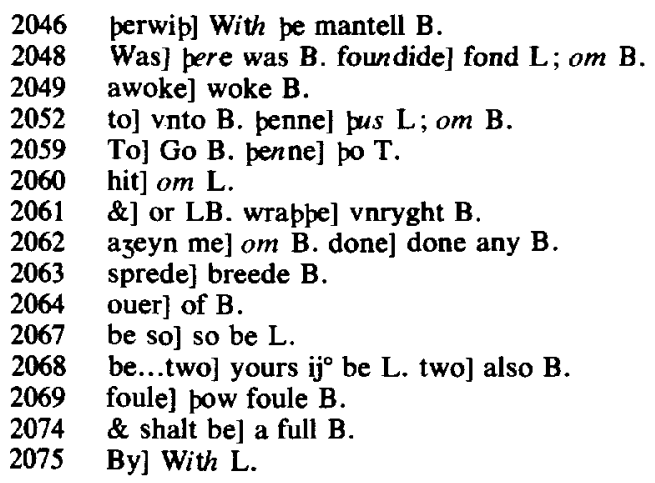


Now shul we parte for pi skornyng

Awey he fledde he and his

Oure lordis enemyes pei were. I wis

Noe pe graciouse $\&$ pe gode

Lyued fourty zeer aftir pe flode

Nyne hundride zeer \& ten sipe fyue

So longe lastede Noes lyue

For his trewe lyf to neuene

He sittep now wip god in heuene

His sones pat I biforn of melt

Al pis world bitwyxe hem delt

To seem asye . to cam aufryk

To iapheth europe pat wilful wyk

2090

Alle pese [pre] were ful ryche

But seem part was noon opere lyche

For be world was as we here

Dalt in pre partyes sere

In pre partyes pryncipal

But pei were not paringal

For asye is wipouten hope

As myche as aufryk \& europe

Asye is pe pridde in dole

And is pe haluendel zitt al hole

Hit is pe best for peryn is

pe holy londe and hepenis

Wip preciouse stoonis spices of prys

In pat lond stondep paradys

Inde and peris . and arabye

Babilone . Iuda and sulie

And mony opere dyuerse cuntre

2079 first hel pay B. second he] bope he B.

2081 second pe] om $B$.

2083 Nyne] Sevyn B. sipe] and B.

2085 lyf] love L.

2086 sittepl is $\mathrm{L}$.

2087 sones] socour L. melt] tolde B.

2088 bitwyxe] bytwene LB.

2089 asye...aufryk] he gaf Asie / To Cam he gaf Aufryke L.

2090 europe...wyk] he gaf Europe L. wilful] wikkyd B. pre] om $\mathrm{H}$. ryche] riche to grope L.

was noon] nas not $L$.

was] om $\mathrm{T}$. we] $\mathrm{z}^{\mathrm{e}} \mathrm{B}$.

not] om L.

zitt] om B.

first and] om B. sulie] Surry B.

dyuerse] om B. cuntre] contreyes B. 
Perynne is babilone pe moost cite

// Aufrik is pat oper partye

Bifore pat wasse called libie

Mony a cuntre perinne es

And hoge citees more and les

Perynne is cartage a cite stronge

And oper many also amonge

Pe myche londe of ethiopye

Ienile . mortaygne \& indie

Pat lond is moost into pe soup

Pere bat blo men are ful coup

// Pe pridde party is not best

Hit is moost into pe west

$\mathrm{Al}$ on pis syde pe grickisshe see

Hadde lapheth to his lyuere

Hit hette Europe where moost today

Abidep of pe cristen lay

Perynne is Roome pe heed cite

Abouen alle pat owe to be

And mony anoper riche kyndom

Pat I to telle haue no toom

Of pese pre bigan to sprede

pe world to fille on lengpe \& brede

Of hem roos mony men

Of dyuerse kyndes sixe sipe ten

Kny 3 t \& pral and fre man

2109 pat oper] pe todyr B. partye] partete $B$

2110 Bifore pat]pat somtyme $B$.

2112 hoge] grete $B$.

2113 is] om T. al pat B.

2114 many also] al so many TB. amonge] one $B$.

2115 pe] A B. of] is B. ethiopye] Echophe B.

2116 mortaygne] nartayrn $L$; mortelage $B$.

2117 pat] This L.

2118 pere] Where $B$.

2119 party] part T; pte $B$.

2121 syde] side is L; halfe B. grickisshe] grekys L; grete B.

2122 Iapheth] Iaphell B. to] vnto L; all B.

2123 moost] om B. today] in fay $L$.

2124 of] most of $B$.

2125 pe] pat $B$.

2126 owe] it ought $B$.

2127 riche] right $L$.

2128 I] it B. haue] haue I B.

2129 Of] On B.

2130 to fille on] full of $B$.

2131 roos] aros B.

2132 sixe sipe] sexty \& B.

2133 Kny ${ }^{t}$ ] Lorde B. \&] om L. pral] kyng B. fre] bonde B. 
Of pese pre briperen bigan

Of sem fre mon of iapheth knyzt

Pral of cam waryed wizte

Bigynne we nowe to telle of sem

And sipen of his barnteem

Sem was trewe in goddes lore

He lyued seuen hundride zeer \& more

pis ilke sem wa[s] cald sedek po

Sipen melchisadech also

Oure swete lady as we fynde

Coom out of pis same kynde

Of salem preest \& kyng he was

pat now het ierusalem in plas

Pe firste he was of opere born

pat wip wyn and breed of corn

Made sacrifise to god so trewe

In tokenyng of pe lawes newe

pis sem lyued I rede of here

Til ysaac was of seuenty zere

Sem hadde fyue sones fre

Of oon to speke is good to me

Pat is of hym of whoos sede

He was born pat bett oure nede

Arphaxat lyued wipouten were

Pre hundride \& eizte \& pritty zere

Foure hundride zeer his son caynan

And eizte \& pritty fro he bigan

2134 briperen] fyrst $B$.

2135 mon] men $B$.

2136 pral] And pralle B. waryed] pat weryed B.

2137-8 om FGHTLB

2141 was] wal $\mathrm{H}$.

2142 melchisadech] mylchysathek $L$.

2144 pis] be LB. kynde] om L.

of] of alle $\mathrm{L}$. of opere] pat was $\mathrm{B}$. born] byforn $\mathrm{L}$.

wip...and] dyd make B. and] om L. of] \& L.

to....so] so to god $B$.

tokenyng] fygure B. pe] po T. lawes]lawe B.

seuenty]seuenten $B$.

sones] sonne $\mathrm{L}$.

of hym] om B.

He...born] Was borne he B. pat...oure] our bote at $L$.

Arphaxat] Arfayat B.

Pre...pritty]CCC and xxxviij L. pritty] twenty $B$.

2160

line om $\mathrm{B}$.

line om B. eizte... pritty] xxxviij $\mathrm{L}$. 
Foure hundride zeer his sone sale

And also pritty zeer and pre

Foure hundride $z^{\text {eer }}$ his sone heber

Wib foure \& fourty sett to per

// Phaleth his sone witterly

Two hundride zeer nyne \& pritty

Ragan his sone pat was

Twelue score zeer saue oon las

Two hundride zeer serut his sone

And pritty was his lyf in wone

2170

Foure score \& eizte nachor had lyue

Thare his sone two hundride \& fyue

2172 fol. $13 \vee$ col. 1

pat oper elde endep in thare

Whiche bigan at good noe

pat tyme was pis world so zonge

pat alle me[n] spak wip o tonge

pat is ebrew for to say

pat iewes speke zitt to pis daye

// Iapheth hadde him sones seuene

A party synful for to neuene

Gomor . madan . Gena . Magog

Tubal . Tiras . and mosog

Pis gomor hadde sones pre

Togoriens . riphat . Asine

Gena had foure oon cethim

Elisa tharsis . and dothahim

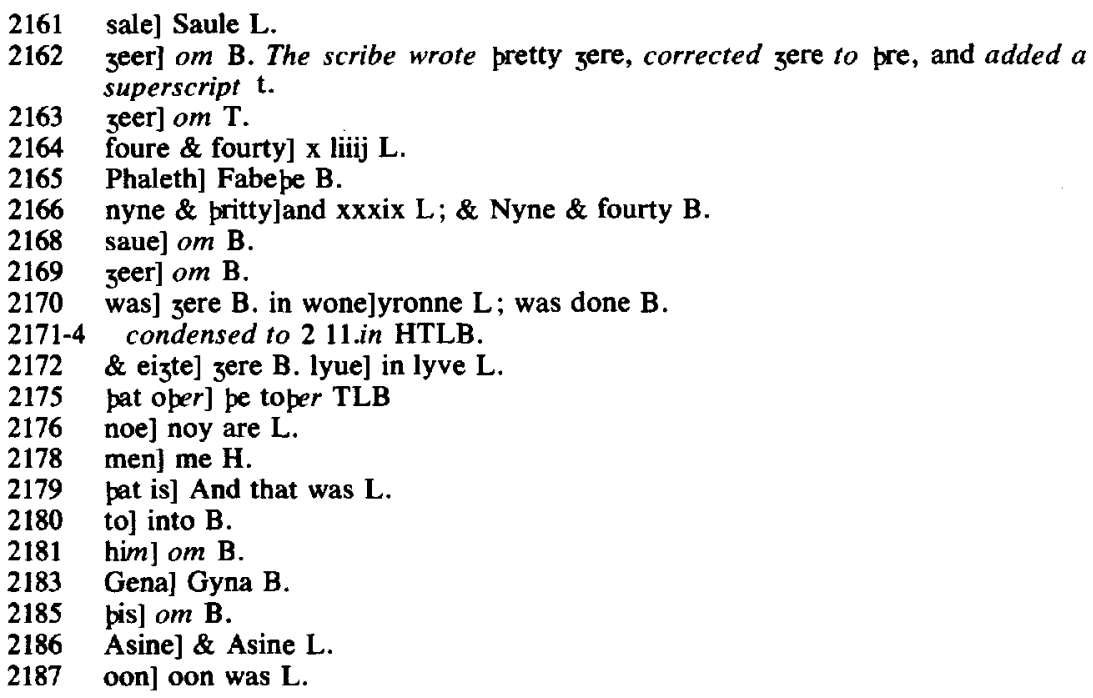


To eillondis pes pei drow

Of hem sprong foly ynow

2190

Cam foure sones had hym

Chus phut canan \& mephaim

Of chus saba \& ielula

Sabatha regma sagabata

Of chus bicam nembrot also

pat in his tyme dide myche woo

For he was proud fers \& felle

Of hym now wol I telle

pis nembrot wip his foule pride

He wende to worche wondrs wyde

2200

Fer aboute men bar his name

Miche he coube of synne \& shame

Of babiloyne kyng stif in stour

And also wrongful emperour

Robber \& monqueller greet

Al he lyued wip euel bygeet

Was per noon pat woned him by

pat myzte of him gete mercy

Ouer al he went wip greet outrage

Pat tyme was pere but o langage

Ebreu pe firste pat adam spak

Fro eest he brouzt an euel pak

Into be felde of semare

fol. $13 v$ col. 2

Sixty werkemen pei ware

To dwelle wip nembroth pei coom

And tooke a counsel amonges hem

A foly counsel took pei soone

2189 To eillandis] ille landys B. pes] all thise L; om B. pei] om L.

2190 foly ynow] folys newe $B$.

2192 \& mephaim] nepthalim B.

2193 saba] come Sala L.

2194 regma] regina $L$.

2195 chus] this Chus L.

2196 dide] was $B$.

2199 wip] wis $T$.

2200 worche] haue wrought $B$.

2202 he coupe] coupe he $B$.

2204 And] om $B$.

2208 pat...him] Of hym pat myght $B$.

2209 Ouer] On B.

2210 was pere] pere was $B$.

2212 brouzt] wrought $B$.

2214 pei] pere $B$.

2216 a] om B. 
To werre vpon pe sunne \& moone Here witt was ful of felony

Perfore a foly coun sel seide I

Of her pryde coupe no mon telle

In sennare pei toke to dwelle

Nembrot hem seide on pis wyse

Me pinkep sires bei were vnwyse

Oure eldres pat biforn vs were

Whenne pei coupe fynde in no manere

For to kepe hem fro pat flood

pat dreynt pe world and ouerzood

I rede we bigynne a newe labour

Do we wel \& make a tour

Wip squyre \& scanteloun so euene

pat hit may reche heizer pen heuen

God shul we conquere wip fizt

Azeyn vs shal he haue no my ${ }^{t}$

Or at pe leest holde hym stille

And lette vs not to do oure wille

pat euer whenne we haue chesoun

Frely may clymbe vp and doun

Pese foolis soone gedered hom

Wip greet enuye pis werk bigon

Two \& sixti fadome brade

Was pe groundewal pat pei made

When ne pei hadde made pe grounde

pe werk bei reisede in a stounde

Wip tyel \& teer wipouten stoon

Oper morter was per noon

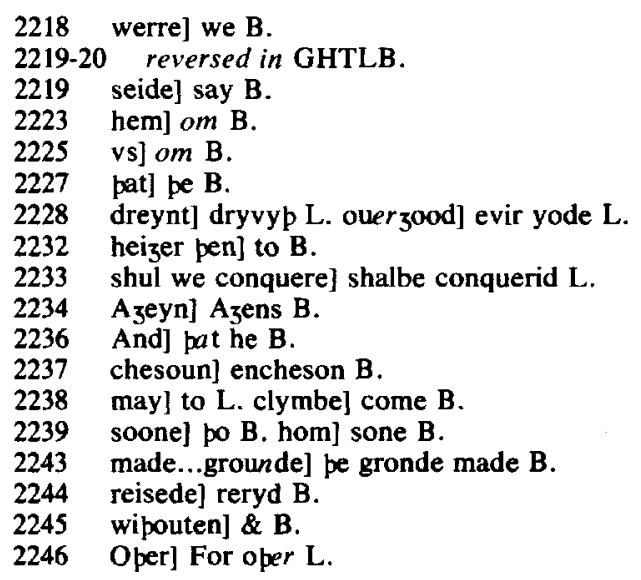


Wip corde \& plum pei wente so hyze

pe hete of sunne myzte pei not dryze

Wip horses \& wip camel hyde

pei hiled hem heete to abyde

pei seide wheper god be wroop or blype

His estres wol we se swype

Now we ben pus fer warre

fol. $14 \mathrm{r}$ col. 1

Oure wille may he not forbarre

// But grete god pat is so hende

2255

A curteys vengeaunce can he sende

pei pat outrage on hym souzte

Lymme no lyf he refte hem nouzte

But so he menged her mood

pat noon opere vndirstood

Of siche speche as he wolde say

Her tongis dyuersed fro pat day

For shame vchone pat werk forsoke

And went away as seip be booke

Perfore hit hette babiloyne

pat shent ping is wipouten asoyne

pere were alle pe speches part

Of dyuerse londis to dyuerse art

First was but oon \& no moo

Now are per spechis sixty \& two

pis tour was selly made on hizt

Fyue pousande steppes stood vprizt

Also eizte score \& fourty perto

pus made pese foolis hem to do

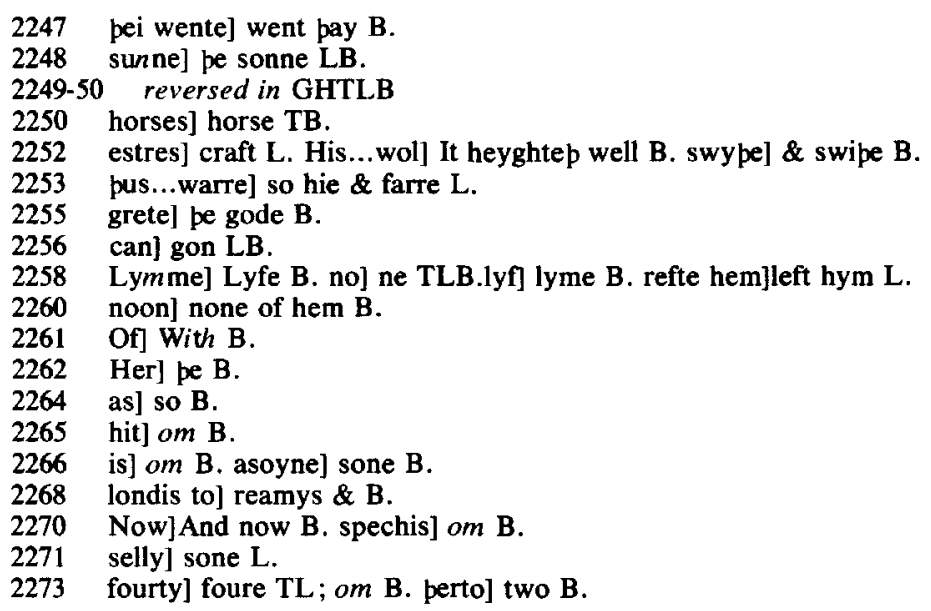

2273 fourty] foure TL; om B. perto] two B. 
Ten myle compas al aboute

pat story tellep out of doute

At pis werke was not sem

$\mathrm{Ne}$ noone of his barnteem

Perfore ebreu her speche han pay

pat iewis holden to pis day

// Pis nembrot was pe firste kyng

pat fonde in maumete mystrowing

Longe he regnede in pat londe

In maumetrye first feip he fonde

pat he bigan lastep zete

Sarazines wol hit not lete

Aftir his fadir pat was dede

A vigur was maad by his rede

2290

He com maundide alle men

As god pei shulde pat ping ken

What for loue \& what for doute

Alle hit worsheped to loute

pis euydense byhelde opere

2295 fol. 14 r col. 2

pat summe for fadir \& als for bropere

For frendes dede pat was hem dere

Ymages pei made of metalles sere

$\mathrm{Bi}$ hem pis lawe was bo bigunne

Soone was hit ouer al run ne

For frendes deep ouer al pe londe

Siche mysbileue vp pei fonde

Fendes crepte bo ymagis wipynne

And ladde folted men to synne

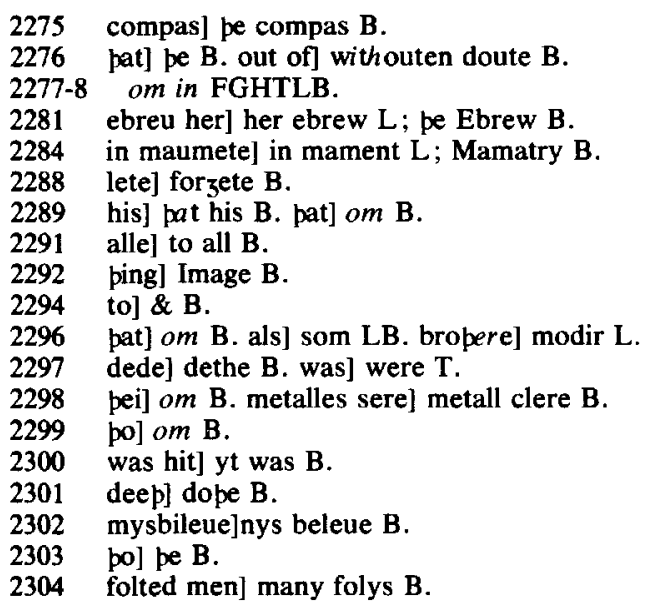


Thre sones had thare oon abram

Also nacor and aram

Thre sones had nacor pe lele

$V s$ and bus and batuele

Of vs coom Iob of bus balam

Of batuel rebecka \& laban

Of aram a sone wip douztris pre

Melcha . loth \& dame sare fre

Of pe pridde elde is now to telle

Who so wole a stounde dwelle

Of Abraham now wol we drawe

pat roote is of pe cristen lawe

I say perfore he is pe roote

For of hym sprong oure alper boote

pat boote pat brouzte vs into myrpe

Pourze pe hooly maydenes birpe

Of hym \& his kyn shul we rede

Pat wondirly bigan to brede

Oure lady wex out of his sede

We pray hir for hir maydenhede

Pat we may of pis story say

Hir to worshepe hir sone to pay

Abraham pat we here of neuen

Was wel loued wip god of heuen

Trewe he was euer in dede

Ful of feip \& of holyhede

$\mathrm{He}$ and his good wyf sare

Ful of chastite pei ware

Two douzteres had aram his broper

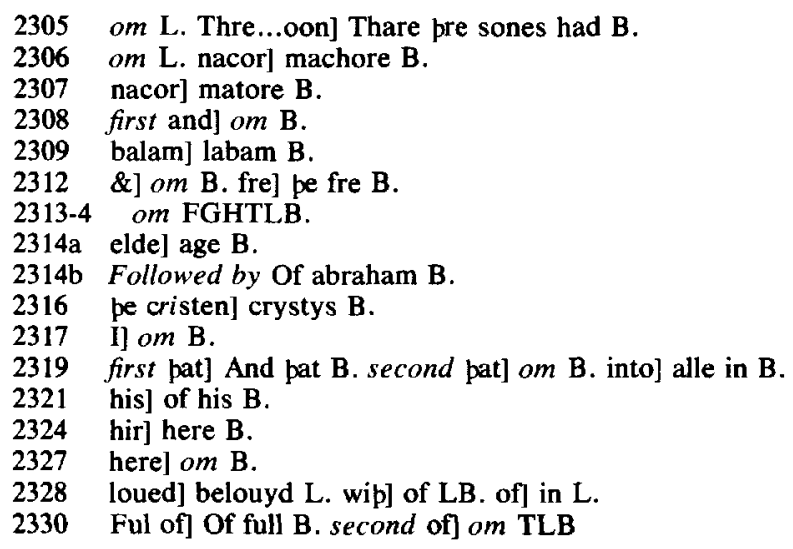


He spoused pat oon nachor pat oper

For bi pe lawe pat pei lyued ynne

2335 fol. $14 \mathrm{v}$ col. 1

Men shulde not spouse but in her kynne

He was bope meke and hende

Oure lorde him made his pryue frende

He loued sopfastenesse \& rizte

perfore oure lord to him hizte

A childe to brede of his ospringe

pat al of praldam shulde bringe

And per shulde also of his seede

So myche puple aftir breede

pat no man myzte pe somme neuen

Moore pen pe sterres of heuen

$\mathrm{Ne}$ penne pe grauels in pe see

So multiplyinge shulde pei be

He leued pis wip herte stabel

pis biheste myzte be no fabel

As he leued so he fonde

Oure lorde helde him trewe couenonde

But longe he ladde him wip delay

To more be mede of his fay

//Of sixty zeer he was $\&$ fyue

When ne his fadir was faren of lyue

For him he was in mournyng pouzt

Til oure lord him counfort brouzt

And seide to hym wip a sown

Abraham loke pou make pe bown

Pou pi catel and pi meyne

Out of pis londe pat ze fle

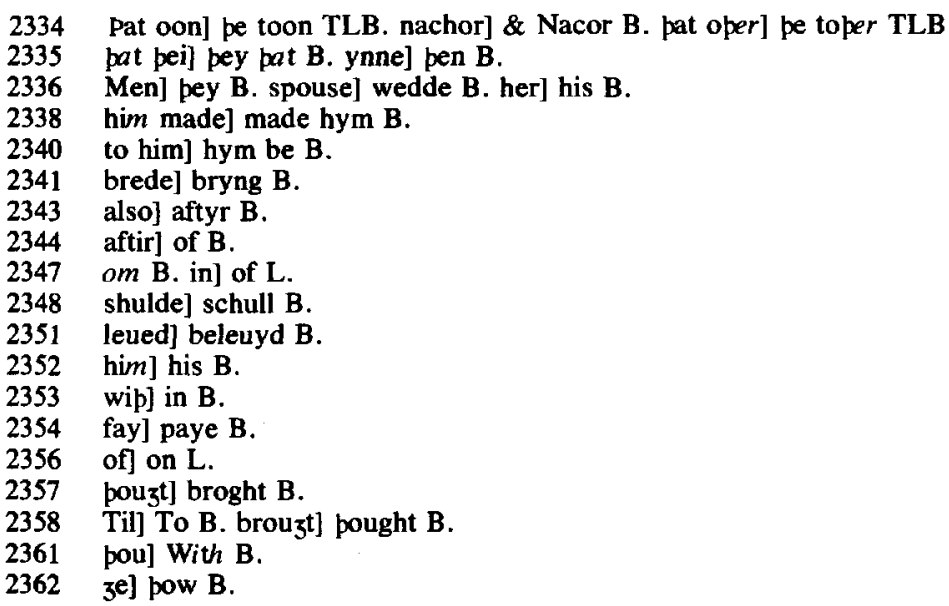


ze shul wende to a bettur londe

To loth pi broper sone in honde

To canaan ze mosten drawe

A lond pat I shal zow shawe

Pou leue aram pe londe of ire

Of canaan to be lorde and syre

pider to wende be not ferde

pere shal be pi kyndely erde

Alle pat wonen per aboute

To pe shul be vndirloute

pere shal pi name reysed be

And alle pe heires pat comen of pe

I shal hem blisse pat pe wol blisse

2375 fol. $14 \mathrm{v}$ col. 2

My blissyng shul pe opere mysse

// Abraham went \& wip him loth

Meyne \& catel wel I woot

He coom \& dwelled he and pei

Bisyde sichen in a valey

But pere felons folk pei fond

Pat myche waasted of pat lond

Als soone as pei pider cam

God him shewed to abraham

And seide abraham pis is pe land

pat pou \& pyne shul haue weldand

Abraham of troube so trewe

By bethel reised an auter newe

He worsheped god kyng of blis

And he him blessed \& alle his

Abraham turned him into pe soup

To se pat londe pouzt vnkoup

In pees he wende hit haue in wolde

As oure lord hadde hym tolde

But soone whenne he had pe lond

An hunger fel I vndirstonde

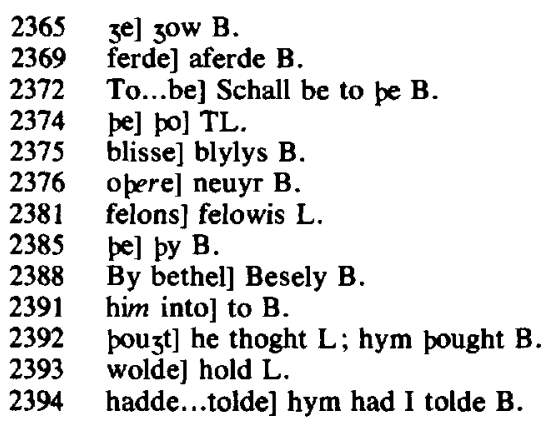


Her corn wanted on vche syde

Hard hit was hem to abyde

Abraham to selle fond no sede

To egipte wende most he nede

Sare his wyf wip hym to lede

Hade pei no corn hem wip to fede

And as pei pidurwarde went

Pis forwarde made pei pere present

//Lem mon he seide soore I me drede

2405

Now we go bi pis vncoup lede

For pou art feir whenne pei pe se

Wip myzte pei wol pe take fro me

Seye pou perfore to oon \& oper

pat pou art my sistir \& I pi broper

Elles pe folk whenne pei pe se

Wol me sle for loue of pe

Sir she seide hit shal be do

Penne coom pei pat cuntre to

When ne pat folk had hir sene

Alle speke of hir she was so shene

And so hir preysed to be kynge

pat he made hir to hym brynge

But god hir kepte pat was hir wip

And saued hir so in his grip

pat myzte no man wip leccherye

Hir body touche wip vilenye

pe kyng was ferd for goddes gram

And delyuered hir to Abraham

And seide why mades pou vs in were

2415 fol. 15 r col. 1

To calle pi wyf pi sister dere

Take hir here and brouke hir wel

Of pyn wol I neuer a del

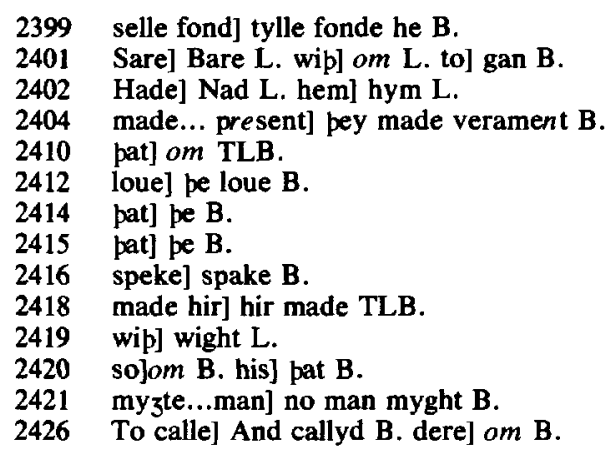


But leuer me is of myn pou haue

Gold and siluer he hym zaue

And commaundide pourze his lond

Men shulde him plese \& haue in hond

And when ne he wolde no lenger lende

pat he most frely hamwarde wende

And alle pe godis he wip him led

To lette him streitly he forbed

Abraham went home \& his wif sare

He loued hir bet pen he dide are

For worshepe pat she made him wynne

And she vnsouzt sakles of synne

2440

Into betel pei coom anoon

pere he firste sett his auter stoon

Bitwene him \& his neuew loth

Beestaile pei hade ynouze I woot

To commune pasture bei took pe lond

pat pere lay nexte her hond

But when ne her stoor bigan to brede

Her pasture po wex al nede

Perfore her herdis stroof for hit

Her beestis nedis most pei flit

Fro pat folk pei were among

Pat dide her stoor myche wrong

Pe nabethens pat lodly lede

Ful of wronge \& wickedhede

pei my $3^{t}$ wip hem haue no rest

pei most part to seke her best

Abraham seide wip wordis hende

Loth my neuew and my frende

pis lond is wyde pat we are ynne

God vs helpe hit to wynne

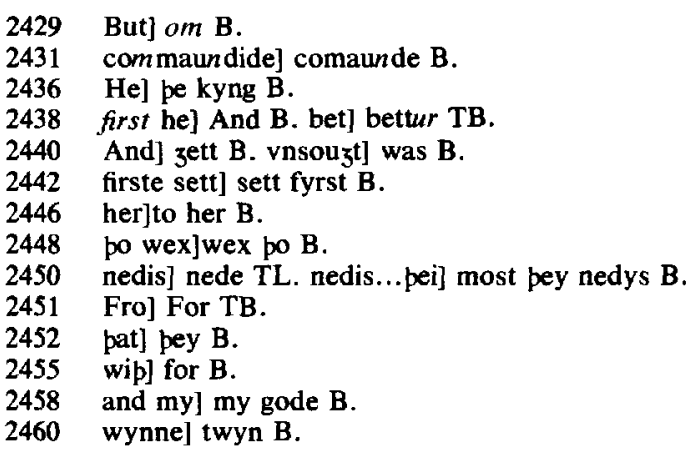


Of pis cuntre pat is so wyde

Pou chese to wone on sum syde

Wheper pou chese on rizt or left

I wol take pat pou hast left

Loth loked toward flum iurdan

A dale he chees to hym pan

A lussom lond \& fair cuntre

Pe flum ran pourze fair to se

pe lond of gomor perby lys

Pat pen ne was lyk to paradys

Pat tyme ar hit had done pe sake

Til god peron vengeaunce can take

pat lond to wone In loth pouzt beste

Abraham chees toward pe eest

pe lond of sodom bar greet blame

For hit was in a wickede fame

Pei synned so foule among hom

pat bope hem cursed god and mon

Abraham last \& his pan

Bisyde pe lond of canaan

Vndir pe foot of mount mambre

pere he chees to sette his se

Pat ilke stide hett chebron

A wondur wynsum stide in won

He made an auter in pat stide

And sacrifise peron he dide

pat oure lord shulde on him mynne

And make him worshepe to wynne

His tabernacle he sette per sone

God lete myracle for hym done

// In pat lond was a werre strong

And hit lastede sum del long

Foure kynges werred vpon fyue

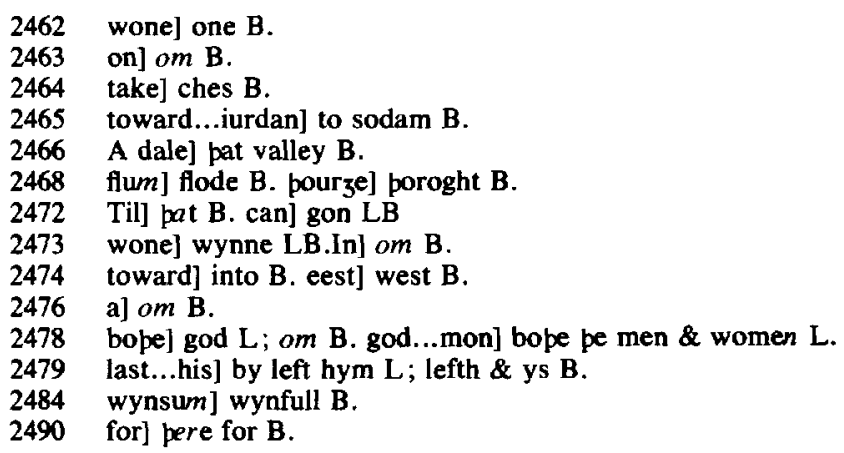


Pe fyue azeyn pe foure to stryue

Pei smoot togider neuer pe latur

2495 fol. $15 \mathrm{v}$ col. 1

In a dale bisyde a watur

So long pei hew on helm \& shelde

pat foure of fyue wan pe felde

pe fyue zaf bak to wynne away

And fellen into a putt of clay

2500

pere fel pei doun al in swowe

And her enemyes pere hem slowe

Sip pei took to wynne pat lond

Al pat pei bifore hem fond

Loth pei tok and led hem wip

Was noon pei wolde graunte grip

pei helde hores was pe lond

For pei hadde pe ouer hond

Hard helde pei loth pat day

A mon vnnepe myzte passe away

To come to Abraham for to telle

Of lothis chaunce how hit felle

Abraham was ful euel likonde

Whenne he herde pis typonde

He dide to geder togider his men

Pre hundride eizte seruauntis \& ten

And pryuely he made hem byde

Til azeyn pe euentyde

And po he brouzte hem to a pas

Men calde pere pen themas

pere he delt his folk in two

pat pe opere shulde, not skape hem fro

pese kyngis hadde of no mon doute

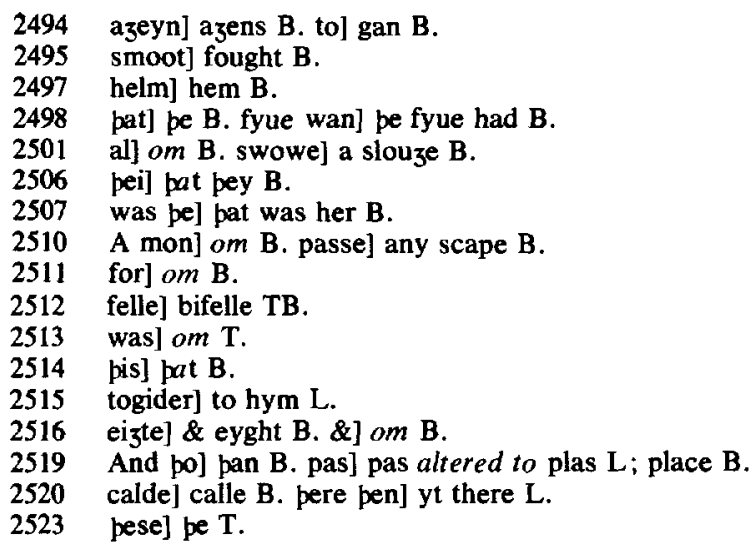


Her folk pei scatered al aboute

Abraham pat was in troupe strong

Hepen men he mett among

Fro hem he delyuered loth

Wip al pat catel vche grot

Slayn were po knyztis pat nyzt

Pourze pe grace of god almy $3^{t}$

Pe folk of sodom were ful fayn

Whenne abraham was comen azayn

Pei sawe her frendis hool \& sounde

And wiste her foos brouzte to grounde

Melchisedech wip wille glade

2535 fol. $15 \mathrm{v}$ col. 2

Offeryng of wyn and breed made

Pat of ierusalemes londe

Was kyng \& prest \& hade in honde

Trewe he was wyse and hende

Of her conqueste took pe tende

Abraham his benesoun 3 af he

And bad alle to hym tentynge be

Of pray wolde abraham nouzte haue

But vche man his owne zaue

Miche was pe loue word pon

pat Abraham gat of mony mon

Pei seide hit was he in sizt

Oure lord in him wolde holde his hizt

// Abraham went hoom \& wip him ledde

His folk \& whenne he was in bedde

In sleep he herde oure lordis steuen

Sopely to him spak in sweuen

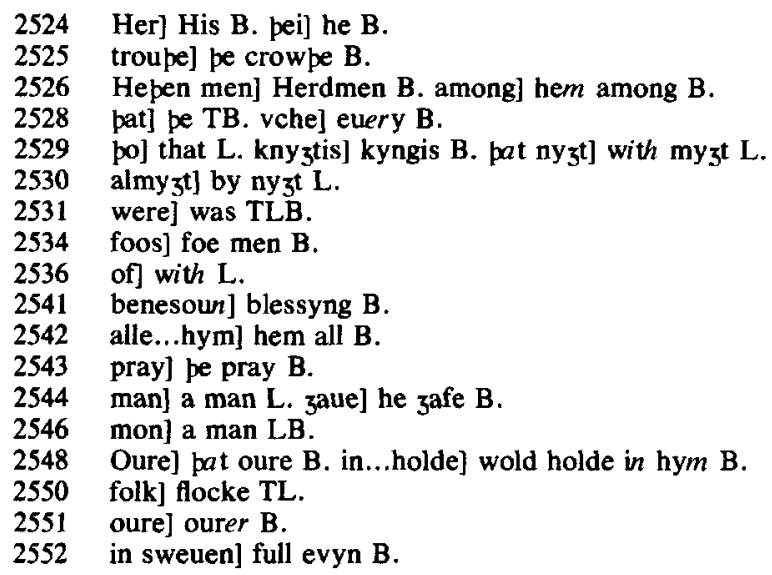


And seide Abraham par pe not drede

I shal pe helpe in al pi nede

pat I haue pe in dede hizte

2555

To wynne bou shal not faile myzte

Lord he seide how may pis be

What is pi wille to zyue to me

Pou wost wel childe haue I noone

But my seruauntis sone alone

Pat seruep me eliazar

Myn heire wolde I pat he war

Sip pou me zaf noon oper barn

Nay seide god I shal pe warn

pat he pyn heire shal not be

But a seede pat comep of pe

Abraham he seide come heroute

Byholde pe sky al aboute

Pe childer pat of pe shul brede

No more shal pou con hem rede

pen sterres in sky or sond in see

To knowe hit shal ful selcoupe be

Be trust in pis pat I pe hizt

pe hit to reue shal noon haue my ${ }_{3}$

Abraham pis word forzaat nouzt

Oure lord to serue was al his pouzt

Penne made Abraham his sacrifise

fol. 17r col. 1

As god him tolde on what wyse

When ne pis was don \& al purueide

$A$ voys penne pourze a cloude seide

pat per aftir a wel longe while

In egipte shulde his sede exile

2553 par] dar $L$.

2554 helpe] kepe B.

2555 I haue pe]pe haue $B$.

2556 shal] om $B$.

2558 is] as B. zyue] wynne L. second to] om B.

2563 Sip] Syn L.

2567 heroute] peroute $T$; oute $B$.

2568 sky al] fyrmament $B$.

2569 be childer] pat chylde B.

2570 shal pou] schaltow B.

2571 first in] or T; on $\mathrm{L}$; of be B. second in] by pe $\mathrm{B}$.

2572 selcoupe] felcoupe $L$; coupe $B$.

$2573 \mathrm{Be}$ ] But $\mathrm{L}$; om $\mathrm{B}$. in pis] well to me $\mathrm{B}$. pe] have $\mathrm{B}$.

2574 pe... reue] To reue pe $B$. noon] no man $B$.

2575-2734 a leaf missing in $\mathrm{H}$. Text is from $\mathrm{T}$.

2575 pis] for pis B. forzaat] pat B.

penne] om $\mathbf{B}$.

2581 per aftir] aftyrwarde B. wel] om B. 
In praldome foure hundride zere

But bei shulde aftir bye hit dere

Pei shulde hem holde in pat prong

2585

But wroken on hem shulde be pat wrong

Penne shulde pe seed of abraham

Azeyn com to her londe pan

In pees her heritage to holde

As tofore was hett \& tolde

2590

Sare was childeles zitt wip pis

pat myche peraftir zerned I wis

She serued hir pis womman

pat Agar hett Egipcian

She seide to Abraham priuely

2595

pou seest no childer bere may I

And siben I may bere no barn

Agar my wom man I pe warn

$\mathrm{Bi}$ pe shal ligge if pou wol so

For I am bareyn me is wo

2600

If any childe of hir were pine

I wolde holde hit as for myne

Sare as she bifore had seid

Bi hir hosbonde agar leid

Agar was wip childe in hy

2605

And liztly let of hir lady

To Abraham dam sare saide

Pat wenche pat I bi pe layde

For she is wip childe bi pe

Greet spit she letep bi me

Abraham hir sone vnswerde

Chastise hir bou hast pe zerde

So chastised sare hir pat day

Pat she was fayn to fle away

But in hir flizte as she zode

An aungel coom biforn hir stode

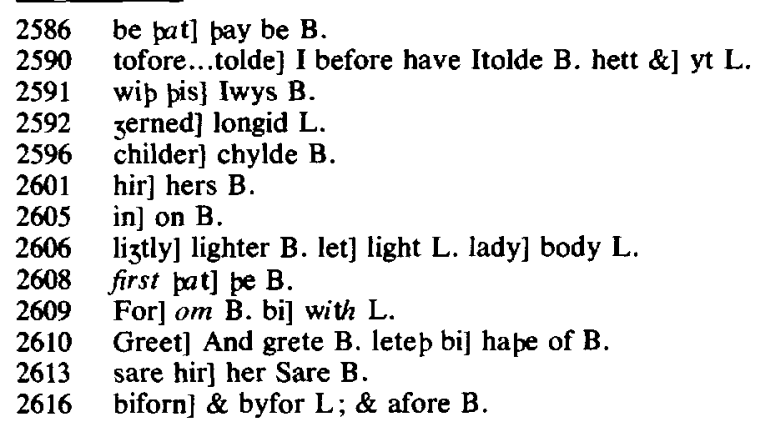


In wildernes bi a welle

pus gan he to hir spelle

He seide Agar whennes comes pou

And whodirwarde woltou go now

Fro my lady she seide I go

For me she dop mychel wo

pe aungel seide wende azeyn

Hir to serue pou be feyn

Wende azeyn I saye for $\mathrm{pi}$

Of pi seed zitt shal multepli

Muchel folke and I pe warn

pou art wip a knave barn

Pou calle him Ismael Agare

God wol couer be of pi care

He shal be fers \& cruel bope

Azein alle ledes wondir wrope

Azein him alle. azein alle he

A wondir wizte mon shal he be

Agar hoom to hir lady went

And serued hir wip good entent

Soone aftir for to telle

She was lizter of ismaelle

When ne he was born abraham had pon

Foure skore \& six zere ouer gon

Of pis childe he was as blipe

As his fadir were brouzt to lyue

Whenne he was fyue skore zere \& nyne

God spak to him a litil tyme

Abraham he seide for me bou go

I shal go for pe also

Multeplie pi seed I shal

\footnotetext{
2619 whennes] when L. comes pou] comstow B.

2620 go] om B.

2622 me...dop] sche dothe me so $B$.

2625 I saye] he sayde $B$.

2626 3itt shal] schall zett B.

2628 pou] pat pou B. knave] om B.

2632 Azein] Azens B, wondir wrope] he schal be lope B.

2633 second azein...he] meyen schall be $\mathrm{B}$.

2634 shal he] he schal B.

2638 lizter] L has lighter, changed to lightyd.

2640 skore] score zere B. zere ... gon] Igone B.

2641 pis] his $B$.

2642 were] was $B$. to] of $B$.

2643 fyue] foure B. zere] om B.

2644 tyme] steuyn B.
} 
He louted \& panked him of al pen ne dud oure lord to eche his name And seide pou hettest now abrahame 2650

Abraham hastou zore be calde pat name no lenger shaltou halde pi name is pus myche to rede As fadir of mony folke in dede And if pou holde my techyng Of pe shal com prince \& kyng pat shul welde al pis cuntre As I bifore haue hette to be pat pou hast had in knowleche pine as heritage shul hit reche 2660 Al pe kyndome of pis lond To haue \& holden in her hond But now I wol a couenant new Of pe \& pine be holden trew An holy token for to ken

To parte zou from opere men Holdep forwarde on pis wise zoure knaue childre ze circumcise pe eiztebe day fro bei be born Pis is to say pat pei be shorn On pat ilke lymme wher wip fol. $17 \mathrm{v}$ col. 1 pei be knowe fro wymmen kip Loke ze do as I say pe As zoure soulis shul saued be Who so is not so. pei may be bolde

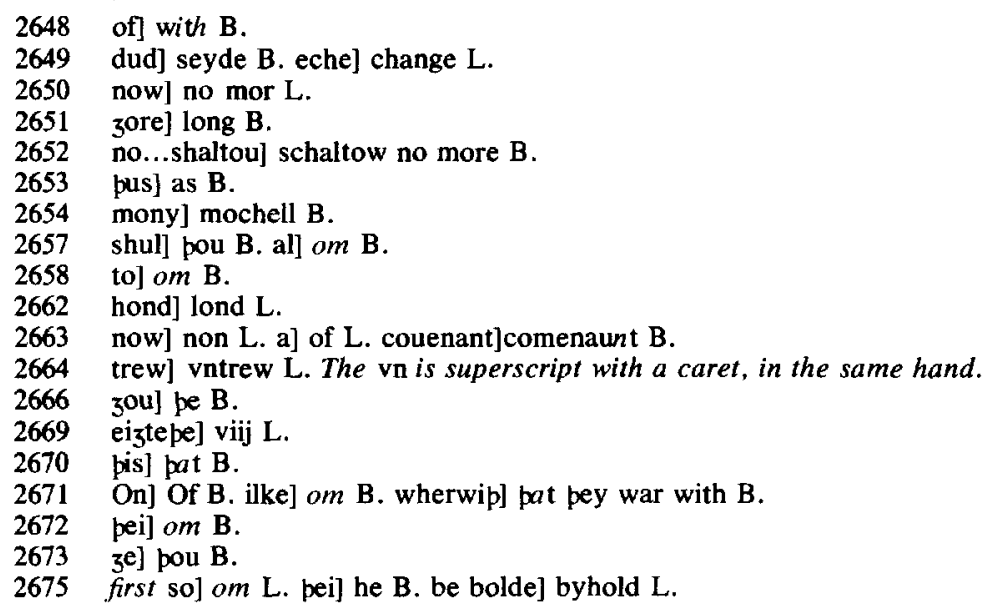


pei shul not of my folke be tolde

pou \& pi childer hit shul bigynne

And al pat wonep pi hous wipynne

Loke fro pe be done away

pe mon pat wol not holde his lay

2680

For pe werke of circum cisyng

Berep greet bitokenyng

Ne pi wif pat hette sare

Fro now shal she hett so no mare

Hir name shal be eched so

2685

Bi hir shal mychel good be do

Suche a son she shal pe bere

pat shal be kyng \& caysere

He shal serue me to queme

pe lawe ful wel shal he zeme

2690

pis couenaunt was faste wip pis

Oure lord went to heuen blis

// Abraham toke his men in sauzt

And dud as god him hadde tauzt

Him self \& ismael he share

And sipen alle his pat men ware

Of pritty zeer fro he was born

fol. $17 \mathrm{v}$ col. 2

Was Ismael when he was shorn

His fadir nynty \& nyne pat day

pei vndirtoke pis newe lay

Wherby pei are kud \& knowen

Po folke pat of her kynde are drawen

//When ne hit was hoot vpon a tide

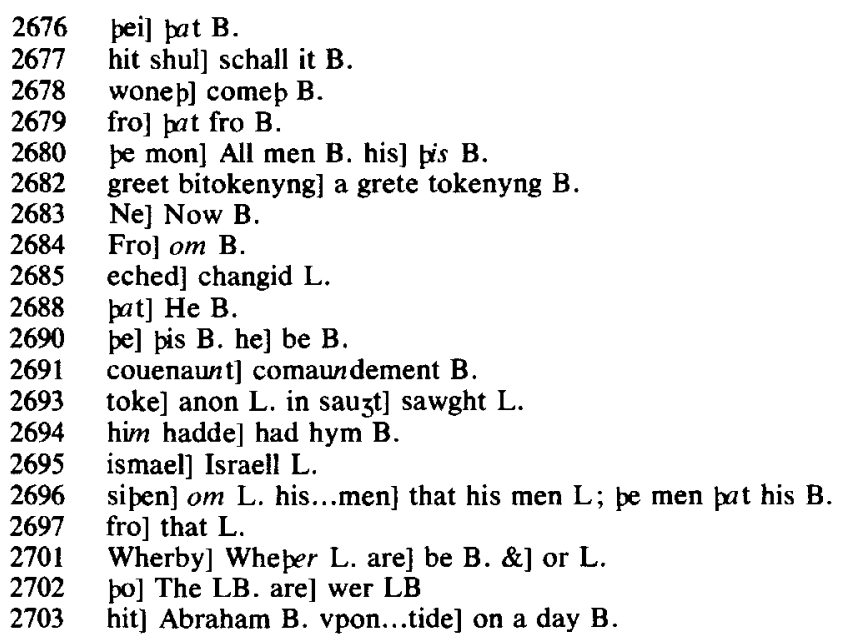


Abraham sat his hous bi syde Biside be dale of mount mambre

He loked him fro \& penne say he

Toward him com childre pre

In likenes of god in trinite

But as oon he honoured po

As o god \& no mo

Pe trinite say he bi pat sizt

And gestened hem wip him pat nyzt

Furst him self her feet wesshe

And sip hem fed wip calues flesshe

Butter \& breed pei eet also

Pei asked sare where is sho

Abraham seide zondir wipynne

Oure lord seide I wol pou mynne

At myn zeyncome bi my lif

A son shal haue sara pi wyf

Sare wipynne pere she sat

Herde pis word \& lowze perat

And seide on scorne wher we shal

Bicom azeyn to childer smal

For elde she wende to bere no barn

But no ping she bouzt may warn

But pat he may his wille do

Bi pat he com azeyn vs to

pou shalt haue childe in litil while

Par pe not for scorne smyle

She seide for sope smyle I nouzt

And if [she] dude hit hir forbouzt

Aftir pis rest vp roos pei

And abraham led him inwey

\footnotetext{
2707 childre] pe chyldym B.

2708 god in 1 pe $B$.

2711 say... pat] se hym be $B$.

2712 And] pey B. gestened] gestid L. hem] om B.

2713 wesshe] he wysch B.

2716 asked...sho] askyr after Sare tho $L$.

2718 poul be L. for sorow sche may no chỳlde wyn B.

2719 3eyncome] yencomyng L. bi...lif] without stryf L.

2723 on] in $\mathbf{B}$.

2724 to] om B.

2725 wende to] thoght my 3 t $\mathrm{L}$.

2730 par...for] pou nede not in L. smyle] to smyle $L$.

2731 She...sope]For sothe she seid L.

2732 And] om $\mathrm{L}$. she] om $\mathrm{T}$. dude...hir] so did she yt $\mathrm{L}$.

2733 rest] sone $B$.

2734 inwey] pe waye $B$.
} 
Oure lord loked to sodomam

And pus saide to Abraham

Abraham he seide fro be

Wol I not hele my pryuete

pou and pyne are me so dere

Pat I wol ze my counsel here

Of sodom haue I herde pe cry

Pe stinche rechep to pe sky

pe world is wors pen men neuen

Pe reeche rechep into heuen

To se wol I myseluen go

Of pat cry if hit be so

Pere wol I take vengeaunce strong

perto shal hit not be long

// Lord seide Abraham pyn are

Shalt pou pyne owne so forfare

Hit semep not to be pi wille

For pe wicked pe goode to spille

pi riztwisnes wol not so

For pe wicked pe gode to slo

If pou pere fynde fyue sipe ten

Fourty or pritty trewe men

Twenty or ellis twyes fyue

Shul alle perfore haue her lyue

Pus seide oure lorde but pere was noon

Trewe founde but loth aloon

Oure lord went forp pon

Abraham to his hous hoom

At oon euentyde two aungels coom

To lothus hous into sodom

Pei fond loth sittyng bi be zate

To hem he roos fro pere he sate

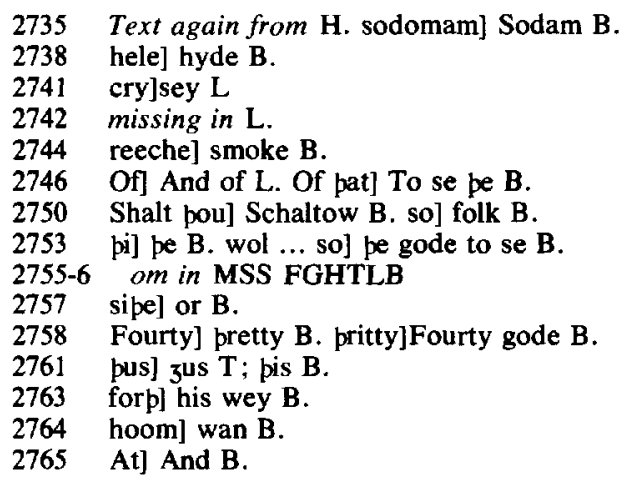


He preyed hem in goddis name

To gestne wip him \& come home

As for pat nyzte \& pei seide nay

But in pat strete dwelle wolde pay

But loth to his hous hem ledde

Wip siche as he had hem fedde

But er pei to bedde were boun

2775

Folke gedered out of pe toun

Foule felouns wip wicked entent

Aboute lothis hous pei went

zong \& olde childe and man

Hem pouzte late pei pider wan

2780

On loth pei cryed pe hous aboute

And bad he shulde sende hem oute

Pe gestes hym cam by nyz te tale

For sope pei seide knowe hem we shale

Her sory synne on hem pei souzte

2785

To haue done hit if pei myzt

But loth er pey were warre

Fast pe dores con he barre

zerne on hem he cryed mercy

Pat pei shulde leue her foly

fol. $16 \mathrm{r}$ col. 2

He seide I haue here douzteres two

Take and do zoure wille wip po

My gestis lete ze lye in pees

For goddis loue wipoute males

pe more loth on hem souzt

Pe more pei preesed \& ceesed nouzt

Al his preyere myzte not avayle

Nadde ben goddes good coun saile

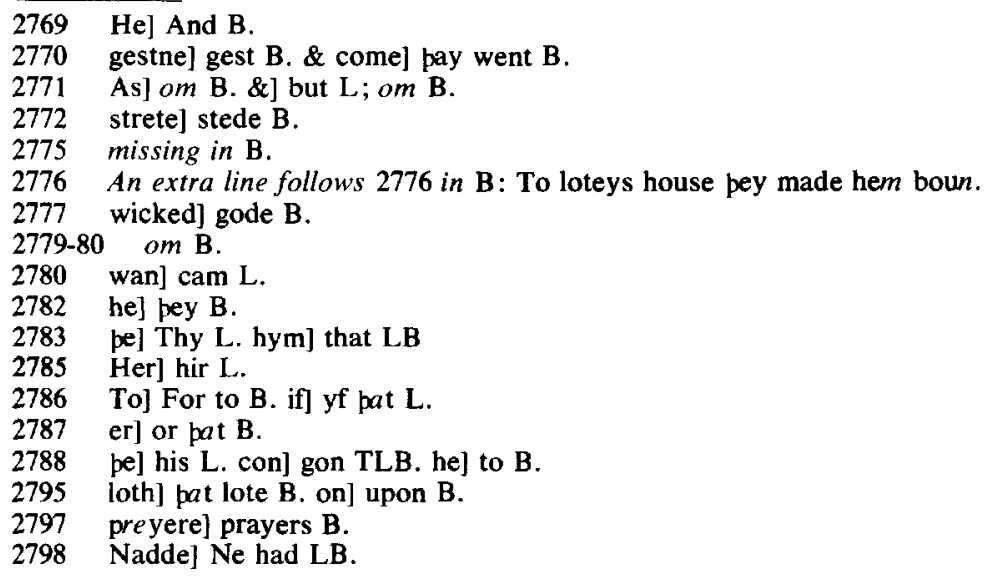


Pat made po synful folk so mad

pei niste where pei were bistad 2800

Oure lord made hem so blynde

Pat dore ne hous coupe pei not fynde

Her owne witt wiste pei nouzt

Whepen pei coom ny what pei souzt

To loth spak on aungel ben

\& seide hast pou here any men

Sone or douzter pat pou owe

To be longynge hyze or lowe

Lede hem swype out of pis toun

Er pat hit be sonken doun

Loth went \& to his frendes spake

Peroute Pei shulden his douztren take

Ryse vp he seide \& fle ze soone

pis cite today shal be fordone

Al pat loth myzte to hem say

Hem pouzte hit was not but play

But erlyer men myzte see

fol. $16 \mathrm{v}$ col. 1

pe aungels bad loth to flee

Pei seide [fle] wip bi meyne

Lest $3 \mathrm{e}$ be lost wip pis cite

Whenne pei seze loth be lettonde

pei hym took by pe honde

His wyf and his douzteres two

pat myzte vp loke per was no mo

Whonne pei were fro pe doute

And brouzte feire pe toun wipoute

$\mathrm{Bi}$ pen be goon pe lizt of day

pei bad hem holde forp her way

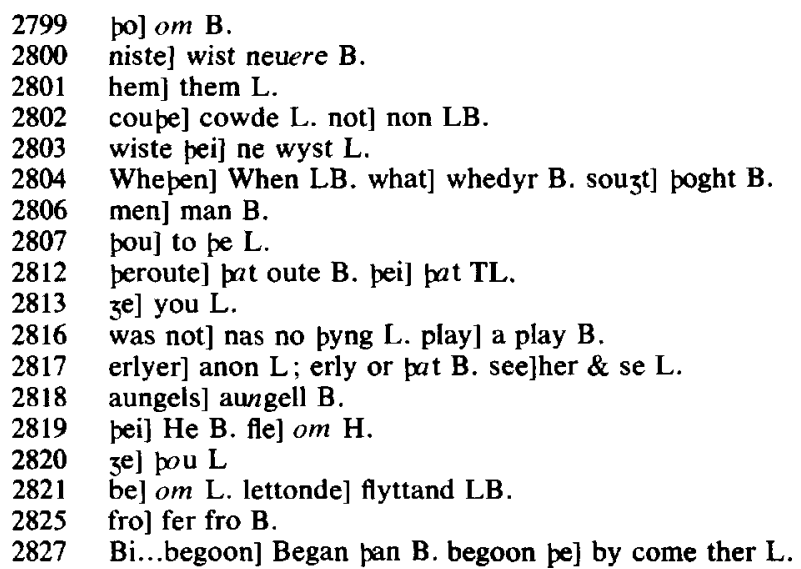


And but pei wolde forfaren be

To loke bihynde hem forbede he

No dwellynge here pat ze make

Til ze pe zonder felde to take

Lest ze be take pese among

And slayn al for her wrong

//Lorde seide loth wip leue of pe

In litil segor wolde I be

pou haste pen ne pider 3 are

For I do nouzt til pou come pare

Bityme pat pe sunne ras

Strong cry in pat toun was

Oure lord let reyne on hem anoon

Fro pe skye fuyr \& brymstoon

Sodom \& gomor wip al pe lond

Pat aboute hem lay nyzehond

Of alle po wonyngis pat per was

2845

Is nouper lafte tre ny gras

Ny no ping of pat lond vnsunke

Siche as pei breu po pei drunke

Lothis wyf pis cry herde

And longed to se how pei ferde

Wondris fayn wolde she fynde

And as she loked hir bihynde

A stoon she stondep bi pe way

And so shal do til domes day

As a salt stoon men seen hir stonde

Pat beestis likken of pat londe

And ones in pe wike to say

Is she clene likked away

fol. $16 \mathrm{v}$ col. 2

2832 Til] To B. to] have L; om B.

2834 her] their $L$.

2835 leue] be leue B.

2836 In] Att B.

2837 haste] haste pe LB.

2838 til] to B.

2840 pat toun] po tounnes T; pe cete B.

2842 pe skye] hevyn B.

\&] om B.

po] the LB.

nouper] pere non $B$.

pat] pis $B$.

first pei] pe $\mathrm{B}$. po] $o m \mathrm{~L}$; suche $\mathrm{B}$. pis] their $L$.

do] stond L; om B. til] to B.

2856

seen] se $B$.

likken] lykkyd B. second pat] pe B. 
And sip pei fynde hir on pe morne

Hool as she was biforne

pere fyue citees were wont to be

Is nouzt now but stynkand see

pat semep as lake of helle

No lyuyng ping may perynne dwelle

If any fisshe perynne be gon

2865

By ledyng of pe flum iurdon

pe lyf is soone fordo wip stynke

Fro hit into pat watir synke

Men fyndep lumpes on pe sand

Of teer no fyner in pat land

Pere stondep euer wondirly

A cloude perfro vp to pe sky

If pou a brond perynne wolt caste

pe fire hit holdep pere stidfaste

Pourze brennyng of pat brymston

Wherof pere is myche won

perby growep sum appel tre

Wip apples selcoupe feir to se

Whenne pei in honde are like a bal

To pouder pourze pat stynke pei fal

2880

Alle cristen men I rede ze take

Ensaumple bi pis wooful wrake

pat al for lecchery done was

pe foulest pat euer coom on plas

pat hit was wicked was wel sene

$\mathrm{Bi}$ pat wreche pat was so kene

Hoot \& stynkynge is pat lake

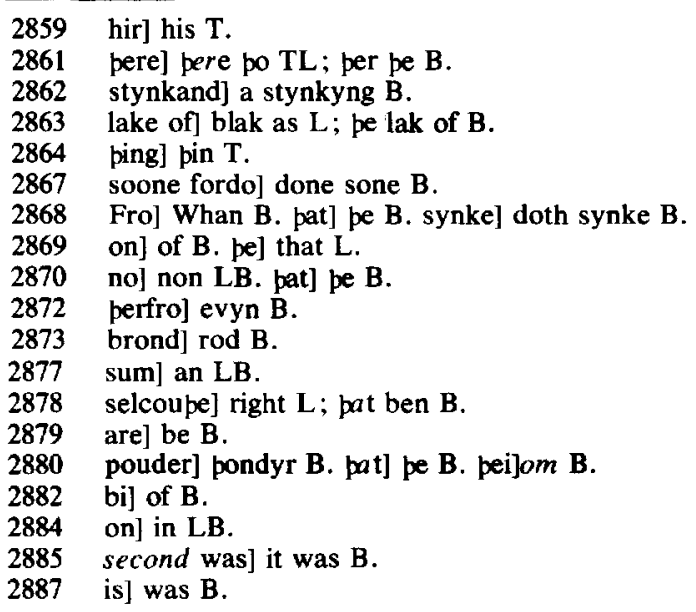


Fuyr \& brymstone was pe wrake Out of kynde her synne was done perfore her kynde lost was soone 2890

Fleep pat synne al pis werde

For pis wreche pat ze haue herde

God forbede ze do pat synne

pat zee in helle perfore brynne

But if ze nede synne shal do

Pe synne of kynde holde zou to

Pe kyndely synne wip wom mon

But sib ne spoused take ze noon

So fer zoure synne folwep nouzt

To forgete him pat zow wrouzt

2900

Mony men for ouerwele

Hymself coupe nouper se ne fele

Til pei synke into pat pit

Pat no man may hem pen flit

So dide pese wrecches of ioye tome

pei douted not goddis dome

Her welpe made hem oon \& alle

In synne and sorwe for to falle

pen coom a doom in hastite

To hem pat longe had spared be

So shal dyze wipouten ende

Pat in tyme wol not amende

//Loth ze herde telle of eer

Into pe felde he drouze for feer

In a caue he hidde him po

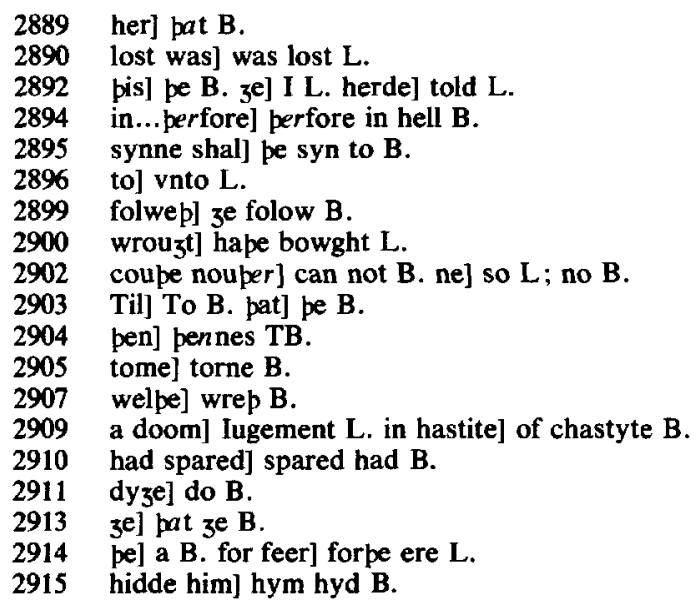


He and his douzteres \& no mo Abraham went on pe morne To pat stide pere he was biforne Had of oure lord taken his leue And say pat soore gan hym greue

Towarde pe cites loked he

A sorweful sizte hit was to se

He sawe pat cuntre al bydene pat so fair biforne had bene

Wip sparcle \& smeke couered abouen

As hit were a brennyng ouen

For hit was goddes riztwis wreke

per azeyn durste he not speke

//Loth hym helde pe caue wipynne

Himself \& his douzteres twynne

But her fadir pat pei pere sawe

pei wende alle men were don of dawe

Pourze pat ilke woful wrake

Pe elder to pe zonger spake

Sister in pryuete to be I say

pou seest pis folk is al away

But loth oure fadir \& we two

Alyue is now lefte no mo

I leue monkynde fordone be

But hit be stored by me \& pe

pis world is brouzte to ende me pink

zyue we oure fadir ynouze of drynk

fol. $17 \mathrm{r}$ col. 2

2916 \&...mol two B.

2918 pat] pe B. pere] pat $B$.

2919 Had] pere he had B. taken] take B.

2921 pe] po TL.

2923 pat] pe $B$.

2924 so...biforne] before so fayre $B$.

2925 sparcle] sparcles TB.

2926 a brennyng] brennyng of an B.

2927 goddes riztwis] rightwes godis B.

2929 hym helde] hymselffe B.

2930 twynne] tweyne LB.

2931 pere]om B. herlpayre B.

2932 wende] wyst L. don...dawe] ouer praw $L$; doun a dawe $B$.

2933 pourze] To B.

2935 in...pe] to be In privite $B$.

2936 folk] worlde $B$.

2937 loth] om B.

2938 Alyue] On lyfe $B$. is now] now is TLB.

2939 fordone] schall stroyed $B$.

2940 me \& pe] pe \& me B.

2941 brouzte] brode $B$.

2942 3yue] 3 ef B. ynouze] zif Inough B. 
Whenne he is dronken witturly

In bed we shul go lye hym by

For myzte we any barnes brede

Me pinke pe world per of had nede

As pei had spoke so pei wrouzt

Pe fadir his owne dede wiste nouzt

He wist not whenne he bi hem lay

But bope wip childe soone were pay

Amon \& moab were geten so

Bitwixe loth \& his douzteris two

Of hem coom so wickede lede

Pat nouper drouze to worpi dede

To a stide pat het damas

piderwarde her wonynge was

Of mony men pat were gode

pei refte catel \& shedde blode

// Abraham siked in hert ful soore

Fro ben he wolde pat he wore

To a cuntre cadades he flit

Abimalech was lord of hit

His sistur he calde sara his wyf

Pat for hir shulde ryse no stryf

He dredde pe folk ful of pryde

Whil he lyued hem bysyde

But hard hit is to kepe I wis

ping pat vche man wolde were his

And namely siche a ping

As is desired of greet lordyng

Abimalech fined nouzt

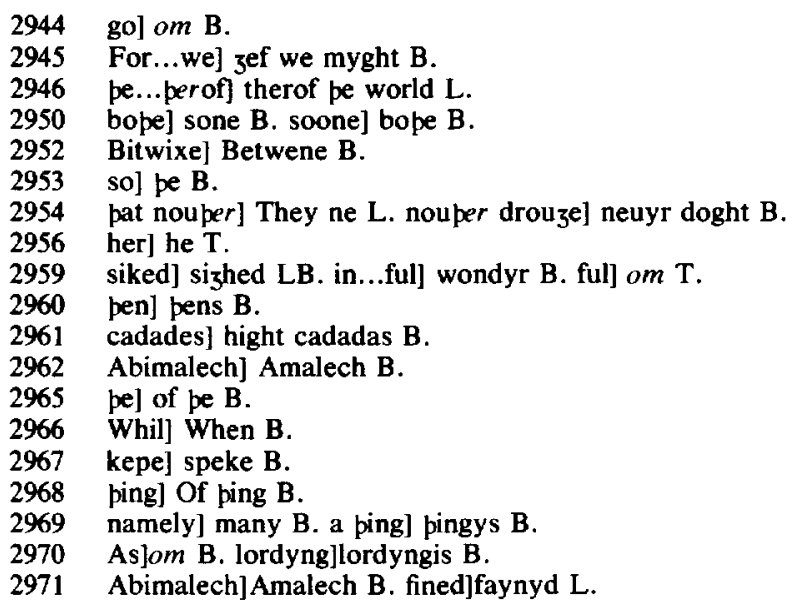


Til sarra was tofore him brouzt

But god on nyzt coom to pe kyng

In sleep \& seide pis tokenyng

Wolt pou kyng short pi lyf

pou hast anoper mannes wyf

Lord he seide wolt pou me sloo

pat wist not pat hit was so

pei tolde bope to oon and oper

She was his sister he hir broper

And also lord wel woost pou

She is clene as she was ar now

I woot he seide be zee clene

Hit were not so had I not bene

Fro touche of hir I saued be

Pat pou shuldes not synne in me

zelde hir to hir husbonde wizt

$\mathrm{He}$ is a prophete holy and rizt

And if pou do any oper rede

pou and byne alle shul be dede

fol. $17 v$ col. 1

// Vp roos be kyng anoon bi nyzt

And calde his men into his sizt

Of his warnyng he hem tolde

Pei were aferde bope zonge \& olde

He dide to calle abraham soone

And seide why hast pou pus done

What haue I done azeyn pi like

pat pus woldes me biswyke

Sir he seide I me bipouzte

pat goddes awe dred ze nouzt

2990

zoure harm wende I so best to fle

2972 Til]To B. tofore]before B.

2973 But] om B. on] at L; be B.

2975 pou] by B. pil pe B.

2977 wolt pou me] wiltow one B.

2978 pat] I B.

2980 he] \& he TB.

2981 woost pou] wostow B.

2982 She] pat sche B.

2983 be] zitt be TLB.

2984 so...not] yf I so nere had B.

2985 Fro touche] For cause B.

2987 wizt] here B.

2989 do] done $L$.

2991 be] pat B. bi ny3t] ryght B.

2993 his] pis TL.

2996 hast pou] hastow B.

2998 pus] pou B. biswyke] vngolyke $L$.

3001 wende...sol I wende B. 
And seide she shulde my sister be

To abraham po zaf pe kyng

In worship mony a ryche ping

And made hym moost to hym priue

3005

Toke him to welde al pat cuntre

Bi pis coom sara to pe tyde

Of birbe my $3^{t}$ she no lenger abide

pen was yssac hir sone born

pat was longe bihet biforn

And circumcised be eiztepe day

Aftir pe custom of pat lay

Pe name of Issac is to say

A mon pat tokenep ioye \& play

And for pe burpe of yssac

Greet ioye dide his frendes make

pat wondir childe ful of hap

fol. $17 \mathrm{v}$ col. 2

When ne he was wened fro pe pap

His fadir slouze sheep \& neet

And made a feest to frendes greet

Mete and drynk he zaf hem alle

pat wolde come to his halle

Isaac was zongur pen Ismael

On a day bitidde and fel

Pat pese brepere pleyed same

Sara bihelde \& pouzte no game

She seide Abraham pat bastard

Do him away he haue no part

Wip my sone of oure heritage

Or elles pou doost greet outrage

3030

I wol whatsoeuer men say

His modir \& he be done away

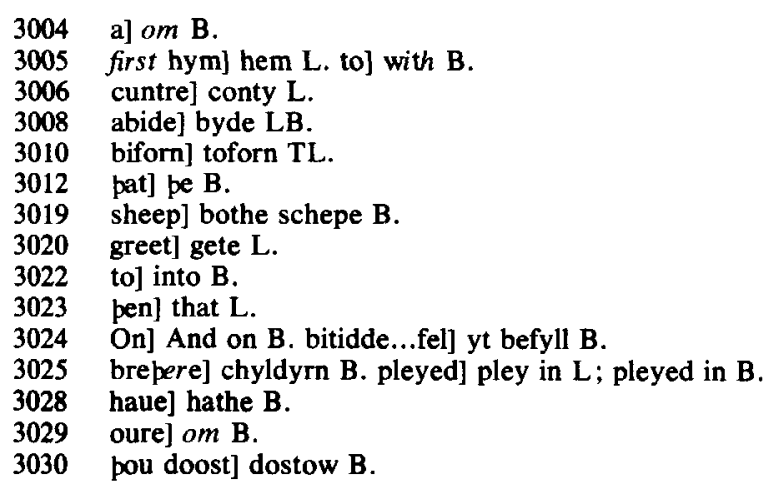


Abraham pis took to herte And pouzte hir wordis ful smerte Herfore he was in heuy pouzte

Til oon aungel him worde brouzte

Abraham he seide pinke not ille

pou most do pi wyues wille

Of pi mayden \& hir barn

Hir biddyng shal pou not warn

3040

For ysaac shal bere pe name

Of pi seed sir abrahame

Of ysmael out of spousage

Shal mony come kene \& sauage

On pe morne whenne hit was day

Bope were pei done away

Out of pat hous was put agar

Hir sone on hir bak she bar

Watir \& breed wipouten more

She tok hir wip \& wept ful soore

Now goop pat wrecche wille of wone

In wildernesse wandrynge alone

Her breed wanted her watir is goon

Hope of her lyues hadde pei noon

By a welle vndir a tre

3055

pe childe she leyde \& gon to fle

For sorwe she myzte not peron seen

But wayted whenne hit deed shulde ben

And whil she mened pus hir mood

Coumfort coom hir sone good

An aungel coom \& seide agare

What dost pou why makes pou care

3033 to] at $\mathrm{B}$.

3034 ful] were full $B$.

3035 Herfore] perfore $B$.

3036 oon] pe B.

3038 do] nedys do $B$.

3040 shal pou] schaltow B.

3043 out...spousagel and hys lynage B.

3044 sauage] sage $L$.

3045 morne] morwe $T$.

3047 pat] pe $B$.

3051 wille] wele $L$. of wone] alone $B$.

3052 alone] in wone $B$.

3053 second her] he $\mathrm{T}$.

3054 Hope] $o m$ L. her] om B. hadde] hope had L.

3056 fle] sle $L$.

3059 And whil] I wylle L. mened] mevid L; mengyd B.

3060 hir sone] to her $B$.

3062 dost pou] dostou TB. makes pou] makestow B. 
God hap herde pi childes cry

Rys \& take hit vp forpi

Lede hym zonder \& haue in mynde

A welle pere pou shalt fynde

And a tre wip fruyt ful goode

For pe and pi childes fode

Here shal pou wip him wone

And foster forp here pi sone

She dide pe childe drink of pe welle

In pat wildernes gon pei dwelle

Longe dwelled pei so poore

Til ismael was waxen more

And elynge lyf pere bei ledde

In wildernes were pei fedde

Whenne he to mon waxen was

Archer was he beste in plas

Whenne he hadde good elde kipt

He spousid a wyf of egipt

And woned pere as wilde man

In pat desert pat hett pharan

// Pis abraham was of longe abode

And also of ful clene lyflode

Oure lord hym zaf his lawe to hede

And made hym patriarke in dede

He seide Abraham I shal be zyue

pe lawe pat pou owe in to lyue

Lord he seide myself and myne

At pi wille al is pyne

I and my wyf are pyne owen

pat are we wel aknowen

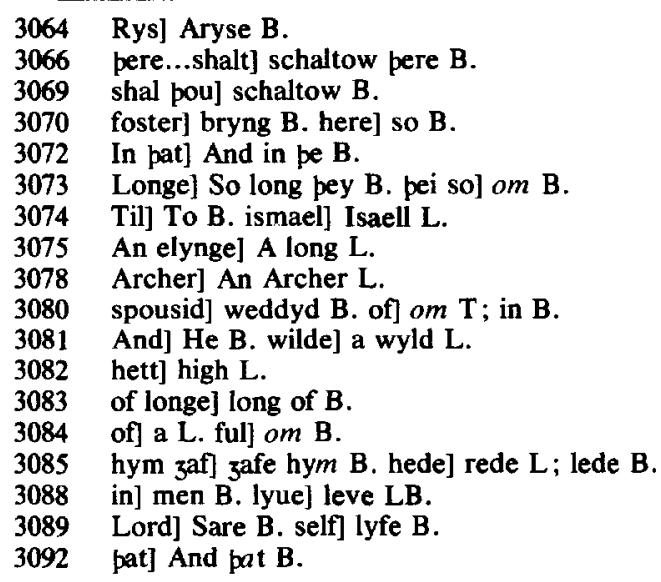


pi biddyng wol we do ful fayn

Shul we do neuer per azayn

What shal I do lord pou me telle

pou shalt go in to pat felle

pere shal pou fynde my messanger

fol. $18 \mathrm{r} \mathrm{col} .2$

Of erpe make pou an auter

Bope of pi corn \& of pi fee

Pere shal pou afferynge make to me

Gladly lord as pou hast seide

Soone was abraham purueide

Of crop of korn and oper catel

To god his tipe zaf he wel

Hit brent reche ros vp ful euen

pe smel was swete \& souzte to heuen

In pat tyme pat I of mene

Pe folk was good pe world was clene

So good bep hit neuer I wis

So myche of welpe so myche of blis

Pouze man myzte neuer so myche welde

So faste hit drawep to doun helde

To wrecched dome al is went

To lerne god zyue fewe entent

pe childe berep now be witt away

Foly is gomen nowaday

Of ysaac now wole we neuen

Pat loued was wip god of heuen

Herep of god al weldonde

How he asayed his trewe seruonde

Wel loued abraham ysaac

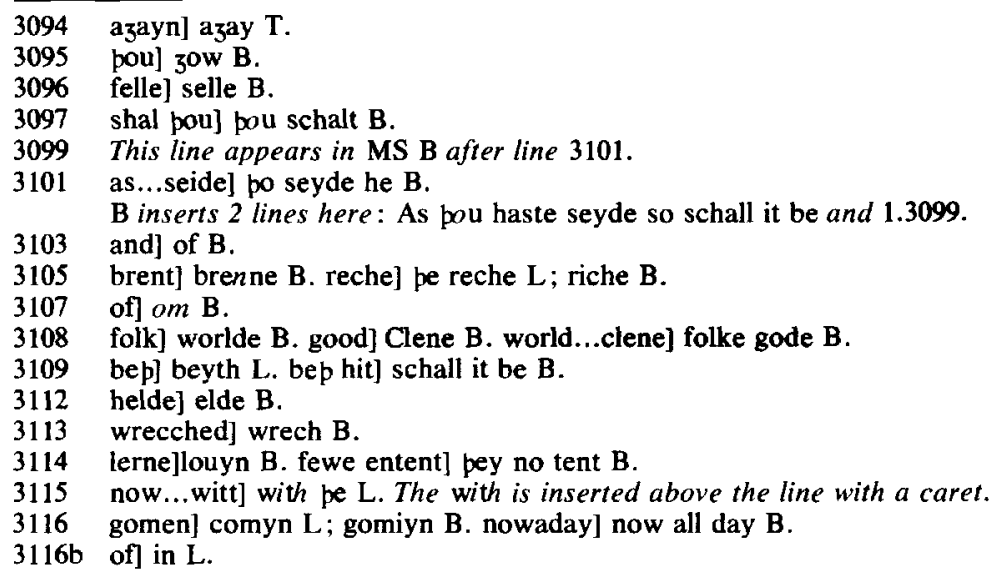


His sely sone wipouten lak

He tauzte him firste god to drede

And so to leue al wickedhede

He bigan to loue hym so

pat myzte he no whyle him forgo

Oure lord wolde as myzty kyng

Asaye abraham wip sum ping

To abraham oure lord spak

And seide where is pi sone ysaac

$\mathrm{Al}$ at pi wille penne lord seide he

I wol pat pou offere him to me

Gladly lord pou me him zaue

Good skil hit is pat pou him haue

To oure lord he was so trewe

pat myzte no pite make him rewe

But he had leuer his childe spille

Pen do azeyn his lordes wille

pis childe was bihet mony a zere

Ar he were sent sough[t] wip preyere

Abraham wende wipouten wene

Pat he shulde his heire haue bene

Now is he asked on pis wyse

To god to make of sacrifise

Pouze hit were grisly and grille

He laft not oure lordis wille

But asked him wipouten abyde

How he him shulde sacrifise pat tyde

3135 fol. $18 \mathrm{v}$ col. 1

And he to telle po bigon

zondir hyze hille vpon

Shal pou brenne pi sone for me

Gladly lord penne seide he

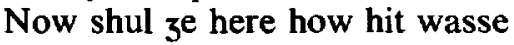

pe childe he caste vpon an asse

And took wip him knaves two

But pei ne wiste whider to go

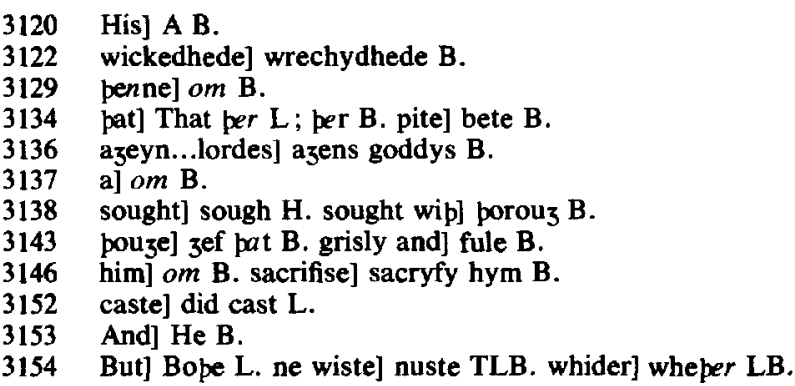


Pat feld he welke dayes pre

To seche pe stide pere he wolde be

When ne he coom pere as he tizt Of pe asse pe childe dude he lizt Toke him wip him no mon more His meyne he bad abyde him pore

His coun sel wolde he no mon say

Why he pat childe brouzte pat way

Swerd ne fyr forzat he nouzt

zong Isaac a fagot brouzte

Sir he seide where shal we take

pat beest oure sacrifise to make

Sip we wip vs brouzte noon

God he seide shal sende vs oon

Wip pis he stood pe childe nyze

And drowze his swerd pryuelye

pat be childe were not war

Er he had done pat char

He lifte his hond him to smyte

But goddis aungel coom ful tite

Ar he myzte zyue pe dynt

3175 fol. $18 \mathrm{v}$ col. 2

His swerde bihynde him he hynt

And bad him pere bisyde him take

A sheep his sacrifise to make

He loked bisyde him in pe pornes

And say hit longe by pe hornes

Pe angel helde stille pe swerd

And saide of coumfort siche a word

Abraham holde stille pin arm

To pi sone pou do no harm

feld...welke]folowyd hym B. welke] went $L$. stide] place $B$. he wolde] yt schuld $B$. ashe] he had $B$.

second pe...he] he dyd doune $B$.

Toke] He toke B. him] he L; om B. no mon] meyne no B.

him] om B.

Sir] fadyr B.

sacrifise] ofryng for $B$.

pryuelye] full preuely B.

were] was $L$.

That he wold a made pat far L.

His] pe B.

bisyde him] besydes $B$.

sheep] ram $B$. to] with to $B$.

bisyde] besydes $B$.

longe] honge TL.

no] none $B$. 
Oure lord forbedep him to slo

pi dere sone pat pou louest so

pou louest hym more wipouten wene

pen pi sone pat is now sene

Wel louest pou hym and drede

Wel shal he quyte pi mede

ze shul his blessyng haue for why

Myche he shal zow multiply

For loue of pi faipful fay

Shal vche lede come to pi lay

God hap today pe visited so

pi dede shal neuer of mynde go

pi buxomnes al folk shal fynde

pat shul be bred of pi kynde

Of pis lettyng he was ful glad

And dude as pe aungel him bad

3200

Pe sheep he sacrifised \& brent

And sipen homwarde he went

Pe fadir gon pe sone forbede

To any man to telle pis dede

Fadir he seide be ful bolde

For me bep hit neuer tolde

pei went azeyn to bersabe

pere pei had lefte her meyne

//Sara had six score zeer \& seuen po

And dyzed wipouten childer mo

Pen ysaac no moo she bare

And abraham for hir had kare

In ebron biried hir abraham

pere firste was buried olde Adam

3185 him] pe hym L; pou hym B. tol om B.

3187 wipouten wene] pat is now sen $B$.

3188 pat...sene] withouten wene $B$.

3189 louest pou] louestou T; pou louest B. and] in $\mathrm{L}$.

3190 shal...pi] pou hast quit hym hys $B$.

3194 lede] chill $B$.

3195 to day] pis day $B$. visited] visit $B$.

3196 pi] pis $B$. of] fro $L$.

3197 al] pe $B$.

3198 be bred] come $B$.

3200 pe] om B. him] om B.

3202 homwarde he] he homewarde B.

3203 gon...sone]pe son gan $B$.

3205 ful] $30 u$ B.

3206 bep] shalle LB. tolde] be told LB.

3210 And] When sche $B$.

3213 ebron] Ebrew L.

3214 pere] pat B. 
Abraham willed in his lyue

pat ysaac had wedded a wyue

And wolde she were if hit myzt be

Of his kynde \& his cuntre

Men shulde hir seche in pat land

pere his frendes were weldand

A seriaunt sone commandide he

Pat moost knew of his pryuete

pat euer had ben at his fyndyng

Fro he was a chylde zing

Vpon his kne he dide him swere

pat he shulde trewe erned bere

And pat he shulde zyue hool entent

To fulfille his com maundement

Frend he seide wende in hye

Vnto mesopothanye

Pere pou woot oure frendes wone

To seke a wyf to my sone

And if she may be founden lele

Brynge hir hoom wip myche wele

But brynge pou him no womman

Of pe kynde of canaan

Sir he seide what shal I do

Pis ilke mayde if pat sho

Wip no catel come wip me

Pen of pin op I holde pe fre

For ysaac wip no forward

Wol I he wende pidirward

Gladly he seide hit shal be done

pis mon [m]ade him redy soone

Fast he hyed to his goyng

Wip tresour greet \& preciouse ping

Suche as maydenes han mistere

$\mathrm{Al}$ pat ten camels myzte bere

3216 wedded] wed $B$.

3217 And] A L; He B.

3220 frendes] kyn B. weldand] wonnand $L$; duellande $B$.

3221 seriaunt] servaunt LB. sone] po $B$.

3227 And] In L.

3228 To] for to $B$.

3230 Vnto] vnt T; Into B.

3232 second to] for $\mathrm{B}$.

3241 no] non $B$.

3242 Wol] Wolde $B$. wende] weddyd $B$.

3244 made] nade $H$.

3246 tresour greet] grete tresoure B. preciouse] ryche B.

3247 mistere] of mistere TLB. 
Ringe \& broche pat were proude

Gold \& stoon for mayden shroude

Pat whoso him say myzt vnderstonde

He comen was fro a riche londe

To mesopothanye soone coom he

And soone he fonde pat cite

Whenne he coom nyzhonde pe toun

By a wel he lizte doun

A preyere made he in pat plas

And pus bisouzte god of gras

Lord he seide pat al welde may

pat my lord honourep euery day

For whos loue he wolde not warn

3255 fol. 19 r col. 2

To sacrifise his owne barn

To whom to seke a wyf I fare

Lord pou sende me oon sumwhare

And so my seruyse set to seme

pat to bi worshepe may be queme

And siche a wyf to ysaac

pat may be good him to tak

Him to ioye \& menske to be

Lord pou graunt pat hit so be

And graunte me bi pis welle here

Tristy to be of my preyere

For bi pis welle wol I byde

What of myn ernede wol bityde

Here wol I be til pat I se

Maydenes come fro pis cite

Her watir at pis welle to drawe

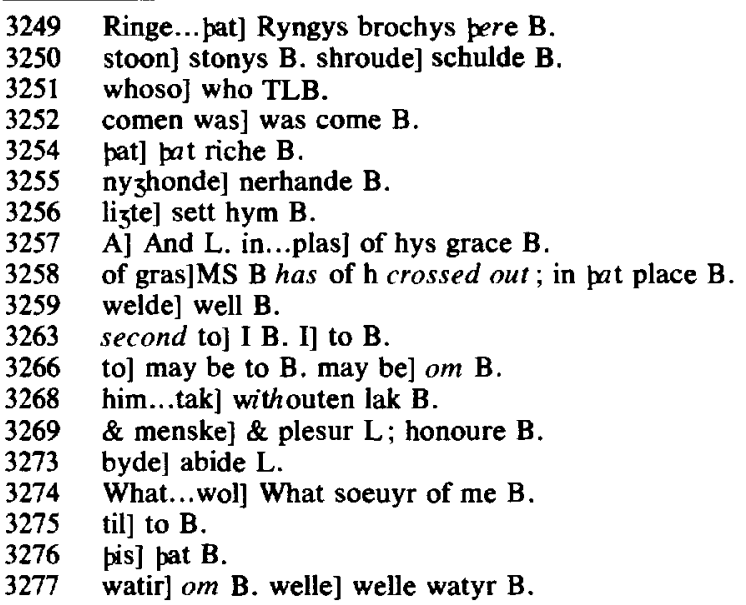


Pere shal I my woman knawe

She pat [shal] bete my pirst

I shal hir holde as for best

3280

He nadde rested but a prowe

Of maydenes he say come a rowe

Pe formast was vnlauzter mylde

Hir semed no ping to be wylde

Was she not of semblaunt lizt

3285

Rebecca hir name hizt

Batuel hir fadir snel

Hir semed alle hir werkes wel

Sittyngly hir watir she tooke

pis mon faste dud on hir loke

$\mathrm{He}$ was witty and deuyse

He seide to hir on pis wyse

Mayden he seide 3 yue me drynke

Myche I haue on pe to pinke

I am a man faryng pe weye

Myn harnay[s] dide I here doun leye

Of my passage I was in doute

For no man knowe I here aboute

Me were lop if I myzte were

Men dude me harm on my gere

Frend she seide pyn askyng

Nis not but litil ping

pou shalt hit haue wip good wille

And pi camailes to drynke her fille

For here vs wantep no vessel

3290

Bolle ne boket ny no fonel

3295 fol. $19 \mathrm{v}$ col. 1

3278 woman] mayden $\mathrm{B}$.

3279 shal] om $\mathrm{H}$. bete] bote L; here bete $\mathrm{B}$.

3280 as for] for be $B$.

3281 nadde] ne had $L$; had $B$.

3282 Of] When $B$. a] on a $B$.

3283 formast] fayrest $B$. vnlau 3 ter] of laghter $B$.

3286 hizt] was ryght $B$.

3287 Batuel] Batuel het TLB.

3288 first Hir] Her B. second hir] he B.

hir] pere $\mathrm{B}$.

faste dud] did fast $L$.

deuyse] wyse $B$.

harnays] harnay $\mathrm{H}$.

knowe] knew $T$.

my] any $B$.

she] she she $L$. pyn] thyng $L$.

Nis not] Ne ys B. litil] a litell B.

fille] The edge of MS B is torn here, \& this word does not appear. ne] om B. no] om B. 
She drouze hem alle ynouze of drinke

Lefte she not for no swynke

pis oper man myzte not blyn

To biholde pis fair maydyn

How alle hir dedes dude hir seme

Pi[s] mon pouzte hem to queme

Mayde he seide by pis hond

Hastou any fadir lyuond

ze she seide \& modir wip al

To house gladly pat wol pe cal

Fodder and hay pou shal be boun

No feirere Inne in al pe toun

He hir zaf a zifte anoone

A golde ring pat brizte shoone

3320

Pankynge god to erpe he fel

Pe mayde ran hoom of hym to tel

She had a broper het laban

He ran forb azeyn pe man

$\mathrm{Bi}$ tokene soone were pei knawe

To ryche gestenyng was he drawe

Penne wist pei bi pis messangere

Abraham was sib hym ful nere

Ete ne drynke nouper he wolde

Til he hadde his eronde tolde

And pe sikernes was made

Likenes to rauen he not hade

Wel be siche a messangere

His message forp to bere

Pat of himself recchep nouzt

3335 fol. 19v col. 2

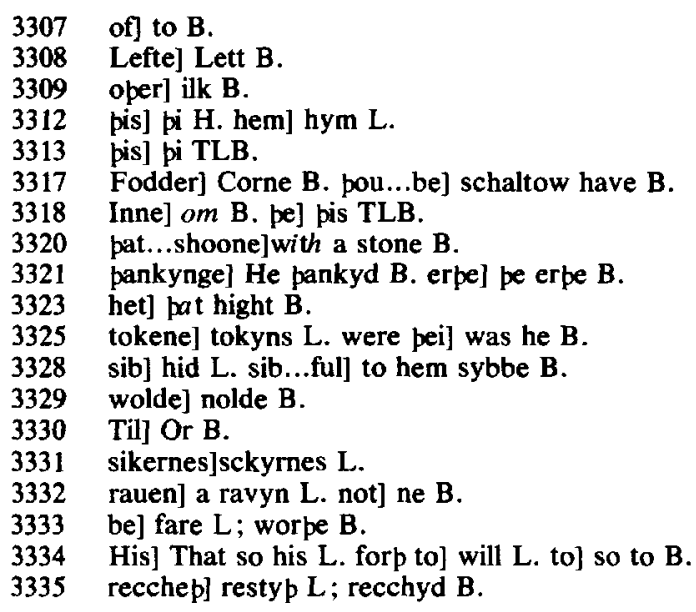


Til his nedes be ful wrouzt

Pe mariage dide he pen ne make

Bitwene rebecca and ysaake

To vchone $z^{\text {af }}$ he $z^{\text {iftis sere }}$

Aftir pat pei worbi were

And clad pe may in ryche wede

As was lawe in pat lede

To vchon he 3 af sum ping

Batuel hym made good gestenyng

A morwe in goddis benesoun

Rebecca was lad of toun

Hir modir als wip hir ladd

Til pei coom nyze bere hir radd

Pere wonynge sir Abraham was

Isaac was not fer fro plas

As Isaac went hym to roo

And pouzte of pingis he hadde to do

$\mathrm{He}$ zeode walkynge bi pe strete

And coom azeynes hem to mete

Rebecca seide what man is he

Pat towarde vs comynge I se

He drouze hir neer \& stille spak

pat is my lord sir ysaac

Hit is pe caiser shal be pyn

Of him shal pou haue soone seesyn

To his bihoue I pe souzt

In sely tyme $\&$ wip me brouzt

pis seriaunt dide hir doun to lizte

In better aray for to dizte

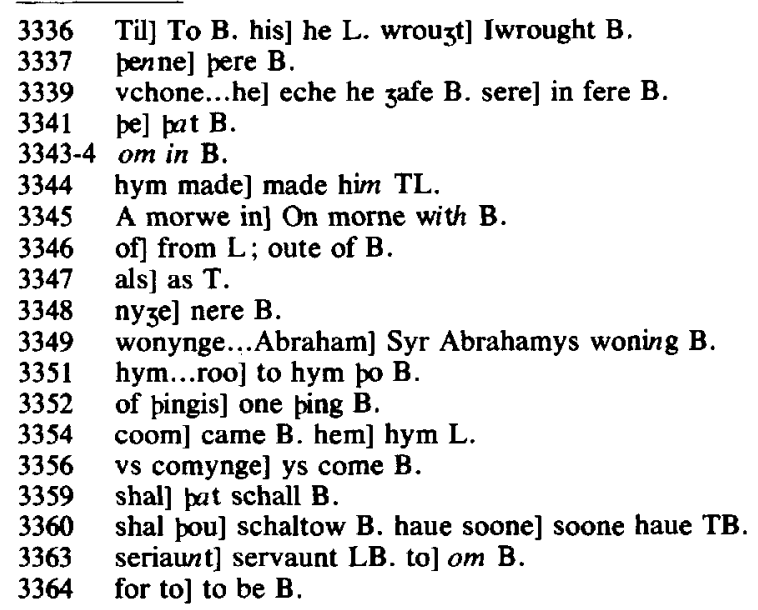


She hir in better wede arayed

A mantel of reede aboue she layed

And pei she shameful was I wis

She lest no countenaunce wip pis

Rebecca and ysaac are samen

Mette wip myche ioye \& gamen

3370

Wip myche myrbe for to mene

Was brouzte to house pat may shene

Penne pei made be mariage

pat fel to riche heritage

pe michel loue of rebecca

3375 fol. 20r col. 1

Falled pe sorwe of dam sara

Suche are nowe alyue ful pike

Forzete pe dede for pe quyke

But pei hit dide for sum resoun

And pourze significacioun

Thre wyues had Ismael

Twelue kyngis com of him to tel

pei helde as myztyest pat day

pe londes pat in pe eest lay

Wondir hit were pe kyn to tel

3385

Pat multiplied of Ismael

Abraham aftir dame sara

Took a wyf het cephura

Of hir he geet a sone madan

And anoper hett madian

Not for lust of leccherye

But his seed to multiplye

As god him hadde tofore hizt

He took a wyf for hit was rizt

Bitwene his childre he delt his auzt

3365 hir] om B. wede] wede her $B$.

3367 pei] bouze $T$; zef $B$. shameful was] schamfast wer $B$.

3368 nol non $B$.

3369 are] in $B$.

3370 wip myche] togedyr with $\mathrm{B}$.

3371 myrpe] ioye $B$.

3372 shene] so schene $B$.

3376 Falled] fellyd $B$.

3377 alyue] on lyfe $B$.

3380 significacioun] singnificacion $B$.

3384 pe] As B.

3388 cephura] Sepura L.

3390 And] om B.

3391 Not for] Bote for no $B$.

him] hem L. him...hizt] before had hym behight B.

for hit] \& pat B. 
His lond to ysaac he bitauzt

For he firste born was in mariage

Bi rizte he hadde his heritage

An hundride zeer seuenty \& fyue

Whenne abraham had lad his lyue

He dized in troupe \& holyhede

His sones douzty were of dede

pei wepte his deep \& so dide moo

Bi sara pei leide hym po

In god was euer his feip fest

3405

Oure lord brynge vs to his rest

Siche a reste to to come

pat we may wip himseluen wone

3408

Now is good to vndirtake

pe story to telle of sir ysaake

Oure lord pat is of goodnes boun

To ysaac $z^{\text {af }}$ his benisoun

Wyse he was \& god he dradde

And gladly dide pat he him badde

Wipouten childe his wyf was longe

pat pouzte him ful stronge

He preyed him pat may al mende

pat he wolde him childre sende

For of his wyf he dredde soore

She shulde be bareyn euermore

Pe gode childre geten of grace

Vnnepe coom pei forb in place

But whenne pei coom wel is knowe

3397 firste...was]was borne fyrst $B$. born] bone $L$.

3398 his] be B.

3399 seuenty] seventyn $B$.

3400 lad] lefft $B$.

3402 douzty were] pat were doughty $B$.

3403 wepte] wepe $L$.

3406 to his] alle to $B$.

3407 Siche] To swich B. first to] om L; for B.

3408 wone] wone. Amen $B$.

3409-10 om CGHTLB.

3410 andirtake] vndirstonde \& take $B$.

$3410 \mathrm{~b}$ sir] om B.

3414 he] god B.

3416 pat pouzte] And pat forpought B. ful] swype B.

3417 preyed] previd L.

3418 wolde] schuld $B$. childre] a chylde $B$.

3421 childre] chyld B. geten of] gete no L.

3423 is] it is $B$. 
Pat pei of goddis grace are sowe

Childe but oon had dame sara

Rebecca hadde rachel \& anna

Nor $3^{\text {itt holy Elizabeth }}$

To haue hir childe coom not eth

pat was Ion be baptist

pat to men shewed crist

3430

Also semep rizt to deme

Bep of rebecca barnteme

She hadde hem not soop to say

Ar pei were souzt mony a day

God het hem childre not forpy

Pat of her seed shulde multiply

And saide I shal zitt be

As wip pi fadir so wip pe

Ysaac zaf to god his tende

And preyed he shulde childer sende

3440

So long he preyed his preyere

Wel was herd wip god so dere

She pat longe had childe forgone

Now she berep two for oone

Of twynlyngis hir pouzte no gamen

pat fauzt ofte in hir wombe samen

So fast in hir dude pei fizte

pat she had reste day ne ny $3^{\text {te }}$

To preye to god ay was she prest

To coun sel hir wat were best

What were beste hir to rede

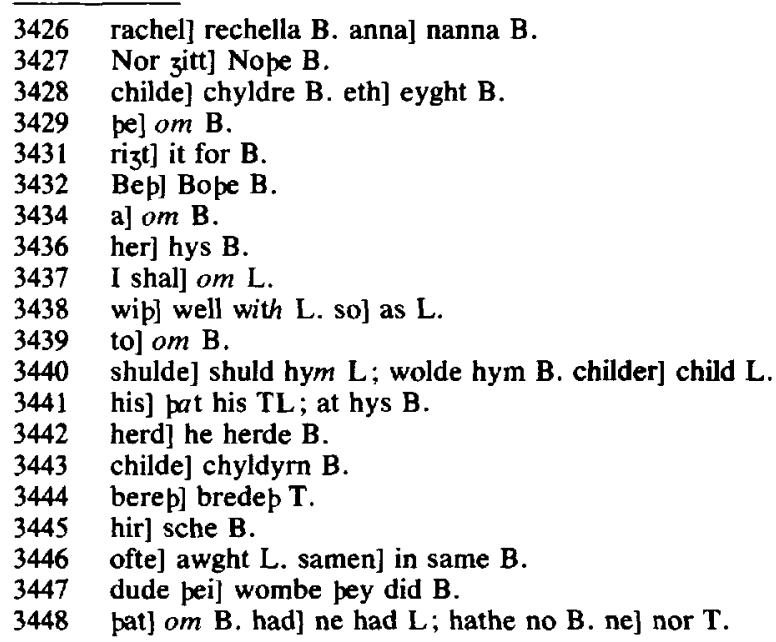


Hir lyf was licly to be dede Wondir strong was her were Pei wolde not pat stryf forbere Til pei had of hemself myzt 3455 fol. $20 \mathrm{v}$ col. 1

To se wherfore pei shulde fizt

Fro pe bigynnyng of pe werd Of siche a werre was neuer herd

Ne siche a stryf of childre twynne

pat lay pe modir wombe wipynne 3460

Btiwene vnborn a batail blynde

Sichon was wondir to fynde

He pat on pe rizt syde lay

His broper ofte wrast him away

And he pat lay on pe left

His broper ofte his stide him reft

Pe lady was ful myche a drad

As womman pat was harde stad

But oure lord god pat is

Had done hir into sikernis

Pourze his verrey prophecie

Pat shulde be po childer nye

Of her were and of her lyf

And what ensaumple bar pat strif

Perfore buxomly she hit bare

And knew coueryng to come of kare

Hir bredynd was ful sore

And hir childyng myche more

Po wex pe fizte more, pen toforn

Whiche shulde be firste born

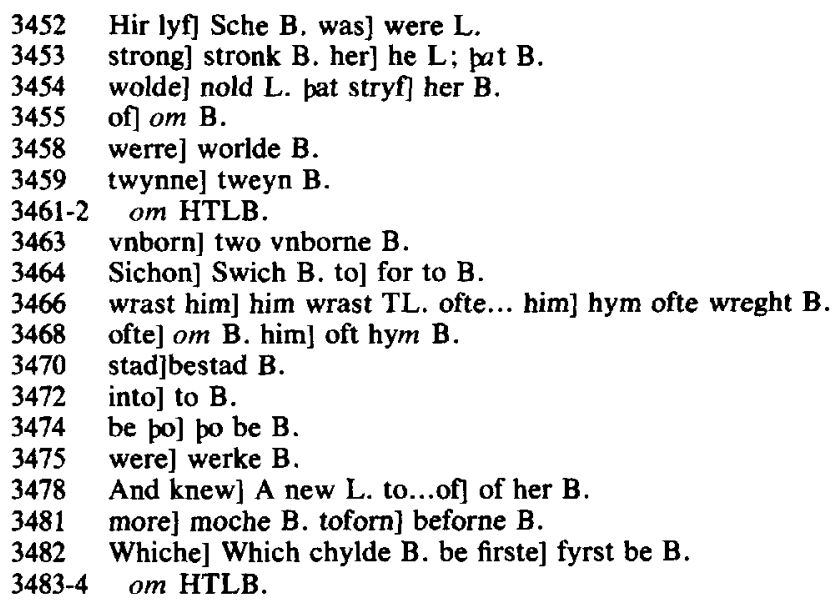


Of pese two breperen pat we mote

pe lasse pe more took bi be fote

In trauelynge \& drouze azeyn

Miche was pe modir peyn

pe first born was rouze of hare

Pe opere childe slezt $\&$ bare

He pat was rouze was reed wip alle

Esau men dide him calle

Iacob hett pe zonger broper

Pe modir him loued more pen pat oper

Perfore nowhere was he sent

But to pe hous took he tent

To tente pe mete $\&$ hous to kepe

perto was he good \& meke

Pe fadir loued esau for fode

For he was an archer gode

fol. $20 \mathrm{v}$ col. 2

3500

When ne he wolde euer was he boun

To gete his fadir venisoun

And as he was as formast born

He dalt al wip tilpe \& corn

Wip opere pingis delt he sere

Wip beestis wode foule \& ryuere

His fadir olde and vnfere

Ofte he fedde wip good dynere

Good was pe world in pat ceesoun

Miche availede benesoun

Of fadris pat wel helde her fay

On childre when ne pei wolde hit lay

Of blessyng may men ensaumple take

$\mathrm{Bi}$ pese childer of ysaake

How pe zonger of pe two

pe blessynge stale his broper fro

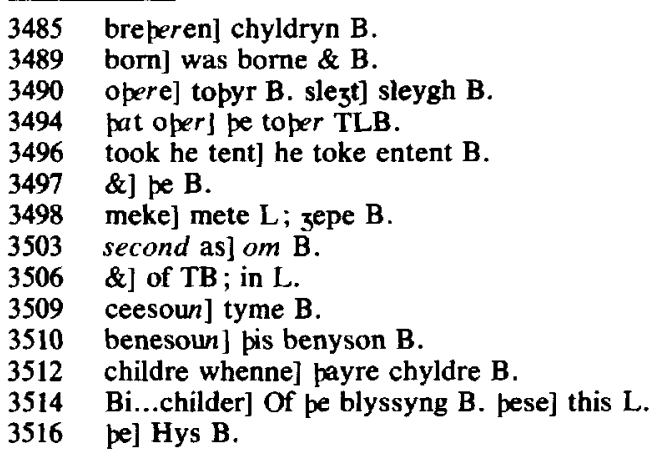


But firste is to be tolde

How esau his broper hit solde

// Esau went forp to hunte

A day as he was ofte wonte

Fer \& neer he had souzte

pat day gamen fonde he nouzte

For haue man neuer so myche nede

Vche day is not tyme of spede

But ofte pat day pat men faile

Moost aboute hit pei trauaile

When ne he was wery forgoon

Hoom he took his weye anoon

Hauke is esy I here say

To reclayme pat hap lost his pray

His broper he fond pat toke tent

To dizte a noble mete present

Of pis mete broper he seide

3yue me sum pat here is greypede

Mete \& drynke pou hast at wille

And longe is sip I eet my fille

Iacob seide nay god hit wit

For pe haue I not dizt hit

pis mete my modir me bitauzt

For pou and I are selden sauzt

fol. 21r. col. 1

3540

Aboute oure forburpe are we wroop

zif pou wolt swere me an oop

pat pou shalt neuer fro pis nyzt

Of pi forburpe cleyme no rizt

Forburpe he seide what seruep me

Broper at pi wille shal hit be

3517 is] it is $\mathbf{B}$.

3519 forp] oute $B$.

3520 A] On a B. ofte] om B.

3521 he] om $\mathrm{T}$. he had] had he $\mathrm{B}$.

3522 fonde] ne founde $B$.

3523 man] a man B.

3524 of] to $\mathrm{B}$.

3526 hit] om B.

3529 Hauke] Hang B.

pat] \& B. tent] entent B.

To] To a B.

haue I] I haue yt $\mathrm{L}$.

are] be $B$.

3541 Aboute] For B. are we] or we were B.

3544 pi] this L. cleyme no] calang $B$.

$3545 \mathrm{me}$ it me B.

Broper] Bropere he seyde B. shal hit] it schall B. 
Wip pat forwarde he made a vow

Almest for hongur I deze now

And for his fille of pat potage

As wrecche he solde his heritage

He eet \& dronke \& went his way

And lost his blessyng fro pat day

$\mathrm{N}[\mathrm{o}]$ bote him was him forpouzt

God wolde hit were his pat hit bouzte

Pis yssac pat worpi man

Sekenes \& elde on him ran

Of body failed him pe myzt

And of yzen also pe sizt

pe body pat so in elde is nome

His day is goon his nyzt is come

Haue a man ben neuer so bolde

When ne pat he bicomep olde

Vnwelde put at him a pulle

His body waxep dryze \& dulle

His heed bigynnep pen ne to shake

His hondes operwhile to quake

Hit crepep crulyng in his bake

Penne his boones bigynne to crake

pe frely faire to falle of hym

And be sizte to wax al dym

Pe frount frounsep pat was shene

Pe nese droppep ofte bitwene

Teep to rote breep to stynke

Only to lyue trauaile him pinke

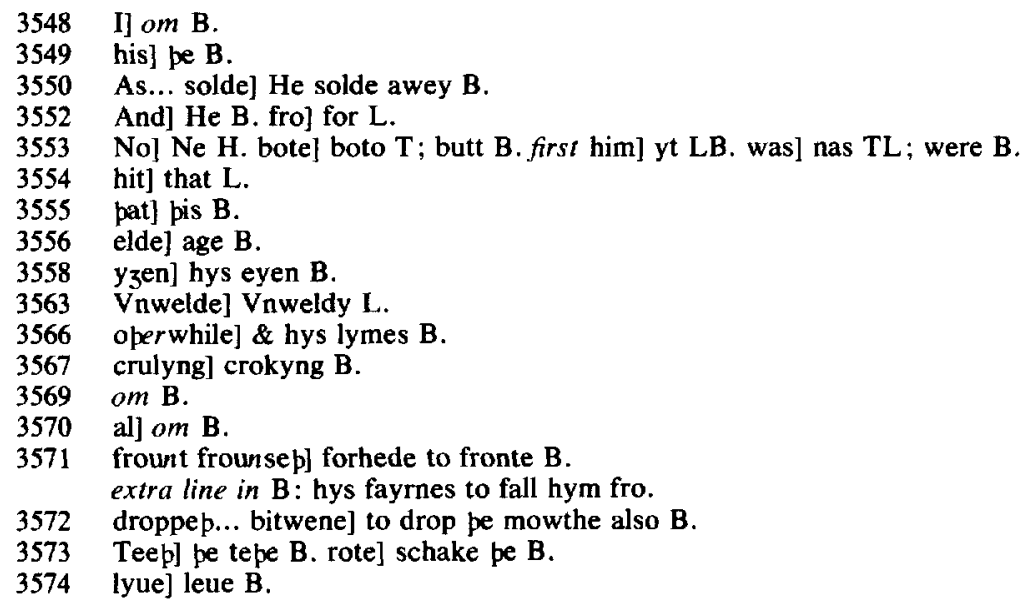


Ezep hit is penne to sporne

He fallep wip his owne torne

He preysep pingis pat ben gone

Pat pen ne bene he preysep noone

Soone penne he wole be wroop

To be at oon sumdel loop

fol. $21 \mathrm{r}$ col. 2

3580

To teche men of his witt

He holdep noon so wise as hit

No ping penne may hym pay

3585

Boldely penne may we say

He pat in pis state is stad

Nis no gle may make him glad

Elde is now a wondir pinge

Alle desiren hit pat are zinge

When ne pei hit haue pei are vnfayn

Penne wolde pei zonge be azayn

Pei wolde be as pei were ore

And pat pei may neuermore

So hap elde pis ysaac led

Pat he sike lip in his bed

Him wantede sizte as I seide er

And calde his sone esau per

Esau leue sone he seide

Go loke pi takel be purueide

3600

And fonde for to stalke so nere

pat pou may sle sum dere

If pou myzte any venisoun gete

Gladly wolde I per of ete

Sone pou hast hidur tille

3605

Gladly done pi fadir wille

Pou art archere wip pe best

Bope in felde and in forest

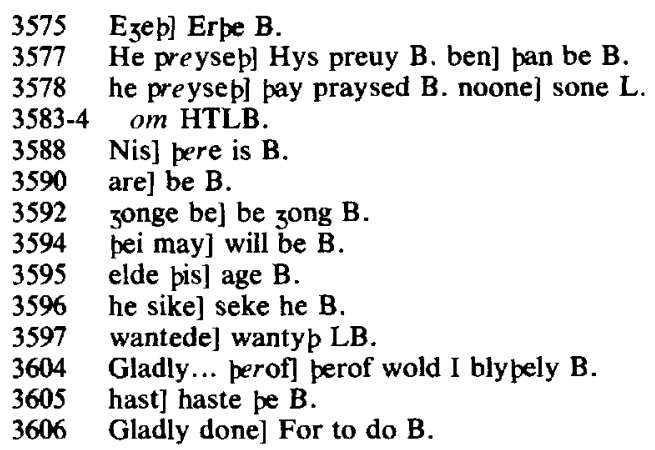


If pou may brynge me any beest

Dizte hit me feir and honeste

peraftir now me longep so

Pere I lyue in bed of woo

Sone he seide I wol not lye

Hit bep not longe ar I dyze

To brynge me venisoun be boun

3615

And pou shalt haue my benisoun

He seide sir gladly \& soone

Wip goddes helpe hit shal be done

His modir tent to ysaac

And herde po wordis pat he spaak

And wist of longe lyf was he nouzt

3620

She went bi syde and hir bibouzt

lacob hir sone she calde hir to

And pus to him seide sho

My leue sone I wol pe warn

For pou art my derrest barn

pi fadir bad pi broper snelle

To fett him mete \& not dwelle

If he any what myzte gete

He shulde him dizte perof to ete

fol. $21 \mathrm{v}$ col. 1

For were he ones perwip fed

Ar he dyzed in seke bed

His benisoun he wolde him zyue

For longe he woot he may not lyue

Leue sone loop me wore

Pat he pi benisoun fro be bere

Vnhappy wrecche he hap ben ay

pi zele shal he not bere away

pou shal do now my counsel

I woot hit wol availe wel

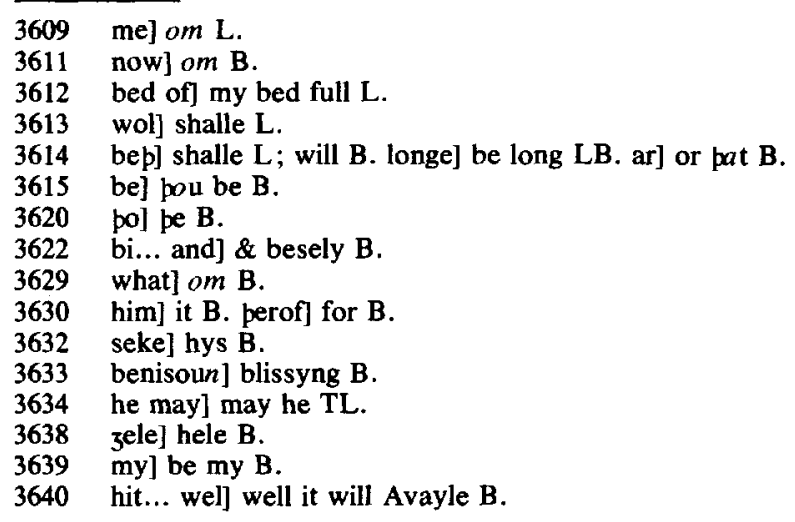


Hyze pe sone pat pou not blyn

Ar pi broper be comen In

Of fatte kydes fet me two

I shal pe teche how pou shalt do

I shal hem dizte to his byhoue

Siche as he was wont to loue

Hit shal him sauour al at wille

Ete he shal perof his fille

When ne hit is dizt pou hit him reche

Do wel as I pe teche

pat he may pe lasse mystrau

Say pou art his sone esau

Fro pe forest newely comen

Venisoun pou hast Inomen

Deyntily dizte to his pay

Pou bidde hym ryse \& assay

pat pou may gete bi pis resoun

Of pi fadir his benisoun

Modir he seide wise is pi lore

But o ping I drede soore

Pou woost my hondis are al bare

3660

And esaues rouze wip hare

If my fadir pat is blynde

May me so wip gile fynde

Of pat benisoun sore I drede

Lest he me curse in his dede

Dowey sone rebecca sayde

Pat malisoun on me be layde

Pat I pe bad brynge me soone

Gladly he seide hit shal be done

fol. $21 v$ col. 2

Iacob went into pe folde

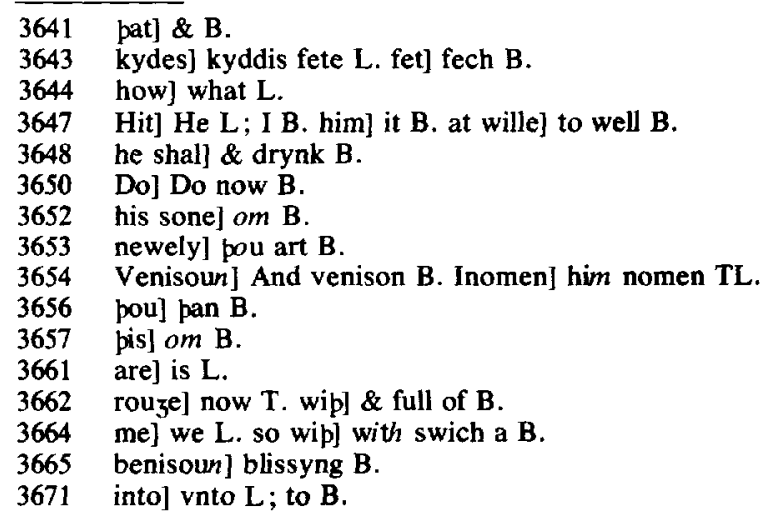


And brouzte pe kides I of tolde His modir smertly hem dizte As she tofore had hym hizte And clad him wip po clopes mete 3675

Of his broper pat smelled swete Wip a rouze skyn hid his hals And hiled perwip his hondis als For his fadir shulde trowe trewe He were his sone esawe 3680

His modir him pis mete bitauzt

He hit to his fadir rauzt

Fadir he seide sitt vp \& ete

I haue pe brouzte pi zernyng mete

What art pou his fadir seide

Sir . esau bi mete haue greide

What maner mete . sir venisoun

Ete and zyue my benisoun boun

How was hit pou sped so soone

Sir god of myzte herde my bone

And sende hit smartly to my honde

Men owe to ponke him his sonde

Come nere sone \& lete me fele

If pou be he I loue so wele

When ne he felde his smellyng cloope

And his necke \& his hondis bope

pis voys he seide . pat I here

Is of iacob wipouten were

But hondis \& hals as I trowe trew

Is my dere sone esaw

3700

pe sauour of pi vestiment

fol. $22 \mathrm{r} \mathrm{col} .1$

Sauerep as pe pyement

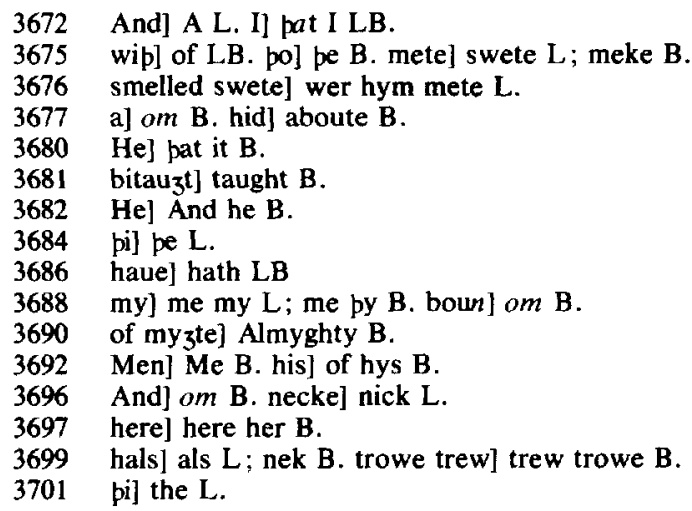


Fadir he seide is per noon oper

No sone als haue I mede

Allas he seide I am in nede

Away he hap my blessyng born

So dude he als pe zondur morn

He hap me done mychel shome

fol. $22 \mathrm{r}$ col. 2

Skilful is iacob his nome

Pat is to say in rizt langage

Putter out of heritage

For I first born shulde ha be

Wip strengbe azeyn drouze he me

And done me als pis vnresoun

To reue me pus my benisoun

$\mathrm{Me}$ is so wo almest I wede

Fadir pis was no broperhede

Counsel me fadir nowe to lyue

What counsel sone shal I pe zyue

And is per fadir no blessyng left

No pi broper hit hap pe reft

And is per fadir noon oper woon

Sopely he seide is noon but oon

In pe dew \& gras also

Shal be pi blessyng where pou go

Wip erpe trauaile so bou do

And preye god sende his dew perto

3760

Lord he seide what is me best

Myn hert bep neuermore in rest

Til pat pis iacob be deed

If I may gete him to any sted

Pus esau wip his manace

Out of pat lond dide lacob chace

\footnotetext{
3737 als] he sayde so $B$.

3740 pe zondur] pis endyr B.

3745 ha] om $B$.

3747 And] Hath L. vnresoun] treson B.

3749 Me is] I am B. almest] pat nere B.

3750 broperhede] broper dede $B$.

3752 shal] schuld B.

3753 And] $o m$ B.

3754 hit hap] hath yt $L$.

3757 pe] om $B$. gras] pe gres $B$.

3760 his] pe B. perto] also B.

3761 me] my L.

3762 bep neuermore] schall neuer be $B$.

3763 pis] ilke B.

3764 tol in $B$.

3766 pat] pe $B$.
} 
I shal forp wende pou dwellest here

My blessyng haue pou sone dere

pi broper be pyn vndirloute

3705

And alle pat wonen here aboute

Alle po sone pat blessen pe

Blessed shal hemseluen be

And alle pat bidde pe malisoun

Shal bere hit on her owne croun

3710

He eet \& dranke at his wille

And penne his [son] cald him tille

His broode blessyng he him zaue

pat his broper wende to haue

He made him lord of al his kyn

3715

Siche pen was his modir gyn

His modir counsel was perto

But god wolde hit shulde be so

// Iacob went when ne pis was done

And esau coom aftir soone

Fadir he seide sitt vp in bed

I haue pe brouzte to be of fed

Of venisoun pat I pe brynge

Ete and 3yue me pi blessynge

His fadir asked what he was

3725

Sir esau pi sone in plas

Sone he seide for my prow

pou were here at me rizt now

I he seide nay god woote

Mizte I not be so lizte of fote

Wip pis zaf yssac a grone

Sone he seide rizt now was one

Pat firste me fedde $\&$ penne me kist

And me bigyled ar I wist

My benesoun now hap pi broper

3705 vndirloute] andyrloute $B$. pat] po pat B. pe] pis B. wille] owne wylle $L$. son] om $\mathrm{H}$. broode blessyng] broper blessid L. zaue] than L. his] pe oper L.

pen] om B.

went] wend $L$.

coom aftir] bo come B.

of] with $\mathbf{B}$.

here... me] wip me here $B$.

Mizte I] I myght B.

perne] om B.

now] om $B$. 
Whenne her modir say hit so He souzte his broper for to slo She sent him soone into aran To hir broper pat het laban 3770 Pere to soiourne for pat sake Til his broper wratthe wolde slake By nyzte pe flom iurdan he wood And pourze a wildernesse he zood He loked where him were best

By pe weye to make his rest A stoon he took pat lay hym by And peronne leyde his heed on hy In sleep he say a ladder strauzt Fro his heed to pe skye hit rauzt On pat ladder say he boun Aungels clymbynge vp \& doun Open him pouzte pe zate of heuen Of god he herde siche a steuen God and lord he seide I am 3785 Of Isaac and of Abraham Iacob he seide pou shalt haue twynne Wyues of pyn owne kynne Two douzteres of laban pyn eeme Pat pou shalt haue wip barnteeme

Wip pe wol I be in pi nede

fol. $22 \mathrm{v}$ col. 1

And make pyn osprynge wyde to sprede

For pine eldres to pe I take

And esau for pe forsake

Glad he was of pat sizt

Him pouzte he slepte softe pat nyzt

On pe morne when ne hit was day

Iacob roos fro penne he lay

He seide oure lord out of were

I wist not his wonynge here

Here is nowe penne seide he

3769 aran] aram $\mathrm{T}$.

3771 soiourne] socour $B$.

3772 Til] To B.

3773 wood] wolde $B$.

3774 a] pe $B$.

3780 hit] om B.

3787 twynne] tweyne B.

3792 wyde] om B. to] \& L. sprede] spede B.

3793 eldres to] ordres for B.

3794 for] fro $L$. pe forsake] pi sake $T$.

3798 benne] pennes $\mathrm{T}$; pere $\mathrm{B}$.

3799 out of] with owen $B$. 
Goddes hous \& heuen entre

pe stoon pat his hede lay on pat nyzt

In tokene he hit set vprizt

And oyle he put vpon pat stoon

3805

And made to god a voys anoon

He seide if god be my frende

And lede me in my waye to wende

And sende mete drynke \& cloop

And brynge me azeyn wipouten lop

Into my kipthe pere I coom fro

If I fynde pat he lede me soo

He shal be my god and kynge

pis stoon shal stonde in tokenynge

And pis place fro nowe shalle

Be cleped goddis owne halle

Of al pe good he dop me welde

Trewely tipe I shal hym zelde

// Iacob wente him forp his way

Where bre flockes of beestis lay

Byside a welle vpon a felde

fol. $22 v$ col. 2

And Iacob say and bihelde

A mykel stoon vpon hit lay

pat beestis dronk at euery day

Pe herdes fonde he bi hem pere

And asked hem whepen pei were

Sir bei seide we are of aran

And knowe ze ouzte he seide laban

Sir zee . \& is he hool and fere zee hool pei seide out of were zondir I se his douztir Rachelle Dryuynge his beestis to pe welle For alle pe flockis comen hidur Vche day to drynke togidur

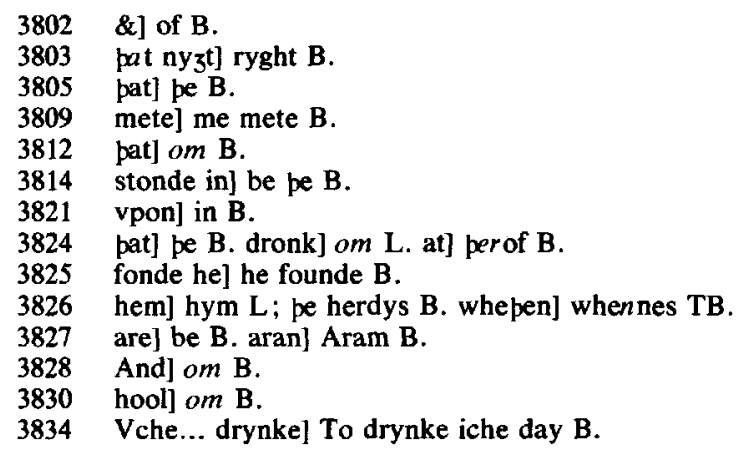


Penne coom rachel pat mayden brizt

Iacob lift vp pe stoon ful wizt

He spak so wip pat damysel

And knowleched him pere wip rachel

He seide what art pou lemman

Sir my fadir hett laban

3840

Aboute pe necke he hir hynt

And cust hir pryes ar he stynt

I am Iacob pi cosyn nere

For pi loue am I comen here

When ne she bigan to vndirstonde

3845

pat iacob shulde be hir husbonde

To laban tolde she pat tipande

And she hym ladde bi pe hande

pei freyned of her frendes fare

And he hem tolde of pat vnswere

3850

Laban pen ne he dide to calle

For fayn of him his frendes alle

Soone he dide him to say

What was pe chesoun of his way

Sir he seide I wol pe telle

For to spouse pi douztir rachelle

penne shal pou serue me seuen zere

Ar pat pou haue my douzter dere

Gladly he seide so shal hit be

Stille wip laban so dwelt he

3860

pe elder suster he forsoke

fol. $23 \mathrm{r}$ col. 1

For she glized seip be boke

For to serue for rachel fre

He was maystir herde of fe

Hit was myche wondir pere

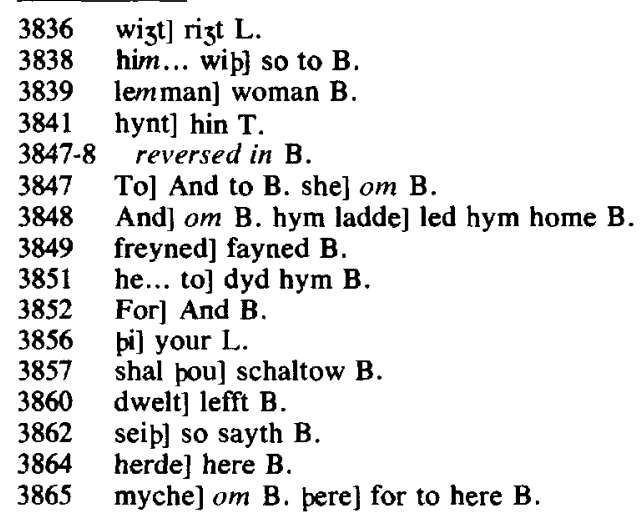


How myche multiplied pei were

When ne bo seuen zeer were gone

Iacob asked his lemmone

Laban seide ful blipely

But pere he dide a tricchery

3870

Whenne he hadde rachel wedde

Lya he stale to his bedde

Bisyde lya al nyzte he lay

His vnwityng til hit was day

But when ne he wist on pe morn

3875

Wo was him pat he was born

Fro hir he roos \& siked soore

And asked who brouzte hir pore

Laban she saide . allas be while

Who wende he wolde me pus bigyle

3880

He asked laban to resoun

Whi he dide him siche tresoun

Oure lawe he seide pat we Inne lyue

Wol firste oure elder douzter be zyue

But mourne pou no maner zet

3885

Pou shalt haue rachel as I pe het

But pat may be noon opere wyse

But for oper seuen zer seruyse

pe while holde lya in bedde

Penne shal pou rachel wedde

pis newe forwarde was made pan

Bitwene iacob and laban

His zeres past \& seuen dayes

Rachel he weddid pe story sayes

//Lya bred childe sone had oon

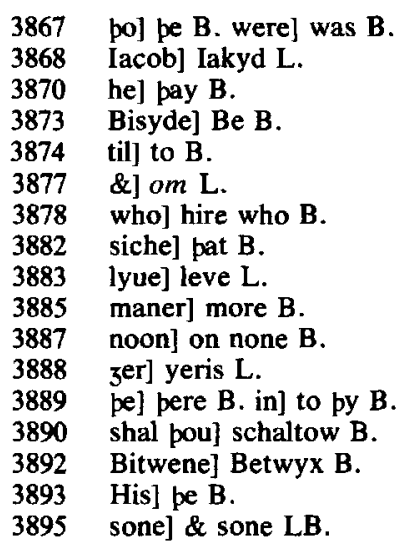


Ruben \& sipen symeon

Penne leuy penne Isacar

Zabulon Iudas sixe breper war

A douztir she hadde hizt dyna

But penne of oper wymmen twa

3900

Hadde foure sones geten of hym

fol. $23 \mathrm{r}$ col. 2

Dan . Gad . Asser . Neptalym

Rachel bar Iacob sones twyn

First Ioseph \& penne beniamyn

pat was pe cause of hir ende

Of hem she dyzed in gesin hende

What of his wyues two in spouse

And als of hondwymmen in house

Twelue sones of po hadde he

And a douzter dyna to be

Iacob wex riche his childer proof

Pourze pe grace pat god him zoof

Talent bigan to take him po

To his owne londe to go

Wyf and childe wip oon assent

Vchon in hond wip opere went

Laban of leue seide hem nay

And pei on nyzt stale away

A god had laban in his boure

Whiche he was wont to honoure

In her flittyng rachel hit fond

Forp she bare hit in her hond

Laban hit missed oueral hit souzt

But his god fonde he nouzt

Iacob went forb his way

On pe feld wipouten he lay

On pe to side of flum iurdon

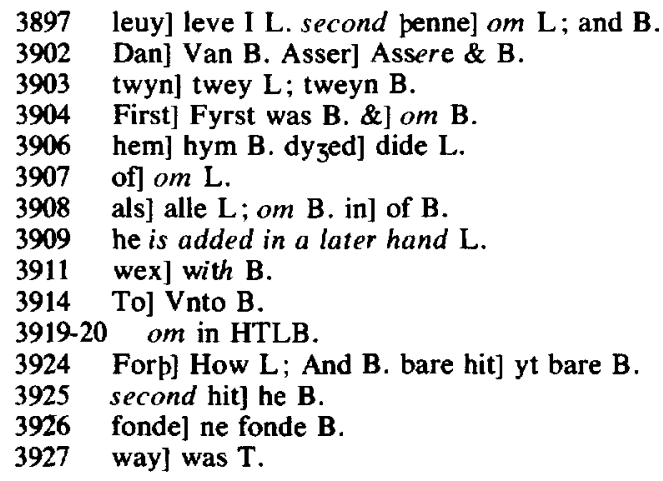


And sent his auzte ouer vchon

Iacob lay bi himself pat nyzt

In hond he kauzte an aungel brizt

So in honde wrastled pay

Al pat nyzt til hit was day

Pe aungel seide let me go

He seide pat wolde he neuer do

Lete him passe for no ping

Til he hadde 3 yuen him his blessyng

Long pei wrasteled togider pore

pat iacob was hurt ful soore

Pe maistir synewe of his pee

pat euer aftir haltide hee

And for pis resoun here new

Of synewe etep neuer no Iew

Pen ne asked god wipouten blame

fol. $23 v$ col. 1

And bad hym say soone his name

Iacob I het . Iacob seide he

So shal pi name no lenger be

pou shalt be calde israel

pat is mon seyng god of hel

For pou azeyn god strong is

More worb azeyn mon be fro pis

Iacob sent penne to fonde

Esau wip sauztelynge sonde

For he was ferde in alle pinge

For to come to his metyng

Whenne he of his comynge herde

Ful wropely to him he ferde

Foure hundride men soone he fonde

To kepe iacob fro his owne londe

And so he shal pat woot I wele

For he is al bisett wip sele

Iacob sent him of his auzt

\footnotetext{
3930 auzte] meyne $B$.

3932 he] hym $B$.

3934 til] to B.

3939 Long] So long B.

3943 new] now LB.

3947 I het] he sayde B.

3950 mon seyng] to sey $B$.

3952 be fro] before $B$.

3953 penne] po $B$.

3958 wropely] worpely L.

3960 owne] om $\mathbf{L}$.

3962 bisett] besyde $B$.
} 
ziftis large hym to sauzt

Pe messangere brouzte vnswere

He coom azeyn him wip greet powere

Iacob led myche folk of his kyn

For doute he dalt hem in twyn

For greet doute he hadde pan

He dalt in two beest and man

Whil esau smoot oon of poo

pat oper part shal skape him fro

Iacob dredde Esau sare

For he was fel wipouten spare

pat if he myzte him ouergo

Wipouten pite he wolde him slo

pus he made his preyere

Lorde he seide my god so dere

pat madest Adam mon of lyf

And sippen of him Eue his wyf

Hadde pei holden pat pou hem bad

pei hadde in endeles ioye ben stad

And also noe trewe and good

Pou sauedest fro pat ferly flood

pou woost lord pat hit is soo

My bropere nowe is my foe

For I pourze my modir roun

Stale fro him his benesoun

Here ouer pis flum last whenne I ferde

I bare in hond but a zerde

And now my lord blessed pou be

Two flockis of folk come wip me

Lord now sende me sum rede

Azeyn esau lest I be dede

For man pat pou wolt helpe in nede

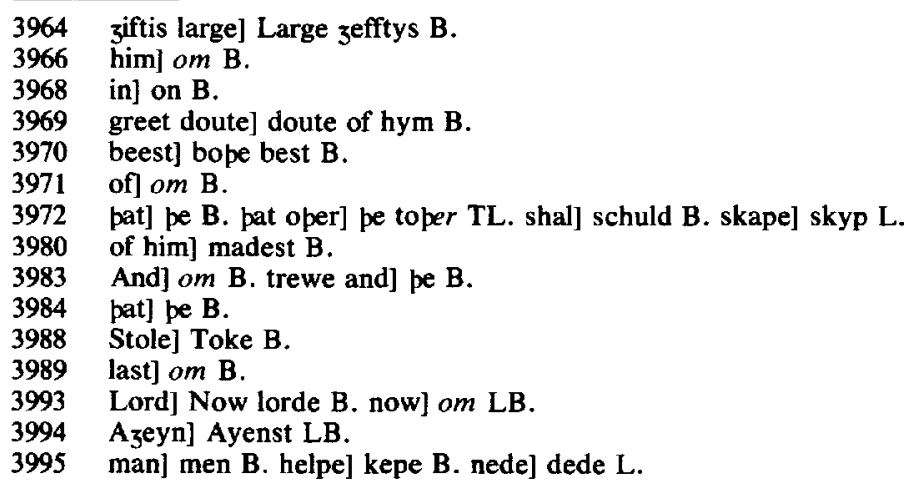


Par hym neuermore drede Of pis auzte pou hast me lent Perof I haue bifore me sent For ar he alle po haue slayn He shal be mased of his mayn 4000 pat while if pou wol pei shul pase And come not in his hond percase Esau coom breem wip greet route Now is iacob in mychel doute He swore if he myzte hym mete 4005 Formast he shulde his lyf lete But whoso god helpe wolle May sauely go at pe folle Whenne esau say him \& his auzt Soone he souzte hym wip sauzte And for his come was ful blipe Pat gan he wip kissyng kype Of siche strengpe is pe holy goost To oonen hem pere wrappe is moost He welcomed iacob ful feire

And knewe him for his fadir heire

Wibouten wrappe or any wrake

Of loue \& pees togider pei spake

Whenne pei had seid pat pei wolde say

Esau went hoom his way

Vnto syer per he coom fro

And iacob to his fadir to go

For zitt po he was lyuonde

Rebecca his modir dede he fonde

Pis ysaac pat I of rede

In bookis is calde pe lastyng sede

He ladde his lyf wipouten blame

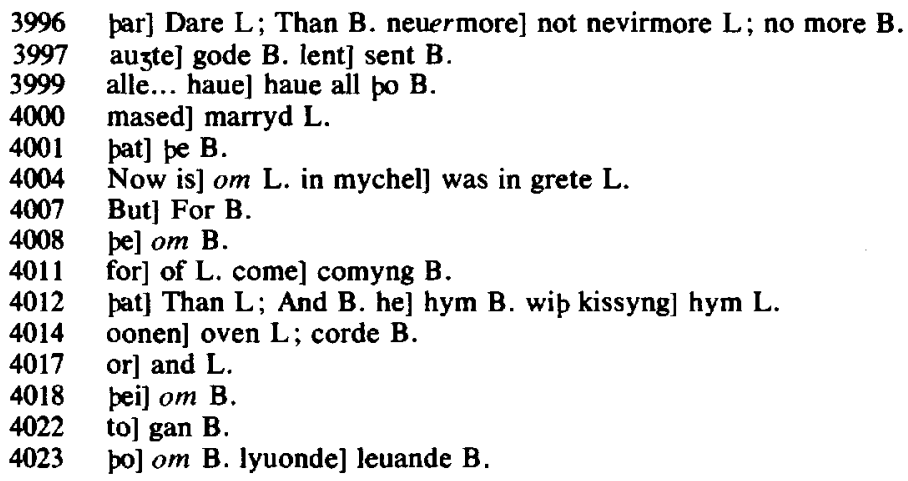


And buried is bisyde abrahame

Nyne skore zeer ouergoone he hadde

When ne he of pis world was ladde

4030

When ne pis douzty man was ded

Pese breperen two toke hem to red

To dele her londes hem bitwene

Penne myzte pei lyue out of tene

To esau fel Ebron

4035

And to Iacob penne Edon

Pe story of iacob bigynnep here

And also of his sones dere

Iacob was wondir riche of $\mathrm{fe}$

Of alle goodis he had plente

$\mathrm{He}$ was ful riche as we rede

Trewe and loued of vche lede

4040

Wel he loued his sones vchone

But so wel as Ioseph noon

He was fair wipouten sake

Of briperen hadde he noon his make

His breperen alle were herdes I saye

4045

But he dwelt at home alwaye

Pis was trew Ioseph pat dredde

His loue word wyde spredde

Pat wise chaste pat gentile

Pat aftir sufferide greet perile

Of po periles pat he was ynne

Sum what to telle I shal bigynne

How he coom out of his woo

Into his wele here also

Ioseph say a nyzte in sweuene

4028 is] om B.

4029-31 In MS B the lines are in the following order: 4030, 4031, 4029.

4031 Whenne pis] And hys B. man] name B.

4032 hem] them L.

4033 hem] them $\mathrm{L}$.

4034 lyue] leue $B$.

4036 penne] om $B$.

4040 of vche] euery $B$.

4043 sake] lak B.

4044 noon] not $B$.

4045 alle were] were all $B$.

4046 he] loseph B.

4048 word wyde] wolde wyde be $B$.

4049 second pat] and $\mathrm{B}$.

4052 shal] will $B$.

4055 say] se in B. in] a B. 
Pat is worpi for to neuene

Him pouzte his fadir her corn shere

pere his elleuen breperen were

Hymself was on pe felde bisyde

To geder corn in heruest tyde 4060

His breper sheeues he say loutynge

fol. $24 \mathrm{r}$ col. 2

To his alone pat was stondynge

Anoper he mette peraftir soone

Him pouzte bope sunne \& moone

And of [be] grettest pat were on heuen

4065

Honoured him sterres elleuen

Alle louted hym on her manere

Rizt as he her lorde were

He hem tolde \& pei seide how

May pis bityde what wenes pow

For to be lord ouer vs alle

pat blisse shal pe neuer bifalle

Fro pis tyme forb neuer pe les

Wip Ioseph were pei neuer at pes

pei hadde enuye to hym strong

pei souzte to greue him ay wip wrong

Wolde pei neuer vpon him se

Fro pat day but wip enemyte

At hoome was moost Ioseph pat childe

His breperen in wildernesse wilde

Wip her fee pe lowes bitwene

As bei were pen wont to bene

$\mathrm{Bi}$ pis story may men se

Men lyued moost po bi fe

Pese breperen pat I spak of ere

\footnotetext{
4056 worpi] worpe $B$.

4057 her] om B.

4063 mette peraftir] pought pat afftyr B.

4064 bope] pat bope B.

4065 pe] om $H$. on] of $L$; in $B$.

4067 louted] honourid $L$.

4073 forp] forwarward $B$.

4074 at] in LB.

4076 souzte] pought B. ay] euer L; om B.

4077 vpon] syp on $B$.

4078 enemyte] envyte $L$.

4079 was moost] moost was TB.

4080 His] And hys B. wilde] wyde B.

4081 her] he B. lowes] londys B.

4082 ben] $o m \mathrm{~L}$.

4083 may men] men may $L$.

4084

fe] pe fe $B$.
} 
Among pe feldes dwellynge were

Pat noon coupe of hem typing telle

Til on a day hit bifelle

Her fadir of hem wite walde

Ioseph his sone to him he calde

4090

Sone he seide pou must algate

Go wite of pi breper astate

Longe is sip I of hem herde

Or of her fee how pei ferde

Fadir he seide I wol ful fayn

4095

Pi biddyng not to stonde azayn

He went forp \& wiste not where

Sopely pat his briperen were

But ar he to his breperen coom

Whil he went he mette a mon

What sekest pou here sone seide he

fol. $24 \mathrm{v}$ col. 1

My breper sir my fadir fe

Pen vnswered pat mon to him

Pou shalt hem fynde in dothaym

He went forb and forper past

4105

Til he hem fonde at pe last

He went forb \& ferper souzt

Til he hem fond lafte he nouzt

Whenne pei seze Ioseph come her broper

Vchone of hem seide to oper

Lo where pe dremere is comen

Bi myzty god he shal be nomen

Lete vs do hym to pe dede

Loke what his dreem wol stonde in stede

Fayn pei were pere hym to fynde

For to haue her wille blynde

If pei bifore him ouzte forbare

Now wol pei hym not spare

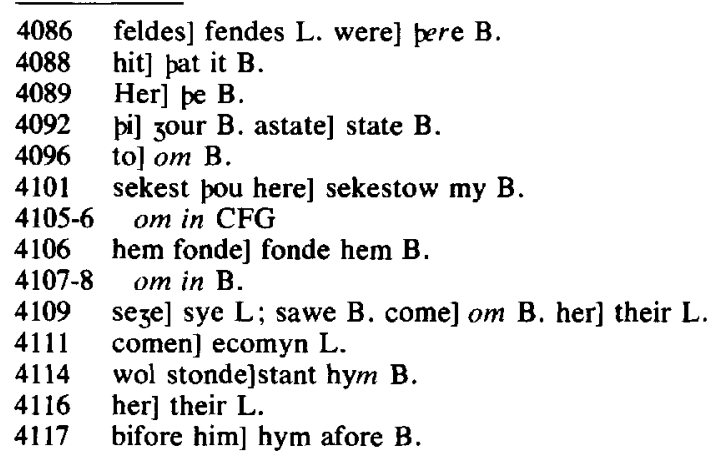


//Oon eldest of pe elleuen was

pat ruben hette in pat plas

Whenne he herde pei wolde him slo

Perfore was him wondir woo

Stynte hit wolde he if he myzt

Pe foly pat his briperen tizt

Alle he say hem in o wille

Her broper giltles to spille

Breper he seide doop not so

I rede ze not zoure broper slo

Pat is zoure owne flesshe \& blode

[T]o murper him hit is not gode

If ze do forsope my wille

Shul ze neuer haue pertille

If ze hit do I zow teche

Sikur may ze be of wreche

And zoure shame shal be coup

Alle men to haue zou in moup

Pat baret rede I not ze brewe

Pat ze foreuer aftir rewe

He hap no ping done why

ze haue not to hym but envy

Wite his fadir he be sloone

fol. $24 \mathrm{v}$ col. 2

His lyf dayes telle I goone

4142

For mon lyuyng pei seide ne wyf

Shal he skape wip his lyf

Whenne ruben seye per was noon opere

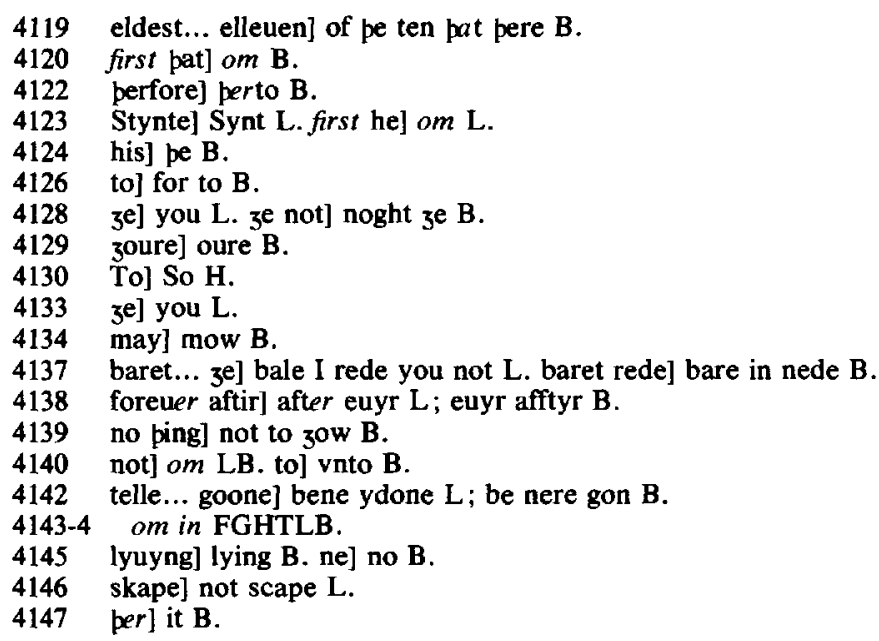


But algate pei wolde sle her bropere

For goddes loue do wey he seide

pat noon honde be on him leide

4150

pat no blood of hym be shede

But if he algate shul be dede

Do hit penne wip siche a wyle

pat ze not zoure hondes fyle

In pis waast I woot a pitt

4155

Drye and watirles is hit

Perouer stondep a mychel tre

Caste him perynne \& lete him be

Til pat he of lyue be brouzt

Pen may we saye we soze him nouzt

4160

His curtel wol we ryue \& rende

And blody to his fadir hit sende

And telle him $\mathrm{p} a \mathrm{t}$ we hit fonde

In be wildernesse lyonde

Say we pat he rent es

Wip wilde beestis in wildernes

penne wole no man saye vs by

Pat we han slayn hym felonly

Do seide Ruben as [I] zow say

He pouzte to stele him quyke away

Anoon pei grauntide pat bihete

pei hent Ioseph bi honde $\&$ fete

Made him naked \& kest him doun

And lafte hym pere in prisoun

Sippe sett hem doun and ete

pei say po comyng bi be strete

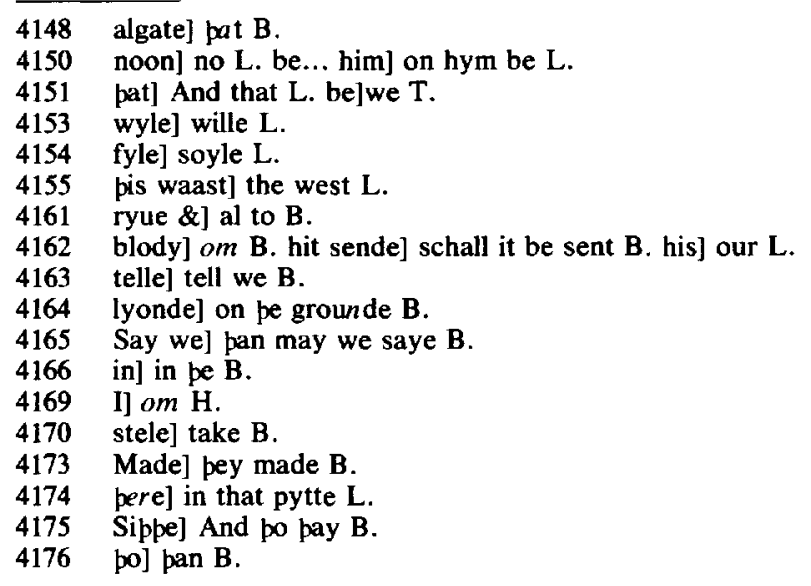


Marchaundis of on vnkoup londe

Of egipte as we in bookis fonde

Wip camailes pat grete burbens bare

Of spicis and of opere ware

Among pese brepere oon per was

Whoos name was calde Iudas

What boote he seide were hit to vs

To fordo oure broper pus

Take we him out of pat den

fol. $25 \mathrm{r}$ col. 1

And sille we him to pese chapmen

4185

pat pei may lede hym to fer londe

To be her pral euer lyuonde

If hit so be he dye pare

Hit is to vs but litil care

4190

And if he be pere lyuynge

His fadir of him hap no tipinge

Pere was Ioseph to seruage solde

For twenti besauntis taken of golde

Now is Ioseph lad out of londe

God holde ouer hym his holy honde

Ruben of hem moost was wys

He wiste not of pis marchaundys

On pe morn he coom \& souzte

Pe pyt but loseph fonde he nouzte

He mourned more pen I con telle

Almest in swoun doun he felle

To his briperen went he soone

And pei him tolde as pei had done

What bote is hit to make mone

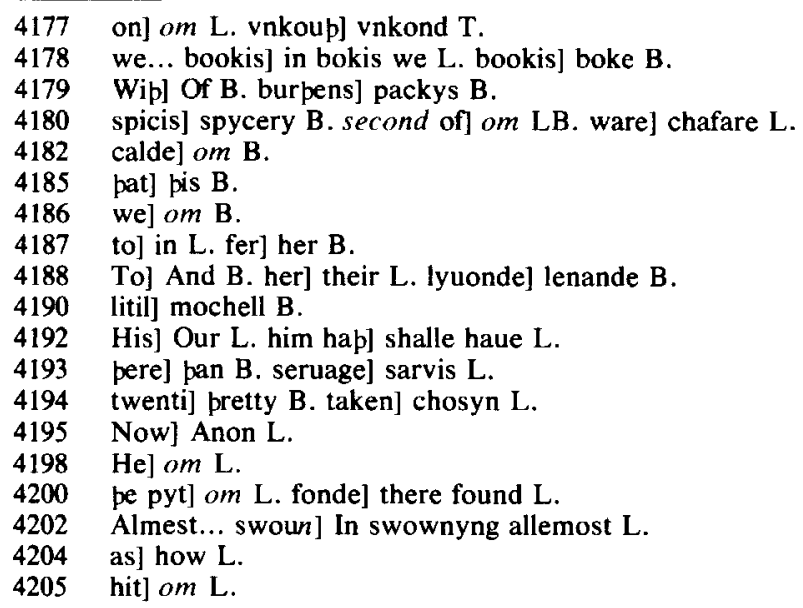


For ping pat coueringe [of is] none

His fadir pei sent witterly

Ioseph curtil al blody

//Whenne his fadir pe curtil knew

Soone bigan he to chaunge hew

A beest he seide my sone hap rent

Allas pat euer I hym out sent

Into pat wylde weye to wende

pat al my loue on hym gan lende

Alas wittles was I pat day

Beestis of hym han made her pray

pis was his cloop hit is wel sene

A pis beest was ful kene

pat hap me refte my derlyng dere

My ioye my gladnes \& my chere

Ioseph pou wast my ioye allon

Now art pou deed \& I haue noon

Ioseph pat was fre and fair

Of al myn auzt shulde ha ben myn heir

For pi goodnesse \& pi fair hew

4225

My kare shal be euere new

I wolde sinke to helle depe

Wip my sone pere to wepe

But al his mournyng for to rede

Ouper to speke hit myzte not spede

4230

His opere sones coom vchone sere

For to amende her fadir chere

But for nouzte pei coomen alle

To counfort wolde he noon falle

No ping may his mournyng mende

fol. $25 \mathrm{r}$ col. 2 
Neuer to his lyues ende

Leue we nowe of iacobus care

To telle of Ioseph \& of his fare

// Pese chapme[n] pat Ioseph bouzt

Into egipte han him brouzt

Pere he was eftsones sold

To a douzty man and bold

To putifar stiward wip pe kyng

Was he sold pat childe 3 yng

He helde Ioseph in menskful lore

pouze her layes on not wore

For pei were of sarasene lede

And Ioseph helde his owne in dede

Sir putifar wel vndirstood

pat Ioseph was of gentil blood

In alle pe dedis pat he wrouzt

God was euer in his pouzt

pe keping of al his auzt

Hap putifar Ioseph bitauzt

Ioseph penne was loued $\&$ dred

Wip wisdoom he his werkes led

For he was curteys and hende

of alle folk fonde he frende

Putifar went into cuntre

loseph dwelt wip his meyne

And hap his goodis vndir honde

Vndir himself al weldonde

Ioseph was wondir fair in face

And filde al wib goddis grace

His lady hir yze on hym cast

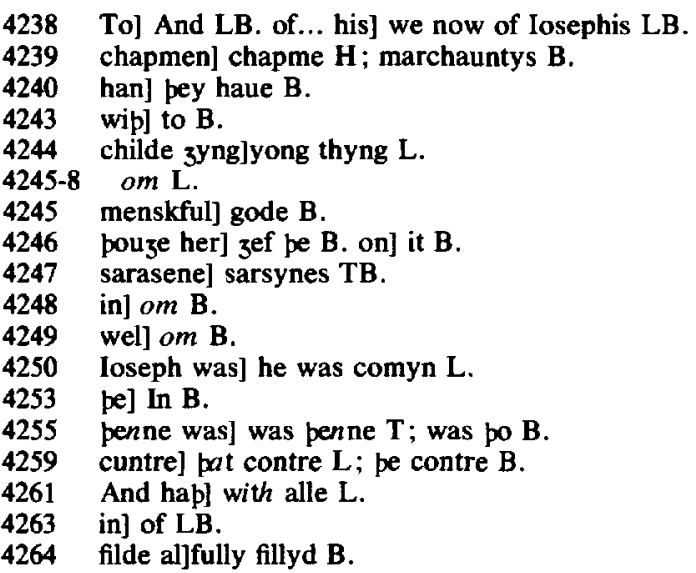


Forward of fool is ep to fast

Foly hit was \& she so fond

Hir loue to sett but hit wolde stond

She kid hit euer \& on hym souzt

And Ioseph lett he wiste hit nouzt

4270

He wiste \& helde hit stille as wyse

And euer she preysed his seruyse

So longe she hap in hert hit hidde

At pe last hit most be kidde

For whosoeuer be glad or blipe

4275

At pe ende wol pryue loue out wrype

Ofte she mened to him hir mone

But euer she fonde him in one

Whenne she pat say hir hert was soor

And longynge had she moor \& moor

4280

In hir foly she was so fest

Pat ny 3 nor day had she rest

What is more hert brest

pan want of ping men loue best

Into siche prisoun to be put

4285

Pat reuep man myzte \& wit

In prisoun I calle hym bistad

Of whom pe hert is neuer glad

Whenne hert hap pe wille I wis

pe body may haue no more blis

Ne no more woo pen likyng woone

Wipouten wille Is likyng noone

Pe strengpe of loue noon may stere

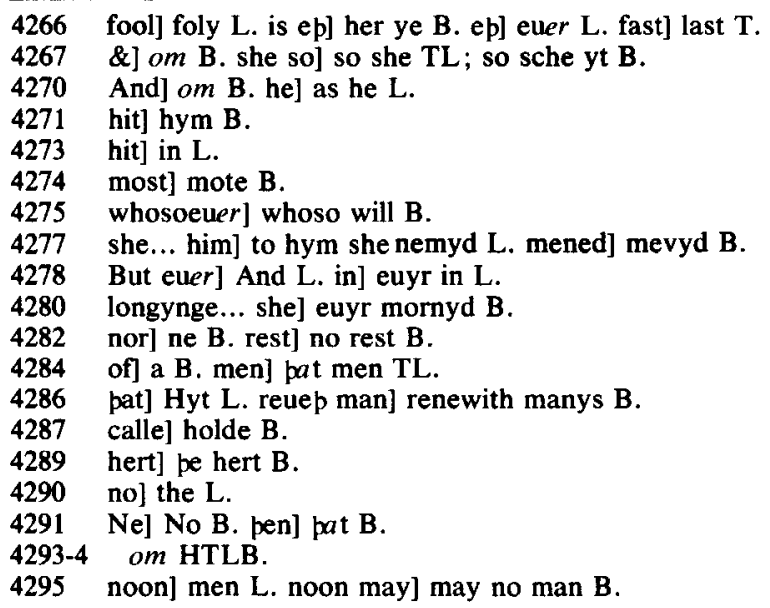


Pouze his herte al steel were Hert of steel \& body of bras Strenger pen euer sampson was pat loue ne may meke wip myzte Sumtyme alone wip oon yze sizt 4300

Ful harde hit is wip him to dele Mannes flesshe he makep ful frele When ne his loke alone may brynge Into his praldome pe kynge And maugrei his do him loute For euer he ledep him wip doute perfore if pou be siche a gome pat pou algate wolt loue ouercome When ne pou seest him loue to pe Stalworpely fro hym pou fle 4310 Fle \& turne pou not pyn yze Or ellis but pou be ful slyze Pourze byn yze pou shalt be shent As ping wip wilde fyre forbrent Firste to brenne pi herte wipynne

And sipen to st[r]angle pe in synne Fle and folwe not I rede

For elles may pou come to dede 4305 fol. $25 \mathrm{v}$ col. 2 Better is in tyme to be forborn

pen folwe pe pray bat is forlorn

Who so dop shal rewe soore

And venge his harme wip foly more

So dide pis wyf pat I of rede

She folwede Ioseph where he zede

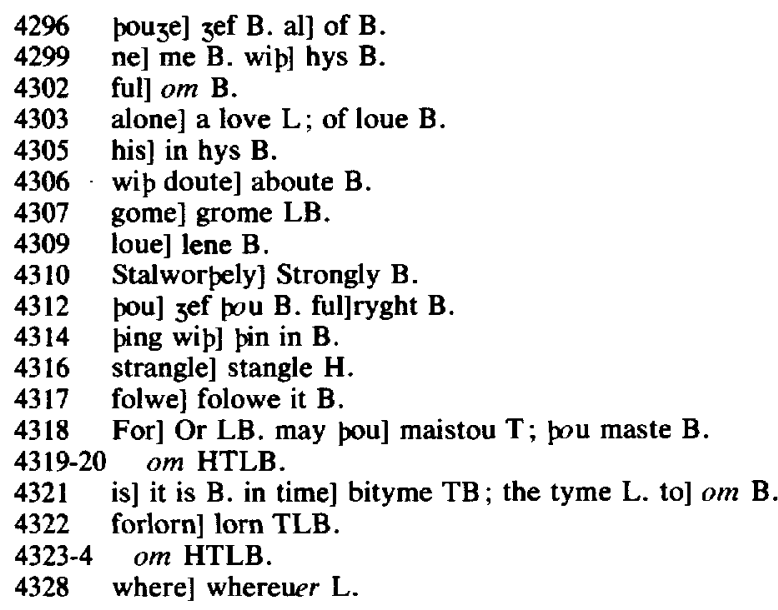


And for she folwynge fond a sporn

She waited hym euel torn

Hirself hadde pe grame \& gilt

Almest also she had him spilt

How she bigan hym to fonde

For to telle I wol not wonde

She souzte on him mony a day

And euer he vnswered hir wip nay

Ioseph pat was hir purueoure

On a day wip mychel honoure

In chaumber gret hir hendelye

And seide madame to mete $z^{e}$ hye

zus she seide [but] er pou go

Speke wip me a word or two

Longe he seide may I not dwelle

Penne bigon she pus to telle

Ioseph lem mon for pi sake

To pe now my mone I make

Bitwene piself alone \& me

Now wole I shewe my pryuete

pat loue me hap brouzte to grounde

Pat I may neuermore be sounde

fol. $26 \mathrm{r} \mathrm{col} .1$

But if my bote ryse on pe

pat pou wolt my lemmon be

Worldes welpe to welde in wone

Inowze pou shalt haue allone

To my lord shal bou be dere

Oper noon shal be pi pere

She toke him aboute pe necke wip pis

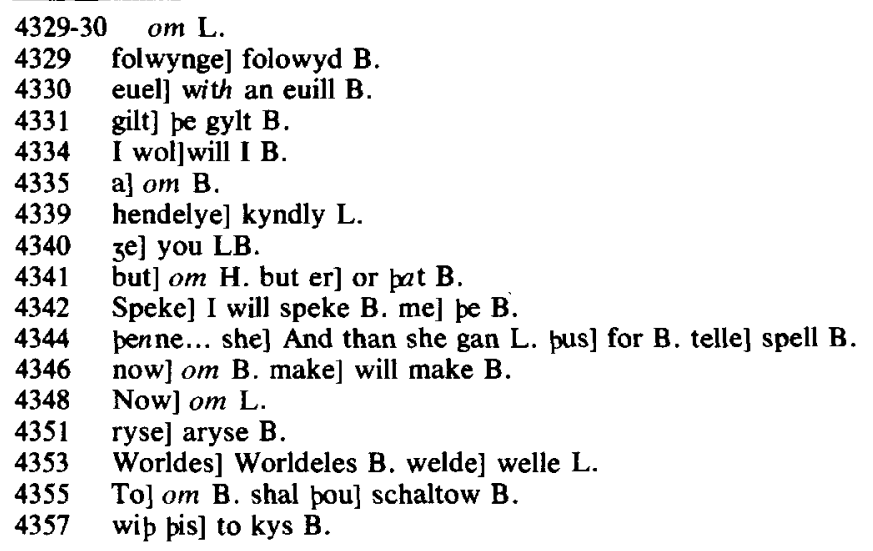


And proferede hir moup to kis

And drowe him towarde hir bed

But Ioseph pat mychel god dred

Do wey he seide pi foly wille

Wolt pou pi self $\&$ me als spille

Putifar me hap bitauzte

Lond and lithe $\&$ al his auzte

And for he tristep my lewete

To kepe his godis he toke hem me

$\mathrm{Al}$ is me take \& not forgone

But pou art his wyf allone

Of pe haue I no maner myzt

If I hadde hit were no rizt

He pat zaf me suche pouste

To bitraye god forbede me

Wip no resoun we ne owe

To oure lord suche tresoun showe

Leuer me is be pore \& trewe

Pen falsely wynne catel newe

Perfore lady wip myzt \& mayn

Drawe pi foly wille azayn

For whoso bigynne wol suche ping

Hym owe to penke on pe endyng

4380

She seide allas Ioseph pis day

Hast pou vnswered me wip nay

If I lyue pou shalt me proue

An euel frend to pi bihoue

I shal pe make wip my housbonde

pe moost hated in al pis londe

4358 proferede] anon she profyrrid L; proferyd hym B. hir moup] hym for L. to kis] with pis $B$.

4359 hir] pe $B$.

4361 wille] dede $B$.

4362 Wolt poul pou wilt B.

4363 me hapl my lord hath me $L$.

4364 lithe] lede $B$.

4365 tristep] troweth in $B$.

4366 godis] gode B. hem] yt B.

4367 is me] me ys $B$.

haue I] $I$ haue $L$.

no riztl nought $B$.

bitraye] bretay $\mathrm{L}$; betray hym $\mathrm{B}$. forbede] he forbade $\mathrm{L}$; forbede it $\mathrm{B}$.

we ne] ne with $B$.

suche] schuld $B$.

4379 bigynne wol] begynnep B. suche] eny $L$.

4382 Hast pou] Hastow B.

4386

pe] om B. hated] Ihatyd B. pis] pe L. 
She drouze his mantel bi pe pane

Whenne Ioseph say no better wane

He drouze she helde be tassel brak

fol. $26 \mathrm{r}$ col. 2

pe mantel lafte \& he zaf bak

4390

Penne fel she into felony

And soone souzte a tricchery

She made a cry alle to here

pat pat tyme in pe pales were

Lady bei seide what is zow

4395

She seide herde ze not how

Pat traytour iewe wolde me shende

pat my lord halt his frende

He wolde haue forsed me in hye

Nadde I be suuner made a crye

4400

Whenne I cryed soone he fledde

And lafte wip me a tokene wedde

His mantel is bilefte wip me

Here be sope may vche man se

Here may men se pe vilany

4405

pat he souzte on his lady

Sir she seide to putifar lo

Was neuer lady serued so

pis shame he hap me done in dede

pis gedelyng of vncoube sede

pis Ioseph souzte on me in bour

To do me pis dishonour

Such hit was pe vilany

Pat he gon seche on my body

perfore as bou art man for be

Loke pou on him wroken be

Putifar commaundide soone

4389 tassel] mantell B.

4390 lafte] kaste $B$.

4392 souzte] pought $B$.

4393 alle tol that alle might $L$.

4394 pat pat tyme] of tho that $L$.

4395 Lady... seide] pey sayde lady $B$. is] eilis $L$.

4397 pat] pis $B$. wolde... shende] will shend me $L$.

4398 halt... frende] hath take to me L. halt] holdep B.

4400 Nadde] Ne had LB; pe] om B.

4402 wedde] in wedde TL; in bed $B$.

4403 is] he B. wip] om B.

4404 sope] trewpe $L$. may... man] eche man may LB.

4405 may men] men may L; man may $B$.

4409 shame] schame syr B. me done] do me L; don $B$.

4410 pis] pe $T$. vncoupe sede] pe vncoupe lede $B$.

4413 was] is $L$.

4416 pou] pat pou B. on... wroken] awrokyn on hym L. 
Ioseph for to take \& done In kingis prisoun for to lye Wipouten raunsoun for to bye 4420

Allas Ioseph pe war \& wyse Euel is quytte pi trewe seruyse For pi goodnes \& pi trewe dede Ful euel is zolden pe pi mede Suche is tresoun of wommon 4425 Stronger in world is founden noon God amende hem pat suche ben And zyue men grace hem to flen Now is loseph in prisoun stronge And lowe lip wip myche wronge And aftir lyked him ful wele For al was turned him to sele Soone was Ioseph holden dere Wip be mayster iaylere Pourze pe myzte of goddes grace 4435 Ouer alle pe prisouns pat per wase Alle pat in prisoun were in bonde Ioseph had hem vndir honde He ferde wip so mychel prifte Pat al was done as he wolde shifte 4440 Pus con god helpe mon in nede Po pat wol hym loue and drede Whil Ioseph pus ferde pere Tweye men of pe kyngis were To prisoun sende for her mysdede What hit was I con not rede pe spensere and be botilere bope

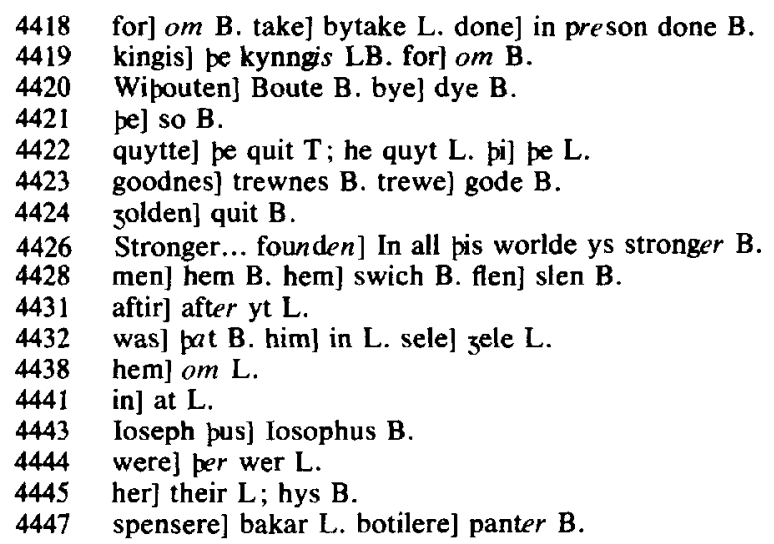


Pe kyng wip hem was ful wrope

But be mayster iaylere

Toke hem Ioseph vnto fere

Whenne Ioseph say hem swipe

Hem to counfort he was blipe

But as pei lay in pat prisoun

A nyzte pei mette a visioun

Of a sweuene pei hadde sene

Eiper gan to opere mene

Ioseph say her droupynge chere

And asked why pei mournyng were

pe botillere for bope vnswerde

Sir he seide we are aferde

For two sweuenes we say in sizt

In oure slepe pis ilke nyzte

What were po for pi lewete

pyn owne sweuene firste telle me

Me pouzte I say a wyn tre

And a bouze wip braunches pre

On pis tre on vche bowze

Heng grapes picke ynowze

Of bo grapis pat per hong

In a coupe me pouzte I wrong

fol. $26 \mathrm{v}$ col. 2

4470

pe kyng was at his mete faste

And in his hond pe coupe I prayste

Ioseph seide wip myzte of heuene

I shal arede wel pi sweuene

Or hit be pis pridde day

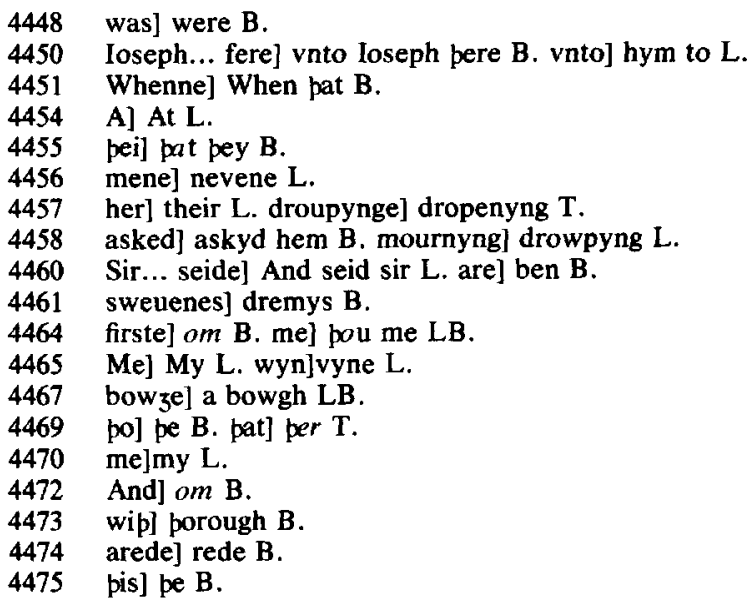


Of prisoun shal pou be take away

And ben aquyt bifore iustise

And put azeyn in pi seruyse

Whenne pou in wele art wip be kyng

For goddis loue on me haue menyng

4480

Pat I may by helpe of pe

Of pis prisoun delyuered be

Firste solde was I fro my pede

And now prisoned sackeles of dede

Pe spensere seide me pouzte I bere

4485

A leep as I was wonte do ere

Wip breed I bar hit on my hede

Me pouzte rauenes hit me reuede

A myche rauen my basket hent

Aboute my hede hit al to rent

4490

Ioseph sei[d] hit bep not longe

Or pat pou on galwes honge

Hit shal wipynne pre dayes be

Shal no raunsoun go for pe

Rizte as Ioseph seide biforn

He was honged pe pridde morn

pe botillere scaped pe same day

And Ioseph stille in prisoun lay

Wip myche kare and also wo

Longe he was forzeten so

Wildenes of welpe of pis botillere

Forzat Ioseph his dreme redere

For man pat walewep al in zeles

And for pat ioye noon angur feles

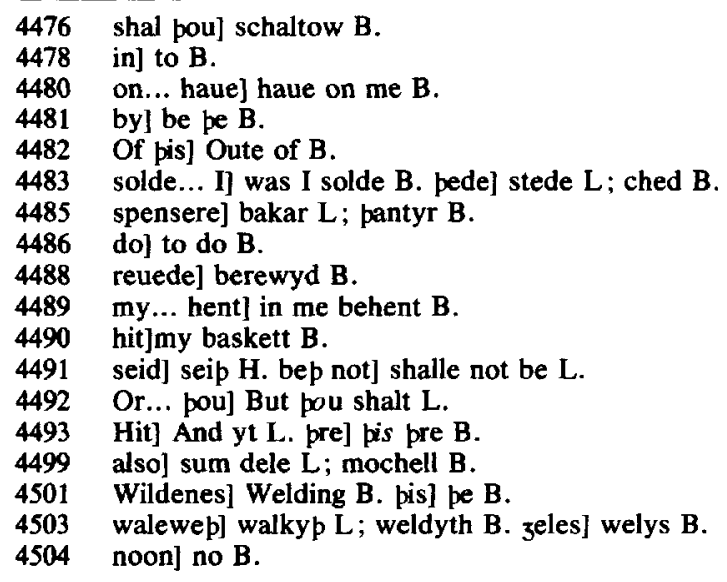


Pouze he haue frend pat is in wo

Oft he is forzeten soo

zore was seid \& zitt so bep

Herte forzetep pat yze not seep

But I dar saye god woot euer

Whoso trewely doop forzetep he neuer

fol. $27 \mathrm{r}$ col. 1

Ioseph lay in pat longyng

Til pat pharao pe kyng

Say in sleep a sweuene on nyzt

He comaundide to him brynge rizt

Clerk knyzt erle \& baroun

To telle to hym his visioun

To wite if any man were

Coude telle what ende hit bere

But per was noon of hem alle

Coude say what shulde bifalle

penne bigan be botillere speke

Of Ioseph in prisoun steke

To be kynge he seide pan

Sir he seide I knowe a man

Pat if he were brouzte in place

I vndirstonde he hap pat grace

Of pi dreem wipouten abyde

He shal pe telle pat wol bityde

Sir whenne ze were wip me wroope

\& wip pe maystir spensere bope

In prisoun were we done in bonde

perynne a iewes childe we fonde

Eyper of vs a dreem we sawe

And he bad vs to hym hem shawe

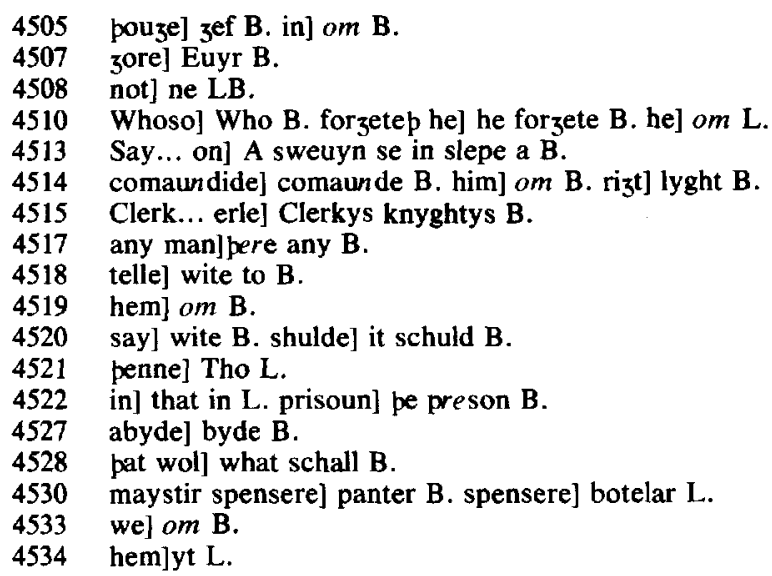


And we bigan al to telle

He tolde vs al pat aftir felle

Go to pe prisoun seide pe kynge

And do hym swipe to me brynge

pat cloping on him newe be done

And pat he come bifore me soone

4540

pe botillere to be prisoun went

Soone perof ioseph he hent

And dide on him newe cloping

And brouzte him sipen bifore pe kyng

On Ioseph hit was wel sene

pat he had longe in prisoun bene

Lene he was \& won in face

As he pat longe was fro solace

pe baronage wondir pouzt

pat he to kyngis counsel was brouzt

Pe kyng called ioseph nerre

And seide I haue souzt nere \& ferre

To fynde a mon my dreme to rede

But hiderto myzt I not spede

Coudes pou telle me what hit wore

My grace I graunte pe euermoore

Sir he seide shewe hit pon

And I shal rede hit as I con

I am redy pi wille to do

If god wole zyue me grace perto

fol. $27 \mathrm{r}$ col. 2

4550

$/ / \mathrm{Me}$ pouzte pat pis zondur nyzt

I coom in a medewe brizt

Flouris \& greses perynne I fond

And ky fourtene perynne goond

4535 bigan al] gan hym $L$.

4536 He] And he L. al] om L.

4539 on... newe] newe on him TL; now on hym $B$.

4542 perof] oute $B$.

4545 On] Of LB, sene] wene B.

4546 had] om L. bene] had bene L.

4547 in] of $B$.

4548 he... was] long pat he had ben $B$. pat] had $L$. was] be $L$.

4550

4552

4555

4556

4559

4560

4561

4562

4563

4564

kyngis] pe kynggis LB.

nere \&] om L.

Coudes] Canst L. Coudes pou] Coudestou T; Canestow B.

euermoore] for euermore B.

pi wille] the while $L$.

me] om L.

zondur] other B.

in] into $B$.

greses] gres $\mathbf{B}$.

ky] bestys $B$. 
Of pe seuen me pouzte ferly

Pei were faire and fatte ky

Pe opere seuene I zeode to se

And als myche wondir pouzte me

Her hyde was clongen to pe boon

$S[o]$ lene say I neuer noon

Hongry \& lene bope were pei

Pe[i] droof pe opere seuene away

In pat medewe so longe pei ware

pei hadde eten to pe erpe bare

Penne me pouzte I folwede a sty

Into a felde and sawe me by

Fourtene eres stonde of whete

Summe of hem were wondir grete

Ful of corn were pei set po

But pe toper were not so

Pei were clongen dryze $\&$ tome

Of pis Ioseph saye me pi dome

zyue me her of good coun saile

And I shal pe neuer faile

Good offis shal pou haue in plas

And be forzyuen al pi trespas

Penne seide Ioseph leue sir kyng

God hap pe shewed fair warnyng

Perfore owe pou bi rizt

To honoure him wip al pi myzt

fol. $27 \mathrm{v}$ col. 1

Sip he bifore hap warned pe

Of pi woo saued to be

For pourze pis ensaumple here

Wite per shal be seuen zere

Of plente in pi kyngriche

Pat is pese seuen fatt beestis liche

4569 hyde... clongen] skin were closyd B.

4570 So]S H.

4572 pei] be $\mathrm{H}$.

4575 folwede] went on $\mathrm{L}$.

4576 felde] pat feld L. and] I B. me by] pereby B.

4577 stonde] I sawe $B$.

4578 Summe] Sevyn B.

4580 toper] oper sevyn $B$.

4581 clongen dryze] drye clongyn $B$.

4583 her of] now a $B$.

4586 al] of $B$.

4587 [oseph] om L.

4589 owe poul pou owe B.

4594 Wite] Whete $\mathrm{L}$. The $\mathrm{h}$ is inserted with a caret. be] come B.

4595 pi kyngriche] pat kyngdom ryche $B$.

4596 pese] pe LB. 
Pes opere seuen woful neet

Bitokenep seuene zeer hongur greet

pat opere zeeres shul be folwonde

pat neuer were siche bifore in londe

Suche defaute shal ben of breed

Pe folk shal be for hongur deed

Sir kyng pis is pi auysioun

Loke piself bi al resoun

For bope pi dremes ben as oon

Perfore I rede pou anoon

Gete pe a good purueour

Pat in pis nede may pe socour

In vche lond men for to sett

To geder vche flfte mett

Of pat tyme pat is plente

Certis he seide so shal hit be

Ioseph pou art mychel of prys

And perto bope war and wys

Noon I se is founde pe liche

Here in al my kyngriche

Stiwarde pou shalt be \& hyze iustise

For wel I triste in pi seruyse

Nay sir he seide take not to spit

For firste wol I make me quyt

Of gilt of putifares wyf

Do wey he seide perof no stryf

Sakles sire haue I dere bouzt

I woot pou tellest hit me for nouzt

pis sakles shame sene hit is

God is wip pi werkis I wis

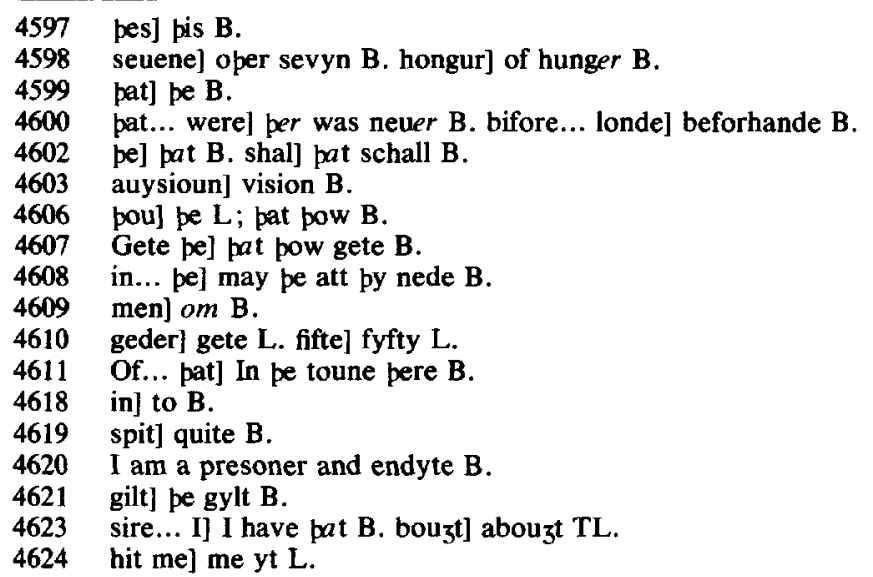


Whenne pe baronage of egip

Say him haue siche worship

Wondir pei hadde how pat he

To pe kyng was made priue

For he was a man vnseene

And hadde in greet myslikyng bene

We wende he had be deed ping

Nay god forbede seide be kyng

He was prisound wip false rede

So hap he lyued in mychel drede

Pat is wel [s]ene in his visage

Men han him done greet outrage

Of my dremes now hap he

Tolde me what of hem wol be

For I woot nowere his make

I wol pat he here vndirtake

Al be worshipe of my londe

Pat I wol ze vndirstonde

And al be wrouzte bi his counsaile

For al my londe hit shal availe

Pe seuene craftis wel he kan

$\mathrm{He}$ is a wondir wyse man

Al his baronage him biforn

To Ioseph han an oop sworn

To him as her keper to tent

And to done his comaundement

Of his owne hond toke be kyng

And dude on iosephs his ryng

Cloping on him he lette falle

Suche as himself was clad wip alle

To ride and go wipoute lettyng

And knele bifore him as kyng

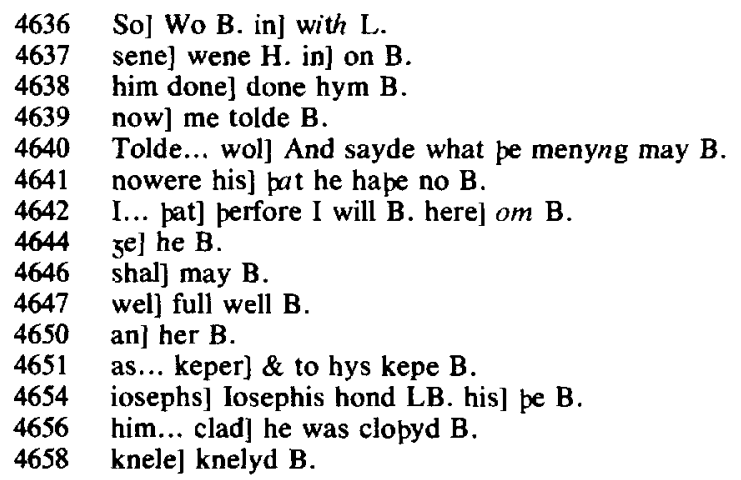


Penne seide Pe kyng Ioseph lo

Pou woost pat I am pharao

Shal noon so bolde be in my londe

Wipouten pe stire foot or honde

His name pei chaungide for pat honoure

And called him pe worldis saueoure

pe kyng him made a wyf to take

Hizt assener a douzti make

Ioseph pouzte on his mistere

Made geder him seruaunt \& squyere

4670

To gete him wriztes in a stounde

fol. $28 \mathrm{r}$ col. 1

Where euer pei myzte be founde

Bernes he made in pat zere

A pousande sett in stides sere

And aftir he commaundide himselue

4675

Depe seleres for to delue

And bi grace wip his witty dede

Filled hem of wyenes whyte \& rede

Whenne pe folk pus sawe $h[i] m$ dele

Wip wyn $\&$ corn flesshe $\&$ mele

And filde po bernes here $\&$ pore

Pe londis of egipt lesse \& more

4684

Pus ferde he po seuene zeeris

4685

pat mo ben a pousande seleres

Filde he wip wynes newe \& fresshe

And larderes wip salt flesshe

Graungis gerneris filde he wip seed

Moo pan I con wip tunge reed

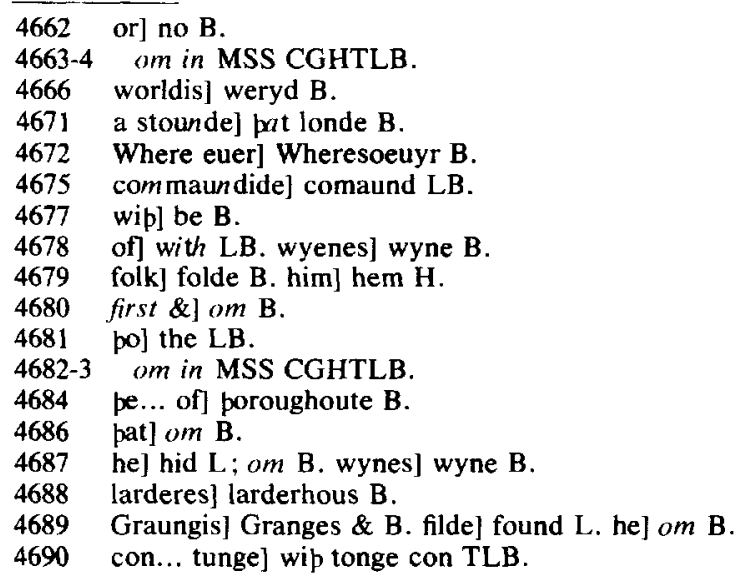


In euery stide laft a wardeyn Penne went he to pe kyng azeyn

For to reste him wip pe kyng

Aftir his greet trauailyng

When ne po seuen zeer were oute

Plowemen oueral pe londe aboute

As pei were wont her seed dide sawe

But al welpe bigon wipdrawe

pe erpe clang for hete \& drye

And so pe wo bigon vp hye

4700

For pat drouzt pat was so strong

Corn ne gras on erpe noon sprong

pe beestis dyzed vp al bydene

For pat hongur was so kene

pat bi pe firste zeer was goon

Vnnepe was pere beest laft oon

pe wrecched pore fonde no fode

Pei were so fele beggynge pei zode

Togider pei flocked in pat lond

By hundrides \& bi pousond

Pei souzte hem rootis as done swyn

Sorwe hit was to se pat pyn

pe childre \& pe men of elde

fol. $28 \mathrm{r}$ col. 2

For hongur lay dede in pe felde

Bifore pe kyng pei coom wip cry

And seide lord pou haue mercy

Of pi folke for hongur is deed

Was neuer moore nede of breed

Pouze men ouer al sowe feldis

Of corn nouzt hit vp zeldis

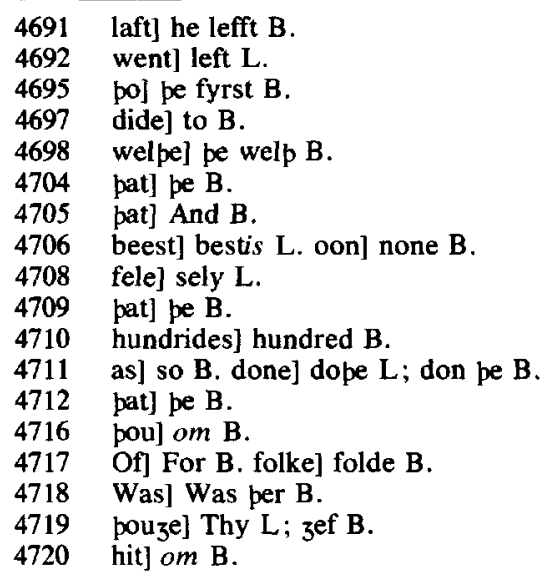


Pe qualme hap beestis ouergoon

But if sum bote be pe on

Pe folke shul dyze alle bidene

Wip qualme pis hongur is so kene

// Pe kyng say pis \& wepte soore

How mennes bodyes bolned wore

Wite we wel in pat tyde

Hadde he in his herte no pryde

Lordyngis he seide wel wite $z^{\mathrm{e}}$

Ioseph my stiwarde fedep me

4730

For derworpely is he pertille

$\mathrm{He}$ is al lord pat is skille

But goop \& fallep him to fote

And pray hym to do zow boote

pat he zyue zow of his corn

4735

Or ze for hongur be forlorn

To Ioseph went pei cryinge pon

Rewe on vs pou blisful mon

And lene vs sumwhat of pi seed

Was neuer eer so myche need

Sum what lene vs bi pi skep

I shal zow lene seide Ioseph

// Ioseph was ful of pite

Lete presshe soone in pat cuntre

Whenne pe seed was al boun

He solde vchone his porcioun

So pat pei myzte skilfully

pei \& her meyne lyue perby

In bokis fynde we of a wyle

pat Ioseph dide pat was sotile

pe chaf of corn he cast operwhyle

Into a watir men calle nyle

For pat watir pat ran pare

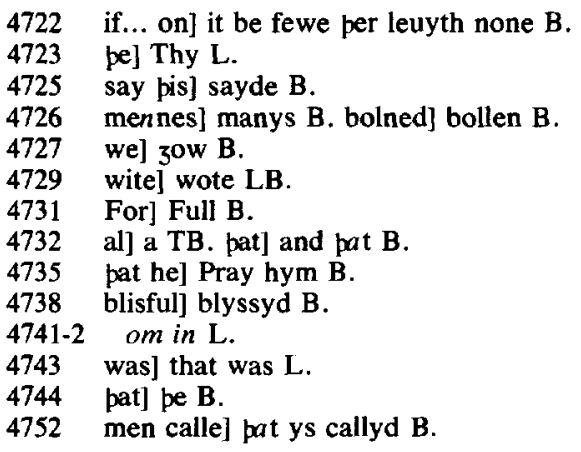


To iacobus hous hit hadde pe fare

pis hongur pat I here of telle

In londis al aboute hit felle

Men mist hit nowhere in no lond

Seuen zeer hit was lastonde

penne lacob \& his sones wore

Wip hongur in poynt to forfare

4760

Sorweful pei were no selcoup

Nouzte hadde pei putte in her moup

Siluer pei hadde \& golde rede

But pei myzte fynde to bye no brede

For hongur soore pis childre dide grete

4765

Iacob wiste not how hit to bete

Ofte he helde vp his hende

To god him for to helpe sende

And pat he myzte menskely dyze

Ar he pat [h]ongur longe shulde dryze

4770

But oure lord god of myzt

Herep monnes preyer in rizt

For pouze he preue his frend wip pyne

Perfore wol he not him tyne

Whenne Iacob was moost in fray

God him counfortide pat al do may

Soone aftir in a litel whyle

Iacob zeode bi pe watir of nyle

He say vpon pe watir gleem

Chaf coom fletyng wip pe streem

Of pat sizte wex he ful blipe

And to his sones tolde hit swype

4755 pis] His L; pe B.

4756 londis al] all londys $B$.

4757 mist] wist $B$. nowhere] neuer $B$.

4760 Wip] For $B$. forfare] fare L; mysfare $B$.

4761 no] \& $L$; non $B$.

4762 hadde pei] pat hadde B. putte] to put TLB.

4764 fynde to] no where $B$.

4765 pis] pese TL. childre] breper B. dide] om LB.

4767 hende] sond $L$.

4768 Tol pat B. him... to] for L; wolde hym B. sende] to fond L.

4769 menskely] lightly L; sone B.

4770 hungur] longur $H$.

4771 of myzt] almyght $B$.

4773 pouze] 3 ef $B$.

4774 he] hym L.

4776 counfortide] comforte B. do] om B.

4781 pat] pe B. wex] was LB. ful] om B.

4782 tolde] he tolde $B$. 
Childer he seide ze liste \& lete

I saw chaf on be watir flete

Whepen hit comep I con not rede

But doun hit fletep ful good spede

If hit be come fro fer lond

Loke whiche of zow wol take on honde

For vs alle to trauaille

Herof is good we take counsail

4790

Azeyn be fleem to fynde pe chaue

Corne per shul we fynde to haue

// Ruben seide to his resoun

Lo I am al redy boun

Oure alper nedis to take in place

fol. $28 \mathrm{v}$ col. 2

zyue me tresour \& let me pace

His broper seide go we alle

In goddes name \& so we shalle

Tresour ynouze wip zow ze take

And I zow pray for goddes sake

When ne $3 \mathrm{e}$ founden han pat ping

4795

pat ze make not long dwellyng

But gop wisely in vncoupe lond

God holde ouer zow his holy hond

pese breper went fro canaan

4805

For per was iacob wonynge pan

Her zongist broper pei left at hame

Beniamyn was his name

pei hyed hem vpon her weye

Soone to egipte comen peye

Whenne pe[i] saye of corn plente

Gladder men myzte noone be

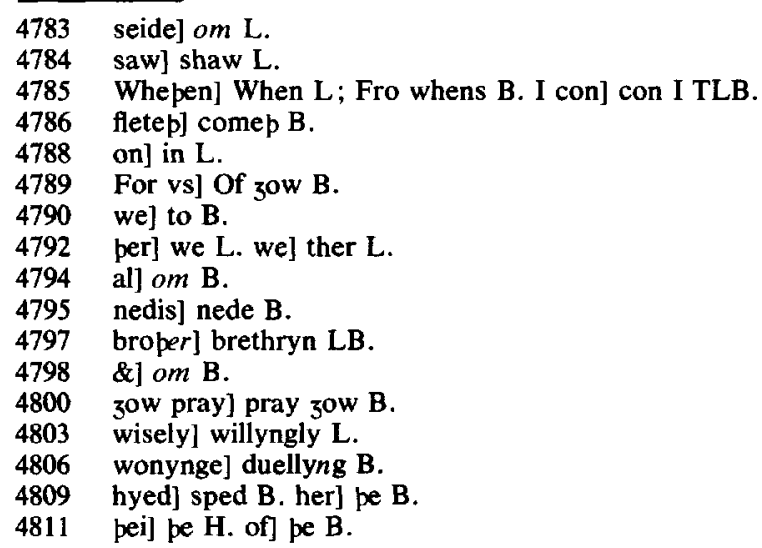


Breed to selle pei fonde \& bouzt

And to loseph soone pei souzt

Men hem tauzte whiche was he

Doun pei kneled on her kne

Coupe pei of hym no knowleche take

And vncoupely to hem he spake

Childer he seide whepen are zee

Sir pei seide of a cuntre

perynne is mony a nedy man

pe lond men callep canaan

Penne seide Ioseph ful vncoupelye

What are ze comen pis lond to spye

Nay pei seide lord vs forbede

But we are comen for greet nede

For bittur hongur pat is bifalle

Oon mannes childer are we alle

Pere is hongur in oure kyngryche

Was per neuer noon hit lyche

Pe folk dyzep vp al bydene

Suche hongur was neuer er sene

Perfore haue we hider souzt

fol. 29r col. 1

A party of money wip vs brouzt

Redy pens haue we to telle

If we may fynde corn to selle

Perfore we prey pe lord hede

Pat pou vs helpe in pis nede

Of pi michel plente here

To selle vs be hit neuer so dere

Haue ze lorde no mystrowyng

pat we shulde come for opere ping

// I shal zow selle but tellep me

What maner man zoure fadir is he

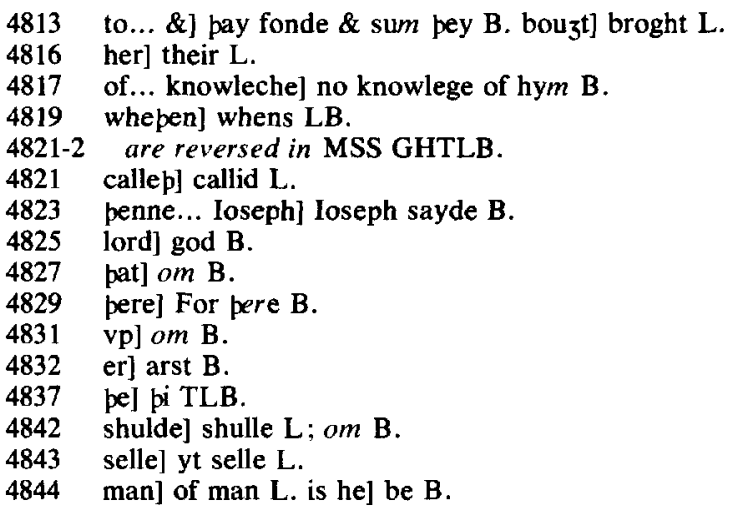


Sir iacob is oure fadir nome 4845

An olde man we lefte at home

Elleuen breper are we lyuonde

Oon at home \& ten in pis londe

What he seide is he pe leest

Sir beniamyn het pe zongest

When ne he bihelde hem on rowe

Wel vchone he coupe hem knowe

His fadir care pouzte he on pore

And perfore he syked ful sore

For siluer he took \& zaf hem corn

4855

And to her In dude hit be born

He lete wayte at a pryue tyde

And dide his siluer coupe to hyde

In a sekke bysyde her corn

And bad hem byde to mete pat morn

4860

Whenne bei had eten $\&$ were boun

For to wende hoom out of toun

Ioseph bigan to sermoun go

And pus shewed hem his resoun po

//Gode men he seide ze shul fare

But of oure kyng I warne zow zare

I am not kyng ouer bis londe

Vche man shal vndirstonde

Oure kyng hett pharao

And al his wille con make be do

Ouer al I drad and also ryche

Nas neuer eer mon him lyche

Of him I telle zow witturly

Of peof wole he haue no mercy

fol. 29r col. 2

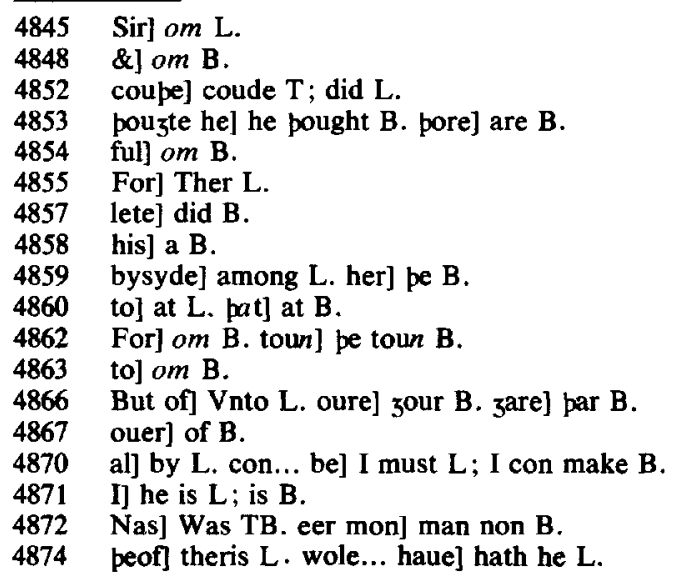


Whoso is taken wip stole pinge

He wole hym do soone to hynge

I say not pis but pat ze

Seme trewe men to be

God graunte zow wel to founde

And brynge zow hool hoome \& sounde

4880

zoure fadir to se hool \& fere

God zou graunte lorde dere

God zow forzelde seide pay

To alle zoure gode $\&$ hauep good day

//When ne pei alle were forp goon

Ioseph seruauntis called anoon

Childre he seide we serue pe kyng

We misse sum what of his ping

If he wite he wol be wroop

God hit forbede pat were vs loop

4890

zondir be peues we trowe wende

And he a peof hem hider sende

Folwep hem \& ransake her ware

Or pei forper fro vs fare

If in her seckis be ouzt founde

Loke pei alle be take \& bounde

4885

$/ /$ Pe sergeauntis pen ne breme as boore

4896

4899

Ran \& ouertook hem pore

4900

Peues pei seide ze shul abyde

Wende ze pe kyngis tresour to hyde

He pat zow hap done socour

Stolen $3^{e}$ haue of his tresour

In euel tyme dide ze pis $\mathrm{d}[\mathrm{e}] \mathrm{de}$

For siche perof wol be zoure mede

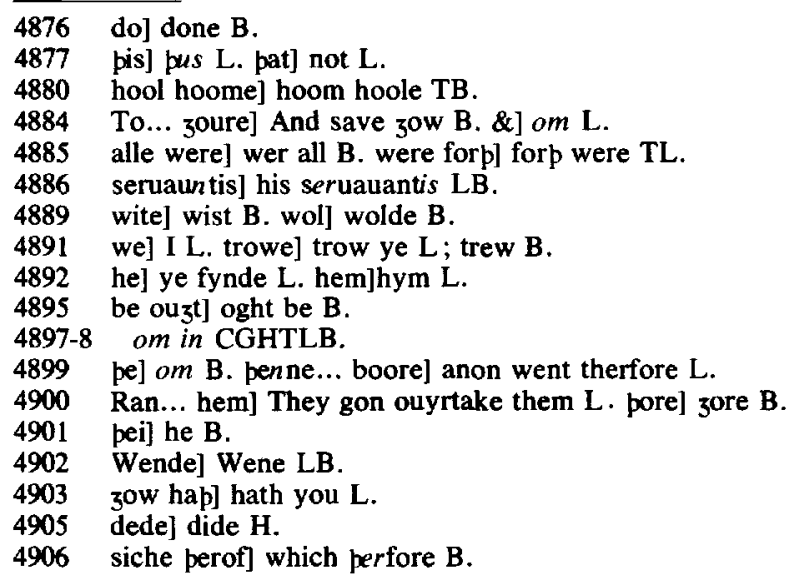


//Certis pei seide leue lordyngis

Haue we not stolen pe kyngis pingis

We are trewe men and lele

Were we neuer wont to stele

We haue wip vs trussed nouzt

But ping pat we trewely bouzt

And so is oure trewe geten ping

For goddes loue do vs no lettyng

Vpon her sackes leide pei hond

4915 fol. $29 \mathrm{v}$ col. 1

pe coupe pei souzte \& soone fond

Traitours pei seide now is sene

Wheper ze be foule or clene

Anoon were pei bounden harde

And brouzte bifore pe stiwarde

4920

And prisounde to be bridde morn

pat moo folke my $3^{\text {te }}$ pei come biforn

Pat while Ioseph sent pen

To kepe her harneys of his men

// pe pridde morn comaundide he

A gederynge of pe londe to be

Forp were brouzte po breper ten

Were per neuer soryere men

pei fel doun at Ioseph fette

And mercy souzte wip reuful grete

pe folke asked what pei shulde be

Peofes quod Ioseph of a cuntre

Pat is hennes fer as pei me tolde

So is sene on her dedes bolde

Whil I solde hem of my sede

4907 lordyngis] lordyng B.

4908 not] none B. pe... pingis] ping B.

4909 lele] sele $\mathrm{L}$.

4912 trewely] haue truly B.

4913 trewe]tewe $T$.

4915 leide pei] pey leyde her $B$.

4916 fond] pey fonde $B$.

4917 is] yt ys B.

4918 ze] pat ze B.

4920 bifore] tofore B. stiwarde] high styward B.

4922 moo] no B. pei] hem B.

4923 pat] The $L$; per $B$. while] whyles $B$.

4924 her] their L. of] by $L$.

4926 tol schuld B.

4927 pol pe TB; their L.

4928 per] they LB. soryere] so sory $B$.

4930 souzte] cryed B.

4933 hennes fer] fer hens $B$.

4934 is] it is B. on] be $B$. 
My coupe pei stale away to lede

Sergeauntis I sent soone on honde

And in her gere my coupe pei fonde

I serued hem \& warned nou $3^{t}$

Of al pat pei me bisouzt

Mete \& drynke I zaf hem bope

And bad hem kepe hem ay fro lope

Sipen I preyed god al weldonde

Lede hem sauely to her londe

Here vpon pei stale my ping

4945

If ze zyue dome men shul hem hyng

// Ponne spak ruben pe eldest broper

Stille menyng to pat oper

Now is comen oure aller sake

Into woo synne and wrake

4950

I seide zow so pis oper zere

ze wolde not my resoun here

As of Ioseph oure broper lele

Wip wrong ze solde him for catele

ze solde hym out of myn assent

pat fynde we nowe here present

Done ze haue pis synne in $z^{\circ} \mathrm{w}$

zoure repentaunce late comep now

Furper may we not stere

Her wille mut we suffere here

4960

Helpe lord pat al hap wrouzt

In oper helpe me triste I nouzt

He mened him bus wip mournyng chere

And wende Ioseph my 3 hit not here

Allas pei seide pat euer we ware

4955 fol. $29 \mathrm{v}$ col. 2

4937 Sergeauntis] Seruantys B. sent] sende T.

4938 my] be L. my... pei] sone bey it B. pei] was $L$.

4939 I] om B.

4940 me] had me $B$.

4942 ay] euer $B$.

4946 If] zefe B. zyue] pe B. shul] sayde B.

4948 Stille menyng] Full styll mornyng $B$. pat] pese $T$; all pe $B$.

4952 ze] And ze B. wolde] nold L.

4955 out of] withoute $B$.

4956 we] 3 e $B$. here] in $B$.

4957 in zow] now $B$.

4959 Furper] For hens B.

4960 Her... we] Nedys mvst vs B.

4961 Helpe] Help now $B$.

4962 me] ne LB.

4963 mened] mornyd B.

4964 myst hit] it myght $B$. 
Born if we shul pus forfare

// Ioseph roos vp fro his stede

To galewe pei wende he wolde hem lede

Ioseph herde her mournyng soore

And left hem as nouzt ne wore

4970

His wille was but to make hem gast

And aftir rewe on hem at pe last

When ne he say her mournyng moone

To pe court he spak anoone

Listene b alle pat hider bep come

4975

Ar ze 3 yue here any dome

A word he seide soop may falle

Al pouze bei be peues alle

Whenne pei were breper alle at home

pei menged me pe zongist nome

4980

I wol do to hem pat grace

Pat pei pe zongist brynge in place

Pat pei lafte at her faderes In

Whiche is called beniamyn

Pe whyle wole I have oon of ten

4985

pat bei zyue to name ruben

To dwelle in hostage here wip me

Til pat pe zongest comen be

pis terme is fourty dayes sett

pat pei pis commaundement not lett

4990

But pei me penne my couenaunt bringe

Elles her hostage shal I hynge

And if pei couenaunt holde I wis

I shal forzyue hem al pis mys

4994

And pus wol I hem preue now

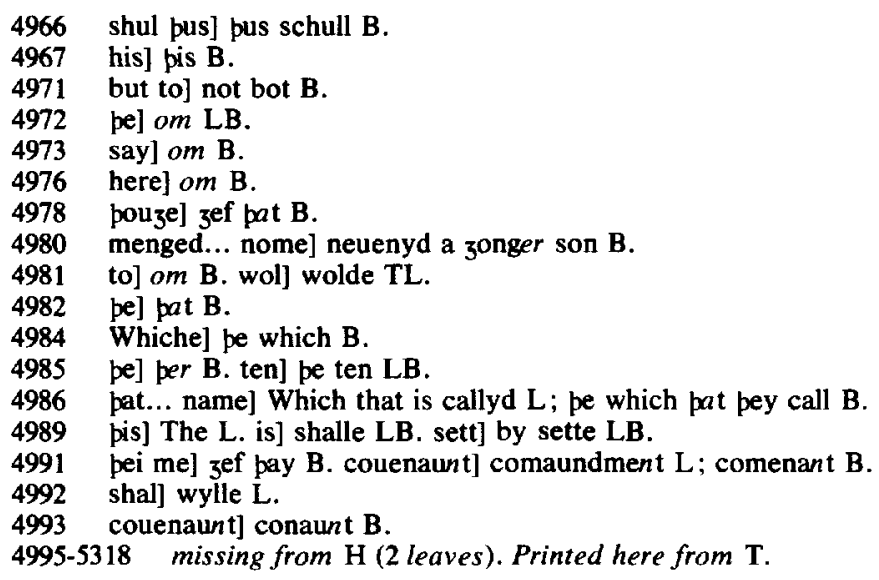


Sir pei seide god zelde zow

For if pat we haue lif perto

fol. $32 \mathrm{r}$ col. 1

zoure commaundement shul we do

Her leue pei toke \& were blipe

And hyzed in her weye swipe

5000

Oure lord lad hem in her fare

pei coom to her fadir zare

pei him cussed swipe soone

And dude her sackes to be vndone

Say me quad lacob how is pis

5005

pat of my childre oon I mis

$\mathrm{He}$ is in egipte allas why

For pere vs toke pe heze baily

To skape wip gile were we fayn

What hope ze shal he be slayn

5010

Nay pei seide god hit shilde

Him shal delyuer zoure zongest childe

How shal beniamin com pare

Sir elles pei wol Ruben forfare zoure eldest son to hede or honge

Haue ze terme he seide how longe

Fourty dayes we drede hit sare

ze most haste zou on zoure fare

Hadde pei soiourned but a stounde

Iacob seide tyme is to founde

5020

Fettep me home ruben blyue

O[r] elles holde ze not my lyue

Ledep wip zou beniamyn

God graunte zow grace pider to wyn

//Lord myztful kyng he seide

Pat paradis to mon purueide

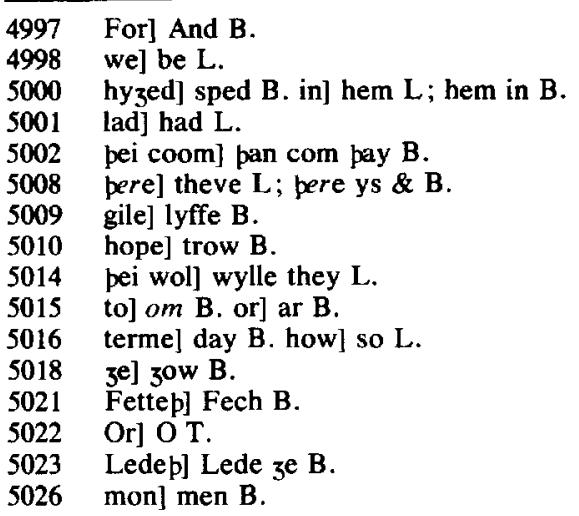


And adam tauzte pere to abyde

With eue pat wrouzte was of his syde

Fro flood pou sauedest noe here

And Abraham temptidest to pe dere

5030

Of his o son offryng to make

And he hit grauntid for pi sake

pat was my fadir Isaac

Til be aungel for him spak

And sauedest me my broper fro

Esau pat wolde me lord slo

Saue my childre hool to me

And haue of Iosephes soule pite

fol. $32 \mathrm{r}$ col. 2

// Pese childre toke wip hem to spende

And redied hem for $p$ to wende

5040

So longe pei went in her wey

Into egipte soone coom pey

pei souzte \& soone pe stiwarde fond

At a gerner him stondond

pere he lyuerey made of corn

pei grette him alle on kne biforn

When ne [Ioseph] gan his breperen se

Muchel ioye in herte hadde he

Ruben pat for him was nomen

Had muchel ioye whenne he was comen

Muchel ioye was Ioseph wipinne

He bihelde penne beniamynne

For whenne pe ton pe toper seze

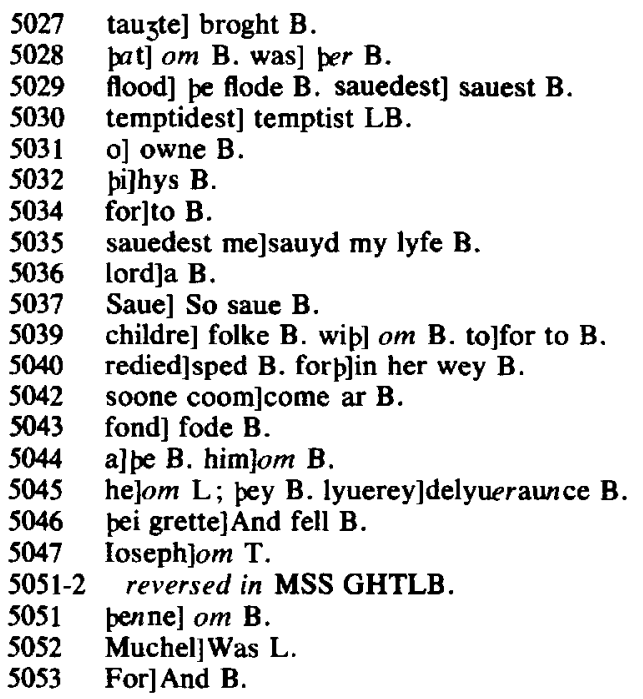


No lenger myzte pei nouper dreze

But bent hem in armes pore

And cussed sixty sipe \& more Ioseph wepte ful tenderly

And sip on benche set him him by

How fare $p$ he seide oure fadir fre

Mi fadir sir farep wel seide he

5060

Knowyng of zoures haue I noon

Mafay broper and al is oon

Knowes pou not me he seide nay

I sawe zou neuer bifore pis day

We are not sibbe sir seide he

5065

zus he seide I telle to pe

Furst wolde pei ha slayn me pes ten

Sip me pei solden to vncoupe men

Al was for I tolde a dreme

pat now is comen to good teme

I hatt Ioseph zoure broper am I

Pei fel in swoun \& cryed mercy

Po pei wende wipouten wene

To haue ben honged al bidene

But Ioseph coumfortid her chere

And wepyng seide breperen dere

zoure gult I haue forzyuen $3^{\text {ow }}$

Forzyue me myn I preye zow now

Forzyue me pat I dud zou take

Into bondes wipouten sake

Pe coupe into zoure secke put I

And pursewed zou dispitously

5054 nouper]lengger $\mathrm{L}$.

5055 hem]hym L. pore]zore B.

5056 sipe]tymys $B$.

5057 wepte]went B.

5058 him him by]hym truly L; hem B.

5059 oure]my L.

5060 sir]om L. seide]ser seid L.

5061 zoures] zow B.

Mafay]My fayre B.

Knowes pou] Knowestow B.

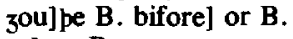

tojom $\mathrm{B}$.

ha... me]me haue slawe $B$. pes]pis LB.

me pei] bey me $B$. vncoupe]straunge $B$.

To... ben] For to be $B$.

pe] Oure B.

dispitously]spytusly $\mathbf{B}$. 
And shamed zou in mennes sizt

I am aknowe I dud vnrizt

Mi wrappe is clene fro me goon

To me I preye zou ze haue noon

B[ut] hyze zou swipe hoom to go

I wol algate hit be so

Makep zoure gere redy to drift

zoure sackes shal I fille of zift

To fette my fadir shul ze founde

5090

Seip him I am hool \& sounde

For zitt have we to com \& bide

Fyue zeer of pis hongry tide

pat make shal mony mon \& wyf

5095

Ar pei be done lese her lyf

Bep not ferde but makep good chere

For zoure hele god sende me here

Not zoure reede but goddes sonde

Was I sende into pis londe

For pharao kyng hap made me

Lord of al pis londe so fre

//Sir gladly at zoure biddyng

Shal hit be to vs a commaundyng

Als soone as we may be purueide

We wol do as ze haue seide

Oure misdede we repente ay

Forzyue vs lord we zou pray

Sip god wolde suche caas shulde falle

He seide I haue forzyuen zou alle

To zoure fadir now hize ze

And telle him pat ze sounde be

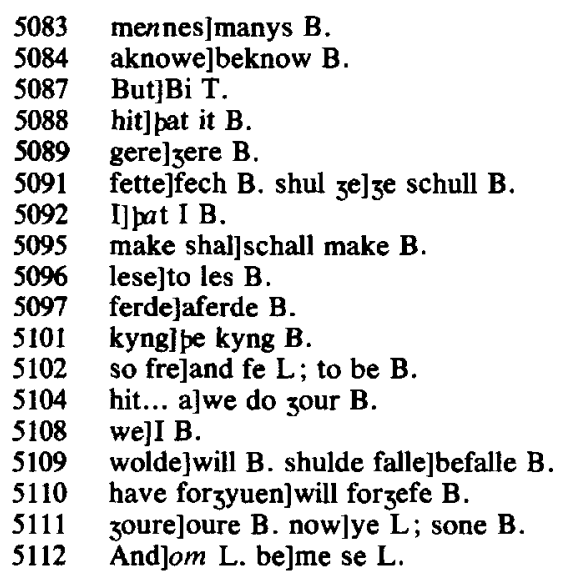


He makep deol for zoure sake pis tiping shal his sorwe slake We shul pei seide make no dwelling

Til pat we him to zou bring

Takep ruben hoome wip zow

And leuep me beniamyn now

He clad him wip pal of affrik here

And sipen zaf hem ziftis riche \& dere

He cussed hem alle in token of sauzt

And sipen to god hem bitauzt

penne zede he hoom to his In

Wip his zonge broper beniamin

He dud on him pal cloping

And on his hond sett riche ring

fol. $32 \mathrm{v}$ col. 2

pese breper zode forp her way

To her fadir soone coom pay

Siluer \& golde pei wip hem ledde

And cloping als for backe \& bedde

Forzeten haue pei al pat care

Pat loseph had done hem pare

Hoome pei coom not prisoners liche

But as pei were kny 3 tis riche

Clad pei were wip riche wede

Her camails charged alle wip sede

Her fadir lay vnhol in bedde

He mizte not sture of pat stedde

To him coom a messangere

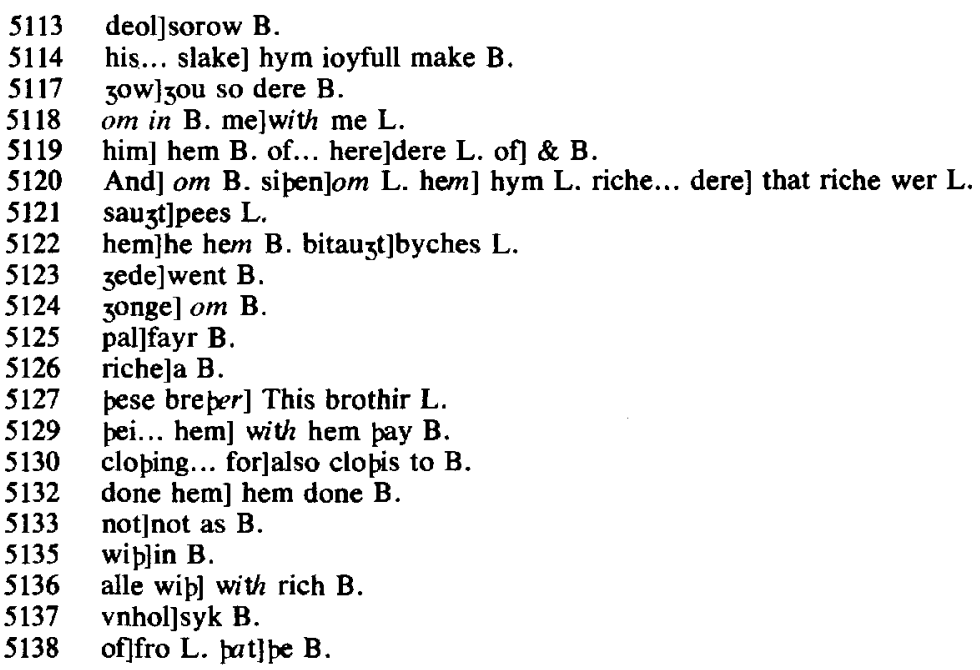


And tolde him sopely in his ere

Sir he seide here good tipinge

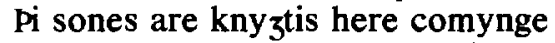

Pou lyest he seide bi god so dere

Ar pei no kny $y^{\text {tis ny }}$ knyztis fere

Sir bi pe feip I owe to zow

5145

pei are knyztis as I trow

For pei are clad in riche pal

And riche ziftis zyuen ouer al

Siluer \& golde pei haue plente

Seistou sop he seide sir ze

If pou trowe not my tale

Rise vp \& se piseluen shale

I may not rise he seide for lame

Wip pat word pei coom alle hame

In at pe dor vpon a route

Heilsynge her fadir for to loute

Sir pei seide tipingis here

fol. $33 \mathrm{r}$ col. 1

Fro bi tweyne sones dere

Oon fro beniamyn oure broper

And fro Ioseph is pe toper

Whenne iacob in bed pat lay

Herde Ioseph named pat day

Anoon his herte bigon to lizt

And in his bed sat he vprizt

His heed was al bare for elde

Vpon his sones he penne bihelde

And say hem clad in riche pal

Seip me he seide now ze shal

What makep zou to mene now

Of my son Ioseph bitwixe zow

Pritty zeer hit is agone

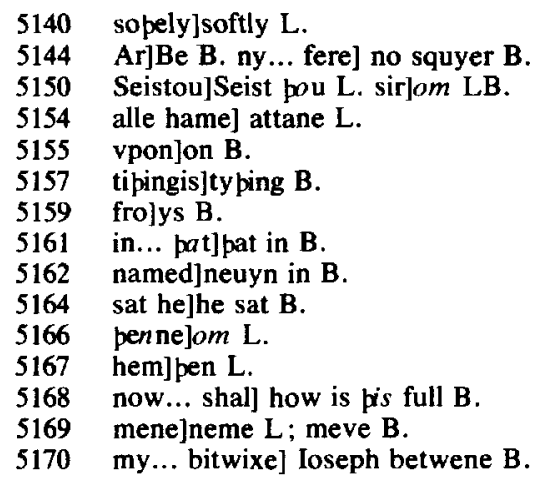


Sip he of beestis wilde was slone ze gabbe \& also done greet synne Of him to me for to mynne Fadir pei seide mistrowe nou $3 t$

pat we any gabbynge haue brouzt

For ioseph hool \& sounde lafte we

Lorde he seide I wolde him se

Certis pei seide pat may god zyue

I wolde he seide no lenger lyue

3 e shul have lif longer pen pider

Haue 3 e brouzte him wip zou hider

Nay sir but $z e$ mot to him fare

He hap sent aftir pe his chare

We shul zou make perynne a bed

Into egipte 3 e shul be led

po wex iacob swipe fayn

His body bigon to quyke azayn

zyue me my clopes penne seide he

Hastily bat we redy be

Childer he seide go we stronge

Into egipte pinke me longe

Israel wip pis vp leep

pat myzte bifore stire no step

Wipouten helpe of any son

pat quake with vche a lymme was won

5199 fol. 33 r col. 2

Iacob hized as he zong were

5200

penne seide ruben fadir dere

I rede studfastliere pou go

What art pou pat biddest so

Ruben zoure son \& what ping

Is of Ioseph wipouten lesing

5172 of] with B. beestis wilde]wyld bestis LB.

5174 mynne]nymme $\mathrm{L}$.

5179 god zyue] not zet B.

5183 but... mot] zow most $B$.

5184 aftir pe] for $3^{\text {ow B }}$. pe]you L.

5187 swipe]wondyr B.

pinke me] me think B. me]we L.

myzte] om L. stire no]anepe myzt L; styrt ne B.

helpe]the help $\mathrm{L}$.

with]byfor L. a]om LB. was] \& was B.

Iacob] Israel B

5200 seide ruben] Ruben sayde $B$.

5201 rede] rede the $L$. studfastliere pou] zow stedefastly or ze B.

5202 art poulertow B. biddest]sayest B.

5203 \&... ping]to telle typyng $L$.

5204

Is]om L. lesing]lettyng B. 
Of egipte sire pat riche londe

$\mathrm{He}$ is maistir al weldonde

How so is pere noon oper kyng

zus sir but he tentep no ping

pe warde he hap of pat kyngriche

Pore \& riche to deme I liche

He delep pe corn of pat cuntre

pis is pe sope leue $z^{e}$ me

Israel mad oon offringe swipe

As pei were wont in pat sipe

God coom to him in a visioun

And seide to Iacob his resoun

Iacob he seide listen to me

Wip pi fadir I was \& I am wip pe

Wende to egipte among pat lede

For I myself shal pe pere fede

And pere forsope shal pou d[ie]

Ioseph pi sone shal louke pin eze

Wip his meyne redy to fare

His sones alle \& her flittyng

Wyf \& childe \& opere ping

In weynes were pei put to lede

pat Ioseph sent hem ful of sede

His meyne pat him folewed pider

Whenne pei were gedered alle togider

Six \& sixti somme on lyues

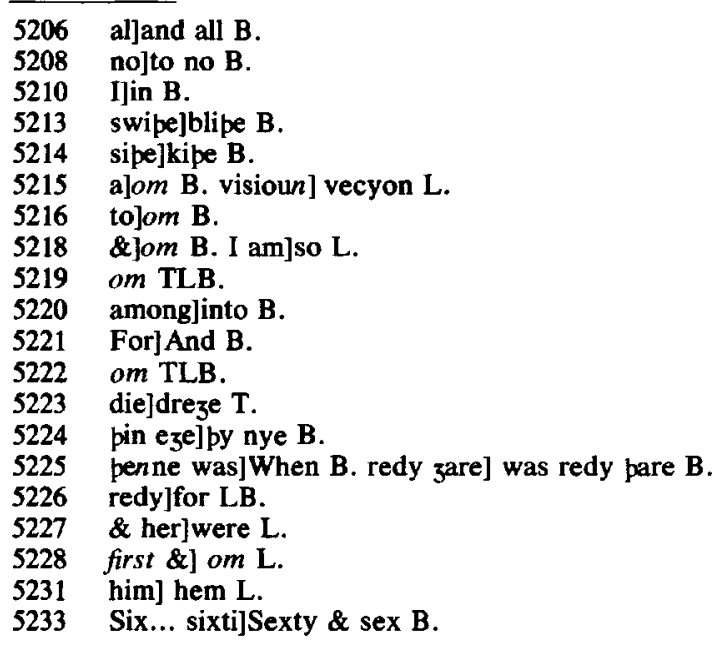


Pei were wipouten sones wyues

And Ioseph hadde sones twyn

Manassen and effraym

po in egipte his wif him bare

Whiche pe kyng had geten him pare

When ne iacob coom egipte nere He sende Iudam his messangere

To telle Iacobes coome to londe

fol. $33 \mathrm{v}$ col. 1

And bere Ioseph perof tiponde

Whenne Ioseph perof herde

Wip his court azeyn him he ferde

When ne pei had cussed a mile \& more

5245

His blessyng zaf he him rizt pore

When ne Ioseph wip his fadir met

Tenderly wip eze he gret

pei grett for gladnes as I trowe

Iacob seide to Ioseph nowe

Of dede wol I me neuer mene

Now I pi face son haue sene

But certeynely be sope to say

Whoso had be bistad pat day

And had pat swete metyng sene

Pei he pre dayes had fastyng bene

Of mete ne drynke bi myn entent

He shulde haue had no talent

Son he seide longe is gone

I wende wilde beestis hade be slone

Wherfore I fel in greet sekenes

Blessed be god pou lyuynge es

Son whi helde pou pe fro me

What cloop was hit brouzte me to se

5234 pei]pere B. wyues]\& wyfes $B$.

5235 Ioseph] Iacob B. twyn] tweyn B.

5238 Whiche] be which B. him ]hem LB.

5241 Iacobes]pat Iacob is B.

5242 And]To $B$.

5243 Whenne]When pat $B$.

5244 azeyn]azens B. he] om B.

Whenne] As L. had cussed]mette L. \&]or L.

His]lacob hys B. he... rizt]hem B.

wipjom L.

mejom $\mathrm{L}$.

II haue B. son haue]om B.

bistad]ther LB.

pat]pe $B$.

pei helzef he had B. had] om B. ne] and LB.

Whan that blody clope was brozt me L. hit... se] pat pey broght me B. 
Pat blody was \& I noot how 5265

Not of me fadir pat se ze now

Into sichen whenne I pe sent

To seche pi breperen pat pider went

So dud I fadir mystrowe hit nouzt

Her mete to hem I redy brouzt

But soone as I pere was comen

Wip euel counsel was I nomen

Whi leue son I shal zou say

Penke ze not how mony a day

Of a dreem is gone ful zore

5275

Leue son were pou take perfore ze fadir vnnepes scaped I

Til marchaundis coom me for to by

To pis londe pei me con bringe

And sipen solde me to be kynge

5280

In prisoun aftir is not to leyn

fol. $33 \mathrm{v}$ col. 2

Was I done to suffer peyn

And was pourze putifares wif

Pat wolde haue brouzte me of lif

To prisoun so whenne I was gone

Me borwed noon but god allone

He pat to his in nede is best

In him I haue my hope fest

He hap delyuered me of my woo

And put me to welpe no mon so

5290

pe lordshipe of al pis lond

To reule \& kepe is in myn hond

Perfore fadir lete $z^{\text {e nouzt }}$

$\mathrm{Al}_{3}$ oure wille hit shal be wrou 3 t

Bope for my breper \& zow

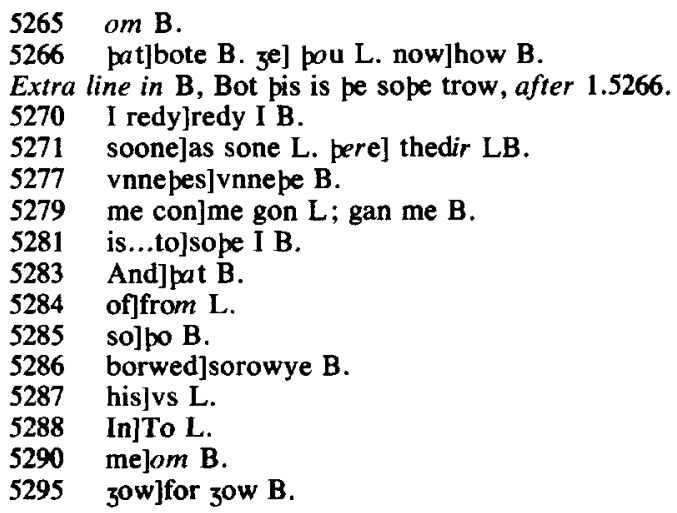


For I ouer alle haue pouste now

To my lord ze com wip me

I shal zou do aqueynted to be

I shal zou aske sum rescet

Wel I woot I shal zou get

5300

Gladly son go we soone

To panke him pat hap for pe done

Knele I shal al bifore pe kyng

And panke him of his grete helping

As his owne in al pat I may

5305

And pou shal bene his seruaunt ay

I shal to pe kyng pe biteche

And sipen pe my blessynge reche

penne I wol me leye to deze

To lyue may I no lenger dreze

5310

Iacob went pen wip his route

His sones twelue him aboute

His berde was side with myche hare

On his heede his hatt he bare

As mon of elde longe forlyuen

Many baret tofore had dryuen

Whenne pei were comen tofore pe king

pei loutide him alle wip hailsyng

Of his come be kyng was fayn

And of his sete roos him azayn

fol. $30 \mathrm{r}$ col. 1

Kust \& sette him on benche him by

5320

And honoured him ful derworpely

pe kyng lete write lettres zare

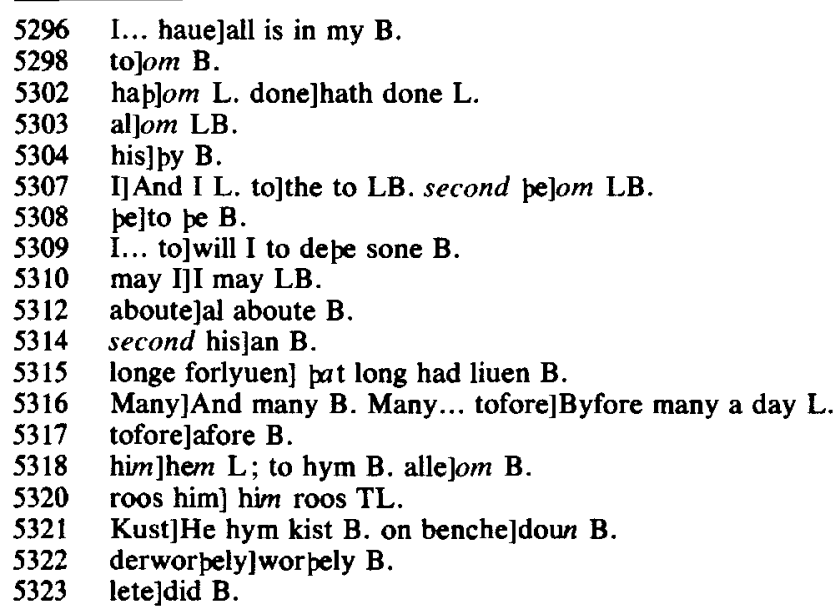


To geder alle wip hasty fare

pe beste in pat londe vnliche

And dide to make a feeste riche

Whenne Iacob say alle plentes were

And alle aboute to make him chere

He preyed po pat pere were lent

To here a litel of his entent

pe kyng to alle bad pees pan

Pus iacob his tale bigan

Pees haue phareo pe kyng

God zyue hym his brode blessyng

Gode men I am as ze may se

An olde man pouze ze knowe not me

Nor I zow to vndirstonde

For I am here in vncoupe londe

Out of ebron born am I

pere lip oure elderes $\&$ so shal I

Pere lip adam pe formast man

And Eue of whom we alle bigan

pe folke pat of hem firste was bred

For pei noping god ne dred

On hem he took vengeaunce sore

But eizte on lyue he lefte no more

Oon was noe riztwis of wham

Bicoom oure feipful Abraham

pat dredde god \& loued hym so

pat for his loue his sone wolde slo

pat was ysaac his childe dere

Whoos sone I am pat ze se here

I am sixe score \& ten 3 eer olde

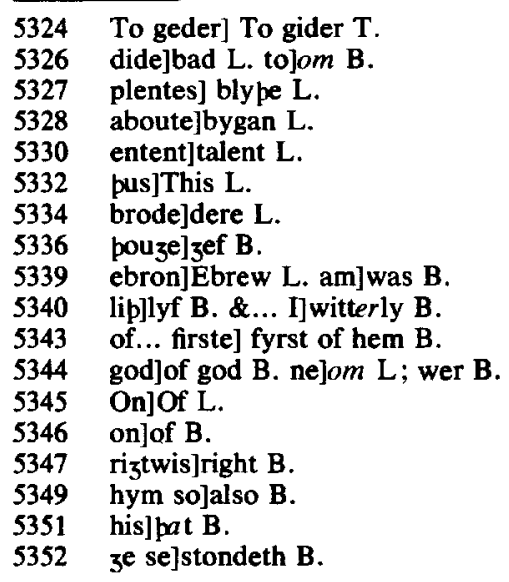


My fadir het ysaac as I tolde

Whenne he was to his endinge boun

I hadde of him my broper benesoun

My broper esau me bysouzt

To disherite me if he mouzte

He flemed me out of my londe

pourze god I haue hit zitt in honde

fol. $30 \mathrm{r}$ col. 2

pese twelue are my sones vchone

5360

Pritty zeer hit is ful gone

pat I hadde lost my sone so dere

Ioseph pat I haue founden here

Of his fyndynge ponke I god so

He saue him fro be fend his fo

He zaf hem alle his blessyng

And to Iacob seide pe kyng

A wyse man is pi sone Ioseph

In al egipte is noon so zep

His witt hap saued me \& myne

Fro mychel nede \& myche pyne

Firste was he here as our pral

Now vndir me mayster of al

I zyue him wonynge stide to lende

For euermore wipouten ende

To him \& his breper elleuene

To chese where pei wol hit neuene

Iacob whenne he leue had lauzt

Wip his sones \& her auzt

Went to a stide hem to plese

Of pasture greet \& hett ranese

In pat stide her lyf pei ledde

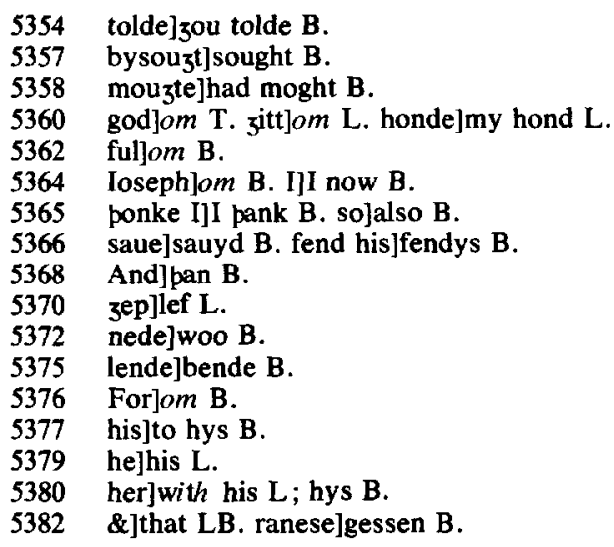


Ioseph hem $3^{\text {af }}$ wherof to be fedde

Faut of breed pat ilke tyde

Was ouer al pe world so wyde

But in no londe so myche wan

As in egipte \& canaan

So longe hadde pei bouzte her sede

Pat her siluer wexe al gnede

When ne pei hadde no ping zare

pat pei myzte to her lyflode spare

pe folk of egipte coom bydene

Byfore Ioseph hem to mene

Lord pei seide to pe we saye

Al oure auzte hit is awaye

Now haue we noon wherwip we may

Lengpe oure lyf fro day to day

5400

No ping is lefte vs but erpe bare

And alle oure bodyes ful of kare

Londes \& lipes wip body we bede

pat pou vs take in pi bondhede

In praldome take oure londis 3 e shal

For seed penne may we sowe wipal

pei solde her londis al for nede

Ioseph bouzte hem al for sede

In al egipte lefte he no lond

Vnbouzte into be kyngis hond

Outake pe lond of pat lede

pat was bitauzte prestis to fede

To kepe[n] hemself for her holde

pe kyng hem fonde as hit is tolde

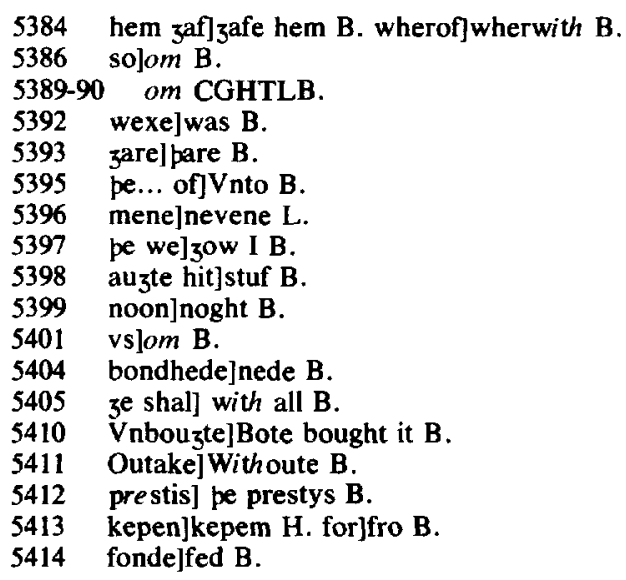


// Pus coupe Ioseph as I seide zow

Awayte his lord pe kyngis prow

His lord he profitide erly \& late

And halpe pe nedeful in her state

Whil hem lastede pat seesoun dere

Iacob pere lyued seuentene zere

5420

In a cuntre pat hett Iessen

Of him were bred mony men

When ne hit drouze to his laste day

To Ioseph pus gon he say

If 1 fonde euer grace in pe

5425

Lay pi hond vndir my pe

And hete me trewely bi couenaunte

pat I not grauen be in pis lande

But hete mi trewely pou pi selue

Shal me wip myne elderes delue

Fadir I bihete pe rizt

Hit shal be done wip al my my ${ }^{t}$

perto pere an oop he sware

Now lyp Iacob in bed of care

He drawep fast to his endyng

And Ioseph dide tofore him bryng

Bope Effraim \& manasse

To blesse his childre preyed he

Iacob in bed him leyde vprizt

For elde al dym wex his sizt

He leide aboute hem eyper arm

And kiste hem ofte 'vpon his barm

My swete sone Ioseph he seide

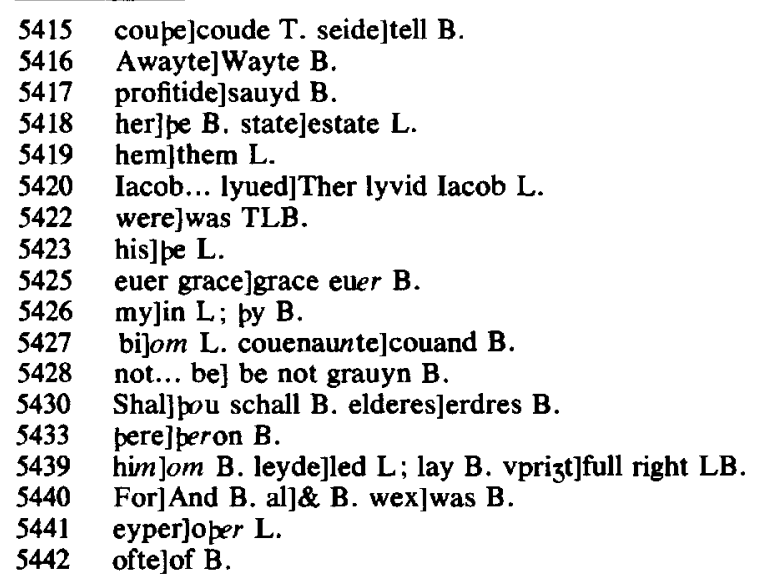


Of pe am I not vnpurueyde

pi fruyt I se bifore myn eze

Now recche I neuer when ne I deze

He leide his hond vpon her croun

And 3 af hem dyuerse benesoun

Soone he seide to Ioseph now

Most I passe god take I zow

5450

God pat was oure elderes wip

Gnaunte zow goyng into zoure kip

pei $z^{\mathrm{e}}$ be flemed here a whyle

He wol zow brynge fro pis exile

His sones he bifore hym calde

And many resouns to hem talde

Bope pat pei shulde ouerbyde

And in her laste dayes bityde

Whenne he endide of his sawe

His sones he blessed on a rawe

5460

To vche he zaf dyuerse benysoun

And aftir leide his heed adoun

He went out of pis wrecched werde

And to his formest fadris ferde

And brouzte is into grace of grip

5465

Lord vs grante to dwelle him wib

Nyze seuen score zeer of elde

Was bis Iacob at his dounhelde

But pre zeer perof was wan

His sones him beer to canaan

And leyde him pere his elderes by

pere he desired for to ly

By ysaac \& by Abraham

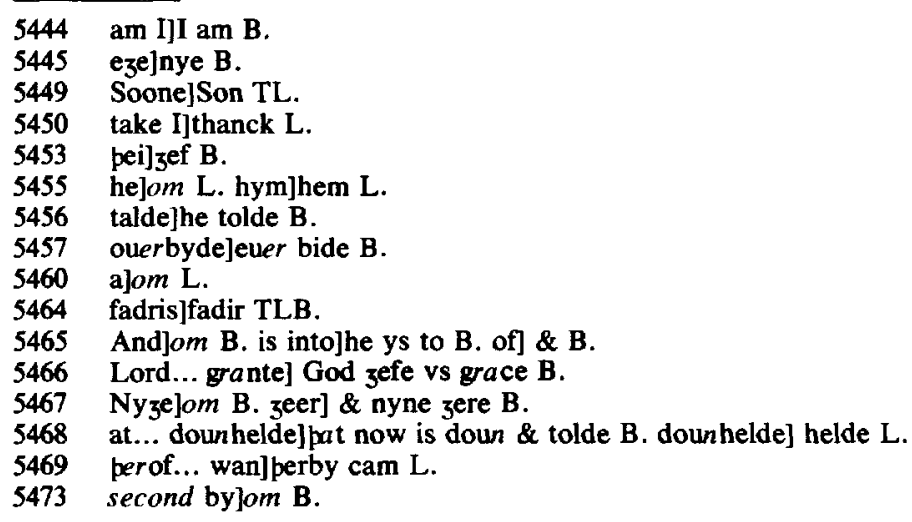


In ebron bisyde olde Adam

pis Iacob pat I of melle

Het bope iacob \& Israelle

pe folk of israel of him sprong

pat pharao kyng helde in wrong

In egipte helde he hem ful harde

As I shal telle soone aftirwarde

5480

Sipen he dyzed Ioseph pe wyse

fol. $31 \mathrm{r} \mathrm{col.} 1$

And endede in oure lordis seruyse

Firste was he buryed in pat cuntre

Sipen borne to his lond was he

pe osprynge pat of Ioseph bredde

5485

Was mychel in pat londe spredde

What of him \& of his breper sede

Were pritty pousande as we rede

Half sixe skore was Ioseph pat day

Whenne he of world went away

5490

Whil pat Ioseph regnede pere

His brepere in egipte pei were

Aftir pei lyued hadde mony a day

Dede \& doluen pere were pay

Of moyses now wole we telle

If $z^{e}$ wole a stounde dwelle

pe whyle roos pere a newe kyng

pat of Ioseph had no knowyng

He made penne a parlement

And seide gode men takep tent

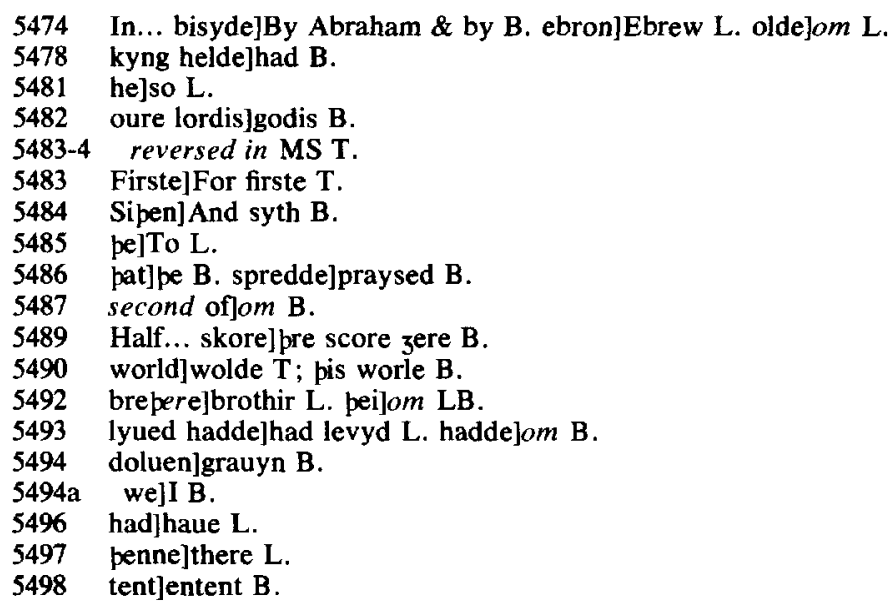


How pe folk of Israel

Is bred among vs so fel

5500

But we kepe vs fro her kynne

Oure lond wol pei fro vs wynne

Sir kyng pat is soop pei seyde

Pei haue zoure lond al ouerleyde

Iosephs kyn ouergoop al

5505

pat to zoure elderes first was pral

Wip oure penyes bouzte was he

Now wol his kyn disherite pe

Sir takep counsel herfore

Was neuer nede of counsel more

Lete vs loke pryuelye

For vs bihouep to be slye

Holde we hem so in doute

pat pei be euer oure vndirloute

If pei azeyn vs take pe fizt

And ouercome vs bi her myzt

I dar saye wipouten fyne

pat we shul so oure londis tyne

Holde we hem perfore in awe

In trauaile bope to bere \& drawe

fol. $31 \mathrm{r}$ col. 2

5520

In werkes pat we han to make

We shul fynde werke for her sake

Vpon her neckis shul pei bere

Bolles wip stoones \& mortere

On hem pe kyng set mony stiwarde

To holde hem in werkis harde

Wip hardenes he helde hem Inne

Soone hadde bei made townes twynne

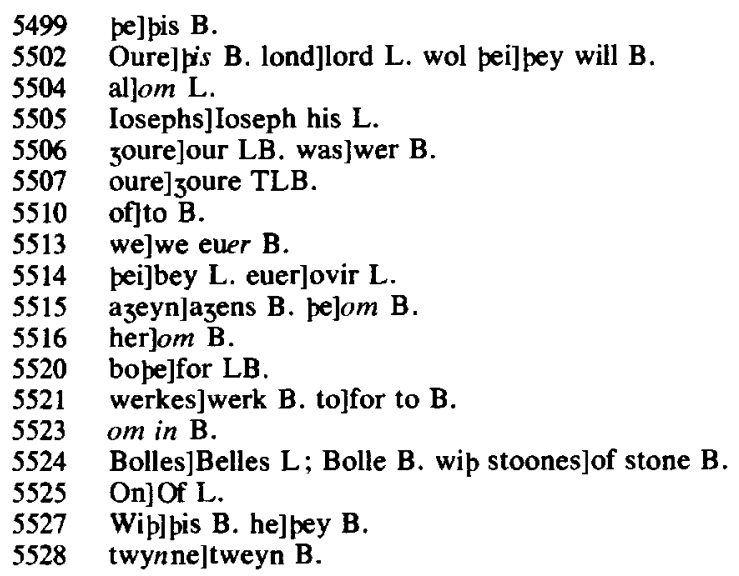


Rameses and Fyton hizte pei pat goddis folk bar to hem cley

But euer as pei dide hem wo pe folke multiplied moo \& moo pe londis folk pat pei wip were Greet enemyte to hem pei bere Ofte wip her wordis smert

Greet tene pei sette to her hert pe kyng wex wondir felle Azeyn pe folk pat I of telle pei hem wiphelde as her foos And wolde no fruyt of hem roos

Whenne wymme[n] were in childing stad

Bremely commaundide he \& bad

Midewyues to be of pat same lond And alle pe knaue childre pei fond Wipouten grip pei shulde hem slo

And mayde childre let hem go Pe midwyues for god were drad And did not as pe kyng hem bad But pei saued po childre lyues pe kyng let calle po mydwyues

Of whiche pat per were twa

Phua pe ton hizt pat oper sephora

To bese two spak pe kyng

Why do ze not my biddyng

Wip po childer of ebrew lay

Sir for pis resoun gon pei say

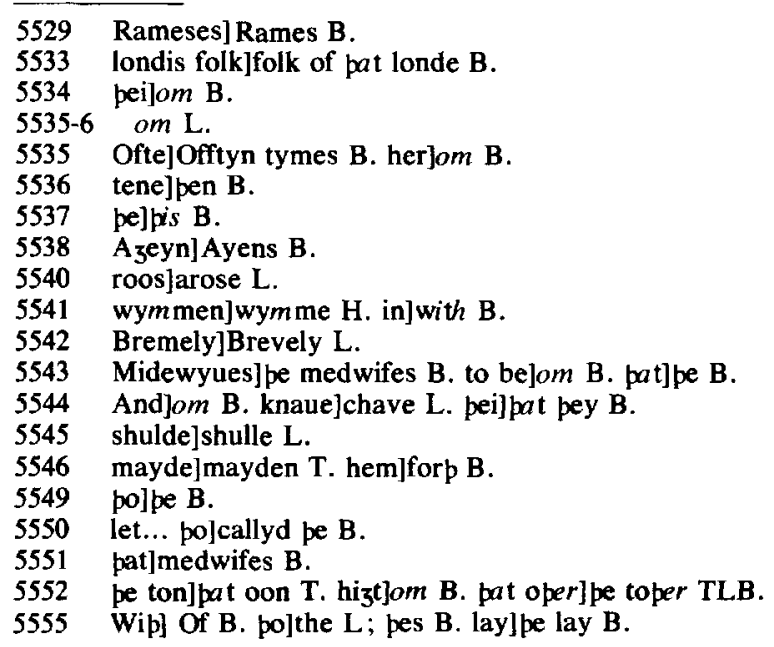


Po wymmen ze shul vndirstonde

Are not like wymmen of pis londe

Vchone con stire fer and nere

fol. $31 \mathrm{v}$ col. 1

Whenne pei come to pat mistere

5560

For ar we come to hem wip my $z^{t}$

pei are lizter bi her owne sleizt

And for po wymmen dide so wele

God hem sent hap and cele

// Penne comaundide kyng pharao

pat alle pat folke wolde fordo

Ouer al his kyndam euerywhere

Whenne wymmen any childe bere

pat of pe kynde of ebrew ware

Men shulde hit in pe flom for fare

Lord he was wicked \& wode

Azeyn pat folke so mylde of mood

For nouzte he wende to sle pat sede

pat god himself wolde of brede

May no man for no chaunce

Fordo pat lordes puruyaunce

Of Israeles seed he pouzte

Be born pat pis world wrouzte

And of his ferpe sone pat was

Geten of lay pat hett ludas

5570

pen wolde he drawe his monhede

Of hym coom kyngis of pat lede

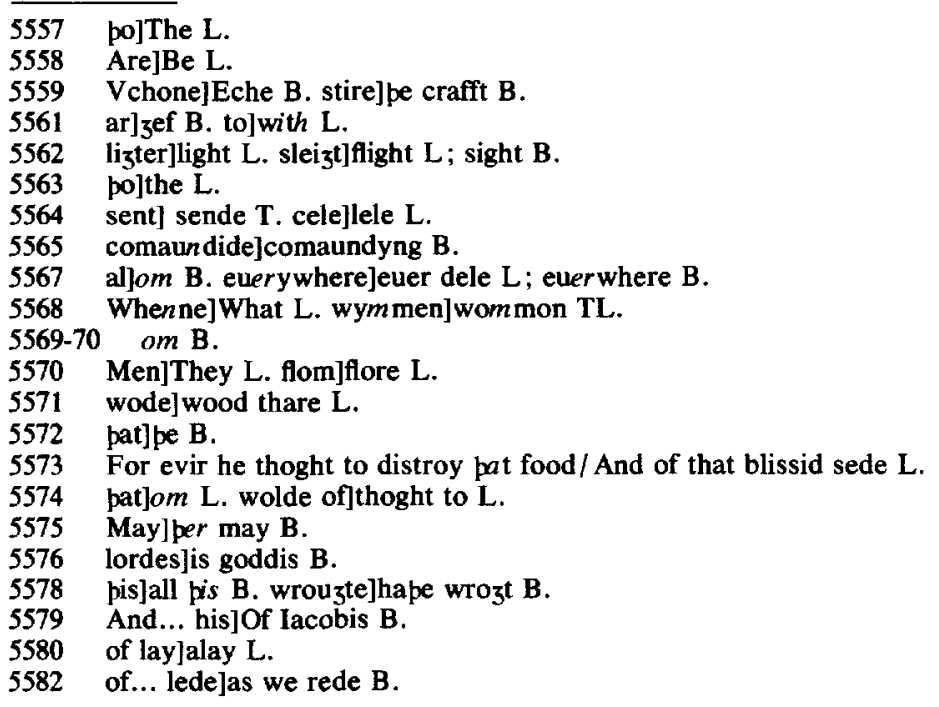


And of his broper leuy bredde Pe prestis pat her lawes ledde Prest and domesman seye I 5585

Bope coom of pis leuy

Whiche moyses was formaste

As I shal telle zow in haaste How he coom firste in place And saued was bi goddes grace

Fro pharao pe kyng feloun pat bad po children to droun Sipen aftir shal be rad How moyses goddes folk lad How he pe comaundementis toke

As hit is writen in holy boke Whenne I se tyme perto pe kyngis kyn I shal vndo Of whom sprong oure saueour And brouzte vs alle to socour pe firste broper pat het leuy A mon was of his genealogy Fro hym but pe opere degre pat of his wyf had childre pre Moyses \& aaron pese twa 5605 And a douzter het Maria In pat tyme born was moyses Whenne pat folk was in pat pres Whenne he was born wibouten pride His modir dide him for to hyde

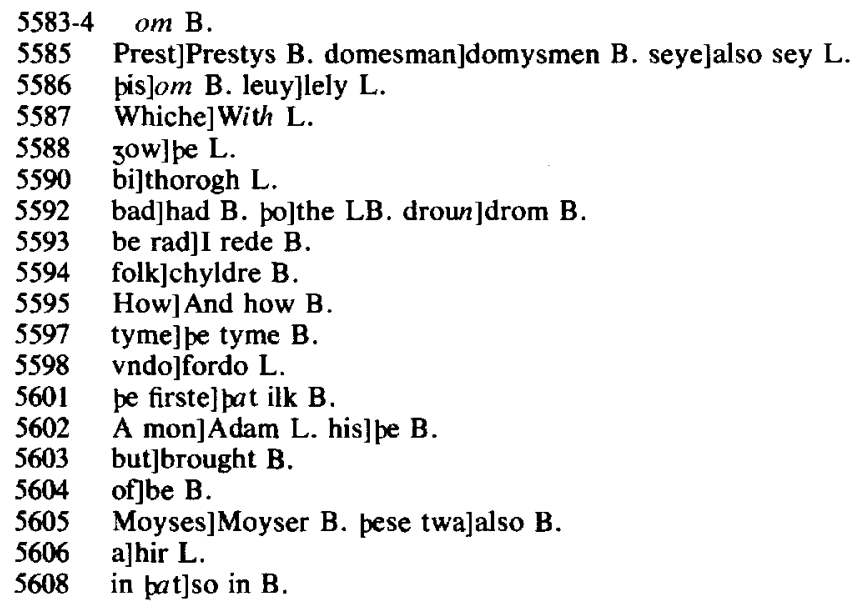


When she two monepis hade him hidde

And hit paste into pe pridde pat she lenger hidde him nouzt

A cofur of zerdes dide she be wrou $3 t$

Dide piche hit so wipoute \& Inne

pat pourze myzte no watir wynne

In pis chiste pe childe she dide

And sperde hit wip pe lidde

Not fer fro pe kyngis home

She leide hit on pe watir fome

5620

Among be risshes in an yle

Soone peraftir in a whyle

pe kingis douztir pere pleyinge zode

And say pat vessel in pat flode

She lete men fette hit to pe lond

A squelyng childe perynne she fond

pat was wondir fayre to se

Of pat childe she hadde pite

Forsope she seide trowe par noon

Of ebrew childre pat pis is oon

5630

pe childis sistir stood perby

Wolt pou I go she seide lady

To fecche a womman of pat lede

ze go she seide I shal hit fede

She went \& fonde pat she souzt

pe childis modir soone she brouzt

pe lady toke hit hir to fede

And for hir seruyse het hir mede

Pe womman vndirtoke hit po

And fedde hit til hit coupe speke \& go

fol. $32 \mathrm{r}$ col. 1

5640

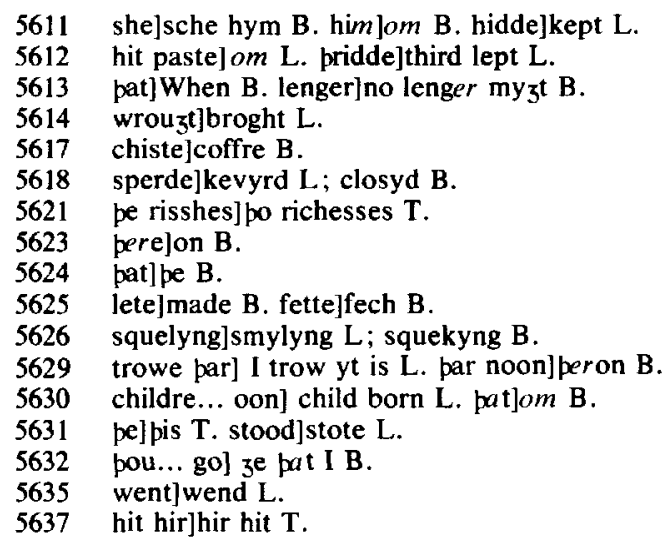


Whenne hit was pryuen of good elde

To pe lady she dide hit zelde

For hir childe penne she him chees

And 3 af hit to name moyses

Moyses was herfore his name

For he was of pe watir tane

Alle pat him sawe in lede

Wondir hadde of his fairhede

$\mathrm{Bi}$ pis coom moyses to elde

pat he myzte hymseluen welde

5650

penne went he out vpon a day

To se pe breper of his lay

To knowe his broper how pei ware

Filed in pat lond wip care

He say a gipcian ful sore

Smyt a iewe bifore him pore

pat braunche of kyn calde Iewes was

pat coom of lacob sones Iudas

Moyses say per were no mo

But himseluen and pei two

5660

To pat egipcian he drouze

Siche a dynt pat he him slouze

When he had slayn him wip his honde

He dalf him soone vndir sonde

Anoper day he went also

And fiztynge fonde he iewes two

He seide to him pat hadde pe wyte

How dorst pou pus pi broper smyte

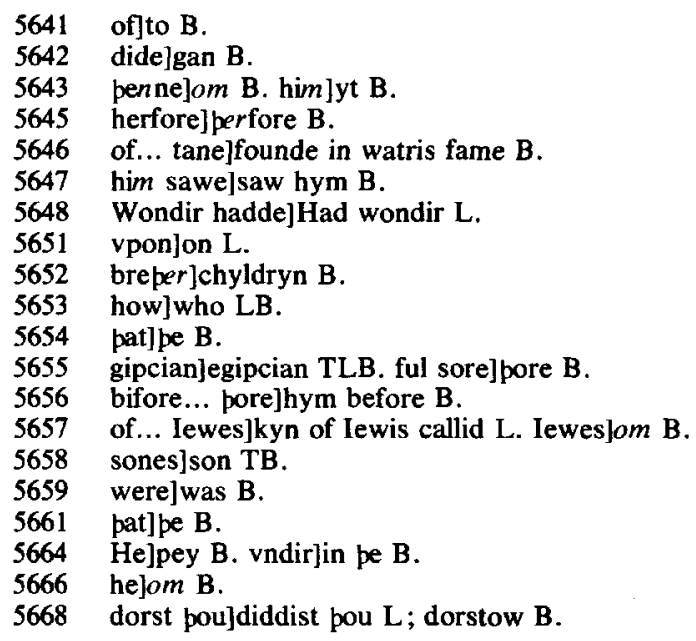


Penne vnswered him pat oon

Sip whenne was pou oure domesmon

5670

Wolt pou me sle herfore

As pou didest pe egipcian not zore

Moyses for pis vmbreyde

Was dredynge in his herte \& seyde

pourze whom is pis how may hit be

5675

Who brouzte vp pis worde on me

pe kyng hit herde \& bad also

Men shulde moyses seke to slo

Moyses say no bettur won

But fledde into madyon

He sette hym pere a welle bisyde

Tipingis to here pere to abyde

pe prest of pis stide bat I neuene

He hadde at home douzteres seuene

pei coom to watir wip her fe

5685

Wherof her fadir hadde plente

As pei to watir drof her beest

Coom herdis \& awey hem kest

Moyses say pei dide hem wrong

Soone he medeled hem among

fol. $32 \mathrm{r}$ col. 2

5680

po herdis fro pe welle droof he

And dide to drynke pe maydens fe

po wymmen went hoom azeyn

And at hem gan her fadir freyn

How had ze so smartly done

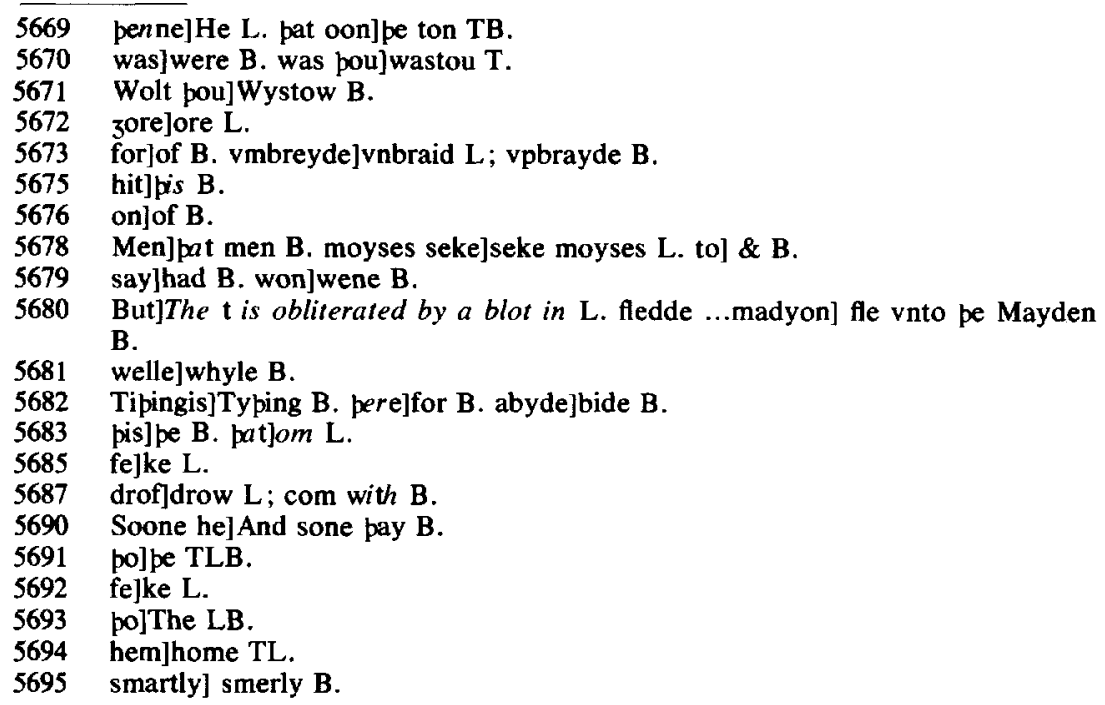


Pat $z^{e}$ are comen home so soone

Sir pei seide bi a zong man

pat semed to be egipcian

Sir pe sope to zow to say

He putte pe herdes alle away

5700

And wip vs he oure watir drouze

And zaf oure beestis drynke ynouze

Where is pat man dop him calle

Sir pei seide gladly we shalle

Moyses pei fette faire \& swete

5705

And wip pe prest raguel he ete

When ne pei were queyntid so to tel

pis moyses \& sir raguel

He weddede of his douteris oon

Sephoram a hende wommon

Two childre dide she to him bere

Gersan and elyezere

// Pis whyle was in Israele

Pe folk lad in mychel vnwele

Her soor was sorwe onne to se

And for to here was greet pite

Hem pei helde harde as bral

On god pei gan to crye \& cal

Azeyn po folke so wip hem ferde

So longe pei calde pat god hem herde

fol. $32 \mathrm{v}$ col. 1

He herde her menynge \& vnquert

And shope perfore in litil sterte

On pat biheste he pouzte pan

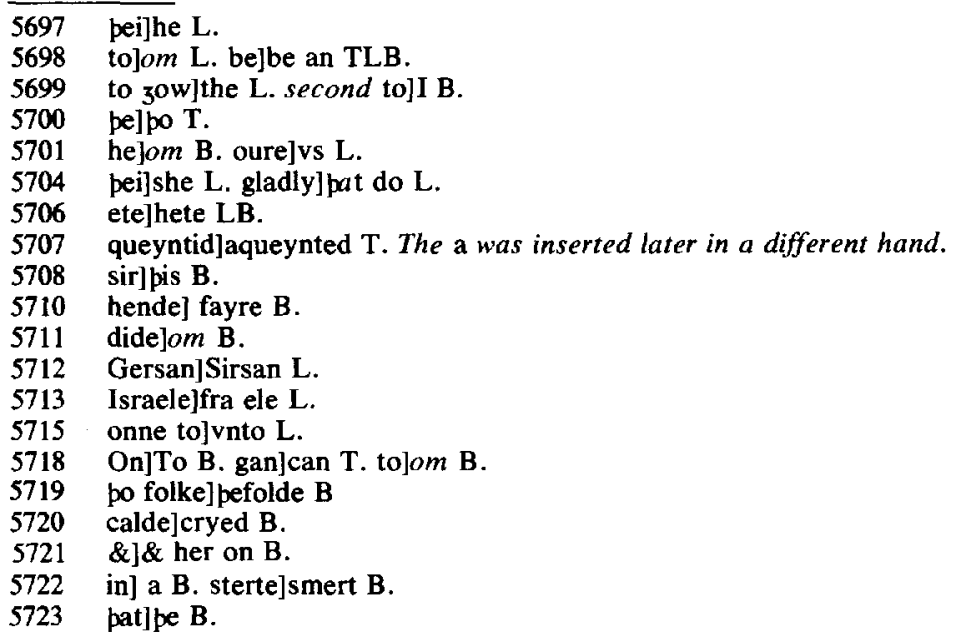


pat he made to olde Abraham

For pat forwarde he wip him fest

His yze of reupe on hem he kest

Bope he halpe hem of her wo

And delyuered hem of her fo

//Moyses pat tyme took kepe

To his eldefadris sheepe

5730

pat was pe prest of madian

Whos douztir he had him tan

His folke he fedde vpon a tyde

By a wylde wodes syde

And as he welke pere wip wille

Bisyde ezeb a litil hille

He sawe a selcoupe sizt to se

Him pouzte brennynge a tre

As hit wip lowe al were bileyde

$\&$ to hymseluen soone he seide

5740

To pat tre I wol go nerre

pat brennyng semep as on ferre

Whenne he pis buske coom to sene

Wip blome \& leof he fonde hit grene

pis was a forshewyng shene

Of modir bope \& mayden clene

pat sipen longe out of prees

Bar a chylde \& she wemles

As pe tre semed to brynne

And penne was pere no fyre perynne

As moyses on fer pouzte

pe tre brennyng \& brent nouzt

5724 oldejeld $L$.

5725 For]Fro L. him fest]fyrst B.

5728 of]om B. folenemyes B.

5731 pe]a B. madian]maryan L; Madan B.

5732 himjom $\mathbf{L}$.

5733 folke]flok B. vpon]on B.

5735 welke]went $B$.

5736 ezeb]Ebell L; ezev B.

5739 hit]he B. al were]were all B.

5740 \&]om B.

5742 brennyng semep]semyth brennyng B. on]eny L; om B.

5744 blome]flour B. \& leof]a lyf L; \& gres B.

5745 forshewyng]feir shynyng $L$; ensample $B$.

5746 modir bope \&] pe modyr $B$.

5747 pat] And TL.

5748 wemles] wenyngles $L$.

5750 And]om B. no]non B. perynne]with in B.

5751 fer]fyre L; pe tre B. 
Penne calde on him oure lord of myzt

Out of pe mychel lemyng lizt

Twyes moyses he calde by name

5755

What woltou lorde here I ame

I am pyne eldres god seide he

For I hem ledde pat loued me

My folk of israel is woo

fol. $32 \mathrm{v}$ col. 2

pei haue ben ledde wronge also

5760

But I wol now her mournynge mende

To pharao I wol pe sende

Pharao of egipte pe kynge

Out of his londe hem for to brynge

Lord he seide what am I perto

5765

Suche a greet nede to do

Go forp he seide wipouten drede

For I myself shal pe lede

pat pei not zeynsaye my sonde

Wip my tokenes pou shalt hem fonde

When ne pou hast brouzte hem fro pat lande

Do hem to make to me offrande

Vpon pe top of pis hille

He seide lord say me pi wille

What shal I saye is pi name

God vnswered wipouten blame

If pei my name wol at pe freyn

Vnswere hem pus azeyn

To zow me sendep he pat es

Pis is my name more ne les

Os he pat is my name pou calle

My menyng shal neuer falle

Do moyses as I pe kenne

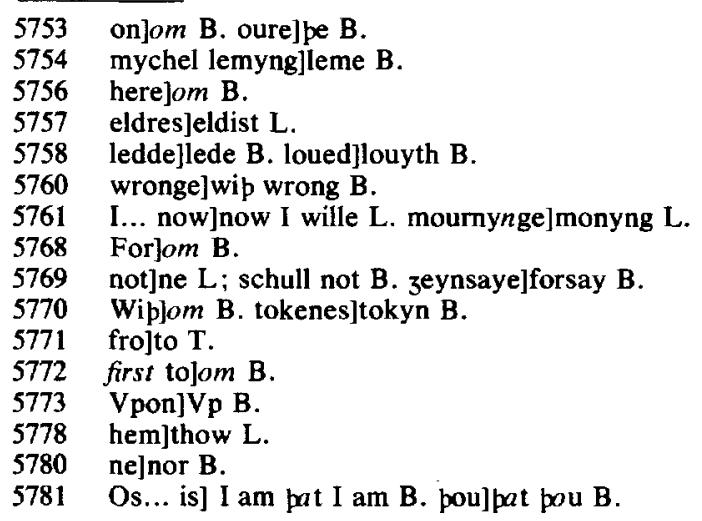


Go geder togider be eldest menne

Of alle my folk of Israel

And seye bat I haue herde hem wel

Pei are in wandrynge $\&$ in wo

Wel I woot pat hit is So

Say I shal hem soone pay

perto shal not be longe delay

5790

I shal hem brynge of pat pralhede

Into lufsom londe hem lede

A lond rennynge hony \& mylke

In al pis world is noon swilke

Sipen shal pou wende also

To pharao pe kyng pou go

Bidde hym lete my folke away

pat he hap holden to pis day

Doynge to hem so greet trowage

pat pei may make to me no knowlache

fol. $33 \mathrm{r}$ col. 1

Into wildernesse londe

I wol hem brynge out of his honde

Wel I woot he is ful pro

Loop him is to lete hem go

He shal me drawe forp on lengpe

5800

Til I delyuere hem wip strengpe

Moyses seide take not in greue

Lord pharao wol me not leue

What hast pou seide god in pi hande

Lorde he sayde I bere a wande

Caste hit on pe gras I bidde

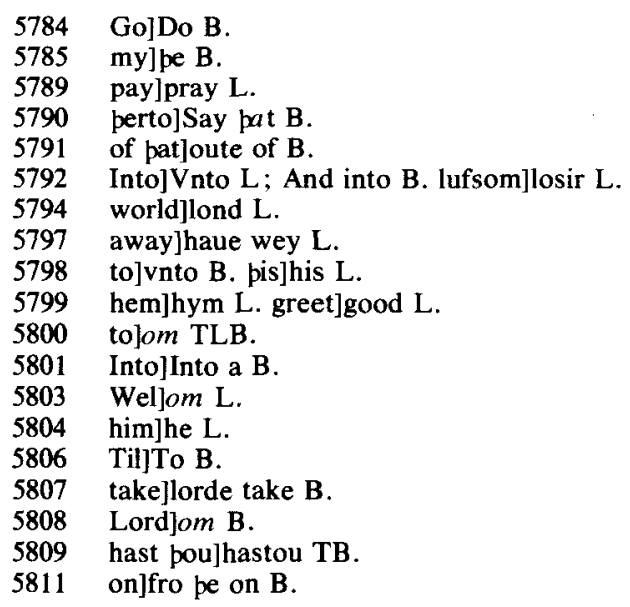


Gladly lord \& so he didde

Whenne hit was on pe gras cast

An eddur hit was \& he was gast

So ferde pat he to fle bigon

To moyses seide oure lorde pon

In pi honde pou not forsake

By pe tail pou hit vptake

When ne moyses hit hade in hande

Hit wex as hit was er a wande

To moyses spake god almyzte

pi honde putt in pi bosum rizte

He put his hone in al in hele

And out he toke hit as mysele

He put hit efte in his speyere

5825

And out he toke hit hool \& fere

Go forp he seide \& if pe kyng

Wol not leue pi firste tokenyng

Who so pe firste wol not trowe

To leue pe opere is his prowe

If pei leue nouper of pese two

To be watir of pe flum pou go

And poure of hit vpon pe londe

And certeynly pou vndirstonde

Al pat pou drawest out of pat flode

Hit shal be turned into blode

Take wip pe aaron also

To pharao kyng seye ze two

pat he lete my folke aperte

Passe to worshepe me in desert

fol. $33 \mathrm{r}$ col. 2

5840

Her sacrifise to make to me

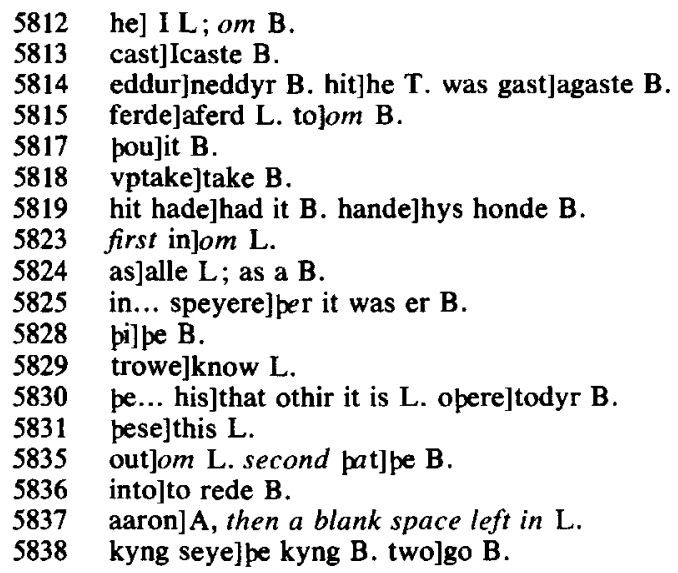


Out of his londe iurneyes pre Now makep moyses him boun As god hym tauzte his lessoun His broper aaron he mette 5845

For god himself her metynge sette

To warne pe eldest of israele And pharao pei went wele pei seide god hymseluen bad His folk pat vndir him was stad 5850

To lete hem of his londe hem dresse

To worshepe him in wildernesse

Kyng phareo zaf his vnswere

What is he pat god \& where pat I shulde for his sonde

Let pat folk out of my londe

Nouper I knowe him pat ze sey

$\mathrm{Ne}$ I wol lete pe folke awey zus pei seide pus wol he pat alle his folke come Iurneyes pre 5860

In wildernesse offerynge to make pat swerde on zow take no wrake He seide wondir of zou me pinke Wolde ze my men take fro swynke pei ryse \& brede ay more \& more

And more if pei ydel wore Blame haue pat hem spare

To holde hem euer harde \& bare Fro pat tyme he bad pat pay Shulde do two iourneyes on a day Vpon hem sett he men to aske Euery day to zelde her taske

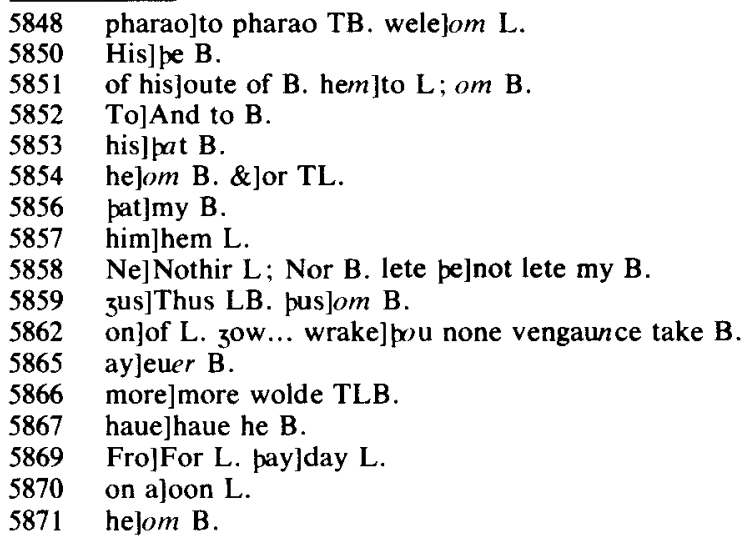


To stonde lete 3 e hem not byde As ze haue done mony a tyde Whoso dop not zoure biddynge Wip sharpe scourgis pat ze hem swynge

Now wolde pei make a wipsawe

Fro her werkes hem to wipdrawe

For to wende to wildernesse

To her lord I noot what he esse

fol. $33 \mathrm{v}$ col. 1

As I euer brouke my hond

I shal hem do dwelle in my lond

penne spak god al weldonde

To moyses his trewe seruonde

When ne pharao askep zow

5885

By what tokene he shal zow trow

5880

Bidde bi broper aaron pon

Caste pe zerde bifore pharaon

Into a nedder hit shal be lent

Anoper tyme forp pei went

5890

Bifore pe kyng into his halle

pere he sat wip his kny 3 tis alle

But not he of her erned herde

Penne took aaron his zerde

And on pe flore he kest hit doun

5895

Hit bicoom a worm feloun

pen calde pe kyng his enchauntours

pe craftiest of his iogelouris

Doun pei caste a zerde vchone

Dragouns pei bicoom anoon

But aarons zerde wexe so kene

pe opere hit woryed al by dene

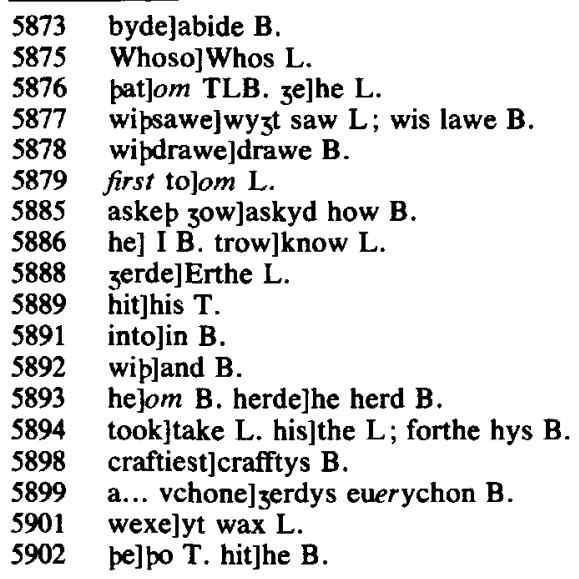


pe kyngis herte wex harde as bras

pe folke he seide zit shal not pas

God seide bo to moysen

5905

pe herte of pharao I ken

Now I woot hit is more

Harder for me pen hit was ore

For pat he wol not me here

Hardenesses shal I sende him sere

5910

Bope on him \& his kyngryche

He shal make mony men myslyche

For he wol pus debate on me

I shal him drenche in pe see

pe firste vengeaunce he on him sende

5915

Men shul mone to pe worldes ende

penne hit was pe firste sonde

Alle be wattris of his londe

Soone wex into blood reed

pat alle po fisshes perinne were deed

fol. $33 \mathrm{v}$ col. 2

For pe root pat peron felle

Bope pen stanke ryuere \& welle

per was in house no vessel fre

pat watir helde of stoon ny tre

So foule al pis watir stonke

5925

Wo was hem pat hit dronke

// Pe toper venieaunce pat him felle

Were frogges pat no tunge coude telle

pat out of banke \& wattris bredde

And ouer al egipte londe spredde

5920

Al pe erpe pei couered so

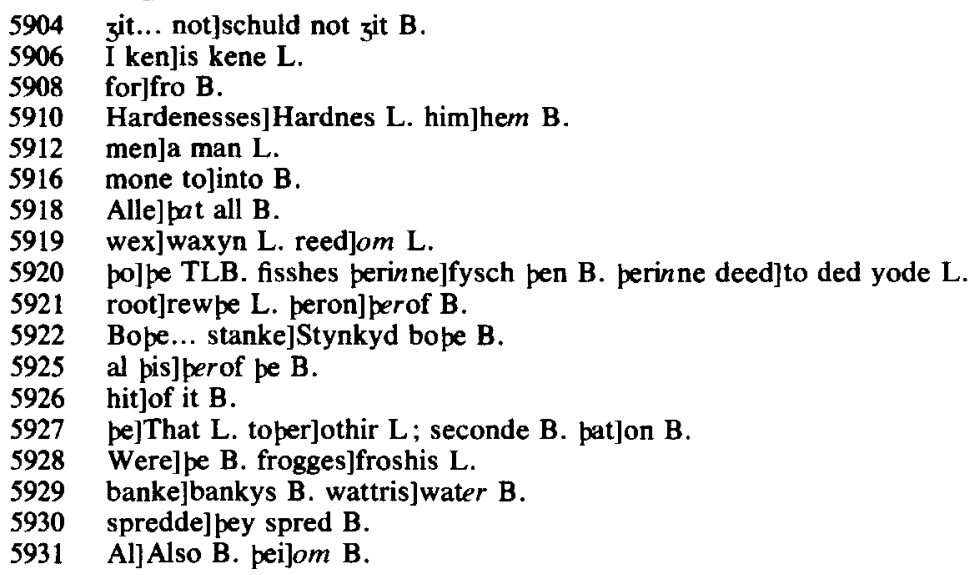


Men my 3 te not fre sette a to Bope in house \& wipoute And ouer al pe londe aboute pen bad pe kyng soone anoon 5935

Calle moyses \& aaron

Preye zoure lord pat he

Do pese froggis away fro me pei seide set vs tyme whenne To preye for be \& pi menne 5940

Tomorwe he seide sir we shal Faste on god po gon pei cal To delyuer pe folk of pat wreche And god was ful soone her leche pe frogges dyzed al bydene 5945

pe hepes wondir was to sene pat men gedered on pe grounde

When ne pharao hadde reste a stounde

He wex al greet in greue

pe folk wolde he 3 yue no leue

For to passe out of his londe pe pridde vengeaunce coom on honde

Al pe poudir of his lande

Wexe flyzes foule sore bitande

Bope pei boot mon \& beest

To flesshe flyzes were pei likest

Al for nouzte hit was no bote Pe folke lete he passe no fote penne sent god on hem a fleze A sharper say neuer noon wip eze

On pharao and his to drauzt

pat ouer al his lond hit rauzt

Saue in pat londe pat het Iessen

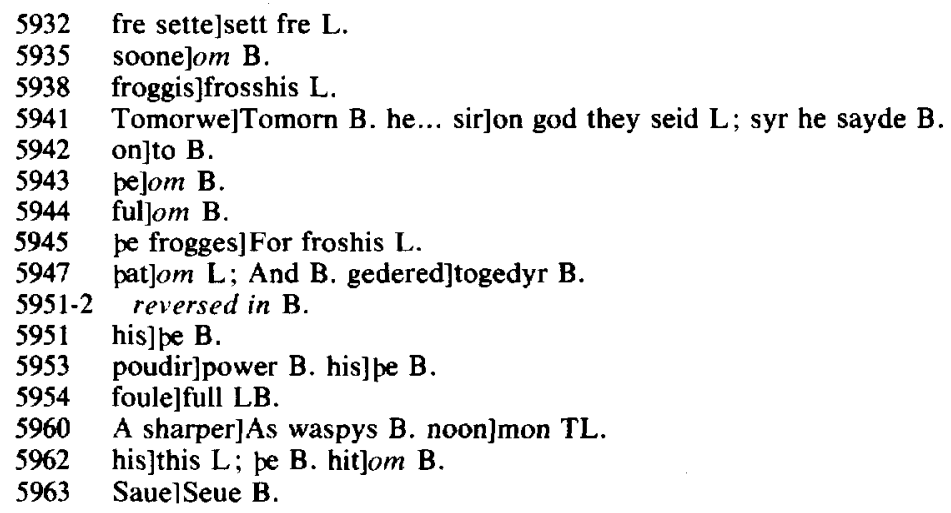


Pere woned goddis owne men Coom noon of po flyze[s] pare 5965 Wel he coupe his owne spare Pouze pei woned in pat cuntre Feire he made his owne fre For pharao shulde vndirstonde Mizty he was oueral his londe Pharao ful false of pees

Calde aaron and moyses

Goop he seide here in my londe And to zoure lord make offronde Wherto shulde ze for per go

Do wey pei seide hit is not so God wol no worshep take of hem pat dwelle among curside men Suche is pe folk of egipt pat make to beestis her worship 5980 Thre iourneyes more ne lesse 5983

Most pei wende into wildernesse To make oure lord worshepe to As he hap bede to be do Wendep he seide sip ze wol go But furper go ze not pen so For me ze preye zus pei seide Tomorwe shal po flezes be leyde Bigyle vs no more in kare pe folke po he lete forp fare Moyses preyed pat oper day

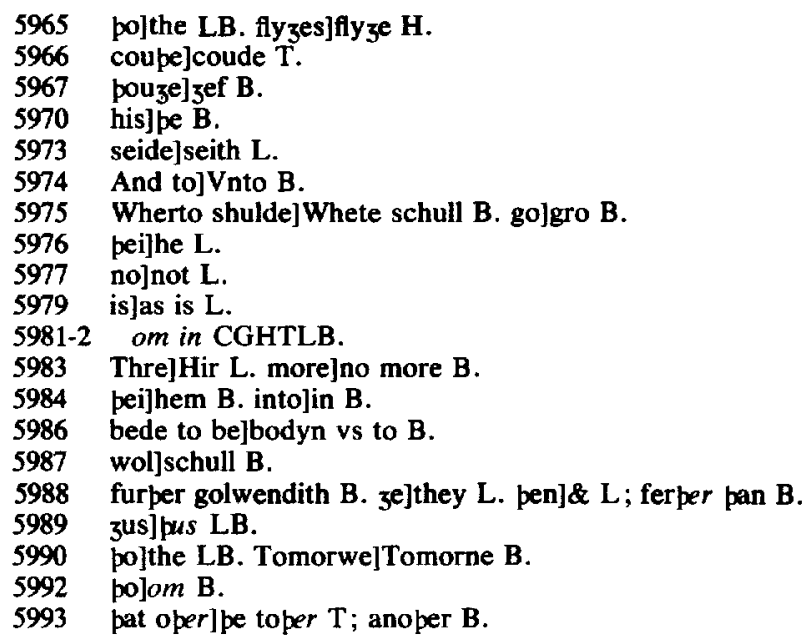


pe flyzes were alle quyt away

pat al pe lond wex so clene

5995

pat neuer a fleze perInne was sene

zit pe kyng hem helde ful pro

For wolde he not lete hem go

// pen sende god a qualme of alle

In pat kyngdome on beestis to falle

6000

Horse and asse mule $\&$ camel

fol. $34 \mathrm{r}$ col. 2

Doun pei dyzed al her catel

Goddis folke pat hadde any beest

Dyzed noon of hem moost ne leest

Pharao sende pat to se

6005

Hool \& fere he fonde hor fe

But euer was pharao in oon

Pe folk awey let he not goon

// pe sixte vengeaunce coom on honde

False pharao for to fonde

6010

Byle and blister bollynge soore

On alle his folke lasse \& moore

Hem was wo on her bodyes alle

Her kyng pei waryed greet \& smalle

zit for nouzte pat men my 3 te sey

6015

Wolde he lete pe folk awey

// Pe seuenpe vengeaunce to tel

Hit was a weder wondir fel

A pondir wip a hayl so kene

Suche anoper was neuer sene

Hayl \& fuyre menged samen

Pat hit ouertoke pouzte no gamen

Bope hit slouze fro hit bigan

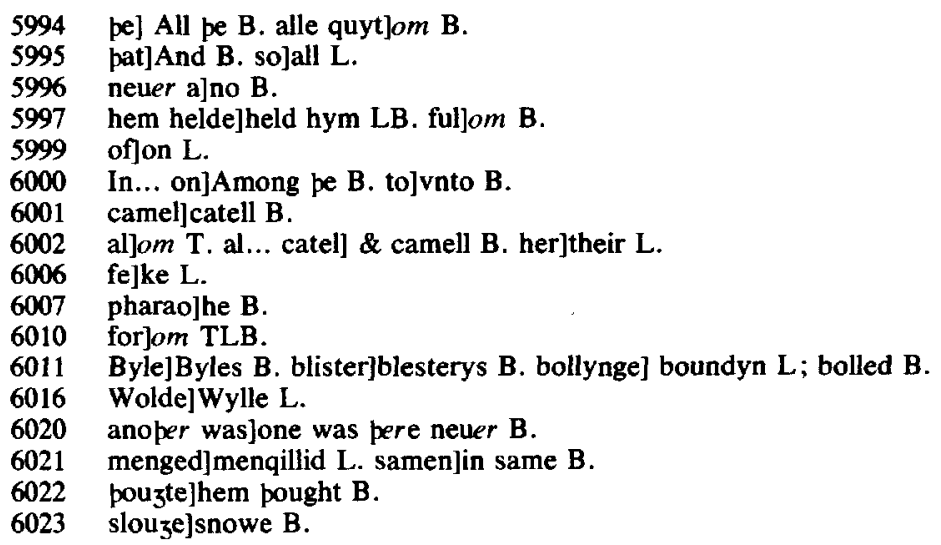


Wipouten house beest $\&$ man

pe trees hit brast pe erpe brynt

6025

At iessen lond pere hit stynt

Of israel for pat tempest

Was nouper harmed mon ne beest

pen seide pe kyng I haue pe wrong

Al pis wreche is on me longe

6030

Preye pi lord sir moyses

pat he wol do pis punder cees

$\mathrm{He}$ is riztwis pat $\mathrm{ze}^{\mathrm{e}}$ on leue

His folke shal go wipouten greue

I and myne mys han done

He preyed pe wedur ceesed soone

Whenne pharao had pat he souzte

Longer forwarde helde he nouzte

// Penne sent god hem a litil beest

Of toop is not vnfoulest

Locuste hit hette in book I fond

I trowe noon siche be in pis lond

pat beest gnow vp al bidene

pat ponder lafte rype \& grene

Of hem were so mony bred

Ouer al pe lond pei were spred

pat men myzte nowhere se

Gras on erpe ne leef on tre

But zit was pharao forsworn

$\&$ false as he was biforn

penne dide god wibdrawe his lizt

And merkenes made more pen nyzt

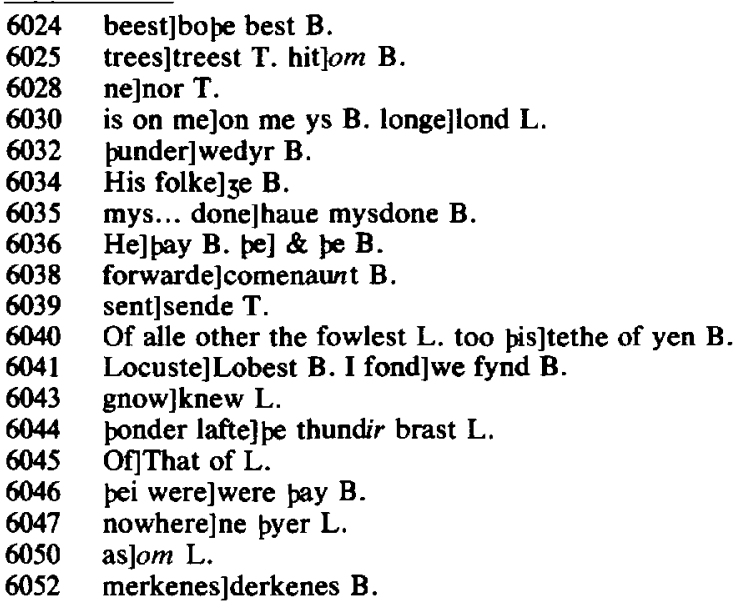


So merke noon my $3^{\text {te }}$ opere se

And pat lasted dayes pre

No man out of stide myzte stere

6055

Gessen cuntre was al clere

zit god fondide pharaon

And sende pe tenpe wrecche him on

Moore pen alle pes opere smert

To sette him sorwe at his hert

6060

Aaron god seide and moysen

Doop he seide as I zow ken

Saye to my folke on pis wyse

pat pei make me a sacrifise

Firste pei me an auter make

6065

And sipen vchone to hous In take

A clene lomb pat is honest

pe blood ze kepe be filbe out kest

And when ne hit is to offerynge bed

pe meyne perwip shul be fed

Loke pei be shod vchone

pat lomb shal ete $\&$ barfote noone

Whoso for pouert is bihynde

pe topere alle shul him fynde

pat lombes blood in alle pinge

ze make perwip a tokenynge

On euery post on vche dernere

pe syne of tayu make ze pere

Wip perf breed \& letus wylde

Whiche pat growep in pe felde

6080

Hit shal not soden be but bredd

fol. $34 \mathrm{v}$ col. 2

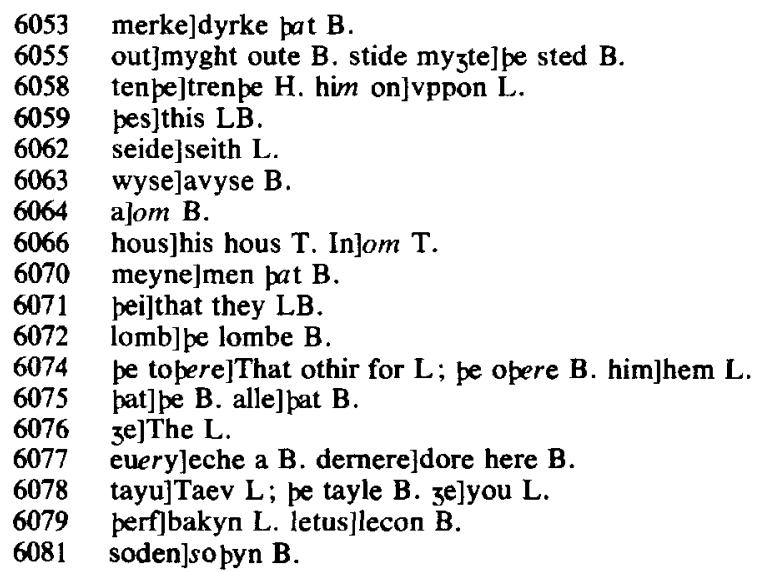


Pe lom pat $z^{e}$ shul be wip fed

pei shul hit ete feet $\&$ heued

Ouer ny $3^{\text {te }}$ no ping perof be leued

And zif ouzte leue or hit be tynt

6085

Do hit in pe fyre be brynt

Beep alle gurd wip staf in honde

Ne hones not whil 3 e are etonde

And I myself seide god almy ${ }^{t}$

Shal passe pourze egipt pat nyzt

6090

Alle pe forbirpes shal I slo

Bope of mon \& beest also

On her godis I wole wrake

On hem I shal my venieaunce take

In mynde shal ze holde pis day

6095

Bope ze \& zoure osprynge ay

Solempnely in zoure lawe

Wip alle worshipes perto to drawe

Penne calde moyses be olde

Men of israel and tolde

6100

Al pat god had hym seyde

And how pis lomb shulde be purueyde

On her poste \& her derner

pe blood pei shulde anoynte per

Straytly he forbeed pat pay

Shulde out of house come ar day

To delyuer hem hap god mynt

And zyue egipcians a dynt

Pe folk was fayn \& loutid doun

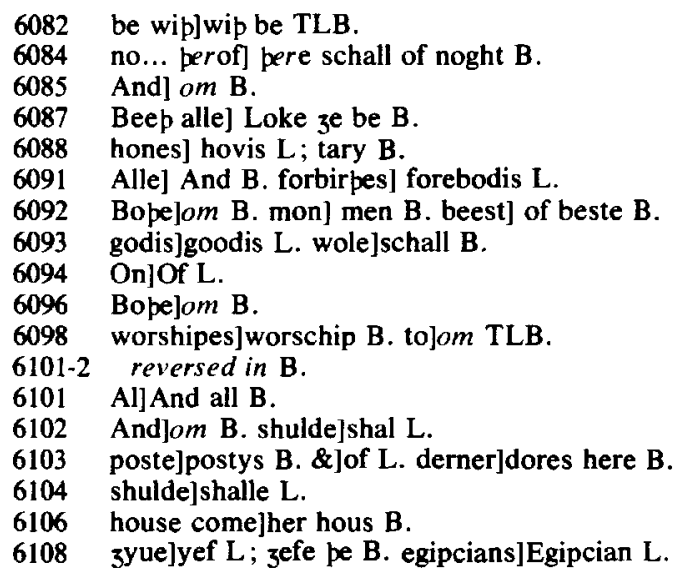


pei went to make her lambes boun

Of pis bodeword were pei glad And duden rizt as moyses bad Soone aftir pat ilke ny $3^{t}$ God as he bifore had hizt Sent anoon his aungel doun

Thourze al egipte in vche toun And souzte her housis al bidene Of po pat were egipciene Of pat meyne lafte he noon At pe laste pat he slouze vchon At pe kyng he firste bigan 6120 pe forburpe slouze beest \& man Wroperhele roos vp pe kyng

And po pat were wip hym dwellyng

Ouer al egipte pe cry was

Mony per were seide allas

per was no hous in pat lond

But perynne was deed mon ligond

By nyzte be kyng sent pon

Aftir moyses and aaron

Goop he seide out of my kith ze and al zoure folk zow wip Make sacrifise zoure god tille

Where and how pat ze wille Take zoure beestis wip zow boun Goop \& 3yue me zoure benysoun pe folk bigan on hem to crye Goop \& doop forp in hye

Dwelle ze lenger any whyle

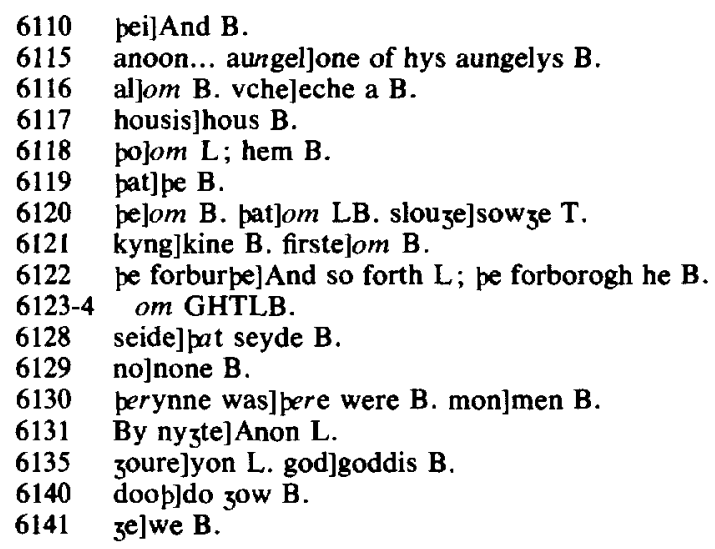


We drede dep wol vs gyle

Fro bis folk pat was in sorwe

pe folk of israel to borwe

Asked siluer vessel sere

And clopes of prys ful dere

God pat grace to hem zaue

Her askyng he dide hem haue

For to reue pat folk so snel

And helpe his folk of israel

pei were when ne pei to go bigon

Six hundride pousand fotemen pon

Wipouten childer wymmen \& broode

pat noon pe noumbre vndirstood

Laft pei not pat horen was

Sheep ne kow oxe ne as

Her wonyng pere wipouten wene

Foure hundride zeer \& two had bene

When ne pis tyme coom to ende

Of egipte goddes hoost out wende

pis owe euer to be in mynde

To israel and al her kynde

To moyses oure lord po tolde

What wyse pei shulde paske holde

And neuermore pat day to ete

Sour breed ny noon opere mete

Ny no day wipinne po seuen dayes

Seuen be firste be story sayes

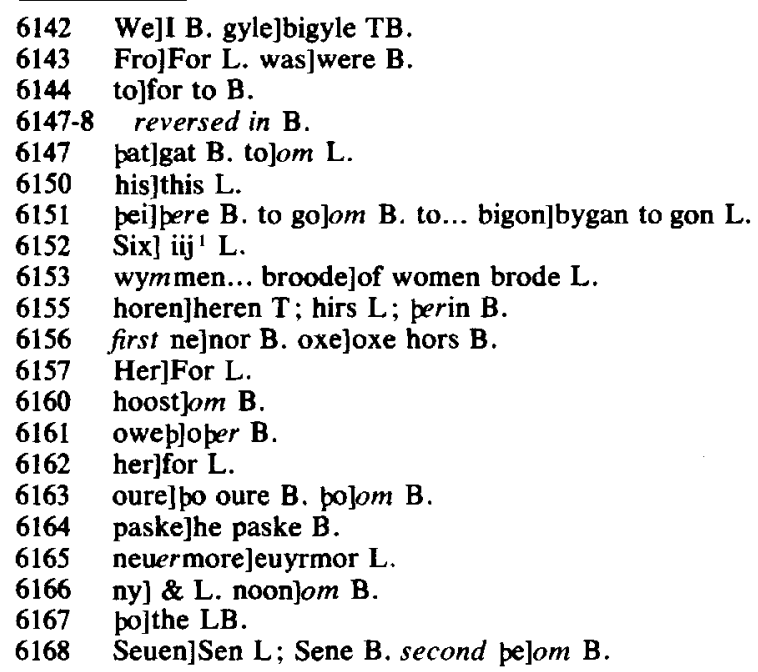


Pe forburpe of her children alle

Fro pat tyme to god let falle

And to him offere at pe leste

Pe forburbe of vche a beste

Mannes childe wip pris be bouzt

And sheep . hors . \& asse [h]e brou ${ }^{t}$

In mynde pis was to vndirstonde

pat he delyuered hem of pat londe

Bi streng pe of egipte he hem drouze

Of mon \& beest forbirbe he slouze

Whenne pharao had hem forp sende

God bad hem to wildernesse wende

Or philistiens wolde wip hem mete

And let hem for to wende her strete

pat folk took pe wylde way

Bysyde pe rede see hit lay

pus goddes folk armed were

Iosephs bones wip hem pei bere

Whenne Ioseph in lyf was stad

zerne he preyed pe folk and bad

pat whenne god sende hem visitynge

Men shulde his boones penne brynge

By a myche wodes syde

pei made hem logges to abyde

God himself hem led her way

Hem to kepe nyzte and day

Wip clouden piler on pat daylizt

Wip fyre piler vpon pe ny $3 t$

In no tyme hem wantide nouper

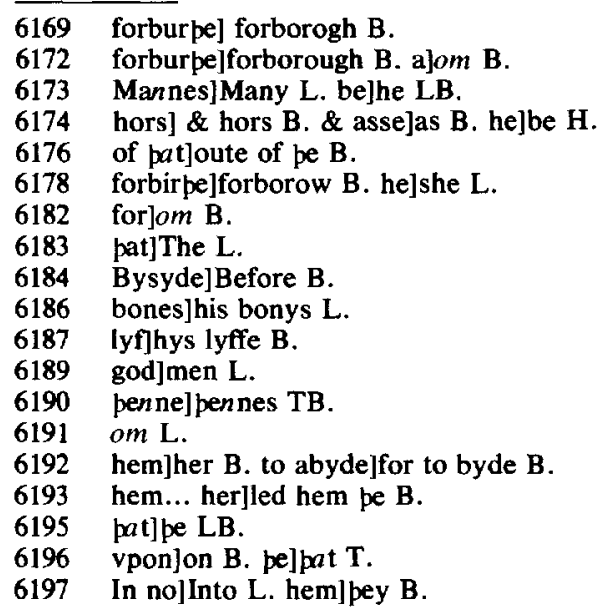


Nyzt or day pei hadde ouper

God hem bad drawe ynnermore

Azeyn on slont pere pei were ore

Into pharaons syde

On hym wolde he shewe his pryde

He shulde wene hem loke pere

fol. $35 \mathrm{v}$ col. 1

Pat pei furper my zte nowhere

Him shulde benne rewe his cast

When ne pe folk were fro him past

He shulde benne himseluen peyn

Algate to brynge pat folke azeyn

Of pe woo he wolde hem mynt

For euer penne he shulde be stynt

pe folk dude so \& were glade

And Innermore her loggyng made

Soone in londe was tiping spred

Pe folk was turned azeyn pat fled

His folke gedered pharaon

Lordyngis he seide what haue we don

Shul we pus lete pis folk away

pat shulde vs serue euer and ay

His folke armed dide he calle

And lete couple his cartes alle

Six hundride cartis wip her geris

On al be hoost he set lederes

When ne he had redy made his hoost

He went wip myche pride \& boost

When ne goddis folke his coom herde

pei bigonne to wexe aferde

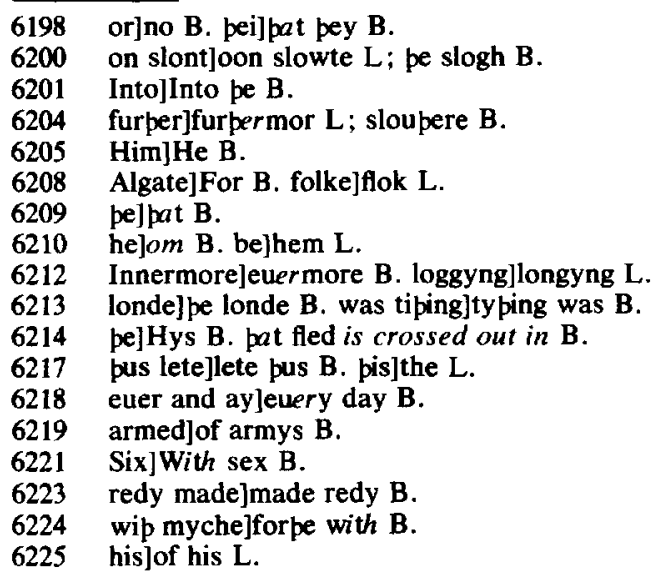


When ne pei him seze aftir hye pe folk of israel bigan to crye On god and to moyses seide In egipte was noon euel vs leide 6230 perfore hast pou vs led hit may falle To wildernes to sle vs alle Why woldes pou vs lede fro pat lond Seide we not pere dwellond To leue vs for vs leuer were pe egipcians to serue pere Al disese for to dryze pen here in wildernesse to dyze

// Moyses vnswered and seide Noon of zow bep myspayde Stondep \& biholdep seide he Goddes myracle shul ze se Goddes miracle and his my ${ }^{t}$ Himself today for zow shal fizt Goop hardily forp zoure wey And god to moyses gon say Moyses pou take pi wande pat pou were wont to bere in hande

Do pe to pe wattris syde Pe see pou smyte wipouten abyde

pou shalt se hit cleue in two And zyue zow redy weye to go

pat shal kyng pharao se Wip his host and his meyne He shal wene zou ouertake But penne shal he haue my wrake ze shul come alle hool to londe Suche is be vertu of pi wonde

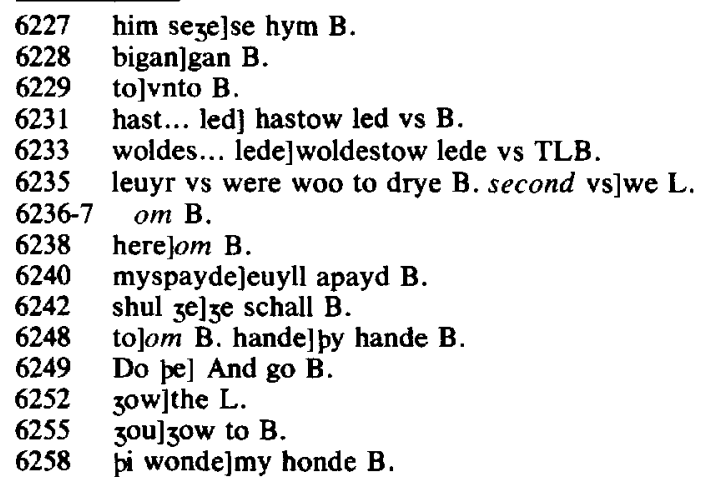


// Moyses dude as god him bad

For pharao was he not drad

In pe see his zerde he smate

Hit cleef \& zaue him redy gate

pe see on eyper syde vp stood

As walles whil pei forp zood

Til pei were passed al pat drede

6265

When ne pe kyng pis say in dede

He folwed wip hoost on hors \& fote

For nouzt caytif was him no bote

He say pe see wipdrawen in twynne

pe brood watir he dide him Inne

6270

Moyses wip his folk al hale

Wipouten wantyng of his tale

He helde his hoost vpon pe londe

And smoot pe watir wip his honde

pen was pere no lenger byde

6275

Togider pe see went bope syde

Bope bihynde hem \& bifore

And drenched mony hundride skore

Kyng knyzt squyere ne swayn

Coom neuer noon of hem azayn

Pus wreked him pe lord of my $z^{t}$

On hem pat wip him wolden fizt

His folke hap he saued sounde

His enemyes brouzte to grounde

po Israelis seide hem amonge

Cantemus domino a newe songe

To god pat had hem saued so

Of al her sorwe and her woo

6260 drad]adrad B.

6261 In... 3erde] With his yerd the se L. In]On B. his]pe B.

6262 Hit cleef]Hymself $L$.

6265 pat]pe $B$. drede]brede $L$.

6266 pis say]se pis $B$.

6272 his tale]a male B.

6273 helde]had B.

6274 honde]wande $B$.

6276 pe... went]went pe see on $B$. went]went on $L$.

6277 hem]om B.

6278 hundride]an hundird $\mathrm{L}$; a $\mathrm{M}^{1} \mathrm{~B}$.

6279 ne] \& B.

6280 neuer... hem]pere neuer one $B$.

6282 On]With B. wip... wolden]wille with hym L; wold with hym B.

6284 His] And his L. brouzte]hathe he brozt B.

6285-6 om B.

6287 had hem]hem hathe $B$.

6288 Of]Fro B. sorwe and]care \& all B. 
And so mot he delyuere vs

Oure dere lord swete ihesus

pese were pe folk of israele

Oure lord chees to hym for lele

For whom he mony miracle wrouzt

Til himself hem turned to nouzt

Ofte fro hym pei dide out reche

6295

Wherfore ofte pei fonde his wreche

As ze may here redily

Forpermore in pis story

Wip her grucchyng on moyses

Ofte dide pei greet males

Of pe tree of lyf shal I tel

And of be folk of Israel

When ne moyses pat folk had lad

Ouer pat see as god him bad

He and his broper aaron

Out of pharaos seruage pon

In sirie vpon pat oper syde

pei made her loggyng to abyde

Whil pei dwelled pere to rest

Of watir hadde pei mychel prest

Wyde pei souzte hit here \& pere

Watir myzte pei fynde nowhere

pe folke pat pere aboute him lay

Vchon gon to opere say

Wheper we shul in wildernes

Dyze for pirste pourze moyses

What shul we drynke seide pay

Moyses pat nyzte in sleep lay

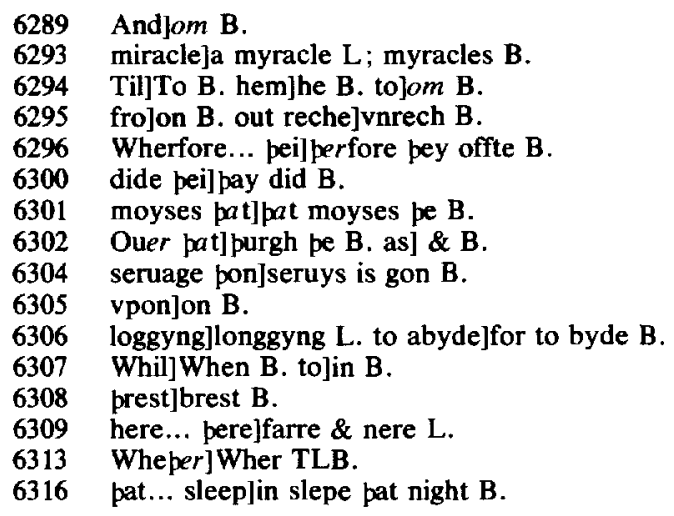


Pat ny $3^{t}$ he zeode \& took rest

Slepyng he lay in pat forest

On morwe he loked him by

He say pat him pouzte ferly

At his heed he say stonde

6320

fol. $36 \mathrm{r} \mathrm{col} .2$

Waxen of cipres a wonde

On his lift hond loked he

Anoper he say of cyder tre

Po he loked on his rizt hand

6325

Of palme tre pe pridde he fand

$\mathrm{Bi}$ po leues pat pei bere

pei kidde of what tre pei were

But moyses for goddis awe

Durst hem not vp drawe

pat oper day he went eke

Wip pat folk watir to seke

Pere he slepte at morwe tyde

He fonde po zerdis hym bysyde

pe pridde tyme so he hem fonde

6335

pat dide him wel to vndirstonde

pat sum tiping shulde per be

Closed in po zerdis pre

Selcoupe ping he seide wip In

Is closed in pes zerdis pryn

6340

pei bitokenen persones pre

And o godhede in vnite

Penne he drouze hem vp first

Wipouten any skape or birst

Whil pei in wildernes were

Po zerdis wip hem pei bere

6317-8 om B.

6319 morwe]pe morne $B$.

6322 Waxen]Wexyng LB.

6325 pojom $B$.

6326 Of]A B.

6327 po]be B.

6328 kidde of]schewyd B.

6331 pat oper]pe toper TL.

6332 pat]pe $B$.

6333 slepte]sleepe B. morwe]pe morn B.

6334 po]the $B$.

6337 shulde]shulle $L$.

6338 po... pre]pe pryd tre B.

6339 Selcoupe]Sercoupe B.

6340 pryn]treyen L; prye B.

6342 godhede]god B. vnite]trenite B.

6345 in]in be $B$.

6346 po]pe B. pei]euer pay B. 
Sip pei fonde pat firpe wipyne

Watir bittur as any bryne

As bryne hit was \& no swetter

To drynke was hit neuer be better

When ne po zerdis were In done

pe watir wex swete ful soone

pat watteres pat so foule stank

Of swetter bo neuer man drank

pat myracle pei say apert

pat dwellyng were in desert

Fro pat tyme held moyses

Po zerdis bope in pris \& pres

Where he walked here or pere

Po zerdis algate wip him were

6360

Whenne he clomb mount synay

fol. $36 \mathrm{v}$ col. 1

po he hidde hem pryuely

Whil he fasted lenten tyde

In erpe he dud hem to hyde

Nouper for dryze ne weete algate

6365

pei chaungide neuer her state

But euer pei helde lyf \& floure

Sauerynge wip a swete sauoure

Of pis moyses lordyngis

I haue zow tolde sum me pingis

Of hym may I not al telle

For hit were to longe to dwelle

But of his trauaile telle I shal

He suffered froward folk wipal

He hem ladde soop hit is

6375

Fourty wyntur in wildernis

6347 patjom B.

6350 was hit]it was $B$.

6351 po]pe $B$. In] per in $B$.

6352 fullom B.

6353 watteres]watir LB. pat]pat pere B.

6355 say]sayde B.

6356 dwellyng]duellid $L$; wellyng $B$. desert]pe zerd B.

6358 po]pe $B$. bope... pres] all of grete pryce $B$. pres]pees $L$.

6360 po]pe B.

6361 clomb mount ] went vp pe mount of $B$.

6363 fasted]fastyn L; fastyd pe $B$.

6365 ne]nor $B$.

6366 her]hys $B$.

6368 wip a]euyr with $B$.

6371 may III may $B$.

6374 wipal] \& prall B.

6375 ladde] fed B. 
God fond hem fode in her nede

Wipouten sowyng any sede

God hymself hem sende foode

Fonde pei neuer noon so gode

Hit snew to hem as hit were floure

6380

Of hony hit hadde lickest sauoure

pe mete pat pei were fed wip so

Manna pei cleped hit po

Hit coom at morwe \& at euenyng

Volatile hem sende bat kyng

pat kyng owe men loue \& loute

Wip alle worshipes to menske \& doute

pere pei hadde myche watir wone

Moyses of pe harde stone

6390

He smoot wip his forseid wonde

And out brast of pat watir a stronde

penne hadde bei watir in pat lond

Plente bope to foot \& hond

But for alle po dedes gode

pat god hem sent to her fode

pe moupes pat of wille were wlank

zalde him euer litel pank

pey her tungis speke resoun

Her hertis euer were tresoun

In pis tyme pat I of spek

Was a lordynge het amalek

pat on hem fauzte \& pei on him

In a stide hett rapidym

Moyses calde sir Iosue

And made him mayster of pat semble

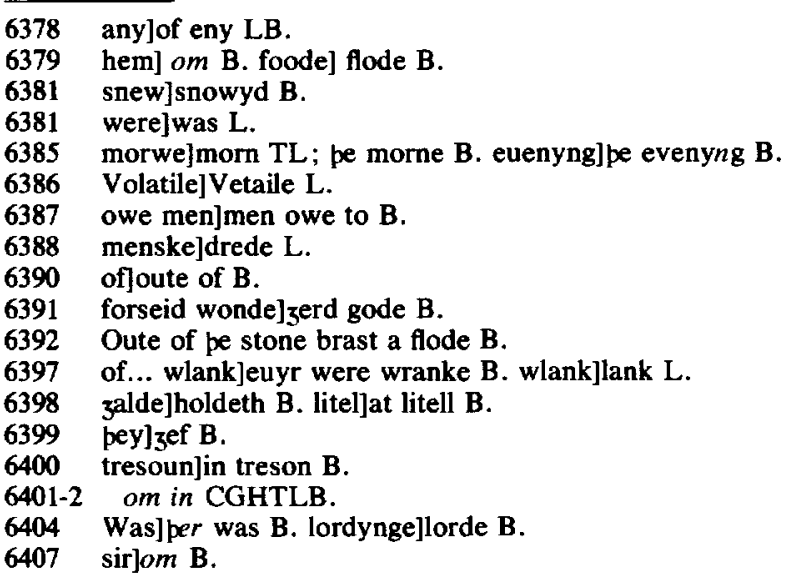


He seide chese pe men and dizt

Wip sir amalec to fizt

6410

And I shal on pat hil stonde

And goddes zerde holde in honde

To pis fizte pei wente anoon

Moyses po and aaron

pei wente vpon pat hille

6415

In hope allone of goddis wille

Whil moyses helde vp his hende

Wel was hit in pat bataile kende

Euer pat whyle witerly

Had goddes folk pe victory

And if he slaked hem any sipe

Amalec won also swipe

So longe he helde hem vp wip pis

pat slake hem most he maugre his

Of werynesse was no wondir

6425

pei gedered stoones \& leyde him vndir

Euer helde he vp and aaron

His hondes til pe fizte was don

Vndir eiper hond was oon

pat helde hym stille as any stoon

6430

$\mathrm{Bi}$ be sunne was at doun helde

Wip Israel was lafte pe felde

// Ietro pe prest of madian

pat was moyses kynnesman

When ne he herde how pei had don

6435

Bitwene Israel and pharaon

To speke wip moyses he cam

Brouzte him his wyf sephoram

Wip two sones she by hym beer

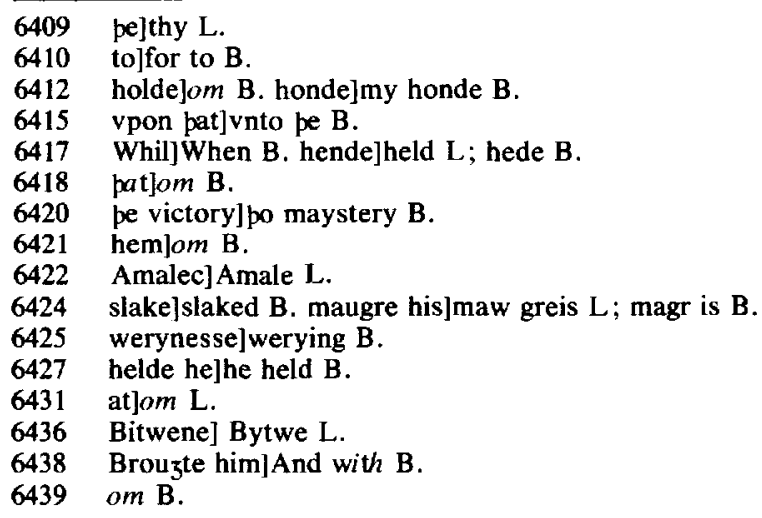


Gersan and Elyaser

pis ilke folke was vntoun to fonde

pat moyses hadde vndir honde

pei dide him wondir greet trauaile

Til letro zaf him counsaile

Vndir bailis to set hem pen

fol. $37 \mathrm{r} \mathrm{col} .1$

In rizt for to kepen hem

Of mony wrongis pat per were

Of whiche men greet charge bere

But pat . pat fel to goostlynes

Shul be tauzte bi trewe moyses

6445

Listenep now to my sawe

Telle I shal of moyses lawe

penne bigan pe folk to say

To moyses go gete vs lay

Moyses seid pat is rizt

We shul hit aske of god almyzt

To faste bihoue zow and me

How longe shal pe terme be

pe terme shal laste fourty dayes

Whil I go to gete zow layes

Here on pe mount of synay

Sir pei seide ful blepely

6460

Moyses wente vpon pat felle

Fourty dayes pere gon dwelle

Whiche he fasted as we rede

To gete lawe his folk to lede

Oure lord coom to hym anoon

And toke him tables two of stoon

Wip his commandementis ten

And bad him teche hem to his men

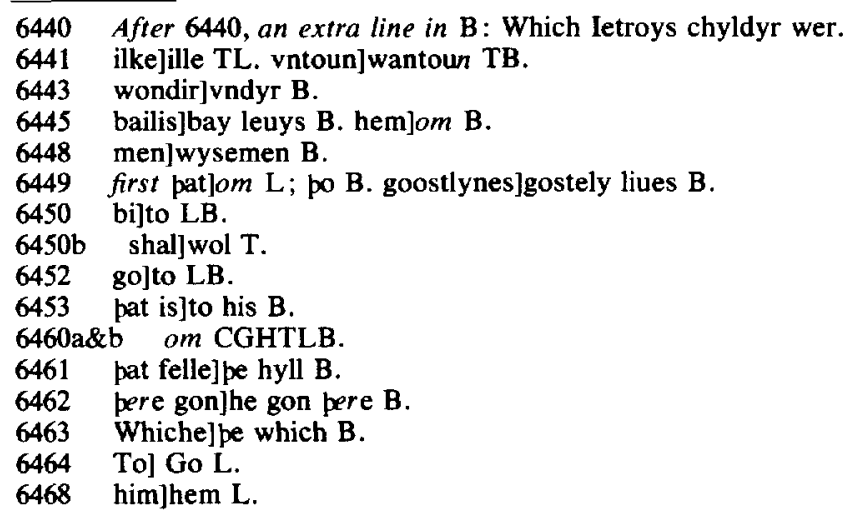


For we owe hem holde for det

In pis book I haue hem set

// Trowe pou in no god but oon

//Ny oop pat pou swere noon

//Holde wel pi holy day

// Fadir \& modir worshepe ze ay

//Reue no mon his lyf pon

//Do no lecchery bi no wommon

//Loke ze no bing ne stele

//Berep witnes noon but lele

// Pi neizebores wif wip wronge pou naue

// Nor beest of his mayden ny knaue

pese are pe commaundementis ten

pat god took to moysen

Firste pe iewes to teche

And sipen pe cristen to preche

If we hem kepe out and Inne

6485

pei wol vs saue fro dedly synne

fol. $37 \mathrm{r}$ col. 2

Whiles moyses was awey

pat false folke wipouten fey

pei seide Moyses was slayn

And neuer wolde come azayn

6490

And summe seide bat he

Was lyuynge \& in lyf shulde be

pei toke her counsel as pei wolde

To make hem a god of golde

po foolis seide hem among

So stalworbe shulde he be \& strong

pat he shal holde vs hool \& fere

6469 we]ze B. hem holde] to holde hem $\mathbf{B}$.

6470 book]koke $T$.

6474 ze]om B.

6475 Reue]Reue ze TLB. lyf]wyfe B.

6477 ze]pat ze B. nelom TB; ze L.

6478 noon]not $\mathrm{L}$.

6479 bou naue]pou nam $L$; ne haue $B$.

6480 knaue]man L.

6482 took] zafe B.

6483 pe]to pe $B$.

6484 cristen]cristen men $B$.

6487 Whiles] Whyles pat B.

6488 pat]pe $B$.

6490 wolde]more schuld B.

6492 lyuynge]lying $B$.

6495 polThe LB.

6496 shulde he]he schuld $B$.

6497 shal]schuld B. 
And kepe vs euer in oure mistere

Whenne manna wol vs wantynge be

He shal vs sende good plente

pus bigan her gyle wip gamen

Her tresour of gold pe[i] gedered samen

A golden calf perof pei blewe

And as god honourid hit newe

Oure god pei seide pis is he

pat brouzte vs pourze pe rede see

Fro pharao and his powere

perfore honoure we him here

pis moyses was dere \& kynde

To god men may hit here fynde

He toke hym tables of pe lawe

As ze herde in my sawe

Whenne he had hem hym take

Pe folke he seide hap don wrake

Sip pou coom fro hem laste

Pou shalt hem fynde vnstidefaste

Lordingis to pis false lede

Manna fel ze herde me rede

Fro heuen fel so greet plente

As a ryme frost onne to se

Whil moyses hym helde a way

For to do hem haue pe lay

Summe of hem pis fast forsoke

And pis riche manna toke

And vndir erpe in hoolis hidde

Azeyn forbode pus pei didde

pus pei were pat tyme vnwyse

pei dide azeynes goddes enprise

When ne moyses coom fro pat felle

Soone herde he tiping telle

pat pis folk ful euel had done

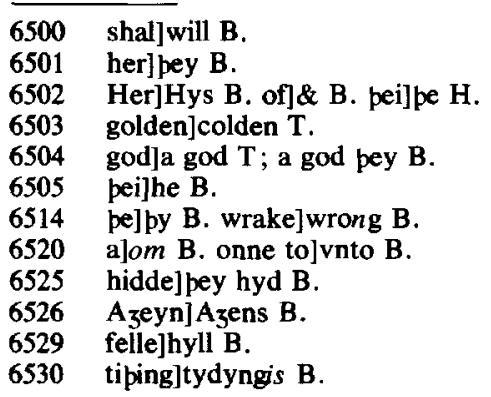


Perof fonde he tokene soone

When ne he was comen into desert

pe calf fond he pere set apert

He herde be greet noyse pare

6535

Aboute pis calf wip mychel fare

So greued he wex in his mode

He myzte say euel ny gode

He ne wist wheper better wore

To turne or wende him forpermore

pe tables pat he in hond bere

In peces he hem brak rizt pere

perwip forpermore he zede

For to se her cursed dede

He say hem knele pis calf aboute

As god hymself to loue and loute

What deuel is pis he seide in greue

Is pis zoure god pat ze in leue

Whenne pei were war of moyses

pei fley awey al in a res

zonge and olde lasse \& more

pe calf alone laft pei pore

Moyses penne called hem togider

Lordyngis he seide I am comen hider

Aboute zoure eronde haue I bene

6555

Why fle 3 e fro me pus bidene

Comep azeyn wipouten doute

Haue ze pese dayes alle fasted oute

pat I zow bad ar I went

Haue ze holde my commaundement

Who hap made pis calf byfore

Hit shal heraftir zow rewe ful sore

6561 fol. $37 \mathrm{v}$ col. 2

6568

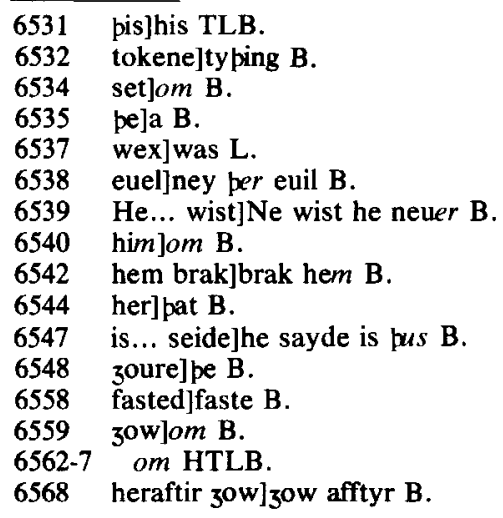


Who made pis calf I most him ken

Who helde pe fast among pese men

Who hap holden my comaundement

And who not sipen I went

Who forzat me \& who nouzt

And who pis gold togider brouzt

Whiche are po togider hit blew

Whiche are po for her god hit knew

Alle pei made hemseluen quyte

Vchone seide I haue no wyte

Par fay seide moyses for nouzt

pe sope algate shal be souzt

I wol myself knowe pe fals

And vche man shal knowe him als

Ful euelhel brake ze pat day

pat I fasted so shul ze say

Allas shul ze say pat sipe

For whenne I weped ze made zow blipe

ze made pis god in to trowe

Whil I went to preye for zowe

Mychel foly dide I pan

pat euer to helpe zow I bigan

Whenne I zow ladde pourze pe stronde

Out of alle zoure enemyes honde

Sipen I asked zoure fode

And god sende zow manna gode

pat $z^{e}$ in erpe ha hud vndir

Mony men on zow shal wondir

Oure lord shal me on zow wrake

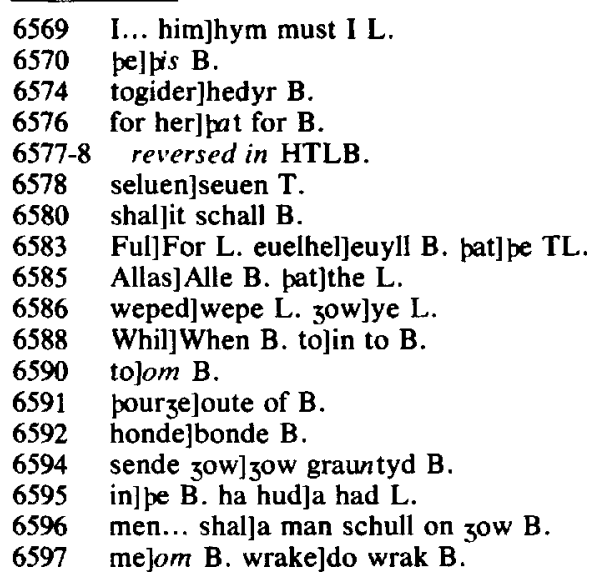


And saue po pat haue no sake Alle are ze trewe by zoure sawes Is noon of zow pis calf knawes ze saye pat $z^{e}$ made hit nouzt Ne neuer coom hit in zoure pouzt Nor ze honourid hit neuer ze say Al of pis ze make hit nay But say me penne wherfore $\&$ why ze made so myche dene \& cry pat I zow say make alle bidene fol. $38 \mathrm{r}$ col. 1 Pourze pe watir hit shal be sene Shewep me soone hit shal be kid Wher ze haue pis manna hid 6610

po puttis whenne pei hem vndid pei fonde but wormes crulyng Imyd

When ne pei sey pis soop to say pat gilty were pouzte no play pis golden calf he made to brest 6615

To precis \& into watir kest

And of pis watir he made vchon

To drynke wheper pei wolde or noon

Alle po men pat gilty were

Gulden berdes soone pei bere

Po pat were wipouten plizt

And helde his commaundement rizt

And trowed to no maumetrye

As was be kynreden of sir leuy

Pe watir proued hem for clene

Was no gold on her berdis sene

Moyses to her zatis zode

pus he seide whenne he pere stode

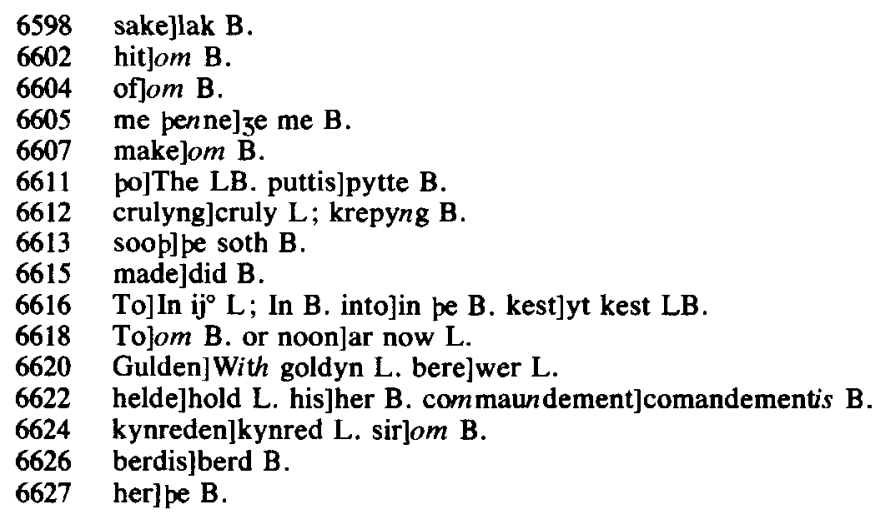


Alle pat are in goddis partye Hider ze come \& stonde me bye 6630

So dude pat were in goddis half

And honoured not pe gilden calf

Goop he seide pat hit be sene

Sleep vp po caitifs al bydene

Vchone went wip swerd in honde

And slowze pere twenty pousonde

Penne gon moyses to hem say

Wite $z^{\mathrm{e}}$ what $\mathrm{ze}$ haue done today

ze haue to god holden vp zoure hondes

And slayn pat goddis wille wipstondes

6640

// zit spak oure lord to moysen

Do he seide as I pe ken

Hewe pe siche tablis he seide

As I bifore pe purueyde

Whiche pou brake \& I shal soone

6645

Wryte hem newe hit is to done

Vpon pe morwe when ne hit was day

fol. $38 \mathrm{r}$ col. 2

Moyses went to fett pe lay

He toke comaundementis ten

For to lede wip his men

Writen wip goddis owne honde

He sent hem pere a fair presonde

When ne moyses hadde brouzt pe lawe

And his folk In face him sawe

Hem pouzte him horned on heed fer

6655

And douted to come him ner

Penne pe lawe he hem vndide

As oure lord to hym gon bide

Off oon arke to hem he spake

In goddis worshipe for to make 
A tabernacle als for to dizt Perof he shewed hem pe rizt pe pre zerdis vp he toke And peryn dide so seip pe boke To bere wip hym to euery stede 6665

Whider he wolde pat folk lede

\section{Listenep now a litil prawe}

For I wol telle of moyses lawe

Now shul ze of po domes here

pat god zaf to moyses sere

Alle to telle hit were gret swinke

But summe are gode to here me pinke

Whoso smytep man in wille to slo

He shal himself be slayn also

Whoso sleep any man wip wille

And bifore hap waited pertille

If he to myn autere flyze

Men shal him pennes drawe to dyze

Who pat fadir or modir smyte

Or elles hem warye $p$ in despite

Dyze pei shal for pat sake

Wipouten raunsoum noon to take

If two chyde \& pat oon

pat oper smyte wip fuste or stoon

So bat he lye short whyle or long

Sipen when ne he may go strong

pe smytere shal quyte his lechyng

And pe skape of his liggyng

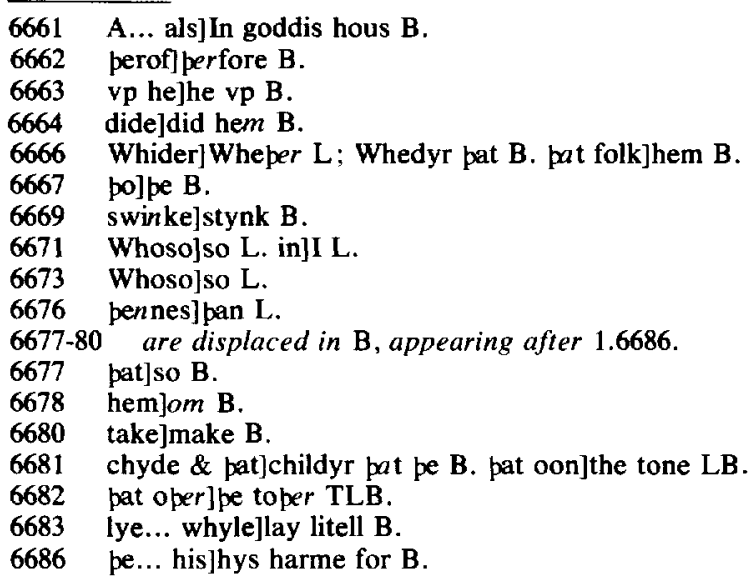


Whoso smytep his seruaunt wip a wand And he be deed vndir his hande He shal be gilty of his synne But if he lyue a day or twynne 6690 pe lord shal vndurly no peyne For as his catel is his sweyne

If mon smyte wyf wip barn Wherfore pe childe is forfarn If so be pat pe modir lyue 6695

To hir husbonde penne shal he zyue

Medis pat men saye is rizt By lokyng of trewe mennes sizt And if she deze perfore pe wyf penne shal he lose lyf for lyf

$E_{3}$ for eze toop for top

Hond for hond loke pis be soop

Foot for foot too for too

Wounde for wounde woo for woo

Whoso smytep out his pralles yze 6705 And makep hym vnsiztilyze Or toop out of his moup smyte He shal him make fre \& quyte

pe ox pat sleep mon wip horn And so was not wont biforn To depe men shal pat beest stone But of pe flesshe ete no mon none pe beestis lord shal go quyte Of alle chalengis \& wyte

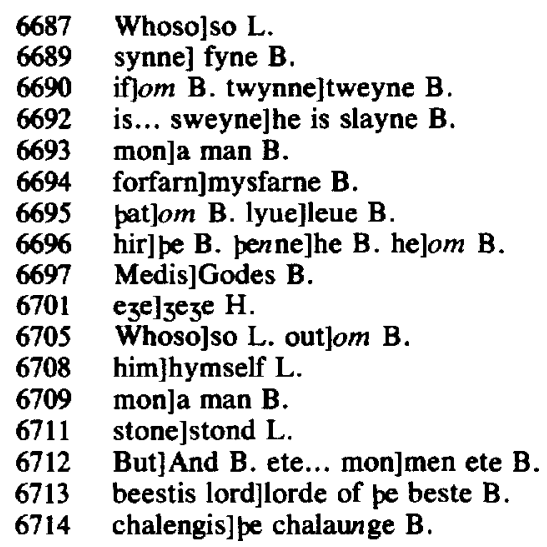


If his lord knowe him kene of horn

pre dayes per biforn

If he sle wommon or mon

pe beest to slauzte shal go pon

And pe lord pat hit izt

Shal vnswere perfore at his my $3^{t}$

6720

If he sle any monnes sweyn

Thritty shillyng of mone[y] azeyn

Shal men zyue pe lorde to mende

pe beest shal wip stoonyng ende

[I]f any man makep a pit

6725 fol. $38 v$ col. 2

And sippen wol nat stoppe hit

If ox or asse or opere beest

Falle perynne leest or meest

pe man pat pis put auzte

Be he wroop or ellis sauzte

Of his beest shal zelde be prys

But pe dede beest shal be hys

If pat myn oxe firste sle pyn

pus bidde god almy 3 tyn

pat pe quyke beest be solde

6735

pe prys bitwixe hem dalt \& tolde

And pe dede careyn also

Shal be delt bitwene hem two

And if he wist hit at pe leest

Pre dayes bifore of pis beest

And no kepyng dude on pat wylde

Ox for ox penne shal he zilde

6717 he]it B.

6718 slauzte]slawghtir LB.

6719 izt]hight L.

6721 sweyn]swyne LB.

6722 shillyng] $f$ B. money]mone $H$.

6723 be lorde schall zeue to amend $B$.

6725 If] The I in MS H is very faint, merely the scribe's guide to the rubricator, which the latter missed.

6727 first or]om L.

6728 leest... meest]meest or leest TLB.

6729-30 om CFG.

6731 his beest]pe dede B. pe]a B.

6732 beest]om $B$.

6736 pe] And pe B. dalt \&] om $B$.

6737 careyn]body $B$.

6740 bifore]afore $B$. pis]pe $B$.

6741 no]non $B$. pat]pe B.

6742 pennejor $B$. hejbe $B$. 
Whoso stelep sheep ox or cow

To sle or selle or oper prow

Oxen fiue for oon he pay

For oon sheep foure hit stonde for lay

peof housbrekynge or digynge ground

If mon him smyte wip depes wound

And pe dede be done bi nyzt

pe smyter penne shal haue no plizt

But if pe sunne be vp bon

Hit shal be tolde for slauzte of mon

If peof haue no fyn ne zift

pat he azeyn may zelde his pift

He shal be solde but if pat he

Haue any auzte may founden be

If he haue any zonge or olde

He shal azeyn zelde double folde

If fyre be kyndeled by vnhap

pourze felde or corn mowe or stak

6760

He pat hit kyndelep in pat felde

He owze pe harmes for to zelde

If I zyue pe forto kepe

Ox or cowe . asse or shepe

Hors or any opere auzte

And hit wip peofis be lauzte

6765 fol. 39r col. 1

Or deed or done into euel my $3^{t}$

Or done away fro monnes sizt

Wip pin oop make pe clene

And pou go quyt of pat I mene

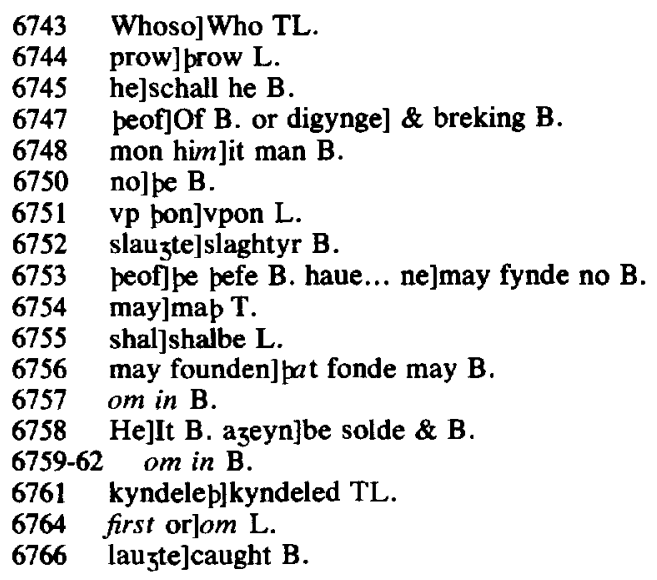


But if pis auzte be stolen in chaunce Pou shalt him make restoraunce And if $I$ lent pe siche a beest pat deed or spilt be at pe leest And I myself not present pou shalt hit quyte bi iugement And elles not namely in dede I lete to hyre for any mede

po pat to wicked dedes drawe God wol pat pei be done of dawe

Whoso dop wip beest pe foul synne He shal be done to depe perynne

Who pat honourep goddes newe Of his sleyng shal no mon rewe To comelyngis loke ze do no gyle 6785 For siche were zoureself sum whyle

Widewe nor childe fadirles Do no wronge ny noon vnpees If 3 e do crye to me pei shal And I forsope wol here her cal penne shal my wreche kyndel so pat soone peraftir I wol zow slo Widewes I shal make zoure wyues zoure childer haue no fadris in lyues

If pat pou lenest any ping pou lene hit not wip okeryng If pat pou whenne pou art wroop

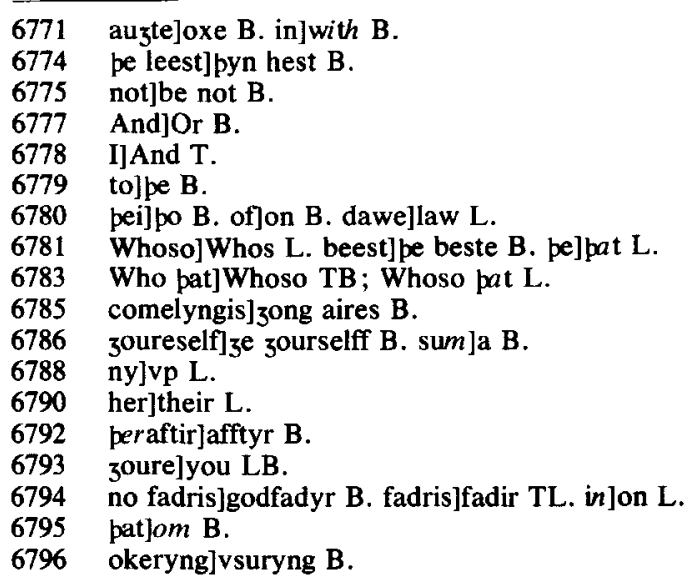


Of sympel mon take wed or cloop zelde azeyn pat cloop I say Ar pe sunne go doun pat day 6800 In hap he hap on bak nor bed Cloop to hile hym but pat wed Elles if pat he to me cryze I shal him here pourze my mercyze

Missaye no prest pat prechep in londe 6805 fol. 39r col. 2 3yue gladly pi tende \& pyn offronde

pe formast sheues of zoure corn

pe firste childe to zow is born

Not pat alone I bid zow

But als pe firste of sheep \& cow

pe childe pat $z^{e}$ to offring brynge

3 e bye azeyn for opere pinge

pe forburpes pat I of telle

Shal seuen dayes wip modir dwelle

pe eiztepe day to offred be

As I haue comaundide be

pe flesshe pat beest bifore hap taast

Ete ze not perof pe last

Lerne not of hym pat is lyere

Ny false witenes noon ze bare

Folewe hem no more pen pi foos

Pat vnto wickede dedis goos

Holde wip none pouze pei be fele Azeyn pe doom pou woost is lele

To riche \& pore pou seest in plizt

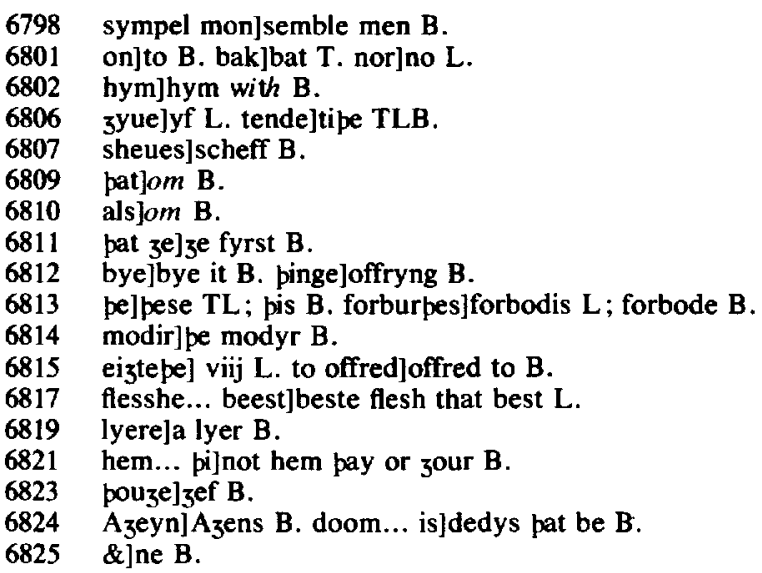


In dome spare pou not pe rizt

pin enemyes beest pou fyndes o stray

pou brynge hit hoom pat wol pi lay

If pou fynde of pyn euel willonde

Vndur birpen his beste biggonde

6830

Helpe hym or pou forper wende

And so pou maist make pi frende

Sle no man wipouten sake

Blendyng ziftis noone pou make

To pilg[r]ym \& to vncoup

6835

Bere pe feire of dede $\&$ moup

ze knowe pe state of comelynge

Of pharaos tyme pe kynge

zoure lond ze sowe seuen zere

And repe perof cornes sere

6840

pe eiztepe lete hit lye stille

Pore mennes hongur to fille

Six dayes shul ze worche I say

And ze shul reste pe seuenpe day

Hors \& asse wommon and knaue

6845 fol. 39v col. 1

pat day shul pei restyng haue

Trowe on no goddes fals

[S] werep not I bidde zow als

Holdep pis wel I bidde zow now

Myn aungel shal go bifore zow

pat shal zow wisse \& sumdel lede

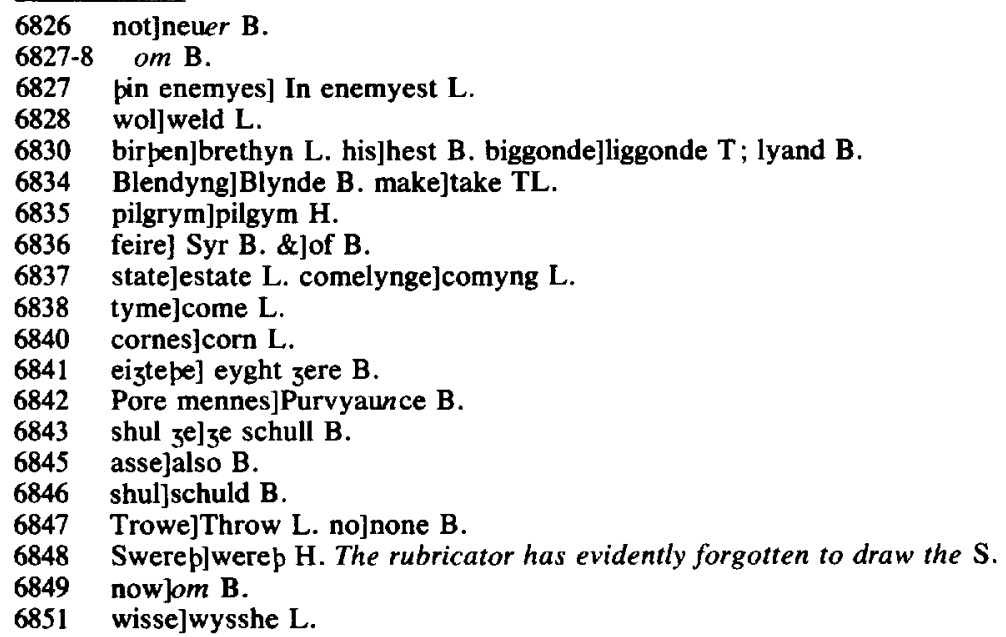


Into a lond of blisfulhede

zoure foos pat zow wolde wipstonde

Shul haue no myzte in foot nor honde

I myself wol for zow fizt

Shal noon ouer zow haue no my $3^{t}$

I shal holde zow my sawe

Whil ze folwe my rizt lawe

Suche was pe lessoun and pe lore

And zitt a pousonde sipis more

pat god shewed to moysen

To do his folk hym knowe \& ken

But lordyngis for pat I

By witenessynge of prophecy

And pourze preef of pe selue dede

6865

To cristis burpe I wol vs lede

Ar he had take flesshe \& blode

Pe firste was Abraham of her brode

To whom was het pat of his sede

Shul alle pe blessed folke brede

And so dide prynce $\&$ als prophete

As god dide to hym bihete

And lordyngis for pat I

May not telle al her prophecy

pat of pat blissed burpe was seyde

Pat longe tofore was purueyde

Of somme of hem pat seyde moost

Of his birpe bi pe holy goost

I shal zow shewe wipouten les

As anentis pis moyses

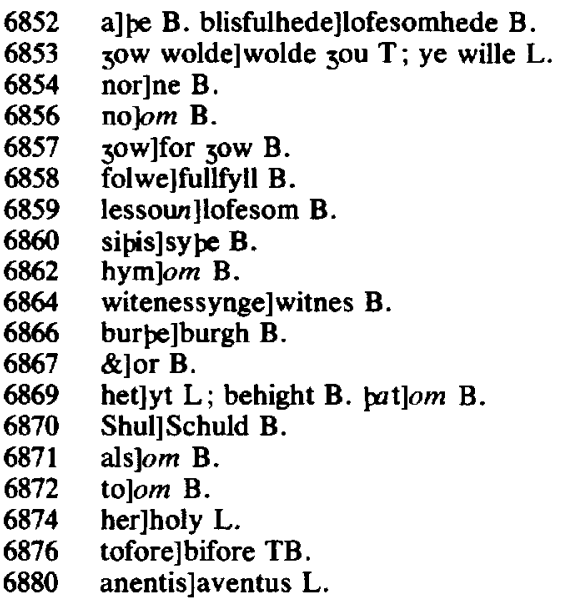


Pis moyses pat I rede of here

Was tauzte pe folke to lede \& lere pat dalt weren in kynredens twelue

Moyses hem bad hymselue

pat vche kynreden to bere a wond

6885 fol. $39 \mathrm{v}$ col. 2

His biddyng durst pei not wipstond

And vche wande pat pei pere bare

He spered hem in her seyntware

And wroot pe name \& seled also

Pat noon shulde opere gyle po

6890

Whenne he hem loked on pe morn

He fonde oon wip leef \& flour born

And for hit was an almaunde wonde

pat same fruyt peronne pei fonde

Almaundis grewen po peron

pe zerde pat fel to aaron

To al pe folk in pat londe

Moyses soone shewed pe wonde

But he tolde hem not pat tyde

What pe tokene wolde abyde

For he her frowardenesse knewe

And pei were of troube vntrewe

pis zerde was done vp to holde

As god of myzt himself wolde

In tokene for to take \& telle

Azeyn pe folk pat was rebelle

To vndirstonde pat god mouzt

Al ping do pat hym good pouzt

pis zerde bitokened oure lady trewe

pe fruyt hir sone swete ihesue

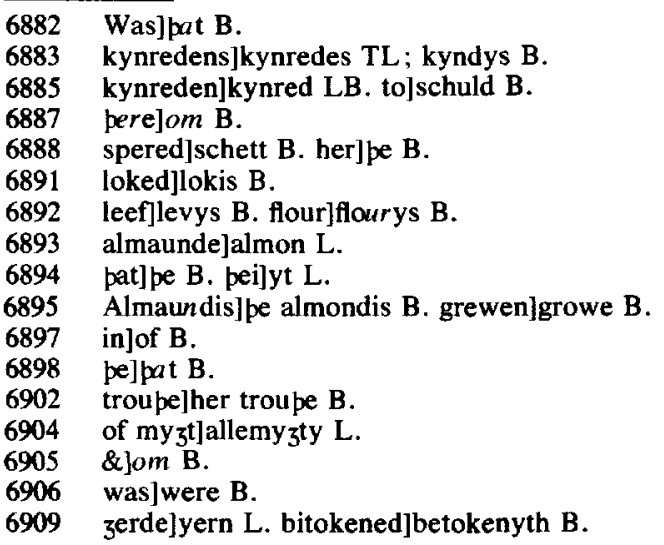


Of pis matere mut I now cees

To telle zou more of pis moyses

Whenne he as god him chees bifore

He lad pe folke in wildernesse pore

Fourty wyntur and no las

6915

Dede in pat desert he was

$\mathrm{Al}$ his elde was sixe score zeer

For he was to god so der

Himself byryed him \& hid

In a pryue place vnkid

6920

For wiste pe iewis where he lay

Honoure him as god wolde pay

pes iewes went wipouten resoun

Into pe londe of promissioun

Pourze moyses ne coom pei nouzt

But losue hem pider brouzt

God aftir good moysen

Made hym leder of his men

Wip his felawe pat calef hizte

po two brouzte hem to rizte

pis Iosue coom of pat kyn po

pat men calle effraym also

In egipte born but fed he was

6925 fol. 40 r col. 1

And leder als wip maystir moyses

6935

pis ilke moyses riztwis of rede

Forzat not ar he were dede

To sette pese holy zerdes pre

In a stide he fonde pryue

6940

pere pei grew lasse ne more

But euer as bei were bifore

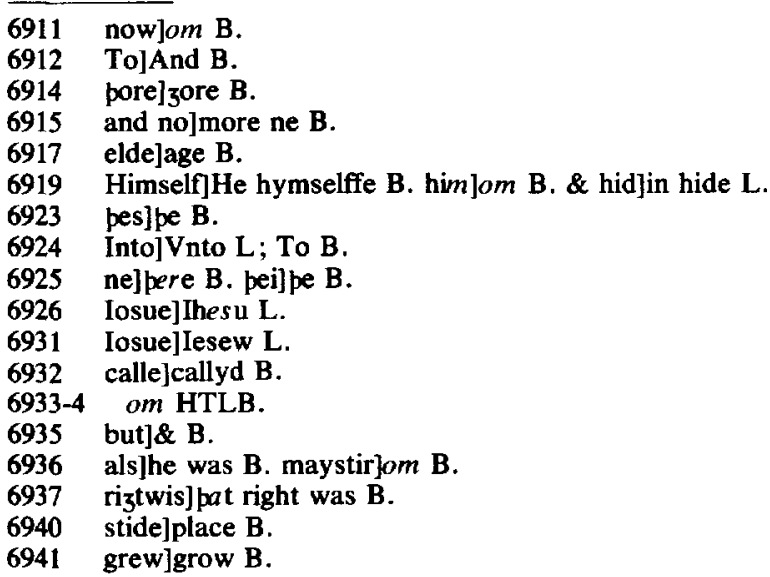


Rizt to kyng dauid dayes

pat lad pe folk in goddis layes

He bi warnynge of goddis sonde

6945

Brouzte pe zerdis to his londe

Whenne aaron was deed pe prest

His sone eliazar was neest

And his fadir astate he beere

Til Iosue we speke of here

Pis iosue was wondir lizt

And maistry had in mony a fizt

Trewely he fauzte for goddis lay

perfore god doubled him his day

And made be sunne stille to stonde

6955

Til Iosue had pe hyzer honde

And whil he past pe flum iurdon

pe watir stood stille as stoon

Til he pe folk had ouer brouzt

Into be same lond pei souzt

6960

Ioseph boones pei wip hem lede

And per grof hem in pat stede

In a lond pat het sichym

Was zyuen in lot to Ioseph kyn

For as bei wan hit wip her honde

pei dalt bitwixe hem pat londe

Vche kynreden of po twelue

fol. $40 \mathrm{r}$ col. 2

Had a lodesmon hemselue

pat shulde her owne kynreden lede

Whenne pat pei to bataile zeode

For pei fonde strong folk hem azeyn

Wip were pat dide hem myche peyn

And wipstood hem pe londe to wynne

6946 pe]po T.

6949 astate]state B.

6950 speke]spak B. here]are B.

6953 fauzte]thoght $\mathrm{L}$.

6954 doubled]dobbyd B.

6960 Into]To B. same]om B. pei]pat he B.

6961 peilom B.

6962 groflgraued $\mathrm{T}$; did grafe L.

6964 Was... lot]pat zeffyn was $B$.

6965 For as]pere B.

6966 peil And $B$. bitwixe]betwene B. pat]pe B.

6967 kynreden]kynrede TB. po] the LB.

6968 lodesmon]Sodec man B.

6969 herlhe T. kynreden]kynrede TLB.

6972 Wip]pat with B. patjom B.

6973 pe]pat $B$. 
But pat was for her owne synne For whil pei helde her lawe in londe 6975

Was no folk myzte hem wipstonde pat alle opere dude my $z^{t e}$ not avayl Whil pei helde goddes counsayl Hem purte drede no man in place But her fizte lasted litil space 6980 Whenne pei moost had of her wille Moost pei dide hemself vnskille Of god almyzty bei laft pe lawe To sarasenes feip gan hem drawe And made wip hem her mariagis 6985 Who herde euer suche men in ragis Suche a kyng coude no man knawe Hem helde from vche mannes awe And euer pei vnskil on him souzt Til pei hemself in praldom brouzt 6990 In praldome were pei worp to be pat wolde not suffere to be fre //Calef coom aftir Iosue Of israel demer was he In his tyme were po fablis writen pat $3^{i t t}$ are as bookis witen Saturneus \& sir Iubitere pat we nowe in fables here And pe first sibile of pers Men fynden of in olde vers //Calef had a sone othomel $\mathrm{He}$ demed pe folk of israel

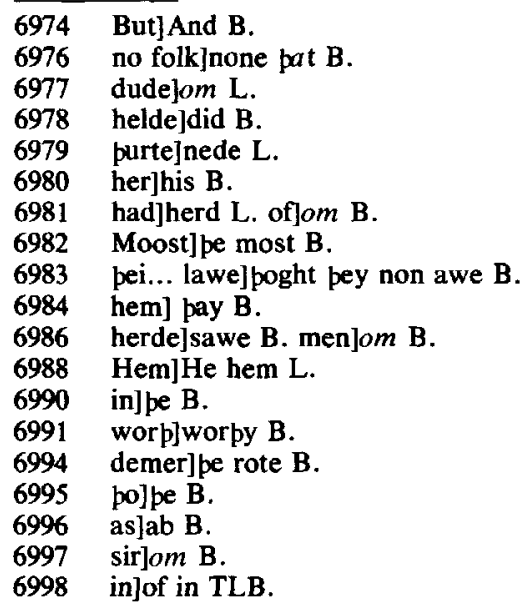


By fourty zeer in his tyme was Pe cite made of thebas Ayoth was penne demestere

Of israel foure score zeere In his tyme was a bataile grym Bitwene Israel \& beniamyn For loue of a deknes wyf Mony a man lost her lyf 7010 Fourty pousande of israele Of beniamyn nyze also fele //Sanygath coom aftir hime Troye was bigonne in his tyme Ten zeer had he pe folk to zeme 7015 Sib his two sones hem dide deme fol. $40 \mathrm{v} \cdot \mathrm{col} .1$ // Barach \& wip him delbora bo pei demed fourty zeer \& moo penne was oon sibile of libye And apollo wip his melodye 7020 Aftir coom Gedeon Pat worshepe in his tyme won Slouze fourty kyngis of hepen sede

Wip pre hundride of hys lede 7023

pen was oreb \& salmana 7025

Zeb and zebee pes opere twa

In tyme of pis Iudeon was

Bope orpheus \& ercules

//Tola ladde pe folk po

Lastyng fourty zeer \& mo

penne roos pe pridde sibila

pat men cleped delphica

Of troye \& grece pe batailes bolde

\footnotetext{
7004 thebas]thobas B.

7005 penne demestere]pe domysman B.

7006 zeere]zere pan B.

7010 her]his B.

7013 Sanygath]Sanytath B.

7015 Ten zeer]Syth B.

7016 hem dide]pey did hym L; did hym B.

7017 wip him]sith B.

7023-4 reversed in MSS GHTLB.

7024 kyngis]knyghtys B. sede]syde B.

7026 Zeb]Zele B. and]om $\mathbf{B}$.

7027 tyme]pe tyme B. pis]om B. was]lwis B.

7028 Bope orpheus] Was oleffernus B.

7030 \&]or L.

7033 pe]tho $L$. batailes]batayle $B$.
} 
Pis sibile myche tofore of tolde

Sir Iare was also long

Her maister \& ledere strong

In grece penne regned preamus

As be olde story tellep vs

In pis ilke iare tyme

Were lettres founden of latyne

// Iepte firste pei helde bastarde

Sipen he helde six zeer her warde

Zamazinis pat tyme bigon

pe wymmen lond wipouten mon

//Ezebon aftir seip be boke

Toke israel to lede \& loke

He ladde hem seuen 3 eer \& more

fol. $40 \mathrm{v}$ col. 2

Alisaundre in pat tyme pore

pat parys auzte rauysshed Elayn

Wherfore many men were slayn

7050

Pe ferpe sibile in pat sipe

In babiloyne bigan to ky pe

Achialon coom aftir hard

Her leder was \& her stiward

He had pat folk ten zeer to get

In his tyme was troye biset

// Labdon had hem vndir honde

And ouer hem was eizte zeer lastonde

In his tyme was troye nomen

And wip pe grekes ouercomen

pere mony modirsone was colde

As hit is in pe story tolde

pat werre lasted so long a pece

per was slayn of hem of grece

Eizte hundride sipe sixty \& ten

7034 tofore of]before B.

7036 Her]For L. ledere]leryd B.

7037 penne]po $B$.

7041 firste... helde]pey held fyrst B.

7042 her warde]forward $L$.

7044 pe... lond]pay wonde landys $B$.

7047 hem]om B.

7049 auztejaght pat B.

7050 were]was TL.

7053 coom]om L.

7055 zeerlom B.

7057 had]om B. vndir honde]vndirhold $\mathrm{L}$.

7060 pelom $\mathrm{L}$.

7061 colde]solde B.

7062 pe]om B.

7065 sipe... \&]tymes B. 
Of pousandis diuerse tyme of her men

Six hundride foure score six pousand

Men of troye fauzte for her land

Herof ben no men in were

For why pe sege lasted ten zere

7070

Wipouten brekyng of pat werre

pat greued bope nyze \& ferre

pat werre semed to be noon oper

But as pat oon half azeyn pat oper

And al pis world hap risen bene

7075

So was per mony cayser kene

But my $3^{\text {te }}$ pei neuer wynne pe toun

Til pei hit wan wip tresoun

And al pe chesoun of pis stryf

Was for rauysshyng of a wyf

7080

Al for fairhede of Elayn

Was pere so mony pousande slayn

// And sipen aftir pis labdon

Her domesman was sir sampson

pat was so strong \& so wizt

7085

Childeles was his modir mony ny $3^{t}$

In hir elde bi goddis grace

fol. $41 \mathrm{r} \mathrm{col} .1$

An aungel het hir childe in place

pat bi his heer shulde so my $3^{\text {ty }}$ be

As twenty men to fele \& se

7090

Vndir philistiens pei were

pat iewes were holden bo pere

Sampson souzte chesoun of stryf

Of philistiens he wolde haue wyf

Vpon a day he went \& sawe

A fair womman of hir lawe

He tolde his frendis soone anoon

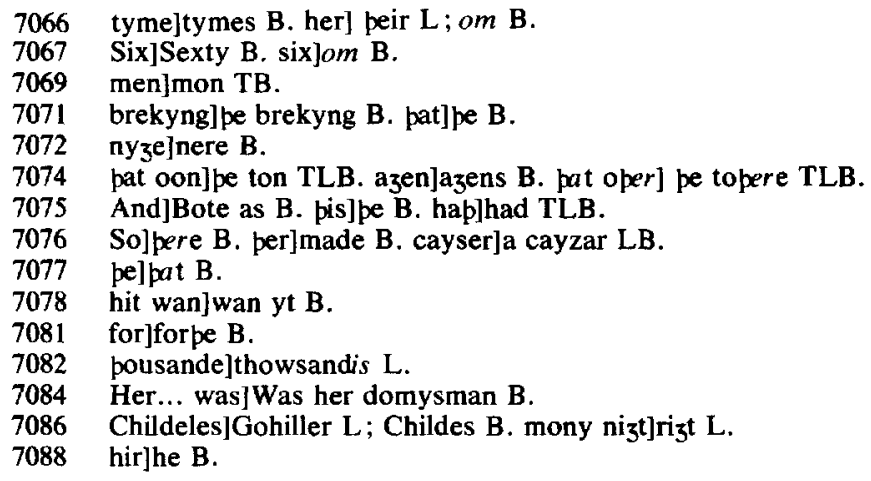


Pat he hade chosen siche a wommon

He toke hem wip him for to proue

Hir to gete to his bihoue

If hir frendis wolde him late

As he wente walkyng bi pe gate

A leouns whelpe ran ouer pwart

Raumpyng to sampson he start

//Sampson slouze pat leon kene

7105

Pe spirit of god in hym was sene

Whenne he hadde his eronde done

Homwarde he went also soone

But a litil fro pat gon

He wente to take his lemmon

As he went pat way azeyn

$\mathrm{He}$ fond in pe leon moup sleyn

A swarm of bees perynne were bred

And wip pe hony he hem fed

His wyues fadir \& modir fre

Of pis hony to ete zaf he

But not he made hem vndirstonde

How he pat hony fonde

At pe feest pere he was stad

A redeles vndo hym he bad

He hett men to 3 yue hem mede

zif pei coupe hit riztly rede

And pei to 3 yue pe same azeyn

If pei hit redde not certeyn

Of pe etyng pe mete out sprong

And pe swete out of pe strong

pis was al whenne pei souzte

pre dayes pei studied aboute nouzte

Po pei bisouzte his wyf pat sho

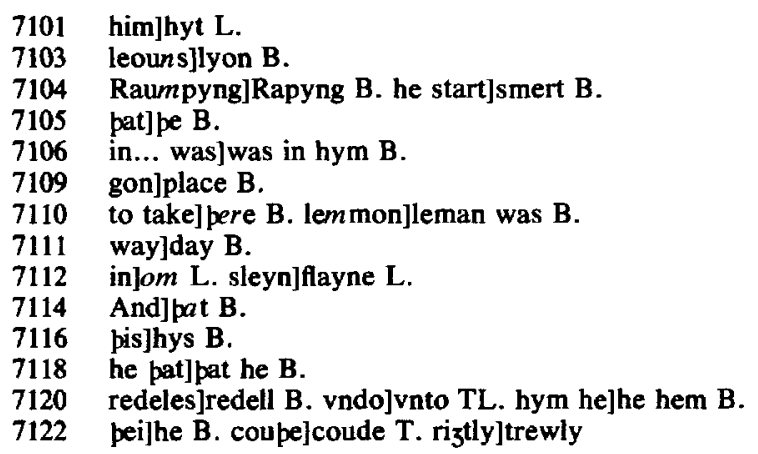


Shulde make hir lord to telle hit hir to

pat bruyd was of biddyng bolde

Sampson al pe sope hir tolde

And she to po pat were hir kid

Soone aftir hit vndid

And pat was a greet folye

Hir lordis counsel to discrye

Sampson for wrappe hir forsooke

And she anoper husbonde toke

Whenne sampson perof herde saye

Now he seide fro pis daye

Owe I to haue no maner wyte

Pouze I philistiens do despite

7150

Pre hundride foxes togider he knyt

I ne woot how he on hem hit

To her tailes fire he bond

And folwynge vche fox a brond

Into philistiens cuntre

7155

pourze pe felde he made hem fle

Whenne pei were ripe he let hem renne

And so her curnes dide he brenne

Her olyues wip her wyne trees

pes foxes brent wip her rees

7160

Pes philistiens wenten oute

And souzten sampson alle aboute

pe iewes were vndir her walde

Sampson bounden soone pei zalde

Po philistiens wipouten les

7165

Ran on sampson in a res

But sampson was ful smart

Out of her handes soone he start

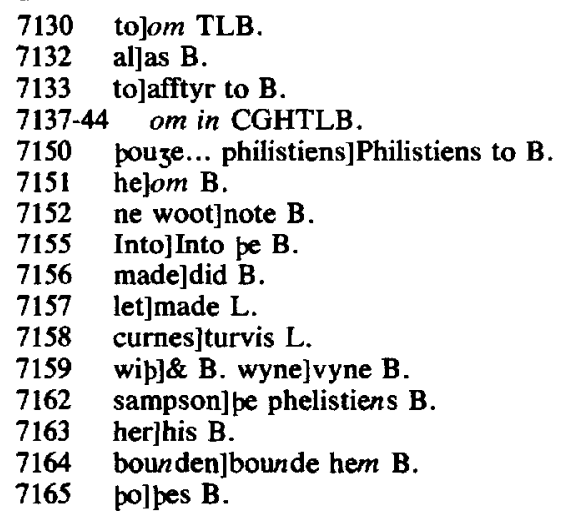


He zaf a breyd so fers \& fast

pat alle his bondes soone he brast

By chaunce he fonde an asse boon

Oper wepen had he noon

Of pat hepen folke he felde

A pousande by tale telde

Sipen he went into a toun

To a wyf bat was comoun

7175 fol. $41 v$ col. 1

Bisydis hir al nyzt he lay

pe philistiens herden say

pei bisett pi toun aboute

pat if sampson coom oute

7180

By nyzt or in be mornynge

To doolful deep pei wolde hym brynge

But sampson pat was so wizt

$\mathrm{Vp}$ he roos amydde pe nyzt

And bar be zatis of pe toun

And leyde hem on an hyze doun

Aftir he chees a wyf po

Dalidam him brouzte in wo

pe philistiens so ful of stryf

Bihet to dalidam his wyf

ziftis grete al for to frayn

Where were sampsons mayn

Longe she freyned hym pat bolde

And siche a gabbyng he hir tolde

Wip seuene senewes who so me bond

I lost my strengpe foot \& honde

His foos po she bad take kepe

$7169 \mathrm{He}]$ And B. breyd]bronde L.

7170 soone he]all to $B$.

7174 by]and mo by L. telde] I tellyd B.

7176 wyf]woman B.

7177 Bisydis]Besyde B.

7179 pi]pe TLB.

7181 in pe]be $B$.

7182 doolful]pe $B$. brynge]bry 3 L.

Butlzett B.

amydde... ny $3^{t}$ ]att mydnyght $B$.

an hyze]pe hight $B$.

him brouzte] which brozt hym $L$.

pe]po TL. solom B.

were]was TLB.

Longe]om B. pat]in pat L; long pat B.

And] pat $B$.

my]pe $B$. foot]by fote $B$.

pojom $\mathrm{B}$. 
And be while he was on slepe

Soone she his fomen calde

To do wip hym what pei walde

7200

Sampson waked of his nap

His bond dide he al to crak

Alle his bondis he brak in two

As pei had ben but a stro

But jit his wyf laft not pus

7205

pourze eggyng of his enemyus

Til she pe sope made him say

Wherynne al his strengpe lay

She seide leef telle me where

Hit is he seide in my here

7210

If hit were of I were not pon

No strenger pen anoper mon

Now hap sampson taken his lyf

In wille to welde to his wyf

Was neuer sampson eer in drede

7215 fol. $41 v$ col. 2

She had in hond his lyf \& dede

In hir wille hadde he bope done

pat shulde ben aftir sene soone

His firste wyf him lered wit

If he coude haue holden hit

pis oper wyf pat he had now

Auzte he not wel to trow

Soore shulde man drede pe brond

pat bifore hap brent his hond

And hard hit is to stond azeyn

7225

pe wif pat leuep not to freyn

7198 on slepe]aslepe $B$.

7202 bond... al]bondis al gan B. crak]knap L; clap B.

7203 he... in]brast on $B$.

7204 pei]it B. but]om B.

7206 enemyus]envious $B$.

7209 where]wheper $B$.

7211 I were]were bow $B$.

7212 Nolom B. mon]pan B.

7213 lyf]lyth $\mathrm{L}$.

7215 Was... eer]Sampson was neuer arst B.

7216 \&]in B.

7217 he]pey $B$.

7218 pat afftyr schall be sore sene $B$.

7219 lered]leuyd B.

7221 had]hath LB.

7222 helhym B.

7223 man]men $B$.

7226 leuepllyuep B. 
Pat ouper for loue or drede of awe Dop man his priuetees to shawe By dronkenes als may bityde Dop man his priuetees to vnhyde 7230 In fondyng ofte men fynde hit so Pryuyest to man is moost his foo Per is noon so myche may greue As traitour derne \& pryue peue And so dide dalida pen

Worpe hir worste of alle wymmen

Hir lordis counsel tolde sho

Hir lordis moost foos to

Hir tyme she tooke a leyser pere

And whil he slept kut his here

Wip hir sheeris wo worpe her hende

And to his foos hym bikende

Penne myzte pei do as pei had mynt

Pourze his here his myzt was tynt

pei dude hym wondir myche lope

7245

Beten hym \& prisound hym bope

Whenne he was done in prisoun

A mon of pat same nacyoun

Gat dalida his wyf to wedde

Sampson was to pe brydale ledde

For he was slyze of harp glew

By pat his heer was waxen new

By a piler was his sete

To myrbe men at her mete

Whenne pei were gladdest at pe feest

7227 loue... of]drede or love L. of]or B.

7228 man]men L; a man B. priuetees] counsayle B. tojom B.

7229 By]In B.

7230 man]hym $B$. vnhyde]be hyde $L$.

Pryuyest to]His preuyest B. to man]with men L. moost]ofte T. so... may] pat may so mochell $B$. traitour]wyffe and traytur B. \&]in L. pryuejom B. peue]tene $\mathrm{L}$. And... dide]Also $B$.

alle wymmen]any woman $B$.

Hir]Vnto her B. foos to]foo B.

kut]kyt of $B$.

wo]om $\mathbf{T}$.

To his lete wyttond $L$.

pei]he $B$.

wondir myche]moche wondir $\mathrm{L}$; mochell $\mathrm{B}$.

second hymjom B.

done]bound $L$.

7253

of]and L. glew]\& glow B.

his sete]he sett $B$. 
Sampson coude wel geest

Somdel waxen was his heer

pe post pat al pe hous vp beer

Wip bope his hondis he hit shook

So fast pat al pe hous quook

7260

pe hous he falde zaf no man grip

His foos he slowze himself perwip

Aftir sampson aldur nest

Was domesmon Ely pe prest

And pouze himself was clene of synne

For gult pat his sones were Inne

Whiche he wist \& chastised nouzt

Her synne on himself he brouzt

Whil he laft at home for elde

Pei went to fizte on pe felde

Slayn were pei pere in sake

And goddes hooly arke I take

Elye his horn panne brake bi chaunce

7277

God sent hit him for vengeaunce

pei made drede siche vncele

pat chastise not her childre wele

Ofte on fadir falle $p$ wrake

pat sent is for pe childer sake

Fourty zeer demed he israel

And aftir coom samuel

He was a selcoupe dou 3 ty ping

pe firste pat noynted mon to kyng

Prophete was sir samuele

Dere to god for he was lele

pe Iewis wip her mychel pride

Sent aftir hym on a tyde

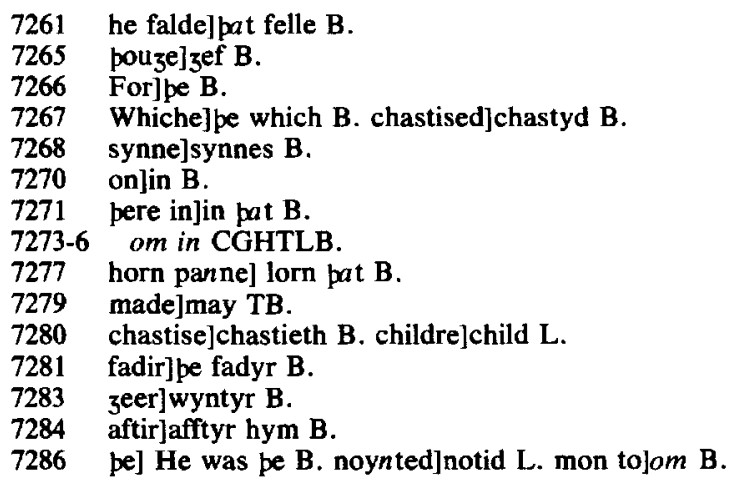


Lordyngis he seide seip me wher tille

Haue ze me fet what is zoure wille

Gete vs a kyng. What are ze wode

Haue ze not a kyng ful gode

pat fro zoure foos pourze see zow ledde

7295

And wip riche manna zow fedde

And mony werkis for zow hap wrouzt

Sir pei seide pou seist for nouzt

Gete vs a kyng pat may vs lede

As we se opere haue in dede

Parfay seide samuele

$z e$ are to frowarde wip to dele

Nouper are ze war ne wyse

For zoure richesse to hyze ze ryse

Now are $z$ e bope in rest \& pees

ze longe ful sore to haue males

Forsope I saye \& shal avow

Ful sore hit shal repente zow

Not zow allone but zoure ospryng

Shal rewe ful soore zoure zernyng

fol. $42 \mathrm{r}$ col. 2

7300

Hit is wel worpi pat who

May pole no wele pole wo

//Sore wepte samuel wip pis

To him coom oure lord of blis

pryes he calde on samuel

Lord he seide I here pe snel

My folk seide god ful frowardly

pei seche \& worche greet envy

pei aske anoper kyng pen me

Euelhele pe tyme shul pei se

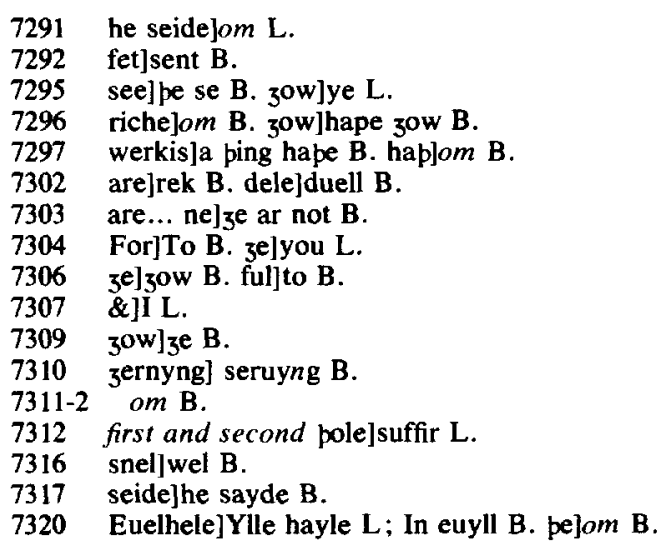


pat pei desire pei shul hit haue

To her owne heed a staue

Among pis folk shal pou fynde oon

pat saul is calde a stalworpe mon

Wip shulderes bope picke \& brade

7325

He shal her kyng be made

Sip pei haue pus forsaken me

He shal be souzte her kyng to be

//Soone bei dide saul be souzt

Founden \& forp was he brouzt

He was hyzer pan any man

By pe shuldres founden pan

pis saul haue bei made her kyng

Wip anoyntyng \& corounyng

Wroperhele to her bihoue

Soone on hem gon hit proue

penne was pere no lenger abyde

Men werred on hem on vche syde

So pat wipinne a twelmonpe stage

7330

pei were put out of her heritage

penne bigon bei to calle \& cryze

pat god on hem shulde haue mercye

And samuel pat wist her woo

Calde on god for hem also

God him bad fille his horn

Wip oyle \& wende forp biforn

Vnto a man pat hett iesse

In bedleem shal he founden be

pou shalt him fynde in bedleem

Seuen sones he hap to barnteem

fol. $42 \mathrm{v}$ col. 1

7340

Oon of hem make pou kyng

For saul dredep me no ping

perfore wip caytif and care

Out of pis world shal he fare

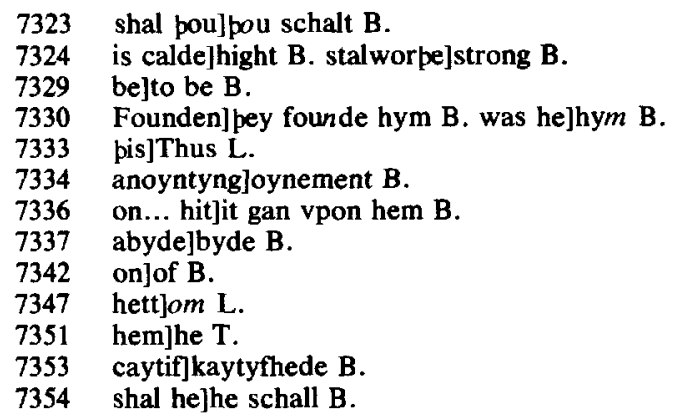


For or pat he be slayn in were

pe fend he shal in body bere

He shal hym trauail day \& nyzt

And lodly his body dizt

// Maffay lord seide samuel

I here not of pat lesse tel

7360

Nor his sones ny him I knowe

pe childes name ze me showe

zis he seide I shal pe kenne

Him to knowe by opere menne

In visage is he brizte \& clere

In reed of hew wip lawzynge chere

His fadir in alle hap sones seuen

pe zongest is he pat I neuene

Bope wys hende \& of good fame

Dauid he hette bi his name

And for pat he is war \& wys

I haue hym chose to pis seruyse

His seed forsope al bydene

Ouer alle men shal I mayntene

His foos shul not azein hym vaile

Him ne his shal I not faile

To be kyng not wol him dere

My benesoun shal he bere

// Samuel went sechyng pe lond

Til he pe hous of Iesse fond

Iesse hym resceyued feire

And samuel him called his heire

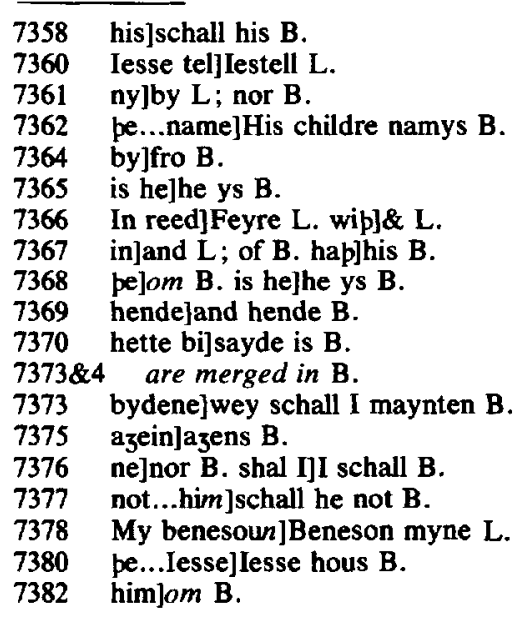


Comen he seide I am iesse

To se oon of pi sones [f]re

Sir he seide wip good entent

7385

zoure word is to me commaundement

His sixe sones pat were at home

Alle he called hem for by nome

But pe zongest was away

Samuel seide sir iesse say

Where is pyn alper zongest sone

$\mathrm{He}$ is he seide pere he is wone

Wip oure sheep vpon pe lowe

Do fet me him I wol him knowe

pei hym fett wip cheer ful swete

7395

He heilsed hendely pat prophete

He knewe him whenne he had biholde

$\mathrm{Bi}$ tokenyngis bifore of tolde

Anoynt he was wipouten abade

And kyng of po iewes made

But pouze he were anoyntide kyng

pe kyngdome to haue in gouernyng

He entermeted him of no ping in dede

But to his sheep azeyn he zede

Goddes goost in him was sent

Fro pen n fro saul hit was went

Dauid coude of dyuerse note

He coude myche of harpe bi rote

When ne he wip his gle wolde game

His sheep assemblede soone same

Of his menstralcy to here

7383 Comen] I am come B. I am]om B. iesse]of Iesse L.

7384 fre] $\mathrm{H}$ had orig. fre, emended to pre.

7390 say]nay $B$.

7392 is] was $B$.

7394 fet me] fech B.

7395 fullom B.

7396 He]And he B. hendely]om B.

7397 biholde]hym behold $B$.

7398 tokenyngis]tokenys LB. bifore of tolde]tofore Itolde]B.

7399 Anoynt]Anoyntyd B. abade] a lade L.

7400 po]the LB.

7401 anoyntide]noyntid TB.

7403 entermetedjentirmete L.

7405 in]to $B$.

7406 penn... saul]saule to hym B.

7408 He... of] Of croud michis B. bi]\& $B$.

7410 assemblede]semblyd B. soone]sope L. same]in same LB.

7411 menstralcy]menstalcy $T$. 
Mony were wont to drawe him nere

// Saul was zitt in stide of kyng

But he myzte do no gouernyng

pe fend was in his body fest

Wherfore he myzte haue no rest

penne seide pei alle what is to do

Of oure kyng pat hap no ro

He is euer out of witt \& wood

How shul we amende his mood

fol. $43 \mathrm{r}$ col. 1

$\mathrm{He}$ is ful of wickedhede

Wo is hym pat he shal lede

penne seide a good man of pat prom

And seide do we litel dauid com

Wip his harp bifore pe kyng

He shal him do to lauze \& synge

Whil he to him takep kepe

pe kyng he shal make to slepe

Forp dud pei dauid brynge

Harpyng a song bifore pe kynge

7420

He made him wip his melodye

Falle on slepe bat was werye

Operwhile wip harp sumtyme wip song

pus he serued pe kyng ful long

Pat euer when ne he was trauailed moost

pourze pat foule sory goost

If he bigon to harpe \& synge

Of his vnro he had restynge

7412 were wont]went L. him ]om L.

7415 in]of L.

7416 Wherfore] Where purgh $B$.

7419 \&]om B.

7420 shul]schuld B.

7421 wickedhede]wrechydhede B.

7422 he]hym B.

of... promjanon $L$.

And seide]om LB. com]to come $\mathrm{B}$.

shal]will B. do]make B.

pe kyng]om B. make to]hym make to fall on slepe B.

dud]do L. dud pei]pey did $B$.

Harpyng... song]He harpyd \& song B.

him]om B.

Falle]Hym falle B.

Operwhile]Somtyme B.

fuljom B.

pat]pe $B$.

he... to]pat he gan B.

vnro]travayle $\mathbf{B}$. 
Pat while coom philistiens in pore

Her feloun foos pat paynemes wore

Her hoost in al pat cuntre spred

pei wasted godes \& awey led

pei brouzte wip hem goly an eteyn

pat in foul hoordome was geteyn

Greet he was \& also hy

He semed sathanas vnsly

Bitwene his ezen pre fote he hade

Lopely was his visage made

Of body greet \& greynes long

Sternely semed he to be strong

Sixe ellen fully he was in hizt

Al redy armed for to fizte

Of his mete was mesure noon

Seuen sheep he wolde ete his oon

// He seide where is saul kyng

And I myzte ones wip him myng

Shulde he neuer bere no croune

I wolde him sle by seynt mahoune

Why comep he not or sent his sonde

Wip him I wolde my fors fonde

Ouper sende he to me hidur

A mon pat we may fizte togidur

Wheper oper ouercomep in felde

Pe topers folke al to him helde

A mon of his azeyn oon of ouris

If oure may wynne his in stouris

pat pei be ouris \& her heires

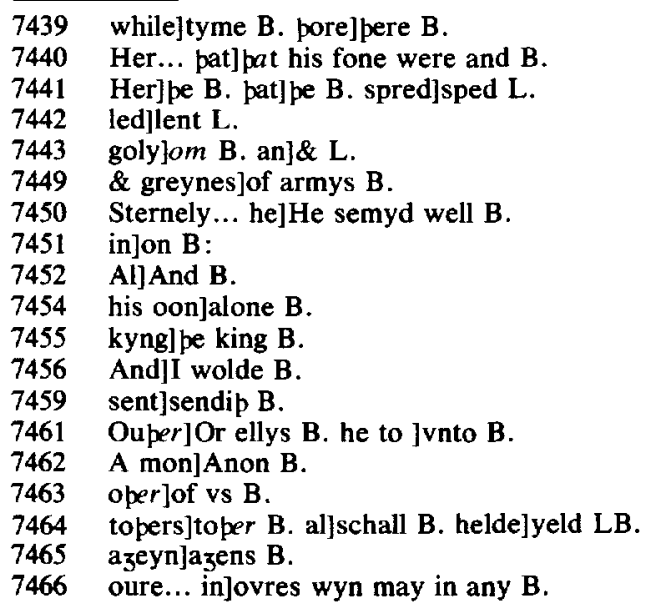


If pei wynne ouris we be peires

Here I byde myself redy

For to fizte for oure party

Vche day [h]e come in place

And batail bede wip siche manace

Euer when ne pe folk him sawe

Hem stode pen of him ful greet awe

Allas seide saul pe kyng pan

Where shal we fynde a man

pat dar pe bataile for my sake

Azeyn pis peof vndirtake

Whoso wolde fizte him azeyn

And him ouercome in bataile pleyn

He shulde be ryche al his lyue

And haue my douzter to his wyue

Dauid pis herde \& forp gan stonde

Sir he seide holde me couenonde

I trowe trewely in goddis myzt

7485

Pat I shal vndirtake pat fizt

Azeyn goly pat is so grym

Wip goddis grace sle shal I hym

Azeyn be zonder wrecched ping

Forsope haue I no drede sir kyng

7490

He tristep al in his owne hand

And $I$ in ihesu al weldand

//To dauid seide saul pe kyng

I drede perto pou art ful $3 y$ ng

Hit is a stalworpe batail wrizt

7468 ouris]vs B. we]they L. be]ar B.

7471 he]we $\mathrm{H}$.

7472 And]om L. bede]to byd L; bade B.

7474 Hem]They L; Off hym pey B. pen]om LB. of him]om B. ful]in L.

7475 be kyng]om $B$.

7476 a]swich a $B$.

7478 pis]be $B$.

7479 wolde]wille L.

7480 him ouercomejouercome hym B.

7481 al]and all $B$. lyue]kyn $B$.

7484 couenond]comenond $L$.

7485 injby $L$.

7486 second pat]pe $T$.

7487 Azeyn]Azens B. goly]Golias B.

7488 grace... I]help I schall sle $B$.

7489 Azeyn pe]Azens pat B. zonder]wondir L. wrecched] cursyd B.

7491 owne]om $\mathrm{B}$.

7492 ihesulgod TB.

7495

stalworpe]strong $B$. 
And pou lernedest neuer to fizt

If he pe sle as god forbede

Alle most we holde of hepen lede

What bote to lese pi lyf leue page

And aftir we do hem omage

Do wey he seide sir hit is no nede

pere god wol helpe par no man drede

Vpon a day my sheep I gette

A bere a lyoun bope I mette

I hadde no helpe but from aboue

of god pat lent me his loue

pei souzte me to rende \& ryue

I leide hond on hem ful blyue

I shook hem by pe berdes so

pat her chaules I wrast in two

Wipouten ouper swerde or knyf

Bope I refte hem hor lyf

He pat me pere pe maystrye zaue

May do me here hit to haue

Hit is not good leue sir kyng

pat mon in god haue mystrowyng

Go penne he seide in goddis grip

And god himseluen be pe wip

Goop he seide \& fecchep in hy

Myn armure to childe dauy

Helme haburioun on him pei dyde

And girde him wip a swerd amyde

Whenne dauid was armed so

Forp a fote my 3 te he not go

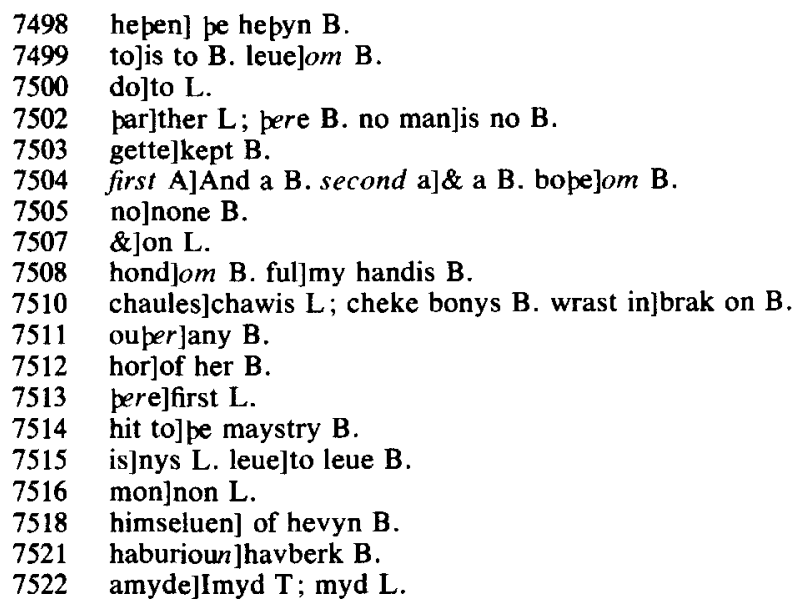


Nouper forp ny zit on bake

But stille stood as a stake

His armure fro him gon he swyng

And toke him but a staf slynge

Whiche he was wont to haue in honde

Aboute his flocke of sheep walkonde

He took fyue stoonys rounde

And put in his scripp pat stounde

Do wey he seide pis opere gere

For I kan noone armes bere

Wip my slynge I shal him felle

Go we pider wipouten dwelle

// Whenne dauid went for $\mathrm{p}$ in route

He saw pe folk pat were in doute

To make hem in hope bolde

pis resoun he hem tolde

fol. $43 \mathrm{v}$ col. 2

Why shulde men ben adred

pat are in riztwis batail sted

And who pat fiztep in pe wronge

Hit helpeth not him ful longe

Nouper may yren nor stele

Were monnes wrongfulnesse wele

God is euer on riztwis syde

Werryng azeyn wrongwis pryde

Perfore god wol for vs fizte

Wel ze woot we haue pe rizte

He vs helpe of his grace

Wip pat he went into place

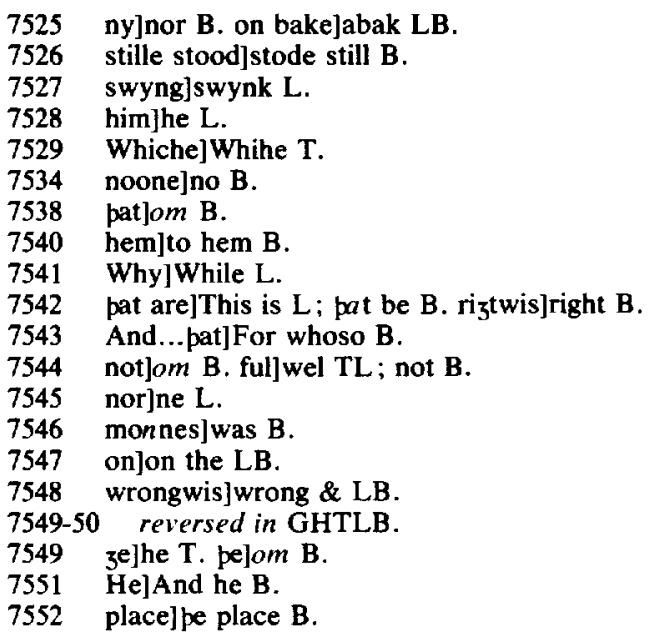


When ne golias on him biheld

Litil he set bi him in feld

But helde hym al in despit

And pus bigan him to flite

Sey wenes pou an hound I be

And wip bi stoon to stone me

Come for $p$ fast wipouten abade

pi flesshe shal foulis fode be made

// Dauid seide if god wol nay

In god I haue fest al my fay

Armed comest pou me azeyn

And I azeyn pe al pleyn

I come azeyn pe in his name

7565

Pat pou hast don despite \& shame

Hym hast pou \& his in despit

Wip his grace I shal hit pe quyt

pi body shal I zyue to zift

To ete be foulis of pe lift

pat alle may wite pat god of myzt

Sauep not mon in wanhope pizt

But fully to trowe in him stidfaste

And stabel in his lawe to laste

// Penne seide goly pou art but dede

Dauid seide god be my rede

Goly seide wolt pou fizte wip me

I rede bityme pou hepen fle

Fle pat wenep haue pe werre

For ar I fle I shal come nerre

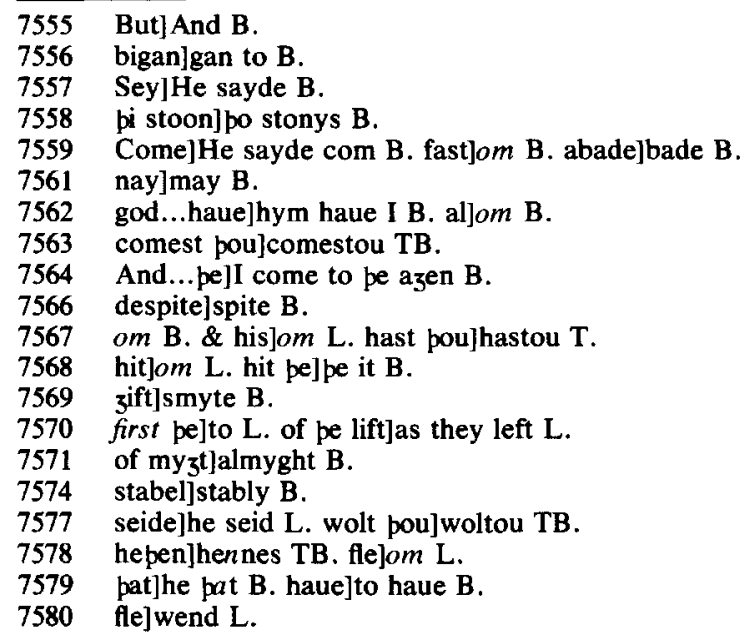


Anoon a stoon he leide in slynge

So myztyly he lete hit swynge

pat in his frount pe stoon he fest

pat bope his yzen out pei brest

Anoon he fel was no ferly

And out his swerd drouze dauy

And heded him wip his owne brond

And brouzte pe kyng to presond

po sarazines pere bisyde

Fledde alle \& durst not abyde

pere were mony felde to grounde

7590

And mony fled wip depes wounde

// Dauid went hoom wip greet honoure

Alle panked god her creatoure

Miche he was soop to say

Loued and drad fro pat day

Pore and ryche zonge \& olde

Loued him alle mony folde

To ierusalem pe heed bar pey

pere daunsed wymmen bi pe wey

7600

In her daunse pis was pe song

pat pei for ioye seide among

Saul hap smyten a pousond

Ten pousond smyten in dauid hond

For pis word was saul wroop

And ofte bope breme and loop

Haue I a pousonde felde how so

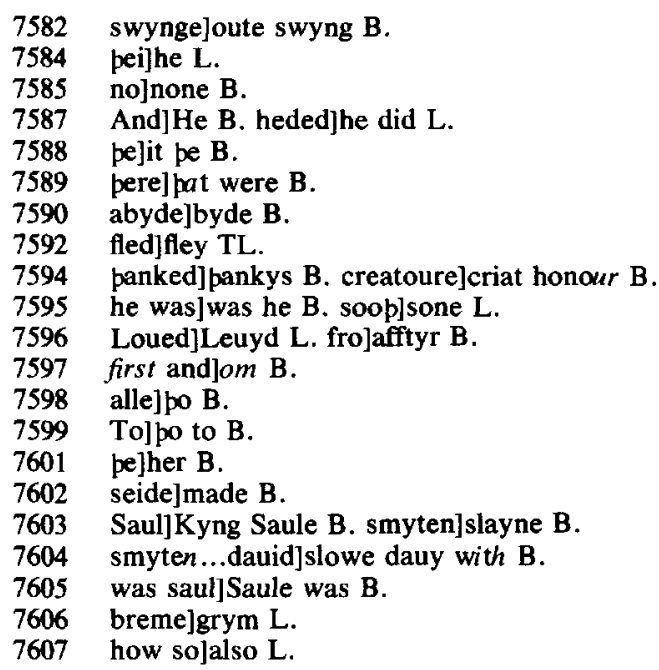


And dauid ten pousonde \& mo

$\mathrm{Bi}$ pis is hym nouzt wone

But $p a t$ he is not kyng allone

For loos pat dauid won pat sipe

Wolde neuer saul loke on him blipe

He hated him as his foo

Fro penne he wayted him to slo

Ofte be pei quyt pis wyse

pat done to liper lord seruyse

pat oper day aftirwarde

pe fend trauailed saul harde

As he was wont bigon to rage

fol. $44 \mathrm{r}$ col. 2

And as dauid cam him to swage

pe kyng smoot to him wip a spere

In tene he wolde him pourze bere And pourze he had his body born

Ne hadde he blenched him biforn

Away boo drouze him soone dauy

But saul dredde him not forpy

Of a pousande men bi tale

He made him ledere \& marchale

He pouzte pus in his mood

pat I him sle hit is not good

But I shal lete hym allone

Philistiens shul ben his bone

$\mathrm{He}$ asked dauid if he wolde

His douzter wedde to haue \& holde

In pat couenaunt for to brynge

An hundride hedes to pe kynge

Of pat folk of hepen dede

Dauid went forp good spede

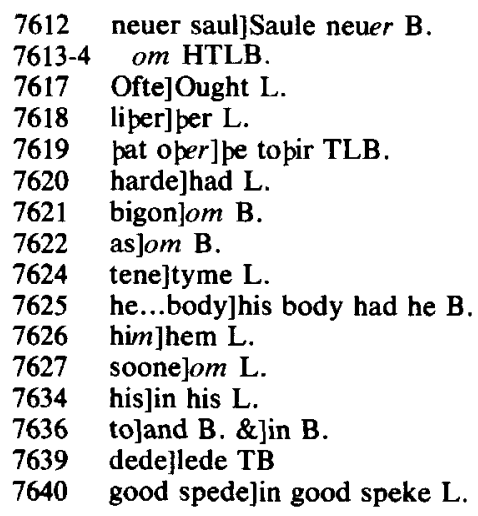


Wip pat folk soone he mett

And wiztly wan of hem pe bet

A $_{3}$ yn pat hundride pat saul sou ${ }_{3}$

Dauid to him pe double brouzt

pe kyng him zaf his douzter anoon

pat het michol a fair wommon

pe kingis sone het ionathas

To dauid trewe frend he was

pe kyng bad whoso myzt go

Dauid his sone in lawe to slo

7650

As his foo him to seche

Ionathas was not payed of pat speche

He preyed bope day \& ny $z^{t}$

To make pe kyng \& david lizt

Bifore be kyng pei dauid brouzt

But aftir soone was al for nouzt

Soone aftir batail roos

And dauid went azeyn his foos

pis bataile was harde ynouze

And dauid of his foos fast slouze

7660

Mony a mon fel vndir sheeld

fol. $44 \mathrm{v}$ col. 1

But wip dauid lafte pe feld

And efte pe fend ful of greef

Trauailed pe kyng to myscheef

And dauid harped wip his harp

7665

pe kyng hent a spere sharp

To smyte him pourze into pe wowze

Dauid blenched in litil prowe

Into his hous pen dauid fled

But ar be kyng wolde go to bed

7670

He sett his men be hous aboute

To wayte at morwe when he coom oute

To sle him if he myzte be mette

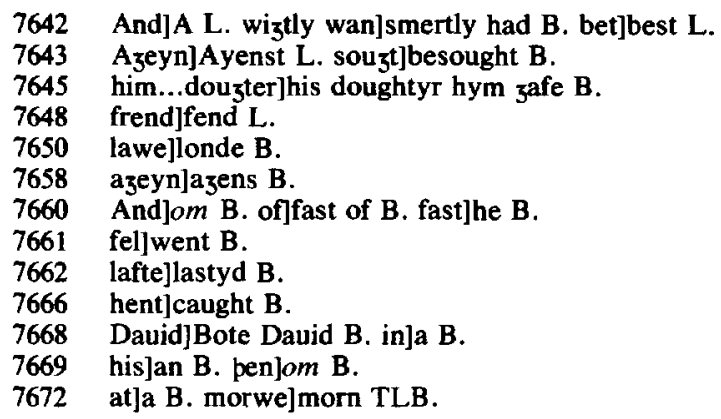


But his wyf by nyzt him out lette

Out at a pryue posterne

He fledde to samuel ful zerne

pat in ramatha was dwellyng

Soone hit was tolde to pe kyng

penne his messangers he sende

To rauysshe dauid wel he wende

7680

But perto myzte pei neuer wyn

For company pat he was yn

And goddis grace pat him was wip

Saued him euer in good grip

Among his kyn in pryuyte

7685

As outlawe po woned he

//Saul souzte ofte here \& pere

Dauid as his foo he were

He wiste if he to lyf my 3 t stonde

He shulde be kyng of his londe

And bo childer of saules sede

Shulde be out dryuen for nede

Perfore he hett hem ziftis ryf

pat my $z^{\text {te }}$ brynge dauid of lyf

In felde \& toun frippe \& felle

Saul souzte dauid to quelle

Often fel so be chaunce

Was pere but goddis desturbaunce

7700

Dauid pat was mylde of mood

Dide euer azeynes euel pe good

Ofte he my 3 te saul haue take

And slayn hym in his owne sake

For fro pe kyngis owne bed

pus he brouzte a pryue wed

On a tyme whenne saul him souzt

Wip al pe my $3^{\text {te }}$ pat he mouzt

He sett his tentis in a dale

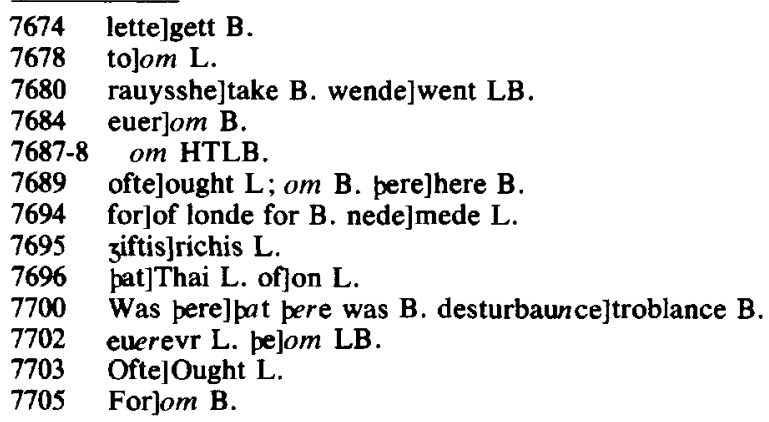


Perof to dauid coom pe tale 7710

Whenne hit was nyzt cald dauy

Of his men ful pryuely

Wip him allone stille pei went

To pe kyngis owne tent

Hymself \& his folk pei fonde

7715

In her beddes fast sleponde

pe squyere hizt Abisay

pat to pe tent coom wip dauy

Sir he seide bi leue of $3^{\circ} \mathrm{W}$

I shal hym sle liztly now

7720

pourze his body I shal him smyte

pat euer of hym shul we be quyte

Dauid seide god hit forbede

Pe to benke to do pat dede

Or euer him do despite or shame

7725

pat noyntide is in goddis name

Of al pat ilke kyngis gere

He took but a coupe \& spere

No more brouzte he wip him oute

Whenne alle slepte him aboute

7730

He zeode til noon my 3 te him dere

Pus he cryed to pat here

How haue $z^{e}$ kepte zoure kyng seide he

His coupe his spere where may hit be

pat bope were set at his heued

7735

Where be pei now bileued

Whenne saul herde pat cry

Is pat he seyde my sone dauy

Dauid seyde I was pore

Why sekest pou me \& wherfore

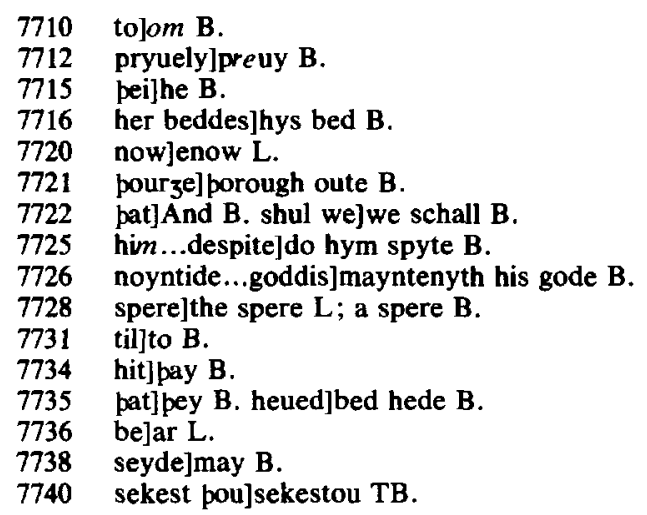


Now pat pou be aknowen

Why sekest pou me \& I am pyn owen

Saul seyde wipouten wene

fol. 45 r col. 1

pe mys is myn wel is sene

Here I leue pe kyngis gleyue

Sendep a man hit to receyue

He pat al riztep wipouten roos

Wol vche mon zelde aftir he doos

//Soone aftir not ful long

Coom batail vpon saul strong

7750

pe saresines hym vmbeset

In harde shour togider pei met

So sharpe was pat shour \& snel

Alle fled pe folk of israel

pere pei fel pat my $z^{t}$ not fle

On pe mounte of gelboe

pe douzty childer pere were sleyn pan

pe kyngis sones \& Ionathan

Of pis batail pat was so snel

pe wors on kyng saul fel

7760

Mony a goode archer pore

Woundide pe kyng himseluen soore

pe kyng seide to his squyere

Drawe pi swerd \& sle me here

Ar I in pis place be ouergone

And wip sarazines hondis slone

pe squyere dude not as he bad

For he was ful soore drad

Saul himself drouze his sworde

And ran euen vpon pe orde

When ne his squyere say him dede

7742 sekest poujsekestou TB. \&]om B. I]om TL.

7744 wel]wece $\mathrm{L}$.

7745 leue]beleue B. gleyue]glebe L.

7748 vche mon]echon $\mathrm{L}$.

7750 vpon]on $B$.

7751 hym]all hym B. vmbeset]were byset L; besett B.

7753 pat]pe B.

7757 pere were]was B.

7758 sones]son B. \& jof $\mathrm{L}$; om $\mathrm{B}$.

7759 pis]pat $\mathrm{B}$.

7760 on]om B. fel]befelle B.

7762 pe...soore]hymselffe pe king pore $B$.

7764 Drawe]Drawe oute B.

7766 sarazines]pe sarsyns B.

7768 drad]adrad $B$.

7770 euen vpon]hymselffe on B. orde]word L. 
He dude himself pat same rede

Vpon his owne sword he ron And dyzed wip his lorde pon

A mournynge day most pat be 7775

Of saul \& his sones pre

And his folke pat were so kene

Now are slayn alle bydene

// pe sarazines on pat oper day

Fond where saulis body lay

pe heed pei smoot of of pat kyng

And sende pe body for to hyng

His men coom bi ny $3^{\text {turtale }}$

fol. $45 \mathrm{r}$ col. 2

Wip hem away his body stale

Pryuely pei dude hit hyde

And dalf hit in a wode syde

Fourty wyntur was he kyng

Now haue ze herde his endyng

penne was dauid comen azayn

Fro amalec pat he had slayn

7790

pat was a strong philistiene

Dauid had zyuen him batel kene

By goddes grace pe felde he wan

Of saul hoost he mett a man

Bifore dauid to fote he felle

7995

Whennes comes pou anoon pou telle

Fro be folke of israele

I com to telle tipingis lele

Pei are discoumfite in pat plas

Saul is slayn and Ionathas

Ar pei bope slayn wherby

Woost pou pat sayde dauy

Bi chaunce he seide I coom rennonde

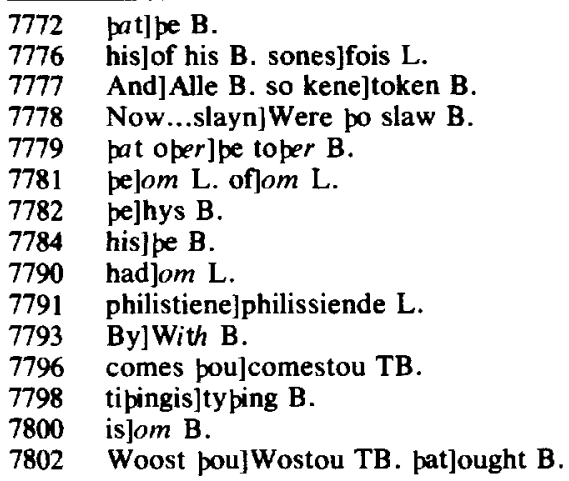


On mounte Gelboe \& fonde

Saul lenynge on his spere 7805

Woundide wip pe sarsynes here

He me bisouzte whenne I him sawe

pat I shulde brynge him of dawe

pourze his body my sword I reef

His hert in two I woot I cleef

7810

I wiste no lenger lyue he my ${ }^{t}$

Lo here his coroune brizt

He wende wel for his typing

To haue payed dauid pe kyng

perwip payed he not dauy

7815

pat shulde he soone dere aby

// Dauid for pis ilke disport

Was he neuer of wors coumfort

He wrong his hondis \& his men alle

pat goddes folk shulde so mysfalle

pei wept pat day til hit was goon

pan spak dauid to pat mon

Why dreddest pou not god he seide

Whenne pou hondis on saul leide

For to do despite or shome

pat noyntide was in goddes nome

Out of my sizt ze lede hym soone

To deolful deep pat he be done

pat fouler dep may no mon dryue

So alle may knowe mon \& wyue

pat whoso leip hond in felony

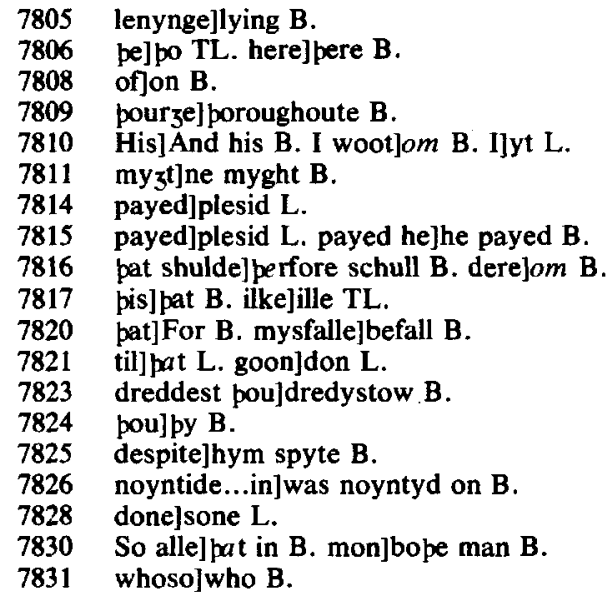


On kyng or seip him tricchery Or ellis him waitep wip despite And may not her of him quyte By doom of fuyr wipouten grip

He dize if he bitake perwip

// Pe pridde elde now is past

perof pis saul was be last

pat elde bygan at abrahame

And endep here in goddes name

Nyne hundride zeer fourty \& two

Hit lasted hit is writen so

Foure pousande six skore \& foure told

Was pis world pat tyme olde

Bytwene abraham \& kyng dauy

Herkene now pe genealogy

Abraham in lawe so lele

pat fadir was of folk so fele

Ysaac his sone in spousaile was

Of him iacob of hym Iudas

Of him phares of him Esrom

Vchone of pese of opere coom

Of whiche aaron wipouten gabbe

Of him coom amynadabbe

Of amynadab coom nason

Of nason coom salmon

Of hym coom boz of him obeth

Of hym iesse pis elde is eth

Firste fro abraham to taste

And so to iesse pe laste

7832 or...him]in any $B$.

7833 himlpat B. wiplin B.

7834 And]pat B. her...him]hym hereof B.

7835 By doom]Bodon B. grip]grefe L.

7836 He dize]pe depe B. perwib]wip B.

7838 pis]om $\mathrm{B}$.

7839 at] of L.

7841 zeer]om B.

7842 lasted]laste $B$.

7843 six]four $B$.

7844 pis]pe $B$.

7846 Herkene]Here B.

7847 so]to B.

7848 sojom B.

7850 iacob]com Iacob B.

7854 him]hem L.

7857 coom boz]cay boye L. obeth]com obeth B.

7858 is eth]sepe B.

7859 Firstelpe fyrst B. taste]cast B. 
Here bigynneb witterly

pe ferpe elde at kyng dauy

Saul is slayn pat sorweful kyng

fol. $45 \mathrm{v}$ col. 2

In his stude dauid douzty ping

pei set a septure in his hond

pat men calle pe kyngis wond

Alle honourid him wip hailsyng

7865

Heil be pou lord dauid oure kyng

Saf \& sounde euer mot pou be

Whil pe folk is vndir be

Dauid was a ful wyse mon

Riztwisly he regned pon

Fro pat he was kyng in londe

Was noon durst his word wipstonde

Fair a courte wip him he ledde

His folk bope him loued \& dredde

He nadde regned but a stounde

7875

Whenne he an hous bigon to founde

A myche tour longe \& brade

In ierusalem he let be made

But be [w]iliest of wynne

Ryuely ofte pei falle in synne

Dauid pat many had in wone

Raft hym his wyf pat had but one

He hadde a douzty kny $3^{t}$ of fame

His wyf barsabe by name

Alas she was fair \& brizt

7885

pe kyng cast ones on hir sizt

He asked what was pat lady

zoure kny ztis $^{\text {wyf }}$ pei seide vry

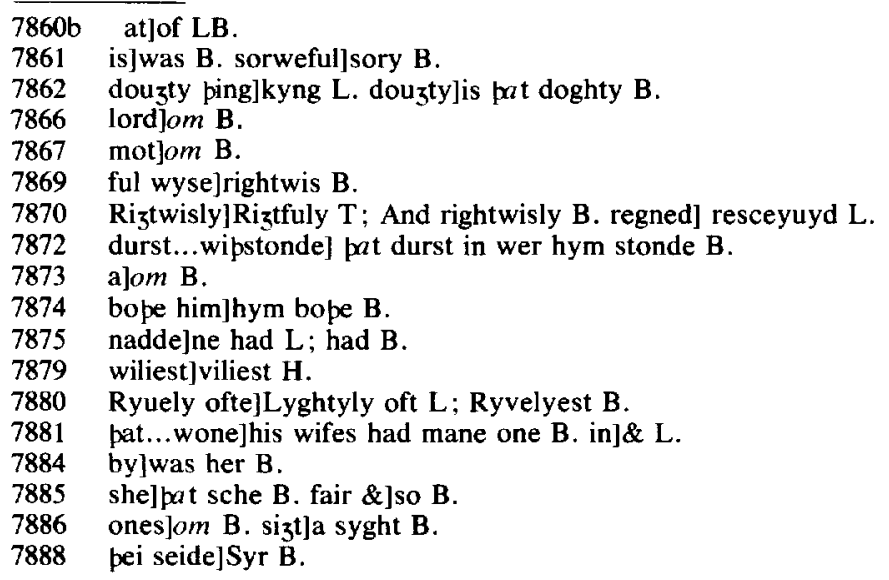


pat vry po was not pare

In kyngis hoost was he forp fare 7890

Whil pis knyzt was away

pe kyng bi pat lady lay

pe lady was wip childe in hye

pe kyng sende po to fette vrye

Whenne vry coom wipouten wite

7895

pe kyng lete soone lettris wryte

And toke hem vry for to bere po

To his marchal of his hoost so

Wip biddyng he hym bisouzt

pat vrye pat po lettres brouzt

Into bataile so shulde be led

7900

pat he shulde soone be deed

fol. $46 \mathrm{r}$ col. 1

Vrye po lettres took \& bare

But he wiste not what pei ware

pe kyngis commaundement was done

7905

Slayn he was in bataile soone

7906

When ne vry was pus brouzte of lyue

7909

Dauid took barsabe to wyue

7910

And hulde hir in his hous fro pan

Til oure lord seide to natan

Go to dauid kyng an say

He hap mysdone azeyn my lay

penne coom pat prophete to pe kyng

7915

And seide him pis in tokenyng

Tweye men were late in londe

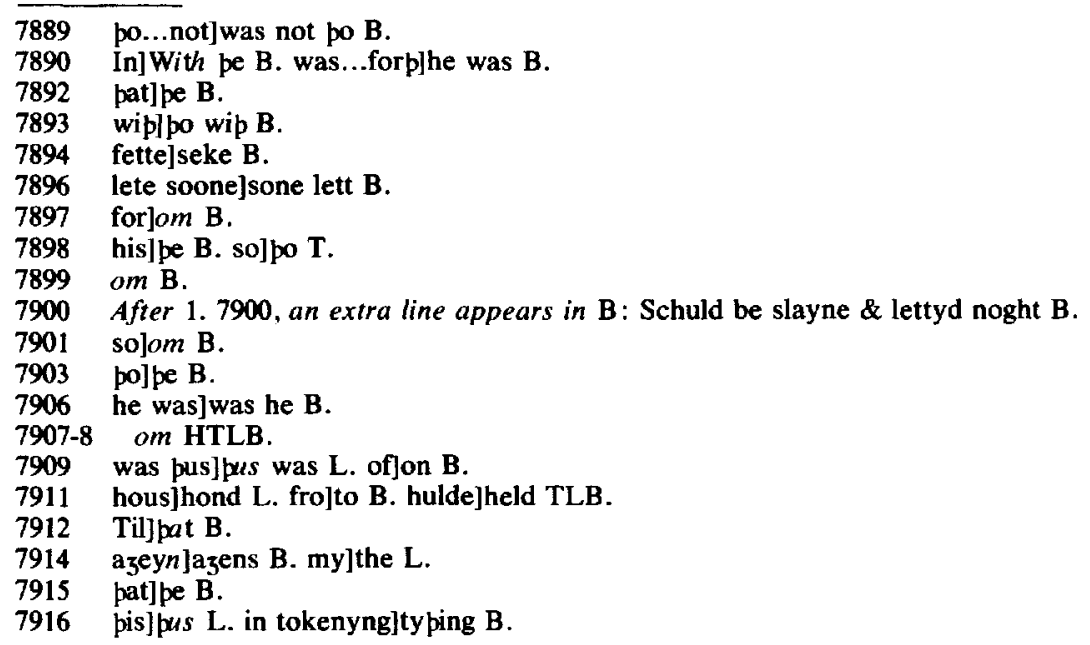


A pore \& a ryche wononde [Pe] riche hadde mychel fe

Of alle godis greet plente 7920

Of welpe he hadde myche wone

pe pore hadde no sheep but one

pat he had wip his siluer bouzt

And fro a lamb hit vp brouzt

pe riche man wip euel hert

7925

To a gest coom ouerpwert

For to spare his owne auzt

pe pore monnes sheep he lauzt

To his mete dide hit be slone

Of his pat nadde but pat one

pe man pat hap done siche dede

7930

Sir kyng what shulde be his mede

Of pis tale pe kyng was wroop

By god on lyue he sweer his oop

pat man he seide is ful of quede

And shal by rizte suffere dede

Sone he seide take good gome

3yuen pou hast pyn owne doome

God made pe kyng of israel

To lede pe folk in lawes wel

pou shuldest han holde be lawe in stede

And hast broken pe lawe pat he forbede

Slayn pou hast pi knyzt vry

And taken his wyf \& layn hir by

of god himself stood pou noon awe

Perfore I coom pe to shawe

pat pi hous he sendep pe word

Shal neuer twynned be fro sword

7918 pore]riche $B$. ryche]pore $B$.

7919 pe]om H.

7921 welbe]sheep TLB.

7924 fro]fre B. vplout L.

7928 monnes]mennys L. lauzt]caght B.

7930 nadde]ne had L; had B. pat]om B.

7931 siche]pis $B$.

7932 shulde]schall B.

7933 Of...kyngl be king with pis tale B.

7934 on lyue]alyve L. sweer]swore L.

7936 And shal]Schuld B.

7940 folk in]folkes in his B.

7943 pi]pat B.

7944 \&...by]in avowtry B.

7945 pou]pe B.

7946 pe...shawe]to do be knawe B. 
Reyse euel he shal on pe ful kene

And pus he seip pe bidene

pi wyues bat pou hast alle

Be zyuen to opere men shalle

pi synne pat pou in priuyte did

Byfore folk hit shal be kid

Synned I haue seide dauid pan

7955

pat is soop seide nathan

perfore shal pou not dy ze I wate

For god hap het pe transolate

pou shalt wite I shal not lye

pe sone of barsabe shal dye

Dauid gat $3^{\text {it a son ponne }}$

pat wyse was \& het salomonne

Whenne dauid knewe his cost of care

Rewed him neuer ping so sare

In tokene bat he rewed his sake

7965

An orisoun soone gon he make

pat het miserere mei deus

Hem owe to say hit pat synnes rewes

Of alle pe salmes of pe sautere

pis salme for penaunce hap no pere

Dauid regned kyng pore

Wyntres twelue or ellis more

Not wipouten stryf \& fizt

zitt helde he wel his owne rizt

Oure lord hym shewed a sizt to say

A ny 3 t as he in bed lay

He pouzte on pe philistiens

pat had hym done mony tenes

Pat souzte his folke to brynge to grounde

Gladly wolde he hem confounde

To make hem sore for him to gryse

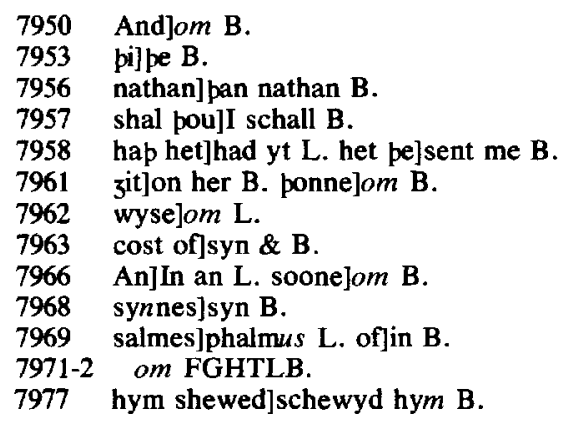


He him bipouzte on what wyse

He him bitauzte to god to kepe

7985 fol. $46 \mathrm{v}$ col. 1

Blessed him \& fel on slepe

penne coom an aungel clere

Was goddes owne messangere

And louesomly to dauid spake

Of sleep dauid now I be wake

7990

Comen am I be to counsaile

Folewe hit \& hit shal pe availe

Sir god pe chees kyng of kip

His hert hap euer ben pe wip

He bidde $p$ pe wende anoone

7995

pat pou passe flum iurdone

Into pat ilke stide pou pase

Where moyses hym doluen wase

pe stide woot no mon but himselue

Oure lord pat pere hym gon delue

8000

A relyk shal pou fynde pere dere

In al pe world is not pe pere

Bitwene erpe and pe lift

May no man zyue a riccher zifte

pou shalt fynde pre zerdes pere

8005

pat moyses ofte wip hem bere

Of cyder palme \& of cypres

Pere were pei sett by moyses

Out of a stide pat hett helym

pider brouzte he hem wip him

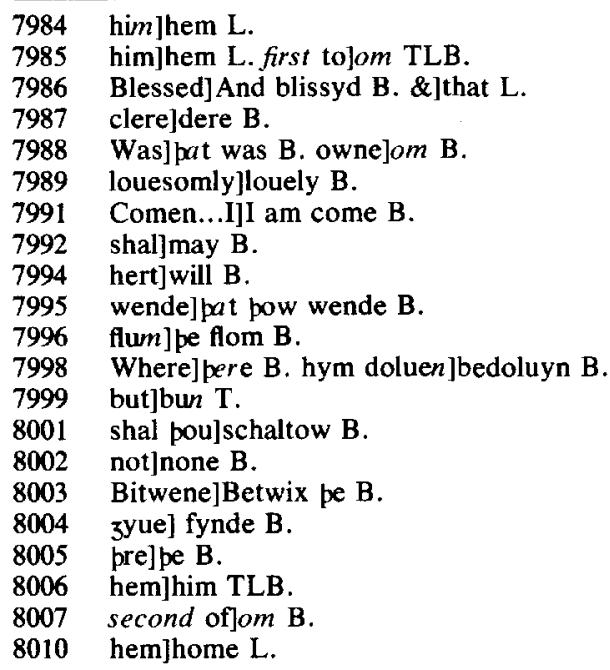


Is no mon forsope con say

Of how greet vertu \& grace are pay

No mannes tunge may telle ny mele

What pei shul bere of soulis hele

Of hem shalt pou haue greet vauntage

To pe and to pi baronage

Whoso restep him vndir pat shadowe

May no ping him cumber nowe

Haue good day now wende I

Geder pyn hoost togider in hy

// Whenne dauid had pis counsel herde

8020

To geder his hoost soone he ferde

He past pe flum his hoost him wip

And wenten hem pourze felde \& frip

Til he was comen into pat place

8025 fol. $46 \mathrm{v}$ col. 2

pat him was beden go to bi grace

He fonde pe zerdes po he coom pere

Eth was to know whiche pei were

He knew hem at pe firste sizt

pe pre were alle of oon hizt

8030

Of o likenes pouze pei were sere

Passed was a pousande zere

Sip pei were set in pat place

And euer grene in goddis grace

Togider pei were in grounde knytt

On o stok pe sope is hit

pe stok was on pat po stode vndir

But be croppes were alle sondir

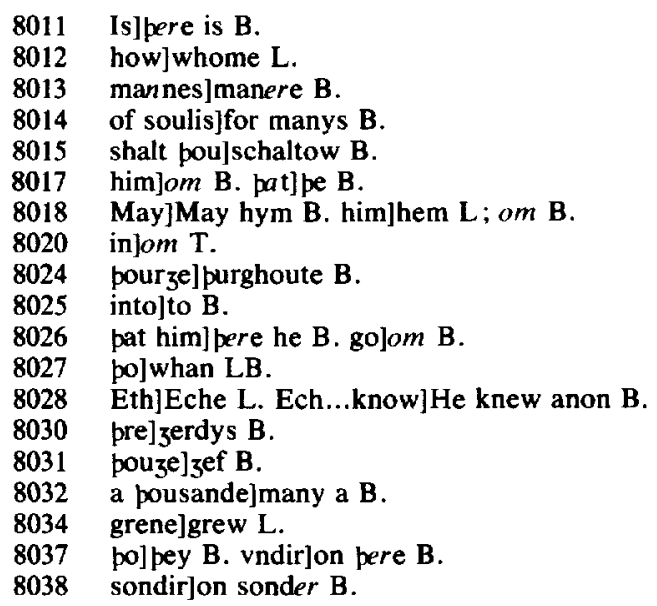


By fruyt \& leef my $3^{t}$ men se

Of what kynde was vche tre

Whenne pe kyng coom nyze po trees

He kist hem crepyng on his knees

He drouze hem vp softe ynouze

Wipouten brekyng any bouze

Whenne pe kyng had hem vp twizt

8045

His hoost honoured hem wip rizt

pe kyng held hem vp to se

A leem shone of po zerdis pre

pat al his hoost my $3^{t}$ se euene

How hit rauzt vp to heuene

8050

penne bicoom pat folke ful blype

For fond pei neuer fro pat sipe

Mon nor beest pat pei met

Pat my $3^{\text {te }}$ hem of her weye let

A riche man woned bi her wey

Was seke \& to him turned pey

He hadde ben seke mony a day

Wipouten helpe of hele he lay

His folk wipouten stille abade

To se pat seke a turne he made

8060

I[n] sekenes sore he fond him stad

Of pe kyng he was ful glad

When ne he bigon bo zerdis to se

On hem he wept for greet pite

Penne was he hool \& sounde in hye

pe swote smel rauzte to pe skye

Wip pe kyng he zeode away

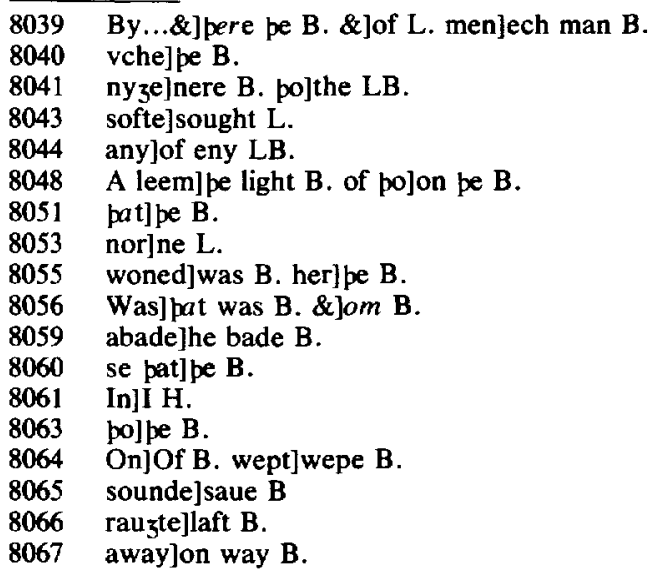


And tauzte hem god \& good day

Faire was pat processioun

pere was many a bolde baroun

8070

As pei wente pe hyze strete

Sarazines foure pe kyng can mete

Blak \& blo as leed pei were

Miche richesse wip hem pei bere

Men say neuer bifore pat houre

8075

So frowarde shapen creatoure

Of her blac hewe was selcoupe

In her brestis pei bare her moupe

Longe \& syde her browes weren

And rauzt al aboute her eren

8080

In her forhede was her sizt

8083

Loke myzt pei not vprizt

Her armes hery wip blak hyde

8085

Her elbowes were set in her syde

Crompled knees \& bouche on bak

pe kyng wondride on hem \& spak

Whenne hem bihelde pe kyngis oost

pei lowzen alle leste and moost

8090

On her knees pei hem sett

And hendely pe kyng pei gret

To pe kyng seide pay

Saaf be pou sir now \& ay

What pou berest lat vs se

8095

To fonde if goddis wille hit be

Shewe vs pe sauyng tre sir kyng

For wel woot we wipouten lesyng

Peyne on pat tre suffere he shal

pe kyng of blis for his folk al

Shewe vs pe tre out of were

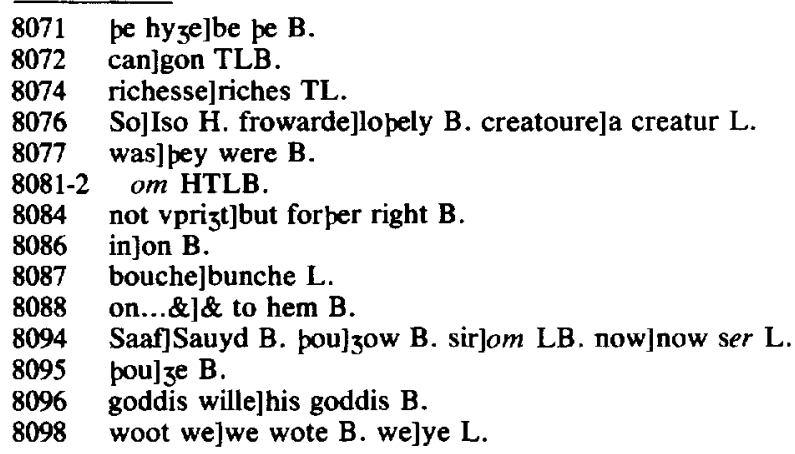


Perfore are we comen here

Byholden vs ynouze hastou

Oure froward shap pou seest now

Ful lopely are we but also loope

Is euel mannes soule \& body bope

pes zerdes pre wipynne her roote

fol. $47 \mathrm{r}$ col. 2

Azeyne alle eueles are bote

pei shul vs zelde bifore pi sizt

Feirenes bi grace of god almy 3

Of hem shal ryse oure raunsoun

And of alle oure synnes pardoun

To hem pat mercy for her synne

Cryep to ihesu of dauid kynne

pe myzte of hem sir lete vs proue

Wip pat be kyng took of his gloue

po braunchis of so mychel blis

He helde hem to hem for to kis

pei kneled \& kist hem also tite

Als soone her hyde bicoom white

And of pe fre blood had bei pe hew

Al her shap was turned new

Of mankynde hadde pei pe met

In rizt kynde were pei set

Bifore pe kyng penne fel pei doun

And maden vchone her orisoun

Pei wepte \& panked god of myzt

Al pat folk pat say pat sizt

Pe richesse pat pei wip hem ladde

pei offered pat pat pei hadde

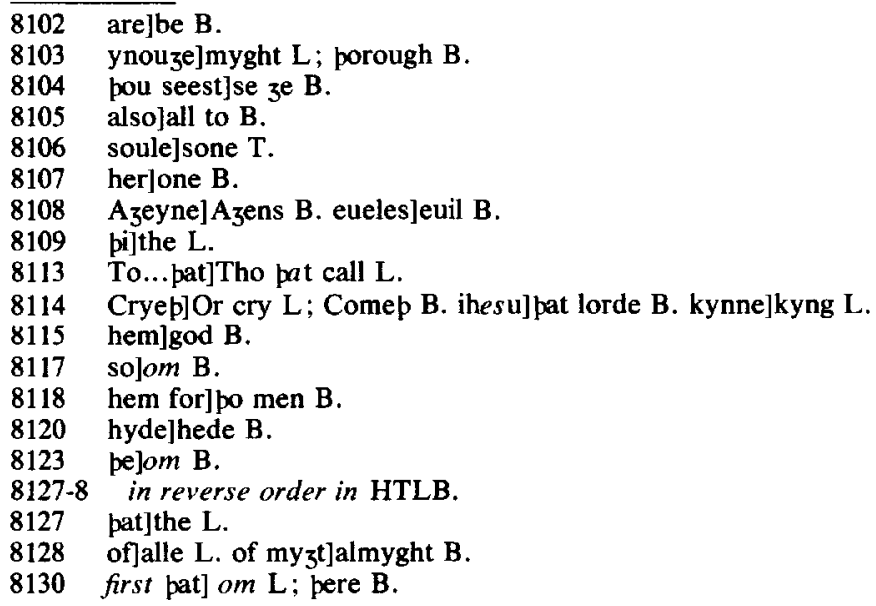


Hemself azeyn pei toke pe sty And wenten hoom to ethyopy

pe kyng went forp pourz a feld Toward a felle bi a doun helde An heremite per fond pei at hoome

In pat mounteyne was halt \& lome

Mychel had he vnhele

Thritty zeer had ben mesele

Ouer al his body was he sore perfore he lyued his one pore

Of grete londes had he lord bene

But alle he lafte hem in pat tene

And for hardenes of his vnhele

He zaf him al wip god to dele And for to ende in his seruyse

pe ny zte toforn of paradyse

Him pouzte he was euen perby

fol. $47 \mathrm{v}$ col. 1

And pat pe good kyng dauy

Wesshe wip a wande his body clene

pat no sekenes was on hym sene

Suche was pe sweuene pat him pouzt

But of po branchis wiste he nouzt

pat pei hem had souzte \& founde

And brouzt to cuntre pat stounde

He wook \& pouzte on pat sizt

And seide lord god of my $3 t$

Why ne were I as hool \& fere

As me pouzt rizt nowe here

Vnnepe had he mened his mood

A leem from po zerdis stood

Rizt into pe ermytage

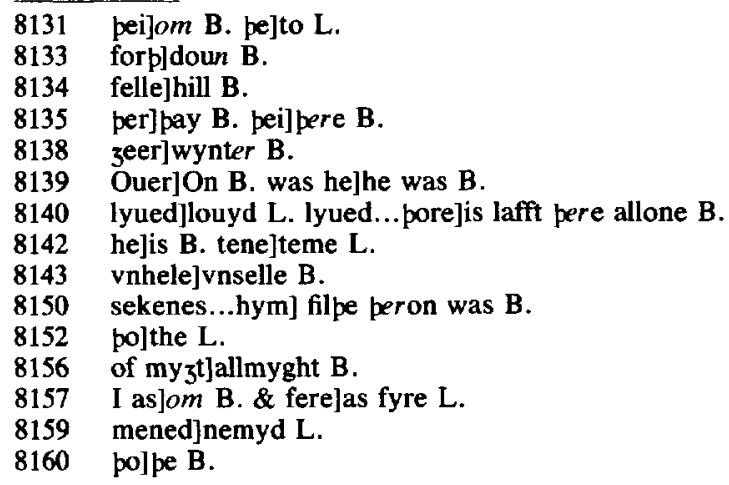


Pe kyng coom \& his barnage

Whenne pei mett wip pat hermyte

Pei heilsed hym wip greet delite

8164

When ne pat he pe kyng had knowen

8167

He seide welcome to zoure owen

Bi bese sir kyng I mysele

Shal be saaf of al vnhele

Me pouzte tonyzte on pis wyse

pat we were bope in paradise

And pat pou wip po wandes wesshe

Al pe vnhele of my flesshe

As any fisshe pou mades me fere

Wip pese zerdes pou berest here

He kissed po zerdes knelynge pere

Was he neuer holer ere

pe kyng pat kynde was in coost

Ladde him forp wip his hoost

8180

And al his lyf did wip him lende

To be kyng was he ful hende

Knyzte he was myche of prys

pe kyng hym quyt wel his seruys

Forp went pe kyng soone pan

Til he coom to flom iurdan

He took pe zerdis in his honde

pe streem stille bigan to stonde

Hit stode pe folk on eyper syde

pe kyngis passage for to abyde

When ne pei were passed ouer pe stronde

And comen into pe toper londe

Wite ze wel pei were ful glad

To be folke pe kyng pen bad

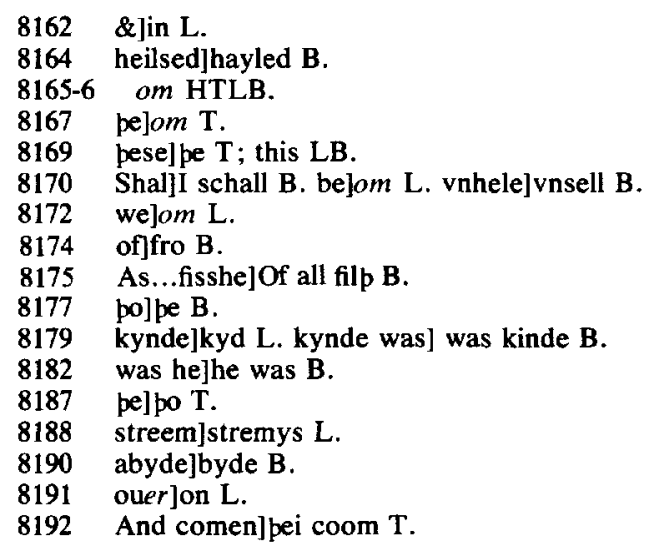


Vchon to sett her pauyloun

As for pat nyzt wipouten pe toun

And on pe morwe when ne pei shul so

Into ierusalem penne go

po zerdis wolde he sette in warde

Wipinne his owne orcharde

8200

pat while wolde he make hym boun

To ordeyne faire processioun

pe nyzte pei rested in pat slade

And of po zerdis greet ioye made

pe kyng aboute hem was zerne

He put hem into a cisterne

And dude bisyde hem laumpes lizt

And made men wake hem al ny $3^{t}$

Penne went be kyng for to slepe

But god pat al hap to kepe

8210

And al ouerloke $\mathrm{p}$ in his sizt

His wille to lette hap noon my $3 t$

Is no ping pat may forbarre

His wille bifore hit is so warre

He pat so myzty is and wyse

$\mathrm{He}$ dide po zerdis for to ryse

In pat cisterne pe rotis honeste

Togider grewen \& were feste

Myzt no man hem atwynne wynne

Wipouten brekynge for no gynne

// Whenne dauid say noon opere bote

But alle po zerdis hadden o rote

pat fastened were in erpe so faste

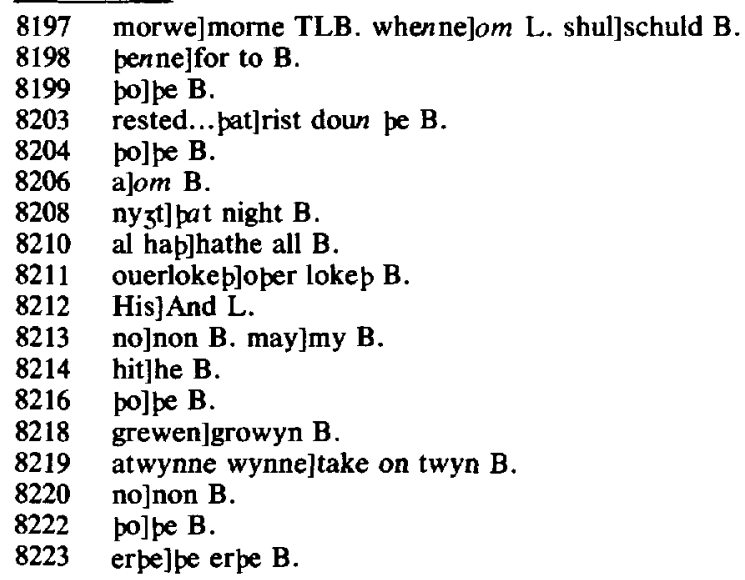


In his hert he was agast

And seide al nacyoun and lede

8225

Owe p oure good lord to drede

Miztful is he \& pat is skil

Of vche dede to done his wil

pe kyng seide no man hem ster

fol. $48 \mathrm{r}$ col. 1

Fro henne sip god sett hem ber

8230

pe kyng made to kepe pat syde

To make pe orcharde more wyde

A wal dide he aboute hit reise

And plauntide trees pat were to preyse

Of cidre palme and of lorere

pat zerde shulde be hymseluen dere

Oper riche trees he souzt

In mony stedes and pider brouzt

Alle fruytes he plauntide in $b a t$ place

For his walkyng and his solace

8240

When ne hit was cloos aboute pat tre

A cercle of siluer nayled he

For to knowe bi pat strengpe

What he wexe in greet \& lengpe

Suche cercles made he sere

8245

Thritty wyntir vche a zere

He dide oon on as I zow say

Euer when ne he took anoper way

pritty wyntir wex pat tre

pat hit was selcoupe for to se

Of cercles pat he tooke away

Offrynge he made to mone on ay

Hit was so charged vche a bowe

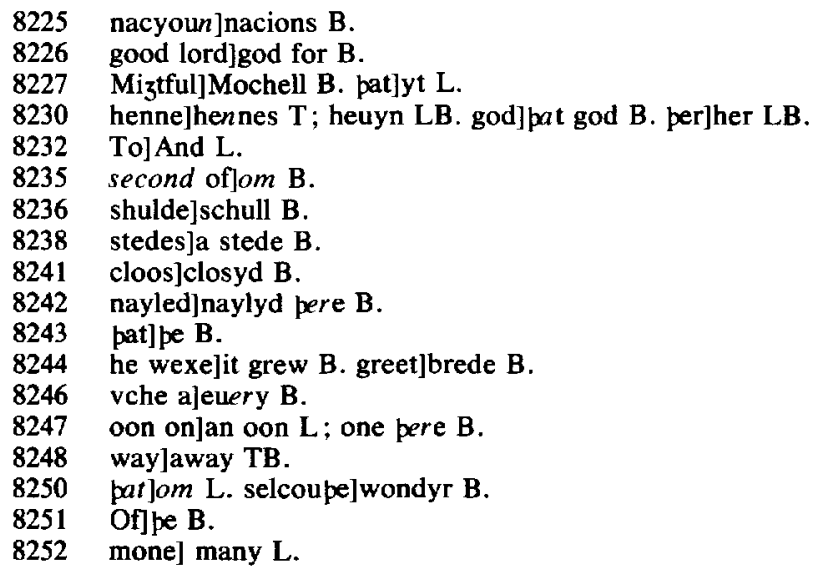


Wip leef flour \& fruyt ynowe

Alle seide pat hit say lasse \& mare

Was neuer tre siche blossum bare

Anoper tre of siche kynde

Myzte no man in worlde fynde

Of worshepe was pis tre to wondir

pe kyng ofte kneled pervndir

8260

In bedes pat he had to say

Knelyng he pervndir lay

Whenne he had made his orisoun

Vndir pat tre he sette him doun

And pouzte vpon mony a pinge

As he pat was a greet lordynge

A temple he pouzte penne to make

To goddis worshepe \& for his sake

Bisily he him bipouzte

How pis tempel shulde be wrouzt

fol. $48 \mathrm{r}$ col. 2

To kepe in his relikes pan

And saue hem in his kyndam

pe holy arke pat pei bare

Aboute wip al her holy ware

Oon was pe tables tweyn

Pat pe ten commaundementis were In

pat god wroot his owne honde

And perinne was aarons wonde

pat bar fruyt po hit was drye

And als of manna sum partye

pe gilden oyle of pe propiciatory

To cherubins as seip pe story

pese pingis pat I telle here

pe kyng hem helde tresour dere

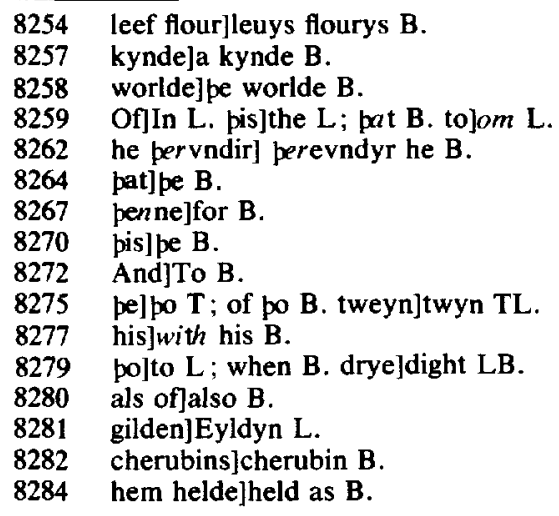


Herfore pouzte dauid kyng

To make hem a riche wonyng

Vndir pis tre pat I of sey

A stapul was of marbul grey

And as he pouzte what was to done

An aungel coom from heuen soone

8290

On a bouze he made his sete

Of pat tre bat was so swete

For wip pat flour pat was so newe

per stood a selcoupe louely hewe

pis aungel pat so brizt shone

8295

Spak to pe kyng pere allone

And seide god pe loke sir kyng

Wel I woot al pi zernyng

Pi wille is worshepe for to wirche

To god himself [a] crafty chirche

But pou shalt wite on what wyse

pat pis werke owe to ryse

God wol not piself hit make

Of pi hondis he wol not take

Siche a werke hit were vnrizt

For werriour art pou ful wizt

And many hast slayn wip pi hond

But pou shalt ellis vndirstonde

Al may hit not bi be be done

Ende hit shal pi sone salamone

fol. $48 \mathrm{v}$ col. 1

8310

pou shalt ordeyne hit in pouzt

By salamon hit shal be wrouzt

He shal be a man of peese

And mychel haue worldes ese

He shal be kyng aftir pi day

Pis is soop pat I pe say

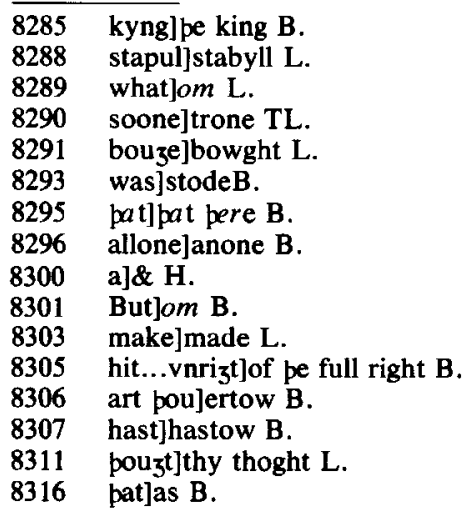


In reste \& pees regne shal he pe temple by hym made shal be He shal haue wite riches \& cele To reule al his kyndom wele 8320

Hit shal be preciouse \& ful proude

pe werke he shal so semely shroude

Relikes shul pereynne be loken

pat euermore shul of be spoken

Bytwene pis \& pe worldes ende

Haue good day now I wende

Dauid vndirstode pis skil

To leue his dede had he no wil

Fully he pouzte to do so

As pe aungel seide him to

pe kyng to his chaumber went

And soone aftir pe queen he sent

For of his lawes pis was oon

Of al his baronage was per noon

Mon nor womman zonge nor olde

pat in his chaumber was so bolde

$O$ foot to sette but pei were calde

When pe kyng speke wip him walde

$\mathrm{Ny}$ not pe queen wipouten leue

Ny noon oper wipouten greue

perfore entrede bersabe

pe queen his spouse \& his priue

pe kyng bat he in hert had hid

To pe queen he vndid

But neuer peles tolde he nouzt

pe bodeword pat pe aungel brouzt

But elles wisely \& ful shert

He tolde as hym lay on hert

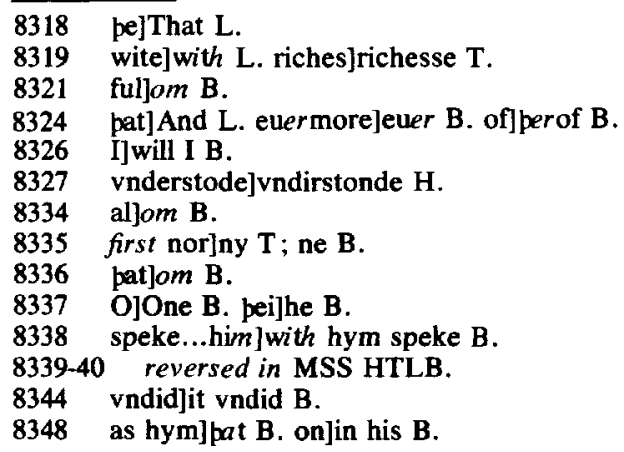


Dame I dud pe hidur calle

fol. $48 \mathrm{v}$ col. 2

As for my weddide wyf of alle

8350

In elde am I waxen now

Of my kyndam what redes pow

To whom shal I hit zyue to lede

Me to turne to menske \& mede

pat lady to hir lorde dide loute

8355

Wip buxom reuerence and doute

She kneled aftir she had stonde

pe kyng took hir vp bi pe honde

As he pat of hir counsel wolde wite

And bope dud hem doun to sitte

8360

He bad hir say \& lett nouzt

What were best as he[r] pouzt

Of his kyndam pat was to say

Who shulde hit haue aftir his day

//Sir she seide now I se

Pat ze wole counsel haue of me

Gladly wolde I if I coupe

pe beste shewe $3^{\text {ow }}$ wip moupe

pe kyndam sir pat is pyn

Pou hit wan wip myche pyn

8370

Also pou haddest greet malese

For to stabel hit in pese

Sir she seide ze haue in lyues

Mony children wip zoure wyues

pat desiren now in stryf

To haue pe kyndam in zoure lyf

pou frely kyng ful of blis

pe beste red me pinke is pis

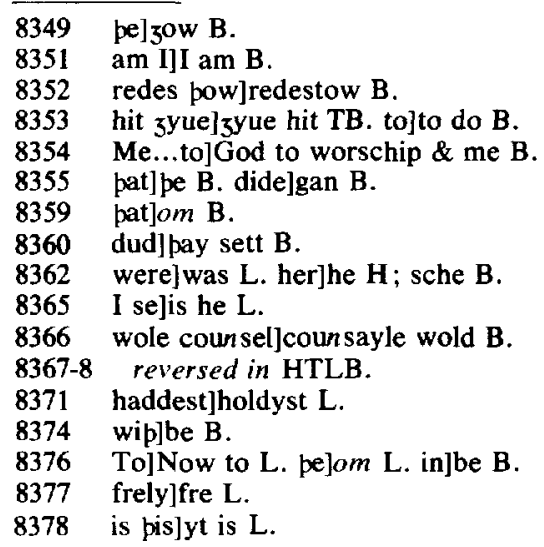


ze zyue hit to whom ze wol

My graunte shul ze haue fol 8380

I bat am pyn owne wommon

Azeynsawe wol I make noon

For salamon my sone is zing

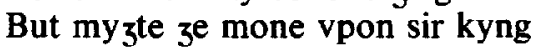

Wel ze woot ze me hizt

8385

Ar ze to spouse me troup plizt

A sone if ze myzt gete wip me zoure heire forsope shulde he be And sip so is I haue me kept pat neuer oper sipen wip me slept

But oon bifore opere had I nou $3 t$

For zoure loue was I widewe wrou $z^{t}$

On what wise par me not tel

Wel ze woot how hit bifel

Blessed be god of myzt

Forzyuen is zow perof pe plizt

I say not now so god me rede

For noon vmbreyd ny for mede

Ny for no desyre pat I haue

Ny couenaunt of zow to craue

For nouper kepe I gabbe ny glose

To say pe sope is my purpose

pouze salomon my sone be zong

$\mathrm{He}$ is wyse and of redy tong

pat neuer dide ne [d]isserued vileny

And geten is wip pi body

He pat better con mende ny peyre

Best worpi is to be pyn heyre

Not forby whom god wol chese

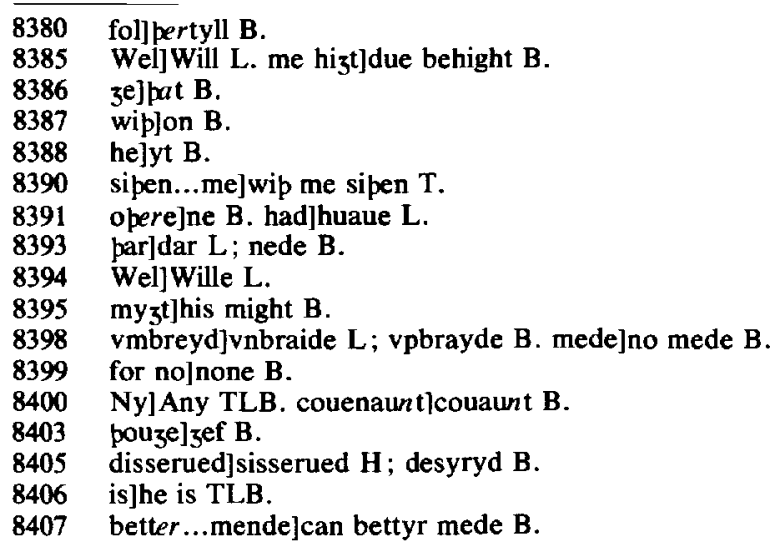


Aftir pi day kyng he bese

Wip siche a knott pe queen him knytt

pe kyng herkened wel hir witt

And curteysly as was to done

He grauntide hir al hir bone

//Dame he seide to pe I say

8415

pat salomon aftir my day

Shal be kyng of pat I wan

If god wol pat hit be pan

He is not zitt but wondir zing

Sett hym faste to good teching

Til he be lerned himself to lede

Bope of clergye \& kny $z^{\text {thede }}$

Lerne of clergye wel he shal

Of wisdome pat is groundwal

pe childe is pewed \& mylde of mode

8425

Loke pat he haue maister gode

But hit be on himseluen longe

He shal be bope riche \& stronge

Dame hele pis vpon pi lyf

For loop me were to rere stryf

fol. $49 \mathrm{r}$ col. 2

Til we se pe tyme and day

He shal be kyng whoso saip nay

perto haue pou no mystrowe

Perfore make I here pat avowe

pis childe was soone set to boke

8430

Clergy wel he vndirtoke

Al his hert he zaf to lore

Myzte noon loue clergy more

By grace of only god of heuen

Soone he coupe pe artes seuen

8440

When ne he coupe of londis lawe

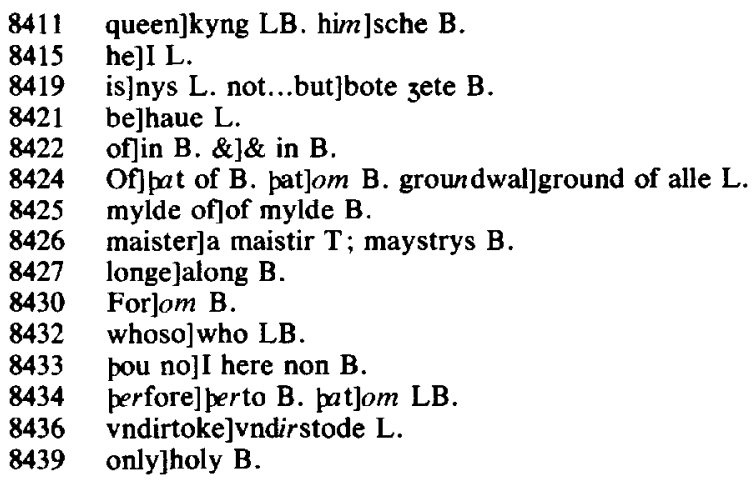


pei made him kyng in litil prawe Was noon azeyn hit olde ne zinge pat salomon penne was ma[d]e kynge His fadir biddyng dide he holde 8445 And al pat euer his modir wolde He helde pat tre dere and derne pat dauid kyng honoured zerne Ofte vndir pat tre he sat And lered mony selcoupe what

For vndir be shadowe of pat tre pe kynde of pingis lerned he Bope of trees \& greses fele Whiche were her vertues lele For what euel vchone $\mathrm{my}_{3}[\mathrm{t}]$ geyn

Wherso pei grewe in wode or pleyn And wheper pe medicyne \& boote Founden were in croppe \& roote Of lore pat he lerned vndir pat tre He made goode bookis pre 8460

Douztily he hem vndid

Wip saumplis of trees \& herbes amyd pe firste book wipouten lees Men calle ecclesiastises pat moost spekep \& wol not wonde How fals pis world is to fonde Of prouerbis is pe secounde booke pat techep aboute hem to loke Azeynes pe worldes wrecched hede How pei shul hem reule and lede pe pridde boke aftir two Cantica men callep hit so A noteful boke of holy writt

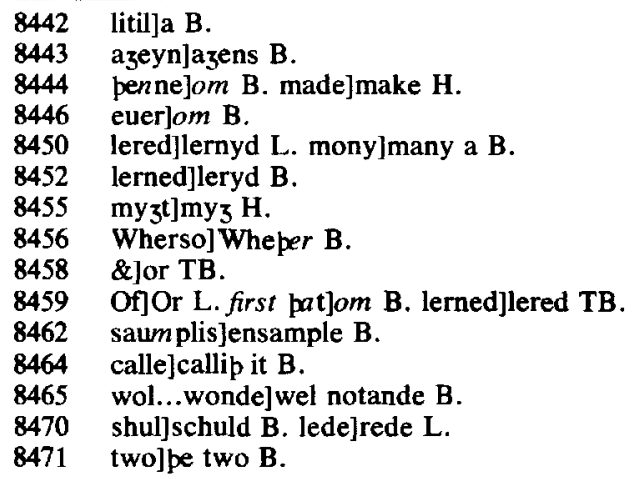


pe book of loue men clepep hit

Of pat loue hit spekep moost

Bitwene monnes soule \& pe holy goost

So crafty was no clerke to say

Fro bat tyme to pis day

Pat him my 3 te wip clergy mate

Ne coupe pe bookis pat he wrate

8480

Whil he sat vndir pe bowze

Of al wisdam he hadde ynowze

// Studfaste stood pat marbul stoon

Ful fer be golden lettres shoon

pei seide sumtyme men shul se

8485

God himself regne in pat cuntre

pat plaunted was bitwene po flouris

pere pe sternes helde her coures

Wel I woot neuer is hit wan

Of floure ne fruyt pat hit hap tan

8490

And in his tyme siche fruyt shal zyue

pat alle his frendis perof shul lyue

Of pat fruyt shulde no mon byte

But he shulde loue hit also tyte

pis writ wip fele was red \& sene

But fewe wiste what hit wolde mene

Bytwene pat he whom bare marye

Heng peron his folke to bye

Bi barnetem of olde adame

Pourze a bite brouzt alle in blame

An appul bite bope man \& wyf

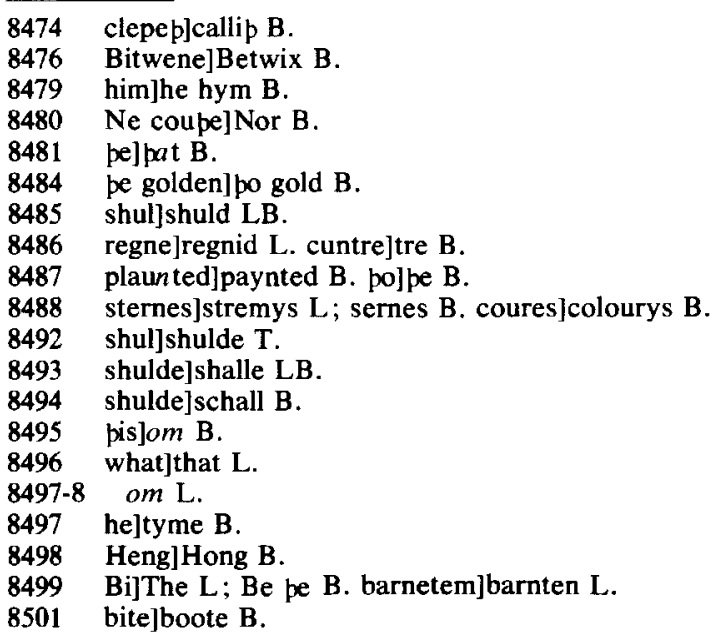


Pe tre was dep pis shal be lyf

And writen is in parchemyn

pat hit coom out of pat pepyn

pe wrecched adam fel fro

8505

And brouzte himself in mychel wo

For so bigan pe cros I wis

Of ihesu cryst kyng of blis

Now is good to go to oure style

pat we haue left of a whyle

fol. $49 \mathrm{v}$ col. 2

And turne to oure story azeyn

8510

To make hit hool \& certeyn

Dauid pat I red of here

Was kyng \& regned fourty zere

His regnyng was of siche renoun

8515

His foos wip him hadde no foysoun

Childer by wyues had he sere

Of whiche I make no menyng here

For he bat myche hap to telle

pe shorter mot nede be his spelle

pis was pat kyng dauy

pat myche spake of prophecy

Of cristis burpe long biforn

pat shulde of a mayde be born

Whiche mayde of dauid sede

Was aftir geten as we rede

As oure lord biforne him hizte

Of hym to sprynge alle pinge to rizt

pis dauid made pe sautere

pat is rad bope fer \& nere

Homer pe poete pat was so ryf

Lyued in pis kyng dauid lyf

And of affryk be strong barnage

Dide make pe cite of cartage

pat to rome was euer queed

8502 pe]pat TLB. pis]om L; pis tre B.

8503 parchemyn]perchemyns $B$.

8504 pat pepyn]pre peppyns $B$.

8506 Andlom $B$.

8512 To] And $B$.

8515 regnyng]reigne $B$.

8516 foysoun]seson $B$.

8517 by...he]he had be his wifes $B$.

8518 I makelhe makep B.

8520 mot]mor L.

8521 kyng] worpy king $B$.

8525 of afftyr of B.

8535 euer]neuer $L$. 
Sip whenne pe kyng was deed He bad his men pat he shulde ly In bedleem his fadyr by

Aftir dauid deep salomone Was kyng sittyng in his trone 8540 He was a boldly bachilere In al pis world had he no pere Of witt \& wisdam as we rede Was neuer a wyser lawe to lede In bed he lay on a ny $3^{t}$ 8545 Biforn him stood an aungel brizt And to him spak wip blisful chere He seide I am a messangere My lord hap sende pe word by me To zyue pe choys of pingis pre fol. 5 Or col. 1 Of strengpe riches and of witt 8550

Chees whiche pou wolt $\&$ haue hit If pou him serue wip hool hert Of pre pou shalt haue oon in quert //Salomon pis vndirstood

Of pis message pouzte him good Witles he seide what is catele Or what is strengpe wip to dele Pat mon no witt hap wip to lede I ches me witt for greet nede

I ponke him pat chois wolde me 3 yue I shal hym serue whil I lyue Wip al my myzte \& my wille He zyue me grace hit to fulfille To salomon seide pe aungel po

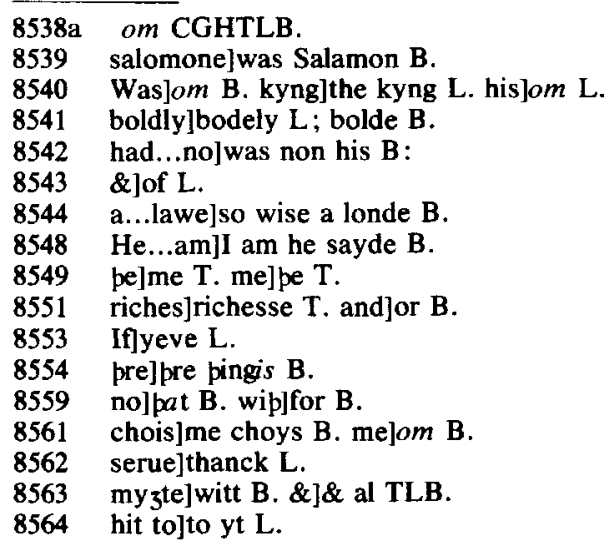


In chois hastou wisely go

And for pou wel hast chosen oon

pou shalt haue hem euerychon

pou shal be ful war in dede

Alle folk shal pe drede

And drednes shal pou haue of [n]on

Of riches shal pou haue greet won

// Pus regned salmon wip pis

In myche ioye \& mychel blis

He loued pe folk of his kyngdome

8575

And pei hym alle chylde \& mon

Alle pat azeyn him dud males

Wip wisdome he hem toke to pes

Al pat his fadir myzt nouzt

Salamon to ende hit brouzt

8580

Ierusalem loued he moost of alle

pere was he sett in kyngis halle

In his kyngdome pe forme dawes

Among his folk he set his lawes

And did hem streitly to zeme

8585

Mizte no man more riztly deme

Among his riztwis domes ryf

Here how he felde a stryf

Mister wymmen were per twynne

fol. $50 \mathrm{r}$ col. 2

pat lad her lyf in sake \& synne

8590

Housyng had pei noon to note

Bope pei dwelt in a cote

Bope on a nyzte lizter were pai

And bope at onys in gesyn lay

Bope were knaues pat pei bare

8566 hastou]hast pou L. wisely go]well I go B.

8570 Alle]As B. drede]rede B.

8571 drednes]drede B. shal poujschaltow B. non]mon $\mathrm{H}$.

8572 shal pou]shaltou T; pou schalt B.

8574 In]With B.

8576 allejleuyd bope B.

8578 hem toke]toke hem B.

8580 hit]om B.

8582 halle]stalle B.

8582a om CGHTLB.

8583 pe formejin pe first $B$.

8586 more riztly]no righter B. riztlyllightly $L$.

8588 he felde]pere fyll B.

8589 Mister]Comon B. twynne]tweyn B.

8590 lad]had L. sake]wrongh B.

8592 Bope...dwelt]pey duellyd bope B.

8593 on a]in oon L. lizter]lyghtyd L. 
Her moderes ful nedy ware

Pei had no credeles ne wip to by

But dide her childre bi hem to ly

Her beddyng was to hem so nede

Hit myzt not be depardide in dede

8600

Of pese wymmen soone pe ton

In bed slepyng hir sone had slon

As wymmen done ryuely

pat zonge childre leyn hem by

When ne she fond hir childe was dede

8605

Coude she fynde no better rede

Fro hir fere she stale hir barn

And laide hiren pere bat was forfarn

So in bed stille she lay

As she had slepte til pe day

pat oper wommon whenne she woke

And bigan hir childe to loke

She fond hit ded liggyng hir by

Alas she seide bat born was I

My childe Is slayn \& I noot how

Colde hap slayn hit as I trow

8620

pe childe in barme to fire she bare

Wel she wende to quyke hit pare

Al for nouzt hit was forleyn

Hit myzte not quyke to lyue azeyn

She hir bipouzte in short while

pat of hir childe she had gyle

When ne she sopely had knowen

pat pe childe was not hir owen

To hir felowe she lep in hy

And perwip $3^{\text {af a mychel cry }}$

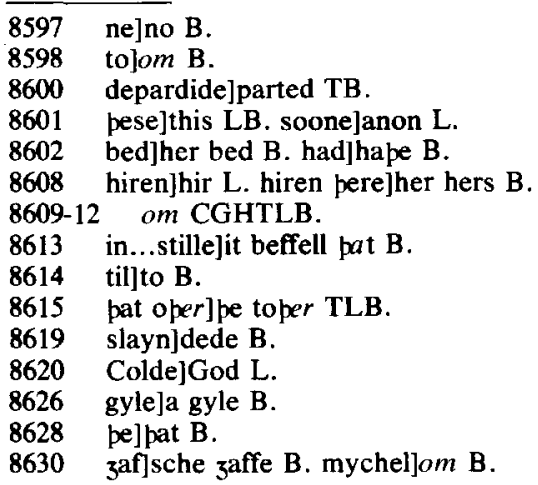


She seide wicked be pe wo Why hastou me bygyled so Of my childe pat myself bere fol. $50 \mathrm{v}$ col. 1 zyue hit me anoon now here 3yue me my childe pou fro me stal

pe toper seyde pou lyest al

I hit bar and hit is myne

pe dede childe sopely is pyne

Pat pou slouze whil pou slept

Ful wel haue I myn kept

She seide pou lyest wik wommon

Pou shalt per of be ouergon

My quyk childe pou hast stolen to pe

8645

But pi dede childe leyd by me

Pou shalt hit zelde to me al

When ne iuggement perof be shal

Wip pis pei coom bifore be kyng

Alle folwede hem olde \& $\operatorname{zin}[\mathrm{g}]$

Mychel pepul of mony toun

Of pat doom to here resoun

Soone wip salomon pei met

Vndir pe tre pere he was sett

pere he moost his witt souzt

Of alle pingis pat he wrouzte

Whenne pei were biforn him pere

First spak she pe quyk childe bere

She seide saf be pou salomone

Kyng sittyng in pi trone

Lord pi pore wommon pou here

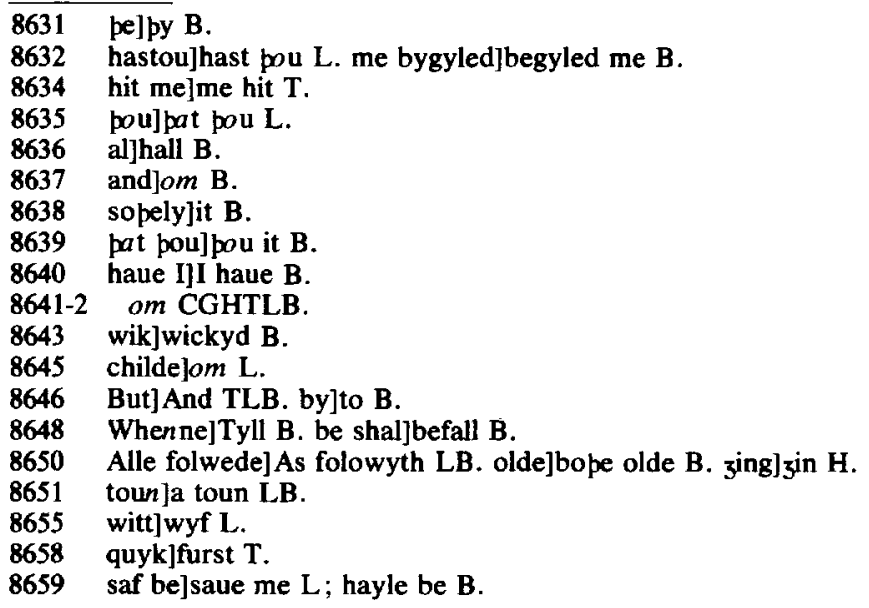


And riztwis deme in pis mistere pese wimmen bat ze se here stonde We are bope in o hous dwellonde Bope at onys wip childe we were 8665 And bope at ones oure childre we bere In wonyng were we stad not wyde And layde oure childre by oure syde But weilawey hit so bifel My fere in bed hir childe dud quel 8670

Sip she layde hit priuely

Whil I slepte in bed me by

And stal my lyuyng childe away

Til I knewe wel by lizt of day Of pis tresoun she had me done I hir resouned also soone But myzte I neuer hidur tille No childe gete for good nor ylle // Pou lyzest seide pat oper pon Ful bitturly as euel wommon 8680 pouzte I neuer bi childe to stele But wommon am I trew \& lele pis childe in myn arme is myn And pat pat is dede hit is pyn Of my wombe pis childe was born

And pou wip shame pin hast lorn Pe ded is pyn \& myn pe quyke Suche wordis spak bat wommon wike pat oper seide allas sir kyng And perwip gon hir hondis wryng 8675 fol. $50 \mathrm{v}$ col. 2 I se my childe is me wipdrawen And shal not come to myn awn

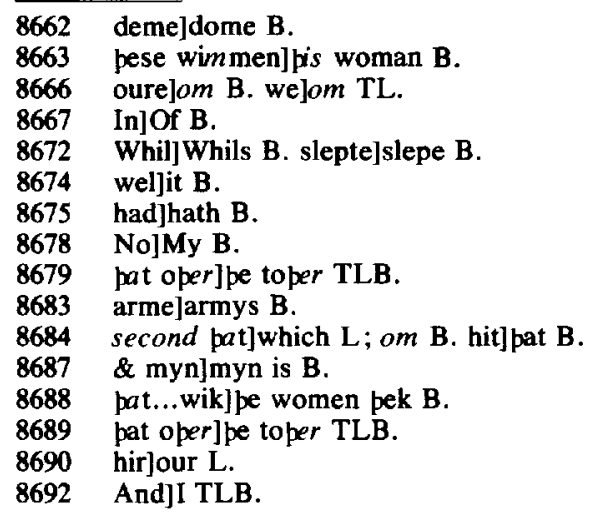


Pou do me bote azeyn pis bolde

For al pe sope I haue pe tolde

pe kyng pat was so sleze a cle[r]k

8695

War \& wyse in al his werk

Of pis pleynt meruailed sore

A caas pat hadde not come bifore

Lordyngis he seide pis wommon here

Seip pat pe quyke childe she bere

8700

Per azeyn seip pat oper

She is pe modir \& noon oper

Part in pe dede haue pei noon

pei clayme perof blood nor boon

But of pe quyke bope wolde be

Modir as ze here and se

But modir may hit haue but oon

To proue hit shul we soone goon

And eyper wolde haue hit al

But parto may pei not fal

8710

Me pinkep by al maner art

Bytwene hem we mot hit part

And sipen bat pei wol so

Wip swerd hit shal be delt in two

Eyper shul to o syde stonde

8715 fol. 51 r col. 1

Anoon fet me my swerd in honde

// Pe womman pat pe modir was

Fel to grounde \& cryed allas

And seide lord god hit shylde

pat pou sir kyng sle my chylde

8720

zyue hir al my childe allone

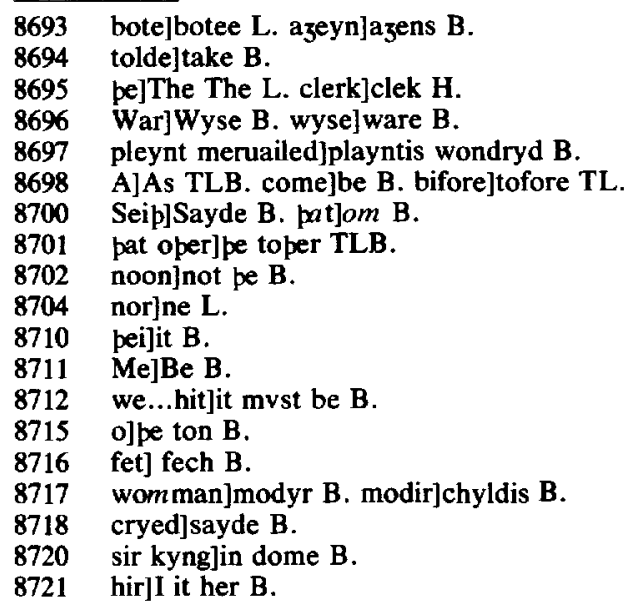


Pat is better ben hit be slone

Of him I zyue to hir my rizt

Or he shulde so be dizt

// Pe toper seide not shal [h]e

8725

Hool be zyuen to me ne pe

But baldely dalt mot he be

As pe kyng hap seide in se

Euer pat oper seide in sawe

Lord lete not my childe be slawe

8730

For no ping per may bifalle

Lordyngis he seide pis here ze alle

To whiche of pese shal I hit deme

Say me what wol best biseme

pei seide sir bi pis day

8735

We noot bitwene hem what to say

He seide herde ze not pat oon

Wolde haue him quyke anoper sloon

pat oon wolde dele pe childe in two

Pat oper wolde not lete hym slo

8740

Wherfore I zou rede

Pe childe be not done to dede

But bitake hym to pat wyf

Pat so fayn wolde haue his lyf

For she pat halt his lyf so dere

His modir is wipouten were

pis doom pei seide is of prise

Alle ponked salomon pe wyse

Hir childe she toke \& hoom she gos

Of pis doom fer sprong pe loos

Alle pat spake of salomon

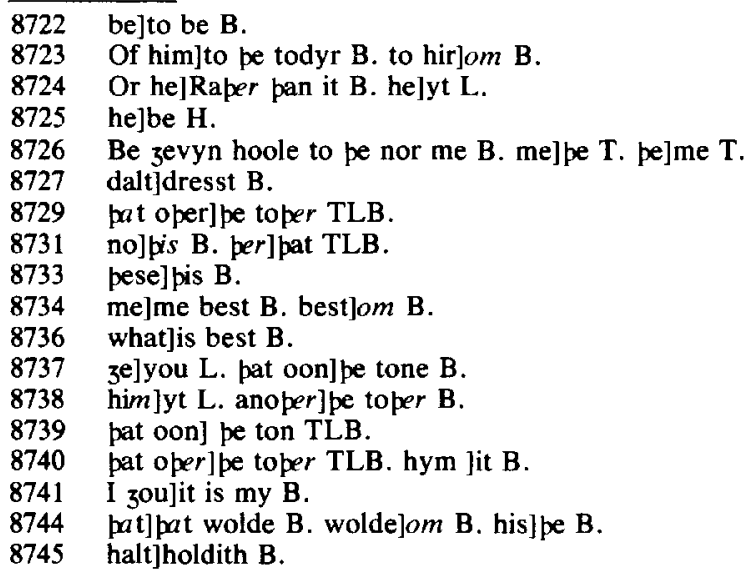

8723 Of him]to pe todyr B. to hir]om B.

8724 Or he]Raper pan it B. he]yt L.

8725 he]be $\mathrm{H}$.

8726 Be zevyn hoole to pe nor me B. me]pe T. pe]me T.

8727 dalt]dresst B.

8729 pat operlpe toper TLB.

8731 no]pis $\mathrm{B}$. per]pat TLB.

8733 pese]pis $B$.

8734 me]me best B. best]om B.

8736 what]is best B.

8737 3e]you L. pat oon]pe tone B.

8738 him]yt L. anoper]pe toper $B$.

8739 pat oon] pe ton TLB.

8740 pat oper]pe toper TLB. hym ]it B.

8741 I zou] it is my B.

8744 pat]pat wolde B. wolde]om B. his]pe B.

8745 halt]holdith $B$. 
Seide so wyse was neuer noon

$\mathrm{Ny}$ craftiere in werke of honde

Was neuer founden noon in londe

Ne neuer noon pat had I wis

8755 fol. 51 r col. 2

So myche wele of worldly blis

When ne salomon was wel at ese

And al his kyndome in pese

In worchynge he bigan to wake

In det he was pe temple to make

8760

pat his fadir him of bisouzt

But of a ping wondir him pouzt

Whil he was tymberyng to pat ping

pat while pe tre bigon to clyng

pe tre pat I bifore of tolde

8765

Po bigon to waxen olde

Vche man seide pat hit seze

Fat hit for elde bigon to deze

And semed wel bi pat purpos

Men shulde no more hit holde in cloos

8770

pe short tale perof to telle

Men be raper shulde hit felle

When ne nede were to be souzt

And to pe temple werk be wrouzt

pe kyng cast by scanteloun

And dide make al be tymbur boun

Whenne al was purueide in place

And bounden togider beem \& lace

pei fond gret merryng in her merk

pe wriztes pat shulde reise be werk

pe best beem pat perynne shulde be

perof wanted hem a tre

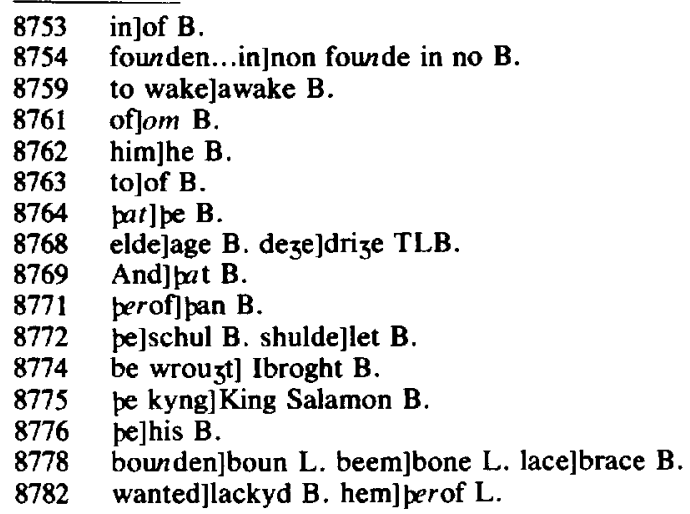


Pe beem pat moost pe werk shulde bynde

pei souzte anoper for to fynde

Mony a wod haue pei pourze gon

8785

But siche tre fonde pei noon

When bei had souzt wipouten spede

Sir kyng pei seide we doute oure dede

Shal perisshe \& al left werk vchone

And spak to kyng salomone

8792

pei seide sir durst we for awe

Oure pouzte wolde we to zow shawe

We haue souzt fer \& neer

To fynde a tre to pis mister

For to fest wip compas slyze

Oure werk togider lowe \& hyze

If we durst seye zow sir kyng

pat ze took not in greuyng

8800

Pe tre pat is in orcharde pin

Wolde brynge oure werk wel to fyn

pe kyng of pis tre vndirstood

Almost menged him his mood

Neuerpeles he graunt pat tre

8805

When ne hit myzt noon oper be

Soone was pat hewen doun

And squyre on leyd \& scanteloun

Pe tre was also mete \& queme

As any man coupe perto deme

8810

But whenne hit was vp bi strengpe

Hit wanted large an ellen lengpe

Anoon doun pei hit let

And fond hit mete ynouze bi met

Efte pei lifted vp pat tre

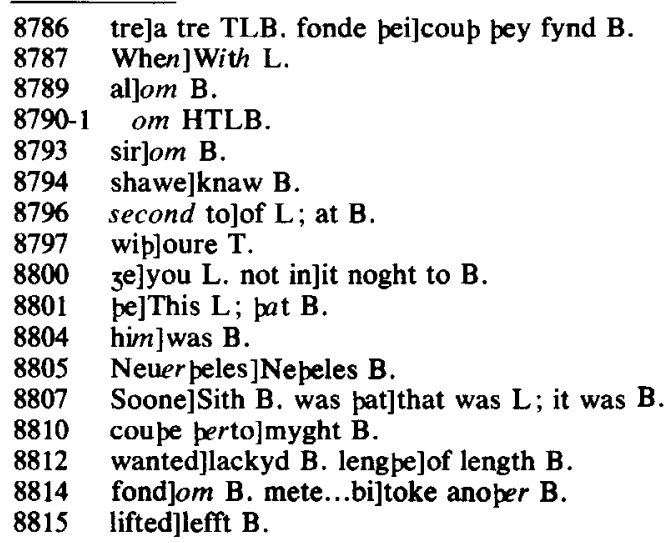


Hit was to short greet quantite pus pei proued hit pre dayes As hit in pe story sayes

But for no profu[r] pat pei dude Hit wolde not pere stonde in stude 8820

When ne pei say no bote ellis pei wente to seche frippe \& fellis

Fynde anoper tre wolde pay

pei hit fonde pe firste day

Pe same day pei hit founden 8825

Pe beem was in his burben bounden

pis tre pei took of cypres

And dude hit in worshepe \& in pees

In pat holy temple grip

And pe pritty cerclis perwip

8830

pat kyng dauid so good

Dude aboute hit whil hit stood

To wite how hit grew by zere

And offered hem as tresour dere

To haue of pat tre lastynge mynde

8835

Of dyuerse tokenes as we fynde

At pe temple for pis resoun

Pei were wip tresour in comoun

$\mathrm{Ne}$ were bei neuer penne spende

Til bei were Iudas bikende

To hym were pei bitauzte \& tolde

Whenne he for hem his lorde solde

Pus seip sum opynyoun

But so seip not pe passioun

Pe tre penne ful richelye

8816 greet]a grete L.

8819 no]to L. profurjproful $H$.

$\mathbf{8 8 2 0}$ pere...in]stonde pere in no $\mathbf{B}$.

8821 no]non LB.

8822 seche]fecche $L$.

8824 firste] fourpe $B$.

8825 pei]bat pey $B$.

8826 beem]tre $\mathbf{B}$. his burpen]cariage $\mathbf{B}$.

8828 dude]putt $B$.

8837 At]Oute of $B$.

8838 comoun]to moun B.

8839 pennelperin $\mathbf{B}$.

8840 were Iudas]to ludas were B.

8841 bitauzte]taght B.

8842 Whenne he]Whem bey B. his]oure B.

8843 seip]sayn B.

8844 so]pus B.

8845 pelpis $B$. 
Was in pe temple don to lye Perof was neuer made ouzte Til pe cros perof was wrouzt pis chirche was made of marbul stoon Suche anoper in world was noon 8850 As was tempel salomone Perynne were alle her relykes done Mony selcoupes to se He wrouzte pere in stoon \& tre Was neuer noon pat coupe wirche 8855 $\mathrm{Ne}$ ordeyne siche anoper chirche But god had zyuen siche wisdome As he $z^{\text {af }}$ to salomon As seye pe men bat pere han been Wipynne \& oute bope han seen 8860 Pritty ellen when ne hit was made Hit hade on lengpe \& ten brade And on heizte hit hadde fiftene Bi crafte ouer al wrouzt bydene Perfore pe beem I tolde of ore 8865 Of elnes was fiftene \& more Whenne pe temple halwed wes Pe tre lay euer stille in pees Mony hit wolde haue done away Mizte pei not stille hit lay And aftir salomones dawe Coom a prest of her lawe perto fyue hundride men he ledde

\footnotetext{
8846 Was] Was done B. don]for B.

8847 neuer made]made neuer $B$.

8850 world] pe world B.

8851 tempel]pe temple of $B$.

8852 alle her]pe B.

8853 selcoupes]mervayles $B$.

8855 Was neuer]pere was $B$. coupe]coude $T$.

8857 But]For B. siche]non swich B.

8858 zaf]did B.

8860 oute bope]withoute pat B. seen]it sene B.

8862 on] of B. bradejon brade T; of brade LB.

8863 on] of $B$.

8864 wrouzt]made B.

8865 of ore]beffore B.

8866 was] hit was $T$; length $B$.

8868 euer]ovyr $L$. in pees]by gras $L$.

8870 stille]so still B.

8871 dawe]days $B$.

8872 lawe)lawys B.
} 
pei my3t not stire hit of pat stedde

Wip ax he wolde haue kut hit pon

8875

Al to soone he bygon

Out of pat tre brast a blase

fol. $52 \mathrm{r}$ col. 1

And brent hem alle in pat plase

Coom noon of hem hoom quik

Cirillus het pat prest wik

8880

pis was a tokenyng of pat tre

pat halwed was as ze may se

Salomon po was ful wele

And vmbset wip hap \& cele

His wyues were wondir to neuene

8885

Queenes had he hundrides seuene

pre hundride lemmons he sayes

Aftir pe lawe in po dayes

Wipinne pe tyme pat I of rede

per coom a lady of pat lede

For to honour hit in pat stude

As mony of pat cuntre dude

She pouzte to make hir orisoun

But vnwisely she sette hir doun

Vpon pis ilke tre wip chaunce

8895

pat men hadden In affiaunce

Soone was pere seen a wondir

Hir clopes bigunne to brenne hir vndir

As pe tre in fire had bene

Pat ilke wommon pat I of mene

8900

pe tre aferd she stirte fra

Hir name was maximilla

penne bigon she for to crye

Wip a voys of prophecye

She seide on pat tre shulde hynge

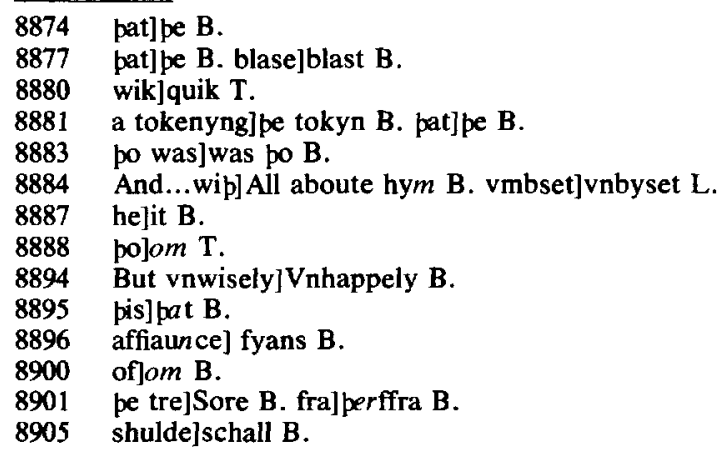


Pe lorde of hele pe blisful kynge

Ihesu crist of mayden born

To saue pe world pat was forlorn

pat shulde pe iewes here \& se

pat shulde pe cros make of pat tre

8910

For pe loue of pis soop sawe

pe felle iewes wipouten awe

For penne nemed she cristis name

On god seide pei pou hast seide shame

She is wod wip fend Itake

8915

Anoon pei heueded hir wip wrake

Send was pere an aungel clere

fol. $52 \mathrm{r}$ col. 2

And vp to heuen her soule bere

Pere in al pe folkes sizt

And seide pat cristiane she hizt

8920

Perfore were po iewis wroop

pat nome to here hem was loop

pis womman was pe first men knew

Martired for loue of crist ihesew

Pese iewes pouzte not zitt ynouze

8925

pis tre out of pe temple pei drouze

A pyt per was ful litil hem fra

Was cald piscina probatica

pe iewes pat were wont to wrong

PerInne pe kyngis tre pei slong

8930

Whersoeuer pis tre lay

God shewed peron his myztis ay

Vche day a certeyn hour

per lizt doun fro heuen tour

Aungels pat were selcoupe shene

8935

To stire pe watir al bydene

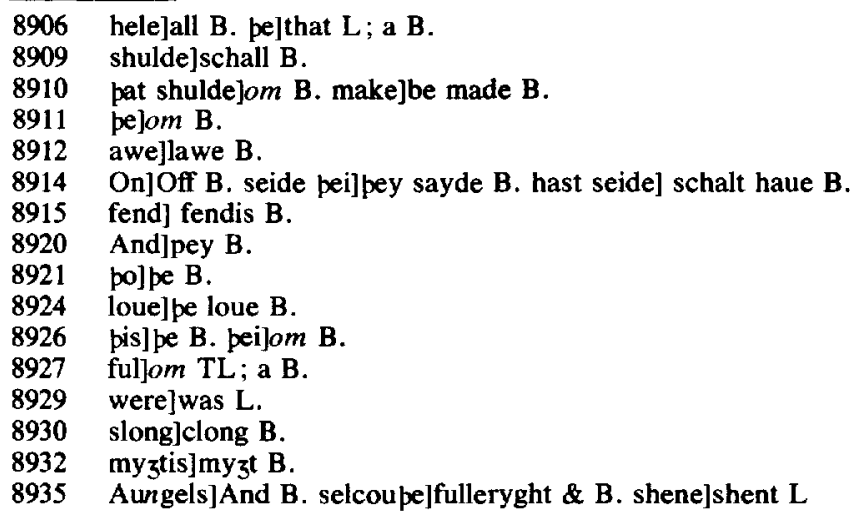


Whenne pat hit was stired so

Men pat lay seek in wo

Whoso to pat watir coom anoon

Of soor hadde he lenger noon

8940

Were his sekenes neuer so strong

Or hadde he lyued neuer so long

pes iewes po crabbed \& kene

When ne pei hadden pis Isene

pei drouze hit penne \& made a brigge

8945

Ouer a litil ryuere to ligge

pe watir of siloe \& pei seide

Whenne hit was ouer pe watir leyde

If her Inne any vertu be

Of olyue wipynne pis tre

Bi synful mennes feet seide pei

Wip goynge shal be done awey

On pis maner pis tre pere lay

Til aftirwarde mony a day

Til sibile coom fer fro kip

To salomon to speke him wip

For to here of his Wisdom

fol. $52 \mathrm{v}$ col. 1

Whenne she to be cite coom

She coom in at pulke $z^{\text {ate }}$

pere pe tre lay in hir gate

Doun she bowed to pe grounde

8960

pe tre she honoured pere a stounde

She laft hir sherte neuer pe latir

And barfot wolde she ouer be watir

To bat tre she gan hir folde

And prophecye perof she tolde

And of domes day namely

How mony men shulde be sory

Whenne pat sibile wip pe kyng

8939 Whoso]Whos L. pat]pe B. coom anoon]first com B.

8943 polom B.

8944 Isene] sene B.

8945 penne]pennes TB.

8946 ryuere]watyr B.

8947 \& pei]it is B.

8951 Bi]With B.

8955 Til]To B. fer fro]from fer B.

8959 pulke]pe B.

8960 hir]pe B.

8961 bowed]loutyd B.

8963 sherte]smok B.

8964 barfot]barfort $\mathrm{H}$.

8968 men]a man $B$. 
Disputed had of mony ping

pe kyng zaf hir ziftis faire

And hamwarde she dide repaire

pis ilke tre pat I of say

pere hit lay mony a day

But hit was in pe temple boun

8975

At tyme of cristis passioun

Let we hit ligge pere hit lise

Speke we of salomon pe wyse

His dedis coupe no mon amende

Suche grace god hym sende

8980

But harde hit was pe dede of synne

pat ordeyned was to adames kynne

pat sorweful werk hemself hit souzte

pat al her sede in sorwe brouzt

Man to falle in fulpe of flesshe

8985

pourze fourme of kynde pat is nesshe

Ouer past hym hap pat caytif kynde

And made kyng salomon al blynde

Blynde of witt \& wisdoom als

And also in his feip ful fals

8990

pourze wymmen pat he loued fele

He fel fro lyf \& soulis hele

Azeynes goddis forbode dide he

And loued ladyes of vncoupe cuntre

Pat made him god to renay

8995

And to forsake his owne lay

Lord god so mychel of myzt

Where bicoom al his insizt

pat dude himself so to spille

Folwynge wicked wom monnes wille

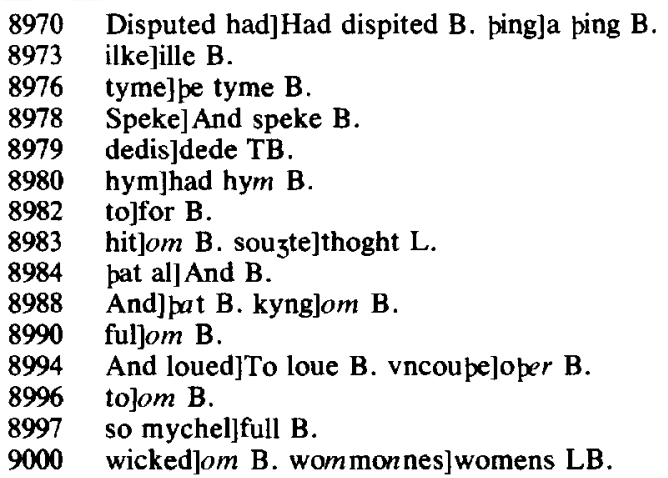


[A]llas erly pi gyle bigon

At adam pat was formast mon

Sampson pat strengest was in lyf

Was bigyled pourze a wyf

Kyng dauid for a wyues sizt

9005

To depe dude a sacles kny ${ }^{t}$

Salomon pat $I$ rede of here

pat neuer hadde of wisdome pere

Sip wymmen han bigyled him so

Who may of hem be siker who

9010

Certis I trowe neuer oon

In pis world of wicke wom mon

pe man she hap in hir bandoun

She bryngep to confusioun

Perfore I say blessed is he

9015

pat dop hym not in hir pouste

For if he loue hir more pen nede

To foly wille she wol him lede

Be he neuer biforn so sly

penne shal he falle into foly

Mistrowe no man herfore pat I

9020

Wol speke of wymmen vileny

If I so dude I were vnhende

I penke no good wommon to shende

Certis pat par no man wene

For in pis world is noon so clene

Creature wip god \& mon

To loue as good wommon pon

pis euel to hem I hit telle

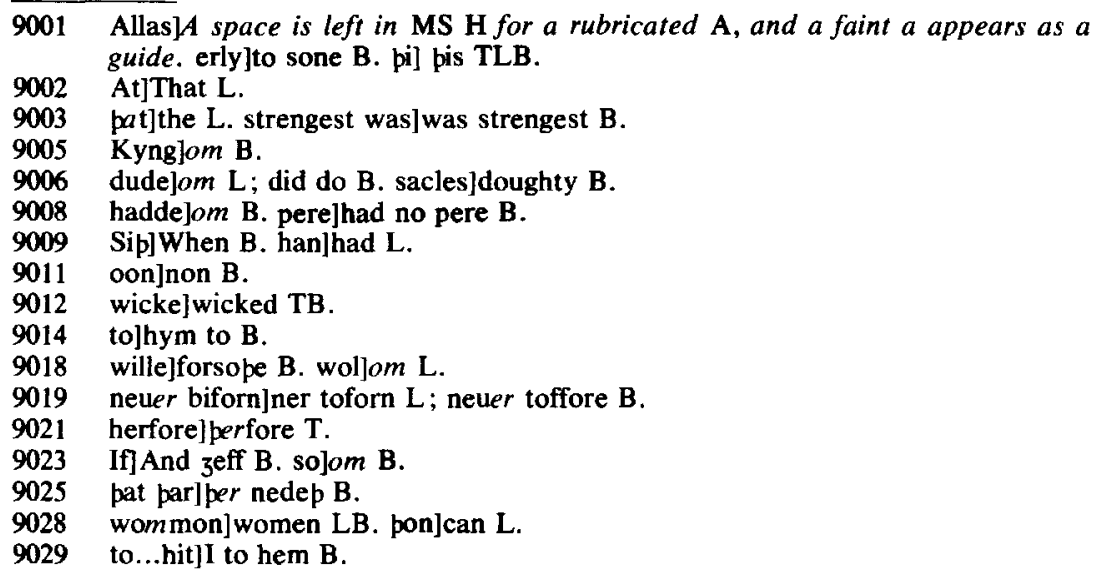


Pat are founden false \& felle

9030

Pe goode are neuer pe wors to preyse

9035

What so men of pe wicked seyse

Whiche are to lacke $\&$ whiche to loue

Her owne werkis wol hem proue

But god pat dyzed vpon be rode

Amende pe wickede \& saue pe gode

9040

Whenne salomon his wille had wrouzt

fol. $53 \mathrm{r}$ col. 1

Wo him was pat euer he hit pouzt

God to wrapthe his soule to fyle

penne repentide hym a whyle

Wip bope his yzen sore he gret

9045

And dude prophetis to be fet

Patriarkis hem coom wip alle

Biforne her feet he doun con falle

And saide hauep of me mercy

Is noon so synful wrecche as $I$

9050

I se wel I haue mysgoon

I haue honoured himself saton

I haue laft my lordis lawe

And to pe fendis fully drawe

// Hastou pei seide bi lawe reneyed

9055

ze ze wayleway he seyed

Whi pei seide dost[ou] so

A womman wrouzt me pis wo

My mysgilt I am aknowen

I were worpi to be drawen

I haue done a wickede dede

pourze a wommon of hepen lede

ze rede me now for goddis sake

zoure counsel I wol vndirtake

9031-4 om HTLB.

9036 so...of]euer $\mathrm{B}$.

9037 \&lom B. second tojar to B.

9039 vpon]on B.

9040 wickede]ill $B$.

9042 him was]was hym B. he]om B.

9044 repentide]repent he $B$.

9046 prophetis]prophecy B. fet]lett B.

9048 doun ]om B. con]gan LB.

9049 of] on LB.

9050 synful] foule a $B$.

9054 fully]foly $B$.

9055 Hastou pei] Hast pou he $\mathrm{L}$. reneyed]renewid $\mathrm{L}$.

9057 dostoula blot obscures the ou in $\mathrm{H}$; dudes pou $\mathrm{T}$; dedist pou $\mathrm{B}$.

9059 mysgilt]gilt B. aknowen]beknawe B.

9062 lede]rede B. 
Alle pei seide what rede con ze

pe reede is holly in pe

pou piself pat art so wys

Firste saye vs byn avys

We shul be to pi biddyng boun

He seide takep of my croun

9070

Pat I no lenger owze to were

My kyngis robe of me ze tere

For my synne fer wol I fle

To vncoupe lond fro pis cuntre

[D]o wey pei seide kyng salomon

pis ping owze not we to don

Nouper we wole ne haue myzt

Fordo be lawe of kyngis rizt

pe lawe pat god hap leyd on kyng

We owze to breke for no ping

9080

What seide he what saye ze now

fol. $53 \mathrm{r}$ col. 2

Shal I haue no rede of $3^{\text {ow }}$

What rede may we saye to be

I wol pat ze vncroune me

Mi lord I haue laft alas

9085

Helpep me in pis caitif caas

Leip on me harde penaunce

Sore is hit my repentaunce

Sip I have serued to haue shame

3yue me shrifte in goddis name

9090

// Pat shrifte was sorweful to sene

Al be cite say bidene

Olde \& zonge gon on him wondir

Pe shrifte pat solomon zeode vndir

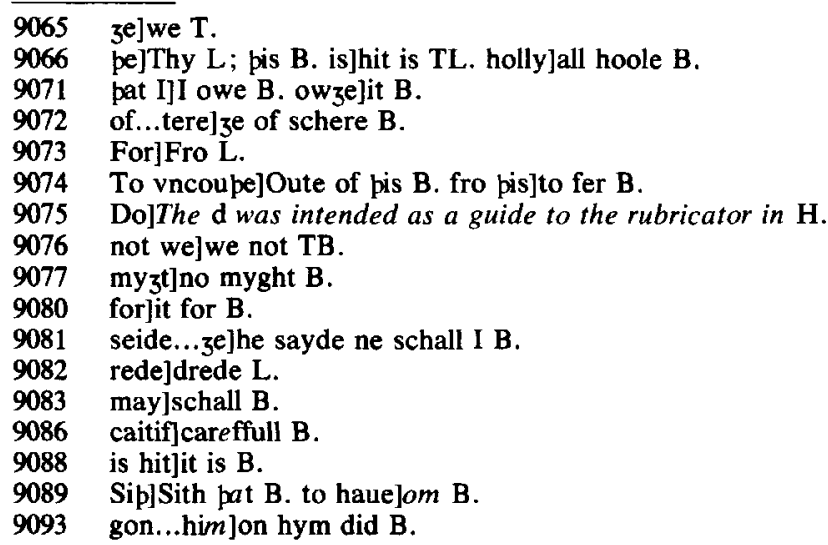


His synne bifore pe greet cite

9095

Wip woful wepyng shewed he

His riche croune of stoon \& gold

He dide firste take of his molde

Of his robe he gan to ryue

And his body al to dryue

9100

He scourgid him bare in pat pronge

Out of his backe be blood sponge

Suche soor shame \& marterynge

Was neuer seyn on siche a kynge

Al he toke in goddis name

9105

And poled mekely pat shame

$\mathrm{Him}$ pouzte al pat to be lite

For to pole for siche a wyte

Wherof tofore he loued be lust

He let ryue hit al to dust

9110

Perfore hit semed wel bi pis

Pat he gat mercy of his mys

What for pe reupe of his mysdede

And for his shrifte he vndirzede

Aftir pe tyme pis was done

A While regnede salomone

Blisfuly ouer al pat lond

His werkis zitt ben lastond

His craftis shul be lastyng ay

Til hit come to domes day

9120

Miche of hym haue I to telle

fol. $53 \mathrm{v}$ col. 1

Mizte I for opere pingis dwelle

On opere pingis most I mynne

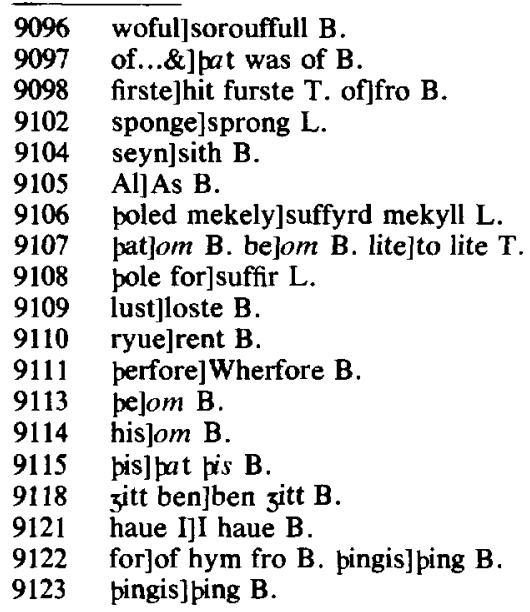


To reken forb oure lady kynne

For perfore moost I vndirtoke

9125

For to make pis englisshe boke

To telle how pat lord of my $3 t$

To hele men ofte had hizt

pat of her seed a mon shulde springe

Monkynde out of wo to brynge

9130

Longe was pis het biforn

$\mathrm{Ar}$ ihesu crist to vs was born

//Of salamon now we ende

pat regned fourty wynter hende

He had hade bope of wele \& wo

9135

His elde was fourty zeer \& two

In bedleem grauen was he boun

pat was his owne fadir toun

Wip menske \& worshepe aftir wham

Regnede his sone pat hett roboam

9140

Pis roboam pat I of mene

Regnede wynteres seuentene

// His sone coom aftir abya po

Pre zeer he regnede \& no mo

// Asa his sone hool \& fere

Regnede oon \& fourty zere

// Josephat his sone in lyue

Regnede twenty zeer \& fyue

pat was elyas pe prophete

God of hym so mychel lete

He styntede reyn bi his preyere

Six monepes \& pre zere

And when ne he preyed eft azeyn

God hem sende plente of reyn

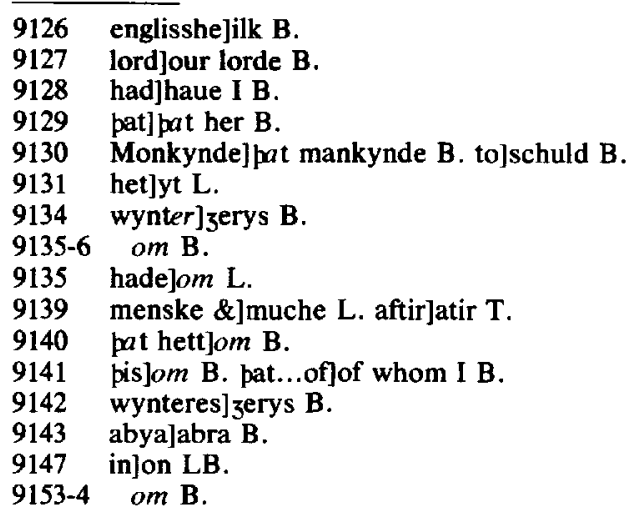


He was pe firste storyes sayes

pat dede men reysed in po dayes

Of Ioseph coom Ioram

pat eizte wynter regnede wip wham

Was a prophete elizeus

And as pe story tellep vs

9160

Ely was pat tyme pare

Translated in golden chare

//Of pis Ioram coom osyas

Of regne fifty wynter pat was

In pat tyme pat I of mele

In pat lond were prophetis fele

Isaias . Ioel . Osee . Abdyas .

Amos . Ionas . \& mecheaas

pe eiztepe sibile bigan to ryse

pat was of prophecye ful wyse

Of ozias coom Iothan

Sixtene zeer he regned pan

Romulus was be firste man

pat regned in rome \& hit bigan

// Achaz his sone aftir him coome

fol. $53 \mathrm{v}$ col. 2

Pat tyme was made pe toun of rome

Sixtene zeer regnede achaz

Of him coom ezechias

He regnede nyne \& twenty zeere

Wel was he loued wip ihesu dere

Penne regned manasses

Pat was his sone wipouten lees

Pat tyme was seip pe story

A sibile pat het of samy

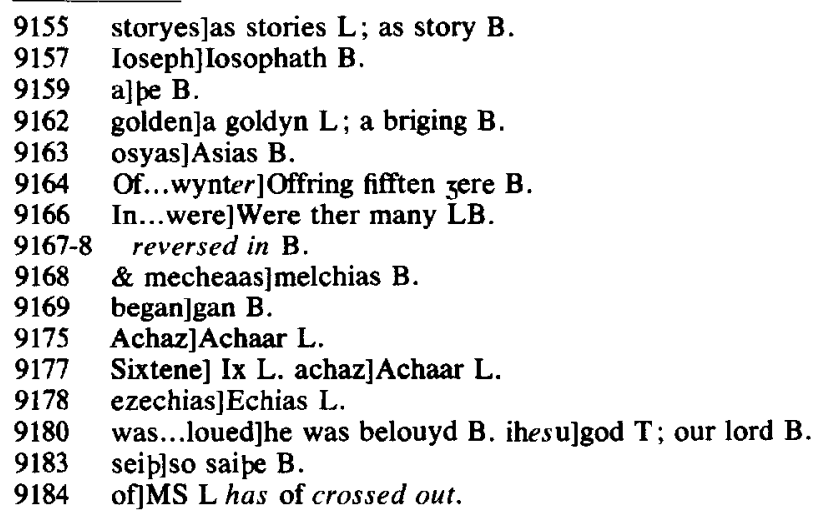


Of pis manasses coom amon po

As his fadir tofore dide go

Foles were pei bope vnslye

pei honoured euer maumetrye

Amon sone het Iosyas

Douzty kyng in his tyme was

9190

Fordide pe toun of nynyue

pat was aboute Iourneyes pre

pat stonden had in tyme pore

Fourty hundride zeer \& more

Pat tyme was prophete Ieremye

Spekyng in his prophecye

Iosias gat Ieconyam

pe transmigracioun was pan

Pat pe book of mynde mas

pere was a kyng sedechias

In pis tyme was pe Iewes lond

Wonnen al into sarazines hond

Ierusalem was stryed \& take

pat kyngdome fel into wrake

And as we in pe story descende

9205

In pat tyme was pe temple brende

9200

fol. $54 \mathrm{r}$ col. 1

Thourze a kyng of babilone

In praldome he had hem done

Nabugodonosor he hizte

Stronge he was of myche myzte

Twelue monepe biseged he hit pon

And for defaute of mete hit won

pe kyng fley out bi nyzt

Wip his boldest men \& wizt

He was take as he fley

His sone slayn in pat wey

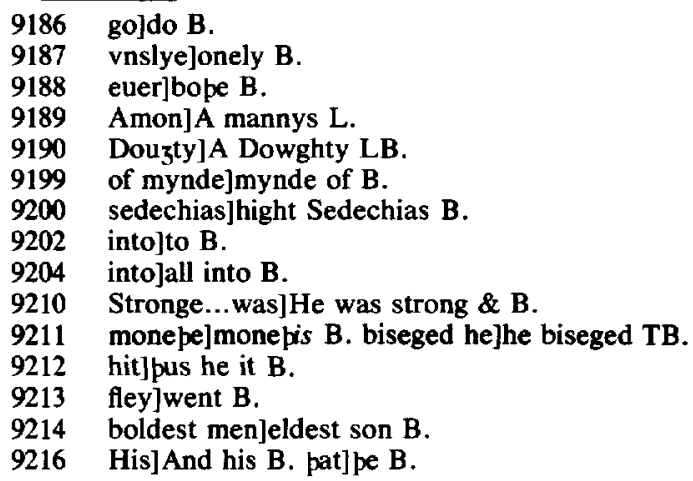


And himseluen dide pei bynde And kest him into prisoun blynde pe iewes were put out of state And her kyngdome al transolate 9220 pat foure hundride zeer had stonde And fifty at pat day ne[re]honde Pe ferpe elde of pe world is tolde Pat was foure hundride wynter olde And fyue \& sixty zeer \& pre But sip pis world bigan to be Is foure pousande six hundride fol Who so redily rekene hit wol 
This page intentionally left blank 


\section{Explanatory Notes}

\section{LIST OF ABBREVIATIONS USED}

The abbreviations of biblical books are the standard ones listed in Biblia Sacra, Denuo ediderunt complures Scripturae Sacrae Professores Facultatis theologicae Parisiensis et Seminarii Sancti Sulpitii (Rome, 1956), xli.

Linguistic abbreviations are also standard:

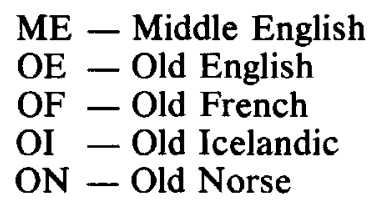

In the following list, the abbreviation used is followed, if necessary, by the full title of the work, and the first word or words of the entry in the Bibliography, where full information can be found.

Ad. \& Ep. - Adrian and Epotys in SMITH, Lucy Toulmin, A Commonplace Book.

Adnot. in Pent. - Adnotationes Elucidatoriae in Pentateuchon. HugH of St, Victor.

Anc. Corn. Dr. - Ancient Cornish Drama. Norris, Edwin, ed.

Anc. Test. - Traduction anonyme de l'ancien testament.

Ancrene Riwle - DAY, Mabel, ed.

Apocalypse of Moses - in CharLes, R. H., ed. Apocrypha and Pseudepigrapha.

Auch. - Canticum de Creatione aus MS Auchinleck in Horstmann, C., ed. Sammlung Altenglischer Legenden.

Ayenbite - Ayenbite of Inwit. MORRIS, Richard, ed.

Book of the Knight of LaTour-Landry - WRIGHT, Thomas, ed.

Cant. Creat. - Canticum de Creatione aus MS Trin. Coll. Oxf. 57 in Horstmann, C., ed. Sammlung Altenglischer Legenden.

Chester - Chester Plays. LUMIANSKY, R. M., ed.

Cleanness - GollanCZ, Israel, ed.

CM-Cursor Mundi. MoRRIs, Richard, ed. 
Conf. - Confessiones. Augustine.

Creat. of World - Creation of the World, Stokes, Whitley, ed. and trans. DCD - De Civitate Dei. Augustine.

Dest. of Troy - "Gest Hystoriale" of the Destruction of Troy. PAnton, ed. DGAL - De Genesi ad Litteram. Augustine.

DGALIL - De Genesi ad Litteram Imperfectus Liber. AugusTine.

DGCM - De Genesi Contra Manichaeos. Augustine.

Dict. théol. cath. - VACANT, A. et al., eds. Dictionnaire de theologie catholique.

DIM - De Imagine Mundi. Honorius Augustodunensis.

Elucid. - Elucidarium. Honorius Augustodunensis.

I Enoch, II Enoch - in Charles, R. H., ed. Apocrypha and Pseudepigrapha.

Etym. - Etymologiarum. IsIDORE.

Fall of Princes - Lydgate's Fall of Princes.

Fest. - Mirk's Festial. Mirk, John.

$G \& E$ - Middle English Genesis and Exodus. Arngart, Olof, ed.

Harley fragment - MEYER, P. "Notice et Extraits...", Romania (1907).

Higden - Polychronicon Ranulphi Hidgen. Higden, Ranulph.

Hist. Jos. - L'Histoire de Joseph. STEUER, Wilhelm.

Hist. Schol. - Historia Scholastica. Perrus Comestor.

$I \& I-I a c o b$ and loseph. NAPIER, Arthur S., ed.

Index - Brown and RoBbins.

Josephus - Jewish Antiquities. Josephus.

Jubilees - Book of Jubilees. ChARLES, R. H., ed.

Kemble - Dialogue of Salomon and Saturnus. Kemble, John M., ed.

Kildare - Die Kildare-Gedichte. Heuser, W., ed.

Leg. Aur. - Legenda Aurea. Jacobus a Voragine.

Legende - LAZAR, Moshé.

Life of Christ - FosTER, Frances A., ed.

Lud. Cov. - Ludus Coventriae. Block, K. S., ed.

"Lydgatiana" - MACCRACKEN, H. N.

Life - Vernon - "The Life of Adam and Eve" in BLAKE, N. F., ed. ME Religious Prose.

MandeVILLE L - Mandeville's Travels. LetTs, Malcolm, ed.

Mandeville S - Bodley Version of Mandeville's Travels. Seymour, M. C., ed.

MED - Middle English Dictionary. KuRATh, Hans and Sherman M. KUhN, eds.

Met. Para. - A Middle English Metrical Paraphrase of the Old Testament. KALÉN, Herbert, ed. Vol. I. OHLANDER, Urban, ed. Vols. II-IV.

Midrash - Midrash Rabbah. Freedman, H. and Maurice Simon, eds.

Myroure - Myroure of oure Ladye. BLUNT, John Henry, ed.

Newcastle Noah - Newcastle Play of Noah's Ship, in DAvis, Norman, ed.

North. Homs. - the Northern Homily Cycle. Northern Homilies.

OED - New English Dictionary. Murray, James A. H., ed.

OEGen. - Genesis in KraPP, George Philip, ed. The Junius Manuscript.

Ormulum - HOLT, Robert, ed.

Piers Plowman - SKeAT, Walter W., ed.

Pilg. Life of Man - Pilgrimage of the Life of Man. Deguileville, Guillaume de. 
Pricke of Conscience - MorRIs, Richard, ed.

Queen Mary's Psalter - WARNER, George, ed.

"Questiones" - "Questiones be-twene the Maister of Oxenford and his

Clerke". Horstmann, C., ed.

Rashi - Pentateuch with... Rashi's Commentary. Rosenbaum, M. and A. M. SilbermanN, eds.

Rev. Meth. - "Middle English Metrical Version of the Revelations of Methodius". D'Evelyn, Charlotte.

SEL - South English Legendary. D'Evelyn, Charlotte and Anna J. Mill, eds.

SELTemp. - South English Legendary, Temporale.

Sent. - Sententice. Petrus Lombardus.

Speculum Vita - in UllmanN, J. "Studien zu Richard Rolle de Hampole". Story of the Holy Rood - Legends of the Holy Rood. MorRIS, Richard, ed.

Sum. Theol. - Summa Theologica. Thomas Aquinas.

Targ. of Jon., Targ. of Onk. - Targums of Onkelos and Jonathan Ben Uzziel on the Pentateuch. ETHERIDGe, J. W., ed.

Towneley - Towneley Plays. England, George and Alfred W. Pollard, eds.

Trad anon. - Traduction anonyme de la Bible entière.

Trin. Camb. - "Zwei Gedichte aus der Handschrift..." Brunner, Karl.

WM. of Shoreham - Poems of William of Shoreham. William of SHOREHAM.

WyntoUN - Original Chronicle of Andrew of Wyntoun. ANDREW OF WYNTOUN.

York - York Plays. SмIтн, Lucy Toulmin, ed.

\section{EXPLANATORY NOTES}

1ff The Trad. anon. opens in a similar way. The poet mentions several popular romances, and then urges his hearers to abandon them and listen to something more edifying. BONNARD, p. 85 prints the relevant passage from the Old French poem. Cf. also the opening of William of Nassyngton's Speculum Viter, 11.35-48; Karl BRUNNER's edition of Richard Cou de Lion, 11.7-20.

3 Only one extant Middle English Alexander Romance could conceivably have been known to the $C M$ poet. The rest were all composed later. See Severs, Manual, I, pp. 104-13, 268-73.

4 Julius Caesar was not a popular romance character.

5 On ME Troy poems see Severs, pp. 114-8, 274-7. The story was told in French from the twelfth century.

7 The story of Brutus, who came from Troy to found Britain was known from at least the ninth century.

13 Dickens and Wilson, Early ME Texts, p. 223 point out that C's "wawan" is the French form of the name. 
15 The best known story of Charlemagne and Roland is, of course, the Chanson de Roland. See also Severs, pp. 80-100, 256-66.

17-8 Only one ME poem is wholly devoted to Tristan. See SEvERs, pp. 75-9, 253-6. MSS CF refer to a specific incident in the Tristan legend, now known only in two MSS of the French La Folie Tristan. See Bossuat, Manuel, items 1657-68, 6312. The reference in MSS GTLB is much more general.

19 Ioneck, MSS CF, is now known only in Marie de France's lai Yonec. The name seems to have been unfamiliar to the scribes also, for it is corrupted to "kyng Ion"' in MSS GTLB.

The story of Isombras is told only once in $\mathrm{ME}$, in an early fourteenth century poem. See SEVERS, pp. 122, 279.

20 The story of Amadas and Ydoine is now extant only in French. See Bossuat, items 1232-40. However, the pair were obviously well-known to ME writers. See Emaré, 11.122-3; Sir Degrevant, 11. 1493-4.

37-8 This exact proverb is not recorded in Whiting Proverbs, but cf. his items F.685 and F.689.

83 MS C's "loue" is an error for "life", as in FGTLB.

111-130 This is the $C M$ poet's own statement of purpose and his description of the structure of his work.

122 The idea of "running over" the history of the world has analogues in other languages. Cf. the explanation of the title of Hugo von Trimberg's historical work Der Renner, which is roughly contemporary with the $C M$ :

Renner ist ditz buch genant,

wanne ez sol renne durch di lant.

131-222 Two French paraphrases have versified tables of contents. The one in Trad. anon. is only about 20 lines long, but that of Geoffroi de Paris takes up eight folios.

188 MSS GHTL have the man sick for 28 years. Only CFB have the correct reading of 38 years. Cf. Ioan. 5:5.

217-20 Neither the sorrows of Mary nor the institution of the Feast of her Conception is found in the southern translation, which ends at $1.23,898$.

219-20 MS E breaks off after $1.24,968$, and is the only extant MS of the $C M$ which ends where this table of contents says it should.

231-50 The poet declares his intention of writing in English for the common people. Cf. Grosseteste, ME Translations, 261/35-8, 362/73-4; Morris, ed., Pricke of Consc., 336-9.

The southern translator omitted some of the references to French (11.237-42). The original author of the poem was writing at a time when the English language was only beginning to oust Anglo-Norman as a literary language. As his sources were almost all in French or Latin, he must have been conscious of himself as a pioneer writer of biblical paraphrases in English. The southern translator, however, would be unaware of the language of the sources. Also by the time he was working on the $C M$, the use of Anglo-Norman must have been well on the wane. See LegGe, Anglo-Norman Lit., pp. 5-6. Cf. Évrat's discussions of the French language as a vehicle for translation, Gen., fol. $2 v$ col. 1 , fol. $25 v$ col. 2.

233-5 These lines are much discussed in connection with the $C M$ 's provenance. Certain linguistic evidence suggests the poem was written in 
Scotland. See Kaluza, "Zu den Quellen", p. 453; STrandberg, Rime-Vowels, xiv-xv; KAISER, Zur Geographie, p. 6; BENNETT and SMIThers, Early ME Verse and Prose, p. 367. These lines, however, seem to rule against that possibility. Kaiser, pp. 5-14, tries to prove that the term "England" applied to all the territory south of the Clyde-Forth line in the fourteenth century. Recent research into Scottish mediaeval history, however, strongly suggests that a fourteenth century poet speaking of "England" is referring to exactly the same territory as a twentieth century reader would understand by the term. See esp. BARRow, "Anglo-Scottish Border", pp. 21-42.

258 Morris' emendation of C's "fro" to "frote" is unnecessary. See MED "fro" n. [Cp.OI fro], meaning "profit, comfort, relief".

267-8 The southern translator missed another chance to explain the title of his poem here. Cf. 11.121-2 above.

$270 \mathrm{ff}$ As promised in the prologue, 11.125-30, the poet grounds his work in the Trinity.

279-88 These lines are suggested by Elucid. I 6, a work which the $C M$ poet here begins to use extensively. The Father created the world ("ordayned" 1.285), the Son maintains it ("gouernep" 1.286), and the Holy Ghost gives it life ("multeplied" 1.286).

289-308 From Elucid. I 3. Similar comparisons are in Augustine, "Sermo de Quarta Feria" vi, PL XL 692 and "De Symbolo: ad Catechumenos Sermo Alius" ix, PL XL 658; ANSelm, De Processione Sancti Spiritus xiii-xiv, PL CLVIII 306-7; OtLo of ST. EmMERAN, Liber de Admonitione Clericorum et Laicorum ii PL CXLVI 247; AELfRIC ed. Thorpe, I 282.

Honorius in the Elucidarium lists the properties of the sun as "ignea substantia, splendor et calor". The CM's "bodi rond" is a poor translation of the first. Aelfric also had trouble with the phrase, and called it "seo lichamlice edwist paet is Pere sunnan trendel". The CM poet's version sounds more like Otlo"s: "corpus in modum rotae constans, et splendorem atque calorem ipsius."

In the CM, the noun "heat" of MSS CF has been miscopied as the adjective "hot" in GHTLB. In these latter MSS, therefore, the three attributes of the sun seem erroneously to be roundness, heat and light, but cf. 1.303 , where the body of the sun more correctly symbolizes the Father.

299 MS C's "erth" is an error.

309-13 God is sometimes referred to as a fountain in scripture. See Ier. 2:13, Ier. 17:13, Ps.35:10. Honorius Elucid. I 4, calls Him "fons et origo", a very common Latin phrase. The "welle pat neuer is dry", however, seems an echo of $I s .58: 11$ : "sicut fons aquarum cujus non deficient aquæ".

311 The corruption of "for" or "forpi" to "ouer" in MSS GHTLB obscures Honorius' original meaning: God is the fountain "a quo omnia procedunt". Elucid. I 4.

314-22 Elucid. I 6.

316 MS C, although unmetrical, is closest to the original reading, translating "ne in nihilum dissolvantur",

319-22 The southern translation omits the widely known Augustinian description of the Trinity as "minning" (memoria), "vnderstanding" 
(intelligentia), and "will" (voluntas). See Augustine, De Trinitate X xii, PL XLII 984. Cf. below 11.562-8.

323-30 Elucid. I 15. L1.327-30 lack a context in CM. In the Elucid. they answer the pupil's question about whether God lived alone before the creation of the world. By the end of the fourteenth century, the idea that God was not older in time than his creation was condemned as heresy by Nicholas EYMERIC in the Elucidarius Elucidarii. See Elucid. p. 491.

331-4 The $C M$ poet picks up the "artifex" image of the previous lines and carries it further. This passage does not come from Elucid. Cf. Augustine's $D G C M 1$ vi, $P L$ XXXIV 178.

332 MSS CF have the better reading. The point is not God's supreme dignity, as it appears to be in MSS GHTLB, but his difference from other workmen. The line was probably rewritten to eliminate "sere" (ON sér).

335-6 These lines pose both a linguistic and theological problem. The linguistic problem concerns the meaning of "euene". Kaluza in CM p. 1704 glossed this word as "image, resemblance, likeness", but this is quite wrong. The $O E D$ prints this line from the $C M$ under "euene" sb.1: "material; subject matter", but this raises the theological issue. If "euene" means material, then the $C M$ poet is saying that God created the world from Himself, ex deo, rather than from nothing. The idea of creation ex deo does appear in the Middle Ages, most notably in the work of Scotus Erigena and Nicholas of Cusa. However, the Church strongly supported creation ex nihilo. Less than 100 years before the $C M$ poet wrote, it condemned the works of Erigena and of two of his twelfth century followers, Almeric of Bena and David of Dinant. People were burned in France in the 1220's for subscribing to this pantheistic heresy. On this subject see esp. Wulfson, "Meaning of Ex Nihilo" and CoHN Pursuit of the Millennium. This is not the sort of doctrine to appeal to a conservative ME poet writing for "lewed folk".

I suggest that the $C M$ poet may be using the word "euene" either to mean "ability, resources, means", as in $M E D$ "evene" (b), or, as in $M E D$ "evene" (c), to mean "occasion, cause". Honorius writes at this point: "Quae fuit causa ut crearetur mundus? Bonitas Dei, ut essent quibus gratiam suam impertiret.",

337-54 Elucid. I 17, 19-20.

341 In spite of Morris' note, $C M$ p. xxxii, MSS CF are closer to the poet's original, translating "In ictu oculi, id est quam cito possis oculum aperire"'.

342 Not in Elucid.

343ff This is the fullest explanation of creation in Middle English. The story in Genesis posed two main problems for mediaeval theologians: (1) did creation occur all at once, as suggested by Eccli.18:1 and Gen.2:4, or over a period of time, as told in Gen. 1; and (2) what exactly was produced by God's first creative act? The $C M$ poet follows received opinion by saying that God, in a single act, created the matter from which the world would be shaped, and then spent six days separating it into elements and ornamenting his work.

344 MSS CG's "first" translates Elucid.'s "semel".

345 Cf. $n$. to $11.335-6$ above.

346 Eccli. $18: 1$. 
347 Perhaps suggested by $S a p .11: 21$ : "sed omnia in mensura, et numero, et pondere disposuisti".

348-58 The poet's first explanation of the nature of the "prima materia" comes from Elucid. I 20. The matter is a jumbled mixture of the four elements (11.349-50), which is later given shape in the six day period described in Genesis $(11.351-2)$. Cf. Petrus Lombardus, who said that matter existed "in forma confusionis ante formam dispositionis". See Sent. II xii, PL CXCII 676.

351 MSS CF read "sythen"; G has "fin", an error for "sin". This latter reading the southern translator miscopied as "ful".

353 The six day period of the Hexaemeron following the opus creationis is further divided. The first three days consist of the opus distinctionis, during which the elements are separated from each other and arranged in a hierarchy. Cf. GEoffroI DE PARIS, fol. 1v col. 2:

$\mathrm{Li}$ secons chapistres dira

Coument Diex le monde estora,

Les iiij ellemens a compas,

L'un plus haut et l'autre plus baz.

354 Honorius writes that in the last three days of the Hexaemeron, God shaped those things "quae sunt infra elementa", that is those things which are made up of the elements. "Infra" was miscopied as "intra" in some Latin MSS, such as BL' Harley 5234 fol.90r col.1. This error in Latin produces the CM's nonsensical line. The error was widely circulated, however, for it turns up in many of the European translations of the Elucidarium. See SchmitT, Die Mittelenglische Version, p.5; the Old French Translation I in MS BL Add. 28260 fol. 37v; REYNAUD, "Elucidarium", p. 221 (Provençal); JonEs and RHYs, The Elucidarium, p. 5 (Welsh); Helgason, The Arna Magnaan Manuscript $674 A$, fol. $4 \mathrm{v}$ (Old Icelandic).

355-8 Not in Honorius. HaEnisCH, $C M$, p. $4^{*}$ suggested that the poet took these lines from Hist. Schol. Gen. i, PL CXCVIII 1055-6, where Comestor names the elements in refuting the atomic theories of Epicurus. In any event, their names would be familiar to the poet from other sources.

359-72 This is a second explanation of the nature of the first created matter, a division which is blurred in the southern translation by the substitution of "And" for "Or" (CF) or "Ayder" (G). The poet attributes this theory to Augustine (1.360) although it is taken from HuGH of ST. VICTOR's Adnot. in Pent. Gen. v, PL CLXXV 34. Hugh was sometimes called the second Augustine, however, and some of his works may have been attributed to Augustine. See Roger BARON, "Hugues de SaintVictor", p. 224. L1.362-8 sum up the Augustinian position. See DGCM I iii, $P L$ XXXIV 176; $D G A L I L$ iii-iv, $P L$ XXXIV 222-7; Conf. XII ii, v-viii, $P L$ XXXII 826-9; $D G A L$ II xi, $P L$ XXXIV 272-3; $D C D$ XI vi.

362 An exact translation of "angelicam naturam", Augustine's interpretation of the "coelum" of Gen. 1:1.

363 Adnot. in Pent. PL CLXXV 34, "pe world" is the physical universe, the "terram" of Gen. 1:1. Time cannot exist without motion and change. Motion and change cannot occur in God, but only in a created thing. Therefore time begins simultaneously with the first motion and change, i.e. with the first creature. See $D G C M$ I ii, $P L$ XXXIV 174-5; $D G A L I L$ iii, $P L$ XXXIV 222-4; Conf. XI X-Xiii, $P L$ XXXII 814-5; $D C D$ XI vi; 
Hist. Schol. Gen. i, PL CXCVIII 1056; Sum. Theol. Q.LXVI art. 4. Thus for Augustine the world is created simultaneously with the beginning of time rather than before time began, as in BeDE, In Pent., PL XCI 191, whose opinion appeared in the Glossa Ordinaria, PL CXIII 69, or in time, as in Thierry of Chartres. See HARING "The Creation and Creator", p. 186 no. 5 .

366-7 This is not the same jumbled mixture of elements described in 11.34950. It seems at first to be Augustine's prima materia, which he conceived to be absolutely without all form (in the scientific sense of the word), as his Old Latin translation of the Bible declared: "Terra autem erat invisibilis et incomposita" (Gen. 1:2).

Cf. a Picard fragment quoted by Berger, La Bible française, p. 266: "Au commenchement du monde crea Dieu le ciel et le tierre mais devant chou li eliment n'estoient mie devisé li un de l'autre..."

368 MS F mistakes "serenes" for "sternes", but this is meaningless as exegesis.

369-72 Even Augustine admitted that matter could not exist absolutely without form, but his solution was to state that the priority of matter over form was not a temporal but a causal one. See $D G A L$ I xv, $P L$ XXXIV 257-8. The explanation given here by the poet, however, is Hugh of St. Victor's modification of Augustine's idea: "[materia] creata est autem informis, non ex toto carens forma; sed ad comparationem sequentis pulchritudinis et ordinis, informi potest dici." See Adnot. in Pent., PL. CLXXV 34.

Note that "shaples" here is used in the technical sense to translate "carens forma". The $O E D$ gives the earliest instance of this usage in Piers Plowman A. Cf. 1. 350 above, where "shaples" is used loosely to mean simply "having no definite or regular shape". Similarly, "of forme vnshapen" (CF "mischapen") in 1. 367 translates Hugh of St. Victor's "informis", although the $M E D$ gives the earliest instance of this technical meaning of "forme" (14b) as Gower's Confessio Amantis 7.214 .

371 "how" in MSS GHTLB is a miscopying of "I tru" (CF).

373-408 A mixture of the accounts of Genesis, Honorius and Hugh of St. Victor: 11.373-81, Adnot. in Pent. vi, PL CLXXV 35; 11.382-94, Gen. 1:10-8; 11.395-402, Elucid. I 20; 11.403-4, Adnot. in Pent., loc. cit.; 11.405-6, Elucid. I 68; 11.407-8, Gen. 2:2-3.

375 MS F's "lift" is the original reading. C's "light" is an error.

The poet passes to the works of the second day without mentioning the creation of the light. This may reflect the author's Augustinian interpretation of the "lux" of Gen. 1:3-5 as the creation or perfection of the "angelicam naturam" or "aungel kynde". See DGALIL I iii, PL XXXIV 222-4; Conf. XIII iii, $P L$ XXXII 846; $D G A L$ I iii, $P L$ XXXIV 248-9; $D C D$ XI ix, xxxiii, $P L$ XLI 323-5, 346-7. Cf. Elucid. I 20 and 27, and also $G \& E$ 61-4 and Met. Para. 51-4.

This line erroneously implies that the stars were created with the firmament, although in fact they did not appear until the fourth day. The poet may have wished to imply that the particular "sky" created on the first day was that which would later house the stars. He may have been thinking of DIM I lxxxvii, PL CLXXII 141 which says of the firmament 
"stellis undiqueversum ornatum". Cf. also BEDE, Hex. I, PL XCI 18:

"Hic nostri coeli, in quo fixa sunt sidera, creatio describitur".

376 MS C's reading "sonded" is a corruption of an original "wit water sonde als cristale", translating Adnot. in Pent. vi, PL CLXXV 35: "de aquis solidatis quasi crystallinus lapis". Cf. DIM I lxxxvii, $P L$ CLXXII 141. See $O E D$ "sound" a. 4.a.: "solid, massive, compact". The readings "clere" or "shynynge" in the other MSS come about because of the widely known properties of crystal. Cf. Whiting, Proverbs, C587-C594.

377-8 MoRris, $C M$, p. xxxii suggested emending "sondid" (C) to "sonderd", which makes much better sense. Without this change, the poet gives no idea of the function of the firmament in separating the waters above from those below. Cf. Gen. 1:7. MS F's reading is a scribal reworking of corrupt lines.

Morris also suggested emending his reading of $\mathrm{C}$, " $\mathrm{p}[\mathrm{e}] \mathrm{se}$ ", to "yse", but "yse" seems to me to be the reading of the MS itself. Two sources known to the $C M$ poet thought of the firmament as made of ice. See DIM I lxxxvii, PL CLXXII 141; Hist. Schol. Gen. iv, PL CXCVIII 1058 ; cf. $G \& E 97$.

384 Most of the scribes had trouble with this line. MSS CG read "gress and frut", translating "herbam... et... fructum" (Gen. 1:11). F makes no sense with "and bad hit [the earth?] grow and frute forb bringe". The southern translator mistook "and" for the northern ending of the present participle. He wrote "grisyng", (HT), as in MED "grassen" v. (a) "to become covered or decked with grass, produce grass". This modifies "hit" (the earth): "And bade the grass-producing earth bring forth fruit". The scribe of L was dissatisfied with "grisyng", however, and wrote "cresyng", as in MED "cresen" v. (1) "To become larger, increase". The scribe of B came close to reproducing the original form of the line by writing "grape \&".

401 "goynge beestis" is an anticipation of Gen. 1:28.

402-6 The poet follows the example of Genesis in giving only a brief account of Adam's creation here and reserving the full details for the beginning of the story of his fall. The biblical structure results from the fusion of two narratives. For details see Ackroyd and Evans, Cambridge History of the Bible, I, pp. $71 \mathrm{ff}$.

403-4 Perhaps from Hugh of St. VICTOR, loc. cit.: "Et merito post omnia factus est homo, qui omnibus praeferendus erat".

405-6 Elucid. I 68 quotes the popular Jewish tradition that Adam was created in Hebron. Cf. Legende 44/2, 45/18; KeMBLE 283; GrosSETESTE, ME Translations 264/126, 356/73; Creat. of World 340; Ad. and Ep. 517; Wyntoun I 67. The $C M$ poet must also have known the equally popular tradition that Adam was created "in agro... Damasceno". See Hist. Schol. Gen. xiii, PL CXCVIII 1067; G \& E 207; Life of Christ 6185-8; Higden 219; Wyntoun I 65; Fall of Princes 500; Chaucer's "Monk's Tale" 2007-8; MANDEville, ed. Letts, p. 48.

411-24 Elucid. I 23, perhaps suggested to Honorius by ANSELm's De Similitudinibus xliii, PL CLIX 623-4.

420 The number of angels created was usually left vague. The pseudoDionysius himself declared that the number was known only to God and 
that earthly intelligence was incapable of comprehending it. See $D e$ Caelesti lerarchia vi and xiv, $P L$ CXXII 1049, 1064. Cf. Dan. 7:10. 425-8 Elucid. I 26.

429-32 Elucid. I 23.

430 The nine orders of angels derive from the tradition of the Celestial Hierarchies of the pseudo-Dionysius, in which the nine orders are ranged in groups of three. The Gregorian tradition does not subdivide the nine orders. See Gregory's XL Hom. in Evang. II Hom. xxxiv, PL LXXVI 1249-50.

432 Cf. Gregory, loc. cit. and note to $11.514-6$ below.

$437 \mathrm{ff}$ The story of the fall of Lucifer is based on $I s$. 14:12-5, Ez. 28:2-19, Luc 10:18, Apoc. 12:3-9.

441-2 Dustoor, "Legs. of Lucifer", p. 232, suggests that these lines are translated from Bonaventura: "Dictus est autem Lucifer quia prae ceteris luxit." However, the connection of the name Lucifer with light is popular in vernacular writings. See WM. OF Shoreham 389; "Lydgatiana" I 13; Kildare 18; Trin. Camb. 10; North. Homs. ; Chaucer's "Monk's Tale" 2004.

445-6 The meaning of these lines has been altered in transmission. The original version said that Lucifer ceased to know God who had created him:

Allas! caitif he kneu him noght,

pat hee drightin pat had him wroght; (CF)

MSS GHTLB, however, by omitting the second "pat", alter the sense to mean that Lucifer forgot that God had created him at all. In these MSS, Lucifer takes a Manichean position on the origins of the powers of darkness. See Augustine, DGAL XI xiii, PL XXXIV 436. The idea that Lucifer denied that God had made him is found in RUPERT OF ST. Heribert, De Victoria Verbi Dei I, xii-xiii, PL CLXIX 1227-8, where it is based on $E z, 28: 2$ and 29:3-4. Cf. Paradise Lost, V 833ff, 853ff, and MCCOLleY, "Milton's Battle", 230-5.

450 Is. 14:14.

451 Lucifer's pride can manifest itself in several ways. Augustine stressed his self-love, which is expressed as vanity in a number of vernacular works. See Cleanness 209; Met. Para. 61-4; Ancrene Riwle, 22/34-6; York I 49-56, 65-72; Creat. of World 114-33; Ayenbite p. 16; Pilg. Life of Man 12564-87; Dest. of Troy 4409. Augustine also said that pride gives rise to envy in $D G A L$ XI xiv, $P L$ XXXIV 436, cf. Sent. II, Dist. v, $P L$ CXCII 661. Envy, either of God $(G \& E$ 273-6) or of the newly created man (as in the Latin Vita Adae et Evae and all its vernacular derivatives, see Mozley, p. 132), is often stressed as the chief sin of Lucifer. By contrast, the author of the $C M$ is most indignant over Lucifer's disloyalty to God who had given him all he had. This interpretation, tinged by feudal concepts, is also found in Piers Plowman B I 110, 112, cf. B XII 41-6, and in Cleanness 210, and is much stressed in the $O E$ Gen. $(267,277,283,291,743)$.

457-9 Is. 14:13.

465-6 Cf. 11. 488-90.

469 The tradition that Michael cast out the devil is based on Apoc. 12:7, but is found also in I Enoch 10:11-16. Few vernacular works, except those specifically in honour of St. Michael, tell of his part in defeating the 
rebels. See SEL 407/189ff; Mirk's Fest. 259; possibly also Trin. Camb. 35-6.

485-6 Perhaps suggested by Elucid. I 43. Cf Anselm, Cur Deus Homo II xxii, $P L$ CLVIII 430, and Woodburn O. Ross, ed., ME Sermons, p. 314.

488-90 Elucid. I 36. The length of Lucifer's stay in heaven is problematical. $E z$. 28:13 could indicate that the devil enjoyed a short period of happiness before his fall, but Ioan. 8:44 could mean that he did not. Many commentators agreed with Honorius that there was no interval between Lucifer's creation and his fall. See Augustine DGAL XI xvi, $P L$ XXXIV 437; IsIDore, Sententiae I x, PL LXXXIII 555; Sum. Theol. Q LXIII art. 6; so too, by implication, Met. Para. 53ff, cf. 1.66.

495 Elucid. I 40. The southern translator miscopies "air" (CFG) as "erpe". $B$ corrects this.

In line 478 the poet simply followed $I s$. in assigning the fallen angels to hell. Here, however, he follows a long patristic tradition which put some of the demons on earth and some in the air. The devil's access to earth is mentioned in $I s .14: 12, E z .28: 17 ; I o b .1: 7,2: 2 ;$ Apoc. 12:9. Cf. Augustine, Ennarrationes in Psalmos CXLVIII 9, PL XXXVII 1943; Sent. II, iv, Dist. vi, $P L$ CXCII 663 quotes Ioan. 14:30: "princeps aeris (alias mundi)"; Hist. Schol. Gen. viii, PL CXCVIII 1061. In Middle English see $G \& E$ 288; Trin. Camb. 14; SEL 408/192, 194, 409/219-21; Life - Vernon 106/78-9; Piers Plowman B I 123; "Quaestiones" 286; Mirk's Fest. 259; Ad. \& Ep. 387-92; Myroure, p. 303.

497-502 Elucid. I 43, 50. The subsequent fate of both good and bad angels was discussed fairly often. See Augustine, $D C D$ XI xiii and XXII i; Enchir. xxix, PL XL 246; Gregory, Moralium XXVII xxxix, $P L$ LXXVI 438; XXXIV vii, $P L$ LXXVI 724; Hom. in Ezech. I vii, $P L$ LXXVI 849; Petrus Lombardus, Sent. II Dist. vii, $P L$ CXCII 664-5; Hugh of St. VIctor, Summa Sent. Tract II 84, PL CLXXVI 84 ; and Thomas AQUinas, Sum Theol. Q. LXIV art. 2. While many vernacular writers mention the devil's eternal damnation, suggested by II Pet. $2: 4$, and Iudae 6, few are concerned with the confirmation of the good angels. Cf. however, Life - Vernon 106/71-5; WM of Shoreham 412-4.

503-4 The poet is characteristically vague about the number of angels who fell. A frequent estimate is one tenth of the number who were created, for Gregory had suggested that man was created as a tenth order to fill up the gap left by the falling angels. See $X L$ Hom. in Evang. II xxxiv, PL LXXVI 1249. Cf. Cleanness 216; Kildare 30; North. Homs.; York I 256-7; VII 19; Cant. Creat. 340-2; Piers Plowman C II 106; Life of Christ 4007-8; Ad. \& Ep. 103-6; Towneley I 142; SEL 408-9.

505-6 Some paraphrases convey the distance through the time it takes the angels to fall, either seven days and seven nights (Auch. 44; Kildare 25 ), three days and nights (OE Gen. 306-8), forty days (Cleanness 224), or nine days (Piers Plowman B I 119).

507-10 The ultimate source of this estimate of the distance from heaven to earth is a passage in Moses Maimonides' Guide of the Perplexed, III 14. Largely through the Legenda Aurea, this topos reached many vernacular works. See Jacobus a Voragine, Legenda Aurea, p. 321; Life of Christ, 8925-38; Pricke of Consc. 7671-86; an anonymous poem of 20-odd lines found in two MSS, Brown and RobBINS, Index 2794; 
"On the Leaps which Christ Took", ed. Person, Camb. ME Lyrics, p. 29 ; as a page filler in a sermon book, MS BL Harley 2250 , fol. $83 \mathrm{v}$; and in a garbled version in Mirk's Fest. 152/24-8. A slight variant on the tradition is found in the French and English versions of the Image $d u$ monde. See O. H. Prior, ed., L'Image du monde, pp. 194-5; the verse version of the same work as in MS BL Harley 4333, fol. 65v; PRIOR, ed., Caxton's Mirrour p. 171; cf. SEL, "Michael III", 418/489-96.

The $C M$ poet attributes this calculation to Bede. I have not found such a passage in Bede's works. However, in one MS, BL Add. 36983 fol. $255 \mathrm{r}$ col. 1 , the third legend of Michael from the $S E L$, which contains this passage, is said to have been translated from Latin to English by Bede. This suggests a mediaeval tendency to credit Bede with writings of this kind because his works on the natural sciences were so well known.

514-6 Cf, 1.432. The poet has used two traditions here. The earlier line implies that nine orders of angels were created and some of each order fell. Man was always intended to be the tenth order. Honorius maintains this in the passage translated there: "novem quidem ordinibus angelorum et decimo hominum." Cf. Gregory, XL Hom. in Evang. II xxxiv, $P L$ LXXVI 1249. In line 516, however, the $C M$ poet suggests that all the angels who fell belonged to a tenth order, and that man was created to replace this order. Ten orders of angels appear in II Enoch 20:3.

517-8 This seems flatly to contradict Gen. 2:7, where Adam is said to be made of earth alone. However, commentators who wished to see man as a microcosm of the physical universe could say that the "limo terrae" was made up of several of the basic elements. See e.g. THOMAS Aquinas, Sum. Theol. Q. XCI art. 1. Cf. also SEL., Laud MS, 318/668-9.

517-52 Elucid. I 59. This passage deals with Adam's physical nature. My analysis of it is based largely on LEFÈrE's, Elucid. p. 115. First the writer says that Adam is composed of the four elements (11.519-20). Secondly he says that various parts of his body resemble the four elements: his head is like the sky or fiery element (521-30), his chest is like the air (531-4), his stomach resembles the sea (535-6), and his feet are like the earth (537-8). Then man's five senses are said to come from the five elements of Aristotelian tradition, which distinguished air from ether as two separate elements. See Aristotle, On the Heavens, Bk. I. Thus Adam's sight comes from fire (539), his hearing from the upper air or ether (540), his sense of smell from the lower air (Elucid. I 59), his sense of taste from water (loc. cit.), and his sense of touch from earth (542). Cf. Augustine, DGAL III iv, $P L$ XXXIV 281. In addition, the hardness of his bones comes from stones (543-4), his nails are like the trees of the earth, his hair like grass (545-6), and in his senses he is one with animals (547-8).

The locus classicus for this kind of statement about man's physical composition is II Enoch 30:8. The tradition was extremely popular in the Middle Ages, both in Latin and in the European vernaculars. See esp. Förster, "Adams Erschaffung", 477-529. J. M. Evans, "Microcosmic Adam" also deals with this topos.

Honorius repeats this description of man in his Sacramentarium I, $P L$ CLXXII 773. For an illustration of Honorius' conception of man as 
a microcosm in a twelfth century German MS, see M. W. Evans, Medieval Drawings, pl. 81.

Certain corruptions have crept into the $C M$ text.

519 Adam's blood is made from water, as in MSS CF, but GHTLB contain the scribal error "body" for "blod". His flesh is made from earth.

520 Adam's heat comes from fire, as in CF. MSS GHTL all contain the corruption of "heet" to "heer", but B corrects it again to "hete". Adam's breath comes from air.

521-2 MS F alone preserves the original translation of Elucid. I 59: "Caput ejus est rotundum in caelestis sphaerae modum." The lines are not spurious, as Morris suggests, $C M$, p. 38 .

527 The seven master stars translate Honorius' "septem caeli", that is the seven planets which are supposed to control men's actions.

531-4 Honorius in fact compares the chest to the air, for breathing and coughing simulate wind and thunder. The $C M$ poet has padded 1.533 by the meaningless addition of lightning with the thunder.

534 The reading "breed" in FGHTLB is a scribal corruption of C's "spred", Lat. "versantur".

539 Adam's sight comes from the fiery element. Scribal error corrupted CFG's "pe ouer fir", Honorius' "ex caelesti igne", into HTLB's "Thonder fyre".

540 His hearing comes from the upper air. Similar scribal error gives "Thonder eyer" in HLB for Lat. "ex superiore aere". MS T has further corrupted "eyer" into "oper".

541 His breath comes from the under air, or wind. MSS HTLB have corrupted "pis vnder wynd", Lat. "ex inferiore aere", to "pis wondur wynde".

542 His senses of touch ("fele") and taste ("fond") come from the earth. None of the MSS correctly translates Honorius' "ex aqua gustum, ex terra habet tactum".

546 Many other versions have veins instead of nails here. Honorius, however, has "unguibus". Note that this is plural, as is B's "nayles".

547-8 This translates Honorius" "sensum cum animalibus".

556 The image of God in man mentioned in Genesis is usually considered to be the soul. See, e.g., Elucid. I 61 ; Sent., II Dist. xvii, PL CXCII 685-6; Hist. Schol. Gen. ix, PL CXCVIII 1063.

557 Honorius used this image to describe the making of the angels in God's image in Elucid. I 54.

558 MS C errs in writing "licam" for "likeness". The resemblance between God and man is, of course, not physical but spiritual.

561-80 Elucid. I 61. The soul is here a microcosm of the Trinity as the body is a microcosm of the physical universe. Cf. 11.319-22, $\mathrm{n}$.

564 Morris, $C M$, p. xxxiii was puzzled by C"s "min" and preferred the readings of GT. However, the rhymeword "thrin" in 1.563 is probably original. "Thrin" (ON prinnr) in C is usually translated to "three" in the other MSS.

585-7 Adam is usually said to have been created a fully formed adult, so that he would be capable of working the land in the Garden. The reference to Augustine is probably to DGAL VI xiii, $P L$ XXXIV 348, but cf. De Peccatorum Meritis xxxvii, $P L$ XLIV 149. The $C M$ poet could also have found this in Hist. Schol. Gen. xii, PL CXCVIII 1066. 
The tradition was so well known in the Middle Ages that the Monk of Sawley added it to his translation of GROSSETESTE's Chateau d'Amour. See Grosseteste, ME Translations, 321/29. Cf. GinZberg, Legends V, p. 21 n. 21.

588 Gen. $2: 8,15$. Cf. $11.405-6$ and note above.

589-94 Elucid. I 64. The interpretation of Adam's name depends on the initial letters of the Greek words for the four directions - anatole, duses, arctos and mesembris. The tradition is a very old one. See Sybilline Oracles iii 24-6; II Enoch $\mathrm{xxx}$ 13-4. It became popular with the Fathers. See Jerome, Expositio Quatuor Evang., PL XXX 533; AugusTINE, In Joannis Evang., IX ii, PL XXXV 1465; Enarratio in Psalmum Xcv 15, PL XXXVII 1236; Bede, In Pent., PL XCI 216; Hugh of St. Victor, De Arca Noe Mystica iv, PL CLXXVI 686. It is also frequent in Irish exegesis. See McNally, The Bible, p. 26. It is attached to many MSS of the Vita Adae et Evae and their translations. See Mozley, 147-8/57. See also Kemble 178-80; Quaestiones 285; Ormulum 11.16384-16419; MACÉ, 369-85.

589 MSS CG's "not pe" is preferable to the "now $3 \mathrm{e}$ " or "mow $3 \mathrm{e}$ " of the southern scribes.

598-602 Elucid. I 64.

617 This begins the account of earth history. Throughout the Old Testament narrative, the poet stresses the world's decline from this state of perfection.

617-38 A conflation of Gen. 1:26 and Gen. 2:19-25.

625-6 The ME poet has Adam sleep during Eve's creation simply to keep him from knowing how God created her. Some MSS of the Elucidarium add the long-standing tradition that Adam's sleep was an ecstatic one, during which he received visions of the future. See Elucid. I 71a, and p. 232. Cf. Hist. Schol. Gen. xvi, $P L$ CXCVIII 1070, and in ME, $G \& E$ 224-6; Chester II 137-40. Jerome, however, objected to this interpretation on linguistic grounds, in Quaest. in Gen., PL XXIII 990.

The southern translator seems to have rewritten 1.625 because of the excess of verbs in the sentence.

633-4 Gen. 2:23 depends on a Hebrew pun. The woman is first named Issa (woman) because she came from Is (man). The Old Latin translation "mulier" completely ignored the pun, as Augustine complained in $D G C M$ II xiii, $P L$ XXXIV 206. Theodotian had tried to translate the word as "assumptio: quia ex viro sumpta est". See Isrome, Quaest. in Gen., PL XXIII 990. Jerome, however, fixed the Latin translation as "virago" from "ex viro sumpta est" in PL XXIII 990.

The $C M$ simply repeats the Vulgate translation, although the pun makes no sense in English. Other ME writers tried to do something with the pun. Some English versions of the Vita Adae give it literally: "this shalle pe cleped mannes deede [vir ago], for she is taken of man". See "Nachträge zu den Legenden" 355/6-7; DAY, ed., Wheatley $M S, 78 / 31-2$. Only $G \& E$ ingeniously tries to render an English pun:

Mayden, for sche was mad of man,

Hire first name đor bi-gan (235-6). 
637 The first "hem" is plural, but the second must be read as singular, referring to Adam, who is to multiply with "her" (1.638). Originally all three pronouns were plural, as in MSS CFG.

659 An intensification of the prohibition in Gen. 2:17 that they must not eat the fruit. Cf. Piers Plowman B XVIII 192; C XXI 200. Other accounts go even further, warning Adam and Eve not to go near the tree. See Rev. Meth. 31 ; SELTemp. fol. 1r col. 1.

660 The "double deep" is a favourite phrase of the $C M$ poet, picked up from Trad. anon. See fol. $215 \mathrm{v}$ col. 2, e.g. Exegetical tradition said that after the Fall, man can suffer the death of both the body and the soul. See, e.g., DCD XIII i-xii; Remigius of AuXerre, Comment. in Gen., PL CXXXI 62. Cf. Pricke of Consc. 1683-99.

663-8 Cf. Honorius' brief discussion of free will in Elucid. I 73. The Trad. anon. also discusses it, fol. $214 \mathrm{r}$. The $C M$ poet is not translating either one exactly, however.

672-82 Trad. anon. fol. $214 \mathrm{r}$ col. 2.

683-98 The idea that no animals would have been allowed to be harmful in Paradise is frequently met. See, e.g., IsIDORE, De Ord. Creat. x, PL LXXXIII 938; AELfric, Homs. of Aelfric, 678/39-40; Alexander Neckham, De Nat. Rerum II clvi, p. 249; Coli, Il Paradiso terrestre, 136, GraF, Miti, 52-4. However, this catalogue of animals in the $C M$ is almost unique among descriptions of Paradise in the vernacular biblical paraphrases. The poet translated it, slightly abridged, from Trad. anon., fol. $214 \mathrm{r}$ col. $2 .-214 \mathrm{v}$ col. 1.

The idea of this catalogue of animals in the French poem comes from $I s$. 11:6-8. This speaks of harmony between wolf and lamb, panther and kid, calf, lion and sheep, calf, bear and dog, asp and basilisk. Latin commentators usually glossed this to refer to the future triumph of Christ and his Church. See, e.g., Haymo of Halberstat, Comment. in Isaiam II, PL CXVI 781; Hervé of Bourgdieu, Comment. in Isaiam II, PL CLXXXI 142-4. However, the future concord of animals was sometimes seen as a return of a past Golden Age. Jerome dismissed this opinion as one of the "fabula poetarum", in a passage which was widely circulated in the Glossa Ordinaria. See Jerome, Comment. in Is. IV xi, PL XXIV 150-1; Glossa, PL CXIII 1251.

691 The griphon does not come from Isaiah. Cf. Hist. Schol. Gen. xxiii, $P L$ CXCVIII 1074 where, in a similar passage, it is paired with its traditional enemy, the horse.

693-4 A southern reviser has altered the Scandinavian word "stang" (ultimately from the Old Norse verb stanga) to "tonge". This is an error of biology, of course, but an understandable one, for the word sting was sometimes erroneously applied to the tongue of a poisonous serpent in the Middle Ages. See OED Sting $\mathrm{sb}^{1} 2$.

698-700 Gen 3:1.

701-10 Translated from Grosseteste's Chateau d'amour, 11.48-59. Is. $30: 26$ prophesies that the brightness of the sun and moon will increase in this manner in the future. The earth's loss of brightness after the Fall, however, is a Jewish tradition, well known to Latin commentators and English writers alike. See Jew. Encyc. "Adam"; Jerome, Com- 
ment. in Is. IX xxx, PL XXIV 362; IsIDORE, De Ord. Creat. $\mathrm{v}$ and $\mathrm{x}$, PL LXXXIII 923-4, 938; Haymo of Halberstat, Comment. in Is. II, PL CXVI 869; Aelfric, Homs. of Aelfric, ed. Pope, 679/56-65; Pricke of Consc. 6356-63; Lydgate, Fall of Princes 596-604; Ross, ME Sermons 317/35-318/2; MACÉ 285-8. Cf. CM 9381-4.

702 MSS GHTLB preserve better readings than MSS CF. Grosseteste wrote "ke ne est ores".

708 MSS CFG preserve the original reading, translating "En terre, en mer, a val, a munt" (56).

712 "Selly" is a miscopying of G's "felly", but can be read as modifying "hym" (Adam).

713-20 Trad. anon. fol. $214 \mathrm{v}$ col. 2. Cf. $\mathrm{n}$. to 1.451 above.

725 The word "warlau" (CF) is frequently used to refer to the devil in ME. See $O E D$ Warlock. MSS GHTLB make the reference even more explicit by calling him Satan.

731 "on hyze" (GHTLB) probably originated in a misreading of "on drei", at a distance. Cf. 1.757 and $n$. The scribe, however, could have visualized the devil looking up at Adam on the heights of Paradise from his own position below in hell.

735 Genesis nowhere connects the serpent with the devil, but other biblical books do. Cf., e.g., Sap. 2:24. Most commentators see the serpent as the devil himself in disguise, but the $C M$ poet speaks of him here as a messenger sent by the devil. In the $O E$ Gen., 11.442ff., a subordinate demon is sent, disguised as a serpent, to do the tempting. Cf. also the Apocalypse of Moses 16:1-5 in which the devil tempts the serpent to rebellion first by persuading him that he should not have to eat Adam's tares. The history of the same motif as it appears in the tenth century Irish work Saltair na Rann is traced in Murdoch, "Early Irish Adam and Eve". For a brief discussion of this motif in art see TrAPP, "Iconography of the Fall", pp. 240-2.

The $C M$ poet oddly omits to mention the serpent with the human face which appears in many vernacular works from the twelfth century on. The latest discussion of this motif is in KELLY, "Metamorphoses", which refers to older scholarship.

738-40 Cf. Gen. 3: 1 .

741-3 The usual reason given for the devil's tempting Eve first is that she is the weaker of the two. See DCD XIV xi; Bede, In Pent., PL XCI 212; Sent. II Dist. xxi, PL CXCII 694; Hist. Schol. Gen. xxi, PL CXCVIII 1072; WM. OF Shoreham 647-51; Herman, fol. $1 \mathrm{v}$.

745 Why did Satan teach the serpent, his messenger, how to tempt Adam (above, 1.735 and note) if he himself is to be in the serpent's skin? The line may be intended metaphorically to suggest that Satan's intentions have completely taken over the serpent's, or it may indicate a second source for the scene. Cf. DGAL XI xxviii, PL XXXIV 444; Hist. Schol. Gen. xxi, PL CXCVIII 1072; Elucid. I 85. A twelfth century Irish work makes the scene more clearly understandable. There the devil persuades the serpent to help him and then says: "Take my counsel... and make we covenant and friendship and go thou not to wait on Adam and give me a place to me in thy body, that we may go, both of us [lit. in our duality], unto Eve and enjoin upon 
her to eat the fruit of the forbidden tree;..." From MacCARTHY, ed., Codex Palatino Vaticanus, $51 \mathrm{f}$.

749-54 Cf. Elucid. I 73.

757 Cf. the Vita Adae et Evae, in which the temptation takes place when Eve is alone, after Adam has very reluctantly left her. See MozLEY $138 / 33$ and the English translations.

758-90 The dialogue between Eve and the serpent is a fairly close rendering of Gen. 3:1-6.

764 CFG's "midward" translates Gen. 3:3 "quod est in medio paradisi".

767 Cf. n. to 1.659 above.

768 Cf. 1.660 and note. MSS CFG do not repeat the reference to the "doubel deep".

775-84 Eve's first sin is wishing to be like God. Cf. Gen. 3:5. The CM poet ignores the difficulties created by the plural noun "dii" in the Vulgate, as do most vernacular writers. Others translate "dii" as the Trinity (Kildare 64) or as angels (possibly $G \& E 332$ ), or say that Adam and Eve wanted to be "As two godes, with god" (Piers Plowman C xxi 320).

776 This phrasing is not from Gen., but recalls Lucifer's own desires. See 1.450 above.

787-8 Eve's second sin is sensuous curiosity about the fruit, Gen. 3:6. Cf. DGCM II xv, PL XXXIV 207; BEde, In Pent., PL XCI 214 ; Sent. II Dist. xxi, PL CXCII 696; Hist. Schol. Gen. xxii, xxiii, PL CXCVIII 1072, 1074; Hugh of ST. VICTOR, De Sacramentis Christ. Fid. I vii 10, PL CLXXVI 290-1; Sum. Theol. Q. CLXIII art. 1. Cf. also the moral lesson taught in Ancrene Riwle 22/36-23/10.

791-27 The poet is here using a source which I have not been able to identify.

792 The correct reading is hard to reconstruct here. Perhaps the original line stated that the devil's promise was immediately shown to be false.

794 C's line is probably original. Its "wayth" (ON vaoi) is often changed in the other MSS. G's "king" is a miscopying of "kin". The southern translator glossed the "king" of his exemplar as "oure lord god". The line is acceptable as it stands in these latter MSS, but is clearly not the original.

795 The fruit is universally called an apple in the vernacular, as in Latin Christianity generally. VON RAD, Genesis, p. 88 suggests this identification may have arisen through the association of "malus"'bad, and "malum"/apple. QuinN, The Quest of Seth, p. 128 traces it to a Targum translation of Cant. $2: 3$ and 7:9 as "paradise apple". Petrus Comestor, however, suggests that the fruit was a fig. See Hist. Schol. Gen. xxiii, $P L$ CXCVIII 1073. Cf. IsIdore, De Ord. Creat., $P L$ LXXXIII 941: "ficum, maledictum delicti Adae, quae totam terram inficeret". Cf. RASHI, 13.

795-6 The apple of Eden is here metaphorically identified with the sour grapes of Ier. 31:29: "Patres comederunt uvam acerbam,/et dentes filiorum obstupuerunt." Cf. $E z$. 18:2. CAssidy, "The Edged Teeth" 227-36 suggests that the identification is first made in the fifth century in Sedulius' Carmen Paschale, from which the $C M$ passage is "a 
lineal descendent". See $P L$ XIX 595, 11.20-5. Augustine, Enchir. xlvi, $P L$ XL 254 also quotes the passage from $E z$. in speaking of the consequences of the Fall. Cf. Old English Phoenix, 11.402-9; Pirke, xiii, p. 95; GinZBERG, Legends V, p. 68 n. 68.

823 For Petrus Comestor, as for most commentators in the Augustinian tradition, the immediate effects of the Fall are mainly sexual. See Hist. Schol. Gen. xxii, $P L$ CXCVIII 1072-3; cf. Augustine, $D C D$ XIV Xv-xxvi. The $C M$ poet, however, takes from the Trad. anon. this description of the disharmony in Paradise after the Fall. It neatly balances the previous description of the harmony in the animal world (11. $671 \mathrm{ff}$. above).

828-38 Trad. anon. fol. $215 \mathrm{r}$ col. $2-215 \mathrm{v}$ col. 1.

828 MED suggests that MS C's "blurded" is an error for "blered". However, G's "lourid" is probably the original reading. Trad. anon. has "Toutes [les bêtes] li firent laide chiere". The southern translator, or his exemplar, miscopied "lourid" as "lord", and a much weaker couplet resulted.

877-84 These lines, like much of this conversation, sound more like Trad. anon. fol. $215 \mathrm{v}$ col. 1 than like Gen. 3.

897-8 These lines are obviously reversed in MSS GHTLB.

901-12 Trad. anon. fol. $215 \mathrm{v}$ col. 2.

901-2 The reference to the serpent's warm nature ultimately comes from a misreading of Gen. 3:1 calidior 'hotter' instead of callidior 'more clever". Cf. Ellis, Golden Legend, I, 172: "Then the serpent which was hotter than any beast of the earth..." Cf. WHITE, Book of Beasts, pp. 186-7.

905 Cf. 1.660 above and note.

909-10 The subjection of woman to man might have called to the French poet's mind the passage from I Cor. 11:3-10 which urges women to cover their heads as a sign of their subjection and shame. Cf. however Pirke xiv, p. 100 , where part of Eve's penalty is that "her head is covered like a mourner".

911-6 The poet makes clear Eve's function as the antitype of Mary, the usual mediaeval interpretation of Gen. 3:15. See the references in Dict. théol. cath., "Eve", V 1651-2.

937-42 The southern translator garbled CG's close translation of Gen. 3:22. He has God addressing Adam (11.937-8) and wrongly asserting that He gave Adam knowledge of both good and evil.

944 The southern translation errs in the pronoun "pei". Only Adam was made in the world, while Eve was formed in Paradise. This is of some interest to commentators such as PETER ABELARD, PL CLXXVIII 243 , and is made the subject of a riddle in the prose Life - Vernon 107/90-3.

945-51 God lectures Adam in somewhat similar terms in Trad. anon fol. $216 \mathrm{r}$ col. 1. The French poem does not mention the oil of mercy (1.955) because this part of the legend does not appear there.

952 Cf. 1.660 above and note.

967-70 Trad. anon. fol. $215 \mathrm{v}$ col. 2 . The rest of the conversation is not in the French poem. 
975-88 MSS GHTLB all omit these lines. A scribe's eye mistook "Adam" on 1.989 for "Adam" on 1.975.

975-9 Possibly suggested by Hugh of St. Victor, Adnot. in Pent. vii, PL CLXXV 44.

981-8 The poet implies that the Fall occurred immediately after Eve was created, for Adam was formed at 9 am ("vndern tide"), and Eve at midday, and Adam lived only three hours in Paradise before the Fall (1.982). Cf. $D G A L$ IX iv, $P L$ XXXIV 395-6; Trin. Camb. 41; North. Homs.

985-8 Elucid. I 91.

994 The southern scribes are clearly dubious about this line. MS H's "fully flecched"/completely turned away, is at least innocuous. T's "fouly flecched" seems to question God's justice in turning Adam out of Paradise, but cf. a similar construction in Anc. test. fol. $3 \mathrm{r}$ col. 1 : "Vilement en fu iete de parais". Morris, $C M$, p. xxxiv reads "flecched", as a variant of "flekked", and thus reads fouly spotted, but this is unconvincing.

995 The wall of fire surrounding Paradise is found in IsIDORE, Etym. XIV iii 3; Rabanus Maurus, De Universo XII iii, $P L$ CXI 334; $D I M$ I viii, $P L$ CLXXII 123 ; etc.

999ff. This description of Paradise includes many of the conventional topoi, and represents a vision of still-existing but unattainable delight. Cf. the present tense used in 1.1006 and $\mathrm{n}$. to 11.1030-1. The loci classici for Christian descriptions of Paradise are Lactantius, De Ave Phoenice, trans A.S. Cook, in OE Elene, p. 124, Pseudo-Tertullian, De Judicio Domini viii, $P L$ II 1151-2; and Avitus, De Mosaicae Historiae Gestis, PL LIX 323-30. See discussions by ColI, Il Paradiso terrestre; Graf, Miti; Patch, The Other World; Giamatti, The Earthly Paradise; Witke, Numen Litterarum; and Duncan, Milton's Earthly Paradise. Graf, Appendice I, prints relevant extracts from twenty sources.

Because the topos is so wide-spread, I shall comment only on unusual features in the $C M$.

1006 In Gen. 2:8, the Septuagint and Old Latin read "ad orientam" instead of "a principio". Most mediaeval writers thus place Paradise in the east. HAENISCH, $C M$, p. $4^{*}$ suggests that this detail in the $C M$ comes from Petrus Comestor, but the poet could have picked it up almost anywhere.

1007 Man worked in the Garden without fatigue. See, e.g., $D G A L$ VIII $\mathrm{x}, P L$ XXXIV 381; Ernaldus of Bonnevalle, Hexaemeron, $P L$ CLXXXIX 1536; Hist. Schol. Gen. Xv, PL CXCVIII 1068.

1009 The idea of a perpetual day without night is found in the pseudoTertullian poem, $P L$ II 1151 and 1152 , but, as Lactantius speaks of a dawn, 1.35, his vision of Paradise presumably includes nights. Cf. CHAUCER's Parliament of Fowles 209-10, and above, 1.646.

1010 Cf. below, 11.1288-90.

1012 The perpetual leafiness of Paradise is stressed in Trad. anon. fol. 212v col. 1. Augustine said that the fruits in the garden would not decay, and referred to Ioan. 6:27 to support the idea. However, he inter- 
preted the passage allegorically. See $D G C M$ ix, $P L$ XXXIV 202. Cf. PSEUdo-TeRTUlLIAN, loc. cit.

1014 Giamatri, p. 70, lists the stress on the beautiful odours of Paradise as characteristic of Christian as opposed to classical, descriptions of Paradise. This may arise from the mention of bdellium, an aromatic gum, in Gen. 2:12. Cf. Trad. anon. fol. 212v col. 1.

1015-26 This description of the four trees comes from Elucid. I 69. Cf. somewhat similar passages in AUGustine, $D C D$ XIV xxvi; RoBertus Pullus, Sententiae II xix, PL CLXXXVI 746.

1027 The "orcharde of delices" exactly translated "hortus deliciarum", which in turn translates the Hebrew words rendered by Paradisus (hortus) and Eden (deliciae). See Jerome, Quaest. in Gen., PL XXIII 988; ISIDORE, Etym. XIV iii 2; etc.

1028 Cf. $n$. to 1.1014 above. The pseudo-Tertullian poem mentions cinammon and amomum, Avitus cinammon and balsam. Cf. ERnaldus, op. cit., 1535. In the Apocalypse of Moses, Adam and Eve take spices with them when they are expelled from Paradise. In the Vita Adae et Evae, Eve and Seth return from Paradise bringing Adam three herbs. See Mozley, 142/10-11.

1030-1 The sweet bird songs of Paradise are stressed by Ernaldus, for instance, Hex., PL XXXIX 1537, and in the Legende, p. 46/27. The original reading of the $C M$ however seems to have referred to the songs of saints in the earthly Paradise rather than to those of birds. Cf. MSS CF. Strictly speaking, the existence of saints is impossible in Adam's time, because they had not yet been born. Their appearance in this passage emphasizes that this is a description of the earthly paradise as it exists now. Cf. above, $n$. to $1.999 \mathrm{ff}$.

1032-8 The well and four streams are also characteristic of the Christian paradise. See GiamatTI, p. 70.

1037-8 The names of the rivers are corrupt only in MSS of the southern translation. MS C now has the biblical forms of the names, "gyon" and "fison", although these are written in a later hand. MSS FG and probably originally $\mathrm{C}$ make the common identification of Phison with Ganges and Gehon with Nile. See Josephus, p. 19; Jerome, Quaest. in Gen., PL XXIII 989; DGCM II x, PL XXXIV 203; BEDE, Hex., $P L$ XCI 45; In Pent., PL XCI 207; Hist. Schol. Gen. xiv, PL CXCVIII 1068.

The first part of the southern translator's "Iulespigre" was a scribal misreading of the minims in "nilus". The second half of the word, "pigre", began in the exemplar of the southern MSS as an attempt to copy an original "phison", but after one letter the scribe's eye slipped upward to the ending of "tigre". Hence the meaningless "Iulespigre".

1039-40 According to Giamatti, p. 70, the precious stones of Paradise are a special characteristic of Christian tradition not found in classical literature. They originate in Gen. 2:11-2. The Septuagint translates the Hebrew word in Gen. 2:12 as "carbuncle" instead of "bdellium", as in the Vulgate, thus reinforcing the tradition.

1041 Paradise is always thought to be remote and inaccessible. Some writers say that it is inaccessible because it is so far away, separated 
from us by vast spaces of land, sea or desert, sometimes filled with wild beasts. The most popular Christian tradition said that Paradise was inaccessibly high, perhaps because it shared something of earth and heaven, as Patch suggests, The Other World, p. 135. This belief is reinforced by II Cor. 12:2-4, whose "tertium Coelum" the Greek Fathers identified with the lunar sphere. See Giamatti, loc. cit.

1042-4 The idea that Paradise, because of its height, escaped the great flood, is often found also, even in pagan authors. The $C M$ poet probably takes his version from Petrus Comestor, Hist. Schol. Gen. xiii, PL CXCVIII 1067.

1050 MSS CFG state that Adam and Eve were the first people to have to work hard. The reading of the southern translation, "pe firste pei were to sawe bigan", results from scribal corruption of "sua"/so to "sau"/ sow. Cain is usually supposed to be the first cultivator. See JosEPHUS 27 ; Hist. Schol. Gen. xxvi, PL CXCVIII 1076.

1052 Cain is not yet cursed, of course, but many vernacular works cannot resist the alliteration. See Cant. Creat. 447; Rev. Meth. 58; Met. Para. 234 ; cf. Hist. Schol. Gen. xxvi, PL CXCVIII 1076, the probable source here. Piers Plowman says that Cain was conceived while his parents were still unrepentant and was therefore cursed (C XI 212-5).

1056 "fode" here means offspring, an allusion that Emerson, "Legs. of Cain", p. 832, missed in discussing the devilish origin of Cain. The idea is a Jewish one, given authority for Christians by Ioan 3:12. See Jew. Encyc. "Cain". Cf. Augustine, In Epistolam Joannis ad Parthos, Tract. V iii, PL XXXV 2012-3; BEDE, In Primam Epistolam Sancti Joannis, $P L$ XCIII 102.

1063-6 Gen. 4:4-5 says simply "et respexit Dominus ad Abel, et ad munera ejus. Ad Cain vero, et ad munera illius, non respexit;" without specifying why Abel's offering was more acceptable. The most popular explanation was that Abel gave his in a better spirit. Cf. Hebr. 11:4 and references in "Abel", Dict. théol. cath. I 29. See also WEATHELy, ed., Speculum Sacerdotale, pp. 66, 95-6. The mystery plays, especially the Towneley "Matacio abel", make great fun out of Cain's unwilling sacrifice.

1070 The original reading must have been C's "sacrilages". The word is plural because it refers both to the coming murder of Abel (OED under "sacrilege... any kind of outrage on consecrated persons or things") and more immediately back to the grudging offering of the tithe. In the Middle Ages, sacrilege was a branch of avarice. See Chaucer's "Parson's Tale": "Espiritueel thefte is sacrilege, that is to seyn, hurtynge of hooly thynges, or of thynges sacred to Christ,... they that withdrawen falsly the rightes that longen to hooly chirche", (X[I]800-1). Cf. Morris, ed., Ayenbite of Inwyt, p. 41.

Probably by missing or omitting a superscribed abbreviation sign for "ri", a scribe has corrupted "sacrilege" to "sacles" (FG), which can only refer very awkwardly to Abel.

1073 C's "chafte ban" (ON; cp. OI kjapt-r)/jaw-bone, is the original reading. The tradition that the weapon used to murder Abel was the jaw-bone of an ass is firmly entrenched in vernacular literature and in art in the Middle Ages. The tradition has been discussed by EMERSON, "Legs. of Cain"; Bonnell, "Cain's Jaw Bone", 140-6; Schapiro, 
"Cain's Jaw Bone"; Henderson, "Cain's Jaw-Bone" ; CoomaraswaMY, Art Bulletin; BARB, "Cain's Murder-Weapon". In England the ass's jaw-bone appears in KeMBLE, 180 ; Trin. Camb. 86; Life - Vernon 112/255; Met. Para. 236; Lud. Cov. III 149; Towneley II 324; Creat. of World 1117. Cf. Anc. Corn. Dr. 539-40 where Cain strikes Abel on the jaw-bone, obviously a corruption of the same tradition. The jaw-bone appears also in Anc. test. fol. 3r col. 1, quoted in BonNARD, p. 97. The earliest picture of Cain holding a jaw-bone is in the illustrations to Aelfric's translation of the Hexateuch, MS BL Cotton Claudius $B$ iv, fol. $8 \mathrm{v}$, dated in the second quarter of the eleventh century.

1075-82 Cf. MalaN, Book of Adam I 79; Apoc. of Moses, xl 4.

1083-4 Cf. Hist. Schol. Gen. xxvii, PL CXCVIII 1077. This is the earliest citation for this proverb in WhITING, Proverbs, M806.

1087-1110 Trad. anon. fol. 216v.

1087-90 Adam instinctively knows that Cain has done an evil deed. Cf. the Vita Adae, Mozley 134-5/23, in which Eve dreams, before the deed, of Cain with Abel's blood in his mouth.

1093-6 In Gen. 4:9 these words are part of the dialogue between God and Cain. Petrus Comestor was apparently bothered by God's asking Cain where Abel was. He explains that God really knew the answer all along, but intended his words as a cry against fratricide. The vernacular poets have evaded Comestor's difficulty by transferring the question to Cain's earthly father. See Hist. Schol. Gen. xxvii, PL CXCVIII 1077.

1098 Genesis does not mention the offering being burned, but the tradition was of long standing. The Hebrew word which appears in the Vulgate as "respexit" was translated as "kindled" by Theodotian, and this was widely reported in the Middle Ages. See Jerome, Quaest. in Gen., PL XXIII 992; cf. Bede, In Pent., PL XCI 215; Hugh of ST. Victor, Adnot. in Pent. iv, PL CLXXV 44; Hist. Schol. Gen. XXVI, PL CXCVIII 1077; "Abel", Jew. Encyc. Various legends grew up in the vernacular. Sometimes God kindled Abel's sacrifice and not Cain's, as in MALAN, Book of Adam I lxxviii, p. 98 ; Trin. Camb. 77-84; Life of Christ 233740; Chester II; Lud. Cov. II 131-6; Townely II 275ff; Evrat, Genèse, fol. 13r col. 2. Sometimes the smoke of Abel's sacrifice ascends to heaven, while Cain's drifts downward and chokes him, as in Life-Vernon 112/243-6; Townely II 275; Geofrrol DE PARIS, fol. 12r col. 2. This may have evolved from a Midrashic interpretation of Gen. 4:5, which translated the Hebrew "wayyihar" (Vulgate "iratus") as burnt up or blackened.See Midrash, p. 184; GinzBerg, Legends V, p. 137 n. 13. In the Trad. anon., which the $C M$ poet has been following, Abel's sacrifice gives off a sweet smell, while the odour of Cain's is foul.

1099 Cf. Gen. 4:8. Instead of the Vulgate's "Egrediamur foras", the Old Latin read "Eamus in campum". Hence the murder of Abel frequently takes place in a field. See EMERSON, "Legs. of Cain", pp. $857 \mathrm{ff}$.

1116 "his owne ymage" of course refers back to Gen. 1:26-7.

1119-20, 1123-42 Trad. anon. fol. $216 \mathrm{v}$ col. $2-217 \mathrm{r}$ col. 1.

1123-6 Cf. $n$. to $11.1093-6$ above. 
1134-42 This is the curse on Cain, Gen. 4:11, strongly mixed with the curse on Adam, Gen. 3:17-8.

1143-60 These lines do not appear in the source the $C M$ poet has been using.

1149-54 Cf. Gen. 4:12.

1153 MS H's unique reading "knowen" for "holden" was accidentally taken over from the previous line.

1161-72 Trad. anon. fol. $217 \mathrm{r}$ col. 1.

1172 Cf. Gen. 4:14.

1175-82 Trad. anon., loc. cit.

1177-8 There are various traditions about the mark of Cain. Some Jewish sources said it was a horn. See Midrash xxii 12, p. 191, which also mentions other traditions. This horn appears in the Cornish Creat. of World 1373. The Septuagint translation, however, instead of making Cain a wanderer, said that he would be groaning and trembling on the earth. This trembling became the mark of Cain in several different works. See Malan, Book of Adam I lXxIX, pp. 102-3; Budge, Cave of Treasures 78, Hugh of St. Victor, Adnot. in Pent., PL CLXXV 44; Hist. Schol. Gen. XXVII, PL CXCVIII 1078; Life - Vernon 113/269-70; Macé 593-6. Cf. EMERSON, "Legs. of Cain', p. 869; GinZBERG, Legends V, p. 143 n. 37.

The $C M$ poet implies that the mark of Cain is a piece of writing. This is a Jewish tradition, apparently suggested by $E_{z} .9: 4,6$, and found in Pirke xxi, p. 156; RAsHI 19. The only other vernacular work known to me which describes this as the mark of Cain is the Trad. anon. fol. $217 \mathrm{r}$ col. 1 :

Niert pas ansic com tu las dist

En fronc te metrai un escrist

Qui te uerra quil ne te toiche

[Mais conoisse ta felonie]

Mon signe de ta penitance

Qui te fera lou amiance

(One line, missing in MS BN fr. 763, is here supplied from MS Arsenal 3516 fol. 6r col. 1.)

1187-9 The same riddle appears in dialogue literature, especially from German sources. See Kemble, p. 290, 295-8. Cf. Parzifal IX 464. The answer here is Abel. He was born before his parents because they were never born at all, but created. His grandmother was the earth, and he had her maidenhead because his was the first blood to be shed on her. The riddle may have been suggested to the $C M$ poet by the following passage from the Hist. Schol. Gen. xviii, Add. 1, PL CXCVIII 1071: "Terra proprie adhuc virgo erat, quia nondum corrupta homine opere, nec sanguine infecta."

1191-1202 Elucid. I 93. HAENISCH, CM, p. 4* thought that this came from Petrus Comestor.

1191 The Vulgate says only that Adam was 130 years old when he begat Seth (Gen. 5:3). This story of his continence for 100 years after Abel's death is widespread. See Hist. Schol. Gen. xxix, PL CXCVIII 1080; Trin. Camb. 101-2; SELeg. 168/27-8; Cant. Creat. 496-8; Life-Vernon 113/278-81; Myroure, p. 191; Rev. Meth. (English translation only), p. $158 / 73-80$, cf. p. 183 ; Anc. Corn. Dr. 619-39. For a variant of this 
story see Malan, Book of Adam, Ixxiii; R. H. Charles, Apocrypha, p. 137; and $G \& E$ 389-408, 421-2. Cf. also GINZBERG, Legends V, pp. $148-9$ n. 50.

1206 Cf. I Cor. 15:45 where Christ is referred to as the new Adam. Cf. also I Cor. 15:20-2; Rom. 5:12-21.

1210 An echo of Christ's commandment in Matth. 22:39: "Diliges proximum tuum, sicut teipsum." The poet changes "proximum" to "breper", thus suggesting that Seth is both an anti-type of Cain, who did not love his brother, and a type of Christ, the enunciator of the new law. This is one of the $C M$ poet's rare hints of a figural interpretation. Cf. n. to 1.1206 above.

1211-3 Elucid. I 93. C's reading is closest to the Latin. Cf. the etymology of Seth given by IsIDORE, Etym VII vi 9: "Seth... positio, quia posuit eum Deus pro Abel."

1216-8 From Hist. Schol. Gen. xxix, Add. 1, PL CXCVIII 1080. Gen. 5:4 merely says of Adam: "genuitque filios et filias". In other vernacular works, the number of sons varies from 30 to 33, depending on whether Cain, Abel and Seth are counted. The number of daughters varies between 30 and 32, according to whether or not the author knew of Cain's and Abel's twin sisters.

1223-36 The author winds up the stories of Cain and Abel and the offspring of Adam by looking ahead to the death of Cain's kindred in Noah's flood.

$1237 \mathrm{ff}$. The $C M$ poet here begins to tell the story of Seth's quest for the Oil of Mercy and the history of the wood of the Cross, both immensely popular in the Middle Ages. The pioneering work of classification was carried out by Wilhelm MeYer in "Die Geschichte des Kreuzholzes vor Christus", and "Vita Adae et Evae". An excellent study has been produced by Esther Casier QuinN, The Quest of Seth. I will not attempt to reproduce her discussion of the variations in the tradition and their transmission throughout the Middle Ages. For work which has been done since her book appeared, see SEVERS, ed., Manual II 441-6 and 635-9.

Briefly, the history of the Holy Cross began in two parts. One told of the life of Adam and Eve after their expulsion from Paradise, and of Seth's journey back to Eden on behalf of his dying father. This is told in the Greek Apocalypse of Moses and, in the form known in the West, in the Latin Vita Adae et Evae. I refer throughout to the text of the Vita published by J. H. Mozley, "The 'Vita Adae"'. Mozley used English manuscripts for his edition, and classified several details in their texts which are specifically English.

A separate legend began with Moses finding rods in the desert, and told of their history through various owners until they were used to form Christ's cross. The introduction to Arthur S. NAPIER, Rood Tree, contains a good early description of the texts. See also Quinn.

These two separate stories were combined to produce what Meyer called the Legende version, telling the history of the cross wood from Seth's quest for its seeds in Paradise. I quote from the Legende text printed by Moshé LAZAR, "La Légende de l'Arbre de Paradis". 
The $C M$ poet has used the Latin Legende as his source for the Adam section of the rood story, and Trad. anon. for the rest.

1237ff. Legende 45/11ff.

1239 Legende 45/11 has "bipennam", a double-edged axe. This was translated "hak" in MSS CF, with the spade added for the rhyme. The spade alone survives in GHTLB and is substituted for the "hak" in 1.1241. Henning LARSEN, "Origo Crucis", 30 adduces the appearance of an oxi/pick-axe in the Old Norse Hauksbók version of the legend as a striking parallel with the $C M$. The source is much more likely to have been the Latin, however.

1240 MSS CF's "sad" is original, translating "cepit ... tristari". HL's "mate" (OFr. mate) is equally good, but GTB's "made" is inferior.

1241 The reviser who dropped "hak" as the rhyme word has left Adam in a very awkward position, with his breast somehow resting on his spade.

1245 BenNeTt and Smithers, p. 1245, point out that "yate ward" was originally two words, "ward" being a verb. Thus C's line, without Morris' suggested interpolation of "es", translates "ad Cherubin... qui custodit... atrium" (Legende 45/13).

1246-50 Not in Legende.

1251-64 Legende 45/17-9.

1256 C's "gren" was accidentally re-copied from the previous line. The original rhyme word was probably "sene", as in GHTLB.

1265-77 Legende 45/14-5.

1271-2 Not in Legende.

1283-1394 Legende 45/20-46/23.

1288-90 This may be the great light of Paradise itself, or it may be the burning wall surrounding it.

1291 Henning LARSEN, "Cursor Mundi 1291" seeks to derive this from an Old Norse version of the story, but MSS CF translate the Latin "signavit se signo theta".

1295-1302 This is in direct discourse in the Latin.

1299-1300 Not in Legende.

1303 The poet uses the word "cherubin" as a proper name. Cf. Life - Vernon $108 / 138$.

1305-88 Legende 46/25-47/48.

1311 The $C M$ poet is not being vague again, but is simply translating his source, Legende 46/26.

1315 Latin "lucidissimum".

1334 "pat made him doute". The Latin has "stupefactus rediit", 46/34.

1343 The child is obviously Christ. The "swapelynge bonde", Latin "pannis involutum", 46/35, echoes Luc. 2:7, 12.

1344 As the angel later explains, Christ is weeping for the sins of Seth's parents. The ME poet, though he translates the restrained "deflet" as "wepep" at 1.1357 , here uses the realistic "squelonde".

1348-9 "in quo cognovit animam fratris sui Abel", 46/36.

1372 Not in Latin.

1375 Latin "infra os ejus pones", 47/42. Cf. below 1.1417, Legende $47 / 51$.

1377 The three trees in the Legende are cedar, cypress and pine, 47/43. MSS CFG preserve the original reading here, but the southern trans- 
lator has changed all the references to the three trees to cedar, cypress and palm. The palm was often cited in other places as one of the woods of which the cross was made. See QuinN's discussion, Quest of Seth, p. 70 and n. 3 , p. 151 , n. 3.

When he changed the third tree in his source, the southern translator of the $C M$ may have had in mind the verses of Eccli. 24:17-8:

17 Quasi cedrus exaltata sum in Libano, et quasi cypressus in monte Sion;

18 quasi palma exaltata sum in Cades,

These images were very often applied to the Virgin. See RABY, Christian-Latin Poetry, p. 366. Thus the southern translator has deliberately altered his original to refer, however obliquely, to the Blessed Virgin, to whom the $C M$ is dedicated.

1380 MSS CF's reading is the original, translating "universis arboribus alcius crescere consuevit" (47/45).

1389-98 This conversation is not in the Legende.

1399-1405 Legende 47/49-50.

1406-12 Not in Legende.

1409 According to Gen. 5:5, Adam lived 930 years. However the Legende says he was $932(45 / 11)$. Aware of the two different figures, the $C M$ poet here begs the question. Cf. SEL 168/31.

The southern translator's new rhyme word "zare", meaning "alert, nimble, active, brisk, quick" (OED Yare $a$ 2) exactly contradicts the intent of the passage as a whole, and especially the following line.

1413-9 Legende 47/51-2.

1421, 1424-30 Legende, 47/53.

1435-48 Cf. Life - Vernon 117/385-8, where Adam is said to have spent 4604 years in Hell. Cf. also Geoffrol DE Paris, fol. 13v col. 2.

1438 The southern translator's change from "ras" to "dized" weakens the line.

1449 The sisters (and' wives) of Cain and Seth have various names in ancient tradition. See Jubilees 4:9,11; MalaN, Book of Adam, I lxxiv, 1xxv. Calmana and Delbora are the names most often used in mediaeval texts. See Rev. Meth. 192; Hist. Schol. Gen. xxv, PL CXCVIII 1076. Cf. below, 1.1501.

1451ff. The $C M$ tries to reproduce the genealogy of Seth as given in Gen. 5 , but gets the ages of four out of the eight men wrong.

1453-4 Gen. 4:26.

1455 i.e. 912 years. Cf. Gen. 5:6-7.

1459-60 MSS CFG preserve the name as "Cainan" (Gen. 5:12-4). The southern translator has corrupted it to "Caym". Cainan lived 910 years.

1461-2 T miscopies the name "maladial", but HLB have the correct form. He lived 895 years (Gen. 5:17). Perhaps a Roman numeral xcv was miscopied as Xxv.

1463 Jared lived 962 years (Gen. 5:20). MSS CF come closer to the correct figure.

1464 MS C preserves the original "kne". See MED kne n. 3, a somewhat uncommon usage, which GHTLB change to "kyn".

1465-6 These lines are based directly on a short text of the Revelations of Methodius: "Quadragesimo autem anno tempore Jareth, transiuit 
primum miliarium seculi." See Rev. Meth. p. 193. Cf. below, n. to 11.2001-6.

1468 Henoch lived 365 years (Gen. 5:23). The poet may have misread Gen. 5:22.

1469-70 From Hist. Schol. Gen. xxx, PL CXCVIII 1081. Cf. Jubilees 4:17; I Enoch 12:4, 14:1; DIM, PL CLXXII 165. In ME, Higden 223 and Wyntoun 269-74 also translate this information from Comestor.

1471 The standard interpretation of Gen. 5:24, which says, "Ambulavitque cum Deo, et non apparuit, quia tulit eum Deus." The tradition begins very early. See Jubilees 4:23; I Enoch 70:1-3; II Enoch 67:2 ; Jerome, Comment. in Amos III xi 2ff, PL XXV 1087; BEDE, Hex., PL XCI 73; Hist. Schol. Gen. XxX, PL CXCVIII 1080; HIGDEN 223; WyNTOUN 275ff; KEMBLE 200, 213 ; Creat. of World 2094-2145. A possible explanation of the ideas connected with Enoch comes from Babylonian tradition. Enoch was the seventh in line from Adam, and the seventh ante-diluvian king of Babylon was also said to have received divine illumination. Interestingly, the Babylonian king was in the service of the sun god, and Enoch's life lasted 365 years, the duration of one solar year. See DrIVER, Genesis, 78.

1471-4 Probably from Hist. Schol. Gen. xxx, PL CXCVIII 1080.

1475-80 Enoch and Elijah are the two men of the Old Testament who did not die but were taken to Paradise bodily to await the second coming. The story of their fatal struggle with Anti-Christ is very old and is based on their identification with the two witnesses of Apoc. 11:3-7. See Bousset, The Antichrist Legend, pp. 203-17. The CM poet may have taken his account of this from Adso's widely known Libellus de Antichristo. See KaluZA, "Zu den Quellen', p. 451.

1481-2 The $C M$ poet now begins to use $D I M$ as a source: "Hujus tempore mortuus est Adam," PL CLXXII 165. KALUZA, "Zu den Quellen", p. 451 first pointed out the poet's indebtedness to this work, but he reported that the $C M$ poet used $D I M$ only in 11.6993-7082 and 91339222.

1493-5 Petrus Comestor discusses various estimates of the length of the first age, Hist. Schol. Gen. Xxx, PL CXCVIII 1081. However, Comestor does not give this figure. Adding the ages of each man at the birth of his eldest son, plus the 612 years of Noah's life before the beginning of the second age, gives a total of 1668 , not 1662 , as in MSS CF. Cf. WYNTOUN, who gives the number of years as $1667,11.283-4$.

1496ff. The Trad. anon. spends considerable time on the family of Cain, having his sons discover the seven liberal arts among other things. The $C M$ poet chose not to translate this. Cf. Gen. $4: 16-24$.

1501-2 See note to 1.1449 above.

1505 MSS CFG preserve the better reading "mad" for "took". Cf. Gen. $4: 17$.

1506 The ages are not given for the descendants of Cain in Gen. 4:17ff. In any event, they all perish in Noah's flood.

1508 From Rev. Meth. 193: "hec prima facta est ante deluuium". The phrase does not occur in Petrus Comestor. In the Revelations, however, and in works derived from it, the city is called Effrem. Cf. Trin. Camb. 88. The $C M$ poet has corrected this to the biblical Enos, 1.1504. 
1509 According to the Vulgate, Gen. 4:18, the line runs from Enoch to Irad. However, the Septuagint and Old Latin translations gave the name Irad as Gaidad. This is the name used here in $D I M$, and therefore the one used by the $C M$ poet, as preserved in MSS CG. The scribe of F was apparently puzzled by this "Gaidat", and rewrote the line. The southern translator made a similar adaptation.

The forms "mamael" (C) and "Mainael" (F) are scribal corruptions of the Vulgate "Maviael" (Gen. 4:18). MSS GHTLB's "malaliel" is a further corruption of this, probably influenced by the "malaliel" in Seth's line. Cf. above 1.1461.

1513-4 This refers to the usual mediaeval interpretation of Gen. 4:23-4 as a song of lament sung by Lamech when, old and blind, he accidentally kills Cain. This story was often told at length in the Middle Ages, especially by authors who knew Petrus Comestor, Hist. Schol. Gen. xxviii, PL CXCVIII 1079-80. Cf. GinzBERG, Legends, V 146-7, n. 44; MaLAN, Book of Adam, II xiii, p. 122; BUdge, Cave of Treasures 78-9; Rashi 21; Rev. Meth. 193; Glossa, PL CXIII 101; Hugh of St. Victor, Adnot. in Pent., PL CLXXV 44-5; see also James, Lost Apocrypha, 10-11. In ME the story is found in G\&E 471-86; HIGDEN 229-31; Wyntoun 191-202; Fall of Princes 735; MandeVILLe L 81; Lud. Cov. IV 142ff.; Creat. of World 1465-1712. In French, both ÉVRAT, fol. 15r col. 2 and MACÉ 709-44 tell the story.

The abbreviated version is unusual, and probably comes from Rev. Meth. 193 which says simply: "filii lamech ceci, qui fuit primus cecus. qui interfecit Caim." D'Evelyn does not note this parallel with $C M$, and HaENISCH, $C M$, p. $5^{*}$ gives Comestor as the source of the passage.

1516-24 Cf. Gen. 4:20-22.

1517 MS C's "loger" is original, from OF logier. The line refers to Gen. $4: 20$ : "pater habitantium in tentoriis".

1525-8 From Comestor, Hist. Schol. Gen. xxviii, PL CXCVIII 1078-9.

1529-30 This story is told of Seth's descendants in JosepHus 33; Creat. of World 2146-2210; and in the Vita - MozLEY 145/52 and its ME translations. Cf. GinzBerg, Legends, V pp. 149-50 n. 53. Comestor, however, had already switched it to the sons of Lamech who recorded the secrets of their crafts. See Hist. Schol. Gen. xxviii, PL CXCVIII 1079 ; $G \& E$ 461-4; Rev. Meth. 163-90; Higden 233; Wyntoun 22340; MACÉ 679-92.

1541-52 From Hist. Schol. Gen. xxxvi and Add, 2, PL CXCVIII 1087. Comestor got the idea from Josephus 57. Cf. Higden 231. D'Evelyn suggested that the ME translation of the Revelations of Methodius took this passage from the CM. See Rev. Meth., 11.191-214. Both the $C M$ and the Revelations say the Great Year takes 100 years to pass, whereas Comestor and Higden both say 600 years.

1548 "mychal spire" translates "magnus annus".

$1553 \mathrm{ff}$ The story of Noah's flood begins in Genesis with the account of the intercourse between the sons of God and the daughters of men which bred a race of giants. This was originally interpreted as describing the fall of man. See N. P. Williams, Ideas of the Fall.

The sons of God have been variously interpreted. Jewish tradition thought of them as sons of noble families. See DrIVER, Genesis 82-3; 
Skinner, Genesis 142 n.; Targ. of Onk. 46; Targ. of Jon. 176; Midrash $26: 5$, p. 213 ; RASHI, p. 25 . The Septuagint translation calls them angels, as do Josephus 35 and Jubilees 5:1, and some early Fathers. See references in EMERSON, "Legs. of Cain", 919-21. However, Matth. 22:30 specifically denies sexual activity to the angels. Later Christian authorities assumed a prohibition on marriage between the descendants of Seth, from whom Christ was to come, with the descendants of the wicked Cain. See EMERSon, "Legs. of Cain", 921.

The $C M$ poet barely glances at the problems of this passage, tacitly accepting the latter interpretation and concentrating on the wickedness of the descendants of Cain.

1553-6 From Rev. Meth. p. 193, as d'Evelyn points out. Comestor gives the date without reference to Jareth. See Rev. Meth. pp. 148-9; cf. Hist. Schol. Gen. xxx, PL CXCVIII 1081.

1557-8 The $C M$ poet sees the early history of the world as a continuing decline from the blessedness of Adam's state. Cf. AQuinas, who asserts that the effects of the Fall made themselves felt over a period of time. See Sum. Theol. II

1569-84 The southern translator has expanded and changed these lines somewhat. Morris' numbering gives a false picture of correspondances.

$\begin{array}{ll}\text { CFG } & \text { HTLB } \\ \overline{1569-76} & 1569-72 \\ 15677-8 \text { (CG only) } & 1573-80 \\ 1579-82 & - \\ 1583-4 & 1581-4\end{array}$

Originally the $C M$ poet mentioned only lust, adultery with their brothers' wives and rape $(11.1567,1573-4,1577-8$ CFG). The southern translator took up the suggestion of the sin against nature and inserted four lines to show that lesbianism and homosexuality were the abhorrent sins (11.1569-72 HTLB). He has much in common with other ME writers who use this story to fulminate against whatever sin they most disapprove of. Thus the SELTemp., fol. 1v col. 1, calls the sin incest, and $I \& I$ 13-20 blames gluttony. Cf. the note to 1.2907 below. The author of the Book of the Knight of LaTour-Landry 62 attributes the flood entirely to women's dress.

1570-1 The poet's description of the two laws is preserved in MSS CG: "par lau/pat es o settnes and o kind", i.e. the positive law and the natural law. The Dict. théol. cath. XI 875 distinguishes the two:

[La loi] est naturelle, si l'obligation qu'elle impose dépend de la nature des choses, positive, si cette obligation dépend de la volonté positive et libre du législateur.

The $C M$ poet could have picked up the concept of the two laws from his reading of GrosSETESTE's Chateau d'amour, 11.111-128.

Isidore's first example of natural law is "viri et feminae coniunctio", in Etym. $\mathrm{V}$ iv 1. This explains the stress on sexual irregularities as being "azeyne kynde".

1574 (CFG)/1578 (HTLB) This comes from Rev. Meth. and is also found in Hist. Schol, Gen. xxxi, PL CXCVIII 1081. Cf. G\&E 529-30.

1602 Gen. 6:6.

1621 "feluns", MSS CFG, is original, a better antithesis with "pe gode" than "foolis" of HTLB which is probably scribal corruption. 
1625-6 The genealogical diagram in MS $C$ is not reproduced in the other MSS, although these lines promise one. Only MSS FL omit the lines altogether.

1627-30 Cf. Gen. 5:32. Haenisch, $C M$, p. 5*, attributes this to Petrus Comestor, Hist. Schol. Gen. xxxi, PL CXCVIII 1081.

1633-60 Based on God's speeches in Gen. 6:7, 13, 17-8.

1636 Cf. 1.482 above.

1644 Cf. Gen. 8:21; Lev. 1:9; Phil. 4:18; and Eph. 5:2. In the latter, the sweet smell of Christ's sacrifice is contrasted with fornication and uncleanness.

1652-5 Perhaps from Trad. anon. fol. 219r col. 1, but the similarity is not striking.

1664ff Two interesting studies have appeared concerning the ark of Noah: ALLEN, Leg. of Noah, and Grover ZINN, "Hugh of St. Victor and the Ark of Noah".

Mediaeval ideas of the ark usually conformed to one of three basic shapes:

(1) Based on the Septuagint reading of Gen. 6:16, Origen's ark was pyramidal in shape. See In Gen. Hom. II, PG XII 161-7; Contra Celsum, IV, PG XI 1095-8; Bede, Hex., PL XCI 89-91; In Pent., PL XCI 221; Allen, Leg. of Noah, p. 71. Cf. also Hist. Schol. Gen. xxxii Add. 1, $P L$ CXCVIII 1083: "Quasi agricolae locutus est Dominus, ut faceret scilicet navem, instar arconii, id est ad conum tendentis, vel forte ab arcendo, quia undique clausa."

(2) Augustine's ark was cubic, having vertical sides with the same floor space on each level. He left the sea-worthiness of such a boxlike craft in the hands of Divine Providence. See $D C D$ XV xxvii.

(3) Hugh of St. Victor interpreted Genesis differently. In his ark, the walls are only 15 cubits high, while the roof rises a further 15 cubits, at a slope of one cubit. The two upper stories of the ark are under the slope of this roof. See De Arca Noe Morali, I iii, PL CLXXVI 627. AlLen, Leg. of Noah, p. 140 describes the ark in the CM as "up-todate... a poetical version of Hugh of St. Victor's ark". This is not the $C M$ poet's conception, however, as is shown by the measurement "Fro grounde to pe tabulment" (1.1678). The tablement is a feature of wall construction, not of roofs. The $C M$ poet, then, is saying that the full height of the ark, 30 cubits or 15 ells, is the same as the height of its walls. His ark, therefore, is more like Augustine's than like Hugh's.

1664 The Vulgate reads: "Fac tibi arcam de lignis levigatis" (Gen. 6:14). The Septuagint, however, has the ark built of square timber, as here. Comestor gives the Old Latin reading "quadratis" as an alternative to the Vulgate's. See Hist. Schol. Gen. xxxii, PL CXCVIII 1082; cf. Glossa, PL CIII 105. Cf. York VIII 73-4, which combines the two readings.

The Trad. anon. says "Larche feras de legiers fuz quarrez", which is interesting as MSS GL use the ME derivative of this Old French word: "quarid" or "quarry".

1666 Trad. anon. fol. $219 \mathrm{v}$ col. 1: "et il meismes fuit maistres charpentiers".

1669-74 The $C M$ poet does not seem concerned to describe the hull of the ark. Salzman, Building in England is useful in understanding the 
structure that Noah is working on here. The $C M$ poet describes it as a timber frame structure filled in with wattle and daub. This is a typical mediaeval building, less grand than a stone structure, but not as humble as the wattle and daub huts of the peasants. See Salzman, pp. 192, 194.

The poet speaks of Noah as the master wright (1.1666), who directs his helpers and is himself responsible for fastening in place the main beams of the building (1.1728). See Salzman, pp. 201-205. The poet speaks of cutting the timber (1.1724) and fastening it (1.1669). This is the process of laying the groundsills in the desired shape, and then attaching to them the uprights, or studs. See Salzman, p. 189. The uprights are then bound together with "balks or horizontal timbers, as opposed to the... studs, or uprights" (SALZMAN, p. 542, n. 2), and "bands" or "laces", that is tie beams, running across the structure from side to side $(11.1671,1728)$. See SAlzMAN, pp. 204, 211, and the illustration between pp. 196 and 197 . Then the wattling process is begun, that is the spaces between the uprights are filled with vertical stakes, interwoven with small branches or "wands" $(11.1670,1672)$. See SAlzMAN, pp. 188-9. Then the wall is daubed with earth, clay, mortar or plaster to fill in the interstices. See Salzman, p. 188. The $C M$ poet has the ark daubed with pitch, as the Vulgate specifies $(1.1673$, Gen. 6:14), and with plaster (1.1674). See SALZMAN, p. 189.

I have found no comparable description of the ark in written sources, but similar woven arks are to be seen in three illuminated MSS of the period. See

(1) CoCKerell, ed., Book of Old Testament Illustrations, p. 79 pl. 14; also in a partial reprint, Old Testament Miniatures, p. 32 no. 13. The hull of this ark, painted about 1250 in Paris, is wickerwork.

(2) WARner, ed., Queen Mary's Psalter, pl. 10 and p. 57. The upper part of the hull is woven in this early fourteenth century work.

(3) Hassall, ed., Holkham Bible Picture Book, fol. 7v, where the superstructure has a timber frame woven with reeds. The pictures were probably done in London, later in the fourteenth century.

The texts in these MSS sometimes try to explain the pictures, usually by saying that Noah was rushed and at the last minute had to finish his ship by weaving rather than continue nailing planks onto the frame. HASSALL, pp. 73-4, offers this explanation of the legends. "The conflicting explanations seem to be rationalizations of a natural misinterpretation of a traditional way of representing the fabric of the ark. This is exemplified in the fifth or sixth century in the Cotton Genesis and perhaps in the bronze door of Monreale Cathedral (c.118090). The original intention was not to represent wickerwork at all but to show "a form of panelling which became common in Cairene work... In its origin it seems to have depended on forms of the Greek fret which are frequently found as pattern on Coptic textiles. This form of panelling was doubtless used because it required only small pieces of timber...", The suggestion Hassall quotes was made by LETHABY, "The Painted Book of Genesis", p. 98.

See my article "“A Schippe Behoues pe to Dight",. 
In spite of the unusually detailed description of the ark in the text of the $C M$, the sketch of the "archa noe" found at the bottom of fol. $12 \mathrm{v}$ of MS $\mathrm{C}$ is of a conventional ship with mast and rudder.

1675-6 Gen. $6: 15$ says that the ark was $300 \times 50 \times 30$ cubits in size. The $C M$ says $150 \times 24 \times 15$ ells. In his reckoning, then, 2 cubits $=1$ ell. Exegetical writers usually agreed that a cubit contained $1 \frac{1}{2}$ feet, as it did in Roman linear measure. See, e.g., Petrus Comestor, Hist. Schol. Gen. xxxii, PL CXCVIII 1083; Hugh of St. Victor, Adnot. in Pent., $P L$ CLXXV 46. An English ell, on the other hand, was 45 inches.

The $C M$ poet is here either using a Scottish ell (37.2 inches) as a rough equivalent for 2 cubits, or he is using a standard Anglo-Saxon unit of measurement. For building purposes the Germanic tribes, both in England and on the Continent, had reckoned 1 cubit $=2$ feet and 4 feet, or 2 cubits $=1$ "cloth-elne". This unit of linear measure was eliminated some time between 1266 and 1303 by the document Compositio ulnarum et perticarum. On the subject see ZUPKo, British Weights and Measures, pp. 10, 20-1, 143.

1678 From Hist. Schol. Gen. xxxii Add. 2, PL CXCVIII 1083 "id est, a fundo usque ad tabulatum".

1679-86 Gen. 6:16. The Vulgate said "mansiunculas in arca facies," (Gen. 6:14) and "deorsum, coenacula, et tristega facies in ea" (Gen. 6:16). This would have been a structure of impressive scale in mediaeval times, where two story houses were the rule even in London. See Salzman, Building in England, p. 197.

1683 Cf. $n$. to $11.1759-60$.

1687-90 Cf. Gen. 6:19-20.

1691-1700 The $C M$ poet describes the arrangement of the decks. Haenisch gives the source of this passage as Hist. Schol. Gen. xxxii, PL CXCVIII 1083. Cf. also Hugh of St. Victor, De Arca Noe Morali I iii, PL CLXXVI 627.

1692 MSS CF preserve the correct meaning, that the birds are to be beside Noah, not beneath him as in MSS GHTLB.

1699-1700 Many descriptions of the ark mention these sanitary arrangements, which are not those of a ship, but of a house constructed over a cess-pit which would be cleaned periodically. See Salzman, pp. 283-5. The commentators obviously conceived the only apertures in the ark to be the door and window specifically mentioned in Gen. 6:16, and even these are kept closed at all times during the flood.

1701-6 Gen. 6:3. Early commentators interpreted the 120 years as the span of a man's life from then on. See Josephus 35; Jubilees 5:8; cf. Pricke of Conscience 11.738-41. The Fathers say, however, that 120 years was the length of time given to men before the Flood in which they might repent. See Quaest. in Gen., PL XXIII 997; DCD XV xxiv; BEDE, In Pent., PL XCI 221 ; Pseudo-Bede, Quaest. super Gen., PL XCIII 292; Adnot. in Pent., PL CLXXV 46; Hist. Schol. Gen. xxxi, PL CXCVIII 1082. So too the Targ. of Jon. This is the point of view of the CM poet.

This explanation still leaves a difficulty however. By comparing Gen. 5:32 with Gen. 7:6, one sees that the Flood came only 100 years after God's promise to Noah. See Augustine's attempt to explain the discrepancy in $D C D \mathrm{XV}$ xxiv.

1709-18 Cf. Gen. 6:18-21. 
1723-30 Trad. anon. fol. $219 \mathrm{v}$ col. 1.

1725 Most literal commentaries also assume that Noah had helpers when he built the ark. See Allen, Leg. of Noah, p. 141; Augustine, Quaest. in Hept. I v, PL XXXIV 549; Piers Plowman C XII 238-43; Chester III 49ff. However, the Anc. Corn. Dr. says that Noah built the ark alone (11.1009-16).

1728 Cf. $n$. to $11.1669-74$ above.

1729-34 Noah's entire sermon is given in Trad. anon. fol. 219v col. 1-220r col. 1. The $C M$ poet summarizes it.

The idea that Noah preached to the onlookers while he worked on the ark is an ancient tradition, found in Josephus 35; MALAN, Book of Adam III ii, pp. 144-5; Budge, Cave of Treasures 100. Cf. II Petr. 2:5; I Petr. 3:20. In the twelfth century it appeared again in the commentary of Rashi on Genesis, p. 28. Cf. GINZBERG, Legends, pp. 174-5 n. 19 for other references. In vernacular paraphrases the motif is rare, occurring only in CM, Trad. anon., the Cornish Creat. of World 11.2294ff, 2346, and $O E G e n$. 1317-9.

1759-60 The window must be capable of being opened from inside so that Noah can later release the birds (Gen. 8:6ff). This seems to be a fairly unusual feature of mediaeval windows, which were more often simply holes in the wall over which shutters would be fastened. See Salzman, Building in England, pp. 198, 256.

The other MSS have mistaken C's verb "loke"/lock for "look", to produce a line which makes little sense in its context.

1761 The $C M$ poet here omits two traditional additions to the Noah story, of which he might easily have been aware. He does not name the women in the ark, as so many commentators did. See UTLEY, "One Hundred and Three Names". Neither does he make Noah's wife a source of difficulty for her husband or a figure of comedy, as so many ME sources did. The tradition that Noah's wife tried to thwart the project is an ancient one. See M. R. JAMES, Lost Apocrypha, pp. 13-5; MiLl, "Noah's Wife". In ME it appears in Chester III; Towneley III; York IX; the Newcastle Play of Noah's Ship 95ff; WARner, Queen Mary's Ps. p. 57 and plates 10-12; Gollancz, Caedmon MS pp. 66, xlv; and cf. Garvin, "Note on Noah's Wife". Note, however, that the Lud. Cov. and the Anc. Corn. Dr., like the $C M$, ignore the comic character of Noah's wife.

The suggestion made by W. Young "Noah and his Wife" pp. 20-1, that the scoffing of the bystanders while Noah is building the ark in the $C M$ may have suggested Noah's wife's scorn to the dramatists is wrong.

1761-98 The Trad. anon. fol. 220r col. 2 has a few lines about the storm, but nothing like this elaborate description. Several of the lines come from the Bible of Herman de Valenciennes, the $C M$ poet's first use of this source. Compare Herman's Bible in University of Chicago MS H.27.B.6.12 fol. 4v and $C M 11.1763-4,1770-4$.

Such lengthy descriptions of the storm which caused the flood are most unusual in ME versions of the Noah story. Cf. only Cleanness 373ff. The CM's storm has two functions. As Mardon, Narrative Unity, p. 69 points out, its savagery prefigures the storms which herald the arrival of doomsday, thus establishing Noah's flood as a type of the final destruction of the world. The scene also calls to mind very clearly the $C M$ 's descriptions of Paradise both before and after Adam's fall. See 
above 11.639-710, 825-36, 999-1044. Rather than perpetual light and a much brighter sun and moon, all is darkness and night. The sight of men and animals swimming together in terror with all enmity forgotten is an ironic recollection of Paradise, when all had lived together in perpetual harmony. L. 1793 may recall the rebellion of Lucifer, which the $C M$ poet had particularly considered to be a struggle over lordship (1.482).

1766, 1768 These descriptions of flood conditions interpret the biblical "fontes abyssi" (Gen. 7:11; 8:2). In Hebrew cosmology, these referred to the great deep under the earth.

1786 MSS CF's "wolf and ram" is probably original. Cf. above 1.685.

1835-6 The story of the Flood in Genesis is compiled from two sources. The $\mathrm{J}$ narrative (Gen. $7: 4,12 ; 8: 10,12)$ conflicts with the calculations of the P narrative (Gen. $7: 11,17,24 ; 8: 3-5$ ) about the length of the Flood. The Septuagint and Old Latin readings add further complications. The length of the Flood was a problem to Latin scholars. See AlLen, Leg. of Noah, p. 70, cf. Roger BACON, Opus Majus, p. 220.

The $C M$ poet has the rain last for forty days (11.1835-6), and the waters prevail for 140 days (1.1851) instead of 150 days as in Gen. 7:24; 8:3. The Flood lasts 12 months in all (11.1917-22). This would agree with the Septuagint text, and also with Petrus Comestor, who argued that the Hebrew calendar differed from his own, and that the Vulgate text meant to state that a whole year had elapsed. See Hist. Schol. Gen. xxxv, $P L$ CXCVIII 1085-6.

1837-8 Gen. 7:20 says fifteen cubits. The $C M$ poet has again used his rough equivalent of two cubits equals one ell. Cf. $n$. to 1.1675-6 above.

1851 Cf. n. to 1.1835-6 above.

1856 C's "knyue" is surely an error.

1860ff. Cf. Gen. 8:1ff.

1869-70 Gen. 8:4: "super montes Armeniae".

1871-88 BueHLer,' “CM", p. 487, pointed out that this passage was translated from 11.312-25 of Herman's Bible. Noah does not consult his sons elsewhere in ME.

1885-8 Cf. Gen. 8:7. This legend is told to explain the continued absence of the raven in almost every version of the flood story. See, e.g., "Flood", Jew. Encyc.; Augustine, Quaest. in Hept. I xiii, PL XXXIV 551; Prudentius, Dittochaeum, PL LX 93 ; Isidore, Myst. Expos. Sac. vii, PL LXXXIII 233; Hist. Schol. Gen. xxxiv, PL CXCVIII 1085; OEGen. 1446-8; SELTemp. fol. LV col. 2; Cleanness, 459ff; WYNTOUN 408-10; Pilg. Life of Man 2405-72; Lud. Cov. IV 246; Towneley III 499-504; Creat. of World 2464-5; Anc. Corn. Dr. 1103-81.

1889-92 Cf. below 11.3332-4.

1911-2 This may reflect the Augustinian speculation that the carnivorous animals had lived on figs and chestnuts during the voyage. See $D C D X V$ xxvii; Remigius of AuXerre, Comment. in Gen., PL CXXXI 76; Hist. Schol. Gen. xxxiii, PL CXCVIII 1084.

1917-20 See note to 11.1835-6.

1921 "perus maior", as HAENISCH, $C M$, p. 6* pointed out, is a corruption of C's "piers mayner", a translation of Petrus Manducator, i.e. Petrus Comestor. 
1923ff. Cf. Gen. 8:15ff. MSS CF's "spak" is original, for Latin "Locutus est'".

1952 MS C's "therst" is surely an error for "theft" as the glossary suggests, $C M$, p. 1773.

1953-60 From Trad. anon. fol. 220v col. 2-221r col. 1. The poet begins with the dietary prohibition of Gen. 9:4. This evidently calls to his mind the passages from Lev. 11:3 and Deut. 14:6 which permit the eating of cloven-hoofed beasts only if they chew the cud. The $C M$ poet describes the dietary laws more fully than does the French poet.

1961 Deut. 14:19.

1962 Deut. 14:12-8.

1963-4 Perhaps based on Deut. 14:9. The southern translator corrupted "fixs" to "flesshe".

1966 The southern translator also corrupted "blod" to "body".

1967-78 The poet returns to Gen. 9:5-6, 9-16.

1985-6 Trad. anon. fol. $220 \mathrm{v}$ col. 2. Once again the poet takes an opportunity to emphasize the need for tithing.

1993-4 Hist. Schol. Gen. xxviii, PL CXCVIII 1079.

1995-2000 Hist. Schol. Gen. xxxii, PL CXCVIII 1082.

2001-6 Rev. Meth. p. 194. As d'Evelyn points out, Rev. Meth. p. 147-8, the $C M$ poet borrows this directly from the short text of Methodius, the "Metody" of 1.2004, and not from Comestor. Comestor does not mention the 612th year of Noah's age.

2013ff. Noah's drunkenness and the curse on Canaan (Gen. 9:20-7). Two main problems arise out of the narrative in Genesis : why was it so disastrous for Ham to see his father naked, and why, if Ham was guilty of an offense, did the punishment fall on Canaan? For the $C M$ poet's answers to these questions, see notes to 11.2028 and 2051-2 below.

2015 MS C's "sloght" is not a mistake for "soght", as the Glossary, p. 1763 states. Rather it must come from OE sleccan, a weak verb meaning to smooth.

2018 The word "vnwarres" reflects the discussions among exegetical writers who sought to excuse the drunkenness of the righteous Noah. See Allen, Leg. of Noah, p. 73; Alanus de Insulis, Contra Haereticos I xxxvii, PL CCX 341, 343. Cf. Piers Plowman, which condemns him for it (C XI 175-7).

2021-40 BUEHLER, " $C M$ ', p. 488, has shown that these lines are translated from Herman's Bible, 11.370-81.

2025 Herman refers to "L'ainsnés des fius" (1.372), but the $C M$ poet calls Ham "His mydelest son", as is implied by the order of names in Gen. 10:1.

2028 Several traditions exist to explain the harshness of Ham's punishment. Latin commentators tend to follow Josephus in saying that Ham's crime lay in mocking his father's nakedness, as here. See JosEpHus 69; Bede, Hex., PL XCI III; Hist. Schol. Gen. xxxvi, PL CXCVIII 1087. Cf. Malan, Book of Adam III xiii, p. 160; Budge, Cave of Treasures, 118.

2047-8 Hist. Schol. Gen. xxxvi, PL CXCVIII 1087. The statement is also found in Hugh of St. VIctor, Adnot. in Pent., PL CLXXV 48.

2051-2 In Gen. 9:25, the curse falls on Canaan, the son of Ham. The CM poet follows Herman who also has Noah curse Ham himself. For con- 
jecture about the biblical curse, see Allen, Leg. of Noah, 77; "Ham", Jew. Encyc.; Von RAD, Genesis, 131-2.

2051 MS C's "pam" is an error for "cham", for only one brother was cursed.

2069-80 From Herman's Bible, 11.398-406. See Buehler, ' $C M$ ', 489.

2070-2 Ham is the natural successor to Cain after the Flood. See EMERSon, "Legs. of Cain", p. 489.

2082 Gen. 9:28: "Vixit autem Noe post diluvium trecentis quinquaginta annis." The reading "fourty zeer" in all MSS is plainly an error. Morris seems to have added the figures in 11.2082-3 to get his running headline "Noah lived 990 years", $C M$, p. 127.

2087-90 Long tradition assigns these parts of the world to the sons of Noah. See Josephus 59-73; Bede, Hex., PL XCI 123; In Pent., PL XCI 228; Hugh of St. VIctor, Adnot. in Pent., PL CLXXV 49; Hist. Schol. Gen. xxxvii, $P L$ CXCVIII 1087 ; cf. Rev. Meth. 354-65; Mandeville L 155.

2091ff. This passage does not come from any of the $C M$ poet's usual sources. A comparison with Isidore's Etymologies, the basis of most mediaeval geography, shows that the $C M$ poet's information is condensed from Isidore. The information may have reached the ME poet through an intermediate source, however.

2096-8 IsIdore, Etym. XIV ii 2-3. Cf. Hugh of St. Victor, Adnot. in Pent., PL CLXXV 49.

2102 Etym. XIV iii 20 and 23 mention Judea and Galilee. The heathens are probably the marvellous inhabitants of Asia mentioned in so many travellers' tales.

2103 Etym. XIV iii 5, 6, 7 enumerates the spices and precious stones of India.

2104 Etym. XIV iii 2.

2105 Etym. XIV iii 5 on India; 12 on Persia; 15 on Arabia.

2106 Etym. XIV iii 14 on Babilonia, 20 on Judea. "Sulie" is a corruption of "surie"/Syria, as Kaluza suggests in his glossary, CM, p. 1818. Note MS B's “Surry". Cf. Etym. XIV iii 16.

2108 Etym. XIV iii 14 on Babylon.

2109-10 Etym. XIV v 1, "De Libya" begins "Libya... hoc est Africus."

2113 Etym. XIV $\vee 8$ on Carthage.

2115-6 These lines are corrupt and may have been transposed. "Mortaygne"

is Mauretania. "Ienile" is a corruption of Gaetulia "Ietule" being misread by a scribe as "Ienile"). "Indie" cannot refer to India, which was discussed in its proper place under Asia, at 1.2105 above. Rather, it is a corruption of Numidia ("Numidie" having lost some initial minims). The same misreadings occur in Trethewey, ed., La Petite Philosophe, p. 40, 1.1231 and n., pp. 117-8: "Puis est Genilie e Indie".

Morris punctuated MS C to suggest that "pis land" of 1.2117 referred to Africa or possibly to "Indie". If the lines are reversed, however, "Ienile mortaygne \& indie" carry on the enumeration of other countries and cities of Africa begun in 11.2111-4. The passage would then continue:

pe myche londe of ethiopye pat lond is moost into pe soup pere pat blo men are ful coup 
Lines $2115-8$, then, clearly translate Isidore's discussion:

Proxima autem Hispaniae Mauretania est, deinde Numidia, inde regio Carthaginensis, post quae Gaetuliam accipimus, post eam Aethiopiam, inde loca exusta solis ardoribus... Aethiopia dicta a colore populorum, quos solis vicinitas torret (Etym. XIV v 17, 14).

Furthermore, of the MED's citations under "blo-man", six connect them with Ethiopia, and only this one line in the $C M$ with India.

2119 The poet says almost nothing about Europe, the best known part of the world in the Middle Ages.

The original reading was CFG's "lest". The southern translation's "best" contradicts 1.2090 .

2132 One would expect the figure 72 here. The Vulgate text enumerates 15 descendants of Noah in Japheth's line, 30 in Ham's and 27 in Shem's (Gen. 10). Similarly the number of workmen engaged in building the Tower of Babel and the number of languages there created was usually 72. See Bede, Hex., PL XCI 123; Hugh of St. Victor, Adnot. in Pent., PL CLXXV 49; IsIDore, Etym. IX ii 2; Hist. Schol. Gen. xxxvii, $P L$ CXCVIII 1087; MCNALLY, Bible, 38. The figure is important, for it reappears in the New Testament as the number of missionaries sent out to preach, excluding Christ's disciples, in $L u c$ 10:1.

In ME, $G \& E 669-70$ mentions the 72 workmen, as does the Quaestiones 285 , although later on in the dialogue the number of languages is said to be 62 . See Quaestiones 287.

The $C M$ poet probably gets his figure from Trad. anon. fol. $222 \mathrm{r}$ col. 1 which says that 62 languages were spoken after the Tower of Babel was abandoned. Although the correct figure, 72, appears everywhere else in the Trad. anon., the $C M$ poet stays with the incorrect one. At various times he says that Noah's descendants numbered $60(1.2132)$, and that 60 workmen built the Tower of Babel (1.2214), but 62 speeches resulted (1.2270), although no descendants of Shem took part in the work (11.2279-80). Also the Tower was 62 fathoms broad (1.2241).

2133-6 The passage is an elaboration of Gen. 9:26-7. Its immediate source is Honorius Augustodunensis' DIM. After the Flood, men are divided "in liberos, milites, servos. Liberi de Sem, milites de Japhet, servi de Cham." See PL CLXXII 166.

The three classes usually mentioned in this context are priests, slaves and knights. The $C M$ passage is the earliest instance in English of the subdivision of the class of commoners into thralls and freemen. See Thrupp, Merchant Class, 289-91. However, as early as the tenth century (probably), the Rigs pula had given mythological sanction to this commonplace of Scandinavian social organization. See Gwyn JonEs, History of the Vikings, pp. $145 \mathrm{ff}$.

2140 Shem lived to be 600 years old (Gen. 11: 10-1).

2141-2 Hist. Schol. Gen. xlvi, PL CXCVIII 1094: "Huic Melchisedech, aiunt Hebraei fuisse Sem filium Noe."

2151-2 The quotation given in the note to 11.2141-2 abcve continues "et vixisse usque ad Isaac." The poet's seventy years (MS C wrongly has seven) is a puzzle. Calculations from the Vulgate involving the age of each man at the time of the birth of his first-born son would indicate that Isaac was 110 years old when Shem was 600. DIM says Shem died in Jacob's time. See PL CLXXII 168. 
2154-6 The poet realizes that the genealogy given in Gen. 11:10-27 is only of the succession of eldest sons from Shem to Abraham. Cf. Augustine's discussion, $D C D$ XVI x.

The genealogy which follows is found also in DIM, PL CLXXII 166.

2157-8 Gen. 11:12-3. MS C's reading "tuenti" is wrong.

2159-60 This Cainan does not appear in the Vulgate here. The $C M$ poet takes him from DIM, PL CLXXII 166, where he is said to have lived 438 years. He comes ultimately from the Septuagint, Gen. 11:12-3, where he has a life span of 460 years. Petrus Comestor points out that the name appears in the genealogy of Luc. 3:36 in the Vulgate as well. See Hist. Schol. Gen. xli, PL CXCVIII 1090. Cf. DCD XVI x; Higden 241.

2163-4 Gen. 11:16-7. Heber lived 464 years, not 444 .

2165-6 "anen" is a mistake for "nine" in MS C.

2172 Gen. 11:24-5. Nahor did not live to be 88 , but 148 . The correct reading would be "seuen score and eizte".

2177-8 Gen. 11:1.

2181-94 Gen. 10:2-7. The order of names is often rearranged for the sake of rhymes.

2186 "Togoriens" is a scribal corruption of "Togorma", as in MSS CF. Cf. the Vulgate "Thogorma".

2187 MS C's "antechim" is an error.

2189-90 Gen. 10:5. GHTLB's "foly" is probably a scribal corruption of C's "folk".

2193 MSS CF have "euila" for the Vulgate's "Hevila". G's "enila" should also be transcribed "euila". The southern translator's "ielula" results from a misreading of minims.

2195 The poet skips the sons of Regma (Gen. 10:7) and the rest of the genealogical information in Gen. 10. to pursue the story of the last son of Chus, Nimrod.

Genesis does not say exactly who built the Tower of Babel, but a very early tradition assigned it to Nimrod because of Gen. 10:10. See "Babel, Tower of', " Nimrod", Jew. Encyc.; Driver, Genesis, 122-3; Menner, ed., Solomon and Saturn, pp. 122-3.

2199-2209 I know no source for this passage. The wickedness of Nimrod was well known, however. See Hist. Schol. Gen. xxxvii, PL CXCVIII 1088.

2208 The southern translator's line is probably a rationalization of a corruption of "maistri" (CF) to "merci" (G).

2210-1 Trad. anon. fol. $222 \mathrm{r}$ col. 1 .

2212-3 Gen. 11:2. C's "felauscap", meaning a crew of workmen, is preferable to readings in the other MSS.

2214 Cf. note to 1.2132. The Trad. anon. says he brought 72 people.

2218 Nimrod and his followers were idolaters, traditionally worshippers of the sun. See the homily "De Falsis Diis" in Homs. of Aelfric II, ed. PoPe, 68/82-4 and the sources there cited. Cf. Hugh of ST. VIcTor, Adnot. in Pent., PL CLXXV 49; Hist. Schol. Gen. xxxvii, PL CXCVIII 1088. A Jewish tradition held that the people built the tower of Babel to the heavens to war on God. See GinzBERG, Legends V, pp. 201-2 n. 88; IsIDORE, Etym. VII vi 22; Wyntoun 1439-40; Gower, Prol. to Confessio Amantis 1020-1. In these lines, the poet presumably made the logical 
connection and had Nimrod make war on the sun and moon. Cf. another Jewish tradition, which said Nimrod wanted to ruin heaven, in GinzBERG, loc. cit. Cf. also below, 11.2232-6.

2224-8 Nimrod's speech reflects the other traditional reason for building the tower, that in it the people would be safe from another flood. See Hist. Schol. Gen. xxxviii, PL CXCVIII 1089. Cf. Trad. anon. fol. 221v col. 2; EVRAT, fol. 25r col. 1; MACÈ 1178-84; $G \& E$ 659-62; Rev. Meth. 326-9; HigDen 249. Lydgate has Nimrod build two towers in the Fall of Princes, one to escape another flood (1079-85) and the second to take heaven away from God (1191ff).

2231 The square and scantillon were both carpenters' tools, the scantillon used for measuring thickness. The two frequently appear as an alliterative formula. See the citations in $O E D$.

2232-6 See note to $11.2217-8$ above.

2233-4 From Trad. anon. fol. 221v col. 1.

2238 From Trad. anon. fol. $221 \mathrm{v}$ col. 2.

2241-2 The Trad. anon. fol. 221v col. 1 gives some dimensions of the building, but none which correspond with these measurements. Cf. n. to 1.2132 above. Jewish tradition held that the Tower of Babel was 70 stairs high because of the 70 families which built it. See GINZBERG, Legends, V, pp. 202-3 n. 88.

2242 The groundwall was a low wall of stone or brick upon which the timber groundsills of a building were often set to preserve them from rotting. See Salzman, p. 201.

2245-6 Gen. 11:3. Bricks were called "tiles" until the fifteenth century, when the word brick came into use. See Salzman, pp. 140-2.

2248-52, 2256-61 From Trad. anon. fol. 221v col. 2.

2265-6 MSS CFG preserve the original reading "schending", meaning confusion. This is the usual interpretation of the word Babel, as in Gen. 11:9.

2269-70 Trad. anon. fol. $222 \mathrm{r}$ col. 1 :

Deuant nauoit ou monde que $i$ langaige

Sesante \& ii enfut par cel outraige

Cf. n. to 1.2132 above.

2279-81 Trad. anon. fol. $222 \mathrm{r}$ col. 1.

2289-2302 Hist. Schol. Gen. xl, PL CXCVIII 1090. Comestor attributes the beginnings of idol-worship to Ninus, which the $C M$ poet alters to Nimrod. From the fourth century on, however, Ninus, the founder of Ninevah, had sometimes been identified with Nimrod the founder of Babel, of which Ninevah itself was a colony. See Gen. 10:11. On this subject see CoOKe, "Euhemerism", 396-410, and Menner "Two Notes on Mediaeval Euhemerism", 246-8. The ultimate source of the concept is Sap. 14: 15-21.

2303-4 These lines are added to the Hist. Schol.'s description of the beginning of idolatry. The idea that devils enter into statues or idols to mislead the people is widespread. Jewish sources describe this happening to a statue made by Enosh, one of the descendants of Seth. See GinzBERG, Legends, V, pp. 150-1, n. 54. French paraphrases tell of it happening to the image of the golden calf. See Herman, 1. 2117; Geoffrol DE Paris, fol. 25v cols. 1-2; Malkaraume, fol. 54r col. 1. However, Panton and Donaldson, ed., Destruction of Troy, 11.4332-57 agrees 
with $C M$ in having the incident happen to Nimrod's statues. Cf. AELfric, ed. POPE, 687-8/197-201.

2307-8 Gen. 22:20-2 names eight children of Nahor, including Hus, Buz and Bathuel.

2309 Hist. Schol. Gen. Iviii, PL CXCVIII 1105.

2310 Gen. 22:23 says Bathuel begat Rebecca. The reference to her brother Laban is an anticipation of Gen. 24:29.

2311-2 MSS CF mention two daughters of Aran, while GHTLB say he had three, presumably counting Lot as a daughter. However, some genuine confusion did exist over this family. A mysterious Jescha appears in Gen. 11:29 but is never mentioned again. For the sake of neatness, Jewish tradition identified Jescha with Sarah. See JosepHus 75; Targ. of Jon. 192; RAshi 47; SkinNer, Genesis, 238. Later commentators accepted the identification, as did ME paraphrasers. The scribe responsible for the reading "three" in MSS GHTLB, then, might have been counting Sarah, Melcha and Jescha as three different daughters of Aran. Cf. however, 11.2333-4.

2315-8 Trad. anon. fol. 222r cols. 1-2. L.2316 appears in French as "Et fuit racine de crestiene foi". The MS which the $C M$ poet used must have had "loi" instead. Abraham, whose obedience is everywhere stressed, makes more sense as a root of Christian faith, rather than of law.

2315-26 Abraham's place in the genealogy of the Virgin is now made clear. 2333-4 Cf. note to 11.2311-2.

2335-6 This was later specifically prohibited by Lev. 18:9 and 20:17.

2343-50 Cf. Gen. 13:16, 15:5-6, and below, 11.2568-72. The "graueles in pe see" metaphor in 1.2347 and 1.2571 comes from Gen. 22: 17 .

2355 Genesis contains some discrepancies in the ages of the patriarchs here. Thare is 70 when he begets Abraham (Gen. 11:26), and Abraham leaves Haran at 75 (Gen. 12:4). At this time, Thare would only have been 145 years old, yet his death in Haran at 205 has already been described (Gen. 11:32). Jerome and Augustine both tried to solve the apparent discrepancy. See Quaest. in Gen., PL XXIII 1006; Quaest. in Hept. I XXv, $P L$ XXXIV 553-4.

The $C M$ poet does not notice the difficulty. He assumes that Abraham left Haran immediately after his father's death (11.2357ff) and the figure sixty-five (1.2355) is a straightforward error for seventy-five. Cf. $G \& E 731-2,739-40$.

2357ff The $C M$ poet seems to take his account more or less from Genesis, but various lines come from Trad. anon. fol. 222v, esp. 11.2364-7, 2395-7, 2410, 2430, 2438.

2364-7 Trad. anon. fol. $222 \mathrm{v}$ col. 1.

2364 MSS CG have the original reading, the northern imperative form "ta" of the verb "take", with the k suppressed. The southern translator, or his exemplar, misread this as "to".

2367 This is the only mention of Ur of the Chaldees, the original home of Abraham (Gen. 11:31), here incorrectly identified with Haran. The biblical account contains a confusion resulting from the joining of the $J$ and the P narratives. The compiler of Genesis tried to reconcile two traditions by having Abraham leave Ur, move to Haran, and then move on from there. However, when Abraham sends his servant to procure a wife for Isaac, 
he speaks as if Haran, not Ur, were his native city. See Gen. 24:4, 7, 10 ; $27: 43 ; 28: 10 ; 29: 4$.

2395-7, 2410 Trad. anon. fol. $222 \mathrm{v}$ col. 2 and $223 \mathrm{r}$ col. 1.

2419 The $C M$ poet does not mention Pharaoh's offers to Abraham, nor the plagues which God sent (Gen. 12: 16-7).

2430 The silver and gold which Pharaoh gave to the departing Abraham comes from Trad. anon. fol. $223 \mathrm{r}$ col. 2.

2438, 2441-2, 2445 Trad. anon. fol. 223r col. 2.

2447-56 Two reasons are given in Genesis for the separation of Abraham and Lot. The $P$ document says that there was not enough pasture for both flocks (Gen. 13:6) while $J$ says that the herdsmen were quarrelling (Gen. 13:7). The $C M$ poet reconciles the two versions.

2470 Trad. anon. fol. $223 \mathrm{v}$ col. 1.

2480 Both the poet of the Trad. anon. and the CM poet omit God's promise in Gen. 13: 14-7.

2481 Gen. 13:18 speaks of "convallem Mambre", but the $C M$ calls it a hill, as does Met. Para. 556, and Anc. test. fol. 5r col. 2.

2489-90 Trad. anon. fol. $223 \mathrm{v}$ col. 2.

2491-2528 Much of this account of the war among the kings is taken from Trad. anon. fol. $223 \mathrm{v}$ col. 2-224r col. 2. See esp. 11.2491-8.

Modern commentators agree that Gen. 14 came from a different source from the rest of the book, and is probably a later interpolation. See Driver, Genesis, p. 155, Von Rad, Genesis, p. 169. The gusto with which the battles are treated in the OEGen. (11.1960ff) is unmatched in ME.

2520 "themas" is a scribal error for "demas", Trad. anon. "damas", probably by confusion of capital $\boxplus$ with capital D. However, Petrus Comestor mentions a place called "Themam" in connection with Ishmael, and the $C M$ poet may have confused the one with the other. See Hist. Schol. Gen. Ivi, PL CXCVIII 1104.

2535-44 Cf. Gen. 14: 18-24, though the speeches are much abbreviated in the ME version.

2537-8, 2540 Probably from Trad. anon. fol. 224r col. 2. Cf. Hist. Schol. Gen. xlvi, PL CXCVIII 1094-5.

2551-76 Genesis reports two separate visions, one waking and one sleeping (Gen. 15:1, 12). The $C M$ poet takes the setting of his one dream from the latter verse. The Trad. anon. also has only one vision, but it is a waking one.

2571 Trad. anon. fol. $224 \mathrm{v}$ cols. 1-2. Cf. fol. $225 \mathrm{r}$ col. 1.

2577-8 The poet omits the details of the sacrifice in Gen. 15:7-11, 17.

2579-2634 Cf. Gen. 15:13-16, 16:1-12.

2595ff. Some commentators were uneasy with the idea of the virtuous Sarah suggesting her husband commit adultery. Josephus 93 had her do it at God's command, while Augustine excused it because the deed was motivated by a desire for progeny rather than by lust. See $D C D$ XVI XXv.

2613-4 Gen. 16:6 reads "Affligente igitur eam Sarai." Augustine, for one, was bothered by the virtuous Sarah, frequent symbol of the Church, having persecuted her slave. See Epist. CLXXXV ii, PL XXXIII 797. So too the Met. Para. 517-26, but not the CM poet.

2637-48 Cf. Gen. 16:15-6;17:1-16. 
2643 Abraham was, in fact, 99 years old, not 109. See Gen. 17:1. Cf. below, 1.2699.

2650-1 The change of name is from "Abram" to "Abraham" in Gen. $17: 5$, although few ME scribes make the distinction.

2653-4 Petrus Comestor makes the etymology rather clearer than does the Vulgate. See Hist. Schol. Gen. 1, PL CXCVIII 1097.

2689 The $C M$ poet does not describe Abraham's laughter at God's promise of a child in his old age, nor record His promises for Ishmael (Gen. 17: 17-22).

2693-2700 Cf. Gen. 17:23-7.

2697 MS F has the correct reading thirteen years. Cf. Gen. 17:25. The other MSS all read 30.

2699 Cf. note to 1.2643 above.

2701-2 Cf. Josephus 95; Hist. Schol. Gen. 1, PL CXCVIII 1097; G \& E 1004 ; Higden 293 ; cf. above 1.2666.

2703-4 Cf. Gen. 18:1.

2705-12 BuEHLER, " $C M$ ', pp. 289-90 first suggested that these lines are based on HERMAN's Bible, 11. 423-6.

2709-10 The angel who speaks to Abraham in the Vulgate is referred to as "Dominus" (Gen. 18:3, etc.) which led most commentators to see the three angels as a manifestation of the Trinity. See, e.g., IsIDORE, $A l$ legoriae, PL LXXXIII 104; BEDE, Hex., PL XCI 167; VON RAD, Genesis, p. 201. Cf. also $G$ \& E 1010-2; SELTemp. fol. 2r col. 1; Met. Para. 573-6 and Piers Plowman C XIX 242-8. These latter two works both use the formula quoted in Piers Plowman: "Tres vidit et unum adoravit."

2713 Cf. Gen. 18:4. By having Abraham himself wash their feet, a further parallel with Christ is brought out. Cf. also Trad. anon. $225 \mathrm{v}$ col. 1 and Anc. test. fol. $5 \mathrm{r}$ col. 2 which also have Abraham washing their feet.

2714-5 Cf. Gen. 18:5-8. This passage bothered early commentators, for according to biblical authority angels did not eat human food. See $I u d$. 13:16; Tob. 12:19; SKInNer, Genesis, p. 300; Von Rad, Genesis, pp. 201-2. Several Jewish commentators say that the angels only gave the appearance of eating. See JosePHus 97; Targ. of Jon. 211, 214 ; Midrash xlviii 14, p. 415; RASHI, 72; GINZBERG, Legends, V p. $236 \mathrm{nn}$. 143-4. Principally through Comestor, this idea spread widely. See Hist. Schol. Gen. li, PL CXCVIII 1098-9; $G$ \& E 1015-8; Cleanness 641-2; Geoffroi de Paris fol. $14 \mathrm{r}$ col. 2 ; Évrat fol. $42 \mathrm{r}$ col. 1.

The poet of the $C M$ was not troubled by this problem, apparently, but an annotator in MS F was aware of it, for he wrote in the margin "hou god et botter [sic] \& botter". See Morris, CM, p. 164, MS F.

2716-48 Cf. Gen. 18:9-21.

2741-2 Trad. anon. fol. $225 \mathrm{v}$ col. 2.

2742,2744 Cf. 1.1644 above, and note.

2749-64 The haggling between God and Abraham recounted in Gen. 18:

23-33 is here much abbreviated. This is standard practice among para-

phrasers. See Josephus 99; Hist. Schol. Gen. lii, PL CXCVIII 10991100 ; $G \& E$ 1041-6; SELTemp. fol. 2r col. 1; Met. Para. 577-84. Among English works, only Cleanness gives a full account of the conversation, 11.713-66.

2761-2 Trad. anon. fol. $225 \mathrm{v}$ col. 2. 
2765-2846 Cf. Gen. 19:1-25.

2810 The Bible does not mention the cities sinking. Cf. however, Herman $469 ; G \& E 1114$.

2848 See Whiting, Proverbs, B529, where many other occurrences of this proverb are cited.

2849-55 From Herman's Bible, 467-74. See Buehler, "CM", pp. 490-1. Lot's wife also turns back on hearing the cry from the city in MALKaraume fol. $5 \mathrm{v}$ col. 2; Geoffrol De Paris, fol. $14 \mathrm{v}$ col. $2 ;$ Anc. test. fol. 5v col. 1; OEGen. 2562-5.

2854 Cf. Josephus 101; Hist. Schol. Gen. liii, PL CXCVIII 1101; OEGen. 2567-71; Met. Para. 612; Malkaraume, fol. 5v col. 2; Geoffrol DE ParIs, fol. $14 \mathrm{v}$ col. 2 ; Anc. test. fol. $5 \mathrm{v}$ col. 1.

2856-60 A similar legend is found in Pirke xxv p. 186, but this is the only other occurrence of this legend that I have found. Beasts are briefly mentioned in SELTemp. fol. $2 \mathrm{r}$ col. 1.

2861-80 Hist. Schol. Gen. liii, PL CXCVIII 1101; cf. xliv, and Add. 1, 1092 and 1093.

2877-80 The story of the dead sea apples is a very popular one. See $G \& E$ 1127-30; Mandeville S 63/1-5; Cleanness 1041-8; Tacitus Hist. V vii; JOSEPHUS, History of the Jewish War III 143-5; IsIDORE, Etym. XIV iii 25; Fulcher of Chartres, Historia Hierosolymitana II iv, PL CLX 867.

2879 The poet originally compared these fruits not merely to round balls but to puff-balls (C "fise bal", $F$ " pis balle").

2881ff This is one of the $C M$ poet's rare direct, moralistic interpretations of the story which he has been telling. Many mediaeval writers delighted in describing the sexual sins of Sodom. See esp. SELTemp. fol. $2 \mathrm{r}$ col. 1 and Cleanness 689-712.

2907 Another popular interpretation of the sin of Sodom, based on $E z$. 16:49: "Ecce haec fuit iniquitas Sodomae, sororis tuae: superbia, saturitas panis et abundantia, et otium ipsius, et filiarum ejus;' See JosEPHus 95; Hist. Schol. Gen. lii, PL CXCVIII 1099 (where the CM poet must have seen it); Petrus CANTor, Verbum Abbrev. cxxxviii, PL CCV 333-4. In ME, see Piers Plowman C XVI 232-3, cf. B XIV 74-80; Ayenbite of Inwit 206.

2912-6 C.f. Gen. 19:30.

2914 The original reading was CFG's "fell", Latin "in monte". Cf. 1.2832 below.

2917-26 Cf. Gen. 19:27-8.

2929-51 Cf. Gen. 19: 30-38.

2953-8 Trad. anon. fol. 226r col. 2-226v col. 1.

2961-3006 Cf. Gen. 20:1-15. This is essentially the same story as that told in Gen. 12 (see above, 11.2357ff). Many commentators ignore the new telling of the same story, except to wonder how Sarah could still have been so dangerously attractive at the age of 90 . See Augustine, Quaest. in Hept. I xlviii, PL XXXIV 560; Hist. Schol. Gen. 1v, PL CXCVIII 1102. Like the $C M$, Trad. anon. and $G \& E$ also tell the story for the second time, however.

2961 "cadades" (C "cades") is evidently the "Cades" of Gen. 20:1, although the Vulgate says Abraham lived "inter Cades et Sur". 
2974 CF's "talking" was miscopied as "tokening" in GHTLB.

3006 The poet omits the curse which had fallen on Abimelech because of his treatment of Sarah (Gen. 20:17-8).

3007-82 Cf. Gen. 21:1-21.

3013-4 This is a loose translation of Comestor's etymology, Hist. Schol. Gen. 1vi, PL CXCVIII 1103. Cf. Jerome, Liber de Nominibus Hebraicis, PL XXIII 824 ; IsIDORE, Etym. VII vii 4.

3024-6 The reason for Sarah's demand that Ishmael be banished is unclear in the Vulgate, which says simply that Sarah saw "filium Agar aegyptiae ludentem cum Isaac filio suo" (Gen. 21:9). The CM poet does not look farther than this, although many explanations were provided in the Middle Ages. See Skinner, Genesis, 322; Driver, Genesis, 210-1; Von RAD, Genesis, 227; "Isaac", "Ishmael", Jew. Encyc.; Jubilees, 17:4; Josephus 107; Targ. of Jon. 221; Hist. Schol. Gen. 1vi, PL CXCVIII $1103 ; G \& E$ 1213-4.

3050 MSS CF have the more accurate reading "trused" for the Latin "imposuit scapulae ejus", Gen. 21:14. This is weakened in MSS GHTLB to "tok".

3055 As Hagar and Ishmael are dying of thirst, the poet's statement that they stay by a well is incongruous. It is, of course, an anticipation of the revelation of 1.3066 (Gen. 21:19).

3061-7 Trad. anon. fol. $227 \mathrm{v}$ col. 1.

3065 The reading "blinde" (in MS F and originally in MS C also) may have been suggested by the sequel in Gen. 21:19: "Aperuitque oculos ejus Deus ;". However the line is now corrupt in all MSS.

3083-94 This is not found in the Vulgate, which continues with the story of the covenant of Beersheba, omitted altogether by the $C M$ poet. BuEHLER, "CM" pp. 491-2, has demonstrated, however, that the ME poet has selected a few details from a long passage in Herman's Bible, 11.419-22, 507-11, describing Abraham's longevity and character.

3095-3116 This passage is even more obviously borrowed from HerMan, 11.513-35. See BuEHLER, "CM", pp. 492-3. It continues to detail the degeneration of the world from its original state, a view which is thematic in the $C M$. The further mention of tithing in connection with sacrifice is also a continuing motif.

3115 MS C's "wil" is an error for "wit", as comparison with the source shows.

$3117 \mathrm{ff}$ The story of Abraham's willingness to sacrifice Isaac was a very popular one with mediaeval audiences. The $C M$ poet does not follow the Vulgate in his retelling of it, nor does he stress the importance of the incident as a figure of the sacrifice of Christ, an allegorical interpretation much favoured in exegesis.

3119-24 Herman, 11.557-63. See Buehler, " $C M$ ", 494. The lines serve to underline the deep and longstanding emotions involved in the incident.

3131 Cf. Herman, 1.571.

3133-46 The poet begins to stress Abraham's absolute obedience to God's order. This is one of the rare places where the $C M$ poet steps in to interpret his story.

3147-80 Cf. Gen. 22:2-8, 10-13.

3152 Isaac is consistently referred to as a child here, which greatly increases the pathos of the situation. A strong mediaeval tradition, ul- 
timately Jewish, made Isaac a man at the time of the sacrifice. See "Isaac", Jew. Encyc.; Von Rad, Genesis, 238; Josephus 113; Pirke XXXI 225; Hist. Schol. Gen. Iviii, PL CXCVIII 1104; G\&E 1284; SELTemp. fol. $2 \mathrm{r}$ col. 2 ; York $X 821$. His maturity is also implied in Met Para. 714-6, 729. The other Abraham and Isaac plays in ME agree with the $C M$ in calling Isaac a child, however. So too does GeoffroI DE Paris fol. 14r col. 1. See Wells, "The Age of Isaac", 579-82.

3168-72 Abraham is concerned lest the boy see the sword as he draws it. Cf. Chester IV 337-40; Lud. Cov. 179-82 and the Malvern windows described in M. D. ANDERSON, Drama and Imagery, 109.

3189-98 Although based on Gen. 22:15-8, the angel's speech has been altered to stress Abraham's obedience further.

3203-6 Abraham's swearing Isaac to secrecy is not in Gen., but was borrowed from Herman's Bible, 11.613-7. See BueHLer, " $C M$ ', 494.

3209-14 The ME poet has already given the genealogy of Nahor, in Gen. 22:20-4, cf. $C M, 11.2307-10$. He omits virtually all of Gen. 23 dealing with the purchase of land for Sarah's burial. This is true of the other ME and most of the French paraphrases.

3215-3400 Most of the following story comes from Trad. anon. fol. 228r col. 1-228v.

3225 Genesis and the Trad. anon. both describe the Hebrew custom of swearing with the hand under the thigh. The $C M$ poet substitutes a more mediaeval tradition.

3230 Mesopotamia is not mentioned here in Gen. or in Trad. anon.

3246-50 The treasure comes from Trad. anon., but the camels are from Gen. 24: 10 .

3260 MS C's "now" is an error for "my".

3283 Kaluza glosses "vnlaghter" as "without fault", (OE leahter). Cf. Morris' note $C M$, p. xxxvii. The French, however, reads "qui ne uint pas riant", so the English was more probably intended to mean "without laughter".

3286-7 From Gen. 24:15, not Trad. anon.

3295-3300 Not in the Vulgate or Trad. anon.

3313-5 There is some confusion over Rebecca's father. Although he never appears, he is usually called Bethuel (Gen. 22:23, 24:15, 24). The negotiations for the marriage are carried on by her brother. Josephus and, following him, Comestor speculated that Rebecca's father was dead. See Josephus 123, Hist. Schol. Gen. 1x, PL CXCVIII 1107. The CM poet ignores the latter opinion to state plainly that Rebecca's father is alive.

3327-31 A condensation of Gen. 24:33-49, in which the messenger retells the whole story.

3332 Cf. above 11.1889-92.

3337 A condensed version of the negotiations in Gen. 24: 53-9 and Trad. anon. fol. $228 \mathrm{v}$ col. 2.

3347 "foster moder" is closer to the Vulgate's "nutricem" than is the "moder" of MSS GHTLB. The line does not appear in Trad. anon.

3349-62 Details come from Gen. 24: 63-5, rather than from Trad. anon.

3363-6 Trad. anon. fol. 229r col. 1. Gen. $24: 65$ calls the garment simply a "pallium". Comestor, Hist. Schol. Gen. 1xi, PL CXCVIII 1107, says that this was an Arabic woman's costume and that it was white. The red mantle comes definitely from the French. 
3369-80 The poet expands on the couple's joy in each other which is suggested briefly in Trad. anon. The poet also continues to stress the contrast between the purposefulness of those times and that of his own, a concept which is not in the French work.

3375-80 Gen. 24:67 and the poet's own reflections.

3381-2 Gen. 21:21 and 25:12-6 mentions the twelve princes which came of Ishmael, but give him only one wife. Cf. Hist. Schol. Gen. 1vi, PL CXCVIII 1103-4, which mentions the two events together.

3384 Cf. Hist. Schol. Gen. 1Xv, PL CXCVIII 1109, which says that Ishmael's sons ruled India.

3387-94 Trad. anon. fol. 229r col. 1:

Sa darrienne femme ot en nom securra

Ne fut pas lealte que avec li se aiosta

MS Arsenal 3516 has the same reading. The MS which the CM poet consulted may have had "licherie", not "lealte". Cf. Augustine, $D C D$ XVI xxy who excuses Abraham's affair with Hagar on the same grounds.

3415-42 This passage links the children of Isaac, born late after much prayer, with other similar children in history.

3426 This line, perfectly clear in $\mathrm{C}$, is meaningless in the southern translation.

3443-88 BUEHLER, " $C M$ ", p. 495 says these lines are a condensed version of HERMAN's 11.640-754. The other ME paraphrases brush hastily over the entire event, as does the Trad. anon.

3491-2 This is the etymology of the name Esau. See Jerome, Liber de Nom. Hebr., PL XXIII 823; IsIDORE, Etym. VII vi 33; cf. Hist. Schol. Gen. 1xvi, PL CXCVIII 1110.

3494-8 The Vulgate merely says "Jacob...habitabat in tabernaculis...et Rebecca diligebat Jacob" (Gen. 25:27-8). The CM poet makes this into a cause and effect ralationship: because Rebecca loves Jacob, she keeps him at home. The Met. Para, on the other hand, says that Rebecca loved him because he stayed at home (1.800).

3499-3500, 3506-16 From Herman's Bible, 11.794-805. See Buehler, " $C M$ ", 495-6.

3506 The line is garbled in the southern translation. MSS FG have the best reading.

3509-16 The comment about the former efficacy of blessings continues the theme of the present degeneracy of the world. Here the poet stresses the seriousness of Esau's crime in selling the blessing which should have been his.

3529-30 See Whiting, Proverbs, H200.

3553-4 The $C M$ poet has followed the Vulgate in simply attributing Esau's folly to his great hunger. Here, however, he adds a note to say that this was all part of God's design. Cf. Hist. Schol. Gen. Ixvi, PL CXCVIII 1110 ; "Creditur enim in utero jam tunc sanctificatus fuisse Jacob." Cf. note to $11.3717-8$ below.

The $C M$ poet, like most other ME paraphrasers, omits the matter of Gen. 26, which includes another version of the story of the patriarch telling strangers his wife is his sister, and an account of Isaac's adventures in Gerar and Beersheba. Only the ME $G \& E$ mentions this 
at all, and the dullness of its brief account of Isaac's moves (11.1513-26) amply justifies their exclusion from the other works.

3555-94 Coffman, "Old Age", discusses this passage. He traces the topos of old age from Horace through Maximianus and down to the Middle Ages. Coffman believes that the immediate source of the $C M$ 's lines was the Pricke of Conscience- 11.766-803, which, however, was written after $C M$.

3595-3700 Based on Gen. 27:1-22, with some expansions in the dialogue. 3701-2 The odour of "piement" comes from Herman, 11.904-5. See BUEHLER, " $C M$ ", 496.

3705-10 Gen. 27:29.

3717-8 Cf. Met. Para. 1.864 and $G \& E$ 1558-60 which also stress that this is part of God's plan. The Book of the Knight of LaTour-Landry goes so far as to praise Rebecca's vision in engineering the misplaced blessing (p. 106).

3719-72 Cf. Gen. 27: 30-44.

3731 Trad. anon. fol. 230r col. 1: "Ysaac se meruoille fait exclamantion." In Gen. 27:33-4 it is Esau who cries out.

3773-86, 3791-2 Gen. 28: 11-3.

3783 Hist. Schol. Gen. Ixxiii, PL CXCVIII 1114.

3787-90 The Met. Para. 918 also has God specify that Jacob will marry twice.

3794 The scribe of MS T has miscopied the end of the line.

3797-3818 Cf. Gen. 28:16-8, 20-22.

3806 C's "voo" (Latin "votum") is original, but GHTLB's "voys" is an interesting substitute.

3819-34 Cf. Gen. 29:1-6. The ME paraphrasers are in general not much interested in this incident. The SELTemp. fol. 2r col. 2; and Met. Para. 79-82 reduce the whole romantic story of the meeting of Jacob and Rachael to a businesslike announcement of the final arrangement.

3835-62, 3867-94 Based loosely on Gen. 29:9-23, 25-8.

3862 Leah's eye trouble varies slightly. The Vulgate says "lippis erat oculis" (Gen. 29:17), - her eyes were inflamed or watering. The Authorized Version calls her "tender-eyed". The ME poet is less gallant. He calls her "glized", having a squint or cast in one or both eyes. Geoffroi de Paris, fol. 17v col. 2 and Jean Malkaraume, fol. 11r col. 1 simply say she was ugly.

3863-6 The Trad. anon. fol. $230 \mathrm{v}$ col. 2 displaces the story of Jacob's work with Laban's cattle, Gen. 30:37ff, and tells it here.

3873-4 The $C M$ poet does not report the tradition that Jacob was too drunk to know the difference. Cf., however, JosEPHUS $145 ;$ Hist. Schol. Gen. 1xxiv, $P L$ CXCVIII $1115 ; G \& E 1675 ; S E L T e m p$. fol. $2 v$ col. 1.

3896-3904 Trad. anon. fol. 231r col. 1. Cf. Gen. 35:23-6. The Met. Para's format is very similar, 11.985-96.

3913-7 The CM poet omits the story of Jacob's trick to increase his herd, and the difficulties he encountered on leaving Laban (Gen. 30:25-31:18).

3921-6 Cf. Gen. 31:19-35. Only MS C preserves the original mention of Laban's pursuit of the fleeing family.

3931-52. Cf. Gen. 32:24-32, slightly rearranged.

3952 The author's etymology of the name Israel is from Hist. Schol. Gen. 1xxxi, PL CXCVIII 1121: "vir videns Deum." Cf. Etym. VII vii 6. 
3953ff The poet has grouped the whole story of the meeting with Esau together, rather than interpolate the wrestling episode in the middle, as is done in Genesis. L1.3953-60 condense Gen. 32:3-8.

3963-4 Gen. 32:13.

3968-72 Gen. 32:7-8.

3973-4010 BUEHLER, " $C M$ ", 497-9, points out the similarities between this passage and HermaN's Bible, 11.1118-54, especially in Jacob's prayer which begins with a recapitulation of history. Cf. Gen. 32:9-12.

4022-4 Hist. Schol. Gen. 1xxxv, PL CXCVIII 1123.

4029-30 Gen. 35:28. Trad. anon. fol. 232r col. 2 says 170 years.

The poet has entirely omitted the story of the rape of Dinah (Gen. 34). This story appealed to the moralists of the Middle Ages. See M. DAY, ed., Ancrene Riwle, pp. 23-4, Book of the Knight of LaTourLandry, pp. 73-4. However, it does interrupt the story of Jacob's life somewhat. $G \& E 1847-62$ is the only ME paraphrase to include even an abbreviated version of it.

4035-6 In fact, Esau received Edom and is the father of the Edomites. See Gen. 36:1,8,9,19,43; Hist. Schol. Gen. 1xxxv, PL CXCVIII 1123.

4041-3 Early Jewish traditions credit Joseph with exceptional beauty in his youth. See the excellent article by Frederic E. FAvERTY, "Legends of Joseph", 79-81. Petrus Comestor quotes Josephus on this point, and Joseph's early beauty gets into many vernacular paraphrases. See Josephus 173; Hist. Schol. Gen. 1xxxvii, PL CXCVIII 1125;G\&E 1910; I\&I 189-92, Geoffroi de Paris fol. 19v cols. 1-2; Malkaraume, fol. 18r cols. 1-2; ÉVRAT, fol. 129v col. 1; MACÉ 2281-8.

4045-6 Trad. anon. fol. $233 \mathrm{v}$ col. 1. This detail comes from the story of Jacob's youth; cf. above 11.3494-8 and note.

4049 MSS FGHTLB's "wise"' is probably original. Comestor called Joseph "sapientior caeteris" in Hist. Schol. Gen. 1xxxvii, PL CXCVIII 1125, also reflecting Jewish tradition. See also FAVERTY, "Legs. of Joseph", p. 82, and $G \& E 1910$.

4055-78 Based on Gen. 37:5-11.

4075, 4079-80 Trad. anon. fol. $233 \mathrm{v}$ col. 1.

4083-4 A further indication that the poet looks on this scene as occurring

in a past time essentially different from the present.

4085-4118 Cf. Gen. 37:12-20.

4105-8 The first two lines appear only in the southern translation. They are obviously not original, but are a ballad-like restatement of a single idea.

4119-68 The speech of Reuben against Joseph's murder is considerably expanded from Gen. 37:21-2.

4145 L1.4143-4, which appear only in MS C, indicate the change of speaker. The scribes of FG did not notice the discrepancy, but the southern translator shows the new speaker by inserting "pei seide" in this line.

4161-9 The actual course of action followed by the brothers is here made part of Reuben's speech of advice. Cf. Gen. 37:20, 31-3.

4170-94 Cf. Gen. 37:22-8.

4174 The southern translator omitted "als" which appears in MSS CFG, thereby changing the statement from a simile foreshadowing Joseph's 
later imprisonment under Pharaoh ( "They left him as if he were in prison") to a literal statement of fact ("They left him there in a prison", i.e. in a place from which he could not escape).

4194 Because Joseph was seen as a type of Christ, commentators often changed the price paid for him from 20 to 30 coins, to correspond with the money paid to Judas in the New Testament. See BEDE, In Pent., PL XCI 263; Roger Bacon, Opus Majus, p. 244; G\&E 1956; SELTemp. fol. $2 \mathrm{v}$ col. 2; ÉVRAT, printed in BonNARD, p. 118. Editions both of Petrus Comestor and of the Vulgate differed in their readings. See Bonnard, p. 118. Compare Hist. Schol. Gen. 1xxxvii, PL CXCVIII 1126 with Joseph HaLL, Selections from Early ME II 643.

The $C M$ poet must have been aware of the alternative readings for the Trad. anon. fol. 234r col. 2 gives both: "Quar lour uendons ioseph $\mathrm{xx}$ ou $\mathrm{xxx}$ besans". He deliberately chose the Vulgate's number.

4197-4211 Cf. Gen. 37:29-33.

4212-36 Jacob's grief is described in much greater detail here than in Gen. 37:34-5. L1.4215-6, 4227-8 are probably from Trad. anon. fol. $234 \mathrm{v}$ col. 1, which also has a very long speech by Jacob here. Cf. also Anc. test. fol. $7 \mathrm{v}$ col. 2.

4237-8 The $C M$ poet, like many mediaeval paraphrasers, omits entirely the story of Judah and Tamar in Gen. 38. In ME, only the Met. Para. pp. 31 ff includes it.

4243 Interpreters encountered a very real difficulty in the story of Joseph's captivity, for his new owner is called Potiphar "eunuchus Pharaonis" (Gen. 37:36, 39:1), yet he has a wife who later tries to seduce Joseph. Furthermore, this Potiphar is often identified with Potipherah, priest of On, whose daughter Joseph marries (Gen. 41:50). What is to be done with a eunuch who possesses a wife and child?

Several ME paraphrases, like the $C M$, respond by translating "eunuchus" simply as an officer or steward. See G\&E 1991; SELTemp. fol. 2v col. 2; Met. Para. 1239. Modern commentators agree that this explanation is etymologically probable. See "Potiphar", Jew. Encyc.; Von RaD, Genesis, 350.

Other, more colourful, explanations were well known in the Middle Ages. Jewish tradition said that Potiphar himself was first attracted to Joseph's beauty, but God moved to protect His favourite by castrating the Egyptian. See Midrash 1xxxvi 3, p. 802; GinzberG, Legends, V pp. 337-8 n. 101; Jerome, Quaest. in Gen., PL XXIII 1046; Hist. Schol. Gen. Ixxxviii, $P L$ CXCVIII 1126-7; $G \& E$ 1995-2008; HIGDEN, p. 305; FAVERTY, "Legs. of Joseph", p. 85. In contrast the CM poet inserts a long passage in praise of Potiphar's broadmindedness, in spite of his Saracen faith. See below, 11.4245-54.

The substitution of Pharaoh's queen for Potiphar's wife which occurs in so many versions of the story, might also have arisen to avoid the awkwardness of a eunuch with a wife. Cf. $n$. to 1.4259ff.

4245 MSS CF's "are" is corrupted to "lare" in G. The southern translator, trying to correct the line, produced the virtually meaningless "in menskful lore".

4248 Perhaps suggested by Trad. anon. fol. $234 \mathrm{v}$ col. 2: "Por ce quil doutoit deu et que sa loy gardoit". 
4249-58 This is reminiscent of Herman's Bible, 11.1190-1204. Cf. especially $C M 3908$ and Herman 1.1201, $C M$ 3909-10 and Herman 1199, $C M$ 3914 and Herman 1197, CM 3916 and Herman 1200.

4255 This seems to be a misinterpretation of Trad. anon. fol. $234 \mathrm{v}$ col. 2 : "Li estrange lamerent et li sien le despirent".

4259ff The story of Potiphar's wife, a favourite in the Middle Ages, is given a greatly expanded treatment in the $C M$. On this whole subject see FAVERTY, "Story of Joseph and Potiphar's Wife".

Several of the French sources used by the $C M$ poet say that the Queen of Egypt rather than Potiphar's wife tried to seduce Joseph. This version of the story was very wide spread and of long standing. It occurs in Tertullian and was especially popular in France, where it appears in Herman's Bible, 11.1205ff; Trad. anon. fol. 234v-235v; Geoffrol de Paris fol. 19v col. 2; Malkaraume fol. 23v col. 2, (cf. Bonnard, pp. 86-7, 43, 59); Warner, ed., Queen Mary's Psalter p. 62 and pl. 29; and Ker, MS BM Harley 2253, fol. 93r. In English the story of Pharaoh's queen is found in I\&I 195ff; WYntoun pp. 333-4; and in the Book of the Knight of LaTour-Landry, p. 76.

FAVERTY, "Legs. of Joseph", p. 88 says simply that "The role of the wicked queen was familiar in popular stories, and temptation by a queen would serve to increase the moral virtue of Joseph." Equally, of course, this version avoids the difficulty of the eunuch's wife. See above, note to 1.4243 .

4259 Gen. 39:11 does not specify where the others of the household had gone when Potiphar's wife tempted Joseph. Hebrew legend said that the men had gone to a public festival. See FaverTy, "Legs. of Joseph" p. 92; Josephus 187 and n.; Hist. Schol. Gen. xc, PL CXCVIII 1128; HeRMan 11.1215-9. Like the $C M$, however, $I \& I 1931-4$ has the servants leave for the country to hunt.

4273-4326 A surprising digression on the force and dangers of love. The moralist gets the better of the historian here, and any similarity with the power of love as extolled in the romances is negated by the concept of sin brought in at 1.4316. Cf. 11.4425-8.

The French paraphrases often seem to pause for reflexion at this point in the story. Anc. test. fol. $8 \mathrm{r}$ col. 1 has a few lines on the torments of love, but without the CM's moralizing. Cf. Hist. Jos. 301/623ff, $364 / 831 \mathrm{ff}$. Two other paraphrases contain a monologue by the rejected queen at this point. See Trad. anon. fol. 235r and Malkaraume fol. $23 \mathrm{v}$ col. 2, the latter printed in BonNARD, "Monologue de la reine d'Égypte".

4276 This is the only citation of this proverb in this particular form in Whiting, Proverbs, L494.

4302 Only MS C preserves the original "mangonele"/a seige engine. The Trad. anon. refers to this weapon in another context on fol. $234 \mathrm{r}$ col. 1.

4316 MSS CF"s "slokend"/quenched is the better reading, carrying on the metaphor of love's fire burning the heart. GHTLB's "strangle" is limp by comparison.

4345-80 The courtly love situation is here reversed, with the lady speaking of love and begging for favours, while the young man stands off.

4357-8 Cf. Trad. anon. fol. 234v col. 1 and Herman, 1.1210. 
4381-6 Potiphar's wife adds threats to her promises of riches to tempt Joseph. Cf. G\&E 2021-4.

4387-4419 Cf. Gen. 39: 12-20.

4389 Cf. Anc. test. fol. 8r col. 2: "e le le tint ferm \& rumpent li tassel".

4395 The misreading of CF's "aleis" as "is" makes the question virtually meaningless in the southern translation.

4407 Potiphar has apparently returned from the country. In the Vulgate the wife has to wait until her husband returns to show him Joseph's cloak, but in HERMAN's Bible, 11.1234-6, the husband himself hears his wife's screams and runs to hear her first complaints.

4408-9 The southern translator has rephrased the lines and eliminated the run-on line of MSS CFG.

4425-8 Other paraphrases declaim against women at this point. See esp. Anc. test. fol. $8 \mathrm{r}$ col. 2 -fol. $8 \mathrm{v}$ col. 1 ; Hist. Jos. 301/607ff, 363/807ff.

4433-98 Cf. Gen. 39:21-40:23.

4446 Trad. anon. fol. $235 \mathrm{v}$ col. 2.

4454 The Trad. anon. also uses the word "uision" here. Furthermore the French poet has a digression on dreams, fol. $236 \mathrm{r}$ col. 2 , in which he shows that a "uision" is the only kind of dream to be trusted.

4473 Some mediaeval commentators were disturbed by any hint of magical powers. In the phrase "wip myzte of heuene", the $C M$ poet firmly establishes Joseph's powers of interpretation as divinely given. Cf. 1.4560 below and Gen. 41:16. Cf. also FAVERTY's discussion of Gen. 44:15, "Legs. of Joseph", 98-100, 102-3.

4491 The southern translator carelessly used the present tense "seip" here, though the scribe of MS L corrected it.

4498-4500 HERMAN, 11.1297-8.

4503-10 This is one of the poet's rare general moralizations.

4508 Whiting, Proverbs, E216 cites several other occurrences of this proverb.

4510 The southern translator corrupted "loues" to "dop". Cf. Whiting, Proverbs, L565. The saying also appears in French: "Qui bien ayme tard oublye."

4511-8 Cf. Gen. 41:1, 8-23.

4514-5 In the Vulgate Pharaoh summons "conjectores" and "sapientes".

See Gen. 41:8. The CM is closer to Herman's Bible here, 11.1312-3:

Manda tous ses barons et tous ses conseilliers;

Dont $i$ viennent baron prinches et chevaliers;

4545-50 A passage of visual description and emotional sympathy which is extremely rare thus far in the $C M$. The poet takes it from Herman, 11.1336-9.

4561-4600 The dream is told as in Herman's Bible, 11.1346-67.

4572 Like the $C M$, Herman does not mention the lean cattle eating the fat ones. Cf. Gen. 41:20.

4579 The southern translation has here preserved a better reading than MSS CFG. "Ful of corn were pei set po", translates Herman, 1.1355: "Les VII cargiés de blé".

4581 Like the $C M$ poet, Herman omits the concept in Gen. 41:24 that the thin ears ate the fat ones.

4605-11 Cf. Gen. 41:26, 33-4. 
4612-46 The remainder of the dialogue in which the king aquits Joseph of the crime against Potiphar's wife is not in Genesis. Cf. however the interchange in Herman's Bible, 11.1369-98 in which Joseph brings up the matter of Pharaoh's wife and is told "Joseph, oublié l'ai". The remarks of the barons also come from Herman.

4647 Herman, 1.1401.

4650-2 HeRMAN, 11.1404-6.

4653-68 Cf. Gen. 41: 42-5.

4668 Several legends about Joseph's wife Aseneth were current in the Middle Ages. See Burchard, Untersuchungen zu Joseph und Aseneth, and DWYER, "Asenath of Egypt in ME". The ME paraphrasers ignore her, however.

4669 ff From this point on, Borland recognizes that the $C M$ poet translates constantly from Herman's Bible for about 800 lines, beginning with Herman, 1.1408. See Borland, $C M$, p. 3.

4674, 4686 The thousand barns and thousand cellars come from Herman, $11.1412,1416,1423$.

4678 The food is more concretely specified in $C M$ and Herman than in Genesis.

4679-83 This is an incomplete sentence in MSS CGHTLB. The $C M$ poet, or an early scribe, erred in writing a preterite tense "filde" instead of another infinitive "fill" in 1.4681. MS F corrects the lapse by supplying a subject, but the original had:

La gent de la contree, quant le voient venir

Et prendre leur aumaille et leur blé departir

Et faire ches greniers tous de leur blê emplir,

(Herman's Bible, 11.1417-9)

MS F alone preserves the original completion of the sentence, 11.4682-3, translating Herman's 11.1420-1:

Les barons de la terre faire tous son plaisir,

Tout le vont enclinant, et tout le vont servir.

4690 A typical expression of the $C M$ poet, perhaps suggested by Gen. 41:49: "copia mensuram excederet".

4695-4747 The harrowing description of famine conditions is added to the Vulgate's bare narrative by Herman, 11.1429-63.

4705 C's "thrid" is an error. Herman writes of "le premier an", 1.1433.

4725 Herman, 1.1445, has the king see, rather than rear, his subjects' distress, as do MSS GHTL.

4732 MSS CFGHL read " $\mathrm{He}$ is al lord", the result of an accidental scribal doubling of the "1". Herman has "sires est et sera" in 1.1449. The scribes of MSS TB have apparently corrected the clumsy reading of their exemplar to "he is a lord".

4749-4803 The Vulgate says simply "audiens autem Jacob quod alimenta venderentur in Ægypto" (Gen. 42:1), without specifying how Jacob came to know this. Several Old French paraphrases, with more sense of drama than of geography, tell how Jacob saw chaff floating down the Nile from Egypt to Canaan and sent his sons to its source. The $C M$ poet presumably took his version from Herman's Bible, 11.1464-93; cf. Geoffrol De Paris, fol. 21v col. 1, reported in Bonnard, p. 43; the Harley fragment, 210/22-3; WARNer, Queen Mary's Psalter, pl. 33 and p. 63 ; Hist. Jos. 377/1340-75. Napier conjectures that the legend was 
probably recorded also on a lost leaf of the ME poem Iacob and Ioseph. See his introduction to $I \& I$, pp. xii-xiii. The $C M$ is the only other work in $\mathrm{ME}$ to record the story, but it also appears as the only legendary subject in the carvings of the chapter house of Salisbury Cathedral. See Cockerell, Book of Old Testament Illus., p. 20 n. 1.

4749-50 The $C M$ poet makes Joseph's action in casting the chaff on the water a deliberate lure for his father and brothers. HERMAN's Bible merely states that this is what Joseph did, but Queen Mary's Psalter and Hist. Jos. both agree with the $C M$ version. Cf. Geoffroi de Paris, fol. $21 \mathrm{v}$ col. 1 who has Joseph order the chaff to be thrown into the river, but without specifying why.

4754 MS C's "ioseph" is clearly an error.

4771-6 The $C M$ poet adds these lines to the narrative showing God dominating the course of history.

4797-8 Not in Herman. Jacob begins to speak at 1.4799.

4805-19 These lines are translated from Gen. 42: 3-4 rather than from Herman, who persists in his geographical error by having the brothers sail on the river to Egypt in 11.1494-9. Cf. above, note to 11. 47494803. Cf. Geoffrol DE PARIS, fol. 19r col. 2 and the Harley fragment, 201/36ff.

4811-22 From Herman, 11.1500-7.

4821 Herman has the brothers say they come from Jerusalem, 1.1507. The $C M$ poet corrects this to Canaan, as in Gen. 42:7.

4825-42 Not in Herman.

4843-50 HERMAN, 11.1514-9.

$4851 \mathrm{ff}$ In the Vulgate, the brothers make three journeys to Egypt. On the first, Joseph takes Simeon as a hostage until they return with Benjamin. He also puts the money they paid for the grain back into the grain sacks. See Gen. 42. Jacob is reluctant to send Benjamin with his brothers, but as the famine persists, he finally agrees. This time, Joseph again puts the payment money back into the grain sacks, and also puts his own silver cup into Benjamin's sack. The cup is discovered, Joseph threatens the apparent culprit, and Judah offers to suffer in his place. See Gen. 43-44. The third journey is made simply to bring Jacob to see his son Joseph.

Herman's Bible alters the Vulgate's account considerably. As soon as they discover corn is for sale in Egypt, four of the brothers return to their ship immediately. Only six brothers, therefore, attend the first audience with Joseph. Joseph sends these six to the ship to fetch the other four. He then puts the gold and silver they have paid him into the grain sacks and has his servants discover this. The cup is never mentioned, and Benjamin is still at home with his father. Ruben, not Simeon, is left as a hostage while the others go to fetch Benjamin at 1.1610. Joseph reveals himself to Benjamin and the brothers go to fetch Jacob to Egypt.

The $C M$ uses Herman's version in the main, but corrects some of it from the Vulgate. The incident of the four brothers who return to the ship is omitted. Also, the ME poet has Joseph put his cup, rather than simply the brothers' gold and silver, into the sack. This leads to some confusion; see note to 1.4888 below. The rest of the story is the same as Herman's. 
Of the other ME paraphrases, G\&E, SELTemp., and the Met. Para. follow the Vulgate in their order of incidents. However, like HERMAN's Bible and the $C M, I \& I$ also has the episode of the cup take place on the first journey, while Benjamin is still at home. See 11.400ff.

4851-5126 From HERMAN, 11.1529-1720.

4856 Herman, 1.1533, has “Porté l'en ont as nés". The $C M$ poet changes the ship to an inn, as in Gen. 42:27 et passim.

4858-62 This is not in Herman, who says that Joseph put gold and silver in the sacks (1.1534), as in Gen. 42:25.

4871-2 MSS CF preserve the sense of Herman, 11.1539-40 better than the other MSS do.

4886 MSS CFG's "sargantz" is original, translating Herman's "serjans", 1.1550 .

4888 The $C M$ poet has already stated that the object in the sack was Joseph's own cup, 1.4858, and he reiterates this in 11.4916, 4936, 4938 and 5081 . Herman, however, had the king's money stolen instead, and the CM seems to hedge in calling the object "pe kyngis pingis" or "pe kyngis tresour" here and in 11.4902 and 4908 below. Cf. I\&I 1.401 .

4899 "breme as boore" is an alliterative formula found frequently in ME. See $M E D$ "breme" a. II b.

4921, 4925 The third morning is not specified in Herman. The $C M$ poet could have taken this detail from Hist. Schol. Gen. xciii, PL CXCVIII 1131.

4924 Herman, 11.1569-70, has Joseph send men to guard their ship and their corn.

4967-72 This is not in Herman. The $C M$ poet reassures his audience of Joseph's motives and the ultimate outcome of the event.

4975 CF's reading is correct.

4995-5000 The ME poet here condenses the conversation and omits some details of the journey found in HERMAN 11.1617-32.

5052 MSS CFG translate Herman, 1.1671: "tous li sans li mua". The southern translator has altered and weakened the line.

5056 MSS GTLB say they kissed sixty times or more, while C says more than forty times. HERMAN, 1.1674, specifies 100 times. The numbers are indefinite, used simply to indicate a large quantity.

5098-5102 This is not in Herman. Borland, $C M$, p. 28, suggests that the passage is close to the variant reading of Herman's Bible printed in Vol. II, Appendix, p. 132. This could equally well come from Gen. $45: 8$, once again showing God's will worked out in history.

5119 Herman says Joseph gave all his brothers African garments. Thus the pronoun "bam" in MS C is plural. However, MSS FGHTLB have the singular, perhaps influenced by Gen. 45:22 and HERMAN 11.1718-9, in which Benjamin gets more clothes than the others.

5127-5377 From Herman, as printed in BARTSCH, Chrestomathie, 11.3-189.

5136 Herman, of course, had their ships loaded, not their camels.

5143 Not "pantener", as Morris printed in MSS CF, but "pautener", Herman's "paltoniers", "A vagabond, rascal" (OED).

5171 The Vulgate does not mention the length of time which has elapsed. Cf. HermaN, 1.177 and below 1.5362.

5184 In Herman, Joseph sends a boat. 
5197-9 The southern translator, having accidentally omitted 11.5197-8 changed "cries" to "hized" to make sense of the passage. MSS CFG preserve something like the original reading. Cf. HERMAN, 11.57-8.

5213-30 At this point Herman has the family board their boat once again to sail for Egypt, and more conversation takes place. See $11.67 \mathrm{ff}$. The ME poet omits this, and reverts to another source, not the Trad. anon., for the story of Jacob's sacrifice and departure. Cf. Gen. 46:1-6.

5231-8 The poet omits the long list of names from Genesis, mentioning only Joseph's offspring. See Gen. 46:26, 20.

5239-42 Cf. Gen. 46:28.

5243-8 From Herman, 11.91-4. The court goes with Joseph in Herman, but not in the Vulgate.

5250-2 Cf. Gen. 46:30. Herman omits this and instead has Jacob fail to recognize his son, 11.95-7. Herman seems to stress Jacob's senility. Cf. 11.68-71 where the brothers laugh merrily at their father's failure to realize that he is already at sea. The $C M$ poet omits such episodes, while keeping many of Herman's other emotional embellishments.

5253-5378 From Herman, 11.99-189.

5280-4 Herman has Joseph say he was sold to the king and tempted by his wife. The $C M$ poet remembers to mention Potiphar's wife instead of the queen, but forgets that he had followed Gen. 39:1 in having Joseph sold to Potiphar instead of to the king. Cf. above 11.4241-4.

5281 Herman has "pestrin" at 1.121, which MSS CF translate as "mister". MSS GHTLB substitute "prisoun".

5313 Apparently from HERMAN 1.196, although the narrative itself has only reached HERMAN 1.138.

5333 MSS GHTLB preserve the original "Pees", which C miscopied as "pis". See Herman, 1.151.

5353 Not in Herman. Cf. Gen. 47:9.

5373-4 Herman, 1.187: "je l'acatai a serf, mais or le franchison". Cf. MS C.

5375-6 MSS CF's reading is preferable.

5378-5414 Cf. Gen. 47:11-3, 15, 19-20, 22. Herman omits these events and passes straight on to the deaths of Jacob and Joseph.

5420-39 Gen. 47:27-48:2.

5426 MS C's "kne" is an error for "pe". Cf. the Vulgate's "sub femore meo".

5440-8 Cf. Gen. 48:10-4. The $C M$ poet has left out the dying Jacob's retelling of his own history.

5448 The poet avoids the squabbling over the final blessing in Gen. 48: 14, 17-9. Cf. below 1.5461 .

5449-54 Cf. Gen. 48:21.

5455-68 This summarizes all of Gen. 49.

5467-9 Gen. 47:28 gives Jacob 147 years, not 137 as the $C M$ poet elaborately calculates.

5470 The $C M$ poet ignores the magnificent funeral described in Gen. 50. Cf. also the description of Egyptian burial customs in Hist. Schol. Gen. cxiv, PL CXCVIII 1140, which appealed to the poet of $G \& E$ 2447-67.

5481-8 From Herman, 11.215-8.

5489-90 110 years, i.e. 5 1/2 score. See Gen. 50:26. 
5495-5502 Cf. Ex. 1:8-10. The $C M$ poet drops Herman as a principal source, apparently because the French poet greatly condenses the biblical narrative, touching only on the highlights of Moses' career. A few odd lines from Herman do appear, however. Many of these parallels were not noticed either by Borland or by Buehler. The $C M$ poet is not using the Trad. anon. here either.

5503-8 HERMAN, 11.1959-62.

5519-70 Cf. Ex. 1:11-22. For the first few lines, the $C M$ poet seems to invent more dialogue in the style of Herman, fitting in the Vulgate detail which the French poet omits.

5571-5600 The ME poet pauses to recapitulate his themes.

5609-46 Cf. Ex. 2:1-10.

5621 The original reading was probably "rushes".

5647-8 Probably from HERMAN 1.1987, although Moses' beauty was well known. See Josephus 265; Hist. Schol. Ex. v, PL CXCVIII 1144; G\&E 2659; Met. Para. 1529-36; SELTemp. fol. 3v col. 1; Malkaraume fol. 42v col. 1 ; MACÉ 3429-31.

5649-5710 Cf. Ex. 2:11-21.

5658 The sense demands that "son" should be singular here, as in MSS CFTB. The southern translator must have copied a plural form from his exemplar, as GHL all have "sones". The scribes of TB presumably corrected their copy.

5711-28 Cf. Ex. 2:22-5.

5729-44 Cf. Ex. 3:1-3.

5733 Not "folke", as in MSS HTL, but "flock", as in CFG. Cf. Ex. 3:1: "cumque minasset gregem...".

5736 "ezeb" is, of course, Latin Horeb.

5745-50 One of the $C M$ poet's rare typological interpretations. This interpretation of the burning bush as a type of the Blessed Virgin is found in hymns and in the Victorine sequence described in RABY, ChristianLatin Poetry, p. 370 ; Bernard of Clairvaux, Sermones de Tempore, PL CLXXXIII 63; WM. OF Shoreham, 127/19, "Hours of the Blessed Virgin" in Littlehales, Prymer, p. 24 ; MACÉ 3541-52 and n.

The closest analogue to the $C M$, however, is in Honorius AugusTodunensis' Speculum Ecclesiae, PL CLXXII 904: "quam ignis Spiritus sancti prole illuminavit, nec tamen flamma concupiscentiae violavit." $\mathrm{Cf}$. note to $11.6909-10$.

5753-5806 Cf. Ex. 3:4, 6-7, 10-14, 16-20. The poet does not describe the Jewish custom, referred to in Ex. 3:5, of Moses removing his shoes in a holy place.

5807-36 Cf. Ex. 4:1-4, 6-9. The ME poet omits Moses' humility and God's further instructions, as told in Ex. $4: 10-14$.

5837 Cf. Ex. $4: 14$.

5838-42 Cf. Ex. 3:18.

5843-7 Cf. Ex. $4: 29$.

The CM poet omits all mention of Moses' speech defect, the reason why Aaron always accompanies him. See Ex. 4:10-6, 30. Jewish legend traced this defect to an incident in Moses' infancy, and the story was often retold, in one version or another. See GINZBERG, Legends V, p. 402 n. 65; Hist. Schol. Ex. v, PL CXCVIII 1144;G\&E 2633-58; Met. Para. 1549-84; SELTemp. 3v col. 1; MaCÉ 3473-3508. 
Cf. Malkaraume fol. 42v col. 2; Josephus 267. G. L. Hamilton's

"La Source" is an excellent discussion of this legend in European literature.

5848-80 Cf. Ex. 5: 1-6, 8.

5859 MS F and the southern translation get the pronoun right, showing that the Israelites, and not Pharaoh, are speaking here.

5862 MS C alone translates correctly the "nobis" of Ex. 5:3 as "hus". The other MSS give the pronoun in the second person.

5883-5908 Cf. Ex. 7:8-14.

5918-26 Based on Ex. 7:19-20. Herman's account of the life of Moses is so greatly abbreviated that he scarcely describes the plagues. On the other hand, the Trad. anon. deals with Moses' story in great detail. The CM's version falls between the two extremes. It must be considered an abridgement of the Vulgate, unless another source, perhaps in French, is discovered.

5927-36 Cf. Ex. 8:3.

5935-51 Cf. Ex. 8:8-10, 12-5.

5953-5 Cf. Ex. 8: 17 .

5959-70 Cf. Ex. 8:21-2.

5971-98 Cf. Ex. 8:25-32.

5999-6008 Cf. Ex. 9:2-4, 7.

6001 Of all the CM MSS, C's line is closes to the list in Ex. 9:3.

6009-16 Cf. Ex. 9:9, 12.

6017-38 Cf. Ex. $9: 23-8,33,35$.

6025 CF's "gresse" is original, translating $E x .9: 25$ 's "herbam agri".

6039-50 Cf. Ex. 10:14-5, 20.

6051-6 Cf. Ex. 10:22-3.

6061-98 Cf. $E x .12: 3,5,7-12,14$.

6099-6121 Cf. Ex. 12:21-3, 29.

6125-64 Cf. $E x .12: 30-3,35-8,40-3$. The translation of the Vulgate is quite close. The ME poet omits repetitious verses, but does not condense material as he had done in his story of the plagues.

6158 The correct figure is 430 years. See Ex. 12:40. MSS CG have 400 years, F 100. MS G has mistaken "to" in the expression "to pen"/ until that time, for the numeral "tua". From a similar MS, the southern translator took his reading 402 years.

6165-78 The instructions in Ex. 12:43-9 concern who is allowed to partake of the feast. The $C M$ poet skips to $E x .13: 3,12-5$.

6179-98 Cf. Ex. 13:17-22.

6199-6252 Cf. Ex. 14:2-8, 10-4, 16.

6230 MSS CF have "graues", correctly translating "sepulcra". G reads "ill", and the southern translation "euel".

6253-8 Cf. Ex. 14:17-8. The ME poet has omitted any mention of the statement, frequently repeated in Exodus, that it is God who hardens the hearts of Pharaoh and the Egyptians. See Ex. 14:17; cf., e.g., $7: 13,9: 12,10: 1,10: 20,10: 27$.

6259-80 Cf. Ex. $14: 21-3,27-8$.

6285-8 The "newe songe" is found in Ex. 15:1-19, and would be known to the $C M$ poet as the most frequently used canticle in the liturgy. See Cabrol and Leclerco, eds., Dict. d'archéologie chrétienne, II 1978. 
6289-90 The poet interjects a prayer of his own.

$6301 \mathrm{ff}$ The $C M$ poet here interpolates the section of the story of the wood of the holy cross which is chronologically appropriate. He had translated an earlier part of this story from the Latin prose Legende. See note to 1.1237ff above. From now on, however, the $C M$ poet uses the version of the story found in the latter part of the Trad. anon. He evidently kept his copy of the Latin Legende at hand, however, as well as his Vulgate, for he uses both to insert several details lacking in his principal source.

NAPIER, Rood Tree, p. xxiii et passim first identified the source of these lines. He prints several extracts from the French poem on pp. 63-7 of his book and a further extract appears in Bonnard, pp. 88-9. References to line numbers in the Trad, anon. are to these printed extracts. Citations from the MS continue to be identified by folio numbers.

QuinN, The Quest of Seth, is again invaluable for tracing the development of this legend and the different versions of it. See also MEYER, "Die Geschichte des Kreuzholzes".

6301-10 Trad. anon. (in Napier), 11.29-37.

6305 The Old French poem says they came to "Elyn" (1.34), the Legende "Ebron" (47/54). The $C M$ poet apparently uses his geographical knowledge to place these in Syria.

6308 The southern translation's "prest" is a closer translation of "Sitivit" (Ex. 17:3) than is CFG's "brest"/need.

6311-5 Cf. Ex. 17:3. This is not found in the Old French poem.

6319-68 Trad. anon. (Napier), 39-87.

6320 MS C's "selly" is probably an error for "ferly".

6326 The Old French poem has "pin" here (1.43), as do MSS CFG. Cf. note to 1.1377 above.

6347 NAPIER, Rood Tree, p. xxvi suggested that this line originally read "Sipen pai fand in Raphindin", translating the Old French "A raphindin les a portees;" cf. $E x .17: 1$.

6347-56 The cross story combines several biblical episodes here. The sweetening of the waters occurred at Mara in Ex. 15:23-5, but the Old French poem places the incident at Raphidim. At the biblical Raphidim, in Ex. 17:1-7, Moses struck the rock to being forth water.

The wood which will become the true cross is here substituted for the biblical tree in Ex. 15:25, or the rod of Moses in Ex. 17:5.

6348-9 The Old French says "Quar plus ere amere que suie:" (1.71).

$6369 f$ The $C M$ poet drops the Trad. anon's cross story here and begins to abbreviate the biblical adventures of Moses.

6373-8 HERMAN, 11.2088-91.

6379-86 The story of the manna is found in Ex. 16. Herman dismisses it in one line (1.2092). The $C M$ poet gathers together various details from the account in Exodus.

6381 Cf. Ex. 16:14.

6382 Cf. Ex. 16:31.

6383-4 Cf. Ex. 16: 15, 31 .

6385 Cf. Ex. 16:8, 12. In fact, God sent flesh to be eaten in the evening and manna in the morning. 
$6386 \mathrm{Cf}$. Ex. 16:13. MS F's unique reading "angel mete pai dide hit calle" could be from the original version of $C M$. The idea of manna as the food of angels is based on Ps. 77:25 and Sap. 16:20. See GinzBERG, Legends, VI p. 17.

6389-95 Cf. Ex. 17:1-7. Herman dismisses the story in two lines (11.20934).

6403-32 Cf. Ex. 17:8-12.

6414 MS C alone preserves the correct reading. The other MSS omit Hur. Cf. Ex. 17:10.

6427 Again MS C preserves the mention of Hur, which the other MSS have dropped. Cf. Ex. 17:12.

6433-40 Cf. Ex. $18: 1-4$.

6433 MS F corrupts "Ietro" to "Petro".

6441-50 A condensed version of Ex. 18:13-26.

6441 MSS CFG probably preserve the correct reading "pis ilk folk was vntelland," (C). The line is a gloss on Ex. 18:13, 18, 22, verses which imply that the administration of law was becoming too time-consuming for one man to manage. The southern translator's "pis ilke folke was vantoun to fonde" makes good sense, however. It implies that the work increased because the people were more evil, rather than more numerous.

6451-67 The prologue to the giving of the commandments is from HERMAN, 11.2095-2106. In Ex. 19, God initiates all the action, but here the people themselves are the first to ask for the law, as they do in GEOFFroI DE PARIs, fol. $25 \mathrm{r}$ col. 2.

6461-4 Herman takes the idea of Moses' fasting forty days from $E x$. $34: 28$, which deals with the renewal of the tablets after Moses had broken them.

6471-80 The $C M$ poet gives a ten line resumé of the ten commandments. Cf. Ex. 20:3-17. Herman does not even list the commandments here.

6487-6504 The $C M$ poet turns once again to HERMAN, 11.2109-16 for the narrative of the golden calf.

6505-7 Expanded from $E x .32: 4$.

6513-6 Cf. Ex. 32:7.

6514 MSS CF's rhyme word "suik"/deceit has been mis-copied in G as "suilk", probably because of confusion with the same word in the previous line. This error makes the line meaningless in $G$. The southern translator seemingly recognized the lapse of sense and rewrote the line.

6517-6614 From HERMAN, 11.2127-2194.

6520 The frost comes from Ex. 16: 14.

6525 The southern translation has preserved a better reading "hoolis", translating Herman's "fosses", 1.2133. MSS CFG have "hepes", (G "helpis'). Cf. below, 1.6611, where CF refer to "holes".

6527-8 MS $C$ has preserved the better reading, translating HERMAN,

11.2134-5:

Mont crient el veel la gent maleüree

Se donques fu salvage, encor n'est pas senee.

6562-7 These lines are omitted from the southern translation but are evidently authentic, translating HERMAN, 11.2161b-2165.

6615-8 Cf. Ex. 32:20. 
6619-26 Ex. 32:20 simply says that Moses ground the golden calf to powder and made his people drink it. A wide spread mediaeval legend added that the powder stained the faces of the idolators but left the faces of the innocent clean. The two French sources which the $C M$ poet has been using report that the mouths of the guilty were gilded. See Trad. anon. fol. 256r col. 1. Herman, 1.2196. Petrus Comestor, Hist. Schol. Ex. 1xxiii, PL CXCVIII 1190, like the $C M$ poet, says their beards were affected, and HAENISCH, $C M$, p. $8^{*}$, pointed to this as the source. The golden beards are found in many places. See SELTemp. fol. 4r col. 1; Met. Para. 1975-80; Macé, 5247-52; Geoffrol DE Paris fol. 26r col. 1; cf. Pirke XLV 356-7.

6627-40 Cf. Ex. 32:26-9. This is not in Herman.

6636 Cf. Ex. $32: 28$ which says 23,000 , not 20,000 .

6641-8 Cf. Ex. $34: 1,4$.

6651 Cf. $E x$. 34:27-8 which says that Moses himself wrote the second set of commandments, at God's direction. The original tablets were written by God's own hand. See Ex. 31: 18, 32:16.

6653-6 Morris' proposed reading of "horud" for "hornd" in his note on this line is wrong. See $C M$, p. xlii. Ex. 34:29 reads "et ignorabat quod cornuta esset facies sua ex consortio sermonis Domini." The horns of Moses are a result of Jerome's translation of the Hebrew word "qeren", which can mean either "horns" or "rays of light".

Some commentators did not believe literally in the horns of Moses. Rashi, the influential Jewish commentator of the twelfth century, said that the horns indicated merely the shape of the rays of light which came from Moses' head. See RASHI, II 196. This explanation was taken up by various scholars, including Petrus Comestor, Hist. Schol. Ex. lxxvii, $P L$ CXCVIII 1192. The idea is reflected in $C M$ 1.6655: "Hem pouzte him horned on heed fer". The Trad. anon. similarly says: "Et fu au puiple descenduz/Si lor sambla estre cournuz". However, nothing in the context suggests that the $C M$ poet is translating here. Cf. MACÉ 5469-71; SELTemp. 4r col. 1.

On the whole subject, see the excellent study by Mellinkoff, The Horned Moses.

6657-66 Trad. anon. fol. $267 \mathrm{v}$ col. $2-268 \mathrm{r} \mathrm{col} .1$.

$6667 \mathrm{ff}$ This is a selection of the laws given by God to Moses in Ex. $21 \mathrm{ff}$.

Herman ignores them, as do most other paraphrase writers.

6671-2 Ex. 21:12.

6673-6 Ex. 21:14.

6677-80 Based on Ex. 21:15.

6681-6720 Ex. 21:18-30.

$6698 E x .21: 22$ reads "arbitri judicaverint." The English poet instead refers to trial by jury.

6703-4 After "pedem pro pede", Ex. 21:25 goes on to list "adustionem pro adustione, vulnus pro vulnere, livorem pro livore." CF's "bla for bla" is thus more correct than MSS GHTLB's "too for too".

6706 CF's "vnmighti for to seie" is original, translating Ex, 21:26 "luscos". G's corruption of "vnmighti" to "vnsihti" would make the servant invisible. The southern translator changes G's reading to "vnsiztilyze", which could possibly mean blind, but probably means simply ugly. See $O E D$. 
6721-58 Ex. 21:32-Ex. 22:4.

6727-30 The southern translator altered 1.6728 , perhaps to do away with

the unaccustomed caesura in MSS CFG:

And ox or hors, or oper aght

Fall in, pe man pat pis pitt aght

Because he completed $\mathbf{1 . 6 7 2 8}$ with a meaningless filler, "Falle perynne leest or meest', the translator had to compose two new lines to convey the meaning of the passage.

6759-62 Ex. 22:6.

6763-72 Ex. 22:10-2.

6773-8 Ex. 22:14-5.

6779-82 The paragraphing marks in MSS FHTLB indicate that two separate laws are involved here, translating $E x$. 22:18-9. A later hand in MS C, however, has interpreted the first two lines to refer to the fate of the beast involved in the sin mentioned in the next couplet:

[to dele wit best what man him draws

Godd wil pe best] be don o daus.

6783-6831 Ex. 22:20-23:5.

C 6779-80

6797-8 Ex. 22:26 is talking about taking a neighbour's clothes as a pledge

("pignus"), but the $C M$ poet apparently understands this as taking them in anger.

6805-6 The $C M$ poet has translated into contemporary terms of priests and tithes the instructions of $E x, 22: 28-9$.

6811-2 Not in Ex.

6833-48 Ex. 23:7-13.

6834 The "Blendyng ziftis" translates "Nec accipies munera, quae etiam excaecant prudentes", $E x .23: 8$.

6839-41 Ex. 23:10-11 orders the people to cultivate the land for six years and leave it fallow the seventh. All the MSS wrongly read seven for six in 1.6839. CF correctly read "seuend" in 1.6841 , while all the others have "eiztepe".

6850-8 Ex. 23:20, 22.

6859-80 The $C M$ poet here speaks more of the shaping of his history.

He omits the rest of Exodus, all of Leviticus and part of Numbers,

to arrive at the story of Aaron's rod.

6884-98 Cf. Num. 17:6-9.

6903-8 Cf. Num. 17:10.

6909-10 The interpretation of Aaron's rod as a type of the Virgin is found

in several places in the Middle Ages. See the Victorine sequence described in Raby, Christian-Latin Poetry, pp. 361, 370; Bernard of Clairvaux, Sermones de Tempore, PL CLXXXIII 63; WM. OF ShoreHАM, 128/27. The closest analogue to the CM's interpretation is in Honorius Augustodunensis, Speculum Ecclesiae, PL CLXXII 904:

"Arida virga quae nucem protulit est virgo Maria quae Christum Dominum et hominem mundo progenuit." Cf. $\mathrm{n}$. to 11.5745-50 above.

6915 The figure of forty years is common knowledge, of course, but may be suggested to the poet here by Trad. anon. fol. $268 \mathrm{r}$ col. 1; "xl ans les auoit porteis/Moyses...".

6918-20 Probably from Trad. anon. fol. 268r col. 1. Cf. Deut. 34:5-6. 
6921-2 Taken from Hist. Schol. Num. xx, PL CXCVIII 1260: "Quod ideo factum autumant Hebraei ne ipsi Moysen pro Deo colerent". Cf. SELTemp. 4r col. 2.

6923-30 The $C M$ poet translates Herman's summary of events, 11.220610.

6937-46 Trad. anon. fol. 268r col. 1.

6947-50 Cf. Num. 20:23-8.

6951ff The $C M$ poet greatly abbreviates Joshua's part in history, but HERMAN's Bible mentions none of his acts at all.

6953-4 DIM remarks of Joshua "sol stetit spatio duorum dierum." See

PL CLXXII 168. Cf. Met. Para. 2967-8.

6955-6 Cf. Ios. 10: 12-4.

6957-60 Cf. Ios. 3:7-4:24.

6961-4 Cf. Ios. 24:32.

6983-4 Cf. lud. 2:11 et passim.

6984 The $C M$ poet uses "sarasenes feip" as a synonym for all idolatry, a common mediaeval practice.

6985 Cf. Iud. 3:6.

6993-7082 These lines are a rapid summary of the Judges of Israel, with a passing reference to events in other kingdoms occurring at the same time. For the Middle Ages, the ultimate source of such comparative time schemes was the work of Eusebius of Caesarea. Eusebius and other canonists of the third and fourth centuries were trying to establish that the Christian religion, which seemed so new, was actually older than the state religions it sought to supplant. Jerome's translation of the work is printed as Translatio Chronicorum Eusebii Pamphili, PL XXVII 11-507. Parts of the work were copied into many later chronicles and histories, among them the Hist. Schol.

HAENISCH, $C M$, pp. $8^{*}-9^{*}$ believed that some of the details in the $C M$ 's lines came from the Hist. Schol. The immediate source of these lines, however, unless otherwise noted, is Honorius' De Imagine Mundi, PL CLXXII 169ff. This source was first noted by KALUZA in "Zu den Quellen", p. 452.

7001 Othoniel in Iud 3:9 is the younger brother of Caleb, not his son. Morris prints the word as "Othomel" in all MSS, but the minims should be read as "ni" instead of " $m$ ".

7007-12 This is based on DIM: "Hujus tempore fuit bellum inter populum Israel et Benjamin, propter uxorem Levitae apud Gabaam constupratam, et a Israel quidem occisa sunt quadraginta millia, de Benjamin triginta quinque et centum viri," $P L$ CLXXII 169.

In the Vulgate, "Ayoth" was indeed a Benjamite, but the enemy he fought was the Moabites. See Iud. 3:15-30. The battle between Benjamites and Israelites occurs in Iud. 19-21 because of the death of the wife or concubine of a Levite, the "deknes wyf" of 1.7009. DIM and hence the $C M$ telescope the two separate incidents into one, and exaggerate the numbers killed. See Iud. 20:35, 46.

7013-4 These lines may be reversed. DIM puts the construction of Troy in the reign of Aioth.

7015 From DIM. The Vulgate gives no length of reign for Samgar, nor does he appear in Eusebius' chronology. Comestor mentions him, but 
does not give the length of this reign. See Hist. Schol. Iud. vi, PL CXCVIII 1275.

7016 The two sons are apparently Deborah and Barack. The poet does not know that Deborah is a woman. Neither is, in fact, the child of Samgar. Barrack is frequently called "filium Abinoem". See lud. $4: 6,5: 1,5: 12$.

7020 DIM does not mention Apollo here. Haenisch has no note on these lines, but he might have cited the passage from Comestor which mentions both Delphos (although not the sybil) and Apollo: "Obiit Liber pater, cujus sepulcrum est apud Delphos juxta Apollinem aureum." See Hist. Schol. Iud. vii, PL CXCVIII 1277.

7023-6 These lines do not correspond to anything in DIM. MSS CF preserve the lines in their original form. First they mention the three hundred men of Gideon's army, as in Iud. 7:7 et passim. Then they name the four kings: Oreb and Zeb from Iud. 7:25, Zebee and Salmana from Iud. 8:5. MSS GHTLB have corrupted the four kings to forty and reversed the order of the first two lines. This leaves the four names dangling. "pat" of CF 1.7025 becomes "pan" in GHTLB and the four rulers of the Midianites are transformed into Judges of Israel.

7027-8 From DIM, PL CLXXII 169, although Haenisch cited Petrus Comestor.

7029 The $C M$ poet skips over the story of Abimilech to get to Thola. He thus ignores Abimelech's three year reign, which is mentioned in DIM as well as in Iud. 9.

7030 DIM and $I$ Iud. 10:2 both say he reigned twenty-three years. MSS CFG are correct, but the southern translator corrupted 20 to 40 . This is the length of reign of many of the other Judges.

7033-4 DIM says simply "Priamus in Troja", without connecting the city with the sibyl.

7037-8 Both DIM and Hist. Schol. Iud. x, PL CXCVIII 1283 mention Priam under the reign of Thola.

7039-40 Not in DIM. Haenisch, CM, p. 8*, pointed out that Petrus Comestor has this notice under the reign of Jair: "Carmentis nympha litteras Latinas invenit." See Hist. Schol. Iud. xi, PL CXCVIII 1283.

7041 Cf. Iud. 11:1. DIM does not mention his supposed bastardy.

7043-4 DIM mentions the amazons here, but the explanation of the word is given only by the $C M$ poet.

7045 HaENISCH, $C M$, p. 8*, suggested that the form of the name, Esebon, is taken from Hist. Schol. Iud. xiii PL CXCVIII 1285. Iud. 12:8 has Abesan, DIM Abessan.

7047 Iud. 12:9 says Abesan led Israel for seven years exactly. MSS CGHTLB all say seven years and more. MS F has seemingly corrected this to "in rowte". The meaningless rhyme which the scribe provides in 1.7048 makes clear that this was probably not the original reading.

7048-50 This is not in DIM. Haenisch, CM, p. 9* pointed to Hist. Schol. Iud. xiv, PL CXCVIII 1285: "Eo tempore Paris Helenam rapuit, bellum decennale surrexit." Comestor refers these events to the reign of Achialon, however.

The $C M$ poet himself was aware that Alexander was another name of Paris the Trojan. Hence C's lines "Alexandre, in pat siquar,/pat 
paris hight, raiuist helayn,_-" (7048-9). Later scribes, less familiar with the Troy story, apparently knew only one Alexander, Alexander the Great. By changing only one word, "hight" to "auzte", one such copyist altered the lines to read "Alexander [the Great], who owned [the city of] Paris,... ravished Helen." This is the meaning in GHTLB. The scribe of MS F rewrote the lines entirely, producing a very weak version.

7056 See note to $11.7048-50$.

7059 HaenisCh, CM, p. 9*, pointed to Hist. Schol. Iud. xv, PL CXCVIII 1285. The source, however, is once again DIM.

7060-3 This is not in either DIM or Hist. Schol.

7064-8 HaENisch, $C M$, p. 9*, supposed that the $C M$ poet used another source here, or that he invented the figures which are not found in Hist. Schol. In fact, he is using DIM again, but his lines are now garbled. DIM says the number killed was 877,000 Greeks and 686,000 Trojans. The number of Trojans is correct in all $C M$ MSS, but the number of Greeks is expressed very unclearly. The original line may have read "Eight hundred sixty seven and ten".

7069-82 Nothing in DIM corresponds to this summary of the Trojan war, although Kaluza said the borrowing from DIM continued until 1.7082. See Kaluza, "Zu den Quellen...", p. 451.

7083-7101 The story of Samson's birth and courtship is greatly abbreviated from the Vulgate. Cf. Iud. 13:2-14:4. The CM poet may be using another source here. Cf. the Met. Para. 3601ff, which treats the story of Samson at greater length than does the $C M$.

7102-34 Cf. Iud. 14:5-9, 12-5, 17.

7137-44 These lines appear only in MS F, although they translate lud. $14: 18$, and are added to complete the story. They must have been missed out in an early exemplar, when a scribe's eye skipped from "priuate" in 1.7136 to the same word in 1.7144 , thus causing most later copies to omit entirely the solution of the riddle.

7145-6 Based on Iud. 14: 19-20.

7147-60 Cf. Iud. 15:3-5.

7161-74 Abbreviated from Iud. 15:11-5.

7175-7204 Abbreviated from Iud. 16: 1-9.

7198 MSS GHTLB have a corrupt version of this line, from which all mention of the binding of Sampson has disappeared. In these MSS, Samson breaks bonds which the reader never knew were on him.

7205-12 Cf. Iud. 16: 16-7.

7213-36 The $C M$ poet draws the obvious moral from the story.

7237-46 Based on Iud. 16: 18-9, 21.

7246 MSS CF have the better reading "blinded", whereas GHTLB read "beten". Cf. Iud. 16:21.

7247-51 In Iud. 16:23, the feast is in honour of the Philistine god Dagon.

The $C M$ poet, or his source changes this into a bridal feast for Delilah and her new husband, and endows Samson with special talent as a harper.

7252-62 Cf. Iud. 16:22, 25, 29-30.

7265-77 Cf. I Reg. 4:3-18.

7273 "ware pai" must originally have been "was it", for the ark of the covenant was captured, not the sons of Eli. 
7274-6 These lines, found only in MS F, correspond to I Reg. 4:18. Cf. 1.7277 in the other MSS.

7278-82 This is a bit of moralizing from the poet.

7283 Cf. I Reg. 4: 18.

7287-7454 From Herman's Bible, 11.2213-2317. See Borland, $C M$, p. 47. 7287-96 HERMAN, 11.2213-20.

7297-7300 This reiteration is not in Herman. It comes from I Reg. 8: 19-20. 7301-10 HERMAN, 11.2221-6.

7311-2 This proverbial saying is added by the poet.

7313-42 Herman, 11.2229-43. The biblical narrative is greatly abridged here.

7343-58 Herman reports God's instructions in direct discourse in 11.224452 , as do MSS CF of the CM. In GHTLB, however, the discourse is indirect. The $C M$ poet is also using the Vulgate here, for Herman does not mention that Jesse lived in Bethlehem. See $C M$ 11.7348-9 and cf. I Reg. 16:1.

7359-7432 From HeRMaN, 11.2253-2306. The expansion and contraction of the Vulgate narrative of I Reg. 16: 10-18, 23 definitely indicates Herman as the source.

7405-6 Not in Herman.

7407-12 Beryl Rowland, Blind Beasts, p. 7, believes that this picture of David playing to his sheep is influenced by the Orphic myth.

7439-54 HERMAN, 11.2309-17.

7451 I Reg. 17:4 says "altitudinis sex cubitorum et palmi". This number does not appear in Herman. The $C M$ poet is here treating ells and cubits as if they were equal. Cf. $n$. to 11.1675-6 above.

7455 Borland found no more traces of Herman's influence until 1.8979. However, I feel that the $C M$ poet has continued to combine Herman's Bible and the Vulgate.

7455-7474 Goliath does not make a speech in Herman. The $C M$ 's version is based on I Reg. 17:8-11.

7475-82 Cf. Herman, 11.2319-21.

7481-2 Herman, 1.2321, says merely "Qui vaintre le porra, mon regne li donrai." The reference to the king's daughter is evidently an anticipation of I Reg. 18:27. Cf. below, 11.7645-6.

7483-9 From HeRMaN, 11.2322-4.

7487 On MS C's "gerard" see Dickens, "Gerard as a Goblin Name".

7491-2 David's brother Eliab, in I Reg. 17:28, accuses David of pride: "Ego novi superbiam tuam, et nequitiam cordis tui;". Both Herman and the $C M$ poet are defending David against this charge.

Herman has already expanded from the Vulgate David's references to his trust in God. The $C M$ translates all Herman's points and gives them greater emphasis. These lines in the English version summarize mediaeval ideas about pride. A Christian hero, to avoid the sin of pride, need not humble himself by not doing the great deeds of which he is capable. Rather he must be sure to attribute his prowess to God alone, and not to himself. The proud man may do exactly the same things as the Christian hero, but he will attribute all his triumphs to his own abilities. See, e.g., Thomas Aquinas, Sum. Theol. I Q. Ixiii art. 3. 
7493-7518 Saul's fears for David are not expressed in Herman, but are based on I Reg. 17: 33-7.

7519-36 The arming of David is from HERMAN, 11.2327-35.

7531 Herman says three stones, 1.2332 . The $C M$ poet has corrected the number to five from I Reg. 17:40.

7537-50 HERMAN, 11.2336-42.

7541-2 MSS CF have "man...es". MS G, however, reads "men...es", a grammatical error which obviously found its way into the southern translation. Scribes corrected it in various ways: "mon...is" T; "men... are" $\mathrm{H}$; "men...be" B.

7544 The $C M$ poet, or perhaps his later copyists, seem to have had trouble with the French idiom in HERMAN, 1.2339: "ne li valt pas .1. gant". The English poet renders "valt" as "helpes" and then searches for a subject. MS C's "Irinnes" was probably suggested by the following line, while F's "hardines" and G's "dredness" are similar attempts to find a subject for the sentence. The southern translator gave up the struggle and allowed the vague "hit" to stand by itself with no obvious antecedent.

7553-71 Cf. I Reg. 17:42-6.

7575-90 From HERMAN, 11.2349-56.

7593-8 From HERMAN, 11.2363-4.

7599-7612 Cf. I Reg. 18:6-9.

7613-5 From HERMAN, 11.2370-1. Herman skips the events between David's fight with Goliath and his accession to the throne. The $C M$ poet accordingly turns to the Vulgate for his material.

7617-8 A philosophical reflection of the poet's on the usual rewards of faithful service.

7619-26 Cf. I Reg. 18:10-11.

7628 All the CM MSS state that Saul was not afraid of David, but this may be an error for an original "now". Cf. I Reg. 18:12: "Et timuit Saul David".

7629-36 Cf. I Reg. $18: 13,17$.

7637-46 Cf. I Reg. 18:25, 27.

7647-52 Cf. I Reg. 19:1-2.

7653-4 MSS CF preserve the original reading "paind"'. MSS GHTLB have corrupted this to "preyed". In I Reg. 19:3-5, Jonathan does not pray to

God, but intercedes with his own father, Saul, for a reconciliation.

7655-75 Cf. I Reg. 19:7-12.

7676-84 Cf. I Reg. 19:18-20.

7685-98 From HERMAN, 11.2368-75.

7705-6 A reference to I Reg. 24.

7707-46 Cf. I Reg. 26:3-13, 15-8, 21-2.

7749-86 Cf. I Reg. 31:1-6, 8-13.

7785-6 The Middle English poet omits the burning of the body in I Reg. $31: 12$.

7789-7828 Cf. II Reg. 1:1-12, 14-5.

7791-3 This parenthetical reference is to the action described in I Reg.

30. David there fights the nation of the Amalekites, not an individual named Amalek, as the $C M$ poet states. Cf. I Reg. 15 in which Saul defeats the Amalekites and kills their king Agag. Amalek himself was 
defeated by Moses and Joshua. See Ex. 17:8-16 and above, 11.640132.

7827-36 From HeRMAN, 11.2390-6. Herman expatiates on the sin of regicide here, although in II Reg. 1:14 the crime seems more like sacrilege: "Quare non timuisti mittere manum tuam, ut occideres christum Domini?"

7835 In II Reg. 1:15 the penalty is swift in coming. This Herman renders correctly as "mort soubite", in 1.2396. This is translated in CM, MSS CG as "ferings ded". MS F changed the death to an "euel" one however and the southern translator apparently misinterpreted "ferings" as "fiery".

7837-60 The $C M$ poet, as usual, marks the end of an age and the beginning of a new one. HaEnisch, $C M$, p. 9* refers this passage to Hist. Schol., but the $C M$ is closer to $D I M$ here. Both $C M$ and DIM calculate the total age of the world at this time, although the totals they arrive at are different. Cf. $D I M, P L$ CLXXII 170.

The summary of the genealogy between Abraham and David is in none of the sources the poet has been using, but is consistent with his avowed purpose of providing a continuous genealogy for the Virgin Mary.

7861-77 Herman, 11.2397, 2401, 2403-9.

7869 The $C M$ poet evidently translated Herman's "fiers" as "aghful", making David an awe-inspiring man. See MED "aueful" adj (b). The other MSS corrupt this, however, G to "waful", and the southern translation to "wise".

7879 ff Herman does not go into details about the beginning of the liason of David and Bathsheba. The $C M$ poet reverts apparently to the Vulgate for his story.

7883-7906 Cf. II Reg. 11:2-5, 14-7. The translation of the Vulgate is not close, however. The poet may be using another source here.

7909-60 Cf. II Reg. 11:27-12:7, 9-14.

7936 In II Reg. 12:6, David proposes only that the rich man restore the lamb four-fold.

7961-2 Cf. II Reg. 12:24.

7963-7 This story of the composition of the Miserere may have been suggested to the $C M$ poet by the Latin Legende. In that work, David composes the Psalm after his great sin, while sitting under the tree which has grown from Moses' wands. See Legende, 50/86.

The $C M$ poet has inserted the passage here, after the biblical version of the story of Bathsheba. He has to omit all mention of the sacred tree, however, because he has not yet told of David's part in its history. When he does tell of it, he uses the version from Trad. anon. which does not mention Bathsheba's adultery, nor the composition of the Psalm.

7973ff The $C M$ poet translates the next 1000 odd lines from the cross story in Trad. anon. Cf. above, $\mathrm{n}$. to $1.6301 \mathrm{ff}$. The first 56 lines, corresponding to $C M 7973-8033$, are reproduced by NAPIER, Rood Tree, pp. 64-5.

7974 The Old French says ten years (1.128). 
8007 Once again, MSS CFG agree with the Trad. anon. 1.159, in having the rods of cedar, pine and cypress. Once again, the southern translator has consistently altered the pine to palm. Cf. above, note to 1.1377.

8009 The Trad. anon. does not here name the place where Moses found the rods: "Dun leu lai ou il les troua" (1.161). However, "Elyn" has already been named in $\mathbf{1 . 3 4}$.

8053-8193 NAPIER, Rood Tree, pp. 65-7 prints $11.202-332$ of the cross story section of Trad. anon., which correspond to these lines.

8058 MSS CFG correctly preserve "hope" for "esperance" (1.207).

8066 The sweet smell is not mentioned in Trad. anon., but came to the $C M$ from the Latin Legende. Instead of the light which shines from the rods when David finds them, as above 11.8047-50, the Legende, 49/74, speaks of a beautiful odour.

8078 Trad. anon. 1.225 has "Au pis lour tienent li manton".

8080, 8106 The Old French lines corresponding to these are missing from the MS. See NAPIER, Rood Tree, p. 66, n. to $11.226,250$.

8081-2 These lines were accidentally omitted from the southern translation. They correspond to Trad. anon. 1.227.

8119 According to 1.8091 , the Saracens are already kneeling. There had been no mention of kneeling in the Old French poem, 11.235-7, and there the poet says merely that they kissed the wands "deuotement" (1.263).

8121 The $C M$ poet translates the French "de gentil sanc" (1.265) by "of pe fre blood".

8125-6 Once again the Saracens kneel. Here, at least, the Old French says "et se mettent a orison" (1.270).

8127-8 These lines are reversed in the southern translation. However, the subject is still the onlookers, not the Saracens.

8132 The Old French says simply that they returned "ou desert" (1.275). However, the Old French poet had already established that they came from Ethiopia (1.220).

8134 See Napier, Rood Tree, p. xxvi n. 2. The Old French MS has "Tant quil uint a une fontaine" (1.277). This is a scribal error for "montaine", the original reading, which the $C M$ poet has translated "felle" and, at 1.8136 , "mounteyne".

8138 Trad. anon. says forty years, 1.279.

8150 The idiom of MSS CF, "pat he was hale sume ani trote", does not appear here in Trad. anon. Cf. below 1.8175. The southern translation is closer to the French: "Et apres se trouoit tout sain" (1.291).

8152-3 MS C has the original reading. Cf. Trad. anon. 11.294-5. The scribe of G seemingly misunderstood "barun" as "branchis", and the southern translator rewrote the couplet accordingly.

8164 MSS $F$ and the southern translation preserve the original reading here, translating Old French "Molt lont doucement salue" (1.306).

8165-6 These lines are omitted from the southern translation. They correspond to 1.307 of the Old French poem.

8169 MSS CFT preserve the correct reading "Thoru pe" or "Bi pe", translating the Old French "Par uos ert gariz li lieprous" (1.310). HLB, however, alter the pronoun, probably on purpose, to refer to the rods rather than to the king. 
8175 This translates the Old French idiom "sainz comme .i. poissons" (1.319). Cf. above, $1.8150 \mathrm{CF}$.

8206-33 As Napier, Rood Tree, p. xxvii pointed out, the $C M$ poet has here combined details from the Latin Legende with the Trad. anon.

8206 The Legende says "Posuit ergo illas in cisterna" (49/79). The Trad. anon. has them planted "a terre dure" (fol. 269r col. 2).

8207-8 Legende 49/80: "Apposuit quidem lumina et custodes."

8210-7 Legende, 49/81.

8218-24 Trad. anon. fol. 269r col. 2.

8224 For the sake of the rhyme, the English poet has exaggerated David's state of mind. The Old French has simply "Porpensa soi quil feroit" (fol. 269r col. 2).

8225-33 Legende, 49/83-4.

8234-8460 Trad. anon. fol. 269r col. 2-270v col. 2.

8235 The southern translator has changed the original pine to a palm even in this line, where the woods in question are not those of the three branches which became the cross.

8240 MS C's "schirting" does not mean comfort, as Kaluza's glossary states, but amusement, from OE (ge)scyrtan. See OED "shurt" v. The Trad. anon. says "ce ert ses depors. ce ert ses desouiz", fol. 269r col. 2.

$8271 C M$ 's "relike" translates Old French "vertuz", fol. 269v col. 1.

8274 Trad. anon. has "sacrement", fol. 269v col. 1. Perhaps the $C M$ poet is consciously avoiding the anachronism.

8288 For "stapul", Trad. anon. has "perron".

8420-6 The French original lays more stress on the knightly virtues than the clerical English translator allows:

Or gardez quil soit bien noriz

Apres de proesces et dars

Quil ne soit vilains ne couars

Et saiche les pars de clergie

Prouesce de cheualerie

Li aufes est de bons mors

Gardez quil ait molt bons doctors (fol. 270v col. 1).

8449-62 The connection of these lines with the following passage describing the writing of Solomon's books is tenuous. L. 8452 is promising: "be kynde of pingis lerned he", or in Old French "Veoit des choses la nature" (fol. 270v col. 1). Insights into the "nature of things" might well result in books such as Ecclesiasticus, Proverbs and the Canticum Canticorum. However, when he comes to describe Solomon's new knowledge, the Old French poet produces only some allusions to folk wisdom about the medicinal properties of plants.

8463-82 The CM poet does not accept the Old French descriptions of the three books, nor even their order of composition. Rather, he composes these lines according to what he knows of the meaning of each of Solomon's books.

8482 After his résumé of the three books, the Old French poet recapitulates the kind of knowledge that Solomon obtained:

Toutes les herbes cognoiscoit

Et quel uertuz chascunne auoit (fol. 270v col. 2).

The ME poet omits the lines. Cf. $n$. to 11.8449-62. 
8483-8508 Trad. anon. fol. $270 \mathrm{v}$ col. 2.

8488 MS G alone preserves the correct reading "stremis", translating the Old French "Des aigues qui ont lou droit cors". MSS CHT have "sternes", an easy scribal error to make, and one rendered more likely by the common occurrence of phrases such as "the stars in their courses". However, MS L also has "stremys", which suggests that the southern translation may also have preserved the original reading.

8497 The awkward word order is dictated by the need to use "marie" as a rhyme word. The inflected ending of the pronoun "whom" makes the meaning unmistakable, however. The Old French simply has "li filz marie".

"Bytwene pat" is a very awkward translation of the original

"Bitwix and" (CFG).

8509-12 The $C M$ poet inserts these lines as he leaves the Trad. anon. and reverts to Herman as a source.

8513-7 HeRMAN, 11.2425-7.

8514 Herman says only that David reigned "longuement" (1.2425). The forty years comes from $D I M, P L$ CLXXII 172.

8521-6 HERMAN, 11.2429-31.

8531-4 DIM, PL CLXXII 172.

8536-8 Cf. III Reg. 2:10.

8539-71 From Herman, 11.2432, 2435, 2438-57.

8575-81 HERMAN, 2460-3.

8583-8614 HERMAN, 11.2474-87. Borland pointed out these parallels in $C M$, pp. $52 \mathrm{ff}$.

8583 MS C's "fourte" is an error for "forme" GHTL, Herman "primes". 8589-90 The Trad. anon. agrees with the Vulgate in calling the women "putains", fol. 271v col. 1; cf. III Reg. 3:16 "mulieres meretrices". Herman has softened this to "femes...menestrés", which the $C M$ poet translates "Mister wymmen". However, his next line shows that the poet still thinks of them as sinful.

8603-4 The $C M$ poet adds this generalization and warning, which is not in his sources.

8609-12 These lines, appearing only in MS F, have no counterpart in Herman.

8615-52 From HERMAN, 11.2490-2508.

8641-2 These lines, appearing only in MS F, are not found in Herman.

8653-6 The CM poet got this idea from Trad. anon. fol. $271 \mathrm{v}$ col. 1. Herman does not deal with the cross story at all.

8657-73 HERMAN, 2509-19.

8658 Herman, 1.2510, says the woman who carried the dead child spoke first. The $C M$ poet means the same woman, but describes her as the mother of the living child.

8679-92 From Herman, 2520-27.

8695 The Trad. anon. here raises a point of mediaeval law: the problem cannot be settled either by "sairemens", that is by swearing, nor by combat. None of the barons is sufficiently convinced of the rights and wrongs of the case to take up the defence of either woman. See fol. $271 \mathrm{v}$ col. 2. 
8699-8716 This recapitulation of the case does not appear either in Herman

or in the Old French cross story. Cf. however III Reg. 3:23-4.

8717-20 HERMAN, 2533-5.

8721-2 Cf. III Reg. 3:26.

8723 Trad. anon. fol. 271v col. 2. The Old French poem uses legal terms here: "Je li clain quite ma partie". Cf. CM 1.8723.

8729-31 From HERMAN, 2537. The remainder of the mother's speech in

Herman is very moving, but it has been omitted by the $C M$ poet.

8732-44 HERMAN, 2541-6.

8747 Herman has the barons say merely "Sire, jugié l'avés" (1.2547).

The Trad. anon. has:

Certainnement sceuent li baron

Quil a iugie droit et raison (fol. 272r col. 1).

8748-56 HERMAN, 2550-6.

8757-8842 The $C M$ poet returns to the Trad. anon. as a source. See fol. $272 \mathrm{r}$ col. $1-272 \mathrm{v}$ col. 1 .

8768 MSS CF preserve the correct reading "dei", for Old French "moroit". 8775-8808 The technical building terms are not found in the Old French poem. Cf. above, 11.1669-74, 2231 and notes.

8843-4 The $C M$ poet is already aware of the sources he will use for the passion section of his poem, and knows that this story of Judas getting the silver from the temple is found only in Trad. anon. which he does not plan to follow.

8845-8 Trad. anon. fol. $272 \mathrm{v}$ col. 1 .

8849-66 The description of the temple does not appear either in the Trad. anon. or in the Latin Legende or in Herman. The description is based on III Reg. 6-7. Several of the Old French paraphrases have quite elaborate descriptions of the Temple, however.

8854 Cf. III Reg. 6:7, 9.

8861-3 Cf. III Reg. 6:2. As he did in the description of Noah's ark, the English poet has here changed the unit of measurement from the biblical cubits to ells. Cf. $n$. to 11.1675-6.

8867-80 Trad. anon. fol. 272v col. 1, 11.916-31. L1.918-31 are printed by NAPIER, Rood Tree, p. 67.

8873 Trad. anon. 1.924 says 700 men.

8880 The extant Old French MS names the priest Arillus, not Cirillus, in 1.930 .

8883-9 These lines are not in the Trad. anon. Cf. III Reg. 11:3.

8894-8921 Trad. anon. fol. $272 \mathrm{v}$ col. 1-2, 11.934-56. L1.932-53 are printed in BONNARD, pp. 88-9.

8902 Trad. anon. 933 calls the lady "Sebile". She is also called "sibilla" in the earliest form of the cross-wood story in MS Bodl. 343. See QuinN, Quest of Seth, pp. 59 et passim.

The name Maximilla is used only in the Legende version of the story. See Legende 51/106 and Quinn's discussion, Quest of Seth, pp. 128-9. The $C M$ poet must call this woman Maximilla, however, because he plans to use the Legende's story of another Sebilla. See below 11.8953-76.

8922 This line summarizes several lines in the French which elaborate the significance of the name for Christians and the Jews' abhorrence of it. See fol. $272 v$ col. $2,11.957-63$. 
8923-4 Napier, p. xxviii pointed out that these lines come from the Legende $51 / 109$.

8925-42 After the story of "Sebile", the CM's Maximilla, the Trad anon. goes on to tell how the wood stayed in the Temple and was honoured there until Christ's time.

However, the episode, told in $C M$, of the wood's being thrown into the "piscina probatica" is found in the earliest Latin cross story known to Meyer, the Historia. It recurs in many versions including the Latin Legende 51/110-3, which the $C M$ poet translated here.

The healing pool stirred by an angel is obviously based on Ioan. 5:2-4. See QuINN, Quest of Seth, pp. 65-6.

8927 MSS CF's "stank" (OF estanc) is a better translation of "piscina" than GHTLB's " pitt". Cf. 1.8936.

8943-76 The story of the wood's being used as a bridge is also found in the Legende 51/114-20. The ME version is considerably expanded from the Latin here, and may in fact have been translated from another source.

8947 The name comes from II Esdr. 3:15 and Ioan. 9:7, 11, where it is a pool rather than a stream. Cf. QuinN, Quest of Seth, pp. 107, 129.

8977-8 Again the $C M$ poet uses this formula when he changes from one source to another.

8979-9000 This is probably an expansion of HERMAN, 2564-7. Cf. especially CM 8997-8 and HERMAN, 2567: "Dix, que devint ses sens".

9001-10 The diatribe against women is not found in any of the sources the poet has just been using. The conjunction of Adam, Sampson, David and Solomon as men deceived by women is common in mediaeval proverbs. See H. Walther, Proverbia, Sententiaeque 1, 519ff, 5026a. The four appear in this context in a Planctus of Peter Abelard. For a discussion of the topos see Dronke, Poetic Individuality, 124-5. For other parallels in mediaeval literature cf. Friend, "Sampson, David and Salomon" and R. W. KING, "A Note on GGK 2414ff".

9014 MS C alone has the word "crachon" (OF cracheron) a worthless person. GHTLB prefer Chauntecleer's remark: "Mulier est hominis confusio". Cf. Carleton Brown, "Mulier...".

9041-85 From Herman, 2573-94.

9060 Solomon does not go quite this far in his repentance in Herman.

9086-90 The CM poet omits Herman's further discussion between Solomon and his advisors, 11.2595-2601. He resumes with HermaN, 2602.

9091-9104 HERMAN, 2603-16.

9097-8 Herman does not mention the crown here.

9099-9100 Herman has " $\mathrm{Li}$ rois oste ses dras et sa char a livree/A.IIII. de ses hommes toute l'ont desciree;' 11.2609-10. Thus MS C's 1.9099 is corrupt and that of GHTLB is to be preferred, while C's unique reading in 1.9100 is correct.

9105-14 The $C M$ poet elaborates more than Herman on the sin and penitance.

9115-20 HERMAN, 2618, 2621.

9121-32 The $C M$ poet returns to his genealogical theme.

9133-9203 These lines are taken from DIM, PL CLXXII 172-3 unless otherwise stated. Kaluza first pointed this out in "Zu den Quellen", p. 451. 
9133-9 DIM, PL CLXXII 172 says simply that Solomon reigned for forty years. Cf. III Reg. $11: 42-3$.

9150-2 DIM gives the length of time simply as three years and does not give God's motive for the drought.

$9162 D I M$ does not mention how Elijah was translated. Cf. IV Reg. $2: 11$.

9163 The $C M$ poet here omits several reigns, and skips to Ozias.

$9164 D I M, P L$ CLXXII 172 gives Ozias' reign as 52 years. Cf. IV Reg. $14: 21,15: 1-2$. Ozias is really the son of Amaziah, whom the $C M$ poet does not mention, rather than of Joram.

9169 MSS CF correctly refer to the sixth sibyl. Cf. DIM, PL CLXXII 172.

9173-6 These lines have been transposed in all the MSS. Ahaz is the son of Jotham, and 11.9175-6 obviously must follow 1.9172. The couplet about Romulus and Rome, 11.9173-4, follows 1.9176 .

This order is confirmed by $D I M, P L$ CLXXII 173, which mentions Romulus and the founding of Rome in the reigns of Ahaz and Ezechias.

9179 Ezechias reigns 28 years in DIM, 29 in IV Reg. 18:2. MSS CFG share the erroneous reading 39 , which the southern translator has apparently corrected from the Vulgate.

9180 Not in DIM. Cf. IV Reg. 18:3.

9183-4 These lines do not appear here in DIM, but come from Hist. Schol.

IV Reg. xxxiii, $P L$ CXCVIII 1415, as Haenisch pointed out, $C M$, p. 9*. DIM, PL CLXXII 173 mentions this Sibyl along with the prophet Jeremiah under the reign of Josias. The $C M$ poet has consciously chosen Petrus Comestor's version.

9186-8 There is nothing about this idol-worship in DIM. Cf. however IV Reg. 21 : 2-9; Hist. Schol. IV Reg. xxxiii, PL CXCVIII 1415.

9194 MS C alone preserves the correct numbers. DIM, PL CLXXII 173 says that Ninevah had stood 1470 years.

9197 HaEnisch, CM, p. 9*, points to Hist. Schol. IV Reg. xxxviii, $P L$ CXCVIII 1418 as the source for the name Ieconias, but this name is found here in $D I M$ also.

9200-18 Cf. IV Reg. 25:1-10.

9204-20 Not in DIM.

9221-2 DIM, PL CLXXII 173 says Jerusalem had stood for 549 years before the transmigration.

9223-8 DIM, PL CLXXII 173 says the fourth age of the world occupied 475 years and the total age of the world at that time was 4610 years. 


\section{APPENDIX A}

\section{Errors in Morris' Texts}

\section{7 baron]T baroun}

$23 \mathrm{sa}[$ nge]s]F $\mathrm{sa}\langle$ nge $\rangle$ s. Similarly $25\langle$ re $\rangle$ de, 29 lath $\langle\mathrm{e}\rangle, 34$ 〈ver $\rangle$ tue, $41 \mathrm{~b}\langle\mathrm{e}\rangle$ takenes, $46 \mathrm{~h}\langle\mathrm{i} m\rangle$.

33 the]C be.

39 pat]C pat.

58 smert]G snert.

67 witouten]C witoten.

70 [nede me dos socure] $\mathrm{G}$ (nede me dos socure).

84 pat]C pat.

85 [mater] $\mathrm{C}$ (mater).

91 pat]C pat.

93 delete? $\mathrm{C}$.

101 Lady]G does not have a decorated capital here.

110 him]G him.

120 Bre[f] $] \mathrm{i}] \mathrm{C}$ Bre $\langle\mathbf{f}\rangle \mathbf{i}$.

134 siben]C sithen.

139-40 [30]u, Es[au]e]T the letters are somewhat rubbed, but legible.

178 bigonne]T bigonne.

185 womman]C wommaM. pat]G pat.

186 pat]C pat.

187 How]G Hou.

188 pat]C pat. aht]C aght.

192 the]C pe.

219 last]C laste. alle]C all.

222 pat]C pat.

225 think]G thinck.

227 worlde]T world.

230 world]C werld.

232 is $] \mathrm{C}$ it.

236 understand]C vnderstand.

241 the] $C$ pe.

252 pat]C pat.

257 to] $G$ so.

270a sounday]C sonunday.

275 pat]T pat.

313 his]F h $\langle$ is $\rangle$.

364 pins] $F$ ping.

372 pat]C pat.

$378 \mathrm{~b}[\mathrm{e}] \mathrm{se}] \mathrm{C}$ yse. sou[n]did]C sondid. 
384 grifyns]T grisyng.

$386 \mathrm{~h}[\mathrm{am}]] \mathrm{F} \mathrm{h}\langle\mathrm{am}\rangle$.

387 iij]J iiii (twice).

409 ensaumple]T ensauple.

428 with]C wit.

454 anttour]G auctour

518 element[e]s]C elementes

519 water] $G$ watir

520 and]om $\mathrm{C}$.

549 things] $\mathrm{C}$ thinges

570 Wouen]T Wonen

587 hep]T liep

604 lussum]T lufsum

611 vnbroken]T vnbrokon

635 tway]G tuay

654 tre]F tree

712 pat]C pat

734 has]F had

740 pat]C pat

746 Wonper]G Wonper

766 /ho]F originally sho, with s erased. So also 772.

770 othere]C oth-r

844 ransumed]G ransuned

888 pat]C pat

897 wommones]T wom monnes

920 werld] G world

921 and] $\mathrm{C}$ an

1001 pareof]G parof

1012 is]G es

1022 werines is the reading in $\mathrm{F}$, not wermes, as Morris' note states.

1031 sautes]C santes

1093 Sun]C Sun

1136 hi[t]]T hi $\langle t\rangle$

1182 YejG pe

1185 birijing]G birijng

1253 yu]G pu

1255 greene]G grene

1287 [he]]C he written in margin

1291 seuid]C senid

1305 ze]G pe

1312 frott]G frort

1335 eet]T eer

1352 pat]G pat

1359 Quen]G Quen

1401 namare]C namar

1417 pepinis]G pepins

1434 pritte]C thritte

1435 When]T Whenn

1440 at]G pat

1446 harwede]T harwide

1462 yer]C per 
1486 seuenti]G seuinti

$1495 \mathrm{a}[\mathrm{r}$ be $\mathrm{t}]$ oper $] \mathrm{C}$ a $\langle\mathrm{r}$ be $\mathrm{t}\rangle$ oper

1516 son]G sun

1520 soñ]F soun. sonne]G soune. son̄] $T$ soun

1553 Whēn]T When n

1554 hundid]G hundrid

1559 amang]G emang

Genealogical table following 1.1626: Mattussael] C Matussael

1628 geten]G getin

1656 graunted]C grauntid

1661 vengeance $G$ vengance

1770 dinned]G dimmed

1785 swan]T swam

1806 miste]T nuste

1834 nohut]G noht

1859 per] $\mathrm{T}$ pus

1878 pe]om $F$

1908 damnyng]T dam myng

1917 with]C wit

1919 rode]T zode

1929 Ti]C Til

1943 pouz] T pouzt

1946 sul]G sal

2019 he] $\mathbf{~} \mathbf{x}$

2039 broiper]C broiper

2126 onejT owe

2129 speede]T sprede

2141 seder]T sedec

2165 witterli]G witterli

2169 hundrid]G hundred

2176 lete]G lele. good]T goood

2193 and] $G$ and

2194 regma]G regina

$2199[\mathrm{p}]$ is $\mathrm{F}$ pis

2210 patjC pat

2218 and]G an

2223 syn]F kyn

2265 p $[a \mathrm{t}]] \mathrm{C}$ p $\langle a \mathrm{t}\rangle$

2268 diueris] $\mathrm{G}$ diuers

Genealogy after 1.2314: The blank space on the right has omer in a later hand.

2317 is]G es

2324 maydene]G maydere

2330 of] $\mathrm{C}$ o

2348 be]C bee

2359 su[ilka]] C su (ilka)

23601 [oke]]C 1 (oke). b[e b]une]C p (e b) une

2414 patjG pat

2420 her]G hir

2421 patjG pat

2426 wij]C wijf 
2483 hezt]F het

2491 pat]G pat

2499 bat]T bac

2500 to]C til. pit]T putt

2506 graunted]G granted

2508 getun]G getim

2520 patjG pat

2522 he]T pe

2530 miht]G mitht

2578 on on]C on

2580 uoice]G voice

2602 mine] mñe

2631 cruell]C cruel

2636 her]T hir

2657 sal]C sol

2691 [ bis]]F' (piis)

2692 bl[is]]F bl is $\rangle$

2695 scare]C sitre

2709 onered]G onerd

2729 chide]T childe

2739 [bou]]F" (pou〉

2772 wald]C watd

2779 and]G an

2796 pressed]T preesed

2847 vn-suukyn]F vnsunkyn

2903 pat]G pat

2915 did]C hid

2970 zorne]F zerne

3008 langer] $G$ langer

3009 pat]G pat

3016 make]F mak

3051 pat]G pat

3118 lete]G lele

3135 Morris' note l: schild]C child

3166 immolatur]C imnolatur

3171 [pat]]F (pat)

3172 [or]]F 〈or

3198 out $] \mathrm{G}$ vut

3219 her]C hir

3220 were]C ware

3268 pat]C pat

3318 toune]G toune

3386 multeplied]G multiplied

3414 bidinge $] F$ bidding

3439 godde]G godd

3474 uye] T nye

3514 pose] $\mathrm{T}$ pese

3593 bie|T pei

3638 zele]T zele

3653 For]T Fro

3693 leue] crossed out in G. 


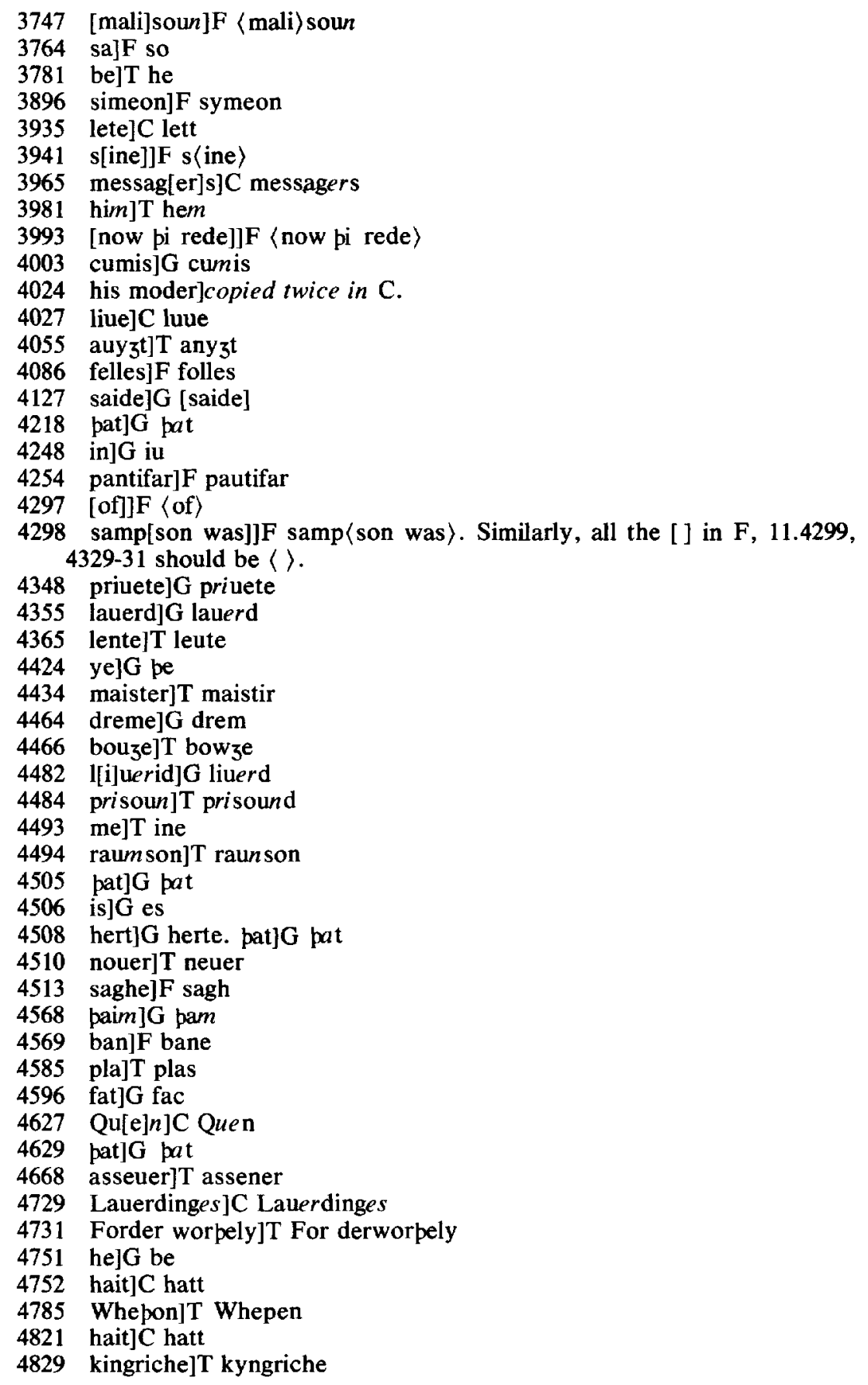


4843 hit]T but

4861 Qu[e]n]C Quen

4990 cuunand]C cunnand

4991

5000 par]C pair

5022 elles]G ellis

5024 grauntt]G grauntt

5058 sitt]C sett

5067 slayn]G slayn

5095 wiif]G wijf

5114 his]G sal his

5118 beniamin]G beniamyn

5220 pat]G pat

5225 yare]F pare

5280 sold]G sald

5287 is]C es

5305 [his aghen in] $\mathrm{C}$ 〈his aghen in〉

5342 bigann]G bigam

5370 to zepe]F so zepe

5382 pat]G pat

5420 paire]C pare

5529 Fitou]G Fiton

5547 godd] $G$ god

5553 wimmen]G wimen

5557, 5558 wimmen]G wimnen

5623 kingis] $\mathrm{T}$ kyngis

5633 fetche]T fecche

5638 se[r]uis]C seruis

5657 branch] $\mathrm{G}$ braunch

5662 pat] $\mathrm{G}$ pat

5756 lauerd]G lauerd

5765 Lauerd]G Lauerd

5770 takins]G taknis

5781 Of]T Os

5821 mightin]G mihtin

5851 hand $G$ hand

5874 his]F pis

5889 neddir]G neddir

5957 al] $\mathrm{G}$ all

6018 suel]F snel

6042 non]G nan

6098 now]G nou

6101 MS C does not repeat had, as Morris' note states, but MS G does, hadd]G hadd had.

6154 number]G nunber

6156 or [ox]]G ox

6167 with me]T withine

6173 he]T be

6235 vs]G us

6251 The first shal is cancelled in $\mathrm{T}$.

6287 quite]C quitte 
6303 aron]G aran

6332 water] G water

6352 water]G water

6397 pat]G pat

6400 were]F ware

6491 oper] $C$ eper

6530 ze]G pe

6610 ze]G pe

6611 putis]G pittis

6646 it]om. G.

6685 lechyng]C leching

6696 pen] $T$ penn

6697 Nedis]G Medis

6734 mightin]G mihtin

6744 oper]G oper

6747 grubband correct in G. Not grulband as in Morris' note.

6758 dubbil correct in G. Not dulbil as Morris' note states.

6783 pat]G pat

6796 leue]T lene

6813 forbirths]G forbirthis

6814 dwel[le]]F dwel(le)

6819 3ou]F pou

6864 prophesi]G prophesi

6866 cristes] $T$ cristis

6896 aaron $] \mathrm{C}$ aaron

6913 Quen]C Quen

6916 wes does not appear in $\mathrm{C}$, as Morris states. The scribe first wrote be es, altered this to he es, then crossed it out and re-wrote he es.

6955 still]T stille

6965 pat]G paii

6996 ay]F ar

6997 Saturnens]T Saturneus

7094 wal[d] ha]C originally had wal ha, altered by a later hand to wald haf.

7157 late]C lete

7162 soghte] $G$ soght

7219-22 The alterations in a later hand are as follows:

7219 pi]C erased. pe]C him

7220 poulC he

7221 pou]C he

7222 poulC hoo

7228 priuetes]C priuetes

7251 fleze]T sleze

7269 left]C lelft

7278 wengaunce] $G$ wengance

7281 oft]G ofte

7312 no]C na

7316 3ejG pe

7339 pat]G pat

7342 godd]G god

7363 zejF be

7377 king|T kyng 
7399 [Enoynted]]C written in a later hand.

7401 poure] $\mathrm{T}$ pouze

7443 pat $] \mathrm{C}$ pat

7462 pat]G pat

7463 queper]G queper

7488 grace]G grace

7495 is]G es

7507 ren[d]]C originally rent, changed in a later hand to rend.

7519 fotte]F fottes

$7535 \mathrm{mi}] \mathrm{G}$ my

7546 men]G man

7614 at]C bat

7625 hody] F body

7649 [wha]]C who is inserted in a later hand.

7659 [pi]s]C < pi >s. So also $1.7660<$ And $>, 7661\langle$ per $\rangle$.

7731 him]C him

7745 gleyne]T gleyue

7746 resceynejT resceyue

7755 slejG fle

7778 bei]C pai

7785 priuelie]C priuelic

7792 gunen]G guuen

7826 pat]C pat

7833 waites]C wattes

7840 nam]C name

7843 [and]]F \&

7851 Efrom]T Esrom

7857 bozlT boz

7858 is]C es.

7859 cast]T tast

$7883 \mathrm{du}\left[3^{\mathrm{t} i}\right] \mathrm{F} \mathrm{du}\left(3^{\mathrm{ti}}\right\rangle$

7900 letter]F letter

7902 hem]F him

7908 par]G pai

$7926 \mathrm{t}$ wert]F thwert

7932 what]G quat

7946 cum]G cum

7989 lonesomly]T louesomly

7997 pat]G pat

8031 ware]F were. a]T o.

8032 thousande]F thon sande

8034 greue]T grene

8075 pat]C pat

8087 Crumpled]C Crumpeld

8110 All]C Al

8131 pe]T pei

8150 pat]C pat

8174 And]G All

8175 pal]F pat

8195 pauylion] $\mathrm{F}$ pauyloun

8202 processioune]G proscessioune 


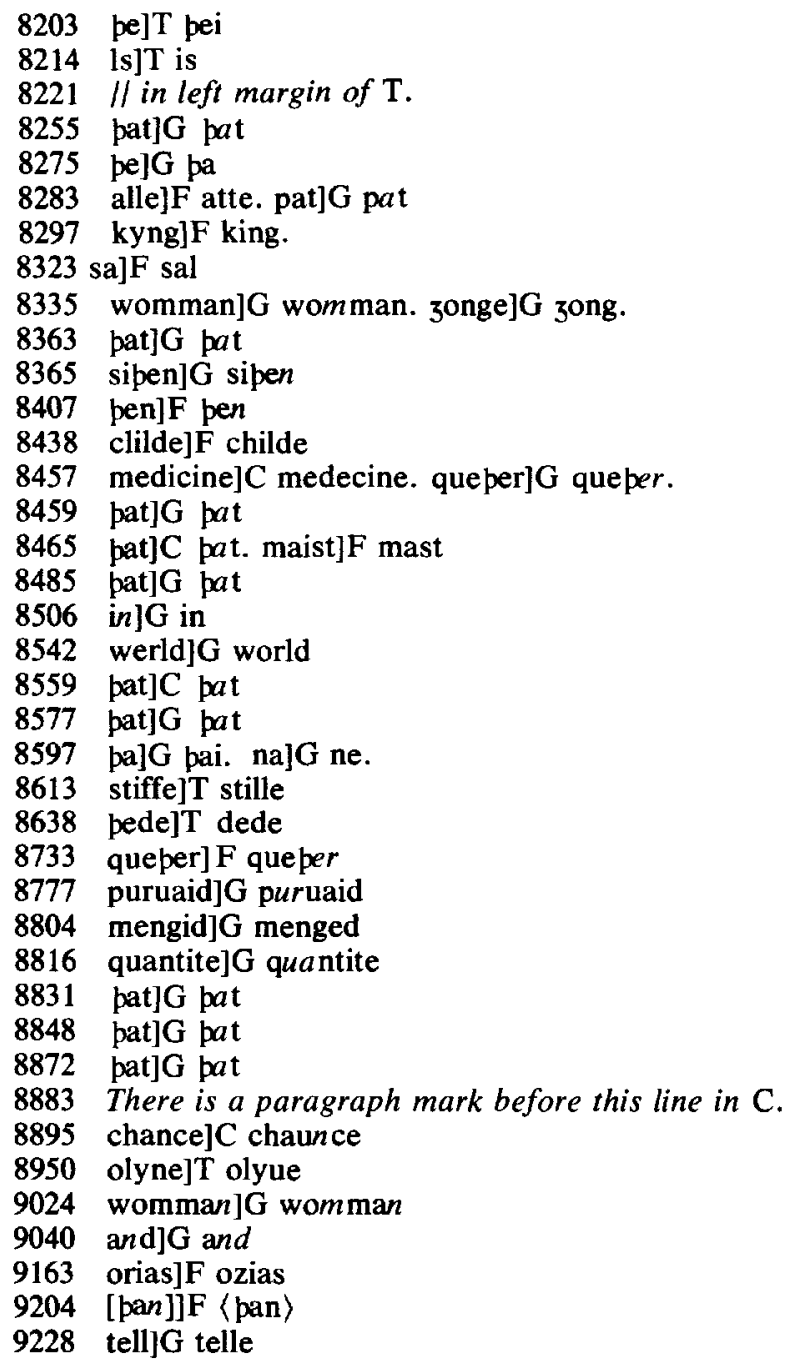




\section{BIBLIOGRAPHY}

\section{PRIMARY SOURCES}

AElfric. Homilies of Aelfric. Ed. John C. Pope. London: Oxford University Press, 1967-8. EETS OS 259, 260.

Sermones Catholics, or Homilies of Aelfric. Ed. Benjamin Thorpe. London: Aelfric Society, 1844.

ANDREW of Wyntoun. The Original Chronicle of Andrew of Wyntoun. Ed. F. J. Amours. Edinburgh and London: William Blackwood, 1903-1914.

Aquinas, Thomas. Summa Theologica. 60 vols. Cambridge: Blackfriars, 1964-6.

ARISTOTLE. On the Heavens. Trans. W. K. C. Guthrie. London: Heinemann, 1953.

ARNGART, Olof, ed. The Middle English Genesis and Exodus. Lund: C. W.K. Gleerup, 1968. Lund Studies in English, 36.

Augustine. Confessiones. PL XXXII.

- De Civitate Dei contra Paganos. Ed. J. E. C. Welldon. London: SPCK, 1924.

- De Genesi ad Litteram. PL XXXIV.

- De Genesi ad Litteram Imperfectus Liber. PL XXXIV.

- De Genesi contra Manichaeos. PL XXXIV.

Quaestiones in Heptateuchum. PL XXXIV.

Bacon, Roger. The Opus Majus of Roger Bacon. 2 vols. Philadelphia: University of Pennsylvania Press, 1928.

BEDE. Hexaemeron. PL XCI.

- In Pentateuchum Commentarii. PL XCI.

Bennett, J.A.W. and G.V. Smithers. Early Middle English Verse and Prose. 2nd ed. Oxford: Clarendon Press, 1968.

Blake, N.F. Middle English Religious Prose. London: Edward Arnold, 1972.

BLock, K.S., ed. Ludus Coventriae. London: Oxford University Press, 1922. EETS ES 120.

Blunt, John Henry, ed. The Myroure of oure Ladye. London: N. Trübner, 1873. EETS ES 19.

BoAs, Marcus, ed. Disticha Catonis. Amsterdam: North-Holland, 1952.

Bonnard, Jean. "Monologue de la reine d'Égypte dans le poème biblique de Malkaraume", in Mélanges de philologie romane et d'histoire littéraire offerts à M. Maurice Wilmotte. Paris: Honoré Champion, 1910. Pp. 49-56.

Bonnardot, F. "Fragments d'une traduction de la Bible en vers français", Romania, XVI (1887), 177-213.

BrANDL, A. and O. ZIPPEL. Mittelenglische Sprach-und Literaturproben. Berlin: Weidmannsche Buchhandlung, 1917.

British Library, MS Harley 3375, fols. 140-9.

Brown, Carleton, ed. Religious Lyrics of the XIVth Century. 2nd ed. rev'd by G.V. Smithers. Oxford: Clarendon Press, 1952.

BRunNer, Karl, ed. “Zwei Gedichte aus der Handschrift Trinity College, Cambridge 323 (B. 14.39)", Englische Studien, LXX (1935), 221-243.

Budge, E.A. Wallis, ed. The Book of the Cave of Treasures. London: Religious Tract Society, 1927.

BurCHARD, Christoph. Untersuchungen zu Joseph und Aseneth. Tübingen: J.C.B. Mohr, 1965. Wissenschaftliche Untersuchungen zum Neuen Testament, 8. 
Charles, R.H., ed. The Apocrypha and Pseudepigrapha of the Old Testament in English. 2 vols. Oxford: Clarendon Press, 1913.

- ed. The Book of Jubilees. London: Adam and Charles Black, 1902.

CHAuCER, Geoffrey. The Works of Geoffrey Chaucer. Ed. F.N. Robinson. 2nd ed. Boston: Houghton Mifflin, 1957.

Daly, Saralyn Ruth. The Historye of the Patriarks. Diss. Ohio State, 1950.

Davis, Norman, ed. Non-Cycle Plays and Fragments. London: Oxford University Press, 1970. EETS SS 1.

Day, Mabel, ed. The English Text of the Ancrene Riwle. London: Oxford University Press, 1952. EETS OS 225.

- ed. The Wheatley Manuscript. London: Oxford University Press, 1921. EETS OS 155.

Deguilleville, Guillaume de. The Pilgrimage of the Life of Man. Trans. John Lydgate. Ed. F.J. Furnivall. London: Kegan Paul, 1899-1904. EETS ES 77, 83, 92.

Deimling, Hermann, ed. The Chester Plays. London: Kegan Paul, 1893. EETS ES 62.

D'EVELyN, Charlotte. "The Middle-English Metrical Version of the Revelations of Methodius; with a Study of the Influence of Methodius in Middle-English Writings", PMLA, XXXIII (1918), 135-203.

- and Anna J. MILL, eds. The South English Legendary. 3 vols. London: Oxford University Press, 1956-9. EETS OS 235, 236, 244.

Dickens, Bruce and R. M. Wilson, eds. Early Middle English Texts. London: Bowes \& Bowes, 1951.

DüwELl, Henning, ed. Eine altfranzösische Übersetzung des Elucidarium. Munich: Wilhelm Fink, 1974. Beiträge zur romanischen Philologie des Mittelalters, VII.

ElbIS, F. S., ed. The Golden Legend. I. 1900; rpt. New York: AMS Press, 1973.

EMERSON, Oliver Farrar, ed. A Middle English Reader. New and rev'd ed. London: Macmillan, 1924.

England, George and Alfred W. Pollard, eds. The Towneley Plays. London: Kegan Paul, 1897. EETS ES 71.

EThERIDGE, J.W., ed. The Targums of Onkelos and Jonathan Ben Uzziel on the Pentateuch. Vol. 1. London: Longman, 1862.

Evrat. Genèse. MS BN fr. 12,456.

Foster, Frances A., ed. A Stanzaic Life of Christ. London: Oxford University Press, 1926. EETS OS 166.

Freedman, H. and Maurice Simon, eds. Midrash Rabbah. London: Soncino Press, 1939.

Furnivall, F.J., ed. Adam Davy's Five Dreams About Edward II. London: N. Trubner, 1878. EETS OS 69.

Geoffroi de Paris. La Bible des sept états du monde. MS BN fr. 1526.

Glossa Ordinaria. PL CXIII.

Gollancz, Israel, ed. Cleanness. London: Oxford University Press, 1921.

Gower, John. Confessio Amantis, in The Complete Works of John Gower. Oxford: Clarendon Press, 1901.

Grosseteste, Robert. Le Château d'amour de Robert Grosseteste Évêque de Lincoln. Ed. J. Murray. Paris: Champion, 1918.

HAHN, A. "Zu Pricke of Conscience v. 7651-7686", Archiv, CVI (1901), 349-50.

Haring, N. "The Creation and Creator of the World According to Thierry of Chartres and Clarenbaldus of Arras", Archives d'histoire doctrinale et littéraire du moyen âge (1955), 137-216.

Helgason, Jón. The Arna Magnaean Manuscript 674A, 4to. Elucidarium. Copenhagen: Ejnar Munksgaard, 1957. Manuscripta Islandica, 4.

Herman de Valenciennes. La Bible von Herman de Valenciennes. II Ed. Otto Moldenhauer. Greifswald: Hans Adler, 1914. 
. "Herman de Valenciennes, Bible de Sapience", in Karl BarTsch, ed. Chrestomathie de l'ancien français. 10th ed. Leipzig: F.C.W. Vogel, 1910. Pp. 71-6.

- La Bible. MS University of Chicago H.27.B.6.12.

Heuser, W., ed. Die Kildare-Gedichte. Bonn: P. Hanstein, 1904.

Higden, Ranulph. Polychronicon Ranulphi Higden. Trans, John Trevisa. Ed. Churchill Babington. London: Longmans, 1869.

HILl, Betty. "The Fifteenth Century Prose Legend of the Cross before Christ", Medium Evum, XXXIV (1965), 203-22.

Historical Manuscripts Commission. 6th report. Appendix. London: Eyre and Spottiswoode, 1877. Pp. 319-20.

Holt, Robert, ed. The Ormulum. 2 vols. Oxford: Clarendon Press, 1878.

Honorius Augustodunensis. De Imagine Mundi. PL CLXXII.

- Elucidarium in Yves Lefevre, L'Elucidarium et les lucidaires. Paris: de Boccard, 1954. Bibliothèque des Écoles françaises d'Athènes et de Rome, fasc. 180.

Horstmann, C., ed. Altenglische Legenden. Neue Folge. Heilbronn: Gebr. Henniger, 1881.

—, ed. The Early South-English Legendary. London: N. Trubner, 1887. EETS OS 87.

- ed. The Minor Poems of the Vernon Manuscript. London: Kegan Paul, 1892. EETS OS 98.

—_, ed. "Nachträge zu den Legenden", Archiv, LXXVI (1887), 459-70.

- ed. "Questiones by-twene the Maister of Oxenford and his Clerke", Englische Studien, VIII (1884-5), 284-7.

$\longrightarrow$, ed. Sammlung Altenglischer Legenden. Heilbronn: Gebr. Henninger, 1878.

Hugh of ST. VIctor. Adnotationes Elucidatoriae in Pentateuchon. PL CLXXV.

- De Arca Noe Morali. PL CLXXVI.

De Arca Noe Mystica. PL CLXXVI.

IsIDORE. Etymologiarum. Ed. W. M. Lindsay. 1911; rpt. Oxford: Clarendon Press, 1966.

Jacobus a Voragine. Legenda Aurea. Ed. Th. Graesse. Lipsiae: Impensis Librariae Arnoldianae, 1850.

JeROME. Liber Hebraicarum Quaestionum in Genesim. PL XXIII.

JoNES, J. Morris and John Rhys, ed. The Elucidarium and other Tracts in Welsh. Oxford: Clarendon Press, 1894.

Josephus. History of the Jewish War Against the Romans. Trans. H. StJ. Thackeray, London: William Heinemann, 1930.

- Jewish Antiquities. Trans. H. StJ. Thackeray. London: William Heinemann, 1930.

KALÉN, Herbert, ed. A Middle English Metrical Paraphrase of the Old Testament.

I. Göteborgs Högskolas Arsskrift, XXVIII (1922).

Kane, George, ed. Piers Plowman: The A Version. London: Athlone Press, 1960.

KEMBLE, John M. The Dialogue of Salomon and Saturnus. London: Elfric Society, 1848.

KER, N. R. Facsimile of British Museum MS Harley 2253. London: Oxford University Press, 1965. EETS OS 255.

KrapP, George Philip, ed. The Junius Manuscript. New York: Columbia University Press, 1931.

Lazar, Moshé. "La Légende de 'l'Arbre de Paradis' ou 'bois de la croix",", Zeitschrift für romanische Philologie, LXXVI (1960), 34-63.

Littlenales, Henry, ed. The Prymer or Lay Folks Prayer Book. London: Kegan Paul, 1895. EETS OS 105.

Lumiansky, R. M. and David Mills, eds. The Chester Mystery Cycle. London: Oxford University Press, 1974. EETS SS 3. 
Lydgate, John. Lydgate's Fall of Princes. Ed. Henry Bergen. 4 vols. London: Oxford University Press, 1924-7.

MCCARThy, B. The Codex Palatino Vaticanus No. 830, Royal Irish Academy, Todd Lecture Series, Vol. III. Dublin: Royal Irish Academy, 1892.

MacCracken, H. N. "Lydgatiana", Archiv, CXXXI (1913), 40-63.

, ed. "The Storie of Asneth", JEGP, IX (1910), 224-64.

Macé de la Charité. La Bible de Macé de la Charité. Vol. I ed. J. R. Smeets. Vol. IV ed. H. C. M. Krabben. Leiden: Universitaire Pers Leiden, 1967, 1964.

MaLAN, S. C., ed. The Book of Adam and Eve. London: Williams and Norgate, 1882.

Malkaraume, Jehan. Bible. MS BN fr. 903.

Mandeville, John. Mandeville's Travels. Ed. Malcolm Letts. 2 vols. London: Hakluyt Society, 1953.

. The Bodley Version of Mandeville's Travels. Ed. M. C. Seymour. London: Oxford University Press, 1963. EETS OS 253.

Menner, Robert J., ed. The Poetical Dialogues of Solomon and Saturn. New York: Modern Language Association of America, 1941. Modern Language Association of America Monograph Series 13.

Meyer, Paul. "Notice de MS Egerton 2710 du Musée Britannique. i. Poème anglonormand sur l'Ancien Testament", Bulletin de la Société des Anciens Textes français, XV (1889), 72-97.

- "Notice et extraits d'un fragment de poème biblique composé en Angleterre", Romania, XXXVI (1907), 184-202.

- "Notice sur deux anciens manuscrits français ayant appartenu au Marquis de la Clayette", Notices et extraits des manuscrits de la Bibliothèque Nationale et autres bibliothèques XXXIII, Part 1 (1890), 71-5.

- "Notices sur quelques manuscrits français de la Bibliothèque Phillipps a Cheltenham', Notices et extraits des manuscrits de la Bibliothèque Nationale et autres bibliothèques, XXXIV, Part 1 (1891), 198-211.

- "Notice sur la Bible des sept états du monde de Geufroi de Paris", Notices et extraits des manuscrits de la Bibliothèque Nationale et autres bibliothèques, XXXIX, Part 1 (1909), 260, 273-4.

- ed. Recueil d'anciens textes. Paris: F. Vieweg, 1877.

Meyer, Wilhelm. "Die Geschichte des Kreuzholzes vor Christus", Abhandlungen der Philosophisch-Philologischen Classe der Königlich Bayerischen Akademie der Wissenschaften, XVI (1881), 101-166.

- "Vita Adae et Evae", Abhandlungen der Philosophisch-Philologischen Classe der Königlich Bayerischen Akademie der Wissenschaften, XIV (1898), 185-250.

Mirk, John. Mirk's Festial. Ed. Theodor Erbe. London: Kegan Paul, 1905. EETS ES 46.

MoRrIs, Richard, ed. Ayenbite of Inwit. London: N. Trubner, 1866. EETS OS 23.

- ed. Cursor Mundi. 1874-93; rpt. London: Oxford University Press, 1961-6. EETS OS 57, 59, 62, 66, 68, 99, 101.

- Legends of the Holy Rood. London: N. Trubner, 1871. EETS OS 46.

. ed. The Pricke of Conscience. Berlin: A. Asher, 1863.

. and Walter W. Skeat, eds. Specimens of Early English. 2nd ed. Oxford: Clarendon Press, 1889.

Mozley, J. H., ed. "The Vita Adae”, Journal of Theological Studies, XXX (1929), 121-49.

"Nachträge zu den Legenden", Archiv, LXXIV (1885), 327-65.

NAPIER, Arthur S., ed. History of the Holy Rood-Tree. London: Kegan Paul, 1894. EETS OS 103.

- ed. Iacob and loseph. Oxford: Clarendon Press, 1916.

Norris, Edwin, ed. and trans. The Ancient Cornish Drama. 2 vols. Oxford: Oxford University Press, 1859. 
Northern Homilies. MSS BL Harley 4196 fol. 107r-107v, and BL Addit. 22, 283, fol. 5 r.

Ohlander, Urban, ed. A Middle English Metrical Paraphrase of the Old Testament. II Gothenburg Studies in English, V (1955), 1-112.

- ed. A Middle English Metrical Paraphrase of the Old Testament. III, Gothenburg Studies in English, XI (1960), 1-131.

burg Studies in English, XVI (1963).

Panton, G. A. and D. Donaldson, ed. The Gest Hystoriale of the Destruction of Troy. 1869; rpt London: Oxford University Press, 1968. EETS OS 39.

Person, Henry A., ed. Cambridge Middle English Lyrics. Seattle: University of Washington Press, 1962.

Petrus Comestor. Historia Scholastica. PL CXCVIII.

Petrus lombardus. Sententiarum. Pl CXCII.

Pickering, F. P., ed. The Anglo-Norman Text of the Holkham Bible Picture Book. Oxford: Blackwell, 1971. Anglo-Norman Texts XXIII.

Prior, O. H., ed. Caxton's Mirrour of the World. London: Kegan Paul, 1913. EETS ES 110.

- ed. L'Image du monde de Maître Gossouin. Lausanne and Paris: Payot, 1913.

Remigius of AuXerre. Commentarius in Genesim. PL CXXXI.

REYNAUD, Georges, ed. "Elucidarium", Revue des langues romanes, XXXIII (1889), 217-50.

Rosenbaum, M. and A. M. Silbermann, eds. Pentateuch with Targum Onkelos, Haphtaroth and Rashi's Commentary. 5 vols. New York: Hebrew Publishing Co., n.d.

Ross, Woodburn O., ed. Middle English Sermons. London: Oxford University Press, 1940. EETS OS 209.

SajavaARa, Kari, ed. The Middle English Translations of Robert Grosseteste's Château d'amour. Helsinki: Société Néophilologique, 1967. Mémoires de la Société Néophilologique de Helsinki, XXXII.

Sampson, G., ed. Cambridge Book of Prose and Verse. Cambridge: Cambridge University Press, 1924.

SARGENT, Michael G. "The McGill University Fragment of the 'Southern Assumption'", Mediaeval Studies, XXXVI (1974), 186-98.

Schmitr, Friedrich, ed. Die Mittelenglische Version des Elucidarium des Honorius Augustodunensis. Burghausen: W. Trinkl, 1909.

Skeat, Walter W., ed. The Vision of William Concerning Piers the Plowman. 2 vols. London: Oxford University Press, 1886.

Small, John, ed. English Metrical Homilies from Manuscripts of the Fourteenth Century. 1862; rpt New York: AMS Press, 1973.

Smalley, Beryl. "A Commentary on the Hexaemeron by Henry of Ghent", Recherches de théologie ancienne et médiévale, XX (1953), 60-101.

Sмiтн, Lucy Toulmin, ed. A Commonplace Book of the Fifteenth Century. London: Trubner, 1886.

- ed. York Plays. 1885; rpt New York: Russell and Russell, 1963.

South English Legendary, Temporale. MS Bodl. Eng. Poet. A. 1.

STEUER, Wilhelm. "Die altfranzösische 'Histoire de Joseph" ", Romanische Forschungen, XIV (1903), 227-410.

Stokes, Whitley, ed. and trans. The Creation of the World. London: Williams and Norgate, 1864.

SuchiER, Hermann. Denkmäler provenzalischer Literatur und Sprache. I. Halle: Max Niemeyer, 1883.

Traduction anonyme de la Bible entière. MS BN fr. 763, fols. 211-77.

Traduction anonyme de l'Ancien Testament. MS BL Egerton 2710, fols. 1-97.

Trethewey, William Hilliard, ed. La Petite philosophe. Oxford: Basil Blackwell, 1939. Anglo-Norman Texts I. 
Ullmann, J. "Studien zu Richard Rolle de Hampole", Englische Studien, VII (1884), 415-72.

Weatheley, Edward H., ed. Speculum Sacerdotale. London: Oxford University Press, 1936. EETS OS 200.

William of Shoreham. The Poems of William of Shoreham. Ed. M. Konrath. London: Kegan Paul, 1902. EETS ES 86.

Wright, Thomas, ed. The Book of the Knight of LaTour-Landry. London: N. Trübner, 1868. EETS OS 21.

ZupiTZA, Julius. Alt-und mittelenglisches Übungsbuch. 12th ed. Wien und Leipzig, 1922.

\section{SECONDARY SOURCES}

ADAmson, J. H. "Milton and the Creation', JEGP, LXI (1962), 756-78.

Allen, Don Cameron. The Legend of Noah. Urbana: University of Illinois Press, 1949. Illinois Studies in Language and Literature, XXXIII, nos. 3-4.

Anderson, M. D. Drama and Imagery in English Medieval Churches. Cambridge: Cambridge University Press, 1963.

AREND, Zygfryd Marjan. "Linking in Cursor Mundi", Transactions of the Philological Society (1925-30), 200-59.

BARB, A. A. "Cain's Murder-Weapon and Samson's Jawbone of an Ass", Journal of the Warburg and Courtauld Institutes, XXXV (1972), 386-9.

BARON, Roger. "Hugues de Saint-Victor: contribution à un nouvel examen de son ceuvre", Traditio, XV (1959), 223-97.

Barrow, G. W. S. "The Anglo-Scottish Border", Northern History, I (1966), 21-42.

BARTH, Curt. Der Wortschatz des Cursor Mundi. Diss. Königsberg, 1903.

Beichner, Paul E. "La Bible versifiée de Jehan Malkaraume et l'Aurora", trans. Paul Mertens, Moyen âge, LXI (1955), 63-78.

-. "The Cursor Mundi and Petrus Riga", Speculum, XXIV (1949), 239-250.

- "The Old French Verse Bible of Macé de la Charité, a Translation of the Aurora", Speculum, XXII (1947), 226-39.

Berger, Samuel. La Bible française au moyen âge. Paris: Imprimerie Nationale, 1884.

Bliss, A. J. "The Auchinleck Life of Adam and Eve", Review of English Studies, new ser., VII (1956), 406-9.

BonnaRD, Jean. Les Traductions de la Bible en vers français au moyen âge. Paris: Imprimerie Nationale, 1884.

Bonnell, John Kester. "Cain's Jaw Bone', PMLA, XXXIX (1924), 140-6.

Borland, Lois. The Cursor Mundi and Herman's Bible. Diss. Chicago, 1929. 427-44.

Bossuat, Robert. Manuel bibliographique de la littérature française du moyen âge. Melun: Librairie D'Argences, 1951. 2 Supplements.

Bradley, H. "The Caedmonian Genesis", in Essays and Studies by Members of the English Association, VI, 7-29. Oxford: Clarendon Press, 1920.

Braswell, Laurel Nichols. The South English Legendary Collection: A Study in Middle English Religious Literature of the Thirteenth and Fourteenth Centuries. Diss. Toronto, 1964.

BRIQUET, C. M. Les Filigranes. 4 vols. Genève: A. Jullien, 1907.

Brown, Carleton. "The Cursor Mundi and the Southern Passion", Modern Language Notes, XXVI (1911), 15-8.

. "Mulier est Hominis Confusio", Modern Language Notes, XXXV (1920), 479-82.

and Rossell Hope RobBins. The Index of Middle English Verse. New York: Columbia University Press, 1943. Supplement. Lexington: University of Kentucky Press, 1965. 
Buehler, Philip. "The Cursor Mundi and Herman's Bible - Some Additional Parallels", Studies in Philology, LXI (1964), 485-99.

Cabrol, Fernand and Henri LeclercQ, eds. Dictionnaire d'archéologie chrétienne et de liturgie. Paris: Letouzey et Ané, 1924-50.

Cambridge History of the Bible. Vol. I ed. P. R. Ackroyd and C. V. Evans. Vol. II ed. G. W. H. Lampe. Cambridge: Cambridge University Press, 1969-70.

Cassidy, Frederick G. "The Edged Teeth" in Studies in Old English Literature in Honor of Arthur G. Brodeur. Ed. Stanley B. Greenfield. Oregon: University of Oregon Books, 1963. Pp. 227-36.

Cockerell, Sydney C., ed. A Book of Old Testament Illustrations of the Middle of the Thirteenth Century. Cambridge: Cambridge University Press, 1927.

Coffman, George R. "Old Age from Horace to Chaucer. Some Literary Affinities and Adventures of an Idea", Speculum, IX (1934), 249-77.

CoHn, Norman. The Pursuit of the Millenium. Rev. ed. New York: Oxford University Press, 1970.

Coli, Edoardo. /l Paradiso terrestre dantesco. Firenze: G. Carnesecchi, 1897.

Coomaraswamy, Ananda K. Art Bulletin, XXIV (1942), 383-4.

COOKE, Daniel. "Euhemerism: A Mediaeval Interpretation of Classical Paganism", Speculum, II (1927), 396-410.

Dareau, Margaret Grace and Angus McIntosh. "A Dialect Word in Some West Midland Manuscripts of the Prick of Conscience", Edinburgh Studies in English and Scots. Ed. A. J. Aitken, Angus McIntosh and Herman Palsson. London: Longmans, 1971. Pp. 20-6.

DeAnesly, Margaret. The Lollard Bible. Cambridge: Cambridge University Press, 1920.

Dickens, Bruce. "Gerard as a Goblin Name”, Times Literary Supplement (Feb. 1, 1941), 55.

Driver, S. R. The Book of Genesis. London: Methuen, 1904.

Dronke, Peter. Poetic Individuality in the Middle Ages. Oxford: Clarendon Press, 1970.

Dunstan, A. C. "The Middle English Canticum de Creatione and the Latin Vita Adae et Evae", Anglia, LV (1931), 431-42.

Dustoor, P. E. "Legends of Lucifer in Early English and in Milton", Anglia, LIV (1930), 213-68.

DWYER, R. A. "Asenath of Egypt in Middle English", Medium Evum, XXXIX (1970), 118-22.

Emerson, Oliver F. "Legends of Cain, Especially in Old and Middle English", $P M L A$, XXI (1906), 831-929.

- "A Note on the M. E. Cleanness", Modern Language Review, X (1915), 373-5.

Evans, J. M. "Microcosmic Adam", Medium Evum, XXXV (1966), 38-42.

Evans, M. W. Medieval Drawings. London: Paul Hamlyn, 1969.

FAUSB $\phi$ LL, Else. A Study of the Phonology and Accidence of the Fairfax Manuscript of the Cursor Mundi. Diss. Manchester, 1954.

FAverTY, Frederic E. "Legends of Joseph in Old and Middle English", PMLA, XLIII (1928), 79-104.

"The Story of Joseph and Potiphar's Wife in Mediaeval Literature", Harvard Studies and Notes in Philology and Literature, XIII (1931), 81-127.

Förster, Max. "Adams Erschaffung und Namengebung”, Archiv, XI (1908), 477 529.

Fowler, David C. The Bible in Early English Literature. Seattle and London: University of Washington Press, 1976.

Friend, Albert C. "Sampson, David and Salomon in the Parson's Tale", Modern Philology, XLVI (1948), 117-21.

Furnivall, F. J. "How Cato was a Paynym and a Christian Too", Notes and Queries, 4th ser., II (1868), 176. 
Garvin, Katherine. "A Note on Noah's Wife", Modern Language Notes, XLIX (1934), 88-90.

Gerould, Gordon Hall. Saints' Legends. Boston and New York: Houghton Mifflin, 1916.

Giamatri, A. Bartlett. The Earthly Paradise and the Renaissance Epic. Princeton: Princeton University Press, 1966.

Glunz, H. H. History of the Vulgate in England from Alcuin to Roger Bacon. Cambridge: Cambridge University Press, 1933.

Gollancz, Israel. The Caedmon Manuscript. London: Oxford University Press, 1927.

Graf, Arturo. Miti, leggende e superstizioni del Medio Evo. Torino: Giovanni Chiantore, 1925.

HAEnisch, Dr. "Inquiry into the Sources of the Cursor Mundi", in Richard Morris, ed., Cursor Mundi. VI London: Kegan Paul, 1892. EETS OS 99. Pp. 1-56.

Hamilton, G. L. "La Source d'un épisode de Baudouin de Sebourc", Zeitschrift für romanische Philologie, XXXVI (1912), 129-59.

Hassall, W. O., ed. The Holkham Bible Picture Book. London: Dropmore Press, 1954.

Henderson, George. "Cain's Jaw-Bone", Journal of the Warburg and Courtauld Institutes, XXIV (1961), 108-114.

Holthausen, F. "Zu dem mittelenglischen Gedicht Cleanness", Archiv, CVI (1901), 349.

Horrall, Sarah M. "The Cursor Mundi Creation Story and Hugh of St. Victor", Notes and Queries, n. s. XXIII (1976), 99-100.

- "An Old French Source for the Genesis Section of Cursor Mundi", Mediaeval Studies, XL (1978), 361-73.

- "A Schippe Behoues pe to Dight': Woven Arks of Noah in the Fourteenth Century", Proceedings of the Sixth Annual Symposium of the Ottawa-Carleton Medieval-Renaissance Club. Ottawa, 1978.

. "The London Thornton Manuscript: A New Collation", forthcoming in Manuscripta.

Hörning, Willy. Die Schreibung der Hs. E des Cursor Mundi. Diss. FriedrichWilhelms-Universitat, Berlin, 1906.

Hupe, H. "Cursor Mundi", Anglia Beiblatt, I (1890-1), 133-6.

- "Cursor Mundi: Essay on the Manuscripts and Dialect"' in Richard MorRis, ed., Cursor Mundi. VII. 1893; rpt. London: Oxford University Press, 1962. EETS OS 101.

- "Zum Handschriftenverhältniss und zur Textkritik des Cursor Mundi", Anglia, XI (1889), 121-45.

James, Montague Rhodes. The Lost Apocrypha of the Old Testament. London: SPCK, 1920.

JAuss, Hans Robert, ed. La Littérature didactique, allégorique et satirique. Heidelberg: Carl Winter, 1970. Grundriss der romanischen Literaturen des Mittelalters, VI/1-2.

JoNes, Gwyn. A History of the Vikings. London: Oxford University Press, 1968.

KAISER, Rolf. Zur Geographie des mittelenglischen Wortschatzes. 1937; rpt. New York: Johnson Reprint Corp., 1970. Palaestra 205.

Kaluza, Max. "Zu den Quellen und dem Handschriftenverhältniss des Cursor Mundi', Englische Studien, XII (1889), 451-8.

- "Zum Handschriftenverhältniss und zur Textkritik des Cursor Mundi", Englische Studien, XI (1888), 235-75.

Kelly, Henry Ansgar. "The Metamorphoses of the Eden Serpent during the Middle Ages and Renaissance", Viator, II (1971), 301-28.

KER, N. R. Medieval Libraries of Great Britain. 2nd ed. London: Royal Historical Society, 1964. 
KING, R. W. "A Note on 'Sir Gawayn and the Green Knight' 2414ff', Modern Language Review, XXIX (1934), 435-6.

KivimaA, Kirsti. "Bitwix and in Cursor Mundi", in Studies Presented to Tauno F. Mustanoja on the Occasion of his Sixtieth Birthday. Neuphilologische Mitteilungen, LXXIII (1972), 134-42.

Kolve, V. A. The Play Called Corpus Christi. Stanford: Stanford University Press, 1966.

Kurath, Hans, and Sherman M. KuHN, eds. Middle English Dictionary. Ann Arbor: University of Michigan Press, 1956-.

LAmberTs, Jacob Justin. The Dialect of Cursor Mundi (Cotton MS Vespasian A III). Diss. Michigan, 1953.

. "The Noah Story in Cursor Mundi (vv. 1625-1916)", Mediaeval Studies, XXIV (1962), 217-32.

LARSEN, Henning. "Cursor Mundi 1291'" in Philologica: The Malone Anniversary Studies. Ed. Thomas A. Kirby and Henry Bosley Woolf. Baltimore: Johns Hopkins Press, 1949. Pp. 164-6.

-2. "Origo Crucis" in If by Your Art: Testament to Percival Hunt. Lancaster, Pa.: University of Pittsburgh Press, 1948. Pp. 27-33.

LegGe, M. Dominica. Anglo-Norman in the Cloisters. Edinburgh: Edinburgh University Press, 1950.

- Anglo-Norman Literature and its Background. Oxford: Clarendon Press, 1963.

LethabY, W. R. "The Painted Book of Genesis in the British Museum", Archaeological Journal, LXIX (1912), 88-111.

LEwIS, Jack P. A Study of the Interpretation of Noah and the Flood in Jewish and Christian Literature. Leiden: E. J. Brill, 1968.

Lubac, Henri de. Exégèse médiévale. Paris: Aubier 1959-62. Théologie, 41, 42, 59.

MCColley, Grant. "Milton's Battle in Heaven and Rupert of Saint Heribert", Speculum, XVI (1941), 230-5.

McInTosh, Angus. "A New Approach to Middle English Dialectology", English Studies, XLIV (1963), 1-11.

McNally, Robert E. The Bible in the Early Middle Ages. Westminster, Md.: The Newman Press, 1959. Woodstock Papers, No. 4.

Magoun, Francis P., Jr. "Chaucer's Ancient and Biblical World", Mediaeval Studies, XV (1953), 107-36.

Mardon, Ernest G. The Narrative Unity of the Cursor Mundi. Glasgow: William MacLellan, 1970.

Mellinkoff, Ruth. The Horned Moses in Medieval Art and Thought. Berkeley: University of California Press, 1970.

MENnER, Robert J. “Two Notes on Mediaeval Euhemerism”, Speculum, III (1928), 246-8.

Mill, Anna Jean. "Noah's Wife Again", PMLA, LVI (1941), 613-26.

Moore, Samuel, Sanford Brown Meech and Harold Whitehall. "Middle English Dialect Characteristics and Dialect Boundaries" in Essays and Studies in English and Comparative Literature. Ann Arbor: University of Michigan Press, 1935.

Murdoch, Brian. "An Early Irish Adam and Eve: Saltair na Rann and the Traditions of the Fall", Mediaeval Studies, XXXV (1973), 146-77.

Murray, James A. H., ed. A New English Dictionary on Historical Principles. Oxford: Clarendon Press, 1888-1928.

Ohlander, Urban. "Old French Parallels to a Middle English Metrical Paraphrase of the Old Testament", in Contributions to English Syntax and Philology, Gothenburg Studies in English, XIV, pp. 203-24.

Owst, G. R. Literature and Pulpit in Medieval England. Cambridge: Cambridge University Press, 1933.

Parent, J. M. La Doctrine de la création dans l'École de Chartres. Paris: J. Vrin, 1938. Publications de l'Institut d'études médiévales d'Ottawa, VIII. 
Patch, H. R. The Other World According to Descriptions in Medieval Literature. Cambridge, Mass.: Harvard University Press, 1950.

Pickering, O. S. "The Temporale Narratives of the South English Legendary", Anglia, XCI (1973), 425-55.

QuinN, Esther Casier. The Quest of Seth for the Oil of Life. Chicago: University of Chicago Press, 1962.

RABy, F. J. E. A History of Christian-Latin Poetry. 2nd ed. Oxford: Clarendon Press, 1953.

Roseins, Frank Egleston. The Hexaemeral Literature. Chicago: University of Chicago Press, 1912.

Robinson, F. N. "A Note on the Sources of the Old Saxon Genesis", Modern Philology, IV (1906), 389-96.

Rowland, Beryl. Blind Beasts. [Kent, Ohio]: Kent State University Press, 1971.

SajavaARA, Kari. "The Use of Robert Grosseteste's Château d'amour as a Source of the Cursor Mundi"', Neuphilologische Mitteilungen, LXVIII (1967), 184-93.

Salzman, L. F. Building in England down to 1540. 1952; rpt. Oxford: Clarendon Press, 1967.

SchapIRo, Meyer. "Cain's Jaw-Bone that Did the First Murder", Art Bulletin, XXIV (1942), $205-12$.

SeVERS, J. Burke, ed. A Manual of the Writings in Middle English 1050-1500. Vols. I and II. Hamden, Conn.: Archon Books, 1967, 1970.

Sharp, D. E. Franciscan Philosophy at Oxford in the Thirteenth Century. London: Oxford University Press, 1930.

ShERWIN, Oscar. "Art's Spring-Birth: the Ballad of Iacob and Ioseph", Studies in Philology, XLII (1945), 1-18.

SkEAT, Walter W. "Cain's Jaw-Bone", Notes and Queries, 6th ser., II (Aug. 21, 1880), 143.

—. "Lucifer", Notes and Queries, 3rd ser., XII (Aug. 10, 1867), 110.

Skinner, John. A Critical and Exegetical Commentary on Genesis. Edinburgh: T. \& T. Clark, 1912.

SMalley, Beryl. English Friars and Antiquity in the Early Fourteenth Century. Oxford: Basil Blackwell, 1960.

. The Study of the Bible in the Middle Ages. 2nd ed. Oxford: Basil Blackwell, 1952.

SNOUfFer, Eugene J. Verbal Syntax of Cursor Mundi (Cotton MS Vespasian A III). Diss. North Carolina, 1971.

SpICQ, P. C. Esquisse d'une histoire de l'exégèse latine au moyen âge. Paris: J. Vrin, 1944. Bibliothèque Thomiste, XXVI.

Stern, Karen. "The London 'Thornton' Miscellany', Scriptorium, XXX (1976), 26-37, 201-218.

StrandBerg, Otto. The Rime-Vowels of Cursor Mundi. Uppsala: Almqvist \& Wiksells Boktryckeri, 1919.

Thompson, James Westfall. The Medieval Library. 1939; rpt. New York: Hafner, 1967.

Thrupp, Sylvia L. The Merchant Class of Medieval London. Ann Arbor: University of Michigan Press, 1962.

Trapp, J. B. "Iconography of the Fall of Man", in C. A. Patrides, ed., Approaches to Paradise Lost. Toronto: University of Toronto Press, 1968. Pp. 223-65.

Utley, Francis Lee. "The One Hundred and Three Names of Noah's Wife", Speculum, XVI (1941), 426-52.

Vacant, A. et al., eds. Dictionnaire de théologie catholique. Paris: Letouzey et Ané, 1909-51.

Vising, Johan. Anglo-Norman Language and Literature. London: Oxford University Press, 1923.

VoN Rad, Gerhard. Genesis: A Commentary. Trans. John H. Marks. London: S.C.M. Press, 1961. 
Walsh, C.M. The Doctrine of Creation. London: T. Fisher Unwin, 1910.

Walther, Hans. Proverbia, Sententiaeque Latinitatis Medii Aevi. Göttingen: Vandenhoeck \& Ruprecht, 1963-9.

WARnER, George, ed. Queen Mary's Psalter. London: Longmans, 1912.

WELLS, Minnie E. "The Age of Isaac at the Time of the Sacrifice", Modern Language Notes, LIV (1939), 579-82.

- "The Structural Development of the South English Legendary", JEGP, XLI (1942), 320-44.

WhITE, T. H. The Book of Beasts. London: Jonathan Cape, 1954.

Whiting, Bartlett Jere. "Notes on the Fragmentary Fairfax Version of the Disticha Catonis", Mediaeval Studies, X (1948), 209-15.

- and Helen Wescott Whiting. Proverbs, Sentences, and Proverbial Phrases from English Writings Mainly before 1500. Cambridge, Mass.: Harvard University Press, 1968.

Williams, Norman Powell. The Ideas of the Fall and of Original Sin. London: Longmans, Green, 1927.

Wolfson, H. A. "The Meaning of Ex Nihilo in the Church Fathers, Arabic and Hebrew Philosophy and St. Thomas", in Mediaeval Studies in Honor of Urban T. Holmes, Jr. and Alex J. Denomy. Cambridge, Mass.: Harvard University Press, 1948. Pp. 353-70.

Woolf, Rosemary. The English Mystery Plays. Berkeley: University of California Press, 1972.

Wormald, Francis and C. E. Wright. The English Library before 1700. London: Athlone Press, 1958.

Wright, C. E. English Vernacular Hands from the Twelfth to the Fifteenth Centuries. Oxford: Clarendon Press, 1960.

Young, Wilfred. "Noah and his Wife: A Note on Three English Miracle Plays", Hermathena, XC (1957), 17-32.

ZINN, Grover. "Hugh of St. Victor and the Ark of Noah: A New Look", Church History, XL (1971), 261-72.

ZuPKo, Ronald Edward. A Dictionary of English Weights and Measures. Madison, Wisc.: University of Wisconsin Press, 1968.

- British Weights and Measures: A History from Antiquity to the Seventeenth Century. Madison: University of Wisconsin Press, 1977. 
Achevé d'imprimer par les travailleurs des ateliers Marquis Ltée de Montmagny le 30 novembre 1978 